GEOTHERMAL INVESTIGATIONS

IN IDAHO

\author{
PART 9
}

POTENTIAL FOR DIRECT HEAT APPLICATION
OF GEOTHERMAL RESOURCES
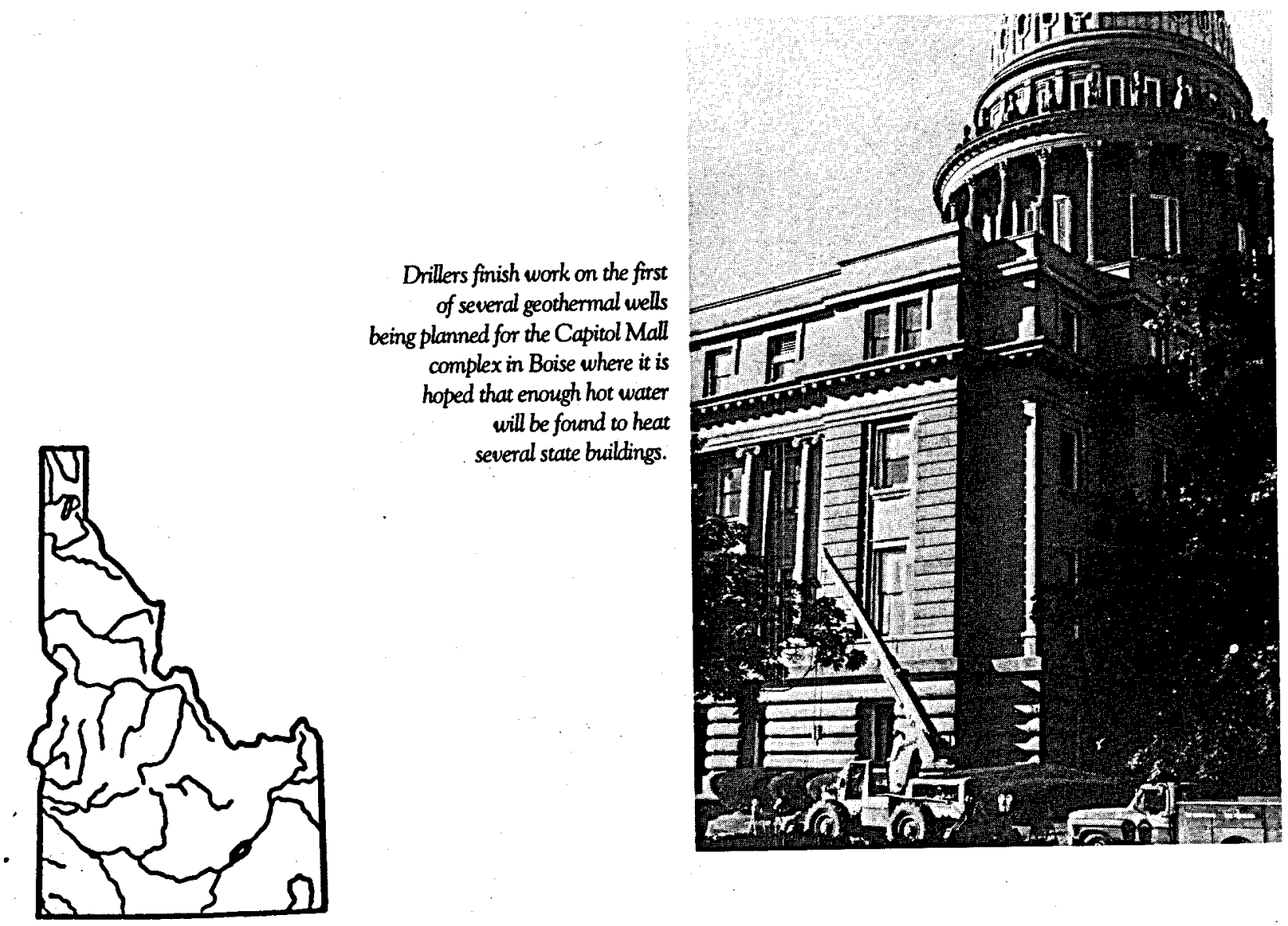

IDAHO DEPARTMENT OF WATER RESOURCES WATER INFORMATION BULLETIN NO. 30 JUNE 1980 


\section{DISCLAIMER}

This report was prepared as an account of work sponsored by an agency of the United States Government. Neither the United States Government nor any agency Thereof, nor any of their employees, makes any warranty, express or implied, or assumes any legal liability or responsibility for the accuracy, completeness, or usefulness of any information, apparatus, product, or process disclosed, or represents that its use would not infringe privately owned rights. Reference herein to any specific commercial product, process, or service by trade name, trademark, manufacturer, or otherwise does not necessarily constitute or imply its endorsement, recommendation, or favoring by the United States Government or any agency thereof. The views and opinions of authors expressed herein do not necessarily state or reflect those of the United States Government or any agency thereof. 


\section{DISCLAIMER}

Portions of this document may be illegible in electronic image products. Images are produced from the best available original document. 
WATER INFORMATION BULLETIN NO. 30

GEOTHERMAL INVESTIGATIONS IN IDAHO

Part 9

Potential for Direct Heat Application of Geothermal Resources

by

John C. Mitchell

Linda L. Johnson

John E. Anderson

With a section on Preliminary Environmental Assessment of Idaho Geothermal Resource Areas

by

Susan G. Spencer

Jacquelyn F. Sullivan

Work performed under U.S. Department of Energy Contract No. DE-AS07-77ET28407

Modification No. $\mathrm{AOO}$

Designation UC-66-2

Idaho Department of Water Resources

Statehouse.

Boise, Idaho

June 1980 


\section{NOTICE}

This report was prepared as an account of work sponsored by the United States Government. Neither the United States nor the United States Department of Energy, nor any of their employees, nor any of their contractors, subcontractors, or their employees, makes any warranty, expressed or implied, or assumes any legal liability or responsibility for the accuracy, completeness or usefulness of any information, apparatus, product or process disclosed, or represents that its use would not infringe privately-owned rights.

The information is the result of tax-supported research and as such is not copyrightable. It may be freely reprinted with the customary crediting of the source. The Idaho Department of Water Resources would appreciate notification of any reprinting of this information. 

TABLE OF CONTENTS

Page

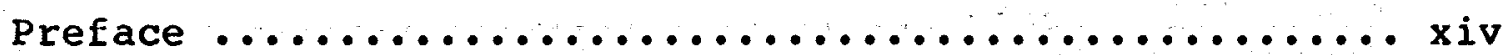

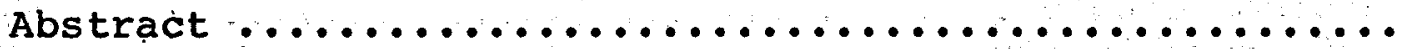

General Introduction $\ldots \ldots \ldots \ldots \ldots \ldots \ldots \ldots \ldots \ldots \ldots \ldots \ldots \ldots \ldots \ldots \ldots \ldots \ldots \ldots \ldots \ldots \ldots \ldots \ldots$

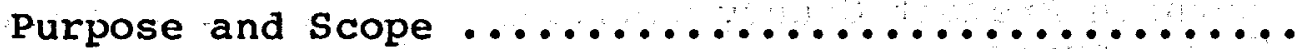

Wel1- and Spring-Numbering System ..............

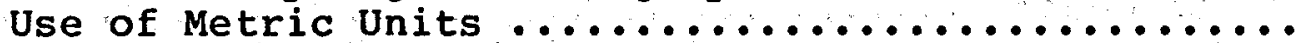
Chemical Geothermorneters $\ldots \ldots \ldots \ldots \ldots$ Present and Potential Geothermal Use in Idaho ...... Organization of Data $\ldots \ldots \ldots \ldots \ldots \ldots \ldots \ldots \ldots \ldots \ldots \ldots \ldots \ldots \ldots \ldots \ldots \ldots \ldots \ldots$

Geothermal Potential of the Northern Idaho

"Panhandle" Region $\ldots \ldots \ldots \ldots \ldots \ldots \ldots \ldots \ldots \ldots \ldots \ldots \ldots \ldots \ldots \ldots \ldots \ldots \ldots \ldots \ldots \ldots \ldots$

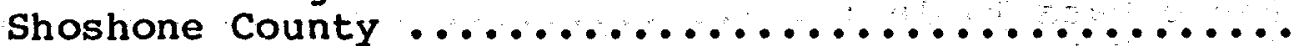

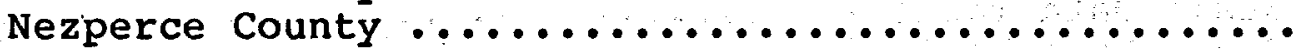
Geothermal potential of the Central Idaho Region .......

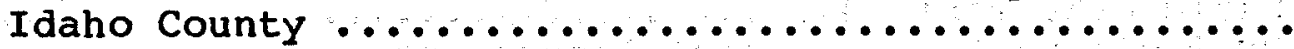
Adams County $\ldots \ldots \ldots \ldots \ldots \ldots \ldots \ldots \ldots \ldots \ldots \ldots \ldots \ldots \ldots \ldots \ldots \ldots \ldots \ldots \ldots$

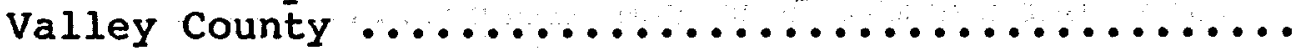

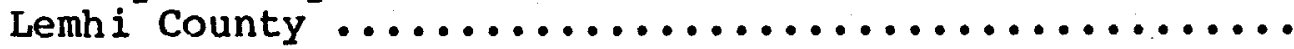

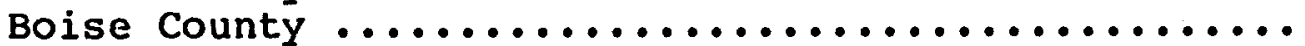
Custer County ................................

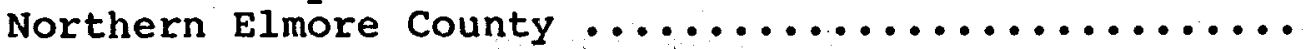

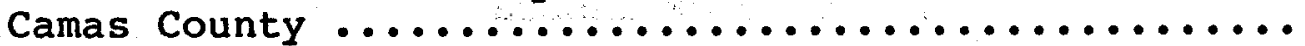

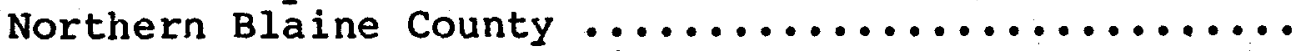

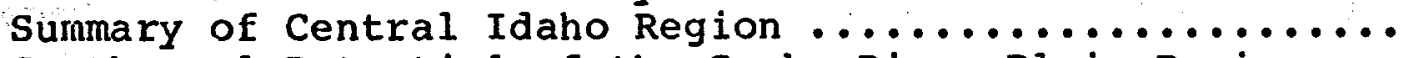
Geothermal Potential of the Snake River Plain Region ... Washington County $\ldots \ldots \ldots \ldots \ldots \ldots \ldots \ldots \ldots \ldots \ldots \ldots \ldots \ldots \ldots \ldots$ Payette county

Gem county

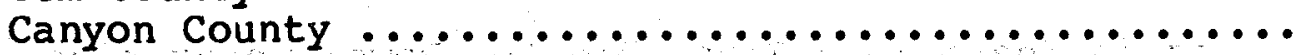
Ada county $\ldots \ldots \ldots \ldots \ldots \ldots \ldots \ldots \ldots \ldots \ldots \ldots \ldots \ldots \ldots \ldots \ldots \ldots \ldots \ldots \ldots$ Southern Elmore County $\ldots \ldots \ldots \ldots \ldots \ldots \ldots \ldots$ Gooding County $\ldots \ldots \ldots \ldots \ldots \ldots \ldots \ldots \ldots \ldots \ldots \ldots \ldots \ldots \ldots \ldots \ldots$ Jerome County $\ldots \ldots \ldots \ldots \ldots \ldots \ldots \ldots \ldots \ldots \ldots \ldots \ldots \ldots \ldots \ldots \ldots$ Minidoka county $\ldots \ldots \ldots \ldots \ldots \ldots \ldots \ldots \ldots \ldots \ldots$ Owyhee County $\ldots \ldots \ldots \ldots \ldots \ldots \ldots \ldots \ldots$ Twin Falls County $\ldots \ldots \ldots \ldots \ldots \ldots \ldots \ldots$ Northern Ereinont County $\ldots \ldots \ldots \ldots \ldots \ldots \ldots$ Butte County $\ldots \ldots \ldots \ldots \ldots \ldots \ldots \ldots$

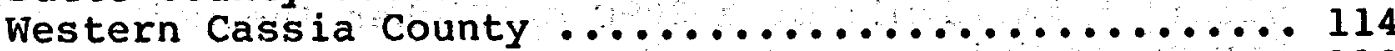
Summary - Snake River Plain Region $\ldots \ldots \ldots \ldots \ldots 18$ Geothermal Potential of the Basin and Range of

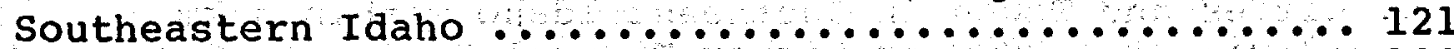

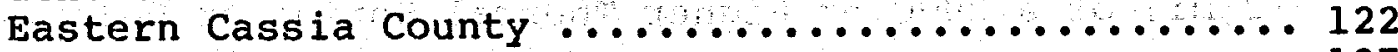

Oneida County .......................... 127

Franklin County .......................... 129

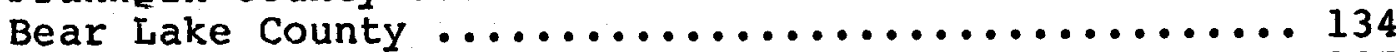

Caribou county ........................... 135

Bannock County ........................... 144 
Table of Contents (continued)

Page

Power County ........................... 147

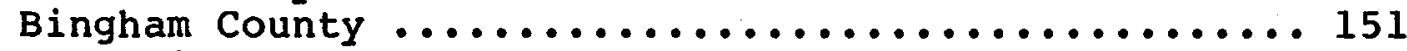

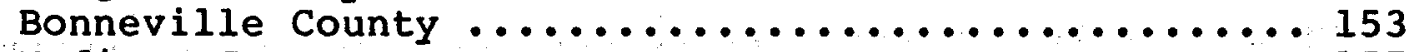

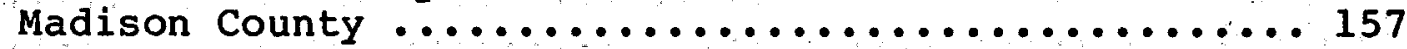

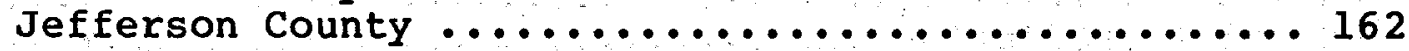

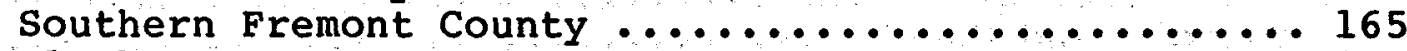

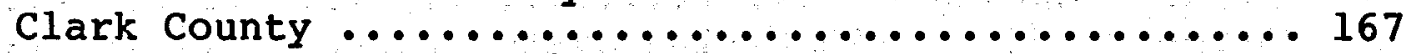

Teton County .......................... 169

Summary - Basin and Range, Central Rocky Mountain

Province, Southeastern Idaho ................. 171

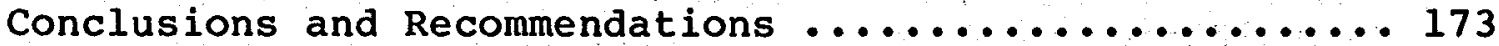

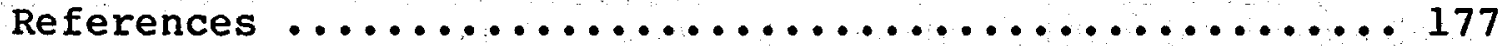

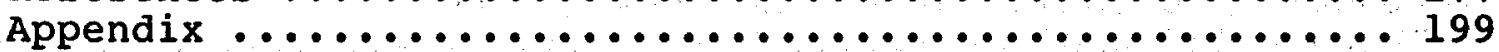

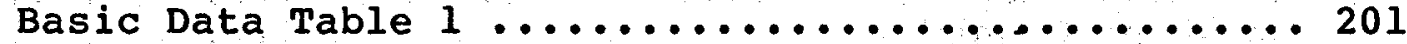

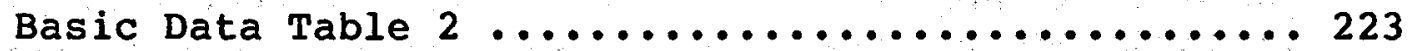

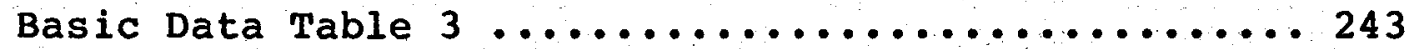

Basic Data Table $4 \ldots \ldots \ldots \ldots \ldots \ldots \ldots \ldots \ldots \ldots \ldots \ldots . \ldots \ldots$

Preliminary Environmental Assessment

Idaho Geothermal Resource Areas ............ 333

\section{LIST OF TABLES}

Tables

Page

1. English Metric Conversion Factors .............. 3

2. Geothermal Development in Idaho - Hot Water Uses .... 9

3. Areas in Idaho most Favorable for Power Generation Based on Surface Manifestations, Geology and

Geothermometery .......................... 13

4. Towns and Recreational Home Areas in Central Idaho within $5 \mathrm{~km}(3 \mathrm{mi})$ of a $20^{\circ} \mathrm{C}$ or Higher Thermal

spring or well ......................... 54

5. Cities and Towns in the Snake River Plain Region

within $5 \mathrm{~km}(3 \mathrm{mi})$ of a $20^{\circ} \mathrm{C}$ or Higher Thermal

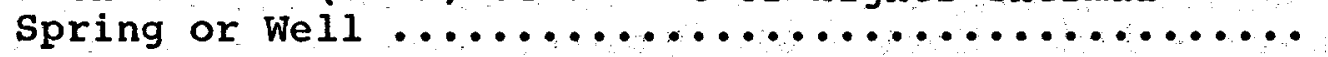

6. Cities and Towns in Southeast Idaho within $5 \mathrm{~km}$

( $3 \mathrm{mi}$ ) of a $200^{\circ} \mathrm{C}$ or Higher Thermal Spring or Well . 172 


\section{LIST OF FIGURES}

Figure

Page

1. Diagram showing the well- and spring-numbering system ............................... 4

2. Temperature conversion graph ............... 5

3. Index map of Idaho showing locations and present uses of geothermal energy ................. 8

4. Required temperatures for geothermal fluids . . . ... 12

5. Index map of Idaho showing areas most favorable for power generation based on surface manifestation, geology and geothermometery .............. 14

6. Index map of Idaho showing locations of counties and subregions covered in this report $\ldots \ldots \ldots \ldots \ldots 16$

7. Index map of Shoshone county showing locations of known thermal water occurrences with surface temperatures above $20^{\circ} \mathrm{C} \ldots \ldots \ldots \ldots \ldots \ldots \ldots \ldots \ldots \ldots \ldots$

8. Index map of Nez Perce County showing locations of thermal water occurrences with surface temperatures of $20^{\circ} \mathrm{C}$ or higher $\ldots \ldots \ldots \ldots \ldots \ldots \ldots \ldots \ldots \ldots . \ldots . \ldots . \ldots$

9. Thermal spring and well location map of Idaho showing their approximate surface temperatures, relations to curvilinear zones, linear and circular features $\ldots \ldots \ldots \ldots \ldots \ldots$ in pocket

10. Topographic maps showing typical central Idaho thermal spring occurrences near sharp river bends .. 23

11. Index map of Idaho county showing locations of thermal water occurrences with surface temperatures

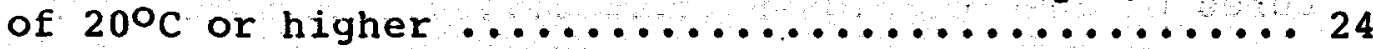

12. Index map of Adams County showing locations of thermal water occurrences with surface temperatures

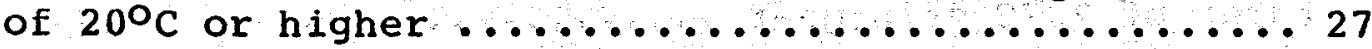

13. Gravity map of Council-Cambridge area, contour

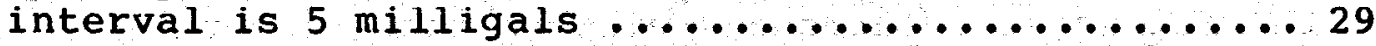

14. Gravity profile near Council .............. 30

15. Index map of Idaho showing known and suspected faults ............................ 31 


\section{List of Figures (continued)}

Figure

Page

16. Index map of Valley County showing locations of thermal water occurrences with surface temperatures of $20^{\circ} \mathrm{C}$ or higher ....................

17. EROS false color infrared Landsat EDISE image of part of west-central Idaho and eastern oregon showing selected linear features and thermal water 10cations with surface temperatures above $20^{\circ} \mathrm{C} \ldots \ldots . .35$

18. Index map of Lemhi County showing locations of thermal water occurrences with surface temperatures of $20^{\circ} \mathrm{C}$ or higher ..................... 38

19. Linear map compiled from Landsat, false color, infrared imagery. Topographic base is from Elk City AMS map (scale $1: 250,000) \ldots \ldots \ldots \ldots \ldots \ldots \ldots \ldots . \ldots 40$

20. Geologic map of the Big creek Hot Spring area in Lemhi County, Idaho .................... 42

21. Aeromagnetic map of the study area ........... 44

22. Index map of Boise County showing locations of thermal water occurrences with surface temperatures of $20^{\circ} \mathrm{C}$ or higher ................... 46

23. Index map of Custer county showing locations of thermal water occurrences with surface tempera-

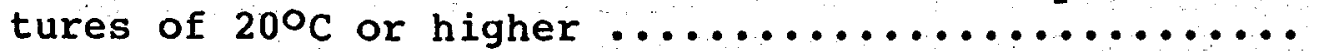

24. EROS false color infrared Landsat EDISE image of central Idaho showing selected linear features and thermal water locations with surface temperatures above $200^{\circ}$.........................

25. Index map of Elmore County showing locations of thermal water occurrences with surface temperatures of $20^{\circ} \mathrm{C}$ or higher $\ldots \ldots \ldots \ldots \ldots \ldots \ldots \ldots \ldots$

26. Index map of Camas County showing locations of thermal water occurrences with surface temperatures of $20^{\circ} \mathrm{C}$ or higher $\ldots \ldots \ldots \ldots \ldots \ldots \ldots \ldots \ldots$

27. Index map of Blaine County showing locations of thermal water occurrences with surface temperatures of $20^{\circ} \mathrm{C}$ or higher $\ldots \ldots \ldots \ldots \ldots \ldots \ldots \ldots$

28. Topographic map of Hailey area showing location of Hailey Hot Springs with respect to the City of Hailey 
List of Figures (continued)

Figure

Page

29. EROS false color infrared Landsat EDISE image of south-central Idaho showing selected linear

features and thermal water locations with surface

temperatures above $20^{\circ} \mathrm{C} \ldots \ldots \ldots \ldots \ldots \ldots \ldots \ldots . \ldots 65$

30. Magnetic anomalies near Bald Mountain and NE of

Sun valley $\ldots \ldots \ldots \ldots \ldots \ldots \ldots \ldots \ldots \ldots \ldots \ldots \ldots, \ldots \ldots \ldots$

31. Idealized block diagram of Magic Reservoir Area in Camas and Blaine counties depicting theoretical

structural control for Magic Hot Springs well $\ldots \ldots 70$

32. Index map of Idaho showing the Snake River Plain

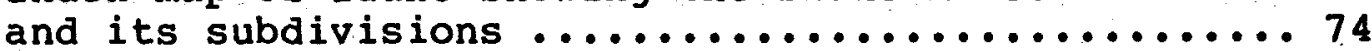

33. Index map of Washington county showing locations of thermal water occurrences with surface temperatures

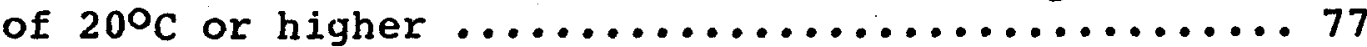

34. 27-Hz apparent resistivity map (telluric line north-south), Weiser, Idaho-Vale, Oregon ........ 79

35. Map of $27-\mathrm{Hz}$ apparent resistivity (telluric line east-west), Weiser, Idaho-Vale, Oregon .......... 79

36. Telluric anomaly map at 20 - to $30-\mathrm{sec}$ period, Vale,

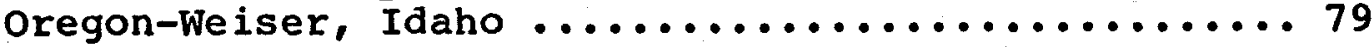

37. Index map of Payette and Gem counties showing locations of thermal water occurrences with surface temperatures of $20^{\circ} \mathrm{C}$ or higher $\ldots \ldots \ldots \ldots . .83$

38. Index map of Canyon and Ada counties showing locations of thermal water occurrences with surface temperatures of $20^{\circ} \mathrm{C}$ or higher $\ldots \ldots \ldots \ldots .85$

39. EROS false color infrared Landsat EDISE image of part of southwestern Idaho and southeastern Oregon showing selected linear features and thermal water locations with surface temperatures above $20^{\circ} \mathrm{C} \ldots \ldots \ldots \ldots \ldots \ldots \ldots \ldots \ldots \ldots$

40. Topographic map of west Boise Front area showing locations of potential geothermal sites ......... 89

41. Map of Boise Front area showing total conductance

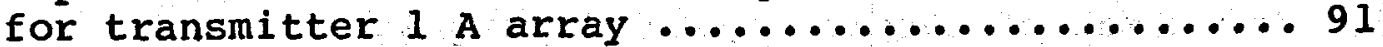

42. Map of Boise Front area showing total conductance for transmitter $2 A$ array $\ldots \ldots \ldots \ldots \ldots \ldots \ldots \ldots \ldots 92$ 


\section{List of Figures (continued)}

Figure

43. Map of Boise Front area showing total conductance for transmitter 1 B array $\ldots \ldots \ldots \ldots \ldots \ldots \ldots \ldots . \ldots 9$

44. Map of Boise Front area showing total conductance for transmitter 2 B array ................... 94

45. Index map of Gooding County showing locations of thermal water occurrences with surface temperatures of $20^{\circ} \mathrm{C}$ or higher $\ldots \ldots \ldots \ldots \ldots \ldots \ldots \ldots \ldots . . \ldots 6$

46. Index map of Jerome and southern Minidoka counties showing locations of thermal water occurrences with surface temperatures of $20^{\circ} \mathrm{C}$ or higher ....... 99

47. Index map of Owyhee County showing locations of thermal water occurrences with surface temperatures of $20^{\circ} \mathrm{C}$ or higher $\ldots \ldots \ldots \ldots \ldots \ldots \ldots \ldots 1$

48. Index map of Twin Falls County showing locations of thermal water occurrences with surface tempera-

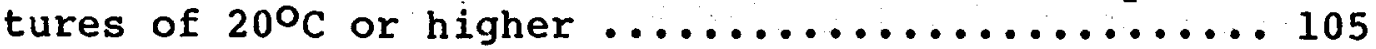

49. Gravity map showing lows near Buhl, east of Jerome and near oakley ...................... 107

50. Aeromagnetic map showing low west of Jerome $\ldots \ldots \ldots 108$

51. Index map of Fremont County showing the locations of thermal water occurrences with surface temperatures of $20^{\circ} \mathrm{C}$ or higher $\ldots \ldots \ldots \ldots \ldots \ldots \ldots \ldots \ldots \ldots \ldots 110$

52. Map of rock types and $26 \mathrm{~Hz}$ apparent-resistivity (telluric line north-south), Island Park, Idaho ... Ill

53. Comparison of skin-depth pseudosections and onedimension inverted section with gravity and magnetic data across the Island Park area ........111

54. Telluric anomaly map at 20- and 30-sec period, Island Park, Idaho .......................... 111

55. Index map of Butte County showing locations of thermal occurrences with surface temperatures of

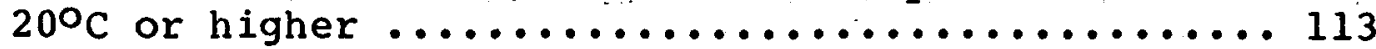

56. Index map of Cassia County showing locations of thermal water occurrences with surface temperatures of $20^{\circ} \mathrm{C}$ or higher 


\section{List of Figures (continued)}

Figure

Page

57. Gravity profile near Oakley ............... 116

58. Interpreted section across the west side of the southern Raft River Valley .................. 124

59. Map of the Raft River Valley region, Utah and Idaho, showing major topographic features and

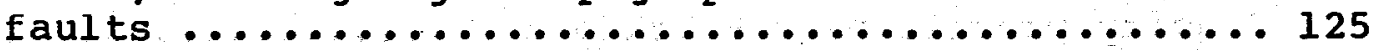

60. Complete Bouguer gravity anomaly map of the southern Raft River valley .................. 126

61. Index map of Oneida County showing locations of thermal water occurrences with surface temperatures of $20^{\circ} \mathrm{C}$ or higher ................... 128

62. Index map of Franklin and Bear Lake counties showing locations of thermal water occurrences with surface temperatures of $20^{\circ} \mathrm{C}$ or higher ...... 130

63. EROS false color infrared Landsat EDISE image of part of southeastern Idaho and northern Utah showing selected linear features and thermal water locations with surface temperatures above $20^{\circ} \mathrm{C} \ldots \ldots 133$

64. Gravity lows from Gem Valley, near Preston in Cache Valley, and near Bear Lake ............. 136

65. Gravity profile near Bear Lake ............. 137

66. Index map of Caribou County showing locations of thermal water occurrences with surface temperatures of $20^{\circ} \mathrm{C}$ or higher ................... 138

67. EROS false color infrared Landsat EDISE image of part of southeastern Idaho showing selected linear features and thermal water locations with surface temperatures above $20^{\circ} \mathrm{C} \ldots \ldots \ldots \ldots \ldots \ldots \ldots \ldots \ldots 141$

68. Index map of Bannock County showing locations of thermal water occurrences with surface tempera-

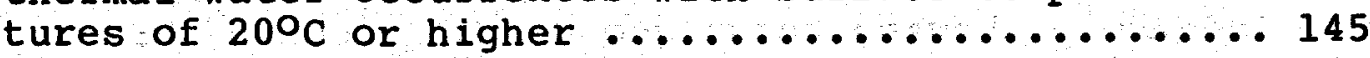

69. Index map of Power County showing locations of thermal water occurrences with surface temperatures of $20^{\circ} \mathrm{C}$ or $\mathrm{higher} \ldots \ldots \ldots \ldots \ldots \ldots \ldots \ldots \ldots . \ldots \ldots$

70. Travertine deposits and associated known thermal springs in southeastern Idaho ............... 150 


\section{List of Figures (continued)}

Figure

71. Index map of Bingham County showing locations of thermal water occurrences with surface tempera-

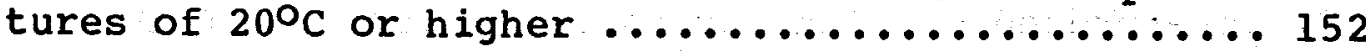

72. Gravity lows south of Blackfoot and Swan

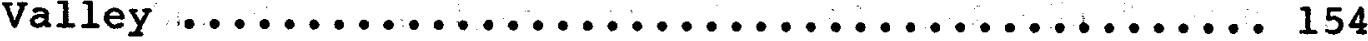

73. Gravity profile near Blackfoot .............. 155

74. Index map of Bonneville County showing locations of thermal water occurrences with surface temperatures of $20^{\circ} \mathrm{C}$ or higher ............... 156

75. Index map of Madison and Jefferson counties showing locations of thermal water occurrences with surface temperatures of $20^{\circ} \mathrm{C}$ or higher ...... 158

76. Bouguer gravity anomaly map of southeastern Idaho showing the location of the Rexburg caldera complex ................................ 159

77. Bouguer gravity anomaly map of the Rexburg area showing the outline of the Rexburg caldera complex as inferred from the gravity data ....... 161

78. Residual aeromagnetic map of the area of Heise Hot Springs showing the location of the gravity high at Heise Hot Springs and a gravity low to

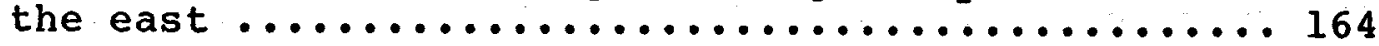

79. Magnetic and gravity profiles and interpreted section across the anomalies at Heise Hot Springs . 166

80. Index map of clark County showing locations of thermal water occurrences with surface temperatures of $20^{\circ} \mathrm{C}$ or $\mathrm{higher} \ldots \ldots \ldots \ldots \ldots \ldots \ldots \ldots \ldots . \ldots . \ldots 168$

81. Index map of Teton County showing locations of thermal water occurrences with surface temperatures of $20^{\circ} \mathrm{C}$ or higher ....................... 170

82. Index map showing known geothermal resource areas (KGRAs) and federal and state leased lands in Idaho 
ACK NOWL EDGMENTS

Many people have contributed to this study in the hope that the information will be of benefit to the people of the state of Idaho.

The United States Department of Energy (DOE) granted financial support, while the U.S. Geological Survey (USGS) made available personnel and laboratory facilities for water quality analyses. EG\&G Idaho, Inc., a prime contractor of DOE, made available laboratory facilities, personnel, and equipment for neutron-activation analyses of trace metals from thermal water samples at the Idaho National Engineering Laboratory.

Field checking of many springs and well locations was accomplished by Andres Garcia, George Denman, Mark Von Lindern and Larry Beard of the Idaho Department of Water Resources (IDWR). Compilation of the computerized data on thermal springs and wells for the two maps was the responsibility of Sharron Chapman, IDWR. Other IDWR personnel, especially Ralph Mellin, provided review assistance and many details for the report.

National Oceanic and Atmospheric Administration (NOAA) published the map Geothermal Resources of Idaho (Plate 1 in pocket) using information on thermal springs and wells supplied by IDWR, the USGS Geotherm data bank, and many other sources.

All of these cooperative efforts are gratefully acknowledged and appreciated; without such generous support, this study could not have been accomplished. 
PREFACE

Geothermal energy (the natural heat energy of the earth) is receiving nationwide attention. Increasing involvement of many parties in the exploration for and development of this energy source has been accelerated by four factors:

1. Ecologically, geothermal energy appears to be a better alternative than other methods of power generation such as nuclear, fossil fuel or hydroelectric.

2. Economically, it competes favorably with hydroelectric and fossil fuel power generation and may be less expensive than nuclear methods.

3. Enormous reserves of geothermal resources have been identified and can be developed if the effort is made to utilize them.

4. Efficient use of all energy sources is recognized as necessary if present energy shortages are to be alleviated and future shortages avoided.

Published information on the geothermal potential in Idaho consists mostly of numerous reports that briefly describe or mention thermal water occurrences in particular areas or regions of the state. Seven published reports (Stearns and others, 1937; Waring, 1956; Ross, 1971; Nichols and others, 1972; Warner, 1972 and 1975; Young and Mitchell, 1973) have been written on Idaho's geothermal potential on a statewide basis. Three of the reports are mainly compilations of pre-existing data collected by various investigators over an extended time interval of approximately 50 to 60 years. Waring $(1965$, p. 26-31) essentially updates the data of stearns and others (1973, p. 136-151). Godwin and others (1971) classified approximately 6,075,000 hectares (15 million acres) of land in Idaho as being prospectively valuable for geothermal exploration. Ross (1971) published geologic and chemical information on about 380 thermal water occurrences, and presented brief evaluations of the geothermal potential of different regions of the state. Nichols and others (1972) identified nonpower uses and the economic impact of these uses on Idaho. Warner (1972 and 1975) dealt with Idaho's geothermal potential based on its regional geologic setting. Other reports deal with localized areas. Young and Whitehead (1975a, 1975b) wrote on the geothermal potential of the Bruneau-Grand View and Weiser areas. Mitchell (1976a, 1976b, 1976c) published information on the northern Cache Valley, Blackfoot, and Camas Prairie areas. 
Wilson and others (1976) reported on geothermal investigations of the Cascade, Idaho, area. Mink and Graham (1977) reported on the geothermal potential of the west Boise area. In addition to the above published reports, there are seven unpublished open-file reports prepared by the U.S. Geological Survey (USFS) that are listed in the selected references. These are available for public review.

In Idaho, the prospects for early development of geothermal energy as an energy source appear excellent. The regional geologic setting appears favorable for the existence of large geothermal fields, although little is known of the full potential of this resource. A great deal more must be learned of geothermal occurrence and utilization. The Idaho Department of Water Resources (IDWR) initiated a study of geothermal potential to generate interest in development of the resources and to properly perform the department's regulatory function (Water Information Bulletin No. 30. Part 1, Young and Mitchell, 1973). The study, prepared jointly with the USGS, located 25 areas in Idaho where indications of potential power development utilizing geothermal energy were found. Parts 2,3 , and 4 of Water Information Bulletin No. 30, prepared by the USGS, studied areas in southwest Idaho. Parts 5, 6, and 7, prepared by the IDWR, studied areas in south-central and southeastern Idaho. Part 8 , prepared jointly by the IDWR and the Southern Methodist University, describes the heat flow regime in and around the Snake River Plain.

There are four objectives common to each of the studies: (1) to encourage the development of the resource through public knowledge of its occurrence, characteristics, origin, and properties; (2) to develop the expertise within the IDWR to properly perform its function of regulation of the resource; (3) to protect the ground and surface waters of the state from deleterious effects that might be brought about by large-scale geothermal development efforts by public or private parties: (4) to protect the geothermal resource from waste and mismanagement because of lack of knowledge of its occurrence, characteristics, and properties.

This study (Part 9 of water Information Bulletin No. 30), prepared by IDWR, summarizes a part of the effort to obtain additional data on the properties, origin, occurrence, and characteristics of this resource in Idaho. It contains information on 899 thermal water occurrences with surface temperatures of $20^{\circ} \mathrm{C}$ or higher from both springs and wells. Chemical analyses of 357 of the 899 total thermal water sites are also contained herein, as well as previously published and unpublished geophysical, geological and hydrological information. 
Thirty-six of the 44 counties in Idaho are discussed in separate chapters of this report. The eight counties not discussed in the report contain no known geothermal water discharges and little is known of their geothermal potential. Six of the eight counties not discussed are in northern Idaho: Bonner, Boundary, Kootenai, Benewah, Clearwater and Lewis counties. The other two (Lincoln and Minidoka counties) are within the eastern Snake River Plain aquifer, which may mask deep thermal anomalies in these counties. 


\section{ABSTRACT}

There are 899 thermal water occurrences known in Idaho, including 258 springs and 641 wells having temperatures ranging from 20 to $93^{\circ} \mathrm{C}$. Fifty-one cities or towns in Idaho containing 30 percent of the state's population are within 5 $\mathrm{km}$ of known geothermal springs or wells. These include several of Idaho's major cities such as Lewiston, Caldwell, Nampa, Boise, Twin Falls, Poctello, and Idaho Falls.

Fourteen sites appear to have subsurface temperatures of $140^{\circ} \mathrm{C}$ or higher according to the several chemical geothermometers applied to thermal water discharges. These include Weiser, Big Creek, White Licks, Vulcan, Roystone, Bonneville, Crane Creek, Cove Creek, Indian Creek, and Deer Creek hot springs, and the Raft River, Preston, and Magic Reservoir areas. These sites could be industrial sites, but several are in remote areas away from major transportation and, therefore, would probably be best utilized for electrical power generation using the binary cycle or Magma Max process.

Present uses range from space heating to power generation. Six areas are known where commercial greenhouse operations are conducted for growing cut and potted flowers and vegetables. Space heating is substantial in only two places (Boise and Ketchum) although numerous individuals scattered throughout the state make use of thermal water for space heating and private swimming facilities. There are 22 operating resorts using thermal water and two commercial warm-water fish-rearing operations.

The geothermal potential in Idaho's future can be most beneficial,.. providing the resource is utilized in an environmental and economical manner. While some thermal waters are being used to their maximum, most heat is dissipated through irrigation practices or is discharged unused.

It appears that the greatest potential for rapid on-line industrial process heat is in the Boise, Nampa-Caldwell, Pocatello, and Weiser areas where geothermal discharges from several wells are known. Existing industry in these areas could possibly be induced to retrofit to geothermal process or space heat if sufficient temperatures and flow rates can be found. 
GENERAL INTRODUCTION

\section{PURPOSE AND SCOPE}

This report was prepared in response to the many requests from Idaho's citizens and industries for authoritative information pertaining to the state's geothermal resources. The report primarily outlines the characteristics, occurrences, and uses (present and potential) of low temperature $\left(\left\langle 150^{\circ} \mathrm{C}\right)\right.$ thermal waters, with minor emphasis on high temperature $\left(>150^{\circ} \mathrm{C}\right)$ waters. The information presented in this report is designed to expand the IDWR data bank, enabling the IDWR to better serve the public and private sector while enhancing the department's regulatory responsiveness. In addition, computerized well and spring data were supplied to the National Oceanic and Atmospheric Administration for the development of the first state geothermal map (Plate 1 in pocket) and to the U.S. Geological Survey for supplementing the geotherm data bank.

The general objectives of the study and report are as follows: (1) describe, in a single reference, the thermal. water chemistry and quality from existing and newly acquired data on thermal springs and wells; (2) evaluate the statewide geothermal potential from the standpoint of direct heat application; (3) pinpoint specific areas and general uses for direct heat application; (4) provide basic data on low temperature resources for potential uses; (5) give recommendations about areas of the state that could receive large benefits from detailed study.

Most locations were field checked to confirm the reported thermal discharge. Several occurrences reported in other publications were looked for but not found. These are not included in this report. Others in remote areas were not field checked but are included and labeled "not field checked" in the basic data tables in the appendix.

\section{WELL- AND SPRING-NUMBERING SYSTEM}

The numbering system used by the IDWR and the USGS in Idaho indicates the location of wells or springs within the official rectangular subdivision of the public lands, with reference to the Boise base line and meridian. The first two segments of the number designate the township and range. The third segment gives the section number, followed by three letters and a numeral, which indicate the quarter section, the 40-acre tract, the 10-acre tract, and the serial number of the well within the tract, respectively. Quarter sections are lettered $a, b, c$, and $d$ in a counter- 
clockwise order from the northeast quarter of each section (figure 1). Within the quarter sections, 40-acre and 10-acre tracts are lettered in the same manner. Well 1S-17E-23aabl is in the NWl/4 NEl/4 NEl/4 of Section 23, T.1 S, R.17 E, and was the first well inventoried in that tract. Springs are designated by the letter "S" following the last numeral; for example, 1S-13E-34bcbls.

USE OF METRIC UNITS

The metric or International System (SI) of units are used in this report to present water chemistry and most other data. Concentrations of chemical substances dissolved in the water are given in milligrams per liter (mg/l) rather than in parts per million (ppm) as in some previous water Information Bulletins. Numerical values for chemical concentrations are essentially equal, whether reported in $\mathrm{mg} / \mathrm{l}$ or ppm for the range of values reported in this report. Water temperatures are given in degrees Celsius ( $\left.{ }^{\circ} \mathrm{C}\right)$. Figure 2 shows the relation between degrees Celsius and degrees Fahrenheit.

Linear measurements (inches, feet, miles) are given in their corresponding metric units (millimeters, meters, kilometers). Weight and volume measurements are also given in their corresponding metric units. Area measurements are also 1 isted in SI units. Table 1 gives conversion factors for these units.

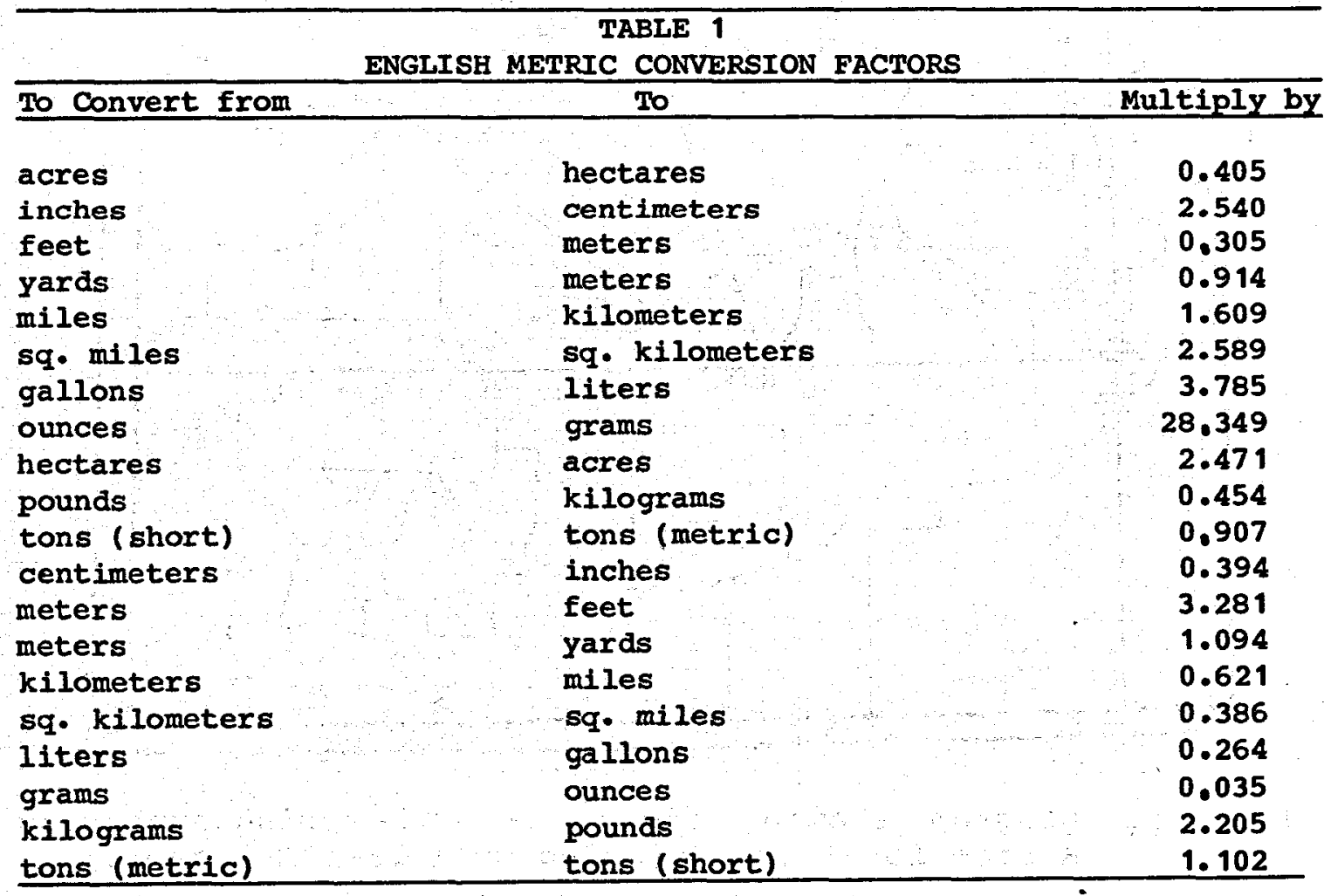




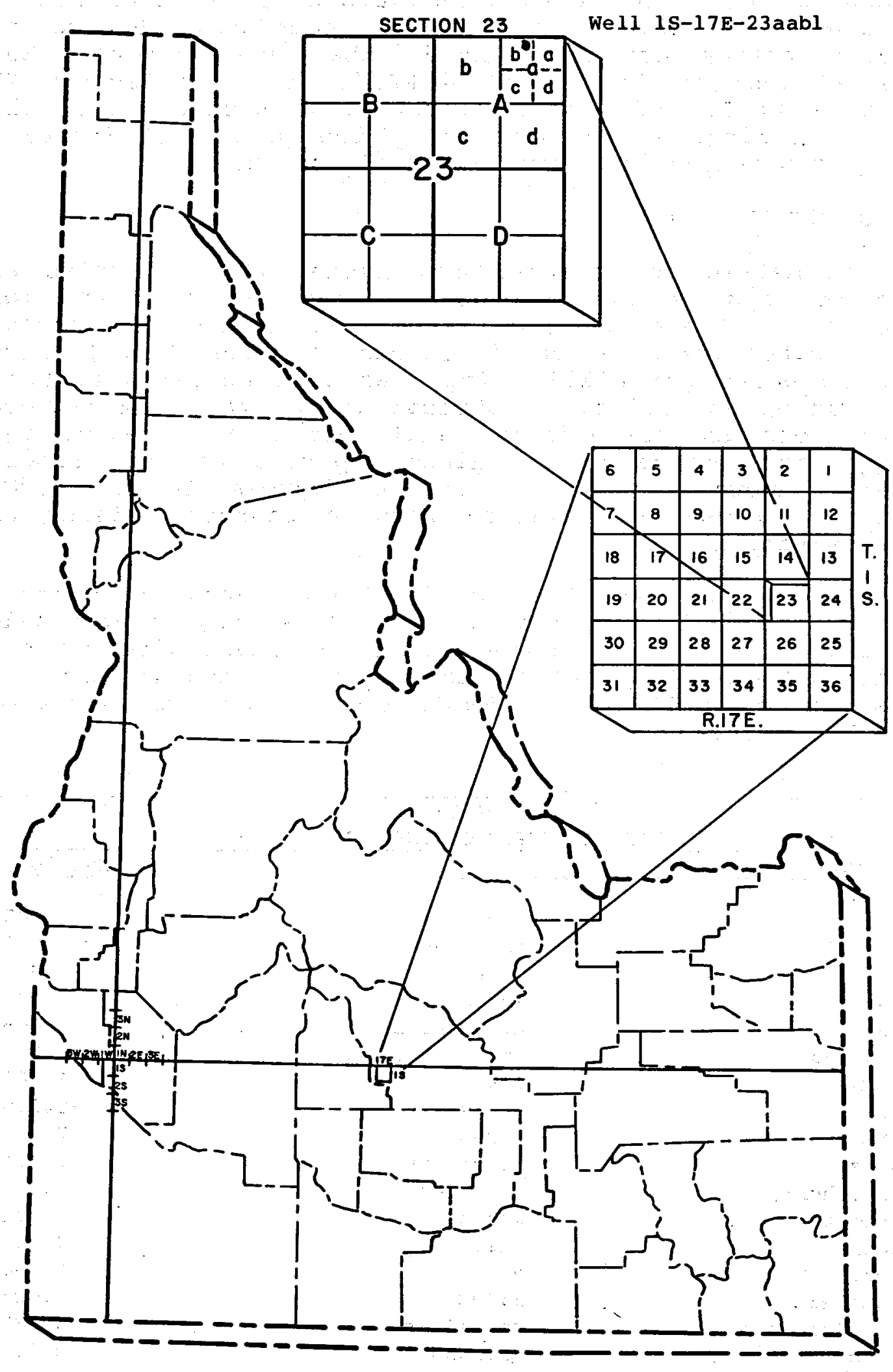

FIGURE 1. Diagram showing the well- and spring-numbering system for Idaho. (Using well 1s-17E-23aabl.). 


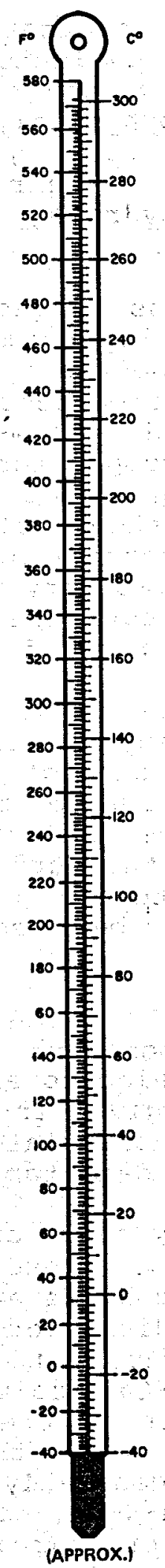

FIGURE 2. Temperature conversion graph. 


\section{CHEMICAL GEOTHERMOMETERS}

In this report, the geothermal potential of various areas in Idaho has been evaluated from five factors, including several chemical geothermometers, water temperature at surface, geology, geophysical, and hydrology. As the chemical geothermometers are original interpretations, they are discussed to clarify their meaning. Much of the geology, geophysics and hydrology is from published reports and is not discussed here.

Preliminary evaluations of geothermal systems are being successfully conducted using chemical geothermometers. In the Raft River Valley of southeastern Idaho, the reliability of these chemical geothermometers has been tested by deep drilling. The quartz and sodium-potassium-calcium (Na-KCa) estimated aquifer temperatures (Young and Mitchell, 1973) and silica mixing model calculations (Young and Mitchell, 1973, unpublished data) agreed very closely (within $10^{\circ} \mathrm{C}$ ) with temperatures found in depth (Kunze, 1975). This proven reliability in the Raft River Valley gives some measure of confidence in applying the same methods to other similar areas of the state.

The degree of reliance to be placed on a chemical geothermometer depends on many factors. The basic assumption is that the chemical character of the water obtained by temperature dependent equilibrium reactions in the thermal aquifer is conserved from the time the water leaves the aquifer until it reaches the surface. The concentration of certain chemical constituents dissolved in the thermal waters can, therefore, be used to estimate aquifer temperatures.

Aquifer temperatures, calculated from the quartz, $\mathrm{Na}-\mathrm{K}-\mathrm{Ca}$ chemical geothermometers and mixing models as well as the atomic ratios of selected elements found in the thermal waters of Idaho, are given in basic data table 2 in the appendix. These were calculated from values of concentration found in basic data table 1 .

In basic data table 2 , there are 10 columns which represent aquifer temperatures. These 10 columns of basic data table 2 were derived using different assumptions as to physical controls governing dissolved chemical constituents in thermal water. In most cases, it appears that the chalcedony (column $\mathrm{T}_{4}$ ) or $\mathrm{Na}-\mathrm{K}-\mathrm{Ca}$ (column $\mathrm{T}_{5}$ ) chemical geothermometers may be the most accurate for thermal water in Idaho. However, in many cases these differ by as much as $20-30^{\circ} \mathrm{C}$. Chalcedony generally estimates temperatures somewhat higher than $\mathrm{Na}-\mathrm{K}-\mathrm{Ca}$, particularly for high $\mathrm{pH}$ waters issuing from granitic terrains. It is not presently known which is closest to the actual aquifer temperature. 
However, as drilling has confirmed the reliability of $\mathrm{Na}-\mathrm{K}-\mathrm{Ca}$ in Raft River Valley in Cassia County and for other reasons, the authors have more confidence stating that $\mathrm{Na}-\mathrm{K}-\mathrm{Ca}$ may be the more accurate. In any case, best correlation is obtained generally between $\mathrm{Na}-\mathrm{K}-\mathrm{Ca}$ and chalcedony chemical geothermometers. In several areas where high water temperatures at the surface $\left(>65^{\circ} \mathrm{C}\right)$ have been measured, good agreement between quartz and $\mathrm{Na}-\mathrm{K}-\mathrm{Ca}$ chemical geothermometers indicates temperatures may be high enough for wet steam or binary cycle power generation.

PRESENT AND POTENTIAL GEOTHERMAL USE IN IDAHO

Geothermal energy has been used in Idaho for a long time. Figure 3 is a map of Idaho showing locations and current uses of geothermal energy in the state. Uses have been made ranging from electrical generation using pelton wheels to catfish farming. Present uses of geothermal energy are tabulated in table 2 (modified from Nichols, et. al., 1.972).

Geothermal energy has been used for space heating in Boise since 1893 and in Ketchum. Currently several greenhouse operations are conducted near Boise for fresh and cut flowers. Other greenhouse operations using geothermal energy are located at Weiser, Grand View, White Arrow Ranch near Bliss, Banbury Hot Springs area in the Hagerman Valley, and on the South Fork Payette River and at Raft River.

Irrigation has been a long-standing use of thermal water in Idaho, although most irrigators consider hot water a nuisance as it must be cooled before being applied to crops. Some report heavier first and last cuttings of alfalfa as the growing seasons may be somewhat extended; however, the effect of the heat may be quite minor as opposed to the effect of the water from an extra early and a late season irrigation.

stock watering in winter is another beneficial use which creates increases in weight gain on less feed with geothermally watered 1 ivestock compared to cold watered livestock.

The Department of Energy's Idaho Raft River Project is designed to gather information on various uses and applications of geothermal energy, including binary cycle power generation, reinjection of geothermal fluids, space heating, and cooling, potato processing, manure and cattle feed processing, irrigation, and aquaculture. In addition, environmental related studies of subsidence, microseismicity, flora and fauna, water quality, and groundwater levels are being made.

Many resorts using thermal water are operated in Idaho. These are listed in table 2 and locations shown in figure 3 . 


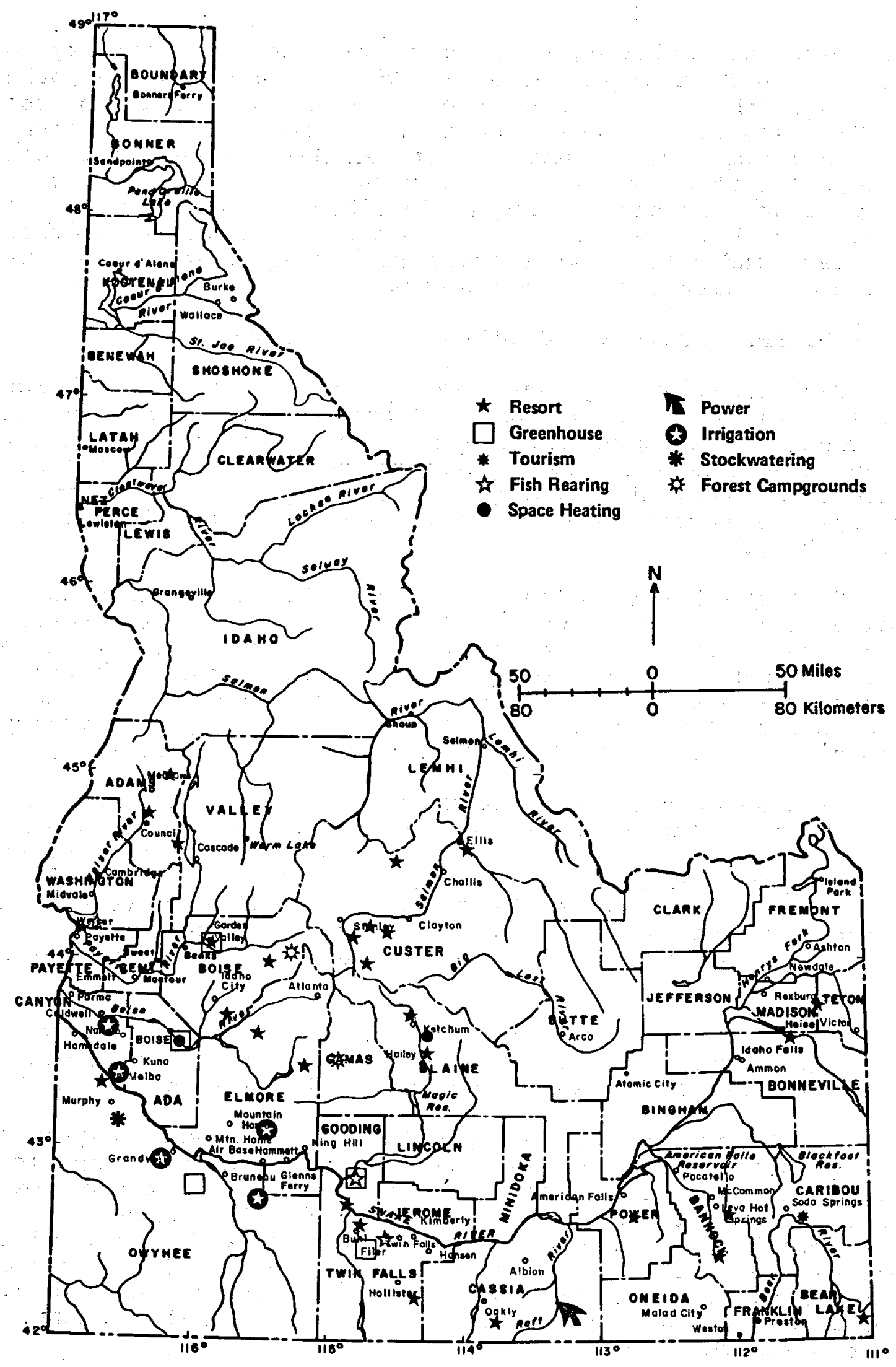

FIGURE 3. Index map of Idaho showing locations and present uses of geothermal energy. 


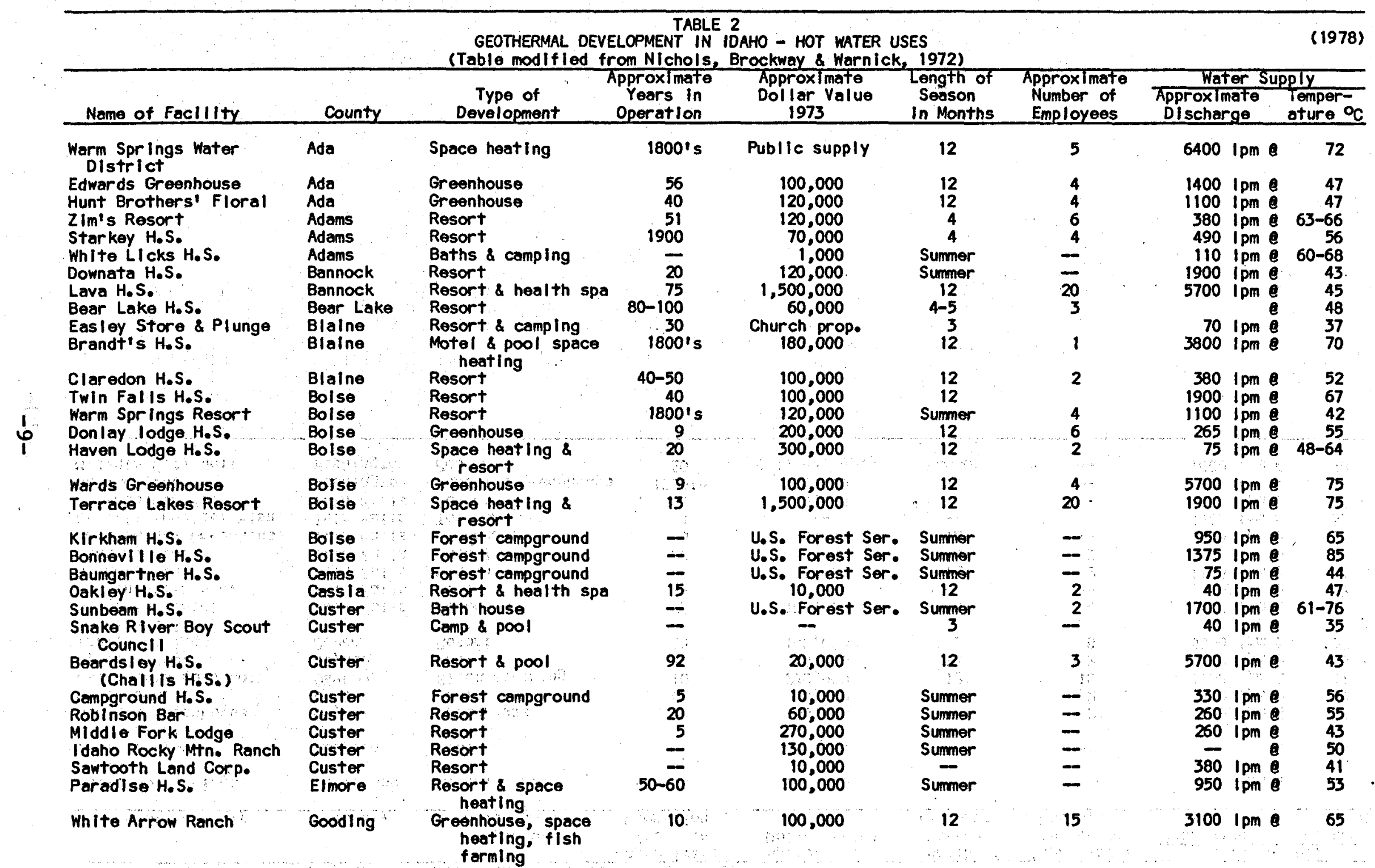


Table 2. Geothermal Development in Idaho - Hot Water Uses (cont inued)

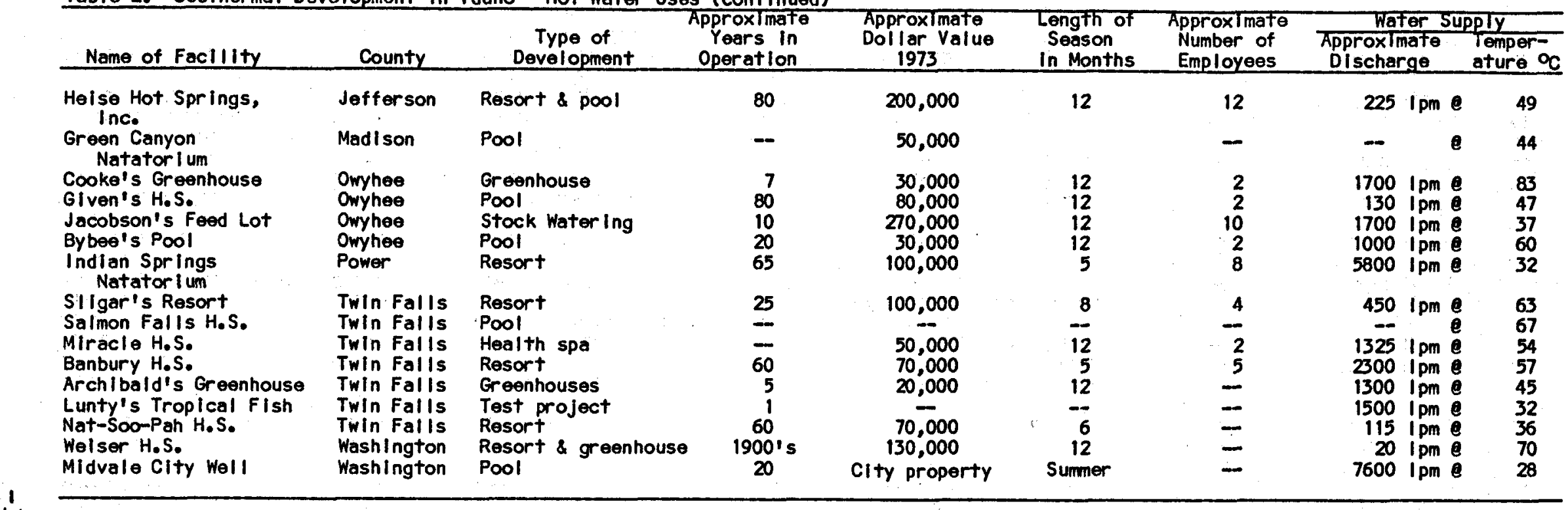


The most famous is probably Lava Hot Springs, a state-owned natatorium and health spa.

Potential uses for geothermal energy in Idaho are many and varied. Figure 4 shows minimum temperatures necessary for agricultural and industrial uses in which geothermal energy has been used or proposed. Many of these uses are related to agriculture, forest products, or tourism--three of Idaho's principal industries. The greatest potential, as far as present knowledge of the resource in Idaho is concerned, is for space heating and greenhouse use. In rapidly growing areas, such as Nampa, Caldwell, Boise, Pocatello, and Twin Falls, thermal water of sufficient quantity might be discovered and used for space heating large buildings and new subdivisions. Groundwater heat pumps generally would give a large energy savings over present heat sources if the water temperature was less than desirable for direct space heating use. Groundwater heat pumps used both for heating and cooling also have a large potential even in areas that have a normal cool groundwater temperature.

The area of greatest potential for greenhouse operation is the Bruneau-Grand View area where high yield irrigation wells tap thermal aquifers where water temperature ranges from $20-84^{\circ} \mathrm{C}$. The area is far from markets and major transportation routes but so is most other farmland in Idaho. Winter crops could conceivably be grown in this area for use in Idaho rather than shipping crops in from states with more favorable climates.

Table 3 and Eigure 5 show 14 areas in Idaho where potential exists for power generation where subsurface temperatures might be greater than $1400^{\circ} \mathrm{C}$, based on the $\mathrm{Na}-\mathrm{K}-\mathrm{Ca}$ and quartz chemical geothermometers. The Blackfoot Reservoir area was chosen on the basis of geology. The $1400^{\circ} \mathrm{C}$ temperature was chosen as the lower limit as it appears that technology and rapidly escalating energy costs may make this limit economically attractive in the foreseeable future. Five locations appear to have aquifer temperatures high enough for wet steam generation. The highest estimated aquifer temperature expected from any of the 141 isted areas appears to be $175^{\circ} \mathrm{C}$ at $\mathrm{Big}$ Creek and Crane Creek hot springs areas in Lemhi and Washington counties. The upper limit given for Battle Creek-Squaw Hot Springs area in Franklin County may or may not be valid, because of uncertainties in interpretation due to travertine $\left(\mathrm{CaCO}_{3}\right)$ deposition at some spring vents. The crane and cove creeks to Weiser area have received initial evaluation by the USGS. Blackfoot Reservoir area and Battle Creek-Squaw hot springs areas have received initial evaluation by IDWR. The other areas need initial assessment work to more accurately determine their thermal potential. Many of these areas are remote and in rugged terrain. Assessment will, therefore, be somewhat 


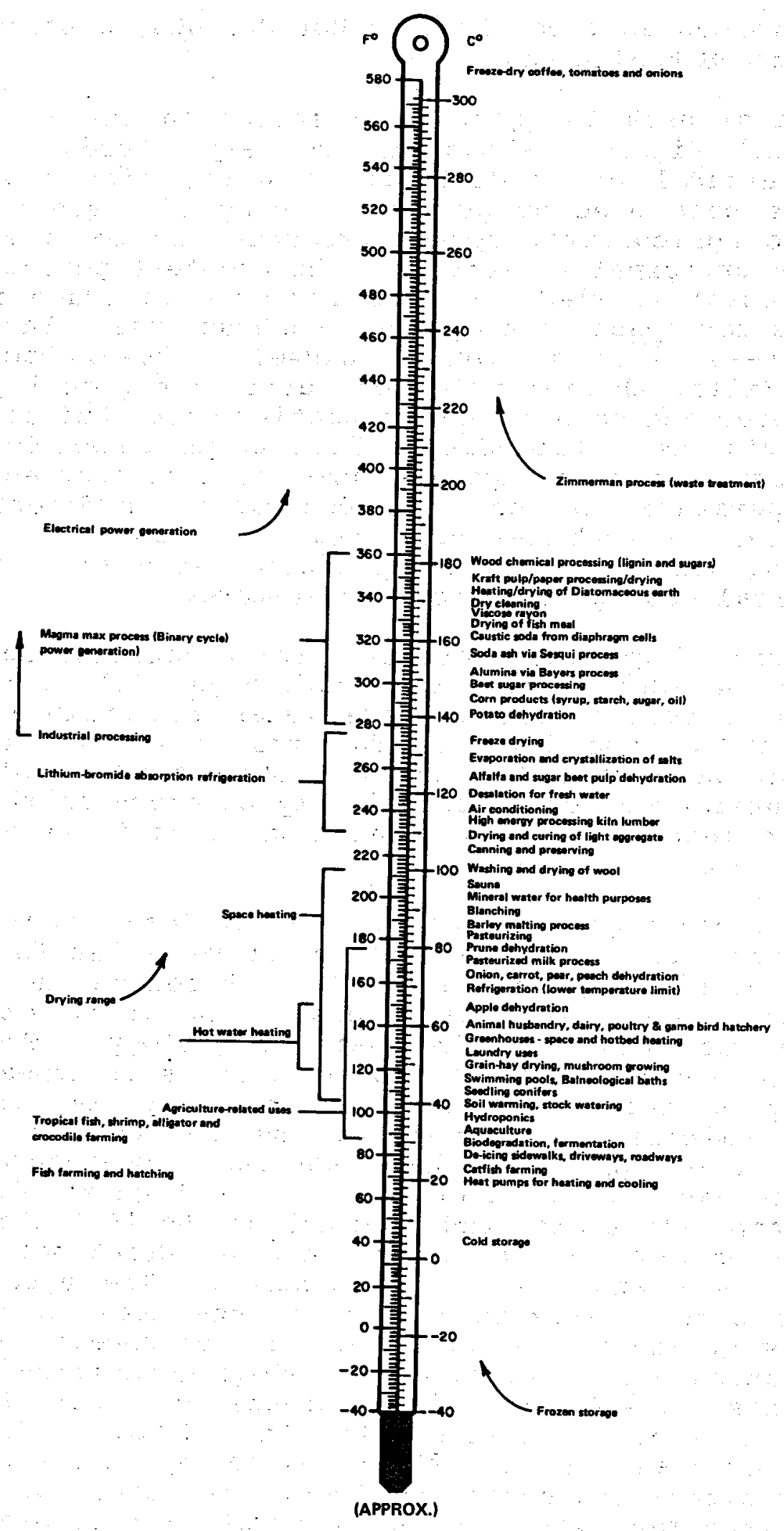

FIGURE 4. Required temperatures for geothermal fluids. 
TABLE 3

AREAS IN IDAHO MOST FAVORABLE FOR POWER GENERATION BASED ON SURFACE MANIFESTATIONS, GEOLOGY AND GEOTHERMOMETERY

\begin{tabular}{|c|c|c|c|c|c|c|c|c|c|}
\hline Area & Location & $\begin{array}{r}\text { Mea } \\
\text { Su } \\
\text { Tem } \\
\text { tur } \\
\end{array}$ & $\begin{array}{l}\text { Ired } \\
\text { ace } \\
\text { ram } \\
\text { oc }\end{array}$ & $\begin{array}{l}\text { *Best E } \\
\text { Subsur. } \\
\text { Na-K-Ca }\end{array}$ & $\begin{array}{l}\text { Estimate } \\
\text { Temp. }{ }^{\circ} \\
\text { Quartz }\end{array}$ & $\begin{array}{l}\text { Princl- } \\
\text { pal } \\
\text { Land } \\
\text { Owner }\end{array}$ & $\begin{array}{c}\text { Type of } \\
\text { Genera- } \\
\text { tion } \\
\end{array}$ & $\begin{array}{l}\text { Area } \\
\text { Number } \\
\text { Flgure }\end{array}$ & Remarks \\
\hline Battle Creok-Squaw H.S. & $\begin{array}{l}15 S-39 E-8 b d c 1 s \& \\
15 S-39 E-17 \text { bcdis }\end{array}$ & Frankl in & 84 & 250 & 150 & Private & Wet steam & 1 & $\begin{array}{l}\text { Could be mixed water - } \\
\text { geothermometers dif- } \\
\text { flcult to interpret. }\end{array}$ \\
\hline Blg Creek H.S. & $23 N-19 E-22 c 1 S$ & LemhI & 93 & 175 & 175 & USFS & $\begin{array}{c}\text { Wet steam } \\
\vdots \\
0\end{array}$ & 2 & $\begin{array}{l}\text { Ridge top discharge, } \\
\text { slilica \& carbonate } \\
\text { depositlon, bolling } \\
\text { at surface. }\end{array}$ \\
\hline Blackfoot Reservolr & $6 S-41 E-19$ bacl & Car Ibou & 42 & $?$ & $?$ & $\begin{array}{l}\text { Private, } \\
\text { BLM, BIA }\end{array}$ & $?$ & 3 & $\begin{array}{l}\text { Picked on basis of } \\
\text { favorable geology } \\
\text { \& geophyslcs. }\end{array}$ \\
\hline Bonnevilile H.S. & $10 \mathrm{~N}-10 \mathrm{E}-31 \mathrm{cls}$ & Bolse & 85 & 142 & 137 & USFS & Blnary cycle & 4 & $\begin{array}{l}\text { Used for a stean } \\
\text { bath and bathing by } \\
\text { campers. }\end{array}$ \\
\hline Crane Crook. H.S. & $11 N-3 W-7 b d b 1 S$ & Washington & 92 & 166 & 176 & Private & Wet steam & 5 & $\begin{array}{l}\text { Near boliling at the } \\
\text { surface. }\end{array}$ \\
\hline Cove Creek H.S. & $10 N-3 W-9 \operatorname{ccc} 1 S$ & Washington & 74 & 172 & 152 & Private & Wet steam & 6 & $\begin{array}{l}11 \mathrm{~km} \text { southeast of } \\
\text { Crane Creek H.S. }\end{array}$ \\
\hline Deer $H_{0} S_{0}$ & $9 N-3 E-25$ bacis & Bolse & 80 & 139 & 147 & Private & Binary cycle & 7 & $\begin{array}{l}\text { Sillceous sinter } \\
\text { deposits. }\end{array}$ \\
\hline $\begin{array}{l}\text { Indlan Creek HiS. } \\
\text { Maglc Reservolr }\end{array}$ & $\begin{array}{l}17 N-11 E-15 a c d 1 S \\
1 S-17 E-23 a a b 1\end{array}$ & $\begin{array}{l}\text { Valley } \\
\text { Blaine-Camas }\end{array}$ & $\begin{array}{l}88 \\
72\end{array}$ & $\begin{array}{l}137 \\
174\end{array}$ & $\begin{array}{l}142 \\
139\end{array}$ & $\begin{array}{l}\text { USFS } \\
\text { Private }\end{array}$ & $\begin{array}{l}\text { Binary cycle } \\
\text { Wet steam }\end{array}$ & $\begin{array}{l}8 \\
9\end{array}$ & $\begin{array}{l}\text { In wilderness area. } \\
\text { Chemistry of waters } \\
\text { somewhat similar to } \\
\text { Raft River. }\end{array}$ \\
\hline Raft RIver & $15 S-26 \mathrm{E}-23 \mathrm{bbcl}$ & Cassla & 92 & 147 & 135 & BLM & Binary cycle & 10 & $\begin{array}{l}\text { Plant under construc- } \\
\text { tlon. Geothermometers } \\
\text { confirmed by drilling } \\
\text { Na-K-Ca most accurate. }\end{array}$ \\
\hline $\begin{array}{l}\text { Roystone } \mathrm{H}_{0} \mathrm{~S} . \\
\text { Vulcan } \mathrm{H}_{0} \mathrm{~S} \text {. }\end{array}$ & $\begin{array}{l}7 N-1 E-8 d d a 15 \\
14 N-6 E-11 \text { bdals }\end{array}$ & $\begin{array}{l}\text { Gem } \\
\text { Valley }\end{array}$ & $\begin{array}{l}54 \\
84\end{array}$ & $\begin{array}{l}150 \\
147\end{array}$ & $\begin{array}{l}147 \\
135\end{array}$ & $\begin{array}{l}\text { Private } \\
\text { USFS } \\
\text { PrIvate }\end{array}$ & $\begin{array}{l}\text { Binary cycle } \\
\text { Binary cycle }\end{array}$ & $\begin{array}{l}11 \\
12\end{array}$ & Presently a natatorium. \\
\hline $\begin{array}{l}\text { White Licks H.S. } \\
\text { Weiser H.S. }\end{array}$ & $\begin{array}{l}16 N-2 E-33 b c c 1 S \\
11 N-6 H-10 c c a l\end{array}$ & $\begin{array}{l}\text { Adams } \\
\text { Washington }\end{array}$ & $\begin{array}{l}65 \\
78\end{array}$ & $\begin{array}{l}145 \\
141\end{array}$ & $\begin{array}{l}145 \\
156\end{array}$ & $\begin{array}{l}\text { USFS } \\
\text { Private } \\
\text { Private }\end{array}$ & $\begin{array}{l}\text { Binary cycle } \\
\text { Binary cycle }\end{array}$ & $\begin{array}{l}13 \\
14\end{array}$ & $\begin{array}{l}\text { Bath houses for } \\
\text { campers. } \\
\text { Presently a natator l ump } \\
\text { with greenhouse opera- } \\
\text { tion. }\end{array}$ \\
\hline
\end{tabular}

*See first footnote in Table 4. 


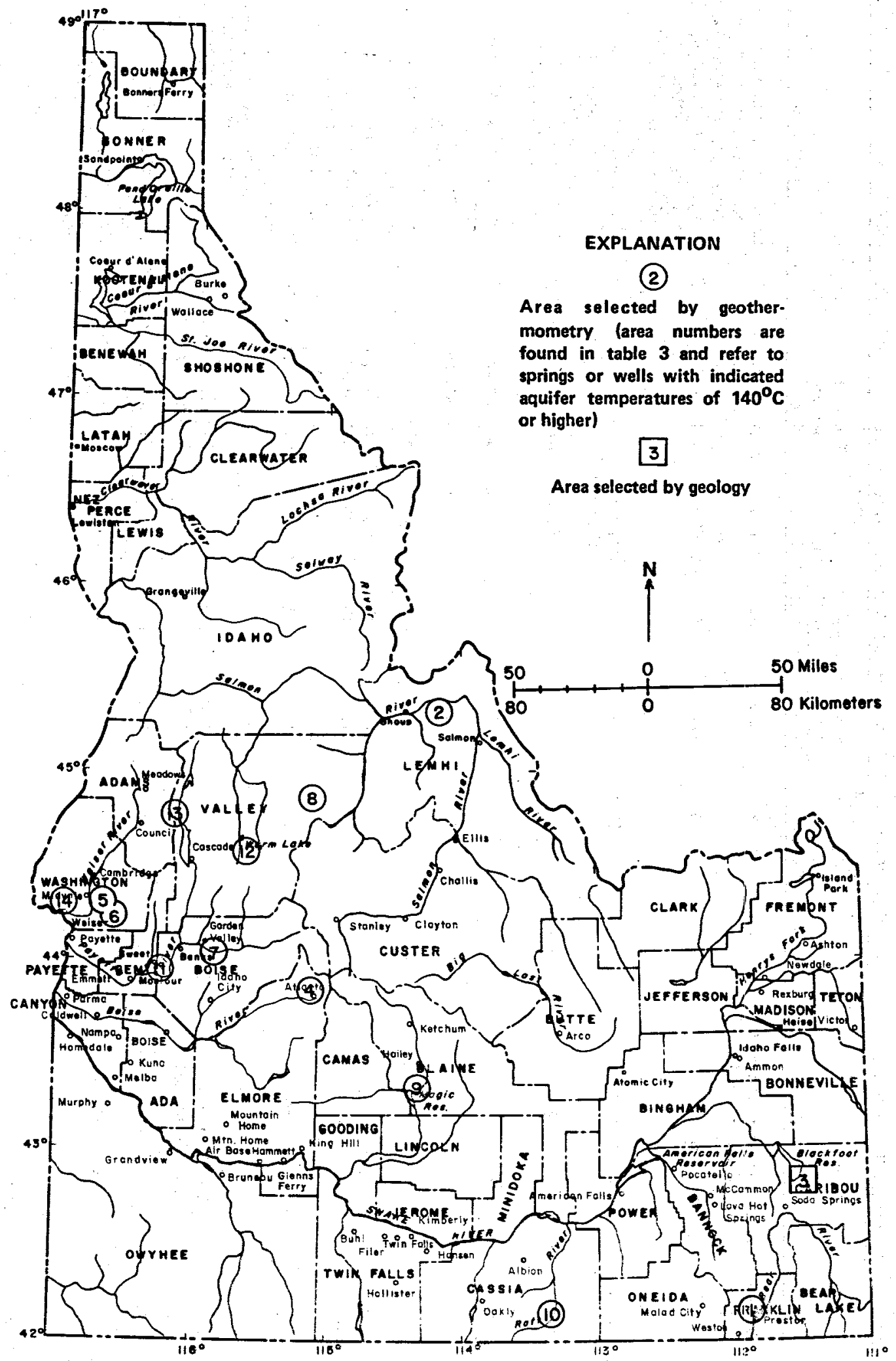

FIGURE 5. Index map of Idaho showing areas most favorable for power generation based on surface manifestation, geology and geotherometery. (Modified from Young and Mitchel1, 1973.) 
difficult and expensive, but if geothermal energy is going to make an impact on Idaho's electrical power base, and it appears to have potential to do so, the initial assessment will have to be made.

\section{ORGANIZATION OF DATA}

This report has been organized into four subregions within the state boundaries due to thermal waters in the separate subregions having different characteristics or modes of occurrence. Individual counties within a specific subregion are discussed in separate chapters. Figure 6 shows the approximate subregion boundaries and the counties they encompass.

Basic data tables containing information on the known springs and wells comprise a major section in the appendix of this report. The appendix also contains preliminary environmental assessments of several geothermal resource areas. 


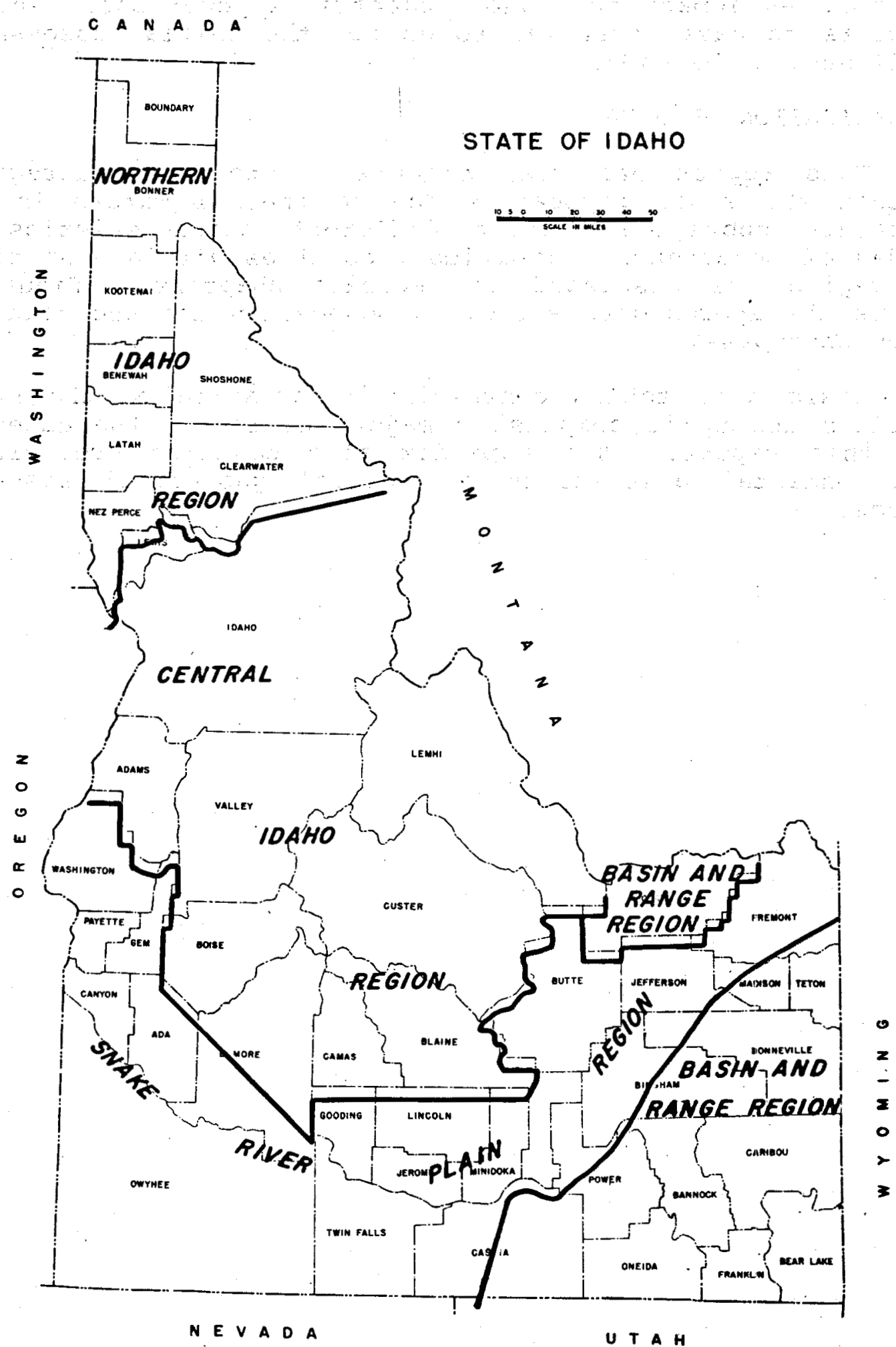

FIGURE 6. Index map of Idaho showing locations of counties and subregions covered in this report. 
GEOTHERMAL POTENTIAL

OF THE NORTHERN IDAHO "PANHANDLE" REgION

INCLUDING SHOSHONE AND NEZ PERCE COUNTIES

There are no known thermal anomalies located in the eight counties that make up the Northern Idaho Panhandle area with the exception of some hot rock material deep in the mines in Shoshone county ( $f$ igure 7) and one warm well in NezPerce County (figure 8 ). Generally very little is known of the geothermal potential of this area. specific information known and relating to the geothermal potential in NezPerce and Shoshone counties follows.

\section{SHOSHONE COUNTY}

Shoshone County, located in the Panhandle area, is known for its silver, lead, and zinc deposits.

The generalized geologic framework of the area consists of Precambrian metasediments of the Belt supergroup formations. These formations have undergone slight metamorphism and are composed primarily of quartzites, argillites, shales, and impure limestones.

The Belt metasediments (undifferentiated) consist of the Prichard, Burke, Revett, St. Regis, Wallace, and Spruce formations with the ore being mainly contained in the lower Burke and upper Prichard formations.

The structure of the area is relatively complex with two major fault trends; one trending northwest-southeast and the other trending northeast-southwest.

Mining has taken place in the coeur d'Alene mining district since the middle 1800's. Currently the Bunker Hill, Sunshine, Crescent, Galena, and Star Morning mines are just a few of the deeper active mines located in shoshone County. Most of the mines in the area are relatively water barren and diamond drilling and/or mining excavation has not encountered a significant geothermal anomaly. Any water needed for drilling or mining purposes is piped into these mines from surface sources.

Thermal gradient studies of the rock temperatures in the mines show temperatures increase from a normal temperature at the surface to those exceeding $400^{\circ} \mathrm{C}$ at deeper levels within the mines.

In the star Morning Mine, rock temperatures were recorded to be $42^{\circ} \mathrm{C}$ at the 7300 ft level. In the Galena 


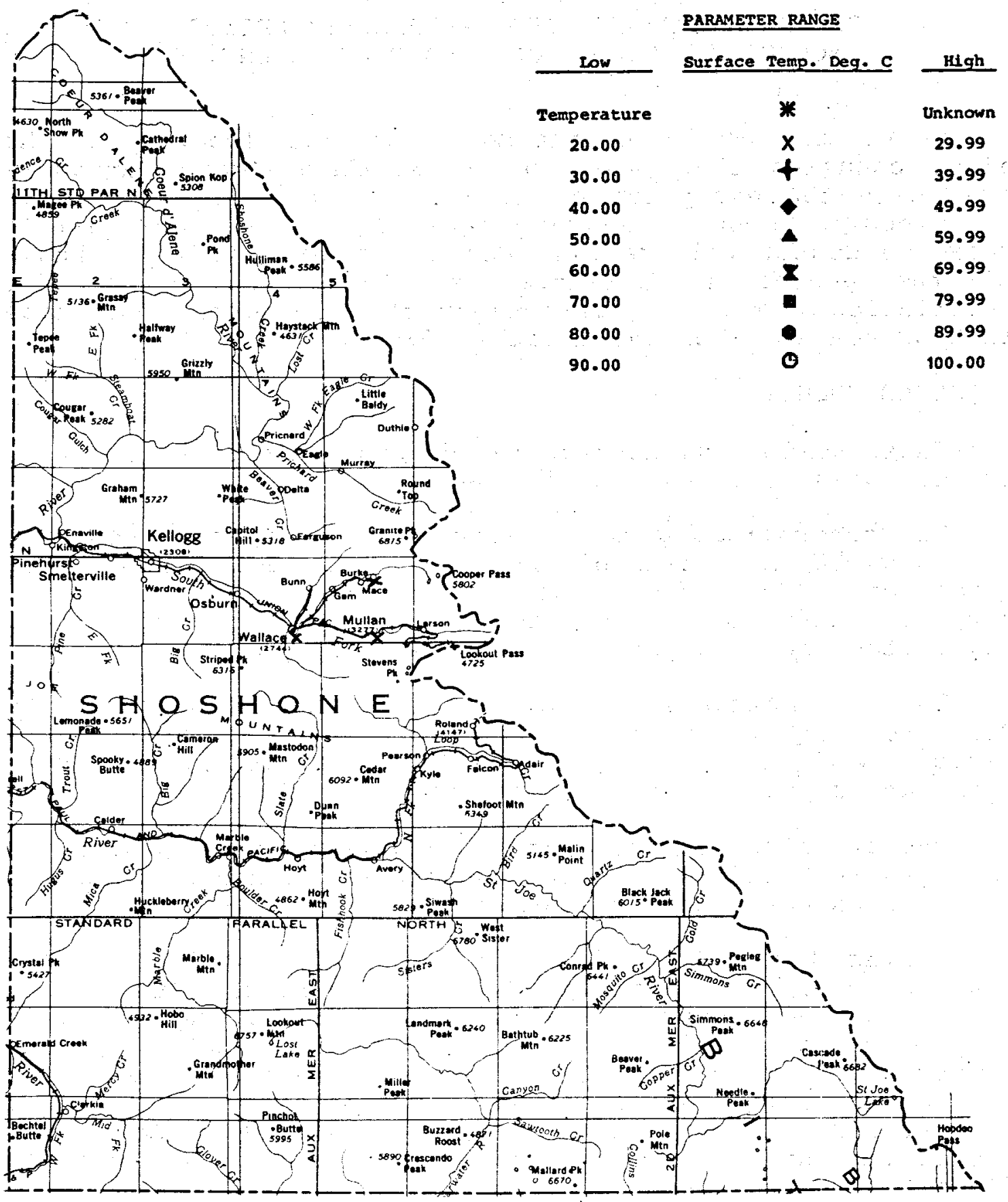

FIGURE 7. Index map of Shoshone County showing locations of known thermal water occurrences with surface temperatures above $20^{\circ} \mathrm{C}$. 


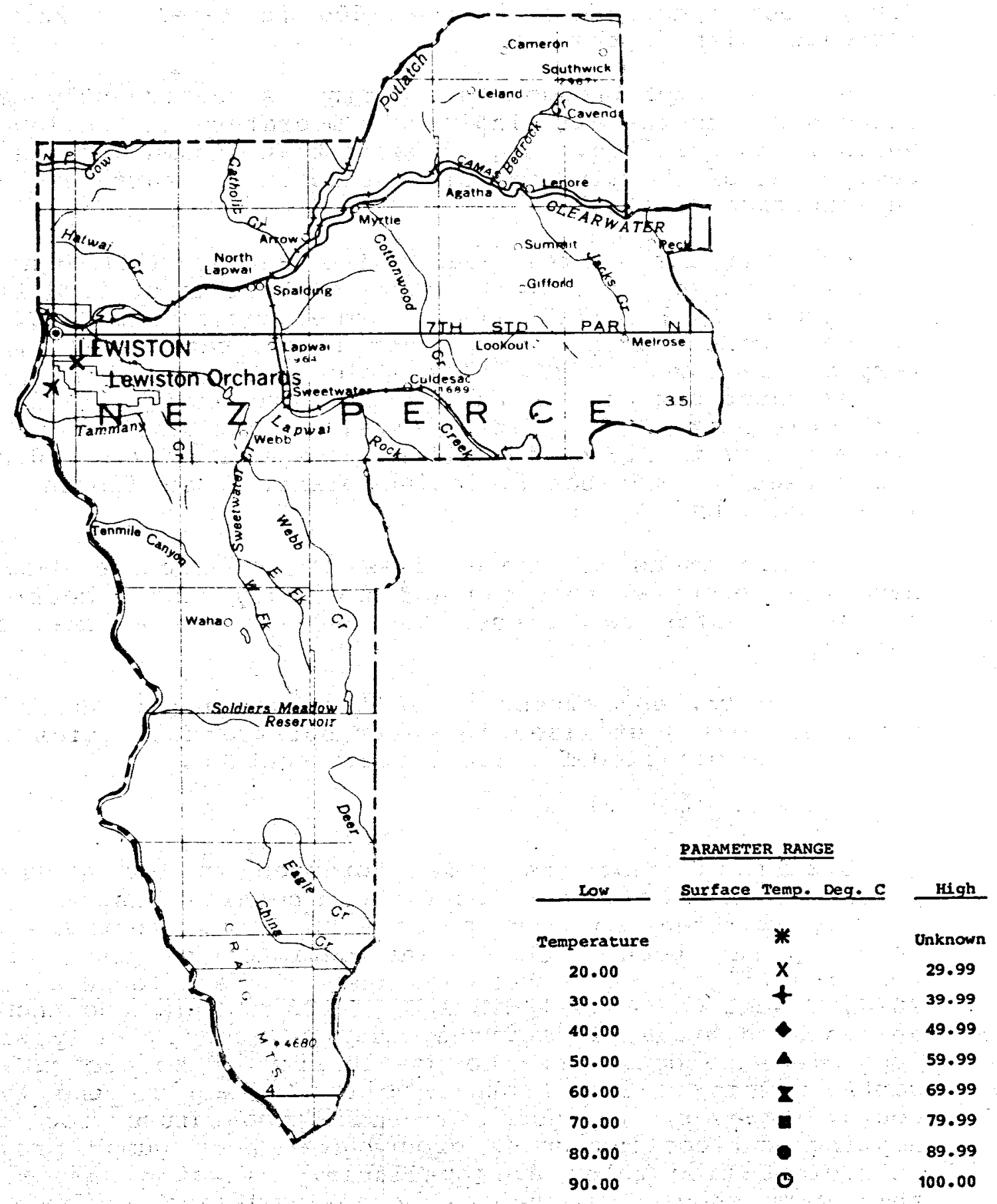

FIGURE 8. Index map of Nez Perce County showing locations of thermal water occurrences with surface temperatures of $20^{\circ} \mathrm{C}$ or higher. 
Mine, rock temperature at the $1600 \mathrm{ft}$ level is $22^{\circ} \mathrm{C}$ and increases with depth.

Surface water brought into a mine is subsequently heated through use to the existing rock temperature at the level at which it is utilized. Excess water that accumulates is then pumped out of the mine and discharged at the surface or used in a surface facility.

For the last three years, the Bunker Hill Mine has expelled excess water at the surface at rates of 43931 iters per minute $(1 / \mathrm{m})$ to $7153 \mathrm{l} / \mathrm{m}$ at temperatures near $22^{\circ} \mathrm{C}$. The Crescent Mine expels excess water at the rate of $7191 / \mathrm{m}$ at temperatures near $37^{\circ} \mathrm{C}$. The Galena Mine in 1978 pumped excess water out of the mine at the rate of $397 \mathrm{l} / \mathrm{m}$ at temperatures near $24^{\circ} \mathrm{C}$. Waters expelled from the Galena Mine are very low in dissolved solids, have a $\mathrm{pH}$ of $7.6+0.2$ and are reused in the beneficiating plant. See figure 7 for mine locations.

Certain areas of these mines at some future date may have the potential to store and naturally heat a sufficient amount of water to be used for large scale thermal space heating.

Presently, any excess water that is pumped out of the mines not being utilized in their surface facilities could possibly be utilized for local space heating.

\section{NEZ PERCE COUNTY}

Little interest has been expressed in the geothermal potential of Nez Perce County and nothing has been previously written on its potential. One thermal well, however, has been drilled near Lewiston by the city of Lewiston. (figure 8). This well has a surface temperature of $20^{\circ} \mathrm{C}$, discharges $4500 \mathrm{l} / \mathrm{min}$ and is $183 \mathrm{~m}$ deep. No chemical analysis is available for the well and, consequently, it is impossible to determine the possibility of hotter water at depth. This well and other wells drilled in the future could, however, be used at this temperature for space heating and cooling using groundwater heat pumps provided sufficient flow rates are available. A water sample from this well should be chemically analyzed and aquifer temperature estimates should be made. It is possible that more and hotter thermal water might be found in the Lewiston area. 
GEOTHERMAL POTENTIAL OF THE CENTRAL IDAHO REGION

INCLUDING IDAHO, ADAMS, VALLEY, LEMHI, BOISE, CUSTER, NORTHERN ELMORE, CAMAS AND

NORTHERN BLAINE COUNTIES

The vast region of central Idaho; including the Idaho batholith, is discussed as a separate section due to similarities in geology, geochemistry, structurally related occurrences, and the depositional features thermal springs in this region have in common.

Most of the thermal water found in this region appears as springs, which range in temperature from $20-93^{\circ} \mathrm{C}$. Locally, several wells have encountered thermal water. It is commonly known that these thermal springs and wells are located along the major and minor streams and rivers in the area. They thus emerge at the lowest possible elevation, although many are found in the upper reaches of drainages. An example are 18 thermal springs that occur along the Middle Fork of the Boise River along a $45 \mathrm{~km}$ stretch between Arrowrock Reservoir and Atlanta. However, a more detailed examination reveals that thermal springs in this region appear rather evenly spaced along narrow arcuate zones or trends, some of which cut across drainage divides (figure 9 in pocket). Other zones follow major drainages, as in the Boise and payette river systems. In some cases, mostly along the longer zones, the spacing tends to increase regularly in one direction. In some cases, where zones intersect, as at Indian Creek and Middle Fork Salmon River, two springs occur near the zone intersections. The arcuate zones range in length from 20 to $80 \mathrm{~km}$ and appear to be very narrow. These arcuate zones are most numerous and well defined in the central batholith region in Idaho. Well drilling and spring locations in other regions of Idaho have revealed similar zones. The regular spacing of springs along these zones appears to result from the regular spacing of linear features associated with them. Why the springs occur at nearly the same point on separate parallel lineaments is unknown but probably is the result of another lineament or structure (not visible on Landsat images) which cross the regularly spaced linears. The springs occur at the intersections.

Springs along these arcuate zones tend to occur (1) near the confluence of streams and/or rivers, such as at Pistol Creek Hot Springs (16N-10E-14dbcls) and Little Pistol Creek Hot Springs (16N-10E-14dbcls); Riggins (24N-2E-14dbdis), Loon Creek (17N-14E-19bdbls) and Hailey Hot Springs ( $2 \mathrm{~N}-18 \mathrm{E}-$ 18dbbls); or (2) near where a drainage is diverted around a large promontory or rock outcropping which projects into the 
stream and around which the stream was forced to make a horseshoe or U-shaped bend. Mormon Bend (11N-14E-20aabls), Riverside (16N-12E-16cbbls), Sheepeater (15N-10E-24bbbls), Sunflower Flat $(16 \mathrm{~N}-12 \mathrm{E}-8 \mathrm{bbb} 1 \mathrm{~S})$, Thomas creek Ranch (16N-12E-17dadls), Lightfoot Hot Springs ( $3 \mathrm{~N}-13 \mathrm{E}-7$ dcals) and Warfield (4N-17E-3lbbcls) Hot Springs are examples of the second type of occurrence (see figure 10). It is conceivable that many undiscovered thermal springs issue from the bottoms of river channels where the flowing water masks the thermal water.

Figure 9 (in pocket) is a superposition of linears from Day (1974) and circular features of Haskett (1974) on a spring and well location map of Idaho. This figure shows that many of the thermal springs and wells are associated (found on or very near) with large linear features that are seen on high altitude U-2 and satellite photos. Few of Day's linears are found to fit the curvilinear zones defined by the spring occurrences, but data strongly suggest structural control for most thermal water in the region. Although the exact nature of the linears is not known, they could represent joints or faults or some other type of rock fracture. One theory of the origin of these thermal springs is that they occur where ancestral joints, formed by shrinkage or contraction of deeply buried, cooling igneous or metamorphic rock complex intersects faults, or other fractures allowing circulation of meteoric (rain and snow) water to depths where the water is heated by hot rock. The hot water being less dense than the colder water rises along the same or other joints, faults or fractures to form a thermal spring. Thus, most of the thermal springs in this region of Idaho probably represent deep circulation of meteoric waters to depths where the water is heated by contact with hot rock in a region or along zones of above normal geothermal gradient or heat flow.

These types of occurrences appear typical. Perhaps the localized geothermal anomalies--those associated with high intensity shallow seated heat sources (intrusions)--might be those which are not associated with arcuate belts or zones. Alternatively, at least some of the zones could represent fractures or other structures into which magma has intruded to shallow depths producing high intensity shallow seated heat sources.

\section{IDAHO COUNTY}

Thirteen thermal springs are known to occur in Idaho county (figure 11). They are fairly uniform in temperature, ranging from 41 to $590^{\circ} \mathrm{C}$. They are not limited to any one locality or rock type, but are found sparsely distributed over a large area. Four springs, Wier Creek (36N-11El3bccls), Colgate Licks (36N-12E-15abdls), Jerry Johnson 

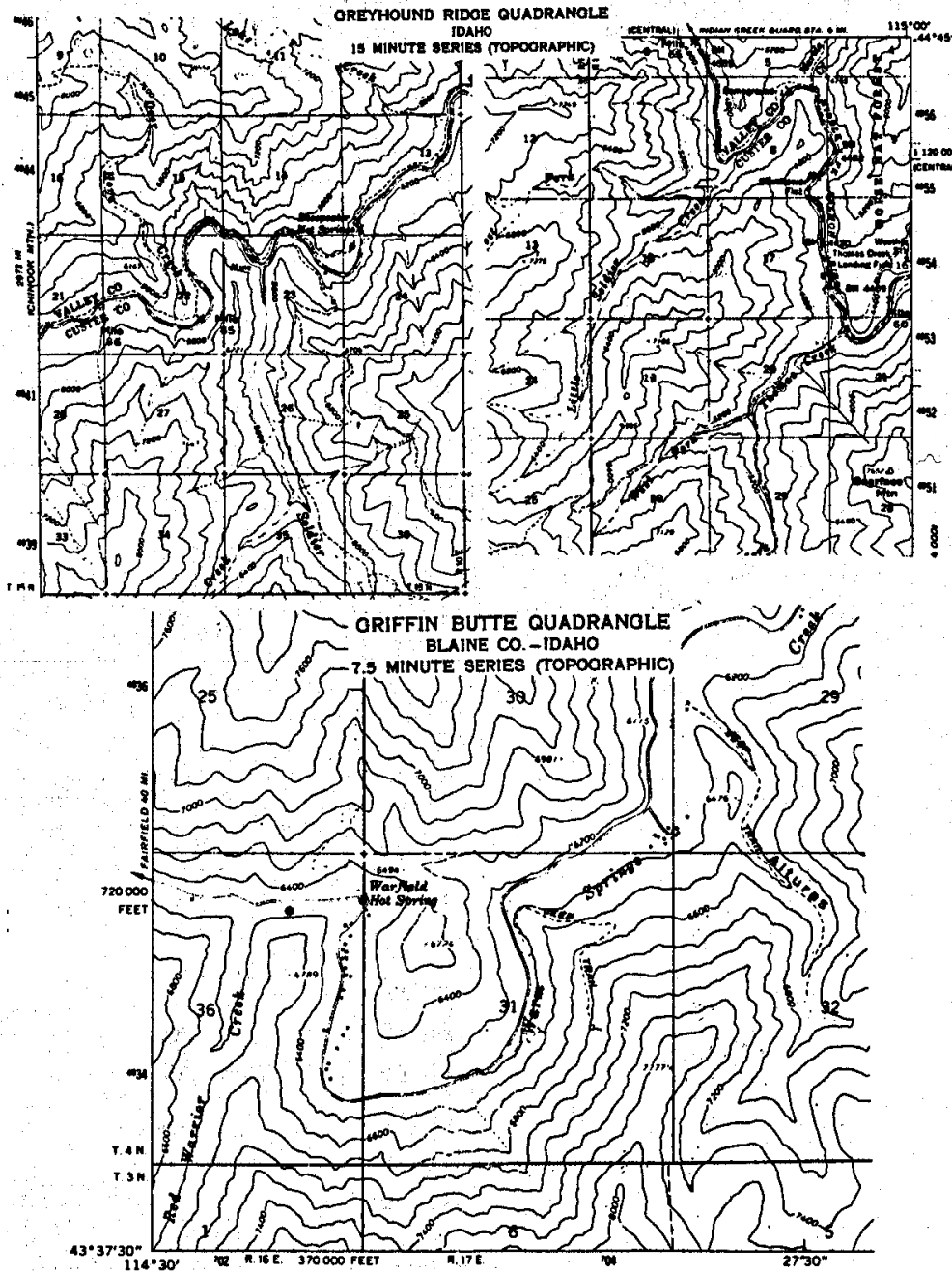

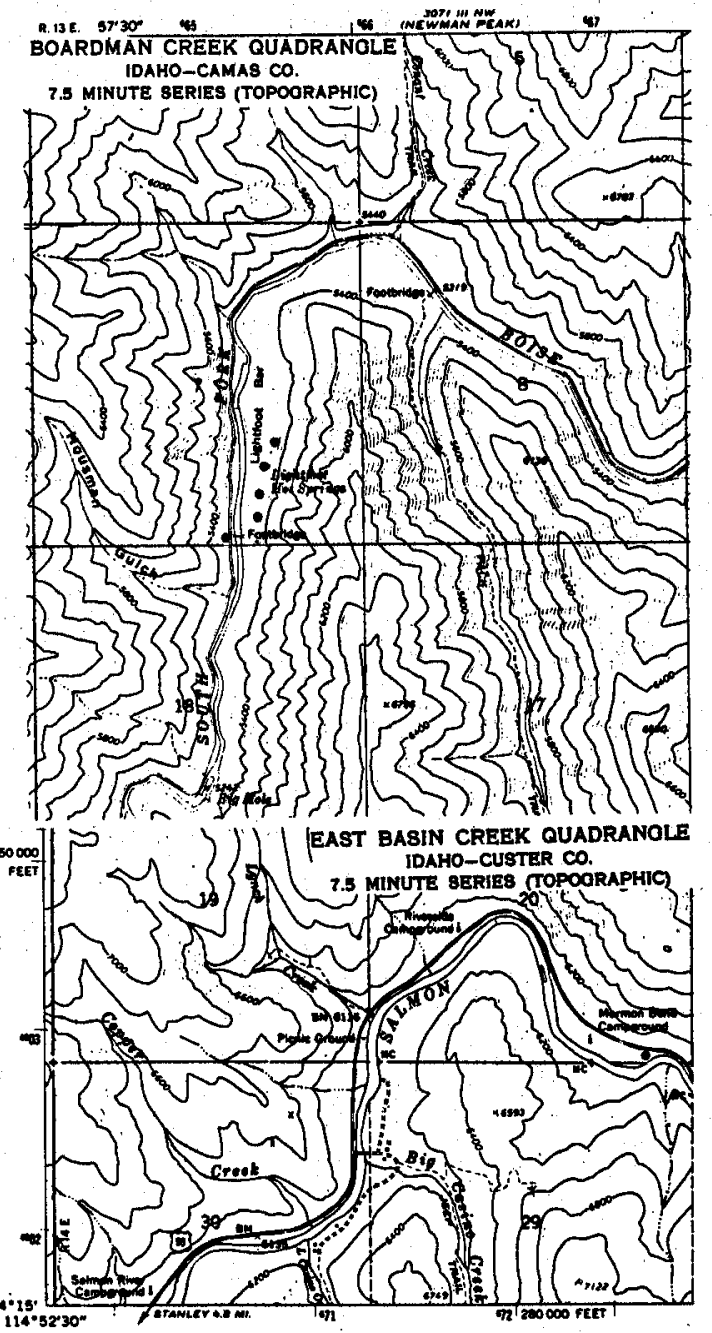

FIGURE 10. Topographic maps showing typical central Idaho thermal spring occurrences near sharp river bends. Black dots indicate spring locations. 
FIGURE 11. Index map of Idaho County showing locations of thermal water occurrences with surface temperatures of $20^{\circ} \mathrm{C}$ or higher.

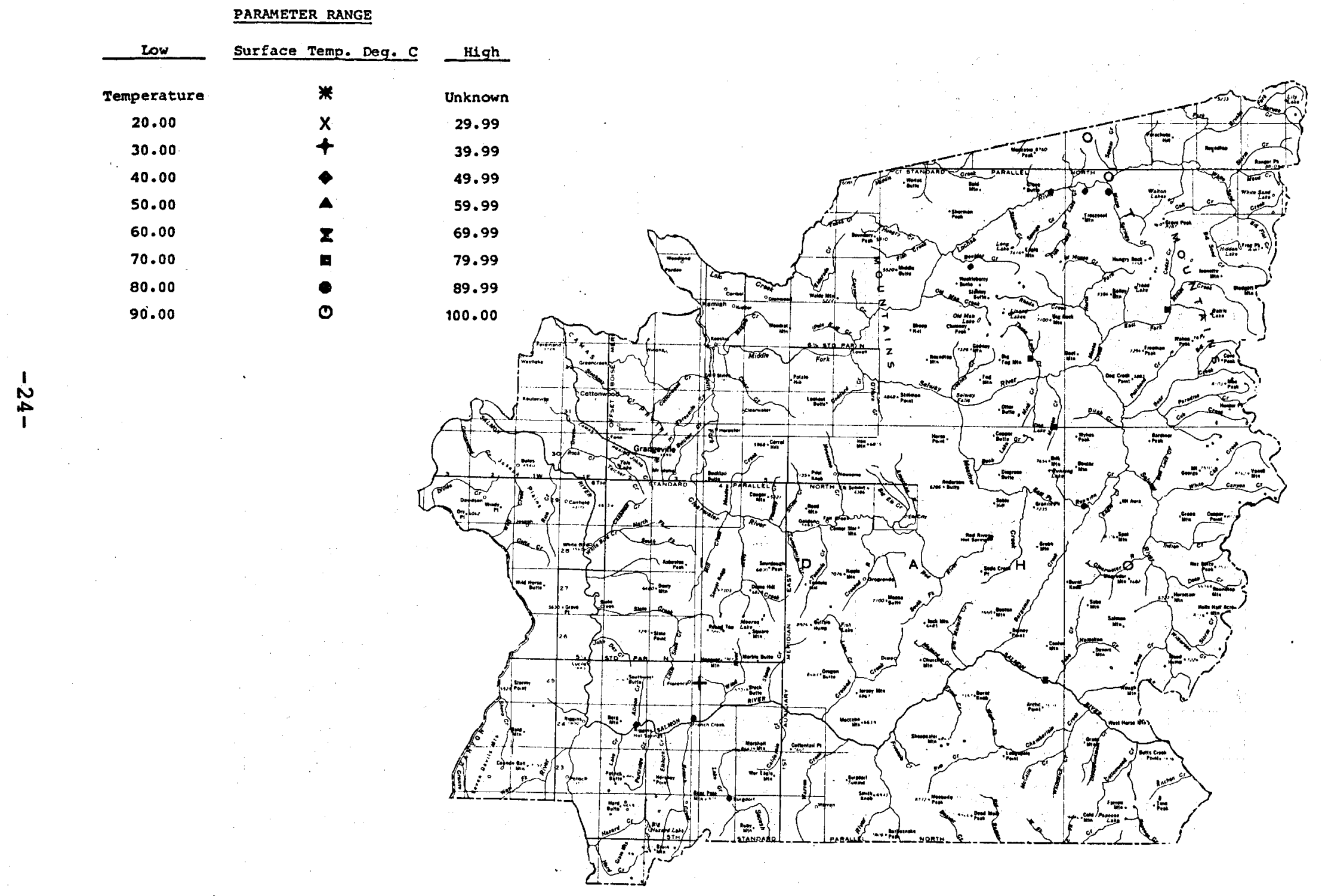


(36N-13E-18addls), and an unnamed spring occur within a small area in northeastern Idaho county on or near the Lochsa River. Most of the other springs are in remote locations, wilderness or recreational areas, accessible only by pack trail. This, along with restricted use of these areas, precludes large scale development. Riggins (24N-2E14dbdls), Burgdorf (22N-4E-1bdc1S), and Red River Hot Springs (25N-12E-3dddIS) are popular resort areas and boast improvements, although the Red River Resort recently burned down and the Burgdorf Resort pools have been officially closed by the district health officials. Jerry Johnson Hot springs is used for informal bathing by campers and backpackers.

Most thermal springs in Idaho county occur within granitic rocks or near contacts of other rock types with granitic rocks. All are associated with known faults or linear features. The best defined arcuate trend in the region is represented by stanley $(34 \mathrm{~N}-10 \mathrm{E}-6 \mathrm{caals})$, stewart $(32 \mathrm{~N}-11 \mathrm{E}-$ 4 caals), Martin ( $31 \mathrm{~N}-11 \mathrm{E}-24 \mathrm{dcd} / \mathrm{s})$ hot springs and Running Springs (29N-12E-14abbls) in east-central Idaho County ( $f$ igure 9 in pocket).

Water quality chemical data from thermal water occurrences in Idaho county are given in basic data table 1. These analyses provide a chemical comparison of thermal water in the area and were used to calculate selected chemical-constituent ratios and to estimate aquifer temperatures.

Chemical analyses are available for only six of the fourteen hot springs found in Idaho county. All of the analyzed springs are low in total dissolved solids, ranging from $582 \mathrm{mg} / 1$ at Riggins Hot springs to $133 \mathrm{mg} / 1$ at wier Creek Hot Springs. The $\mathrm{pH}$ of these waters is alkaline, ranging from 8.1 to 9.0 , except for Red River Hot springs. These springs have a flouride content of $23 \mathrm{mg} / 1$ whereas other sampled springs in the county have a flouride content of less than $6 \mathrm{mg} / 1$. Typically, the waters in Idaho county are similar to most other thermal waters throughout central and southwestern Idaho that issue from granitic rock or areas thought to be underlain by granitic type rocks.

Aquifer temperatures calculated from the silicia and $\mathrm{Na}-\mathrm{K}-\mathrm{Ca}$ chemical geothermometers and mixing models, as well as selected atomic ratios, are given in basic data table 2 . Maximum subsurface temperature expected from wells drilled in the area of springs for which chemical analyses are available probably would not exceed $100^{\circ} \mathrm{C}$ and may be most closely approximated by the chalcedony or $\mathrm{Na}-\mathrm{K}-\mathrm{Ca}$ temperature, columns $T_{4}$ and $T_{5}$, basic data table 2 . 


\section{ADAMS COUNTY}

Seven thermal springs and two wells are known in Adams County with measured surface temperatures exceeding $20^{\circ} \mathrm{C}$ (figure 12). The two wells are located near the town of Council. Both are fairly low temperature at $22^{\circ} \mathrm{C}$. Several other wells in the council area have above normal temperatures of up to $17^{\circ} \mathrm{C}\left(10^{\circ} \mathrm{C}\right.$ above mean annual temperature). We $1116 \mathrm{~N}-1 \mathrm{~W}-15 \mathrm{bacl}$ is $35 \mathrm{~m}$ deep and was drilled within $0.4 \mathrm{~km}$ of the Hornet creek-Weiser River confluence. The other well, $16 \mathrm{~N}-1 \mathrm{~W}-1 \mathrm{lacd} 1$, was drilled to a depth of $64 \mathrm{~m}$ near the valley-mountain boundary fault zone near Grossen Canyon. No chemical analyses are available from these wells. Samples should be collected to help determine their geothermal potential.

Starkey Hot Springs (18N-1W-34dbbls), an attractive resort area, discharges $5001 / \mathrm{min}$ of $56^{\circ} \mathrm{C}$ water near the confluence of Warm springs Creek and Weiser River where the Weiser River bends north and abruptly turns south again in the steep-walled canyon surrounding Fort Hall Hill. Starkey Hot Springs appears structurally typical of the thermal spring occurrences in central Idaho. Aquifer temperatures indicated by $\mathrm{Na}-\mathrm{K}-\mathrm{Ca}$ and chalcedony chemical geothermometers are 70 and $77^{\circ} \mathrm{C}$, respectively. These temperatures could have uses up to and including the lower temperature limit of refrigeration (see figure 4). Dissolved solids and flouride concentration are low, being $348 \mathrm{mg} / 1$ and less than $1 \mathrm{mg} / 1$, respectively. The $\mathrm{pH}$ is 8.6 . The chemistry of the water suggests a source rock not similar in chemical or mineralogical constituents to granitic rocks.

Council Mountain Hot Springs $(15 \mathrm{~N}-1 \mathrm{E}-2 \mathrm{bab} 1 \mathrm{~S})$ is located $2.5 \mathrm{~km}$ up Warm Springs Creek from its confluence with the Middle Fork Weiser River southeast of Council. It issues at $68^{\circ} \mathrm{C}$ and $190 \mathrm{l} / \mathrm{min}$ from Quaternary alluvium near granitic rock. No other information is available on this thermal spring. Its location appears atypical of most springs in central Idaho.

White Licks Hot Springs (16N-2E-33bccls) is located in the Middle Fork Weiser River drainage and issues from Quaternary alluvium near Miocene basalt and Cretaceous granitic rocks. Ross $(1971$, p. 9) reported that white Licks Hot Springs occurred on a relatively short north trending fault and had an abnormally high mineral content. Water issues from numerous spring vents at 63 to $65^{\circ} \mathrm{C}$ (Young and Mitchell, 1973, p. 9) and has a slight sulfur odor. The quartz and $\mathrm{Na}-\mathrm{K}-\mathrm{Ca}$ chemical geothermometers estimate aquifer temperatures of 142 to $145^{\circ} \mathrm{C}$, the lower limit of binary cycle power generation, might be found in the area by deep drilling. 


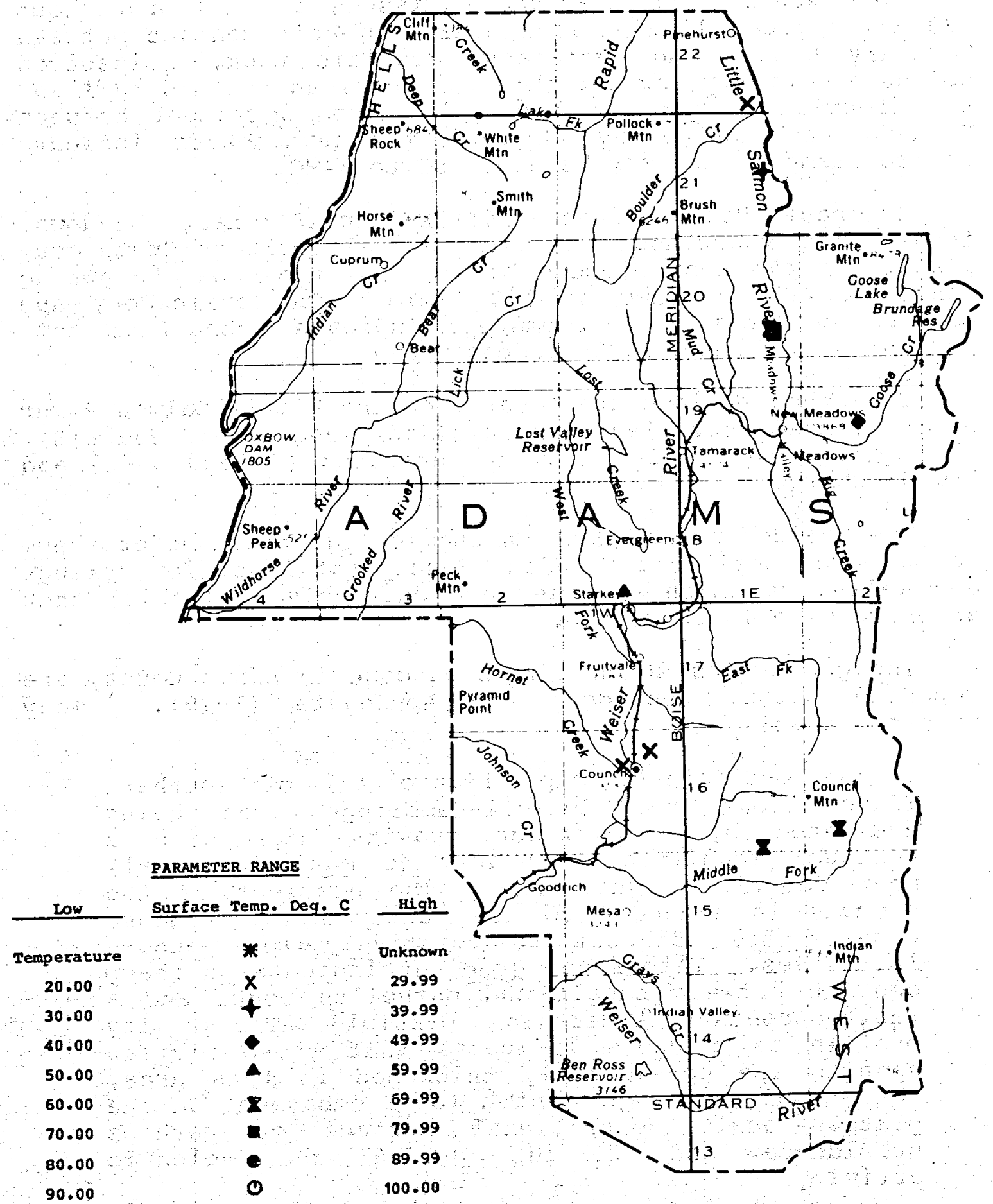

FIGURE 12. Index map of Adams County showing locations of thermal water occurrences with surface temperatures of $20^{\circ} \mathrm{C}$ or higher. 
Zims Resort $(20 \mathrm{~N}-1 \mathrm{E}-26 \mathrm{dda} / \mathrm{S})$ issues at $65^{\circ} \mathrm{C}$ and about $380 \mathrm{l} / \mathrm{min}$ from alluvial fill near the fault contact between Tertiary basalt and Cretaceous granitic rock. Dissolved solids are fairly low for this part of Idaho at $666 \mathrm{mg} / 1$ and the flouride content is $2.3 \mathrm{mg} / 1$. Good agreement between $\mathrm{Na}-\mathrm{K}-\mathrm{Ca}$ and chalcedony chemical geothermometers indicate aquifer temperature may be about 83 to $84^{\circ} \mathrm{C}$.

Krigbaum Hot Springs (19N-2E-22ccals) near Meadows, issues from a northeast trending normal fault in Cretaceous granitic rocks near Miocene basalt from two separate spring vents at 40 and $42^{\circ} \mathrm{C}$ at $1501 / \mathrm{min}$. The chalcedony and $\mathrm{Na}-\mathrm{K}-\mathrm{Ca}$ chemical geothermometers indicate subsurface temperatures of 91 and $96^{\circ} \mathrm{C}$, respectively.

The other springs are located on the Little Salmon River north of Meadows Valley (22N-1E-34dadls and $21 \mathrm{~N}-1 \mathrm{E}-23 \mathrm{abalS}$ ). The springs have fairly low temperatures (26 and $30^{\circ} \mathrm{C}$ ) and low discharges.

The chalcedony and $\mathrm{Na}-\mathrm{K}-\mathrm{Ca}$ chemical geothermometers seem to be more consistent in Adams County (at least for springs and wells for which analyses are currently available) than anywhere else in the state.

The geophysics which have been done in Adams county are reported on by Donaldson and Applegate (1979). They reported that:

...the preliminary map (figure 13) of southern Idaho shows the Council-Cambridge area being dominated by a distinct gravity high with a residual magnitude of nearly $40 \mathrm{mgal}$ (milligal) near Council (figure 14). The gradient of the anomaly is enhanced to the east where the dense basalts lie adjacent to relatively low density intrusives. This steep gradient indicates a sharp contact between basalt and batholith rocks and a faulted contact is certainly possible. The gravity profile as a whole indicates that these plateau basalts are considerably thickened in this area. The anomaly may represent a local embayment on the plateau-basalt depositional surface or perhaps subsidence and filling during the volcanic activity.

Bond. (1975) shows many faults in this area and Witkind (1975) classifies several faults as active (figure 15). The faulting patterns (Bond, 1978) suggest that alluvial-filled river cut valleys in this area may be fault controlled. Unfortunately, the gravity data is very sparse and does not define the valley margins or allow any estimation of their depths or structural controls. 


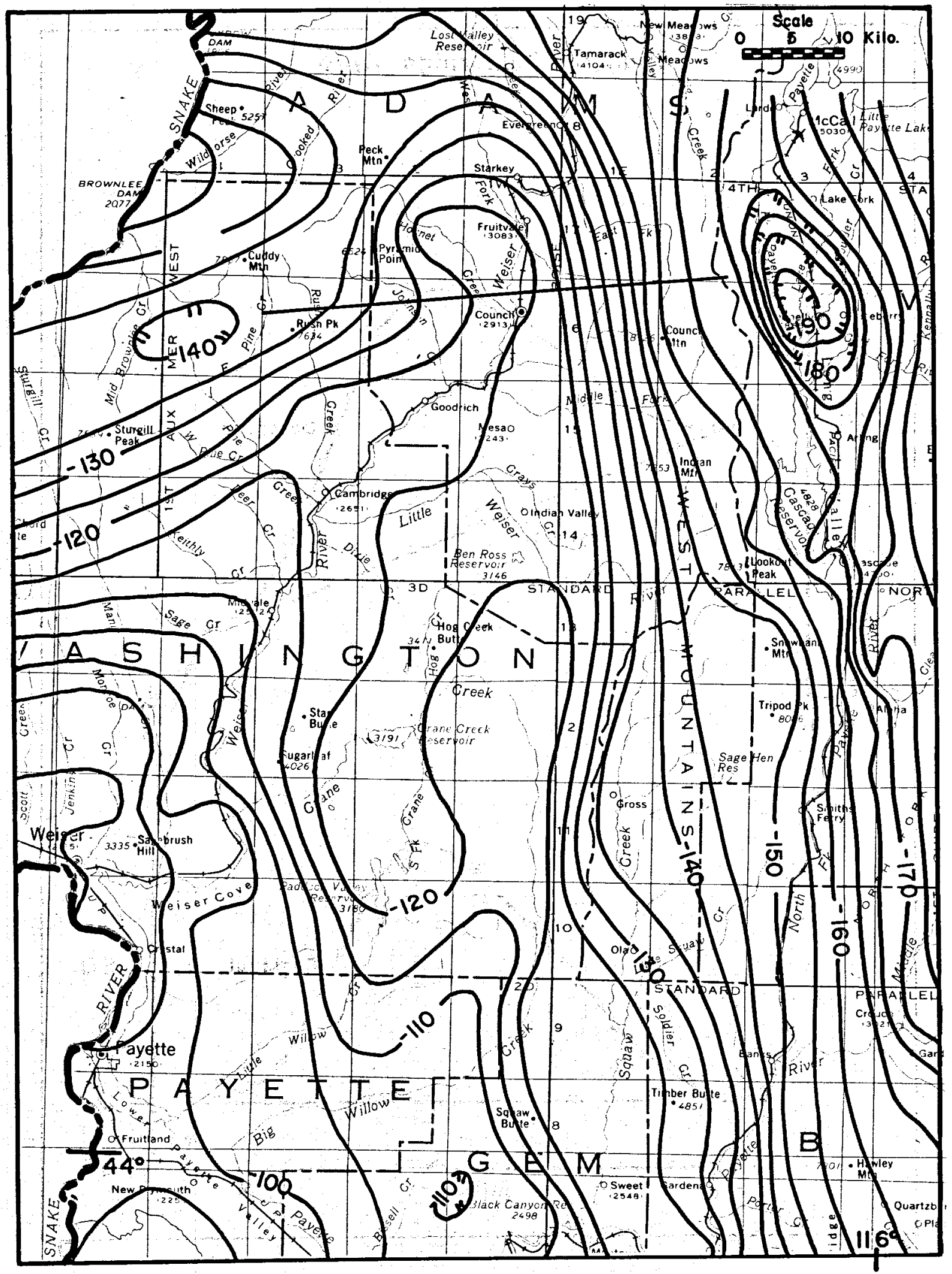

FIGURE 13. Gravity map of Council-Cambridge area, contour interval is 5 milligals. (Mabey, Peterson, and Wilson, 1974). 


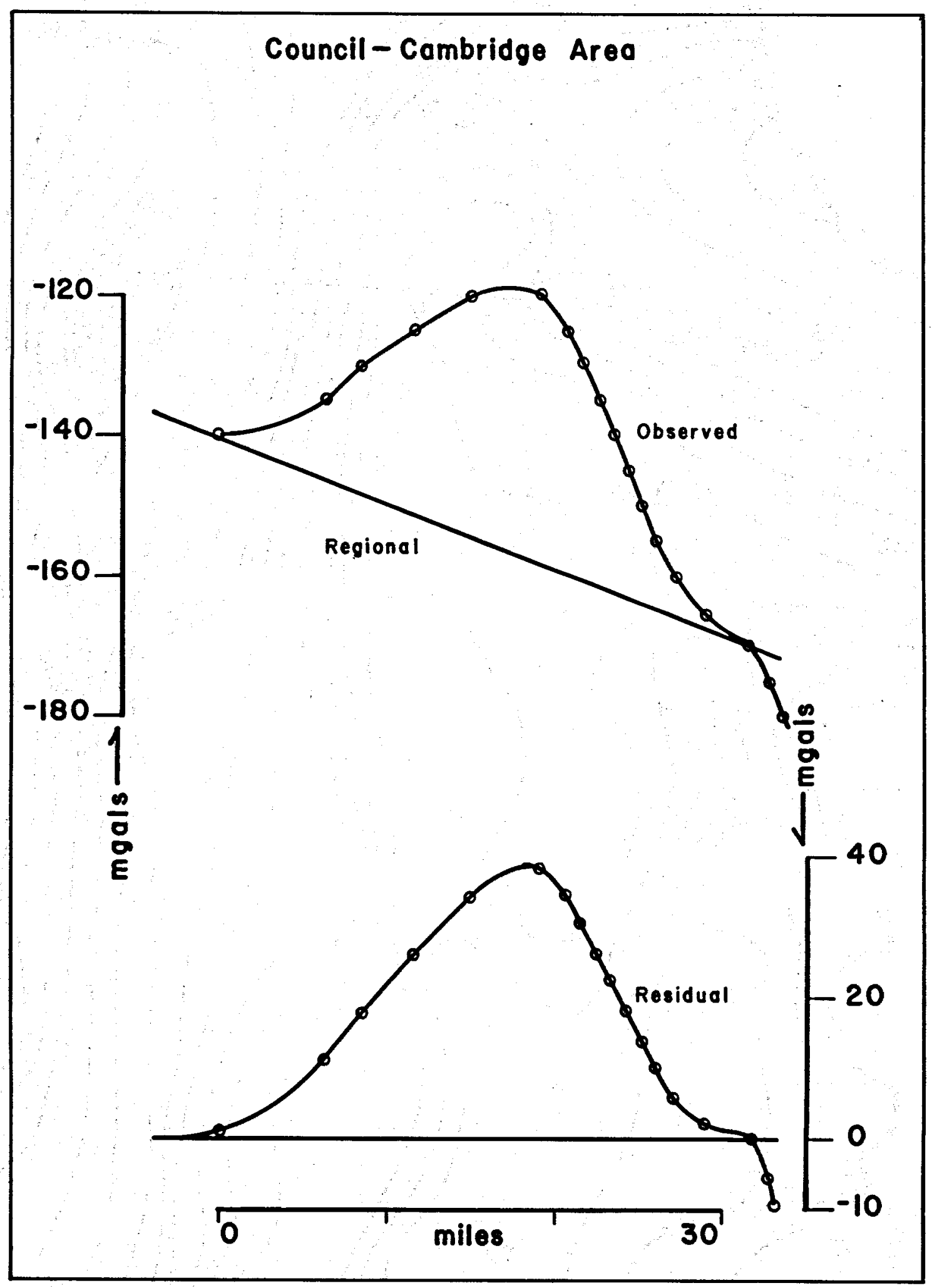

FIGURE 14. Gravity Profile near Council (from Donaldson and Applegate, 1979). 


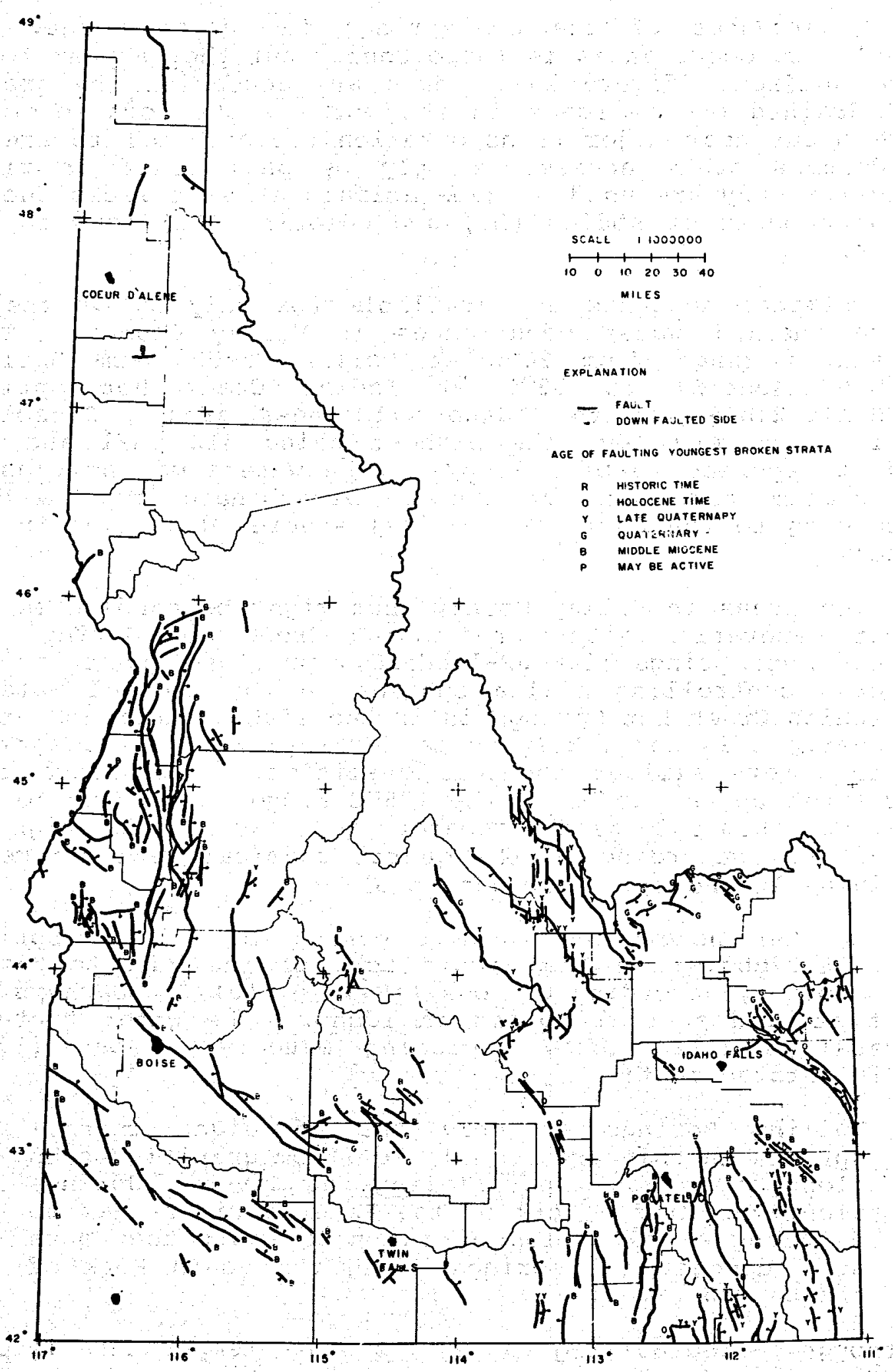

FIGURE 15. Index map of Idaho showing known and suspected active faults. (Modified from witkind, 1975.) 


\section{VALLEY COUNTY}

Occurrences of thermal springs in valley county are similar to occurrences in Idaho County but they appear to be more numerous (figure 16). Many are accessible by graded and drained gravel roads in the more remote locations and some occur near major transportation routes. Others are in wilderness areas accessible only by pack trail or river travel. Many are used by game animals as salt licks due to minor amounts of sodium ( $\mathrm{Na}$ ) and chlorine (Cl) ions in the water.

Chemical analyses are available for only 20 of the 41 known thermal water occurrences in Valley County. Temperatures range from $20^{\circ} \mathrm{C}$ at Dollar Creek Warm Springs (16N-6E-14cccls) to $88^{\circ} \mathrm{C}$ at Indian Creek Hot springs (17N-11E-2lbls) in the Idaho wilderness area. Dissolved solids are very low, the highest being $412 \mathrm{mg} / 1$ and the lowest reported to be $192 \mathrm{mg} / 1$. The waters may be classed as sodium carbonate or sodium bicarbonate type waters according to the dominant chemical species dissolved in the water.

Two areas in Valley county that might be candidates for power generation sites are Indian Creek Hot springs and Vulcan Hot Springs (14N-6E-1lbdals), provided quartz is the mineral controlling silica content in the thermal waters. As Indian Creek Hot Springs is in the Idaho wilderness area, however, it is not likely to be developed. The two springs exhibit very similar chemical qualities. Subsurface temperatures appear to be in the $135^{\circ} \mathrm{C}$ range, according to the $\mathrm{Na}-\mathrm{K}-\mathrm{Ca}$ chemical geothermometer and may be as high as $145-150^{\circ} \mathrm{C}$, according to the quartz chemical geothermometer (columns $T_{5}$ and $T_{1}$, basic data table 2. )

Another noteworthy thermal spring is Boiling springs (12N-5E-22bbcls) on the Middle Fork of the Payette River. This spring, according to Ross (1971, p. 10), is perhaps the best studied thermal spring in Idaho. The water contains several metallic ions, including mercury. Ross (1971, p. 10) stated that:

Boiling springs is only one of eight thermal springs in this area. All flow from granitic rocks along shear zones paralleling the river. springs along the Middle Fork of the Payette River seem to be along an extension of the same fault that acts as a conduit for springs along the South Fork of the Salmon River.

Although called Boiling Springs, surface temperature is only $85^{\circ} \mathrm{C}$. Subsurface temperatures appear to be not much higher, only $89{ }^{\circ} \mathrm{C}$ according to the chemical geothermometer. 


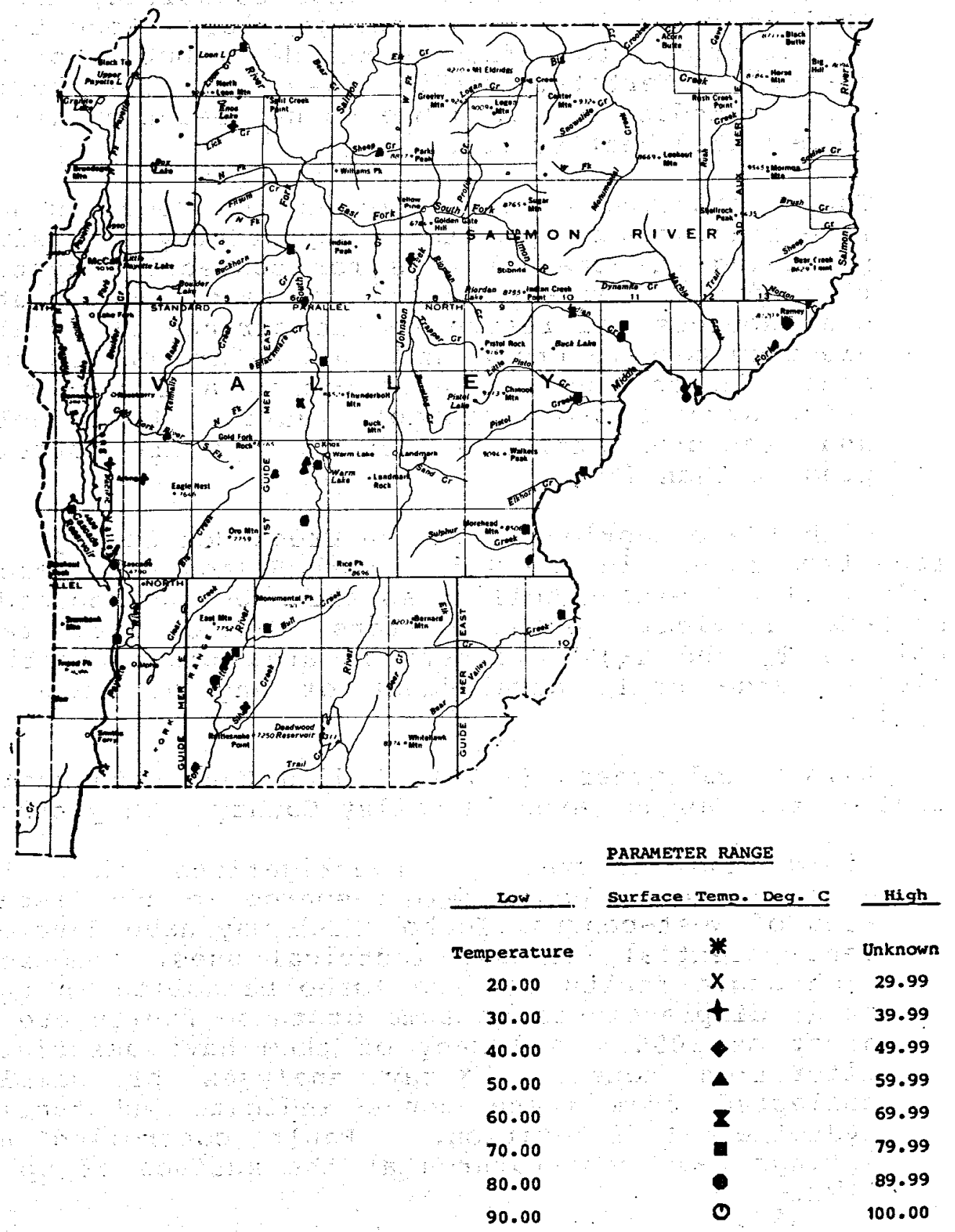

FIGURE 16. Index map of Valley County showing locations of thermal water occurrences with surface temperatures of $20^{\circ} \mathrm{C}$ or higher. 
Cater and others (1973 p. 383-389) discussed the thermal springs in valley and Custer counties along the Middle Fork of the Salmon River and stated:

Thermal springs in the Idaho primitive area are in an area of ...volcanics and tectonic activity. Most rocks are Cretaceous Idaho batholith, Eocene Challis volcanics and Eocene granite. Rock types do not appear to influence the distribution of the springs. Tertitary mafic dikes near the thermal springs indicate a possible mutual relationship to deep-seated heat sources.

The igneous rocks are not porous, but numerous surface fractures and faults are apparently extensive, providing the channel ways for convective systems that permit surface waters to reach deep-seated heat sources and return to the surface at greatly elevated temperatures. All springs are on numerous small faults and fractures within a few feet of major streams along probable faults. Most faults and fractures strike N. $45^{\circ} \mathrm{W}$; dips are normally greater than $45^{\circ}$.

With the exception of Indian Creek Hot Springs, subsurface temperature in the Middle Fork Salmon River area probably will not exceed boiling as shown by the chalcedony and $\mathrm{Na}-\mathrm{K}-\mathrm{Ca}$ chemical geothermometers (basic data table 2 , columns $T_{4}$ and $\left.T_{5}\right)$. Wilderness area classification precludes large scale development of any of these thermal springs.

Wilson and others (1976) studied the geothermal potential of the Cascade area in Valley county. They stated:

Field and laboratory investigations show the existence of a geothermal resource in the cascade area of west-central Idaho which may have development potential for non-electrical uses. Numerous high angle faults cut the Idaho batholith in this area; displacements on some of these faults are as great as $3050 \mathrm{~m}$ and many of them have associated alteration zones. $X-r a y$ analyses of samples collected from these zones indicate substantial hydrothermal alteration. Fault controlled hot springs have temperatures at the surface of up to $71^{\circ} \mathrm{C}$.

Microseismic monitoring in the area suggests that east-west trending faults are active, supporting the plausibility of an accessible geothermal resource. 


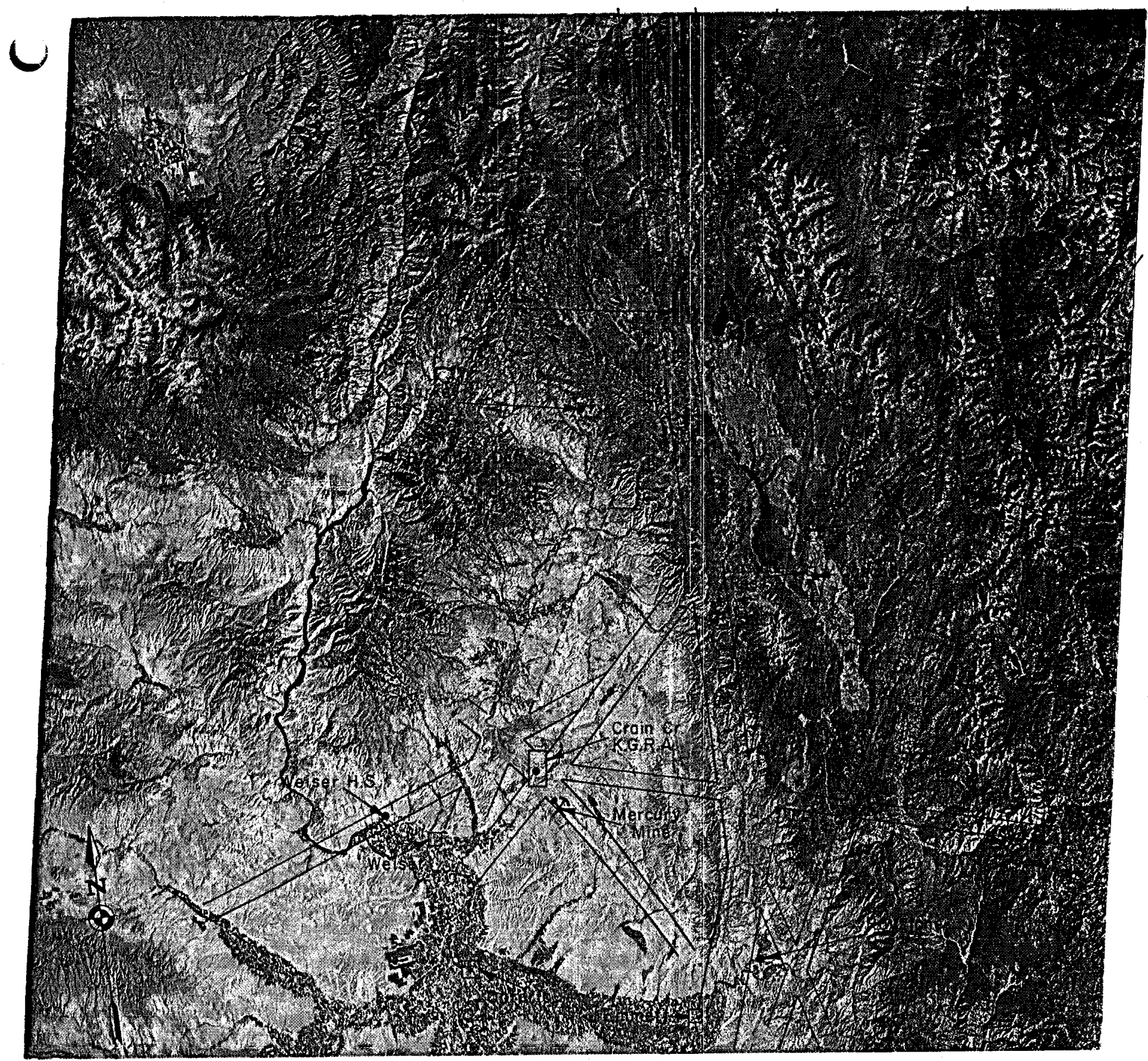

FIGURE 17. EROS false color infrared Landsat EDISE image of part of west-central Idaho and eastern oregon showing selected linear features and thermal water locations with surface temperatures above $20^{\circ} \mathrm{C}$. Note: Linear features occur between the black lines. 


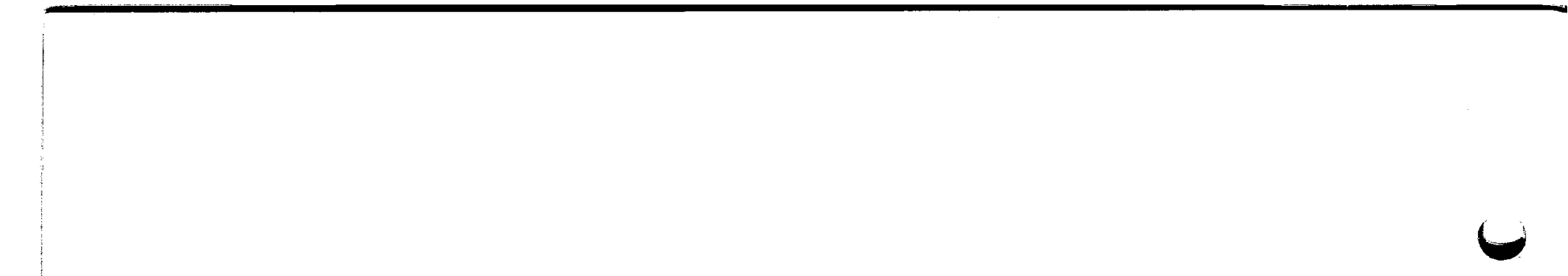

\section{$\checkmark$}

36 
The domestic groundwater supply for most of the area is from very shallow wells, most of which are developed in the upper 200 feet of the valley floors and derive their water from joints rather than from fault systems. Preliminary data indicate no connection between the thermal systems and the water supply for the area.

The Na-K-Ca and chalcedony chemical geothermometers suggest aquifer temperatures may be as high as 46 to $66^{\circ} \mathrm{C}$ near the city of Cascade.

Thermal water is associated mostly with granitic rocks of the Idaho batholith.

Earth Resources observation Systems (EROS) digital image enhancement system satellite image (figure 17) of the Cascade-Long Valley area shows that Cascade lies near the intersection of major linear features. These may control the occurrence of thermal water in the area. other thermal water occurrences in west-central Idaho and selected linear features associated with them are also shown on the image.

\section{LEMHI COUNTY}

Eleven thermal springs have presently been documented in Lemi County (figure 18). About half are in remote (primitive or recreation) areas which precludes development. Chemical data have been collected for only four of the eleven thermal springs located in Lemhi county.

The hottest thermal spring in the county and one of the hottest in Idaho is Big Creek Hot Springs (23N-18E-22cad1S) which has a surface temperature of $93^{\circ} \mathrm{C}$ (boiling). It is located high in the Hot Springs Creek drainage (over $330 \mathrm{~m}$ above the Salmon River, the major drainage in the area) near panther creek at the top of a divide (ridge top discharge). Quartz and $\mathrm{Na}-\mathrm{K}-\mathrm{Ca}$ chemical geothermometers both indicate subsurface temperatures are $160-175^{\circ} \mathrm{C}$. Both siliceous and carbonate deposition is found near active vents. Water is presently used by big game hunters as a steam bath. Big Creek Hot springs appears from available data to date to be one of the best prospects in Idaho for power generation.

Bennett (1977) reported on the geology and geochemistry of the Blackbird Mountain-Panther Creek region in Lemhi County, Idaho. He stated (p. 4):

The Panther Creek region is located in the Salmon River Mountains. The area is characterized by flattopped mountains and moderate to steep V-shaped canyons. This entire section of Idaho is quite striking from the air as concordant elevations give 


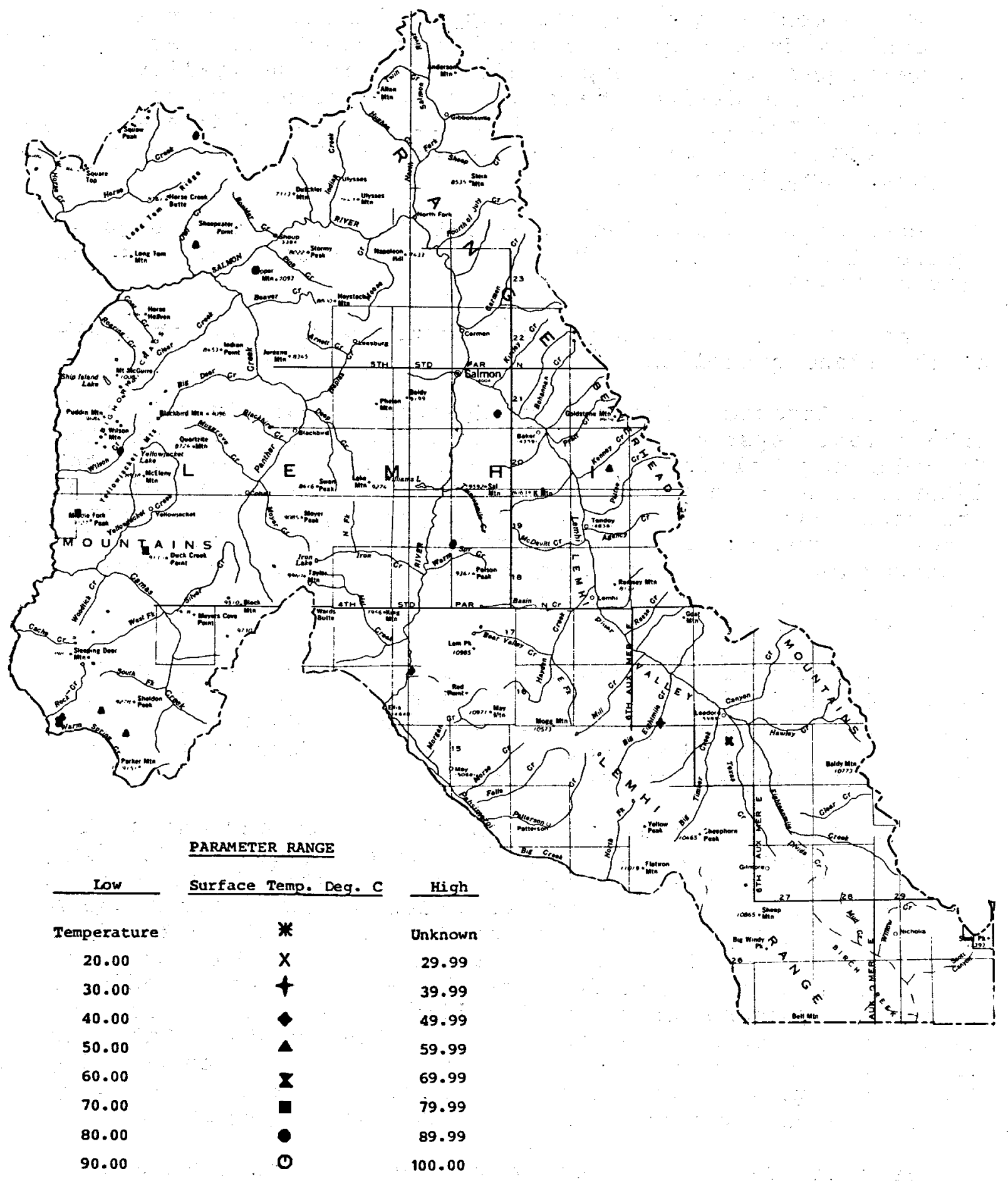

FIGURE 18. Index map of Lemhi County showing locations of thermal water occurrences with surface temperatures of $20^{\circ} \mathrm{C}$ or higher. 
the appearance of a flat plain stretching from the Bighorn Crags (Tertiary pluton) which rise above the general remnant surfaces. Elevations range from $976 \mathrm{~m}$ in the Salmon River Canyon to over $2,700 \mathrm{~m}$ in the western part of the study area.

Bennett further stated (p. 8):

The rocks in the Blackbird Mountain quadrangle are, for the most part, precambrian metasediments and intrusives which have undergone several episodes of folding and faulting. Large scale thrust faulting, block faulting, and Tertiary igneous activity (both intrusive and extrusive) have added to the complexity. Lack of good stratigraphic control greatly complicates the interpretation of the geology; indeed, even the gross ages of the main units remains questionable.

Bennett's linear map of the area is included here as figure 19. He noted five major trends:

a. There are three prominent sets of linears, a northwest set, a northeast set and a northnorthwest set.

b. A set of linears which outlines the eastern edge of the Crags pluton may represent a curvilinear fracture system associated with emplacement of the pluton. These linears trend northwest along Roaring Creek, northsouth just east of Cathedral Rock and northnortheast along Yellowjacket Creek.

c. Many of the major drainages appear to coincide with linear segments such as the Panther Creek-Napias Creek Iineament.

d. Linears appear more concentrated in the area of Blackbird Creek, Musgrove Creek and Porphyry Creek. In this area, the intersection of northeast and northwest linears forms a boxwork pattern. Several of the northeast linears are confined to a belt bordered by the Panther Creek-Napias lineament to the east and the headwaters of Blackbird Creek, Musgrove Creek and Porphyry creek to the west.

e. Comparison of figures 20 and 21 shows that the -150 gamma contour, which may represent the western limit of the Leesburg stock, coincides with linear segments just east of 


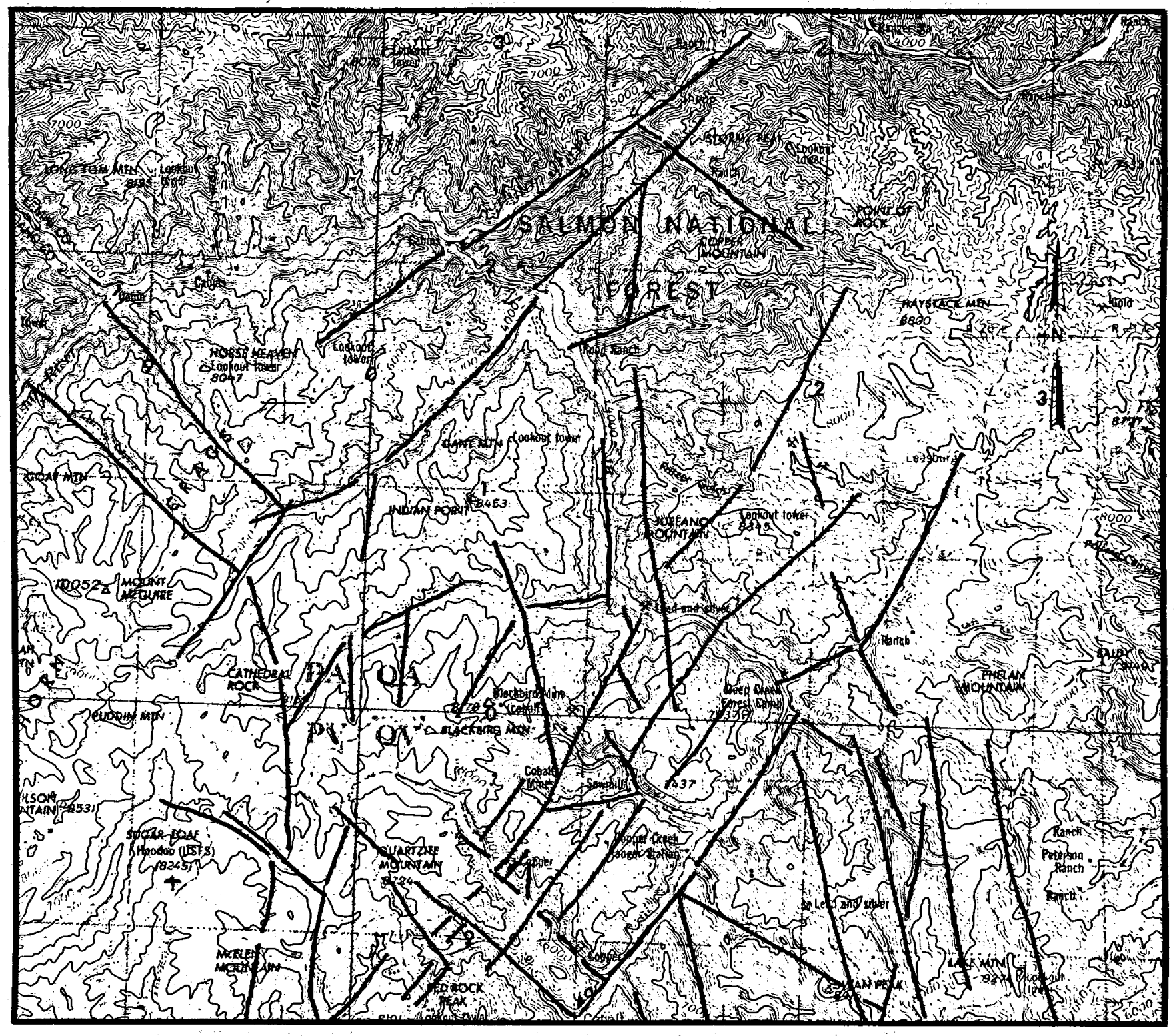

FIGURE 19. Linear map compiled from Landsat, false color, infrared imagery. Topographic base is from Elk City AMS map (scale 1:250,000). From Bennett, 1977, p. 33 . 
the Panther Creek and along Napias Creek and Moccasin Creek.

of interest to this study are the 1 inears that intersect in the vicinity of Big Creek Hot Springs. The Hot Springs Creek part of the Clear Creek-Hot springs creek Iineament has been mapped as a fault (figure 19). The north trending lineament approximately follows the Augen-Greiss-Yellowjacket Formation (figures 19 and 20 ).

of interest to this report is Bennett's aeromagnetic map of the area as shown in figure 21 . Bennett reported that:

A positive magnetic anomaly (maximum +150 gamma) is expressed northwest of Leesburg on Camp Creek.

Bennett believed this represented the magnetic expression of the Leesburg stock. Bennett reported that:

The small part of the stock exposed along Arnett Creek extends from the +50 gamma contour across the 0 gamma contour. The -100 gamma line which surrounds the +150 ine (south of Haystack Mountain) marks the western limit of silver, lead and molybdenum anomalies which are probably related to the stock. The -150 gamma contour near Jureano Mountain extends along the Leesburg fault and may mark the western limit of the stock in the subsurface.

The area enclosed by the -210 gamma line over Gant Mountain and the surrounding -200 gamma line are most likely expressions of the augen/ellipsoidal gneiss unit and its subsurface extension to the northwest beneath the undifferentiated metamorphic rocks. In fact, most of the area which is less than -150 gammas, within the study area, appears to be related to the outcrop patterns of the augen gneiss.

Big Creek Hot Springs 1 ies on the -170 to -200 gamma trough. This trough follows the general trend of the Hot Springs fault.

The land is administered by the U.S. Forest service (USFS). Until leases are issued, prospects such as Big Creek Hot springs cannot contribute to our energy supply. The area is remote but not roadless. The nearest sizable market for electricity would be Missoula, Montana; however, recent electric wheeling legislation could allow development by utilities located out of the area.

Salmon Hot Springs (20N-22E-3abdls), $10 \mathrm{~km}$ south of Salmon, has a surface temperature of $45^{\circ} \mathrm{C}$, and is the 
FIGURE 20. Geologic map of the Big Creek Hot spring area in Lemhi County, Idaho

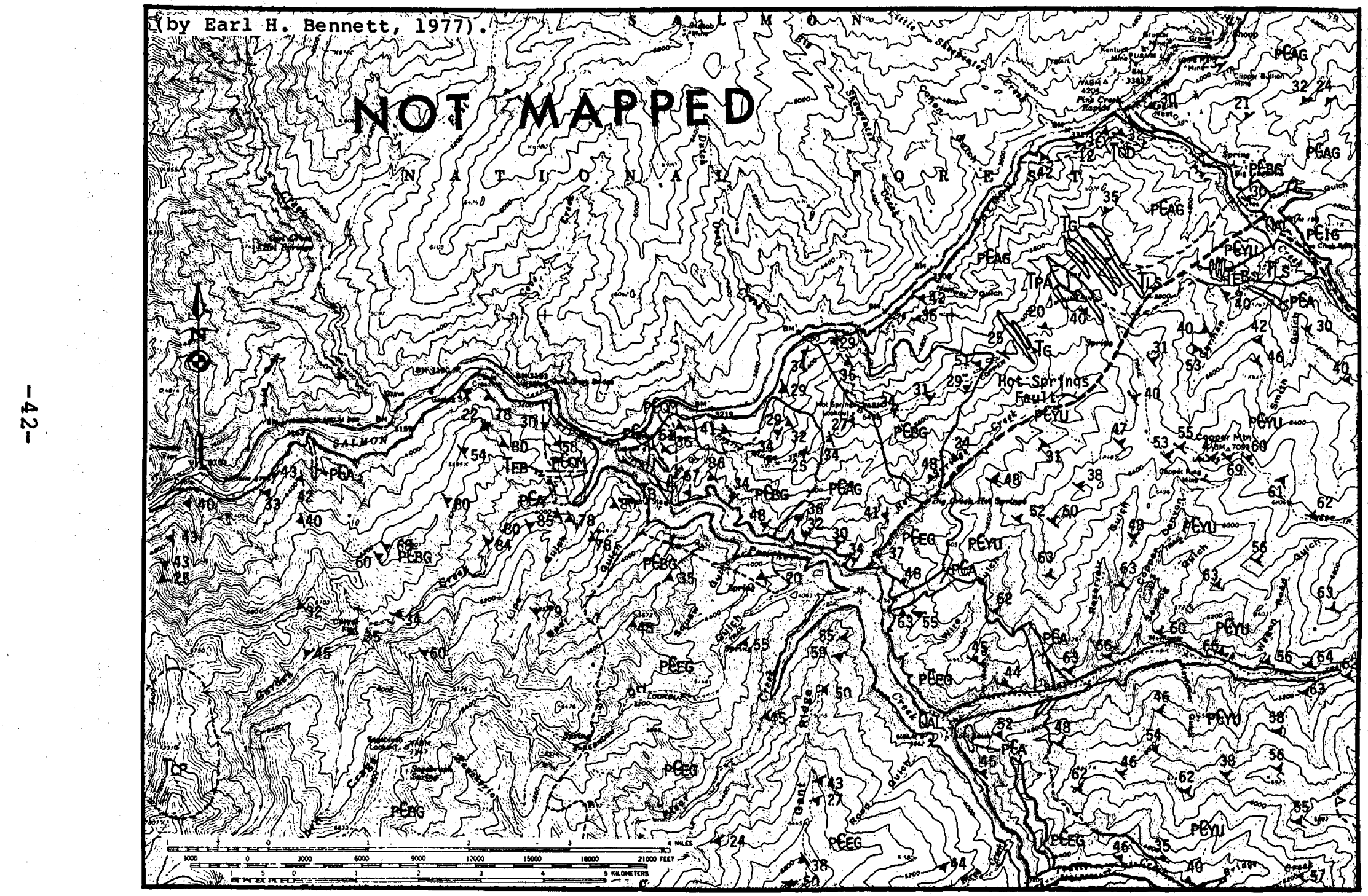




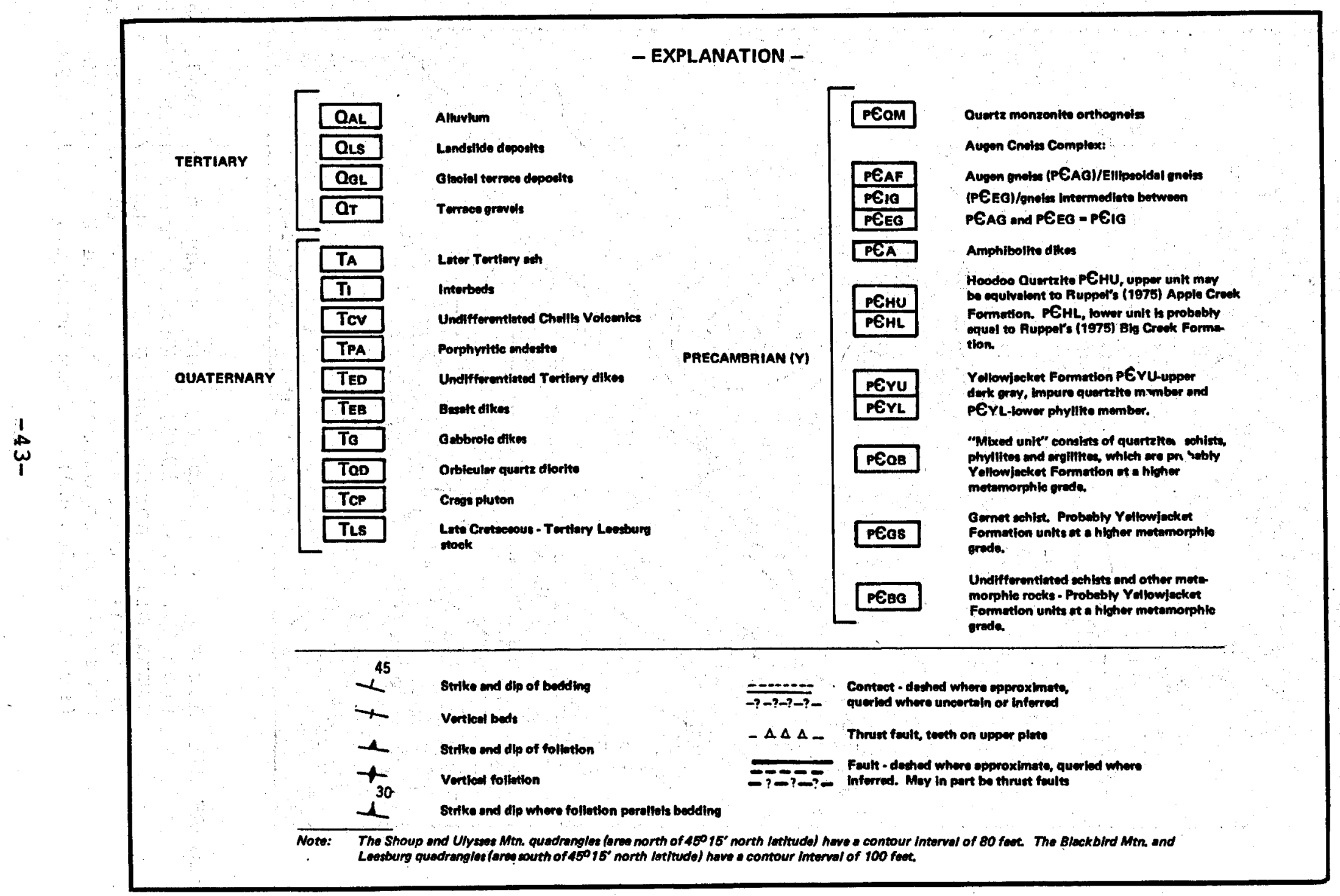




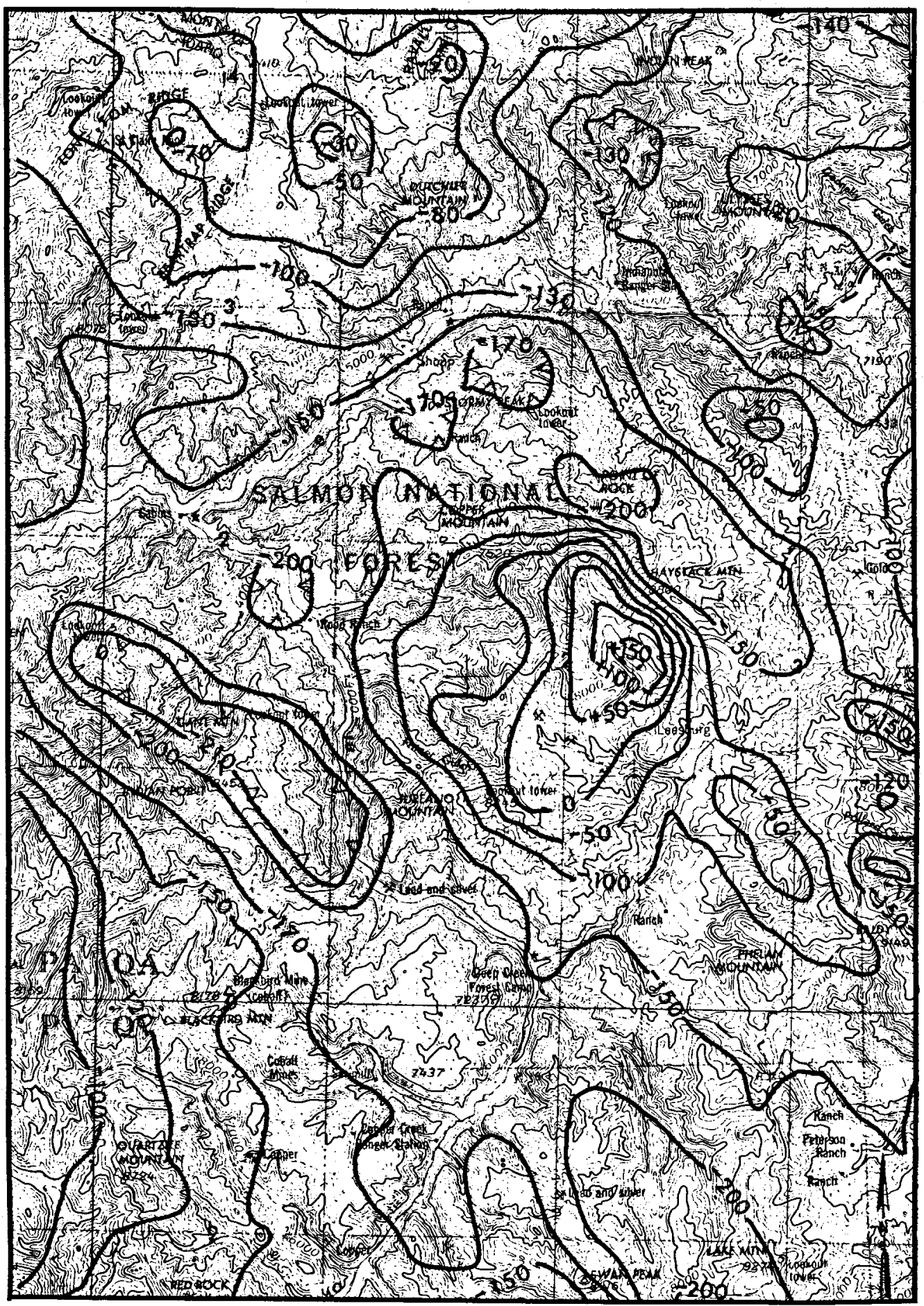

FIGURE 21. Aeromagnetic map of the study area (modified from U.S.G.S., 1975). Map is drawn with a 6.17 gamma/mile north and a 3.92 gamma/mile east regional trend removed. Magnetic contours are overlain on topography from the Elk City AMS map (scale 1:250,000). From Bennett, 1977, p.28. 
nearest of any thermal springs in Lemhi county to a meaningful population center. Aquifer temperatures at salmon Hot Springs appear to be only $50^{\circ} \mathrm{C}$ by the chalcedony chemical geothermometers (basic data table 2) although the $\mathrm{Na}-\mathrm{K}-\mathrm{Ca}$ chemical geothermometer indicated temperatures may be as high as $204^{\circ} \mathrm{C}$. This discrepancy could be caused by mixing of hot and cold water or precipitation of calcium in the subsurface. There is excess travertine deposition by the spring. This site might have potential for space heating in or near Salmon.

Sharkey Hot Springs (20N-24E-34cccls) issues from oligocene silicic volcanic rocks along a northwest trending fault. It is actively depositing small quantities of carbonate material and apparently formerly deposited silica. It discharges $30 \mathrm{l} / \mathrm{min}$. Measured surface temperature is $52^{\circ} \mathrm{C}$. Maximum subsurface temperature is thought to be best represented by the chalcedony chemical geothermometers at $104^{\circ} \mathrm{C}$. Sharkey Hot springs is somewhat removed from population centers but is accessible by an improved road.

A spring (16N-21E-18adcls) located on the Salmon River discharges $25 \mathrm{l} / \mathrm{min}$ and has a surface temperature of $46^{\circ} \mathrm{C}$. It issues from the alluvial material probably overlying Precambrian quartzite. This spring deposits small quantities of carbonate material locally. Subsurface temperatures may best be represented by the chalcedony chemical geothermometer at $57^{\circ} \mathrm{C}$.

\section{BOISE COUNTY}

Thermal springs in Boise County are most numerous along the South Fork of the Payette River (figure 22). Garden Valley lies at the confluence of the south and Middle Forks of the Payette River and is popular as a summer home resort area. Several thermal springs and at least one thermal well are in the Garden Valley area. Two thermal springs exist near Idaho City. One, stope Warm springs (6N-5E-33abcls), occurs in an abandoned mine adit. The other, Warm Springs (6N-5E-33adc1s), has been developed into a popular resort. Idaho city is also a popular summer home area where use could be made of thermal water for space heating.

Little is known of the characteristics of thermal water as only six chemical analyses are available from 19 known thermal occurrences in Boise County. More sampling of thermal water occurrences should be undertaken to more fully assess the area's geothermal potential.

In general, the dissolved solids are low except for flouride and sulfate concentrations in those thermal waters sampled; generally, the water is a sodium bicarbonate type. 
FIGURE 22. Index map of Boise County showing locations of thermal water occurrences with surface temperatures of $20^{\circ} \mathrm{C}$ or higher.

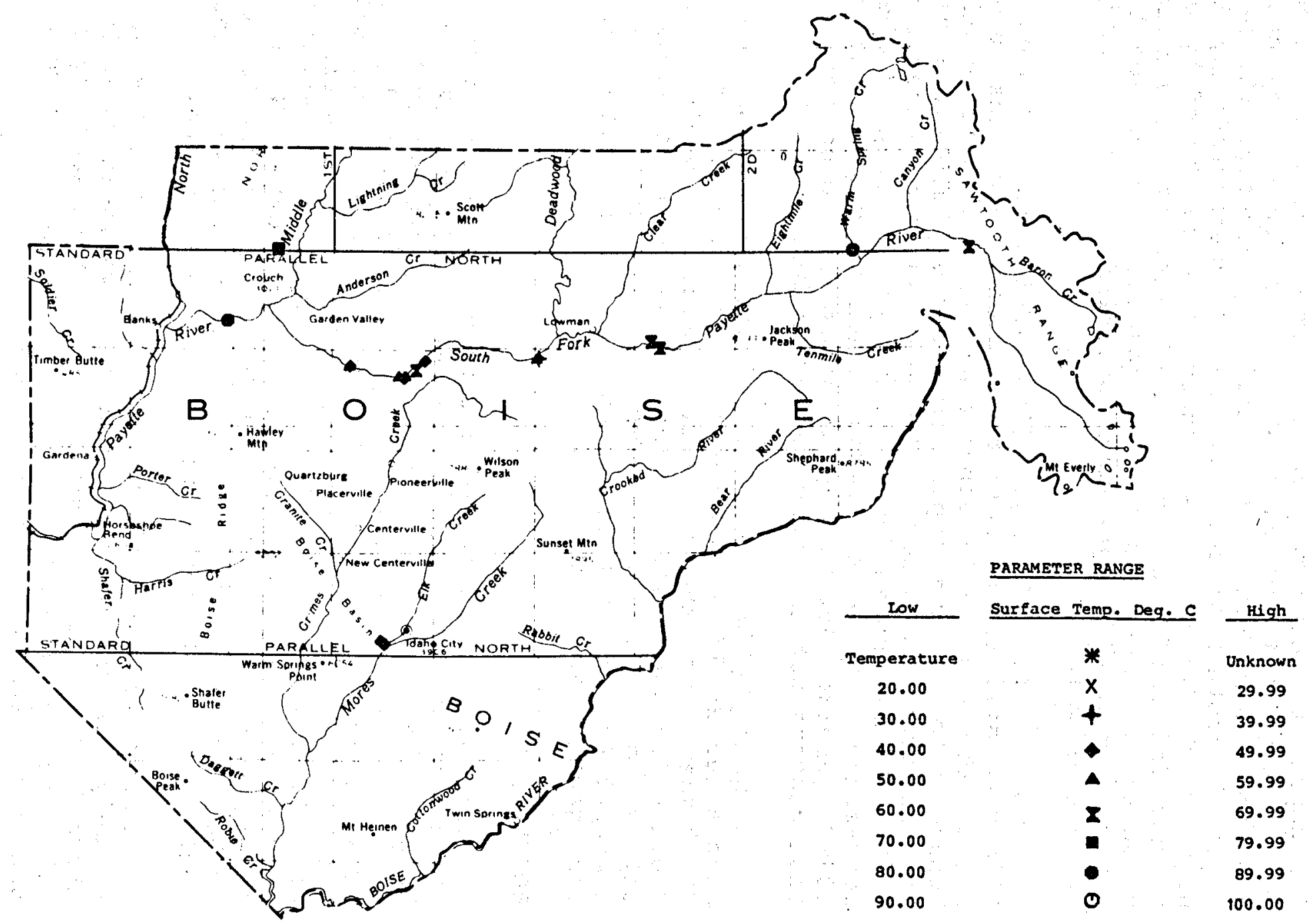


Bonneville Hot Springs (10N-10E-31bccls) is the hottest thermal water in Boise county at $85^{\circ} \mathrm{C}$ and has a $1400 \mathrm{l} / \mathrm{m}$ discharge issuing from a fault in granite (Ross .1971). Bonneville Hot springs may have potential for binary cycle power generation, as the quartz and $\mathrm{Na}-\mathrm{K}-\mathrm{Ca}$ chemical geothermometers estimate temperatures of 137 and $142^{\circ} \mathrm{C}$.

Deer Hot Springs ( $9 \mathrm{~N}-3 \mathrm{E}-25 \mathrm{bacls})$ might also have potential for binary cycle power, as quartz and $\mathrm{Na}-\mathrm{K}-\mathrm{Ca}$ chemical geothermometers estimate temperatures of 147 and $134^{\circ} \mathrm{C}$. Deer Hot springs has a surface temperature of $80^{\circ} \mathrm{C}$ and discharges $76 \mathrm{l} / \mathrm{min}$.

Other thermal springs are much cooler having surface temperatures between 46 and $67^{\circ} \mathrm{C}$ and subsurface temperatures between 60 and $104^{\circ} \mathrm{C}$, according to the $\mathrm{Na}-\mathrm{K}-\mathrm{Ca}$ and chalcedony chemical geothermometers. The $\mathrm{Na}-\mathrm{K}-\mathrm{Ca}$ chemical geothermometer indicates subsurface temperatures cool in a fairly systematic way from a high of $142^{\circ} \mathrm{C}$ at Bonneville Hot Springs in the upper reaches of the South Fork Payette River to a low of $63^{\circ} \mathrm{C}$ near Danskin Creek Hot Springs (8N-5Elbccls).

Sacajawea Hot springs (10N-11E-3laadls) in the upper reaches of the South Fork Payette River drainage has not been sampled, but has a surface temperature of $68^{\circ} \mathrm{C}$ and reported discharge of $3801 / \mathrm{min}$.

Twin Springs ( $4 \mathrm{~N}-6 \mathrm{E}-24 \mathrm{bcb} 1 \mathrm{~S})$, a developed resort, is so named because a thermal and nonthermal spring occur in close proximity and is located in the lower reaches of the Middle Fork of the Boise River above Arrowrock Reservoir. The thermal spring discharges water at $67^{\circ} \mathrm{C}$. Subsurface temperatures may be as $\mathrm{high}$ as $104^{\circ} \mathrm{C}$, according to the chalcedony chemical geothermometer. The Na-K-Ca chemical geothermometer predicts $60^{\circ} \mathrm{C}$, unexplainedly $7^{\circ} \mathrm{C}$ below measured surface temperatures.

\section{CUSTER COUNTY}

Thermal springs in Custer County (figure 23) are similar in occurrence to springs in most of the rest of northcentral Idaho occurring near drainage confluences or near ridge points that protrude into the stream. The thermal waters are generally low in dissolved solids and have high pH values. About half are on lands administered by the USFS and many could be developed for recreational uses. One, Stanley Hot springs (10N-13E-3cabls), has now been covered over.

Generalities on thermal spring occurrences along the Middle Fork of the Salmon River were given earlier in the section on Valley County. These are in remote areas, so 


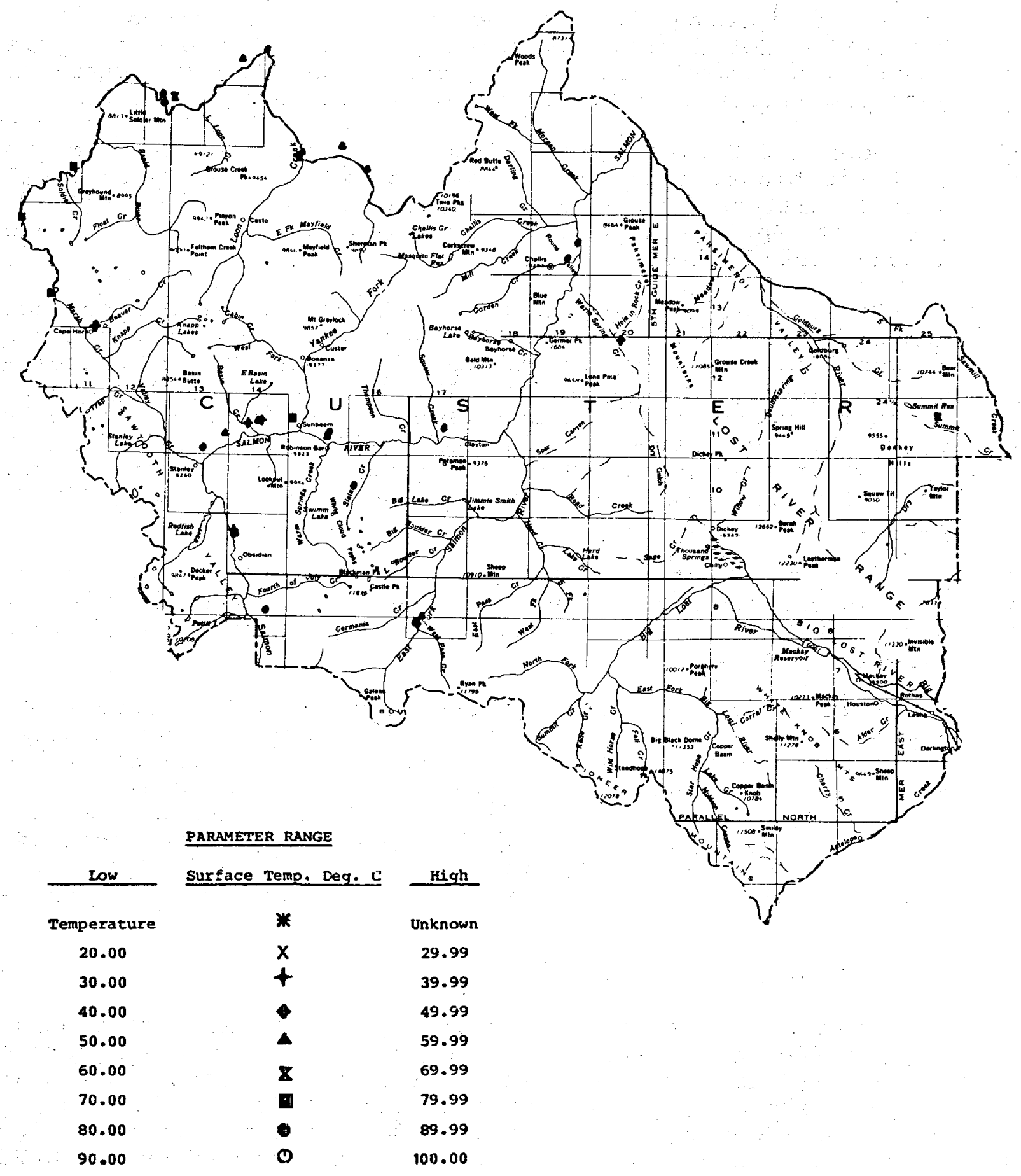

FIGURE 23. Index map of Custer County showing locations of thermal water occurrences with surface temperatures of $20^{\circ} \mathrm{C}$ or higher. 


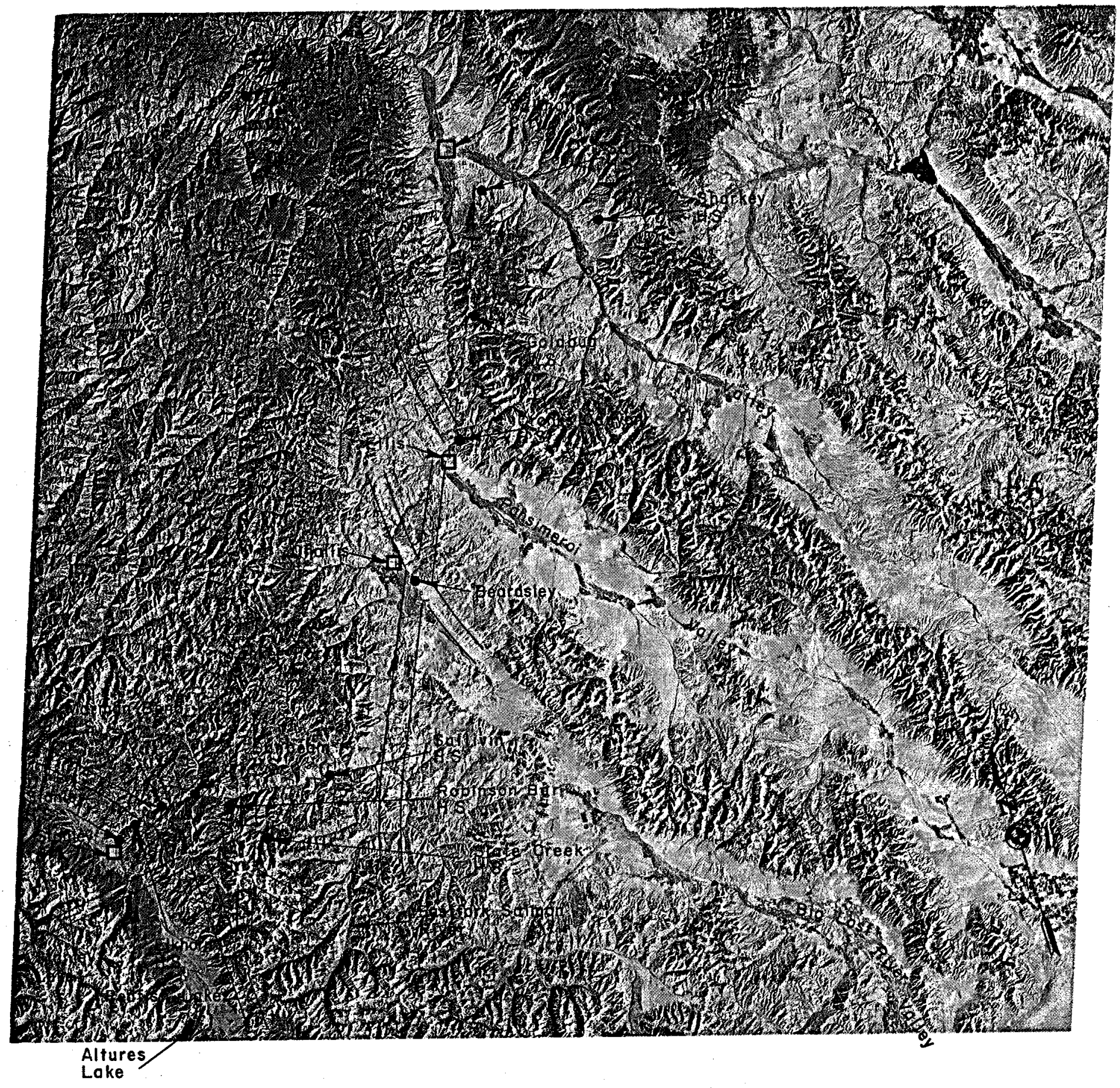

FIGURE 24. EROS false color infrared Landsat EDISE image of central Idaho showing selected linear features and thermal water locations with surface temperatures above $20^{\circ} \mathrm{C}$. 


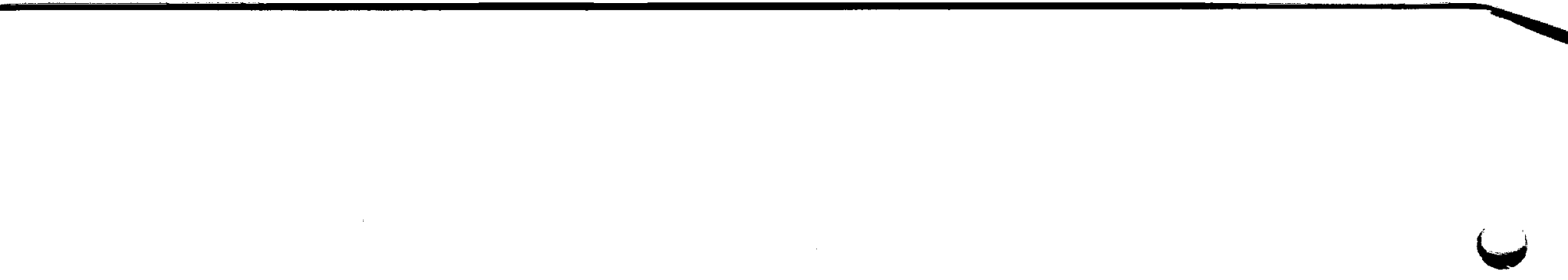


large scale development for industrial purposes is not likely. Springs along the main Salmon River between Smiley creek and Salmon generally lie within recreation area boundaries on both private land and land administered by the USFS. Some of these springs have potential for recreational uses. Several are presently used as such and others have been previously used for such purposes. In areas that are being developed for recreational home sites, springs could be utilized for space heating. Some of these springs might be used similar to the way springs in Boise county are used by the Idaho Department of Fish and Game as a heat source for game bird production, particularly wild turkeys and grouse. As most of the area is far from markets and few good transportation facilities exist, most other uses appear to be excluded, although locally small scale uses, such as greenhouse operations, might be feasible.

Figure 24 is an enhanced Landsat false color infrared image of part of Central Idaho showing locations of selected thermal water discharges and linear features. The common occurrence of springs and lineaments is not striking on the figure. Nevertheless, several major linear features are shown near the thermal springs or wells. The chemical geothermometers are highly variable for custer county. Highest aquifer temperatures appear to be near $104^{\circ} \mathrm{C}$ in the area of Basin Creek, Mormon Bend and Sunbeam Hot Springs.

\section{NORTHERN ELMORE COUNTY}

Thermal springs in northern Elmore County (figure 25) are distributed along the major drainages -- the North, Middle, and South Forks of the Boise River. These occurrences along the drainages are similar to other springs in central Idaho.

Ross (1971, p. 13 and 14) states that:

More than a dozen thermal springs occur along the lineament that marks the main Boise River and its Middle Fork tributary. All the springs issue from granite, in areas transected by granitic and mafic dikes. Between Twin Springs (4N-6E-24bcb1S) in Boise County and weatherby Mill well (6N-9E-35acal) springs average one every 2 miles. A single spring $(6 \mathrm{~N}-11 \mathrm{E}-35 \mathrm{dca}$ (S) is northeast of Altanta along the same lineament.

The $29^{\circ} \mathrm{C}$ water from the flowing well at weatherby Mill is considered by local residents too mineralized to drink, al though total dissolved solids are similar to those in the other springs.

Approximately a dozen thermal anomalies (figure 25) occur along the upper reaches of the South Fork of 


\section{EARAMETER RANGE}

Low

Temperature

20.00

30.00

40.00

50.00

60.00

70.00

80.00

90.00

Surface Temo. Deg. C

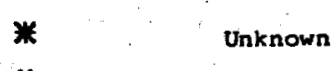

$x$

29.99

$-39.99$

49.99

59.99

69.99

79.99

89.99

100.00

$\mathbf{0}$

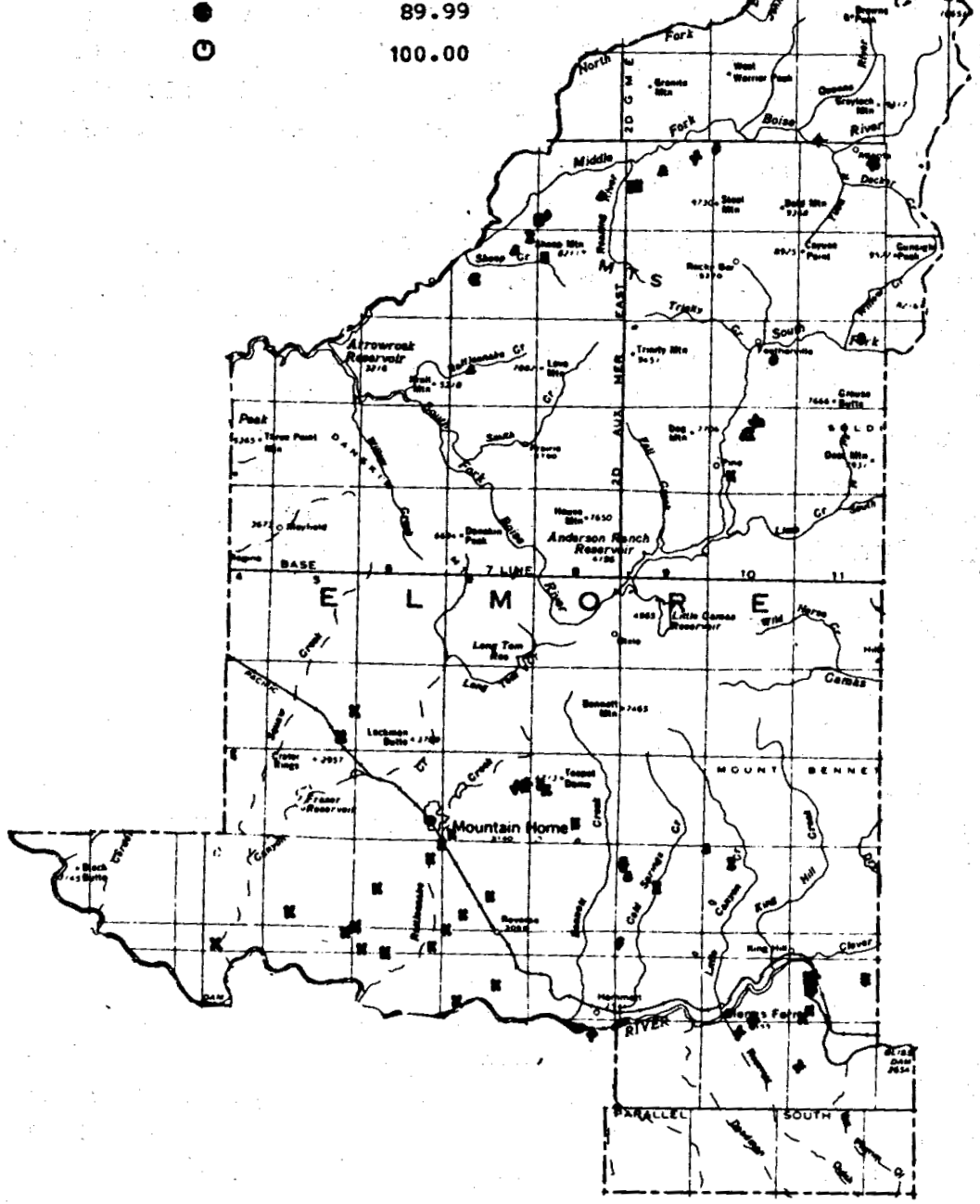

FIGURE 25. Index map of Elmore county showing locations of thermal water occurrences with surface temperatures of $20^{\circ} \mathrm{C}$ or higher. 
the Boise River and its tributaries. All are in granitic rock, much of which is cut by mafic and pegmatitic dikes.

Paradise Hot Springs ( $3 \mathrm{~N}-10 \mathrm{E}-33 \mathrm{bdblS})$ utilizes $60^{\circ} \mathrm{C}$ water in a swimming pool at a resort. A mile south, Bridge Hot Spring (2N-10E-5acals) and related seeps flow more than $150 \mathrm{gpm}$, also at $60^{\circ} \mathrm{C}$. $A$ warm spring (3N-10E-10abals) and several warm wells are at Featherville. The $46^{\circ} \mathrm{C}$ water at Baumgartner Hot Spring ( $3 \mathrm{~N}-12 \mathrm{E}-7 \mathrm{dcd} 1 \mathrm{~S})$ is used for bathing facilities at a Forest service campground. Lightfoot Hot Spring ( $3 \mathrm{~N}-13 \mathrm{E}-7 \mathrm{dcalS})$ apparently was used at one time for domestic heating and for irrigation of a small meadow. Maximum temperature is $62^{\circ} \mathrm{C}$.

Highest temperatures along the South Fork of the Boise River are at the east and west extremities of the regions.

The chemical geothermometers indicate some of the hotter of the low temperature thermal water in Idaho might be found in northern Elmore County. The $\mathrm{Na}-\mathrm{K}-\mathrm{Ca}$ and quartz chemical geothermometers indicate temperatures as high as $126^{\circ} \mathrm{C} \mathrm{might}$ be found by drilling at Neinmeyer Hot springs (5N-7E-24bddls). At Latty Hot Springs (3S-10E-3lddbls), temperatures might be as high as $137^{\circ} \mathrm{C}$. Most of the other springs in the area show subsurface temperatures below $80^{\circ} \mathrm{C}$, according to the $\mathrm{Na}-\mathrm{K}-\mathrm{Ca}$ chemical geothermometer.

Most of these thermal springs are on lands administered by the USFS and several more probably could be developed by the USFS for recreation purposes. Those that occur near vacation homesites (table 4 ) could probably be developed for space heating, provided flows could be augmented by drilling. Some of them could be used by the Idaho Department of Fish and Game as a heat source for game bird production.

\section{CAMAS COUNTY}

Camas county (figure 26) contains several thermal springs and wells. Many are in the unpopulated Soldier Mountain area to the north of Camas prairie. These occurrences are similar to the rest of the thermal springs in central Idaho. They are limited to the south Fork of the Boise River and its tributaries in northern Camas county. Located here are Worswick (3N-14E-28caals), Preis (3N-14E19dac1s), Wardrop (1N-13E-32abbls) and Lightfoot (3N-13E7dcals) hot springs. Worswick Hot springs is probably the most extensive thermal spring in Idaho covering more than 10 acres and having dozens of vents, according to Ross (1971). 
TABLE 4

TOWNS AND RECREATIONAL HOME AREAS IN CENTRAL IDAHO WITHIN 5 KM (3 MI) OF A $20^{\circ} \mathrm{C}$ OR HIGHER THERMAL SPRING OR WELL

\begin{tabular}{|c|c|c|c|c|c|c|c|c|c|c|}
\hline Town & County & Location & $\begin{array}{l}\text { Spring } \\
\text { or } \\
\text { Well } \\
\text { Surface } \\
\text { empera- } \\
\text { ture oc } \\
\end{array}$ & $\begin{array}{r}\text { Est } \\
\text { Subs } \\
\text { Temper } \\
\begin{array}{c}\text { Mino } \\
\mathrm{Na}-\mathrm{K}-\mathrm{Ca}\end{array} \\
\end{array}$ & $\begin{array}{c}\text { Max. } \\
\text { imated } \\
\text { urface } \\
\text { ature oc } \\
\text { Chalcedony }\end{array}$ & $\begin{array}{l}\text { Total } \\
\text { Dissolved } \\
\text { Sollids } \\
\end{array}$ & $\begin{array}{c}\text { Present } \\
\text { Water } \\
\text { Use } \\
\end{array}$ & Population & $\begin{array}{r}\text { Surface } \\
\text { Owner }\end{array}$ & Remarks \\
\hline Atlanta & Elmore & $5 N-11 E-3$ & - & - & - & - & - & - & - & $\begin{array}{l}\text { No chemical anal- } \\
\text { yses aval lable, } \\
\text { summer home } \\
\text { sites. }\end{array}$ \\
\hline Cascade & Valley & $14 N-3 E-36 a b d 1$ & 43 & 46 & 66 & 193 & Munlclpal pool & 916 & City of & - \\
\hline $\begin{array}{l}\text { Chall is } \\
\text { Clayton }\end{array}$ & $\begin{array}{l}\text { Custer } \\
\text { Custer }\end{array}$ & $\begin{array}{l}14 N-19 E-23 d d d 1 S \\
11 N-17 E-27 b d d 1 S\end{array}$ & $\begin{array}{l}40 \\
41\end{array}$ & $\begin{array}{l}60 \\
58\end{array}$ & $\begin{array}{l}68 \\
99 * *\end{array}$ & 640 & $\begin{array}{l}\text { Natator i um } \\
\text { Natator I um } \\
\text { Recreation }\end{array}$ & $\begin{array}{l}850 \\
41\end{array}$ & $\begin{array}{l}\text { Private } \\
\text { Private }\end{array}$ & $\begin{array}{l}\text { Summer home sites. } \\
\text { Summer home sites. }\end{array}$ \\
\hline $\begin{array}{l}\text { Council } \\
\text { Ellis }\end{array}$ & $\begin{array}{l}\text { Adams } \\
\text { Custer }\end{array}$ & $\begin{array}{l}16 N-1 W-15 \text { bac } 1 \\
16 N-2 E-18 \text { adc } 15\end{array}$ & $\begin{array}{l}22 \\
46\end{array}$ & 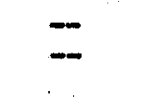 & $=$ & -- & Irrlgation & 923 & Private & Springs in Lemh I \\
\hline $\begin{array}{l}\text { Feather- } \\
\text { ville }\end{array}$ & Elmore & $3 N-10 E-10 a b a 1$ & 43 & - & - & - & Space heating & - & Private & Summer home sltes. \\
\hline $\begin{array}{l}\text { Garden } \\
\text { Valley }\end{array}$ & Boise & $8 N-5 E-10 b d d 1 S$ & 55 & 74 & 80 & 237 & $\begin{array}{l}\text { Space heating, } \\
\text { private swim- } \\
\text { ming }\end{array}$ & - & Private & Summer home sltes. \\
\hline Halley & Blaine & $2 N-18 E-18 d b b 1 S$ & 59 & 83 & 100 & 272 & Space heating & 1,840 & Private & $\begin{array}{l}\text { Heated Hiawatha } \\
\text { Hotel. }\end{array}$ \\
\hline I daho City & Bolso & $6 N-5 E-30$ acd 15 & 41 & - & - & - & Natator I um & 194 & Private & $\begin{array}{l}\text { No chemlcal anal- } \\
\text { yses aval lable, } \\
\text { summer home sites. }\end{array}$ \\
\hline Ketchum & Blaine & $4 N-17 E-15 a a c i s$ & 71 & 88 & 101 & 324 & Space heating & 1,780 & Private & $\begin{array}{l}\text { Heats several con- } \\
\text { domini ums. }\end{array}$ \\
\hline Meadows & Adams & $19 N-2 E-22 c c a 1 s$ & 43 & 91 & $96^{* *}$ & 489 & Unused & - & - & $\begin{array}{l}\text { Public water sup- } \\
\text { ply. }\end{array}$ \\
\hline $\begin{array}{l}\text { Stan ley } \\
\text { Warm Lake }\end{array}$ & $\begin{array}{l}\text { Custer } \\
\text { Valley }\end{array}$ & $\begin{array}{l}10 N-13 E-3 c a b 1 S \\
15 N-6 E-14 c d b 1 S\end{array}$ & $\begin{array}{l}41 \\
55\end{array}$ & $\begin{array}{l}47 \\
62\end{array}$ & $\begin{array}{l}76 \\
83\end{array}$ & $\begin{array}{l}210 \\
258\end{array}$ & $\begin{array}{l}\text { Unused } \\
\text { Unused }\end{array}$ & -52 & Private & $\begin{array}{l}\text { Bath house \& pool. } \\
\text { Near summer home } \\
\text { sites. }\end{array}$ \\
\hline
\end{tabular}

* Minlmum and maximum subsurface temperatures are based on the chemical geothermometers from baslc data table 2. Both are given to call the reader's attention to the uncertaintles involved in their interpretation. Maximum temperatures should be viewed with some skepticism. The geothermometers are useful in initial assessment of geothermal areas to establish priorities for further work In these areas.

* Minimum temperature is chalcedony temperature. Maximum temperature is Na-K-Ca temperature. 


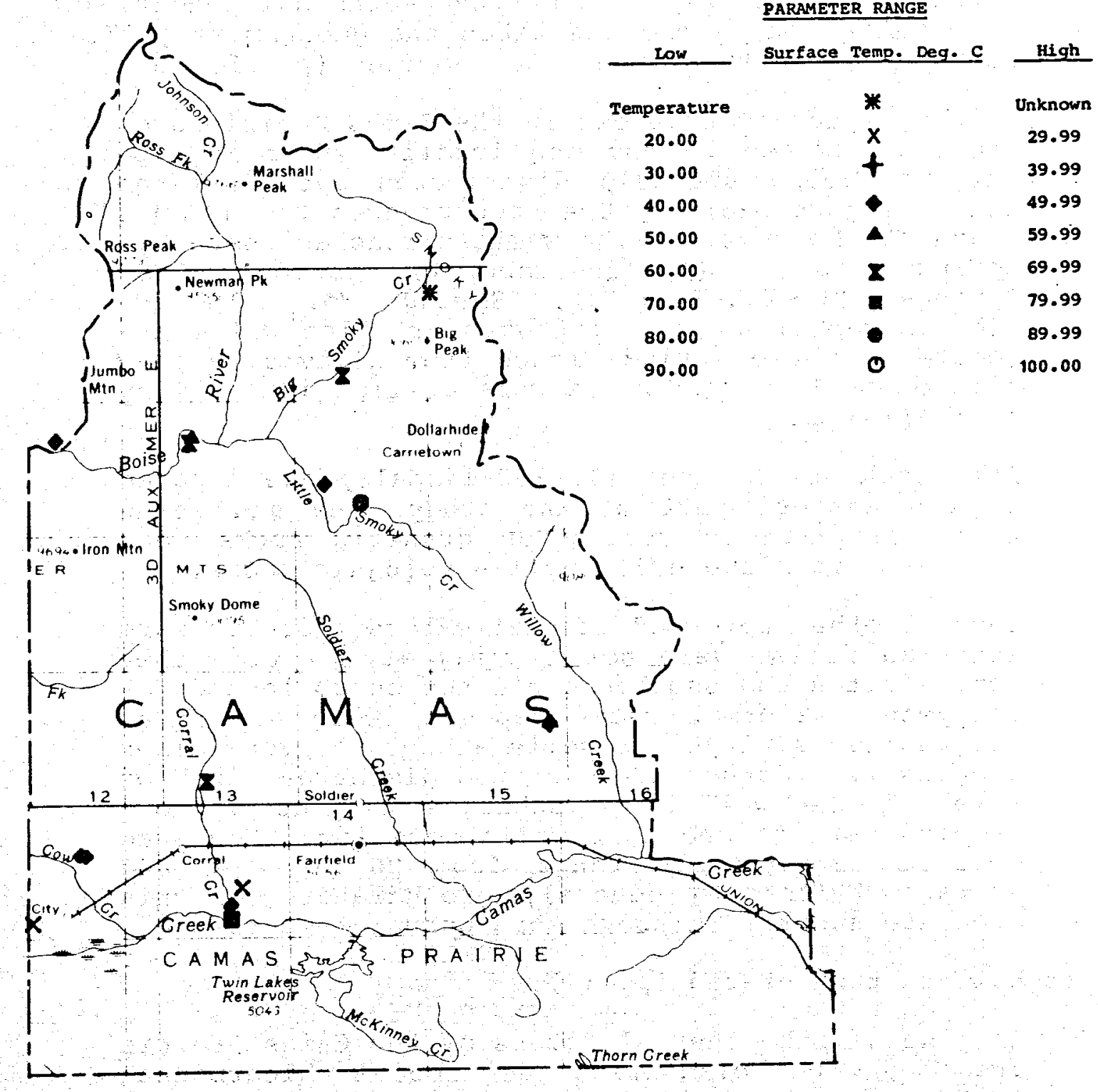

FIGURE 26. Index map of Camas county showing locations of thermal water occurrences with surface temperatures of $20^{\circ} \mathrm{C}$ or higher. 
Most flow at temperatures near $76^{\circ} \mathrm{C}$. Total discharge from the entire spring is over $1500 \mathrm{l} / \mathrm{min}$. Ross (1971, p. 14) reported that the entire area, which is brecciated, bleached, and silicified, was the probable intersection of several fault zones.

Mitchell (1976c) reported on the geothermal potential of southern Camas county and described the geochemistry of the thermal springs in this area. He reported ( $p .15)$ that:

Thermal water occurrences in the Camas Prairie area are not limited to any one locality or rock type but are found sparsely distributed over a large area (figure 26). The occurrences seem more abundant, however, in the western reaches where Hot Springs Ranch (1N-13E-32abcls), Barron's Hot Springs (1S-13E-34bcblS), Spring No. (1S-12E16cbals-cabls) and several warm artesian wells are located. These springs issue from alluvial valley fill deposits. The wells were drilled into valley fill alluvium.

Elk Creek Hot Springs (1N-15E-14adals) are located in the eastern part of the study area and issue from fractures in cretaceous granitic rocks near Eocene(?) to Miocene(?) Challis volcanic rocks.

Several other reported thermal waters (notably warm artesian wells) were not flowing at the time they were visited and samples could not be collected for analysis. Thermal water deposits were absent at all visited springs and wells except for very minor evaporative incrustations around discharge pipes of some of the wells. Discharges of the various sampled springs and most wells were low. Measured surface temperatures range from 26 to $72^{\circ} \mathrm{C}$ and average $53^{\circ} \mathrm{C}$. In general, groundwaters in this area are about $10^{\circ} \mathrm{C}$ above mean annual temperature.

Mitchell further stated (p. 17):

In general, the thermal waters of the Camas prairie area can be classified as sodium bicarbonate $\left(\mathrm{NaHCO}_{3}\right)$ type waters although the dominant element found in Hot Springs Ranch (1N-13E-32abcls) water is silica rather than sodium. With the exception of Magic Hot Springs well (1S-17E-23aabl) these thermal waters are typified by:

1. High silica contents (50-90 $\mathrm{mg} / 1$ ) compared to low total dissolved solids of less than 365 $\mathrm{mg} / \mathrm{l}$; 
2. High $\mathrm{pH}(7.8-9.2)$;

3. High carbonate compared to most thermal water in Idaho;

4. High fluoride contents compared to most thermal and cold groundwaters in Idaho;

5. Low calcium (Ca), magnesium (Mg), potassium (K), and chloride (Cl) contents.

Typically, these thermal waters are chemically similar to thermal waters found discharging from Cretaceous granitic rocks, or areas believed to be underlain by these type rocks elsewhere in Idaho (Ross, 1971, p. 23), (Young and Mitchell, 1972, unpublished data, and Young and Whitehead, 1975a, p. 30 ).

The cause of this chemical "fingerprint" for these waters is not well understood. At least three hypotheses might explain some of the observations.

1. Abundance of certain elements may reflect the availability of the elements in various minerals found in the granitic rocks and the minerals' solubility in heated water or steam. For example, the high fluoride content might be traced to the abundance of fluorite or fluorapatite, and its solubility at reservoir temperature, and $\mathrm{pH}$, or to fluoride, concealed in interlattice silicate structures of hydroxyl bearing minerals such as the micas or amphiboles, which are found in the granitic rocks.

2. High fluoride waters may reflect an appreciable quantity of magmatic waters or volcanic gasses. observations of gasses from volcanoes indicate magmatic waters should generally be high in volatiles such as fluoride, ammonia and boron.

3. High fluoride waters might be explained by enrichment of fluoride in a steam phase separated from water having a lower fluoride content (volatile enrichment).

The first explanation of the high fluoride content is considered by this author to be the best hypothesis because of:

1. The widespread occurrence of fluoride-rich thermal waters in Idaho; 
2. Their close association with granitic rocks or areas believed to be underlain by granitic rocks;

3. Lack of fumarolic, geyser, and related geothermal activity (which would indicate volatile enrichment processes are actively taking place);

4. Low concentrations of other volatiles, i.e., ammonia and boron, chemical constituents found in volcanic gasses, and which are also capable of enrichment in separated stean: In nearly all geothermal systems investigated to date, isotopic studies have not revealed any magmatic or juvenile water contributions to these systems.

5. Thermodynamic calculations indicate that thermal waters from Elk Creek Hot Springs (1N-15El4adals), which issue directly from fractures in granitic rocks, are in equilibrium with fluorite at the measured spring temperatures. Fluorite is known as an accessory mineral in certain granitic rocks in Idaho.

6. In general, granitic rocks are known to contain relatively much fluoride, mostly in fluroapatite, but, in some cases, a fluoride concealed in interlattice spaces of hydroxyl bearing minerals such as the micas or amphiboles where it substitues for hydroxide due to size and charge similarities.

The geochemical data suggested to Mitchell (1976c, p. 22) that the thermal waters in the Camas Prairie area are from low temperature systems.

The chalcedony equilibrium chemical geothermometer $\left(\mathrm{T}_{4}\right.$, basic data table 2) or $\mathrm{Na}-\mathrm{K}-\mathrm{Ca}$ chemical geothermometer ( $\mathrm{T}_{5}$, basic data table 2 ) are considered the most reliable and representative of actual aquifer temperatures in most cases because of these considerations:

1. Thermal waters issuing from granitic terrains are generally considered to be supersaturated with silica with respect to quartz (Holland 1967, p. 393). Therefore, the quartz equilibrium chemical geothermometer $\left(\mathrm{T}_{1}\right.$ and $\left.\mathrm{T}_{2}\right)$ and mixing models ( $T_{9}$ and $T_{10}$ ) may not be valid because of excess silica in many of these springs and wells. 
2. In no case does amorphous silica control silica concentration in the thermal water. The belowmeasured surface temperatures and in some cases below-zero temperatures predicted by the amorphous silica chemical geothermometer indicate that the thermal waters are considerably undersaturated with silica with respect to this phase. No exceptions to this generalization were noted from basic data table 2 in the Camas Prairie area.

3. No unusual conditions are suggestive of mixed hot and cold waters, such as cold spring seeps in the vicinity of the hot springs or wells, were observed.

4. Discharges were, in general, very low throughout the area, indicating little, if any, mixing of hot and cold waters. Exceptions to the low

- discharges are found only in drilled holes.

5. The low Na-K-Ca predicted aquifer temperatures are in general agreement with measured surface temperatures, indicating little mixing of hot and cold water, or that equilibrium conditions have been maintained since the waters have left the thermal aquifer. The low predicted $\mathrm{Na}-\mathrm{K}-\mathrm{Ca}$ aquifer temperatures show fair agreement with the chalcedony equilibrium aquifer temperatures.

6. The low chloride and certain other element concentrations found in these therinal waters could be the result of mixing. However, mixing would dilute certain other chemical constituents found in relatively high concentrations such as fluoride and carbonate.

7. Walton (1962, table 2, p. 35) reported higher calcium concentrations in cold groundwaters in the area than were found in the thermal waters. Dilution of thermal waters with cold groundwaters would mean the premixed thermal waters would have to be nearly devoid of calcium in order for the nixed water to show the calcium concentration found in the thermal waters. Thermal water devoid of calcium from granitic rocks is considered unlikely.

8. The extremely widespread geographical area in which these type waters are found would make it highly unlikely that such uniform mixing conditions could exist as to recognize these 
waters by merely looking at unsynthesized geochemical data.

9. Arnórsson $(1970$, p. 537,1975, p. 763) found that chalcedony generally controls silica concentration in Icelandic thermal waters when aquifer temperatures are below $100-110^{\circ} \mathrm{C}$. Chalcedony equilibrium aquifer temperatures are below Arnórsson's upper limit. Chalcedony equilibrium is, therefore, indicated if this criterion is applicable to the Camas prairie.

10. The depths postulated as necessary to give rise to the measured surface temperature are reasonable for the origin of these waters.

Mitchell (1976c, p. 25) concluded:

The Camas prairie thermal waters are probably meteroic waters circulating to shallow (approximately $1,200 \mathrm{~m}$ ) depths along fractures or fissures within the granitic rocks underlying and along the margins of the prairie. Heated waters are discharging upward into the sediments of the Prairie, perhaps through faults or fissures within the underlying granite concealed by valley fill. Some water subsequently discharges to the surface, forming springs. The source of the heat related to the granitic rocks is unknown.

The possibility of a large thermal aquifer or reservoir within the sediments filling the basin is negligible due to the apparent shallow depth of the valley fill materials as shown by the two wells penetrating the entire thickness of sediments near the basin center. Any possibility of a large thermal reservoir could lie in large faults in highly fractured granitic rock underlying the prairie. Fracture permeability may allow sufficient circulation and recharge to allow large volumes of water to be withdrawn if the fault system could be penetrated by drilling. Hot and cold groundwaters at depth probably are not mixing to any apparent degree. The thermal waters ascending from shallow depths could be cooling by conduction during their ascent to the surface.

Maximum temperatures encountered in drilling to 900 to $1,500 \mathrm{~m}$ are probably only about $100{ }^{\circ} \mathrm{C}$. Temperatures of this magnitude would be sufficient to have some industrial applications. These industrial applications and approximate temperatures necessary for them are shown in figure 4 . 


\section{NORTHERN BLAINE COUNTY}

Northern Blaine County (figure 27) is another region in Idaho where geothermal resources have been an energy source of long standing. Fifteen thermal springs are known in northern Blaine County. Several wells have been drilled near some of the thermal springs that yield hot water as at Magic Hot Springs. (1S-17E-23aabl), Hailey Hot Springs ( $2 \mathrm{~N}-$ 18E-18dbbls), Clarendon Hot Springs (3N-17E-27dcbls), Guyer Hot Springs (4N-17E-15aacls) and Easley Hot Springs (5N-16E10dbc1s).

Easley Hot springs is being used as a natatorium. The drilling of $a$ well at Magic Hot springs increased the temperature by $36^{\circ} \mathrm{C}$ from 38 to $74^{\circ} \mathrm{C}$. These waters have been used to space heat small cabins. At Magic Hot springs Landing, chemical geothermometers indicate aquifer temperature could be near $175^{\circ} \mathrm{C}$, which would make this area a candidate for power generation using methods similar to those planned for Raft River in Cassia County. Even a small power plant at this site could furnish much of the power needs for this rural area of Idaho. Cascading uses could be made of the power plant effluent.

In Blaine County three warm water wells occur near the northern margin of the eastern Snake River Plain near Carey, and three more occur $3 \mathrm{~km}$ northwest of Picabo. Condie Hot Springs (1S-2lE-14ddcls) occurs near Carey Lake.

The Hailey area is located in south-central Idaho on the Big Wood. River drainage. The geologic framework of the area consists of undifferentiated Paleozoic and Mesozoic marine sedimentary rocks. Hailey Hot Springs is located about $3 \mathrm{~km}$ from Hailey (population $1,840,1976$ ) on Democrat Gulch, a tributary to croy Creek which in turn is a tributary to the Big Wood River with confluence at Hailey (figure 28). Sufficient thermal water might possibly be withdrawn from near Hailey Hot springs to space heat the entire town of Hailey. The surface temperature of the spring is $59^{\circ} \mathrm{C}$. The chemical geothermometers suggest a temperature of 78 to $97^{\circ} \mathrm{C}$ might be encountered by deeper drilling. It is not known at what depth this temperature might be encountered, but it may be as deep as 900 to $1200 \mathrm{~m}$.

Hailey Hot Springs' structural setting is typical of the hot springs in central Idaho; that is, many do occur near the confluence of streams, indicating fault or similar structural control. Fault controlled geothermal systems may provide a significant resource in Idaho for local use, as has been found at Raft River and Boise. Hailey Hot Springs occurs on the curvilinear zone connecting Clarendon Hot Springs, Warfield Hot Springs, and Easley Hot Springs (see 
FIGURE 27. Index map of Blaine County showing locations of thermal water occurrences with surface temperatures of $20^{\circ} \mathrm{C}$ or higher.

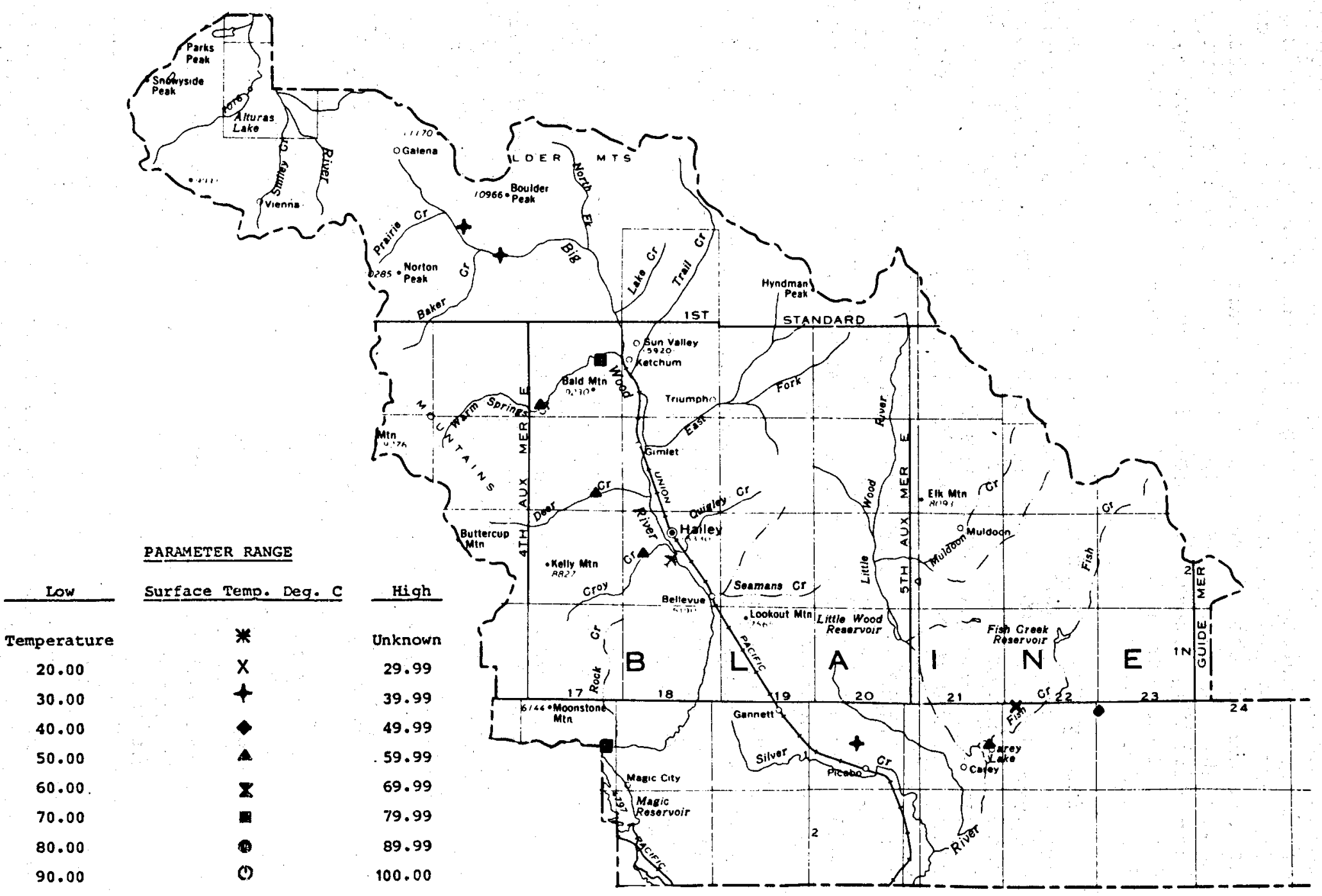




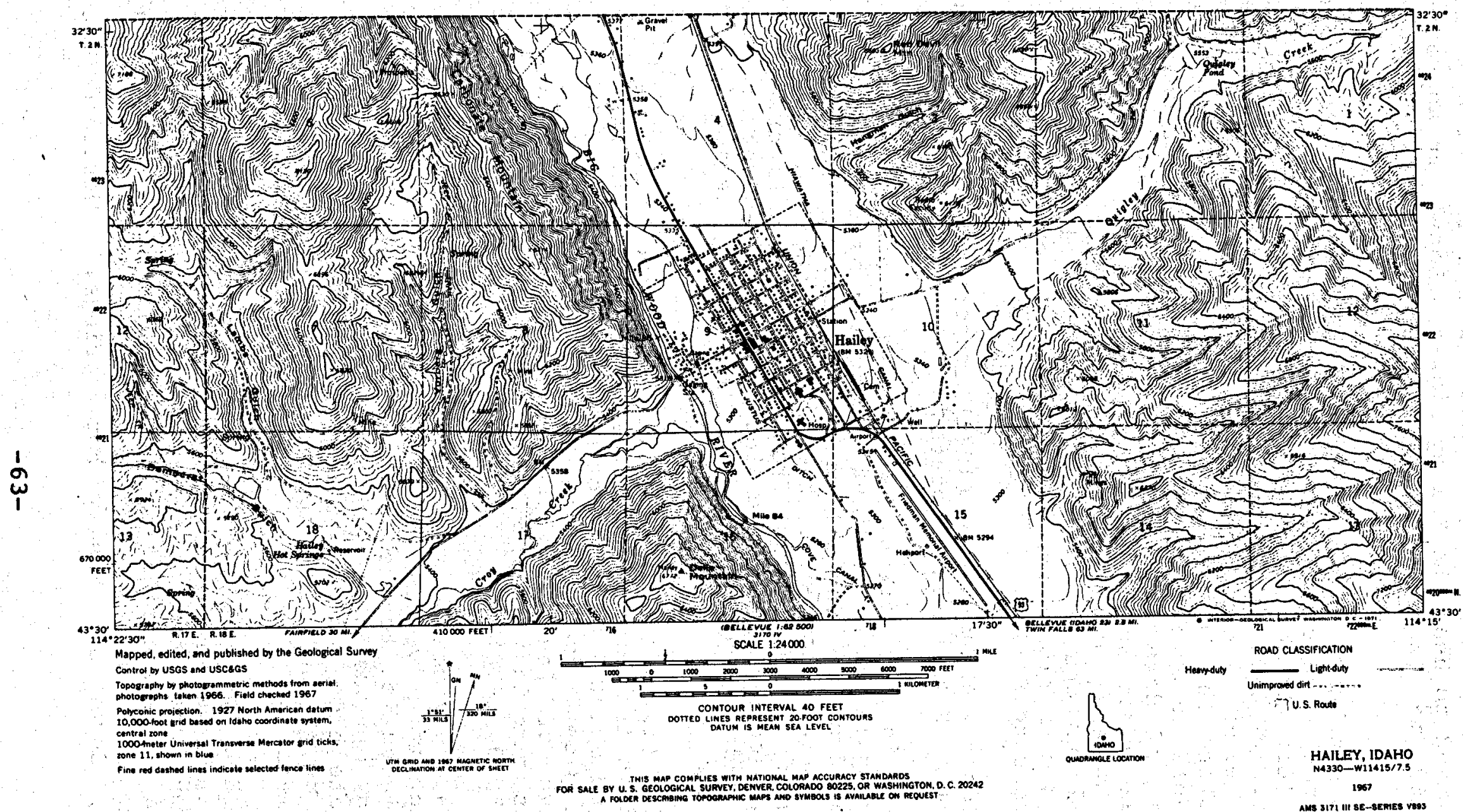

FIGURE 28. Topographic map of Hailey area showing location of Hailey Hot Springs with respect to the City of Hailey. 
figure 9 in pocket and figure 29). Hailey Hot Springs was formerly used to heat the Hailey Hiawatha Hotel, an approximately $560 \mathrm{~m}^{2}$ (square meter) structure which recently burned.

It is not known at present which structure or structures control the occurrence of thermal water at Hailey Hot Springs (Big Wood structure, Croy Creek-Quigley Creek structure, or Democrat Gulch structure). To confirm the size and exact location of the geothermal reservoir for space heating the town's buildings and residences, it will be advisable to evaluate, in some detail, reservoir characteristics and determine the amount and characteristics of geothermal water which could be witharawn for use. This would be done by drilling observation wells, running well tests and perhaps drilling exploration holes to see if existing water flows could be augmented, or a new source found closer to Hailey.

Donaldson and Applegate (1979), reporting on geophysics in the Hailey-Ketchum area, stated:

Gravity in the Ketchum-Hailey area is dominated by a strong regional gradient controlled by the transition from the snake River Plain gravity high to the gravity low over the Idaho batholith. Any detailed interpretation from gravity in this area would necessarily involve increasing the amount of data and carefully removing the strong regional gradient.

Witkind (1975) (figure 15) has identified an active fault in the lower Wood River Valley which is terminated about $7 \mathrm{~km}$ north of Hailey. Distortions in the regional gradient contours are, however, suggestive of faulting further up the valley and faults are indicated on the Idaho state Geologic Map (Bond, 1978).

A relatively small-amplitude, low-frequency magnetic high roughly centered over Bald Mountain and an associated low to the north may be indicative of a buried igneous unit (see figure 30). A strong elongate $\mathrm{high}$ and associated low centered about 15 miles NE of Sun Valley appears to be a near surface phenomena.

Guyer Hot Springs (4N-17E-15aacls) near Ketchum on Warm springs Creek is another area where thermal water is presently being used for space heating. Guyer hot springs occurrence is very similar to that at Hailey Hot springs and lies along a suspected curvilinear zone connecting Hailey, clarendon, Guyer and Easley hot springs. Warfield Hot 


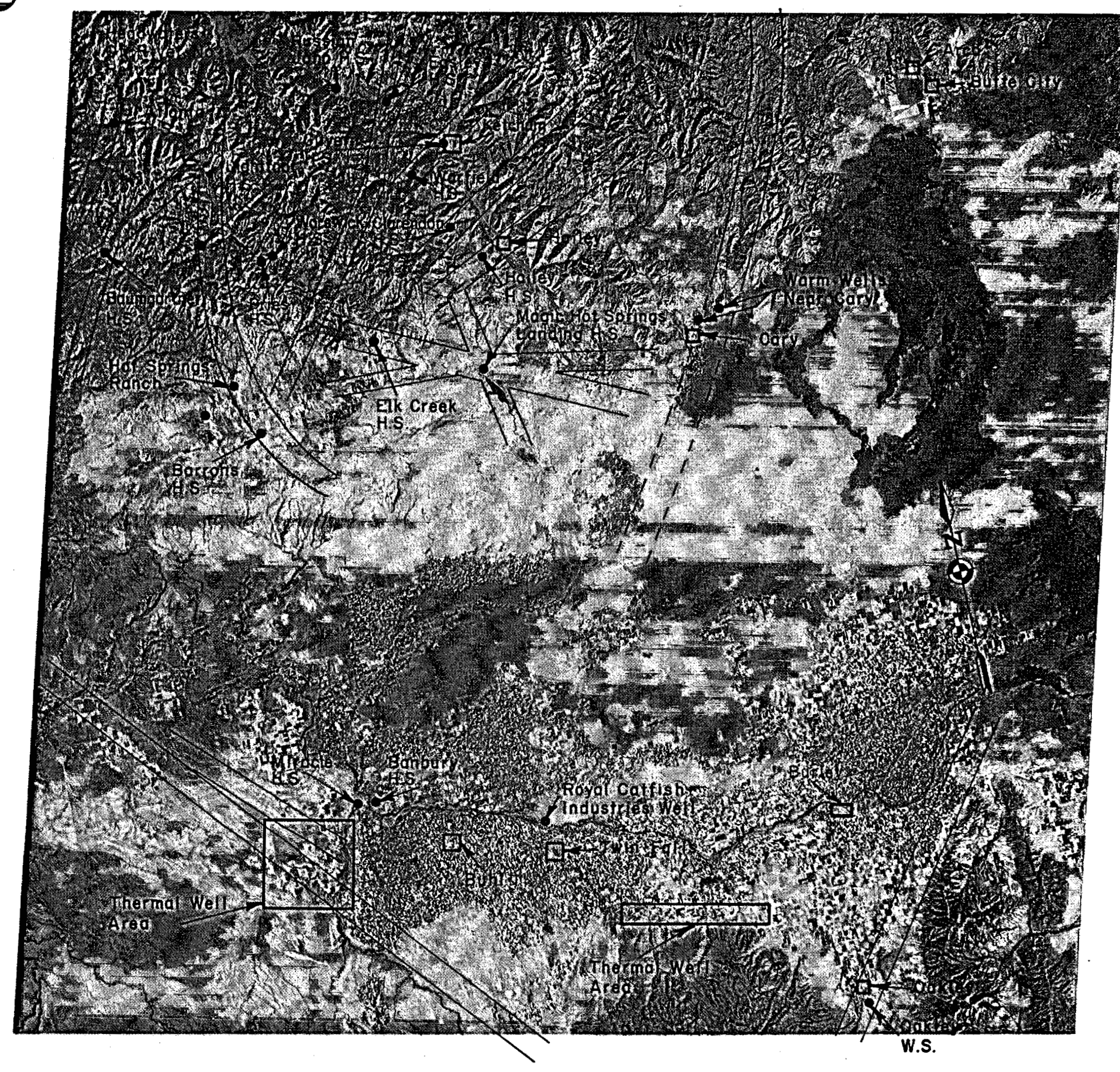

FIGURE 29. EROS false color infrared Landsat EDISE image of southcentral Idaho showing selected linear features and thermal water locations with surface temperature above $20^{\circ} \mathrm{C}$. 


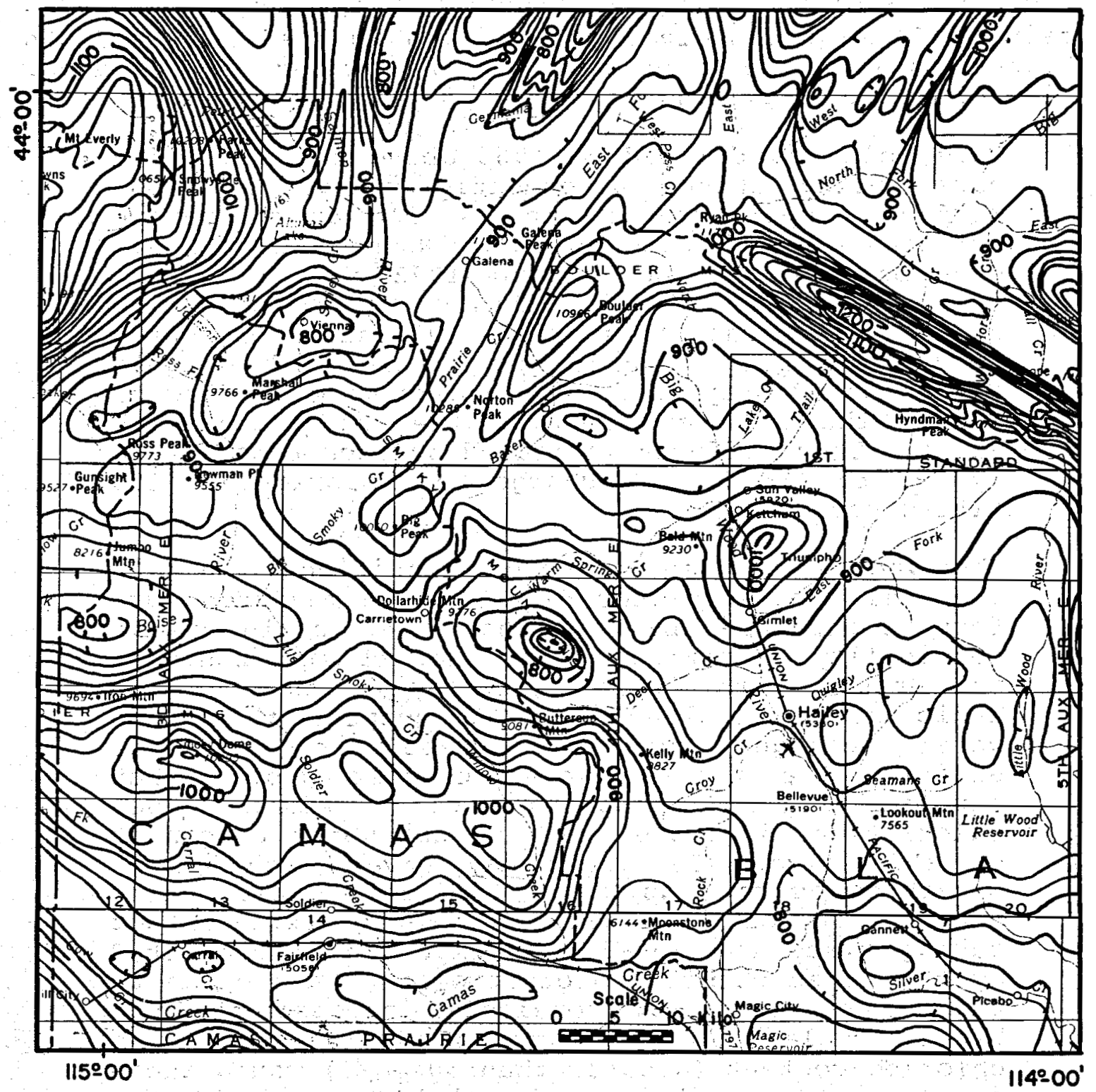

FIGURE 30. Magnetic anomalies near Bald Mountain (right of center) and NE of Sun Valley (upper right) (U.S. Geological Survey, 1971). 
Springs is further up Warm Springs creek from Guyer and will probably be used to heat vacation homes near Ketchum in the future.

Magic Hot Springs Landing was reported on by Mitchell (1977) who stated that water from Magic Hot Springs well (1S-17E-23aabl) near the north shore of Magic Reservoir contained $978 \mathrm{mg} / \mathrm{l}$ dissolved solids, $105 \mathrm{mg} / 1 \mathrm{silica,} \mathrm{and} \mathrm{was}$ higher in chloride than other thermal water in the area. Mitchell stated (p. 23):

This well was drilled in 1965 above the site of a warm spring which subsequently ceased to flow. Surface temperature of the spring water before drilling of the well was $36^{\circ} \mathrm{C}$ (Ross 1971 , p. 56). When neasured in the fall of 1973 the well had a surface temperature of $72^{\circ} \mathrm{C}$. In 1975 , during attempts to cap this well, artesian pressures reached 30 psig (pounds per square inch gauge), then started dropping. The owners were in fear of losing the well and removed the newly installed valve. These efforts increased surface temperature by $2^{\circ} \mathrm{C}$ to $74^{\circ} \mathrm{C}$ and discharge to approximately 250 liters per min.

The indicated disequilibrium conditions ( $\mathrm{Na}-\mathrm{K}-\mathrm{Ca}$ chemical geothermometer differs from measured surface temperatures by more than $20^{\circ} \mathrm{C}$ ) could mean a possibility of mixing of the thermal with nonthermal groundwaters. The proximity of the well to Magic Reservoir leads one to suspect that cold water leakage from Magic Reservoir could be entering the thermal water conduit system that supplies Magic Hot springs well. Mixing model calculations indicate that the hot water component of this mixed (?) water may have reached temperatures as high as $200^{\circ} \mathrm{C}$ with cold water making up about 708 of total water. Even if mixing is not taking place the $150-175^{\circ} \mathrm{C}$ temperatures predicted by the other chemical geothermometers are close to that temperature now considered necessary for a binary cycle geothermal power plant. The high chloride content (greater than $50 \mathrm{mg} / 1$ ) would indicate that this system would probably be a hot water rather than a dry steam system.

The marked difference in chemistry between Magic Hot Springs well waters and other thermal waters in the Camas prairie area would indicate: (1) Magic Hot Springs well waters have been at higher temperatures than the other thermal waters in the area, and/or (2) the aquifer or reservoir rocks for Magic Hot springs well waters are mineralogically 
and/or chemically different from the aquifer or reservoir rock for the rest of the prairie area. Although in many instances it is possible, using geochemical methods, to determine the aquifer or rock type from which thermal waters are in equilibrium, available data does not indicate which rock type could constitute an aquifer. The geology of the area would, however, suggest the aquifer to be either Quaternary alluvium, Middle Pliocene basalts of the Idaho Group, Lower Pliocene Idavada volcanic rocks, Eocene or Miocene Challis volcanic rocks, Cretaceous granitic rocks, or perhaps a combination of two or more of these.

The heat source for these waters could either be (1) an intruded sill or stock, related perhaps to the Holocene basalt flows found south of Magic Reservoir, or (2) a regionally high geothermal gradient and heat flow. Brott and others (1976) have determined that geothermal gradients and heat flow along the margins of the Snake River Plain are higher (about 3 HFU) than the regional norm which would indicate a regional heat source rather than a localized anomaly.

Springs :

Mitchel1 (1976) further stated (p. 15) that Magic Hot

-..well was drilled near the intersection of two curvilinear features that are probably faults. These faults may represent the controlling structure for the occurrence of thermal water in this particular part of the study area. Landsat false color infrared satellite imagery shows one of these lineaments as extending northwesterly, from near the southern tip of Magic Reservoir, along its eastern shoreline, and into the Soldier Mountains as the northern margin of the study area. The other feature extends at a slight northwesterly angle along the northern margin of the Claybank Hills and into the Soldier Mountains. Malde and others, 1963, show a fault lying somewhat east of and nearly parallel to the Magic Reservoir (?) fault. Their mapped fault passes through the Claybank Hills and lies very near Magic Hot Springs well.) A hypothetical block diagram showing the possible control of Magic Hot springs well is shown in figure 31 . 
FIGURE 31. Idealized block diagram of Magic Reservoir Area in Camas and Blaine counties depicting theoretical structural control for Magic Hot Springs well. In reality, the faults depicted may represent more broadly defined zones of faulting rather than single plane surfaces as represented on paper. The trend of these features are fairly well known, but the direction of movement of the Magic Hot Springs fault is unknown. (From Mitchell, 1976c.)

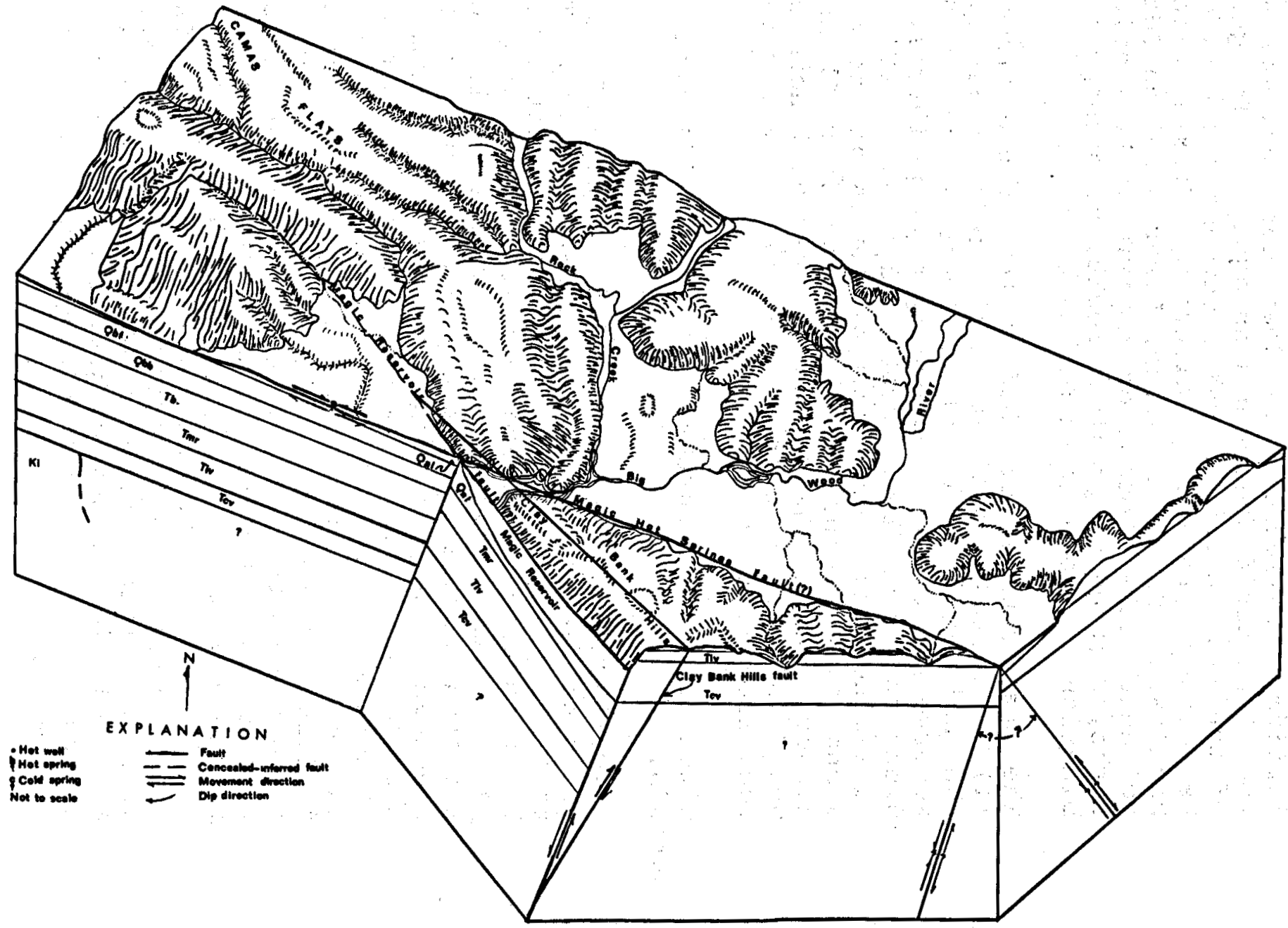


Most thermal water in central Idaho occurs as springs, although several well drillers have accidentally discovered thermal water while drilling for cold water. Most of these springs appear to be fault controlled, therefore, prospecting for new thermal water areas would probably be most profitable along the major drainages near large river bends, near stream confluences, near gaps in suspected curvilinear zones connecting existing known thermal springs or along major lineaments. Significant amounts of thermal water may yet be undiscovered as it may be discharging directly into river bottoms where it cannot be observed. A thermal scanner could conceivably be used for river bottom prospecting.

Several of the larger towns, notably Cascade, Hailey, Ketchum and Council, occur within $5 \mathrm{~km}$ of a thermal water discharge. These towns should probably receive first priority in initial assessment surveys, as they contain the greater population concentration (see table 4 for a complete listing). Many of these and smaller communities could heat public buildings and schools with geothermal water. Some may have small industries that could utilize geothermal fluids. Geothermal water could also be used for space heating in recreational home areas. Recreational uses could be increased, particularly by the usFs. Game bird hatcheries might be established at some sites by the Idaho Department of Fish and Game. 

GEOTHERMAL POTENTIAL OF THE SNARE RIVER PLAIN REGION INCLUDING WASHINGTON, PAYETTE, GEM, CANYON, ADA, SOUTHERN ELMORE, GOODING, JEROME, MINIDOKA, OWYHEE, TWIN FALLS, NORTHERN FREMONT, BUTTE AND WESTERN CASSIA COUNTIES

The Snake River Plain region of Idaho is endowed with certain geologic features that favor the occurrence of geothermal energy. The Snake River Plain is one of the largest and possibly least studied (in terms of origin) structural features of the North American continent. It extends some $480 \mathrm{~km}$ in a broad arcuate plain from Weiser near the west-central border of Idaho, southeastward to Burley, thence northeastward to its abrupt termination with the western $\mathrm{rim}$ of the Island Park caldera in eastern Idaho adjacent to Yellowstone Park. In width, the plain varies from $32 \mathrm{~km}$ in the west to $90 \mathrm{~km}$ in the east (see figure 32).

The Snake River Plain is generally divided according to surface and shallow subsurface geology into the northwestward-trending western snake River Plain and a northeasterntrending eastern snake River plain for purposes of discussion. The dividing line between the two subregions, is approximated by the salmon Falls Creek-snake River area in western Twin Falls and Gooding counties. Elevations vary uniformly from a low of $700 \mathrm{~m}$ near Weiser to a high of $1,830 \mathrm{~m}$ near the Island Park caldera rim. The gently undulating plain is flanked on the east, southeast, and northeast by transverse mountain ranges and valleys. Other structural features, faulting, lineament, and joint patterns surrounding the plain are generally parallel to (in the western Snake River Plain) or transverse to (in eastern snake River Plain) the borders of the plain.

The Snake River enters the plain from the southeast through a mountain valley in the eastern part of Idaho. The Snake River flows along the southern margin of the plain until it reaches the western border of Idaho, then abruptly swings across the plain, exiting through Hells Canyon. Smaller streams and rivers enter the plain from adjacent mountains and valleys.

The plain proper represents the surface of a thick sequence of silicic, andesitic, and basaltic lava flows interlayered with volcanic ash, tuff and sedimentary material. Estimates of the thickness of this sequence varies from 3,000 to $9,000 \mathrm{~m}$. Volcanic cinder cones and buttes puncture the thick pile of volcanic and sedimentary material throughout the entire plain in many places. Many of these volcanic and sedimentary units are water saturated. 


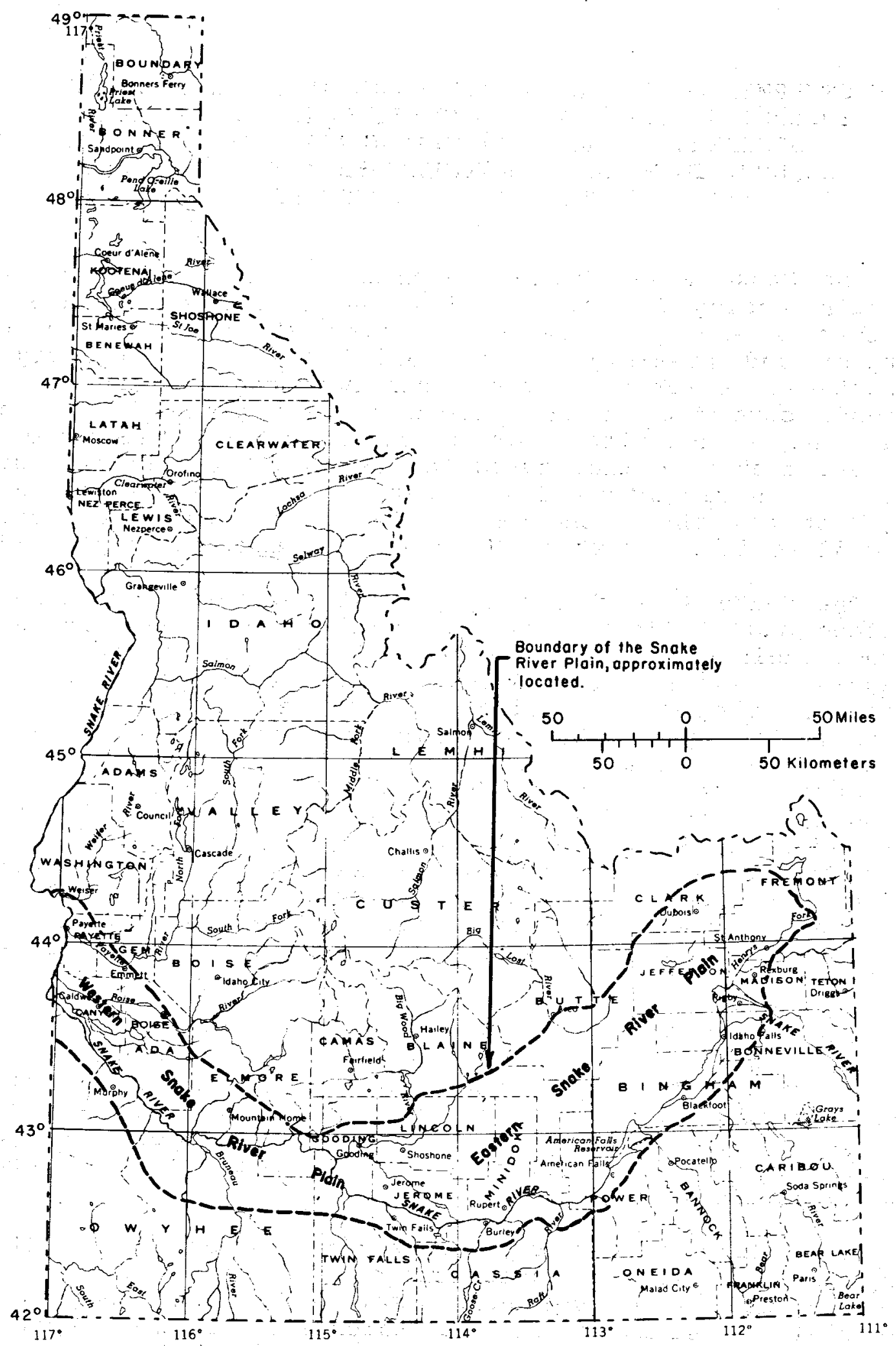

FIGURE 32. Index map of Idaho showing the Snake River Plain and its subdivisions. 
One of the largest fresh groundwater bodies known, the Snake Plain aquifer with more than $1.2 \times 10^{9}$ cubic meters of water withdrawn annually, underlies a large portion of the eastern Snake River Plain.

The Snake River Plain is also one of the more youthful geologic features in Idaho. It apparently had its inception in Pliocene time some 3-15 million years ago. Volcanism has continued sporadically through Holocene time (the present epoch). This volcanism and associated deformation has apparently migrated from west to east, as age dating of volcanic rocks by Armstrong and others (1975) has shown decreasing ages of rocks from west to east. This widespread deformation and volcanism, both rhyolitic and basaltic, are fundamental features of geothermal provinces.

Brott and others (1976) determined that heat flow throughout the Snake River Plain is consistently 0.5 to 3 HFU (heat flow units) higher than in areas of normal heat flow. The higher values are found along the margins of the plain. Although few heat flow measurements could be obtained above the snake plain aquifer due to the aquifer's masking effect, Brott and others (1978) showed that elevation changes from west to east in the plain could be due to thermal expansion of underlying hot rocks. Consequently, the rocks beneath the eastern snake River Plain where elevations are highest should be much hotter than those beneath the western Snake River Plain. This concept is strengthened by Armstrong's rock age dates.

Although the eastern snake River plain may ultimately have higher geothermal potential than the western snake River Plain, most thermal water wells have been drilled in the western snake River Plain. These wells extend in a belt some $65 \mathrm{~km}$ wide and $270 \mathrm{~km}$ long, which stretches from Raft River in the extreme south-central part of Idaho, northwestward to Weiser in the west-central part of Idaho (Plate 1 in pocket). Another, shorter and narrower belt, about $80 \mathrm{~km}$ long and $15 \mathrm{~km}$ wide, extends northwestward from Weiser through the council-Cambridge area to Meadows. This belt contains numerous wells with surface water temperatures exceeding mean annual temperature by $5-10^{\circ} \mathrm{C}$ and several up to $200^{\circ}$ (see map, plate 1). Thermal springs generally seem confined to the margins of the snake River plain as do thermal wells in the eastern snake River Plain, or are found along the Snake River.

Three areas in Idaho where thermal aquifers may exist are located within the large western snake River Plain thermal zone. These are the Lake Lowell-Nampa-Caldwell area, the Blue Gulch area west of Buhl, and the Bruneau-Grand View area in northern Owyhee county. Others may exist, but well drilling has not revealed their extent 
to date. Some evidence indicates these aquifers may be recharged through large faults in the subsurface.

Discussion of the geothermal resources in the western Snake River Plain region follows on a county basis. No geothermal resource was found in tincoln County.

\section{WASHINGTON COUNTY}

Washington county contains several areas where there are thermal water discharges (see figure 33). Weiser Hot Springs ( $11 \mathrm{~N}-6 \mathrm{~W}-10 \mathrm{acb} 1 \mathrm{~s})$, northwest of Weiser, has long been utilized for swimming, balneological bathing, and greenhouse operations as well as small scale space heating. Several small diameter wells yield enough water at the site of a former hot spring to carry on the above operations. Another location which indicates promise of electrical generation capability is the crane creek Hot springs (11N-3w-7bcbis) area northeast of Weiser.

Young and Whitehead (1975, p. 31-32) summarized the geothermal potential of these areas.

The Weiser area comprises about $518 \mathrm{sq} \mathrm{km}$ in southwestern Washington County and includes two subareas having thermal water: the Crane creek subarea, which is about $19 \mathrm{~km}$ east of Weiser, and the weiser Hot springs subarea, which is about $8 \mathrm{~km}$ northwest of Weiser.

Although the surficial geology of the Crane creek and Weiser Hot Springs geothermal subareas is somewhat different, the general stratigraphy is similar. Volcanic and sedimentary rocks of Permian and younger age, granite of Cretaceous age, or the older basalts of the Columbia River Group of Miocene and Pliocene age may underlie the Weiser area. However, the scant data available indicate that the reservoir rock is most likely composed of the older basalts of the Columbia River Group. Miocene and Pliocene (?) sedimentary rocks, termed the Payette Formation, overlie older basalts and are, in turn, overlain by a younger sequence of basalts of the Columbia River Group. For the most part, sedimentary rocks of the Idaho Group of Pliocene and Pleistocene age overlie the younger basalts. Alluvium and colluvium of pleistocene and Holocene age cover much of the older rock units, particularly in the lowlands and valleys.

Gravity surveys indicate that the weiser area is at the northwest end of a large regional gravity high that is associated with the western snake River 


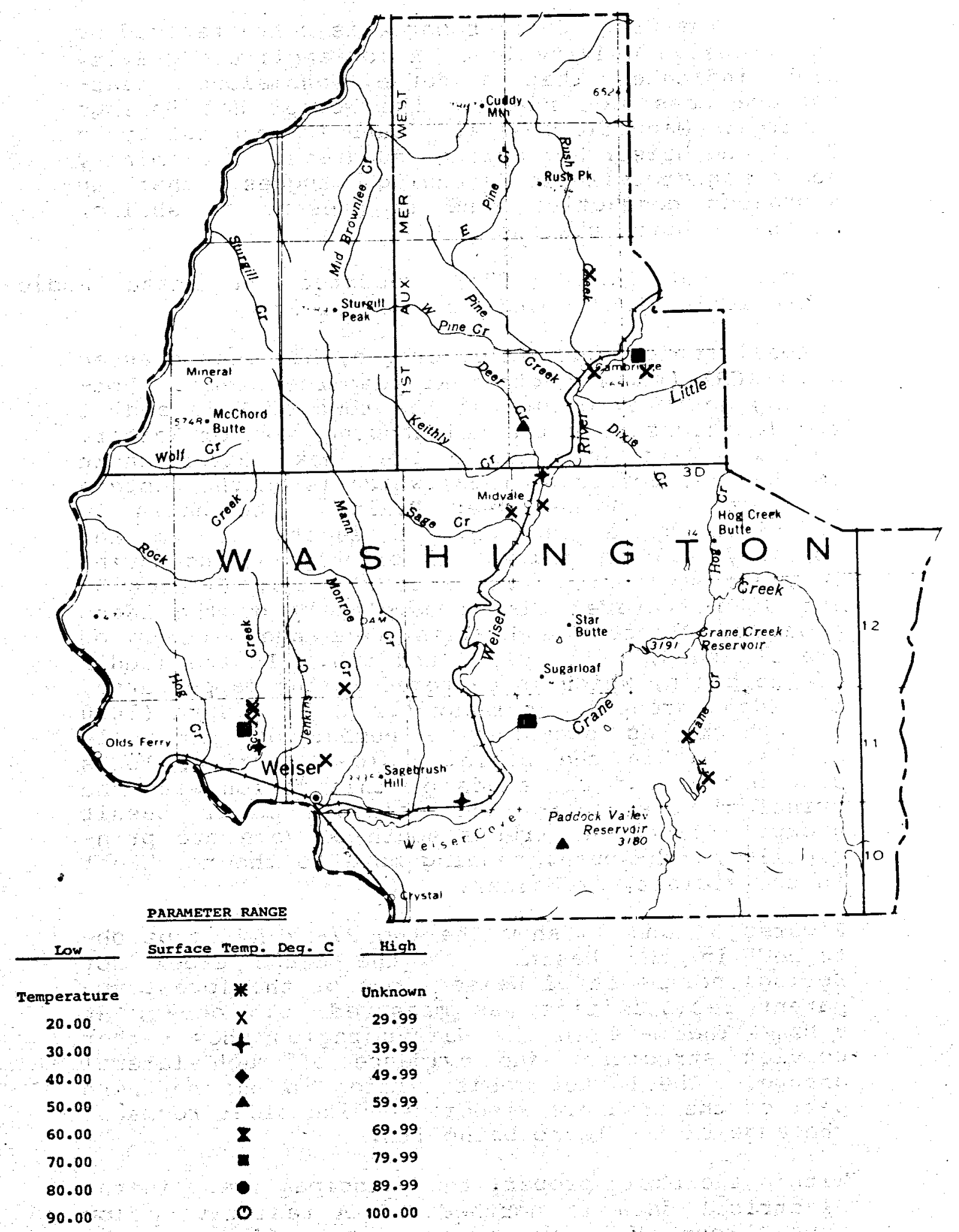

FIGURE 33. Index map of Washington County showing locations of thermal water occurrences with surface temperatures of $20^{\circ} \mathrm{C}$ or higher. 
Plain. The Crane Creek subarea is characterized by an extensive gravity low. A low-amplitude gravity high indicates that a dense, anomalous, nearsurface mass may underlie the Weiser Hot Springs subarea. Magnetic lows are found in both the crane Creek and Weiser Hot Springs subareas. Preliminary audio-magnetotelluric soundings suggest that an anomalous conductive zone is present at shallow depths in both subareas.

Hoover and Long (1975) reported on these audiomagnetotelluric (AMT) soundings and stated:

A small region near Vale, Oregon, has been classed as a KGRA (known geothermal resource area). Hotspring activity occurs at the town of vale and at two locations near the neighboring town of Weiser, Idaho. This area is in the snake River basin (Newton and Corcoran, 1963) which is on the western edge of the snake River Plain. The basin is underlain by a section, at least $1.5 \mathrm{~km}$ and possibly $4.6 \mathrm{~km}$ thick, of principally nonmarine Cenozoic sediments. The area shown in figures 34 and 35 is covered almost completely by the Idaho group of Pliocene and Pleistocene age made up of gravel, sand, silt, clay, and ash. In the middle of the basin, which is centered in the mapped area, the Idaho group is at least $1.2 \mathrm{~km}$ to $1.5 \mathrm{~km}(5000$ $f t$ ) thick, as shown by a number of gas wells drilled within the basin. older Tertiary rocks crop out around the edges of this region with the principal one being the Columbia River basalt group. Structural trends south of Vale are principally north-south, bending more to the northwest in the vicinity of Weiser.

Figures 34 and 35 show the two 27-Hz AMT maps obtained in the basin. At the Crane Creek Hot Springs northeast of weiser, one of the lowest apparent resistivities was measured, $0.5 \mathrm{ohm}-\mathrm{m}$, at $8 \mathrm{~Hz}$. The maps in the weiser region show rather complex structures and evidence of much lateral change. The higher resistivities in the northern part of the area are associated with older rocks at the edge of the Idaho batholith.

Within the basin proper, the principal trend in the electrical data is northeast. A resistivity low runs through Vale and extends about $20 \mathrm{~km}$ to the southwest. Extension of this trend northeast runs into the low at Crane Creek about $20 \mathrm{~km}$ northeast of Weiser. A local high of about $16 \mathrm{ohm}-\mathrm{m}$ just northeast of Vale, apparent only in figure 34 is 


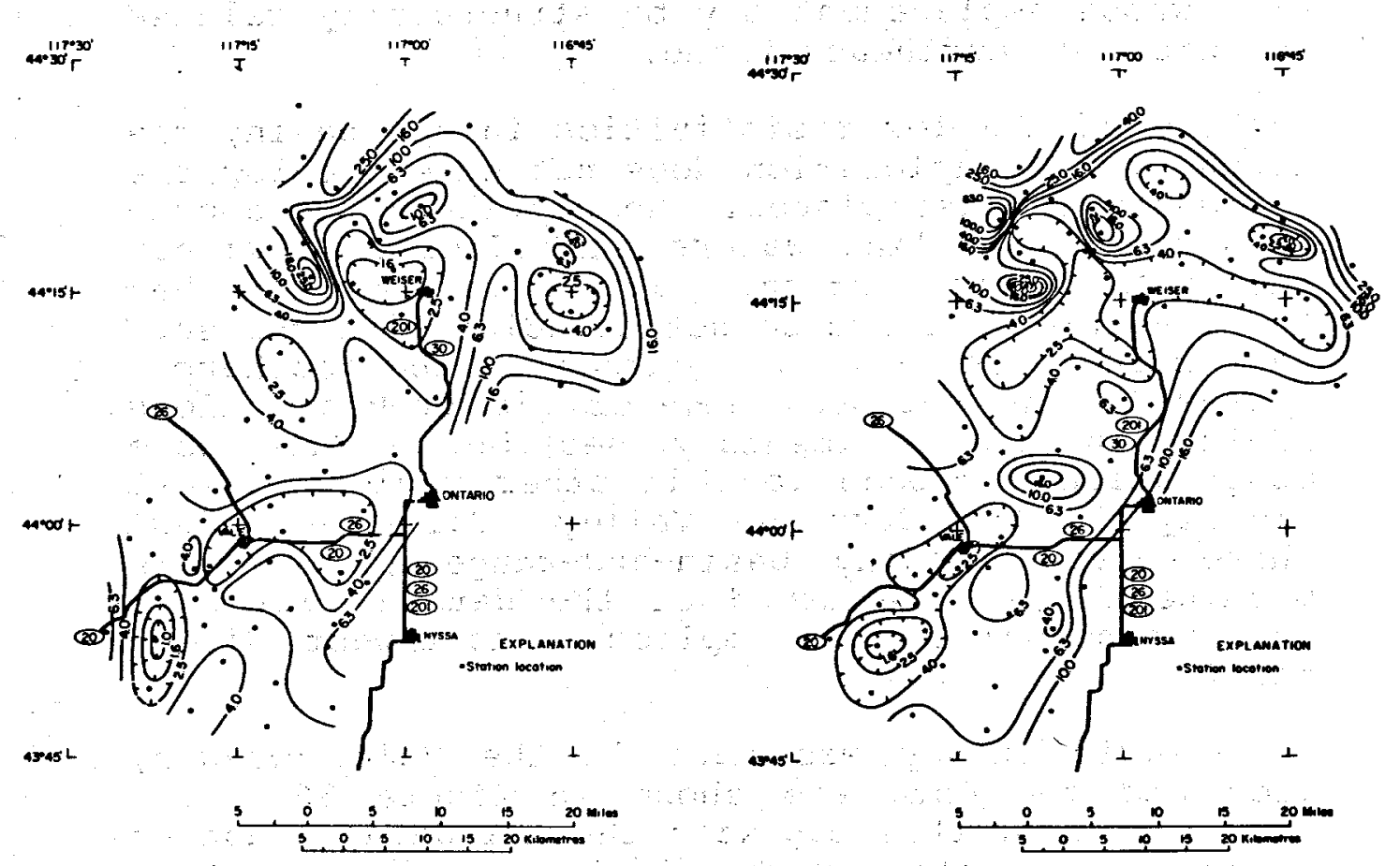

FIGURE 34. 27- Hz apparent-resistivity map (telluric line northsouth), Weiser, Idaho-Vale, Oregon Contours in ohm - meters.

FIGURE 35. Map of $27 \cdot \mathrm{Hz}$ apparent resistivity (telluric line east-west), Weiser, Idaho-Vale, Oregon. Contours in ohm - meters.

(Hoover and Long, 1975.)

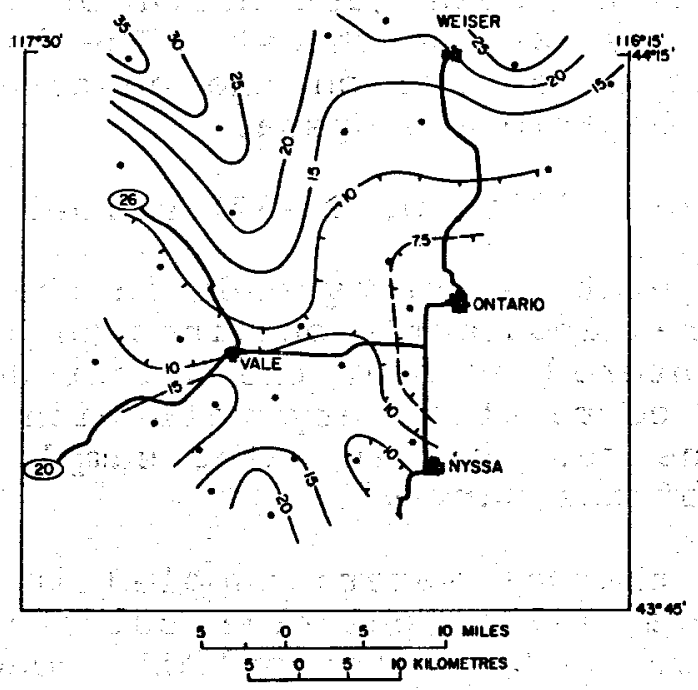

FIGURE 36. Telluric anomaly map at 20- to 30-sec period, Vale, Oregon-Weiser, Idaho. Contour interval $2 K=10 \sqrt{J}$. 
also on the same trend. This high is related to the rocks comprising Malheur Butte, next to which the sounding was made. This is a small prominent plug whose emplacement may be structurally related to this same northeast trend.

Because of the low resistivities in the basin, the depth of AMT exploration does not extend below the sediments in most places. We attribute the anomalies to hot, saline waters and alteration within the sedimentary section. It is interesting that the electrical trends do not coincide with the surface structural trends. Leakage of the geothermal system to the surface, however, is probably along faults in the sedimentary section. This same observation has been made in other regions - most clearly in the surprise Valley, California KGRA where north-trending basin-and-range faulting is prominent, yet the trend of the data relating to the geothermal system implies a northwest direction.

A telluric survey was made in the Vale, Oregon, area and the data are shown in figure 36. The correlation of this map with the AMT data is not as direct as in Island Park, which might be expected. The AMT survey is sampling principally the young basin sediments, while the telluric data sample a larger part of the crust and may be reflecting basement topography. A low saddle in the telluric data, however, is seen just north of vale with a trend to the east and northeast. The lowest values on the telluric map are on the eastern edge near the towns of Ontario and Nyssa.

Young and Whitehead (1975, p. 31-32) stated further that:

A ground-temperature survey made in the Weiser Hot Springs subarea apparently outlines an area of high heat flow centered or near the weiser Hot springs, and it also correlates very well with high boron concentrations measured in water samples collected in the area of the survey.

Most of the thermal waters sampled in the Weiser area are of a sodium chloride sulfate or sodium sulfate type. Dissolved-solids concentrations ranged from 1,070 to $1,140 \mathrm{mg} / 1$ for thermal water in the Crane Creek subarea and from 225 to $852 \mathrm{mg} / 1$ in the Weiser Hot Springs subarea. Thermal water sampled in the Crane Creek subarea had noticeably higher concentrations of chloride and boron than did thermal water sampled in the Weiser Hot Springs subarea. 
Measured groundwater temperatures ranged from 13.0 to $92.0{ }^{\circ} \mathrm{C}$, and were highest at a spring in the Crane Creek subarea. Estimated aquifer temperatures, using the silica and the sodiumpotassium-calcium chemical geothermometers, ranged from 153 to $177^{\circ} \mathrm{C}$ in the Crane Creek subarea and from 3 to $157^{\circ} \mathrm{C}$ in the Weiser Hot Springs subarea. Estimated aquifer temperatures for samples from wells at the Weiser Hot springs ranged from 141 to $157^{\circ} \mathrm{C}$. In the Crane Creek and Weiser hot springs subareas, respectively, estimated maximum temperatures at depth, using the mixed water method, ranged from 212 to $270^{\circ} \mathrm{C}$ and from 200 to $242^{\circ} \mathrm{C}$ with percentages of cold water ranging from 67 to 76 percent from 70 to 97 percent.

Analyses of hot-spring deposits from active and inactive-spring vents indicated that, although the mineral constituents in samples from both subareas are similar, the deposits in the Crane Creek subarea contain much greater amounts of sinter than those from the Weiser Hot springs subarea. This indicates that the water depositing this material was at temperatures in excess of $180^{\circ} \mathrm{C}$ at depth.

The source of the heat for the thermal water in the Weiser area is believed to be a cooling young intrusive implanted at shallow depth in late Miocene or early Pleistocene time, or above-normal heat flow caused by the high temperatures at relatively shallow depth resulting from a general thinning of the earth's upper crust in this area.

Aside from the power generation possibilities in the Crane Creek area, the Weiser and crane creek hot springs represent areas where geothermal energy could be harnessed for agricultural use as well. The weiser area is on the Union Pacific Railroad Mainline with a spur branch extending into the Crane creek subarea to very near the springs. The entire Vale, Ontario-Weiser area is a rich, agricultural area where approximately one-third of the nation's onions are grown. Much of Idaho's fruit and sugar beets are also grown in this area. Uses such as onion, beet pulp, and fruit drying suggest themselves. Meat packers could make use of the thermal water for refrigeration.

Thermal waters also extend northeastward, in a belt from Vale, Oregon, through Weiser to Council-Cambridge in Washington County to the Meadows area in Adams County (see Plate 1 in pocket). Little is known about the councilCambridge area geothermally except that there are approximately eight wells ranging in temperatures from 20 to $30^{\circ} \mathrm{C}$ and one hot spring at $69^{\circ} \mathrm{C}$. Discharge of wells ranges from 
379 to $1500 \mathrm{l} / \mathrm{m}$. The wells range in depth from 56 to 283 meters. Chemical analyses of discharge water from these wells should be made to establish priorities for further work in this area.

PAYETTE COUNTY

Little is known of the geothermal potential of Payette County. Nine thermal wells are known to have been drilled there and all are relatively cool, between 20 to $29^{\circ} \mathrm{C}$ (figure 37). Four are in the southwestern corner of Payette county north of Parma. Two more are up Little willow Creek about $13 \mathrm{~km}$ northeast of Fruitland. Two occur about $5 \mathrm{~km}$ east of Fruitland and one occurs $.4 \mathrm{~km}$ east of Payette.

Highest surface temperatures were measured up Little Willow Creek at 25 and $29^{\circ} \mathrm{C}$ from wells $9 \mathrm{~N}-3 \mathrm{~W}-21 \mathrm{bdcl}$ and 9N-3W-19ddal. Well head temperatures of $20^{\circ} \mathrm{C}$ have been measured from wells $9 \mathrm{~N}-5 \mathrm{~W}-35 \mathrm{ccbl}$ near payette and $8 \mathrm{~N}-4 \mathrm{~W}-7 \mathrm{ccdl}$ near Fruitland.

No chemical analyses are available from any thermal wells in Payette County. Assessment of the resource should begin with sampling the hottest ones and those near Fruitland and Payette. It is possible that more and hotter water could be found in the Fruitland-Payette-ontario area where several food processing plants are located.

GEM COUNTY

Four thermal anomalies are known in Gem County (see figure 37). Roystone Hot springs (7N-1E-8ddals) may have potential for binary cycle power generation. Roystone occurs near the intersection of a prominent north trending lineament that connects with the Dry Valley thermal anomaly north of Boise and a less pronounced northeast trending lineament (figure 17). These are visible on enhanced false color composite sateliite images of the area. Surface temperature at Roystone Hot springs is $55^{\circ} \mathrm{C}$ and discharge is 75 $\mathrm{l} / \mathrm{m}$. As estimated by the quartz and $\mathrm{Na}-\mathrm{K}-\mathrm{Ca}$ chemical geothermometers, subsurface temperature is 147 and $1500^{\mathrm{C}}$, respectively.

A spring (7N-1E-9cdc1s) about .4 km from Roystone Hot springs has a $45^{\circ} \mathrm{C}$ surface temperature and may have an aquifer temperature between 84 and $106^{\circ} \mathrm{C}$ according to the $\mathrm{Na}-\mathrm{K}-\mathrm{Ca}$ and chalcedony chemical geothermometers.

A well $9.5 \mathrm{~m}$ deep has been drilled recently near Emmett in Gem county. This well has a surface temperature of $24^{\circ} \mathrm{C}$ which is sufficient for space heating if groundwater heat pumps are used. No other data are presently available for this well, but its presence suggests that the Emmett area 


\section{PARAMETER RANGE}

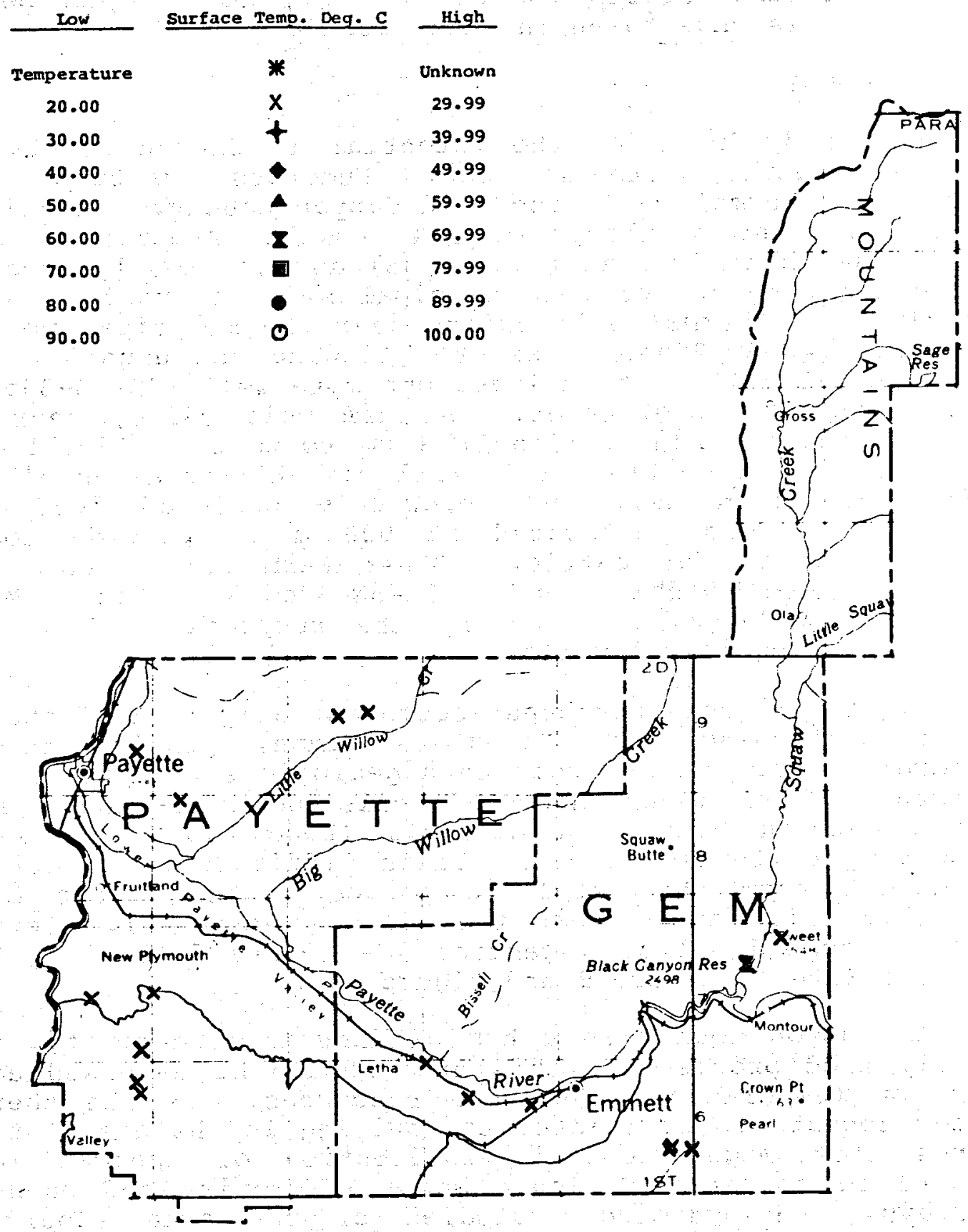

FIGURE 37. Index map of Payette and Gem counties showing locations of thermal water occurrences with surface temperatures of $20^{\circ} \mathrm{C}$ or higher. 
may have potential for low temperature geothermal energy. A chemical analysis should be obtained from the well to see if subsurface temperatures might be substantially higher before other work is undertaken in this area.

\section{CANYON COUNTY}

Little is known of the potential in Canyon county for low temperature geothermal use. Numerous low temperature $\left(20-41{ }^{\circ} \mathrm{C}\right)$ thermal wells occur in Canyon County. In a large area south and southeast of Lake Lowell, numerous $20-30^{\circ} \mathrm{C}$ wells have been drilled (figure 38) and are mostly used for irrigation. Water for the municipal swimming pool in Nampa is $31^{\circ} \mathrm{C}$. A thermal well exists near the municipal pool in Caldwell (4N-3W-28aabl presently flowing and unused). The city of Caldwell owns at least one more well (4N-3W-35abdl) which provides $20^{\circ} \mathrm{C}$ water. A warm well $\left(41^{\circ} \mathrm{C}\right)$ near the Simplot feedlot ( $4 \mathrm{~N}-3 \mathrm{~W}-19 \mathrm{adcl}) 3 \mathrm{~km}$ south of Caldwell provides water for cattle. This well was drilled as an oil and gas exploration well and reportedly produced "very hot water," but was perforated at $900 \mathrm{~m}$ to provide cooler drinking water for cattle. Other warm wells exist near Parma (5N-5W-9adbl and $5 \mathrm{~N}-5 \mathrm{~W}-4 \mathrm{dcd} 1 \mathrm{~S})$ and Melba $(1 \mathrm{~N}-2 \mathrm{~W}-36 \mathrm{caal})\left(24^{\circ} \mathrm{C}\right)$ owned by the respective cities and operated as municipal wells.

Figure 38 shows northeast-southwest alignment of thermal wells stretching from Parma to Nampa, passing through Caldwell, which might indicate a geologic structure of some length. This linear trend of wells has been mapped as a fault between Nampa and Caldwell (Bond, 1978). Due to obscuring cultural features, it is difficult to identify a lineament from the satellite photos, although one might possibly exist on or near the wells (figure 39). Several closely spaced wells in central Ada County fall along this trend (Plate 1, figure 9 and figure 38 ).

As Canyon County is a hub of industrial activity, primarily food processing, this area should be assessed early for low temperature geothermal resources. As the thermal water appears to be related to faulting in the area, structures that might control distribution of thermal water should be sought. Geologic mapping, gravity and magnetic surveys, and hydrologic studies of the area should be accomplished first to determine gross structural patterns. Reflective seismic and resistivity surveys could be designed and run from the previously mentioned data base to site several drill holes in promising areas near Nampa or Caldwell. (This has been started through the purchase of oil exploration survey data as part of the IDWR-DOE Nampa-Caldwell area study.) From here, stepout surveys or drilling should be undertaken in other parts of the western Snake River Plain to uncover other favorable geologic struc- 


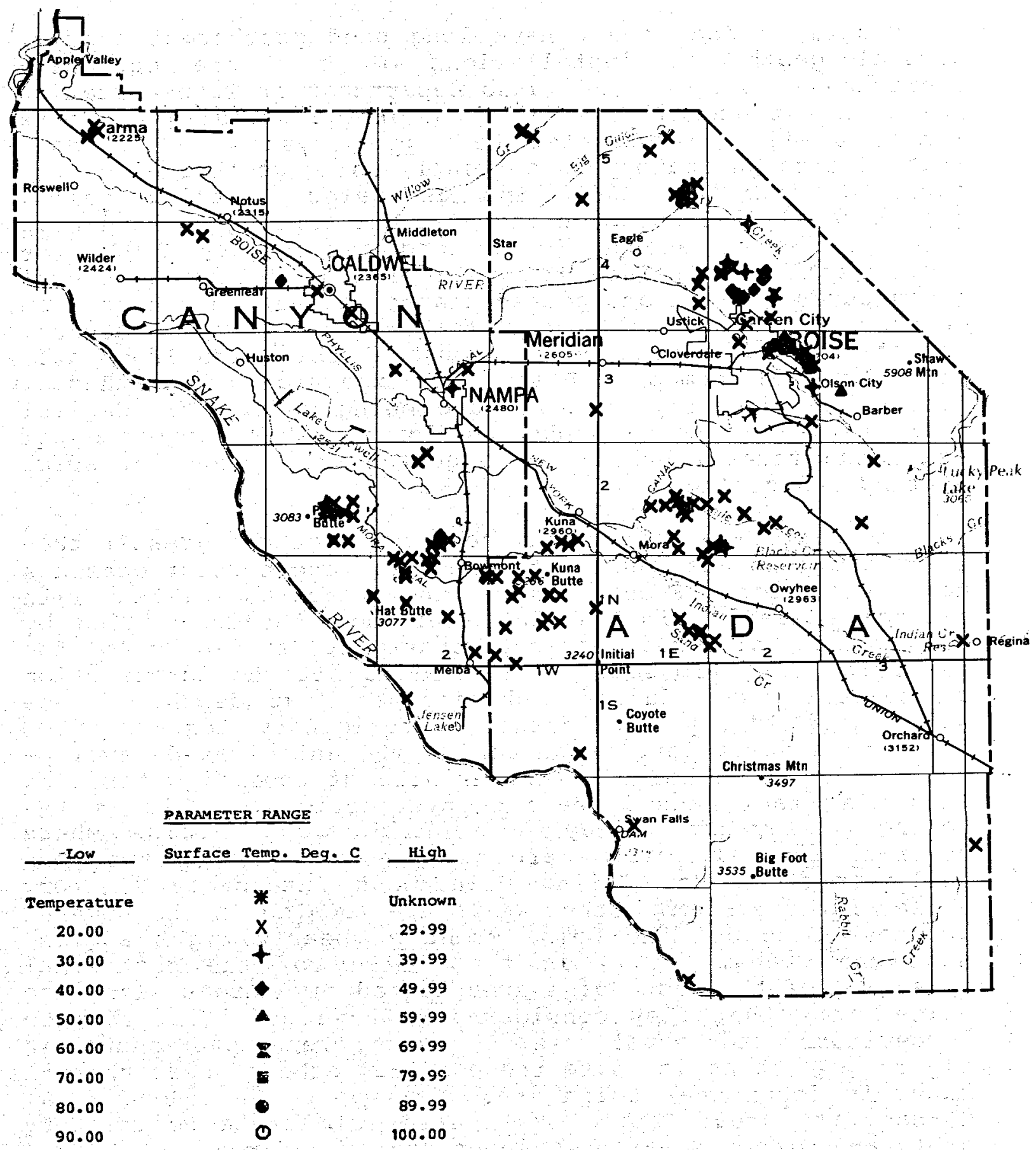

FIGURE 38. Index map of Canyon and Ada counties showing locations of thermal water occurrences with surface temperatures of $20^{\circ} \mathrm{C}$ or higher. 
tures where thermal water may be found. These types of exploration could lead to discovery of many valuable energy resources in this section of Idaho.

\section{ADA COUNTY}

People in Ada County have long used geothermal energy. Several geothermal installations of note are currently operating in Boise. The Idaho Department of Transportation heats and air conditions its main office building on state street using a groundwater heat pump system. The Idaho State Health Laboratory is currently using geothermal energy obtained from the Warm springs Water District wells. Approximately 185 homes on and near Warm Springs Avenue have used geothermal energy (well head temperature $74{ }^{\circ} \mathrm{C}$ ) for their heat source since the turn of the century. Several greenhouses for cut and potted plants derive their heat from geothermal wells (well head temperature $47^{\circ} \mathrm{C}$ ). Several domestic wells provide heat throughout the Boise Front area to individual homes. Plans for expansion of geothermal heating by the city of Boise are being made. The Capital Mall Complex is being looked at for possible conversion of state and federal buildings to geothermal energy for space heating and cooling.

There are 119 wells (well head temperatures greater than $20^{\circ} \mathrm{C}$ ) known in Ada County (figure 38 ). The hottest ones are near the Boise Front, where they are associated with extensive, large displacement faulting. Wells drilled by Boise State University Geology Department, funded by DOE for the Boise city Project, were sited to hit the intersection of several known faults and lineaments at depth. These wells were highly successful. Preliminary tests by DOE indicate a sufficient resource for the anticipated development in downtown Boise. Another area of thermal water also lies near fault and lineament intersections. This is the Spring Valley-Dry Valley area northwest of Boise where several thermal wells are located. Here, the Dry Valley-Roystone Hot Springs lineament intersects the Dry Valley fault system. Other wells are located in the several gulches which cut the Boise Front at nearly right angles. Mink and Graham, 1977, in their study of the geothermal potential of the west Boise area, sited five areas along the Boise Front that they considered to have potential for low temperature geothermal use. These areas are shown in figure 40. In addition to these areas, others where thermal water is found near Boise are: Strawberry Glen Road area, Garden City area, Capitol Mall area, old state Penitentary area, and Glenwood Street-Chinden Boulevard area.

Donaldson and Applegate (1979) have conducted reconnaissance level resistivity surveys along the Boise Front to determine thermal water, locations. They state: 


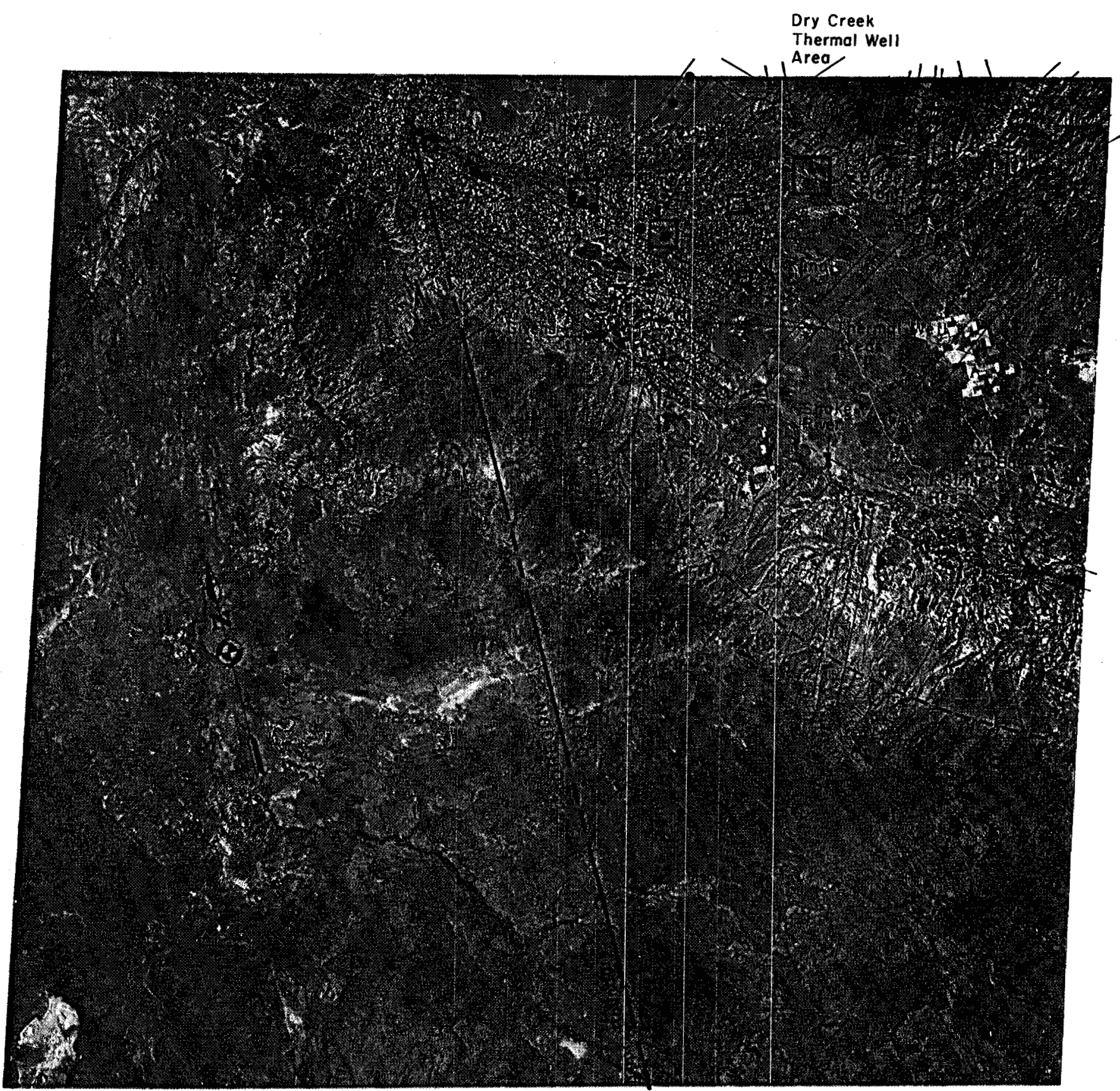

FIGURE 39. EROS false color infrared Landsat EDISE image of part of southwestern Idaho and southeastern Oregon showing selected linear features and thermal water locations with surface temperatures above $20^{\circ} \mathrm{C}$. 


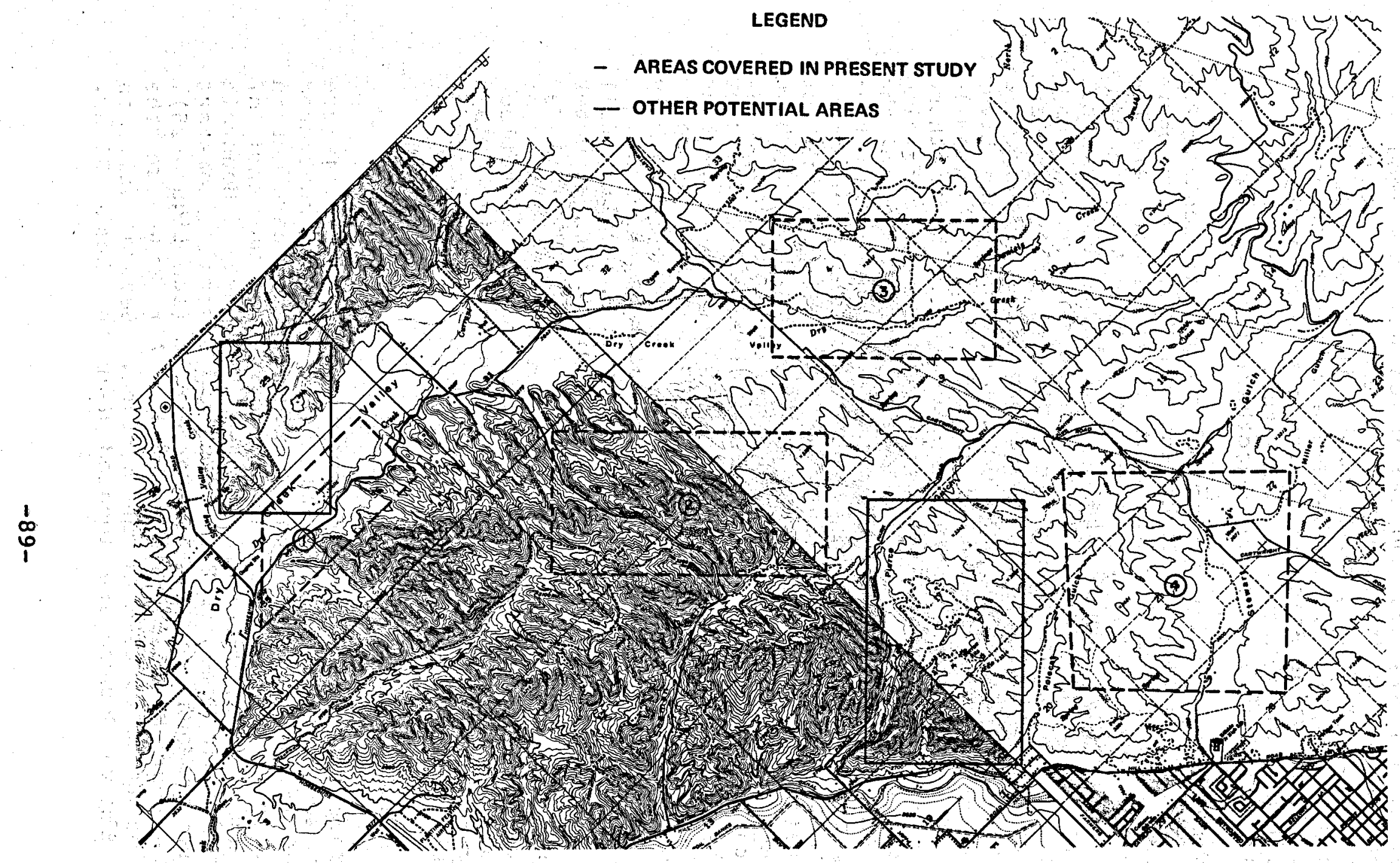

FIGURE 40. Topographic map of west Boise Front area showing locations of potential geothermal sites. (Modified from Mink and Graham, 1977.) 
of direct interest are the resistivity surveys (Eigures $41,42,43$, and 44) which have outlined several anomalously conductive areas. The steep resistivity gradients associated with these anomalies probably reflect the presence of faults intersecting the major Boise Front fault at high angles. Such fault intersections, where they are proven to exist, offer very attractive geothermal prospects.

A large number of irrigation wells occur in central Ada County in the vicinity of Eight and Ten Mile creeks where well head temperatures in this part of Ada County are between 20 and $25^{\circ} \mathrm{C}$. Another group occurs near Kuna in west central Ada County. There are several large linears that apparently extend from the Middle Fork Boise River drainage and appear to cross the snake River Plain in the Eight and Tenmile creeks area. A long, more pronounced linear runs northwest-southeast up the axis of the western snake River Plain and intersects the other linears south of Tenmile creek. Knowledge of the type of geologic features these linears represent appears to be fundamental to obtaining much more information on geothermal occurrences in the western Snake River Plain region. A speculation is that they represent surface expressions of basement or other faults or rock fractures. They may act as conduits for thermal water. Recharge of these systems could be anywhere along thein. There could even be interbasin transfer of groundwater along some of the regional linears and transfer could take place anywhere from one kilometer or less to tens of kilometers or more. Any holes drilled for the purpose of obtaining thermal water would have to be very carefully targeted to intersect faults or rock fractures where thermal water may be circulating. In the alluvium and valley fill sediments away from the mountain front faults, thermal water conduits would be difficult to locate. Analysis of large scale enhanced false color Landsat images may allow some of these faults to be found. A systematic program of reflective seismic profiling across the western snake River Plain is highly recommended to determine the location and depth of any faulting in the area.

\section{SOUTHERN ELMORE COUNTY}

Numerous thermal wells and several thermal springs are known in southern Elmore County. Springs are scattered widely but are principally located along the northern margin of the western snake River Plain northeast and east of Mountain Home. Some wells are located just west of Mountain Home and Mountain Home Air Force Base and several kilometers to the east of Mountain Home Air Force Base (see figure 25). The wells near Mountain Home and the Air Base are the coolest, being 20 to $25^{\circ} \mathrm{C}$ at the surface. Several wells in southern Elmore county are located near the snake River. 


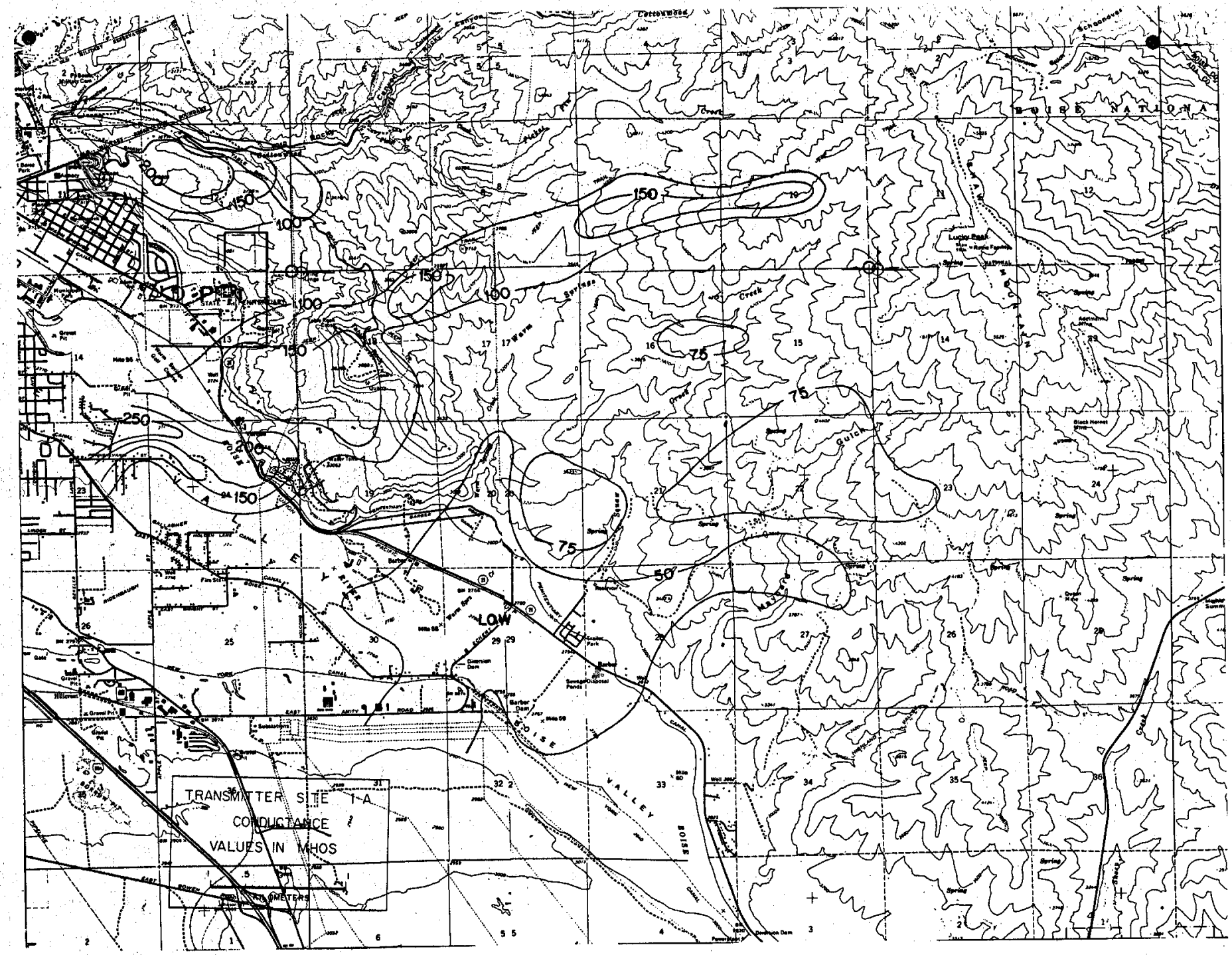

FIGURE 41. Map of Boise Front area showing total conductance for transmitter $1 \mathrm{~A}$ array (Donaldson and Applegate, 1979, modified). 

FIGURE 42. Map of Boise Front area showing total conductance for transmitter 2 A array
(Donaldson and Applegate, 1979, modified).

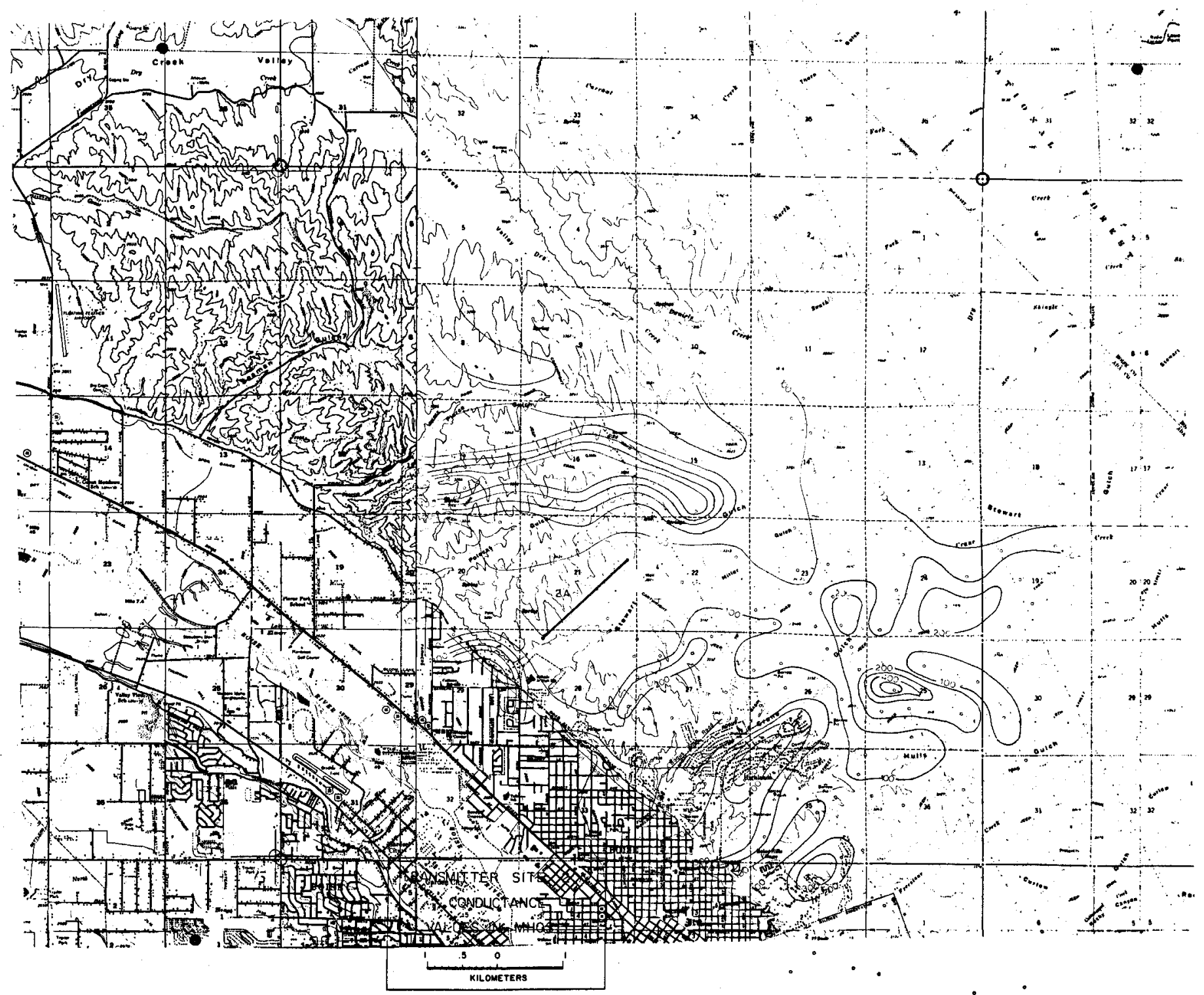




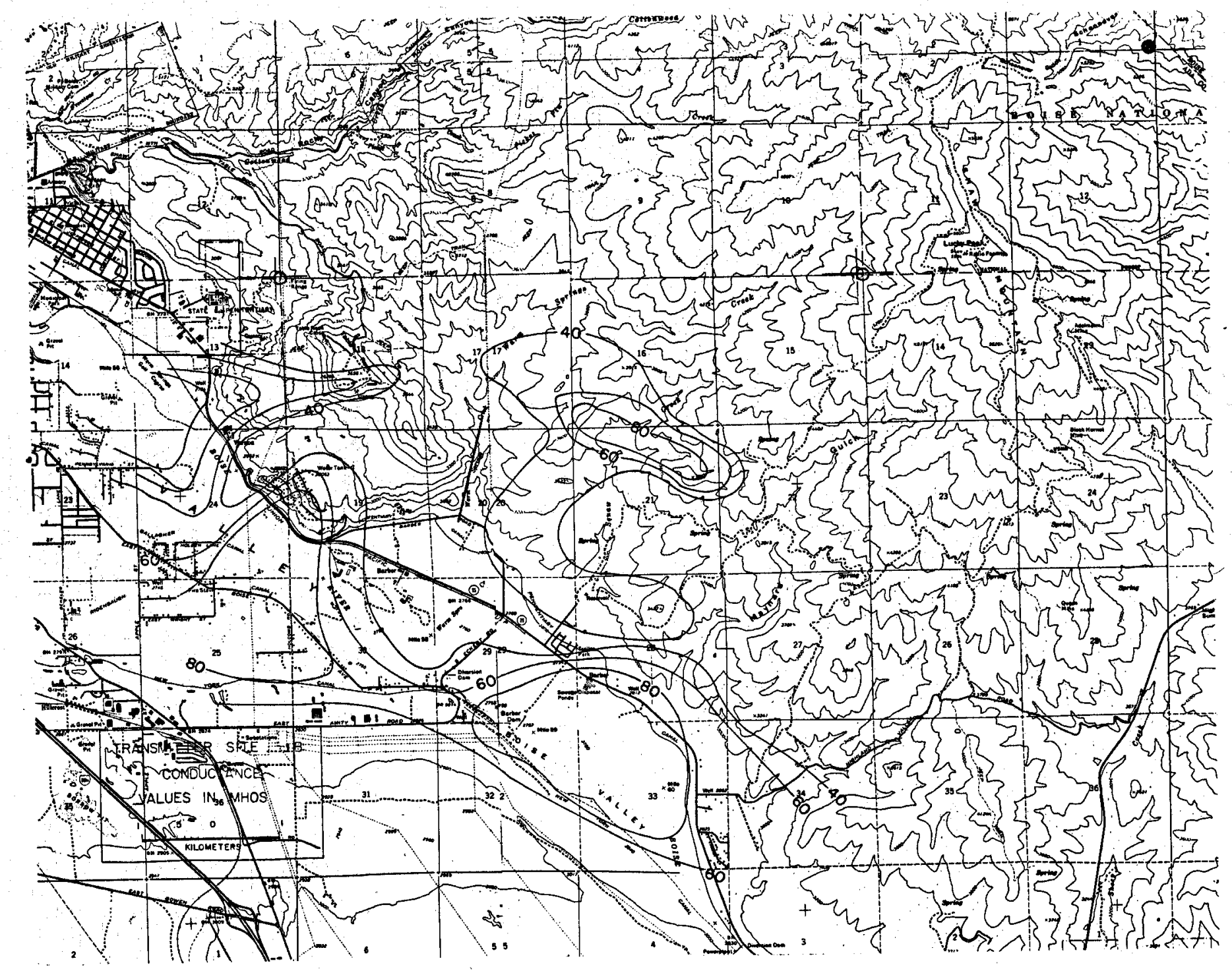

FIGURE 43. Map of Boise Front area showing total conductance for transmitter 1 B array (Donaldson and Applegate, 1979, modified). 
FIGURE 44. Map of Boise Front area showing total conductance for transmitter 2 B array (Donaldson and Applegate, 1979, modified).

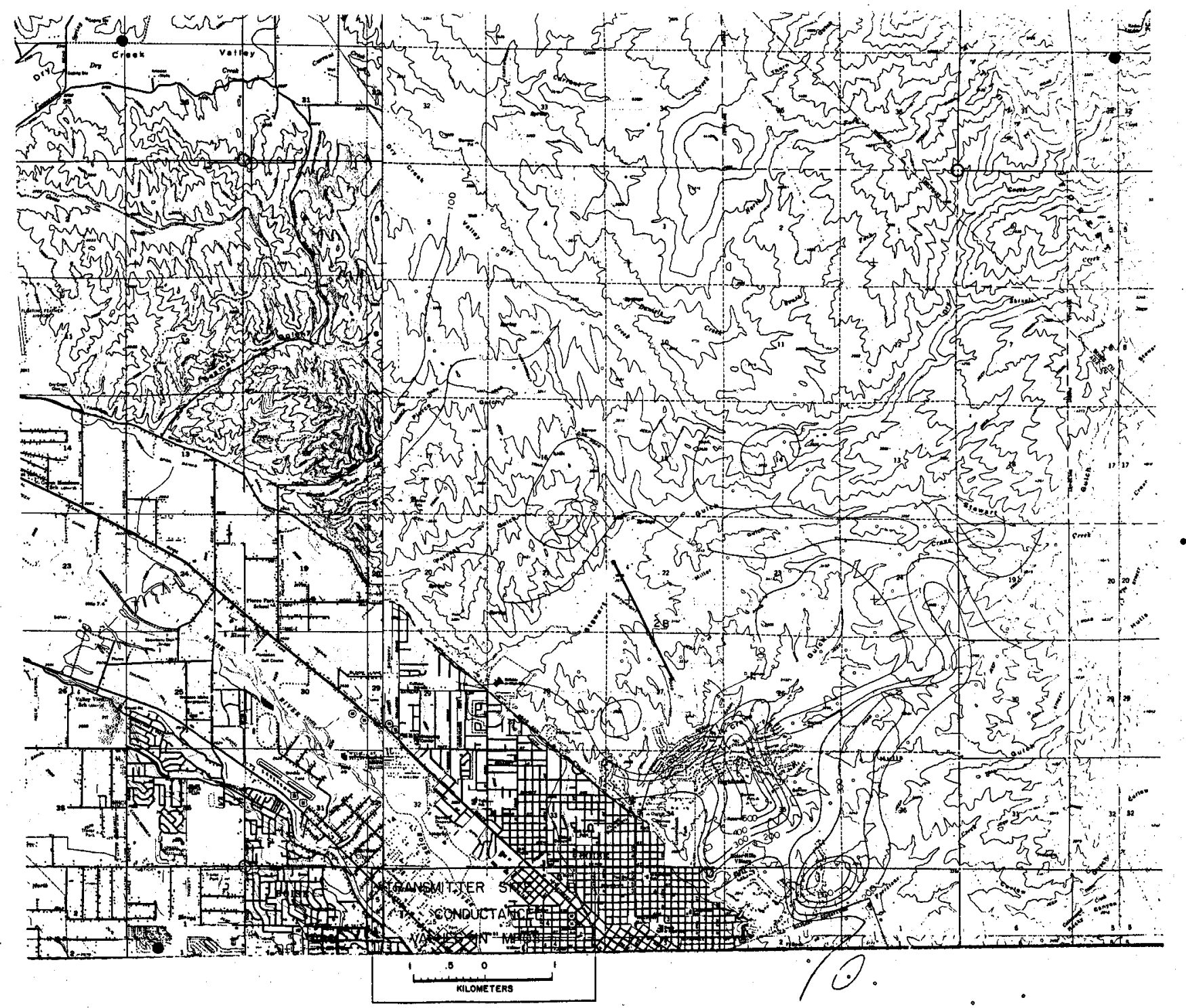


Some of the wells drilled near Mountain Home and east of the Air Base form linear patterns that could reveal structural control for the thermal water occurrence. The alignment is transverse to the western Snake Plain axis and, as in Ada and Canyon counties, thermal water occurrences could be at least partially controlled by faulting running across the plain. However, the springs and wells that occur along the plain margin seem to be influenced by structures running parallel to the western snake Plain axis or northwest-southeast.

Mountain Home and Mountain Home Air Force Base are the two principal population centers in southern Elmore county where thermal water occurs and where greatest use could probably be made for it. Other towns are King Hill and Glenns Ferry. Low temperature $\left(20-30^{\circ} \mathrm{C}\right)$ thermal wells are located within $5 \mathrm{~km}$ of the above sites. Prospecting for more thermal water in each of these areas might prove fruitful, and the prospect of hotter water at depth is possible. These areas should be further investigated to determine their full potential, beginning with chemical analyses of existing thermal well waters so an estimate can be made of the maximum water temperature through the use of chemical geothermometers.

\section{GOODING COUNTY}

Seven thermal anomalies occur in Gooding County (figure 45). Four wells and a spring occur along clover Creek near the foot of the Mount Bennett Hills and another occurs near the snake River. All are in western Gooding county and far removed from most population centers.

Chemical analyses are available on three of the seven thermal sites in Gooding County. White Arrow Hot Springs (4S-13E-30adb1S) is the hottest at $65^{\circ} \mathrm{C}$. Agreement between the chalcedony and $\mathrm{Na}-\mathrm{K}-\mathrm{Ca}$ chemical geothermometers $\left(108^{\circ} \mathrm{C}\right.$ and $112^{\circ} \mathrm{C}$, respectively) indicates subsurface temperatures are probably in this range. However, in drilling the well at White Arrow Hot Springs, the owner reports blue quartz was found in the hole. The quartz chemical geothermometer predicts temperature of $135^{\circ} \mathrm{C}$. White Arrow is presently the scene of private agricultural research and commercial production of tomatoes in geothermally heated greenhouses. Idaho Image (May-June, 1975) reported the following activities at white Arrow Ranch by Bob Erkins:

Tomatoes are harvested at the White Arrow Ranch at Bliss from september through July, when temperatures range from 38 to $-2^{\circ} \mathrm{C}$.

Tomato plants are very sensitive to extremes of temperatures; however, the secret at White Arrow 


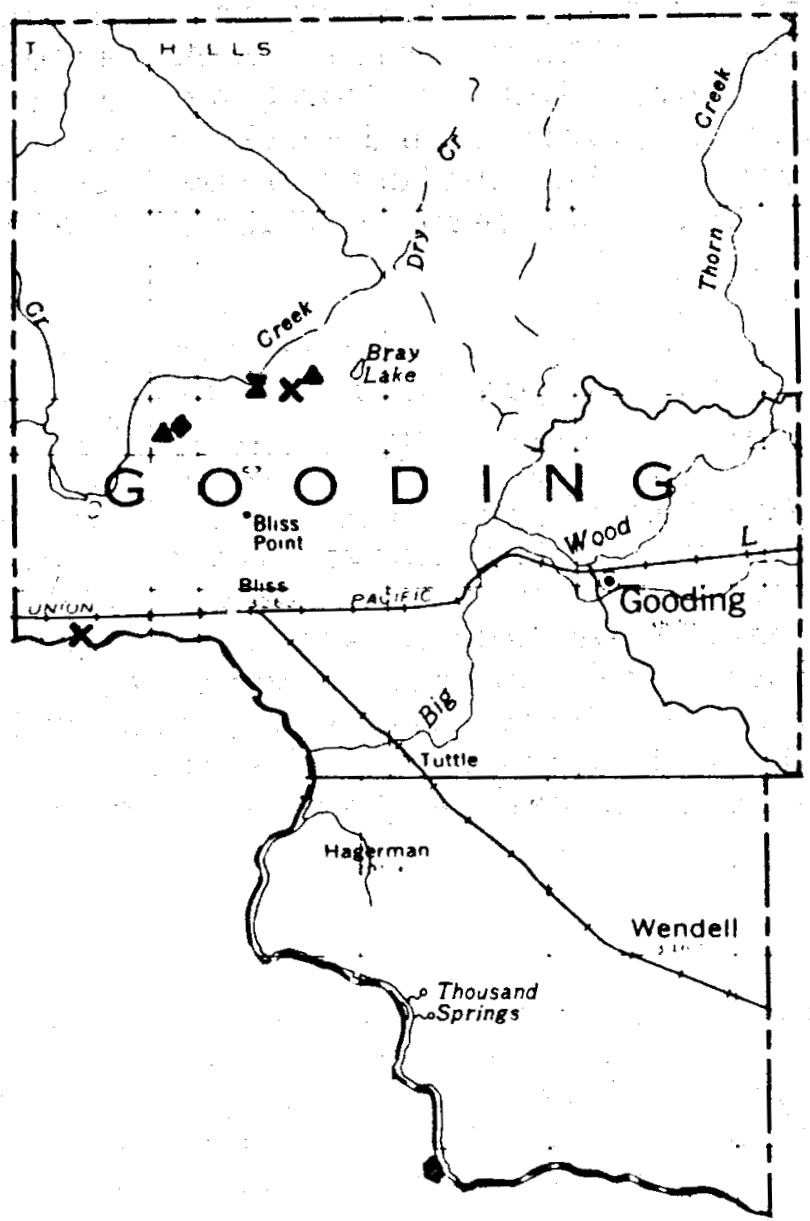

\section{PARAMETER RANGE}

\begin{tabular}{c} 
Low \\
\hline Temperature \\
20.00 \\
30.00 \\
40.00 \\
50.00 \\
60.00 \\
70.00 \\
80.00 \\
90.00
\end{tabular}

\begin{tabular}{|c|c|c|c|}
\hline urface & remp. & Deg. C & High \\
\hline & * & & Unknown \\
\hline & $x$ & & 29.99 . \\
\hline & 4 & & 39.99 \\
\hline & 0 & & 49.99 \\
\hline & $\Delta$ & & 59.99 \\
\hline & $x$ &.$\cdot \cdot$ & 69.99 \\
\hline & a & 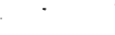 & 79.99 \\
\hline & e & & 89.99 \\
\hline & 0 & & 100.00 \\
\hline
\end{tabular}

FIGURE 45. Index map of Gooding County showing locations of thermal water occurrences with surface temperatures of $20^{\circ} \mathrm{C}$ or higher. 
Ranch is that they use a large natural hot spring to maintain optimum growing temperature during the winter in their two 12 by $40 \mathrm{~m}$ hothouses.

The water which comes from the ground at a temperature of $65^{\circ} \mathrm{C}$ flows into heat exchangers at the end of the building. Air is blown across them and through large plastic pipes and carried the length of the building. Hot water is also carried through some $3 \mathrm{~km}$ of black plastic pipe which provides further radiant heat.

In hot weather, the south end of the building can be opened and ventilation provided by six large exhaust fans. The temperature is further controlled by blowing air through large cooling pads through which cold water is dripped.

Throughout the year, according to owner Robert A. Erkins, the temperature can easily be maintained at between $18^{\circ}$ and $28^{\circ} \mathrm{C}$. Production is stopped in the summer months not by the weather, but because that is the season when there are plenty of tomatoes already on the market from growers using more conventional methods.

Just getting out of the experimental stage and into full production, White Arrow Ranch has been shipping about 600 pounds of tomatoes per week but, within the next month or two, expects to be shipping around 4,000 pounds per week. Erkins projects a crop of up to 30 tons of tomatoes annually from a quarter acre of space.

Some 3,000 Manapal tomato plants were planted for the first crop. Erkins said it was one of several hothouse varieties that could have been used.

Future plans include cucumbers and potted house plants. Land is already cleared and piping in for 12 more hothouse buildings, although their construction will not be completed until they are needed.

The key to the system is a free-flowing hot spring which provides heated water at a rate of 3800 $1 / \mathrm{min}$, much more than needed for any projected expansion. Erkins said his electric bill is not high, but dependable power supply is important to proper operation of the system. In the two existing buildings some 18 electric fans are used for heating and cooling. In addition, three electric pumps move the well and spring water used to water 
the tomato plants. (Water from the hot spring is not used for this purpose.)

Erkins requires only one employee to operate the first building. One of his most important functions is to walk through the structure three times a day with a gasoline-powered blower strapped on his back to pollinate the plants. Tomatoes are normally pollinated by wind, but there is none in the buildings.

One of the biggest problems, according to Erkins, was a lack of data. There have been other hothouses using natural hot water, but no one seèmed to be able to provide much really expert information, so much had to be learned by experimentation.

Erkins and his wife have been in the trout farming business in Idaho for 23 years, but it is their first venture in tomato growing. White Arrow Ranch was originally settled in the $1800^{\prime} \mathrm{s}$, but had been deserted for some time before being purchased by the Erkins. It was named for an Indian tribe that had camped at the site and which was noted for making white arrowheads.

$A$ well in Gooding County $(4 \mathrm{~S}-13 \mathrm{E}-28 \mathrm{abbl})$ is $47^{\circ} \mathrm{C}$ at the surface, with the $\mathrm{Na}-\mathrm{K}-\mathrm{Ca}$ and chalcedony chemical geothermometers indicating temperatures of $98-105^{\circ} \mathrm{C}$ at depth. Uses similar to that of White Arrow could probably be made with this water. Another well (5S-12E-3aaal) is $57^{\circ} \mathrm{C}$ at the well head; the $\mathrm{Na}-\mathrm{K}-\mathrm{Ca}$ and chalcedony chemical geothermometers predict maximum subsurface temperatures from $70-83^{\circ} \mathrm{C}$ might be found in this area.

Little information is available from the other wells in Gooding County.

\section{JEROME COUNTY}

Royal Catfish Industries has used geothermal water to raise catfish in Jerome County (figure 46). The operation is now closed. Thermal water at $43^{\circ} \mathrm{C}$ is discharged from a thermal well (9S-17E-29dbbl) located along the snake River north of Twin Falls to supply water to the facility which had 30 fish rearing ponds. Subsurface temperatures predicted by the chalcedony and $\mathrm{Na}-\mathrm{K}-\mathrm{Ca}$ chemical geothermoineters are 89 and $930^{\circ}$ respectively. No other thermal water is known in Jerome county and the potential for further prospects is unknown. 



\section{MINIDOKA COUNTY}

Little information on the geothermal potential of Minidoka County is available. The area is underlain by the Snake plain aquifer, which may mask thermal occurrences throughout the eastern Snake River plain. A single thermal well (9S-23E-28ccal) (figure 46), drilled for the city of Paul, encountered Pliocene and Pleistocene basaltic lava flows to a total depth of $137 \mathrm{~m}$, discharges $22^{\circ} \mathrm{C}$ at 7570 $1 /$ min. Its occurrence suggests more and possibly hotter water might be found in the area. No chemical analysis is available, therefore, speculation about possible subsurface temperatures cannot be made. Uses up to and including groundwater heat pump space heating and cooling could be nade of the thermal water at existing discharge temperatures. A chemical analysis of the well waters should be made to ascertain the possibilities of obtaining hotter water in the area through deeper drilling.

\section{OWYHEE COUNTY}

The Bruneau-Grand View thermal anomaly zone (figure 47) in southwest Idaho is the largest geothermal area in the western United States, rivaled in size only by the geopressured zones in the Texas-Louisiana Gulf Coast region. Renner and others (1975, p. 39) estimate that $1100 \mathrm{x}$ 1018 joules of heat (above $15^{\circ} \mathrm{C}$ to $10 \mathrm{~km}$ of depth) are contained in rocks and water beneath an estimated $2250 \mathrm{sq} . \mathrm{km}$ of land area. Thermal water ranging in temperature from 20 to $84^{\circ} \mathrm{C}$ is extracted from more than 100 domestic, stock, and irrigation wells from two different types of aquifers sedimentary and volcanic rock. Many of the wells are artesian and range from 150 to nearly $1100 \mathrm{~m}$ deep. They are concentrated mostly in four areas - Bruneau River valley, Little valley, Grand View, and oreana where farmland is available for agricultural use. Young and Whitehead's (1975, p. 44-45) assessment of the resource in this area is summarized.

The rocks in the Bruneau-Grand View area range in age from Late Cretaceous to Holocene. Rocks of the Cenozoic Era have been subdivided in four groups: (1) an unnamed sequence of rhyolitic and related rocks, (2) the Idavada Volcanics, (3) the Idaho Group, and (4) the Snake River Group. For convenience, these rocks units have been divided into two major groups according to their hydrologic properties: (1) the volcanic-rock aquifers that include the Idavada Volcanics, the Banbury Basalt of the Idaho Group and undifferentiated silicic volcanic rocks; (2) the sedimentary-rock aquifers, which include chiefly sedimentary units of the Idaho and Snake River Groups. 


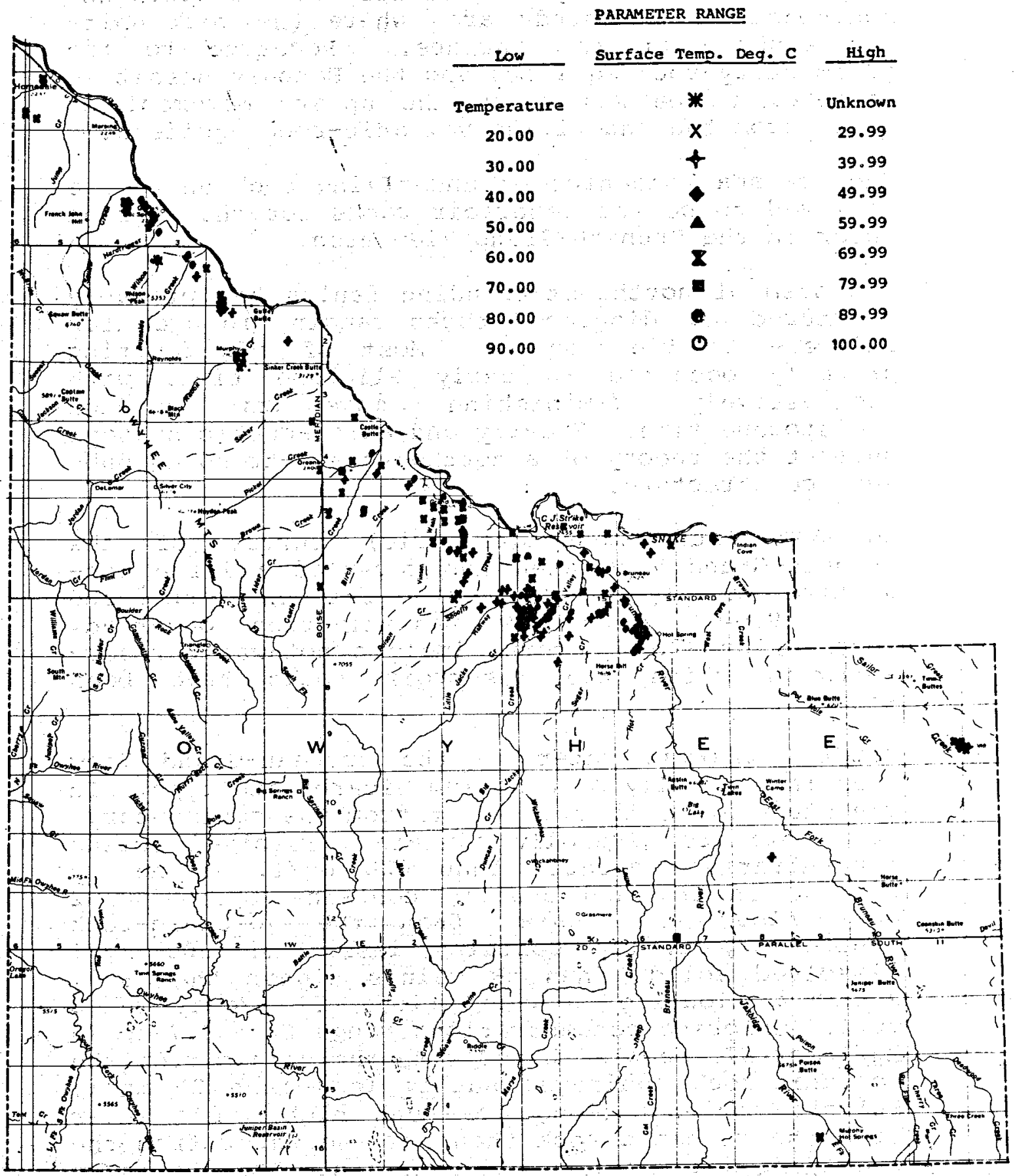

FIGURE 47. Index map of Owyhee county showing locations of thermal water occurrences with surface temperatures of $20^{\circ} \mathrm{C}$ or higher. 
Recharge to the volcanic-rock aquifer (except the Banbury Basalt) is thought to be chiefly from precipitation in the higher altitudes to the south and southwest of the study area where the rock units are exposed at the surface. Recharge to the sedimentary-rock aquifers and the Banbury Basalt is believed to be mainly by the upward movement of water from the underlying volcanic-rock aquifers.

The Idavada Volcanics or underlying rock units are believed to be the reservoir rocks for the thermal water in the Bruneau-Grand View area.

A system of northwest-trending faults has probably fractured and displaced rocks ranging in age from Pliocene to Pleistocene. Most of the faulting probably occurred in early pliocene time, with progressively diminishing movements through Pleistocene time. Gravity and aeromagnetic surveys support the theory of a northwestward-trending subsurface structure.

An AMT (audio-magnetotelluric) survey of the Bruneau-Grand View area has revealed a large conductive anomaly in the region between oreana and Grand View. The low resistivities observed, approaching 2 ohm-meters, imply a hot-water reservoir in which the reservoir rocks have been altered.

Sampled thermal water in the Bruneau-Grand View area is generally of a sodium bicarbonate type. In the study area, thermal water from the sedimentaryrock aquifers generally contains dissolved solids concentrations greater than $600 \mathrm{mg} / \mathrm{l}$, is nearly neutral in $\mathrm{pH}$, and usually contains less than 2 mg/l flouride. Water from the volcanic-rock aquifers generally contains less than $500 \mathrm{mg} / 1$ dissolved solids, has $\mathrm{pH}$ values higher than 8.0 , and has flouride concentrations in excess of 8 $\mathrm{mg} / 1$. Chloride concentrations range from 2.7 to 79 $\mathrm{mg} / \mathrm{l}$ for all sampled water with the values from the volcanic-rock aquifers usually less than $20 \mathrm{mg} / \mathrm{l}$. sulfate concentrations are much higher for water from the volcanic rock than for the water from the overlying sedimentary-rock aquifers. The chemistry of the thermal water from the volcanic-rock aquifers is very similar to that of thermal water flowing from the granitic rocks of the Idaho batholith.

(Note: Recent deep drilling in the area has revealed the existence of granitic rock underlying the silicic volcanic rock aquifers.) 
Ratios of concentration of selected chemical constituents are used to distinguish water from the volcanic-rock and sedimentary-rock aquifers. The chloride-fluoride ratio is probably the best indicator with ratios generally less than 0.6 for water from the volcanic-rock aquifers. Chloride-boron ratios of the hotter water aquifers showed a marked decrease near Bruneau and Grand View because of increased boron concentrations.

Measured groundwater temperatures at the surface in the Bruneau-Grand View area range from 9.5 to $83^{\circ} \mathrm{C}$ with the higher temperatures $\left(40\right.$ to $\left.83^{\circ} \mathrm{C}\right)$ found in the water from the volcanic-rock aquifers. Temperatures of the water from the sedimentary-rock aquifers seldom exceed $35^{\circ} \mathrm{C}$. The observed groundwater temperatures in the volcanic-rock aquifers seem to be related to the depth to the aquifers.

The gas in samples collected from water in the Bruneau-Grand View area consists primarily of nitrogen, oxygen, and methane. Me thane was found primarily in samples from the sedimentary rock aquifers. Analysis of the gas in water from the volcanic-rock aquifers indicates that the gas is essentially that contained in meteroic water recharging the system.

Mineral deposition at wells and springs in the Bruneau-Grand View area is noticeably absent, largely because of the low dissolved-solids concentration in the water.

The source of heat for the deeply circulating thermal waters in the Bruneau-Grand View area is believed to be an above normal geothermal gradient. This above normal gradient could be related to a thinning of the earth's upper crust in this area.

The Bruneau-Grand View area represents a complex geothermal system consisting of several aquifers that may be interconnected by faulting and by wells that have been drilled through the overlying sedimentary rock aquifers into the volcanic rock aquifers. The complexity and intermingling of water from wells drilled into the various aquifers precludes accurate subsurface determinations for every wel1. Consequently, only aquifer temperatures are given in basic data table 4 (in basic data table 2 all available aquifer temperatures are given) for wells cased at least two thirds of their total depth and to those with surface temperatures of $40^{\circ} \mathrm{C}$ or above. These estimated aquifer temperatures suggest that the waters in the Bruneau-Grand view area have never been very hot $\left(100\right.$ to $\left.110^{\circ} \mathrm{C}\right)$ and in 
some cases may have come from depths where temperatures are even cooler $\left(70\right.$ to $\left.100^{\circ} \mathrm{C}\right)$. Deep drilling in the area has given conflicting results, although the most accurate seems to come from Phillips Petroleum's Lawrence D. No. 1 well (5S-1E-24adl) with a reported bottom hole temperature of $108^{\circ} \mathrm{C}$ at a depth of $2,672 \mathrm{~m}$.

Young and Whitehead's study was limited to an area south of the snake River. It is not known whether the aquifer systems extend north of the snake River. Warner (1975) postulated the existence of a large northwest striking left lateral rift system near the present course of the snake River, with clockwise or northwestward rotation of about 80 $\mathrm{km}$ of the northern block relative to the southern block. Rifting postdates formation of the sedimentary and volcanic rock aquifers of the Bruneau-Grand view area." If this rifting hypothesis is correct, the sedimentary and volcanic rock aquifers in the Bruneau-Grand View area have been rifted also, and the other "half" of this thermal anomaly may have been subsequently shifted northwestward to now 1 ie somewhere between Boise and Weiser. Indeed, much thermal water has been found by well drillers: in Ada, Canyon, Payette and Washington counties.

\section{TWIN EALLS COUNTY}

Thermal water in Twin Falls County (figure 48) is widely scattered occurring principally in the northeastern and eastern part of the county. There are 56 thermal water occurrences with surface temperatures of $20^{\circ} \mathrm{C}$ or above.

Miracle (8S-14E-3lacbls) and Banbury (8S-4E-33cbals) hot springs are resorts located along the Snake River in northwestern Twin Falls County. Several wells are also located along the Snake River north and west of Buhl.

A number of wells have encountered warm water in the Blue Gulch area northwest of Balanced Rock and west of Salmon Falls Creek. A fairly large warm water aquifer may exist here, judging from the number and spacing of thermal wells. A general alignment of wells and springs along the eastern margin of the thermal anomaly may indicate faulting or other geologic structure that may control thermal water here. A large northwest-trending linear feature (figure 29), which stretches from Mountain Home to Salmon Falls Creek $(90 \mathrm{~km})$, may also control thermal water here and feed the aquifer system. Wells generally average $190 \mathrm{~m}$ deep and well head temperatures average about $27^{\circ} \mathrm{C}$.

A well $0.8 \mathrm{~km}$ east of Buhl may indicate some potential for low temperature geothermal use in the Buhl area. No other information is available on this well except that the well head temperature is $26^{\circ} \mathrm{C}$. 


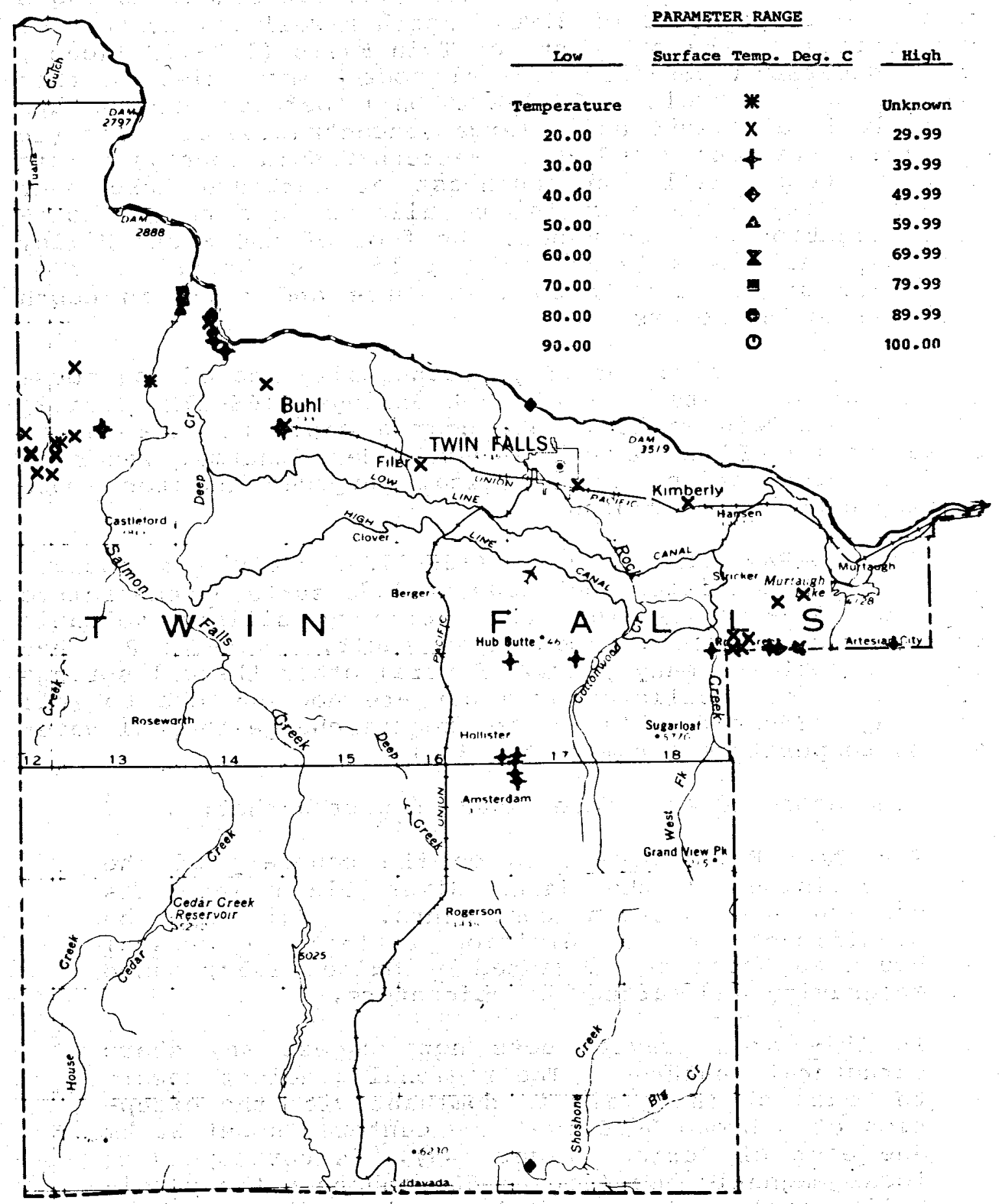

FIGURE 48. Index map of Twin Falls County showing locations of thermal water occurrences with surface temperatures of $20^{\circ} \mathrm{C}$ or higher. 
The city of Filer owns a well (10S-16E-8cdal) having a well head temperature of $27^{\circ} \mathrm{C}$. Another well temperature of $290^{\circ} \mathrm{C}$ exists on the outskirts of Twin Falls (10S-17E-14ccdl) and indicates a possible thermal source may exist in this area also. A well (10S-18E-26bbal) between Hansen and Kimberly is also $20^{\circ} \mathrm{C}$ and a large concentration of wells ( 10 in Twin Falls County and 20 in western Cassia County) exists east of Cedar Hill and southwest of Murtaugh Lake near Artesian City. These wells are aligned in a nearly eastwest direction and occur near the foot of the South Hills. This may indicate a large fault could exist here. Most of the wells are in the 27 to $37^{\circ} \mathrm{C}$ range and range in depth from 150 to 365 meters.

Perhaps the first or only geothermally heated dog house in the world exists at Magic Hot Springs (16S-17E-30acals) in southern Twin Falls County near a small private resort close to the Idaho-Nevada border. Here thermal water is used for recreation, balneological purposes and for space heating a number of cabins.

Nat-Soo-Paw Warm Springs (12S-17E-3lbabls) is located $5 \mathrm{~km}$ east of Hollister and flows at $36^{\circ} \mathrm{C}$ surface temperature from Quaternary alluvium near Tertiary silicic volcanic rocks along a possible concealed fault. Nat-Soo-Paw has been a resort for many years. Several other thermal springs existed in the Hollister area but are now dry due to well drilling. Several wells in the area discharge thermal water of low temperature (from 20 to $38^{\circ} \mathrm{C}$ ).

Donaldson and Applegate (1979) reported that:

The Twin Falls area lies on the boundary of the subdivision of the snake River Plain into its eastern and western components. This may be significant if the division reflects a crustal break as has been suggested by Malde (1959) based on gravity and earthquake epicenters.

In this area gravity does not suggest any sharp structural features. The regional gradient toward the axis of the plain is dominant with the exception of a broad 5-10 mgal low centered about $23 \mathrm{~km}$ due east of Jerome (figure 49). A corresponding local magnetic low (Eigure 50) enhances the possibility that a structural depression exists. There are no active faults documented by witkind (1975) in this subarea but Day (1974) has mapped lineaments from ERTS imagery which approximate the trend of the western plain in direction (figure 10).

A series of warm wells in the southern portion of this area match quite closely the trends of 3 active faults reported by Witkind (1975). 



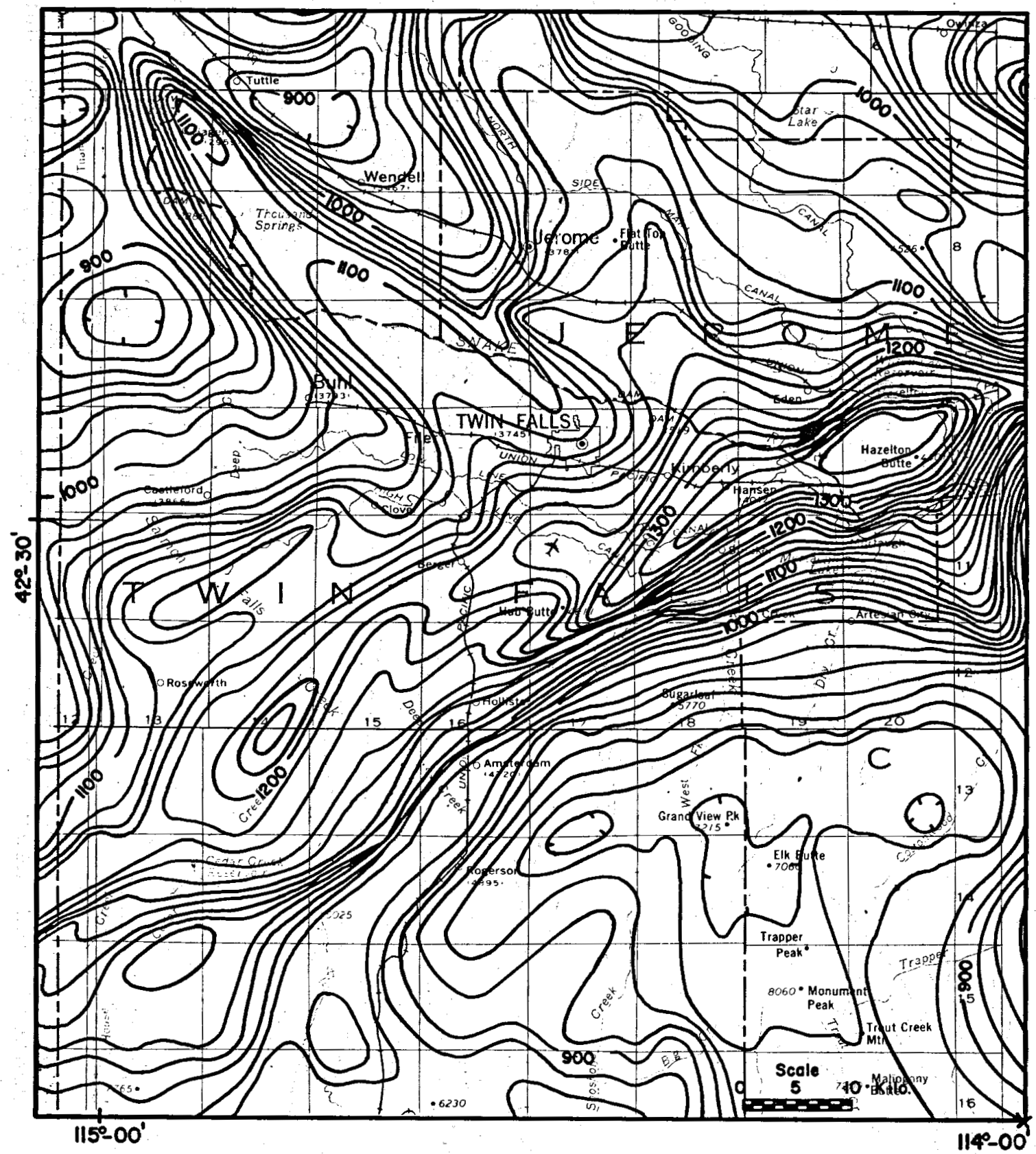

FIGURE 50. Aeromagnetic map showing low west of Jerome (upper right) (U.S. Geological Survey, 1971). 
Extensive geothermal leasing activity is ongoing in the Island Park basin in east-central Fremont county near Yellowstone Park (figure 51). Stearns and others, (1939, p. 28-29) recognized this basin as a caldera. Hamilton (1965, p. Cl) described the "Island Park caldera" as "an elliptical collapse structure 29 by $37 \mathrm{~km}$ in diameter that was dropped from the center of a shield volcano composed of rhyolite ash flows." Hamilton further described the caldera as:

...part of the Snake River-Yellowstone province of intense Pliocene and Quaternary volcanism of olivine basalt and rhyolite. In this province, as in other bimodal volcanic provinces, rhyolite and basalt erupted from vents interspersed in both time and space, and simultaneous eruptions of both liquids from the same or nearby vents are known to have occurred. In the Island Park caldera the eruptive sequence and geometry suggest that the large magma chamber contains liquid rhyolite overlying liquid olivine basalt.

Hoover and Long (1975, p. 1,062) stated:

Current geologic evidence suggests that a Yellowstone-type system does not exist at Island Park because the last major rhyolite body was emplaced about one million years ago and subsequent eruptions were of basaltic composition coming from the mantle along fractures in the older caldera (R.L. Christiansen, oral commun., 1975). The general absence of hot springs also suggests an old system. AMT and telluric surveys were made in August 1974 to study the possible existence of concealed hydrothermal activity.

The generalized geology of rock types in the caldera is shown in figure 52 with the $7.6 \mathrm{~Hz}$ north-south AMT data. The caldera stands out as an area of high resistivity, generally above $100 \mathrm{ohm}-\mathrm{m}$ surrounded by a region of intermediate values. Within the caldera local highs around $1000 \mathrm{ohm}-\mathrm{m}$ are associated with small rhyolite domes on the surface, and most hidden by later basalt flows. The AMT data shows the possibility of another rhyolite body on the western rim of the caldera which has been covered by tuff and rhyolite flows and may represent a source for some of these materials.

An east-west cross section is shown in figure 53 . Included in the figure is a skin-depth 


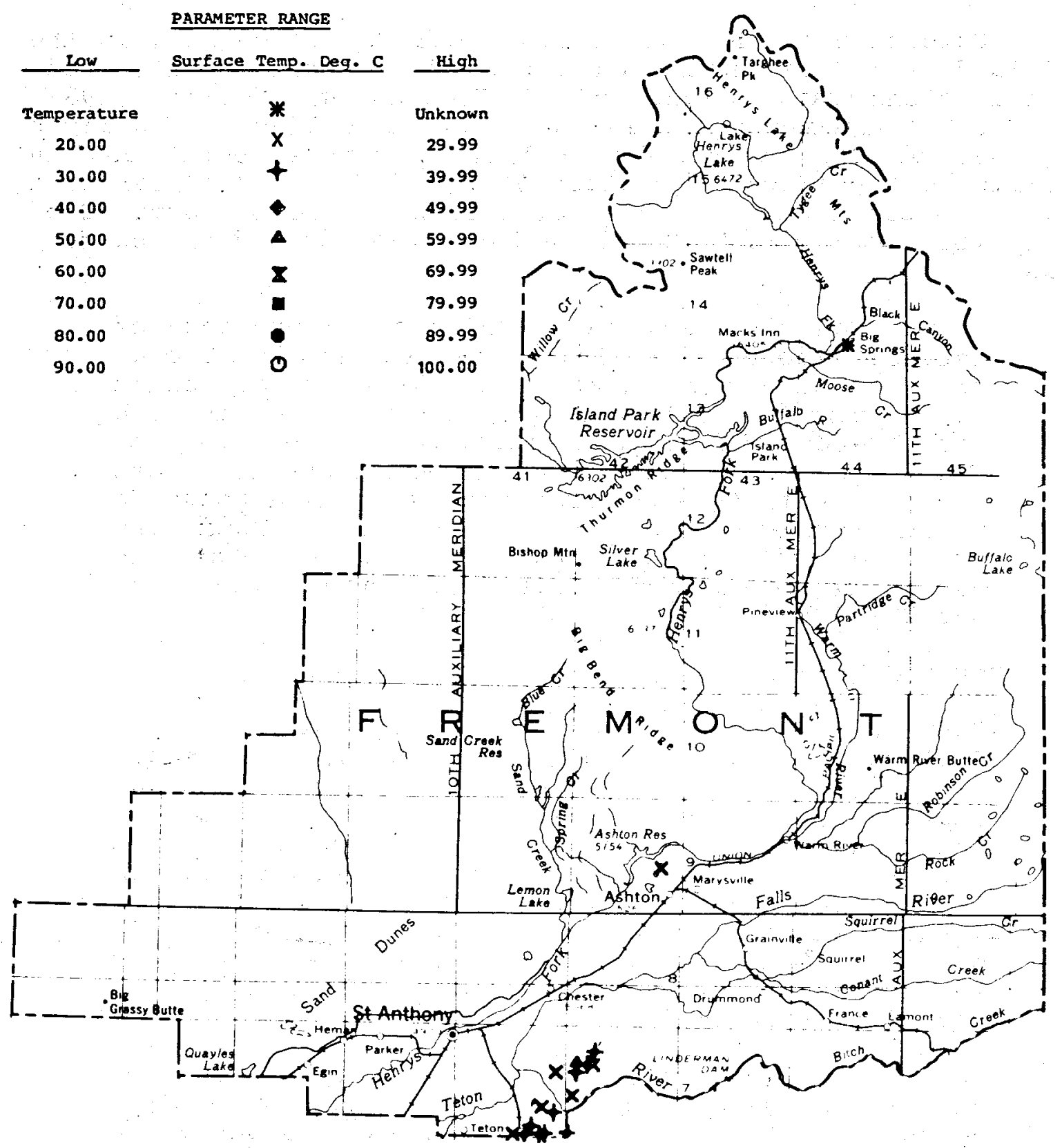

FIGURE 51. Index map of Fremont county showing the locations of thermal water occurrences with surface temperatures of $20^{\circ} \mathrm{C}$ or higher. 


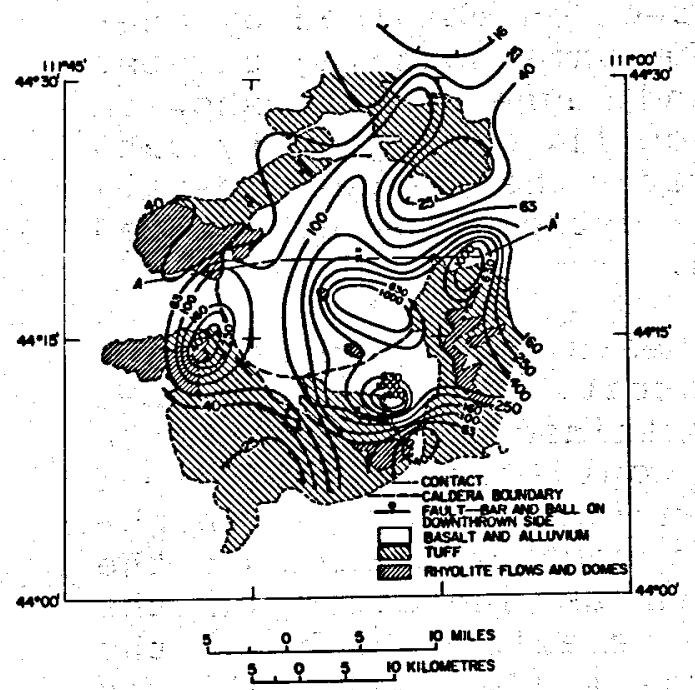

FIGURE 52. Map of rock types and $26 \mathrm{~Hz}$ apparent-resistivity (telluric line north-south), Island Park, Idaho. Contours in ohm 'meters and logarithmic basis.

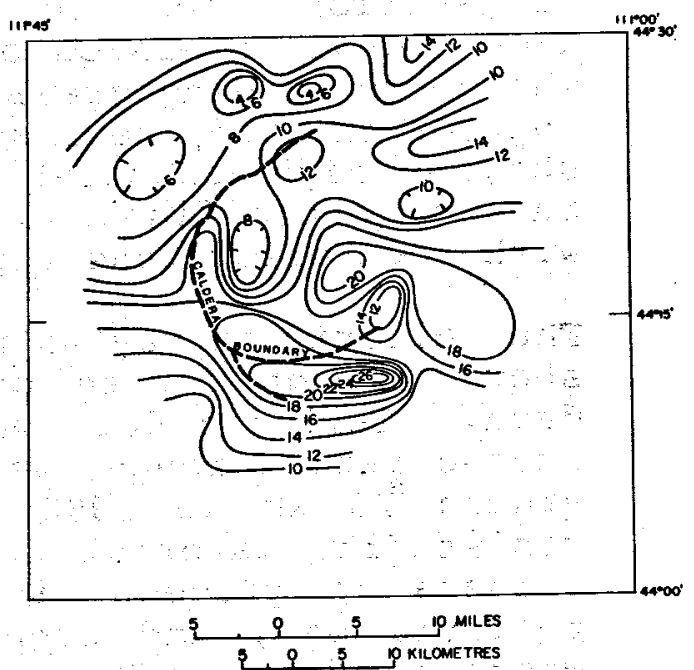

FIGLRE 54. Telluric anomaly map at 20 - to 30 -sec period, Island Park, Idaho. Contour interval $2 K=10 \mathrm{VJ}$.

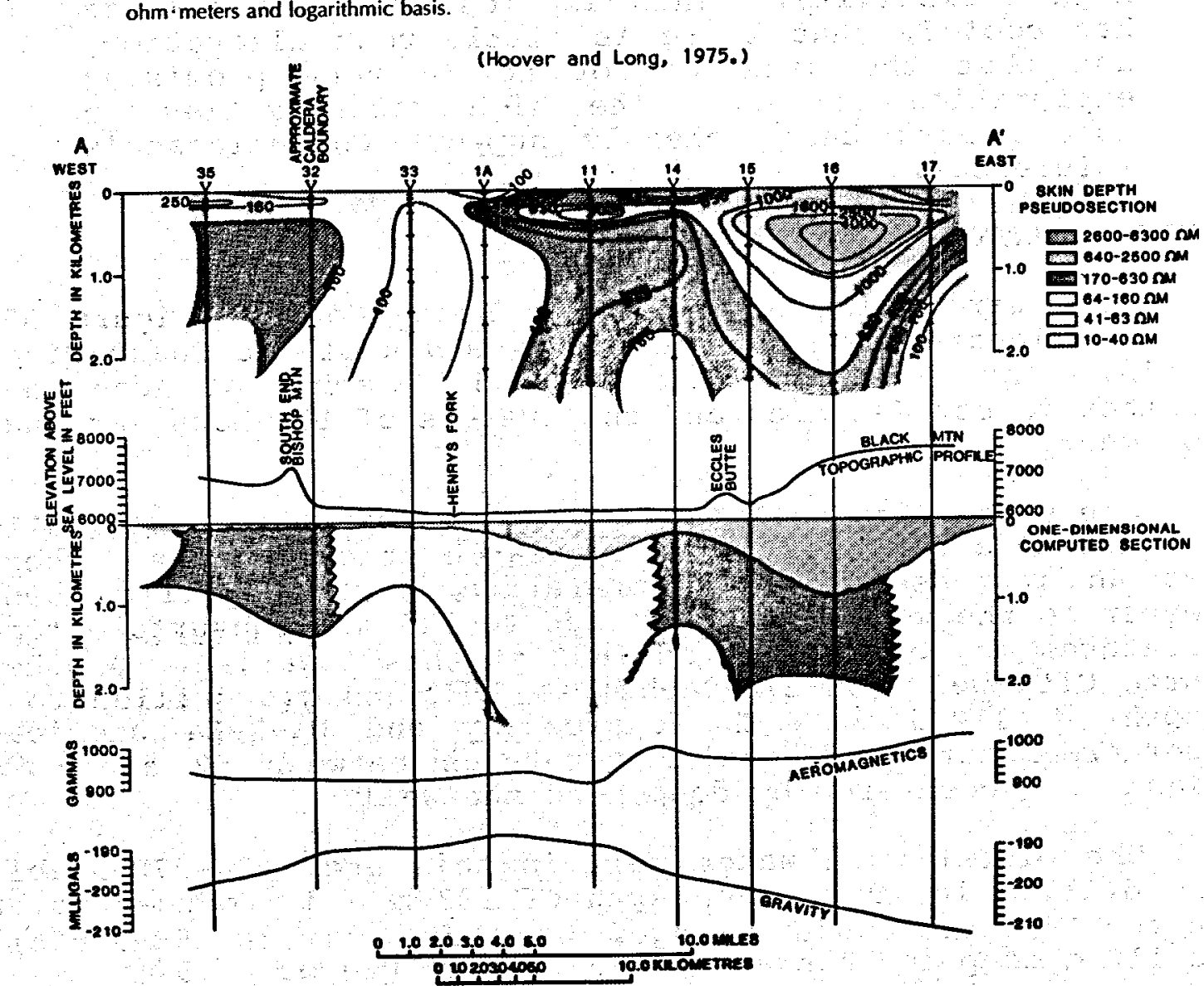

FIGURE 53. Comparison of skin-depth pseudosections and one-dimension inverted section with gravity and magnetic data across the Island Park area. Line of section $\left(A-A^{\prime}\right)$ shown in Figure 6. 
pseudosection obtained by contouring the apparent resistivities at their corresponding skin depths on the section, and a second section obtained by onedimensional inversion of the same sounding curves. The corresponding gravity and magnetic data show an edge of the body near station 11. The gravity data show a high associated with the caldera partly masked by the flanks of the extreme low associated with the Yellowstone region.

The telluric survey data appears in figure 54 which shows a high degree of correlation with the AMT data. Telluric data was obtained in the 20 to 30 second period range, which would give a skin depth around $25 \mathrm{~km}$ in $1000 \mathrm{ohm}-\mathrm{m}$ material. The highresistivity material in the southeast part of the caldera is present at depth as indicated on the telluric map, and even the smallest high on the western edge can be seen as well. The telluric data also clearly shows the caldera as a region of high resistivity. This implies that the caldera has cooled, that there is little rock alteration, and that the area is not now a very promising exploration target. The high resistivities in Island Park basin clearly support Christiansen's inferences.

\section{BUTTE COUNTY}

Four warm wells are known in Butte County (figure 55) and are located near the northern margin of the Snake River Plain. Three are in Butte City, $5 \mathrm{~km}$ south of Arco, and another is between Arco and the Craters of the Moon National Monument.

One Butte City well (3N-27E-9abbl) $\left(35^{\circ} \mathrm{C}\right)$ was originally drilled to a depth of $259 \mathrm{~m}$ in search of cold water. There was an increase in the temperature as the drilling went deeper so the well was backfilled to $145 \mathrm{~m}$. Subsurface temperatures may be as high as $76^{\circ} \mathrm{C}$ at this location. Another Butte City well $(3 \mathrm{~N}-27 \mathrm{E}-9 \mathrm{abb} 2)$ is $33^{\circ} \mathrm{C}$ and was drilled to a depth of $152.5 \mathrm{~m}$. The chalcedony and $\mathrm{Na}-\mathrm{K}-\mathrm{Ca}$ chemical geothermometers indicate temperatures between 52 and $54^{\circ} \mathrm{C}$ might be encountered by deepening the well.

The oldest warm water well in this area (3N-27E-9aabl) was drilled in 1919 to a depth of $183 \mathrm{~m}$ and produced water in the $40^{\circ} \mathrm{C}$ temperature range. Another well (3N-25E-32cdcl) is $110 \mathrm{~m}$ deep and has a surface temperature of $43.5^{\circ} \mathrm{C}$.

Butte City-Arco might be an area where use of thermal water for space heating could prove feasible. As other wells in the area have not encountered thermal water, it 
PARAMETER RANGE

Low

Temperature

20.00

30.00

40.00

50.00

60.00

70.00

80.00

90.00

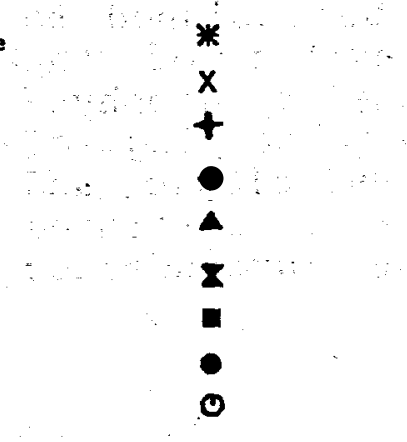

Unknown

29.99

39.99

49.99

59.99

69.99

79.99

89.99

100.00
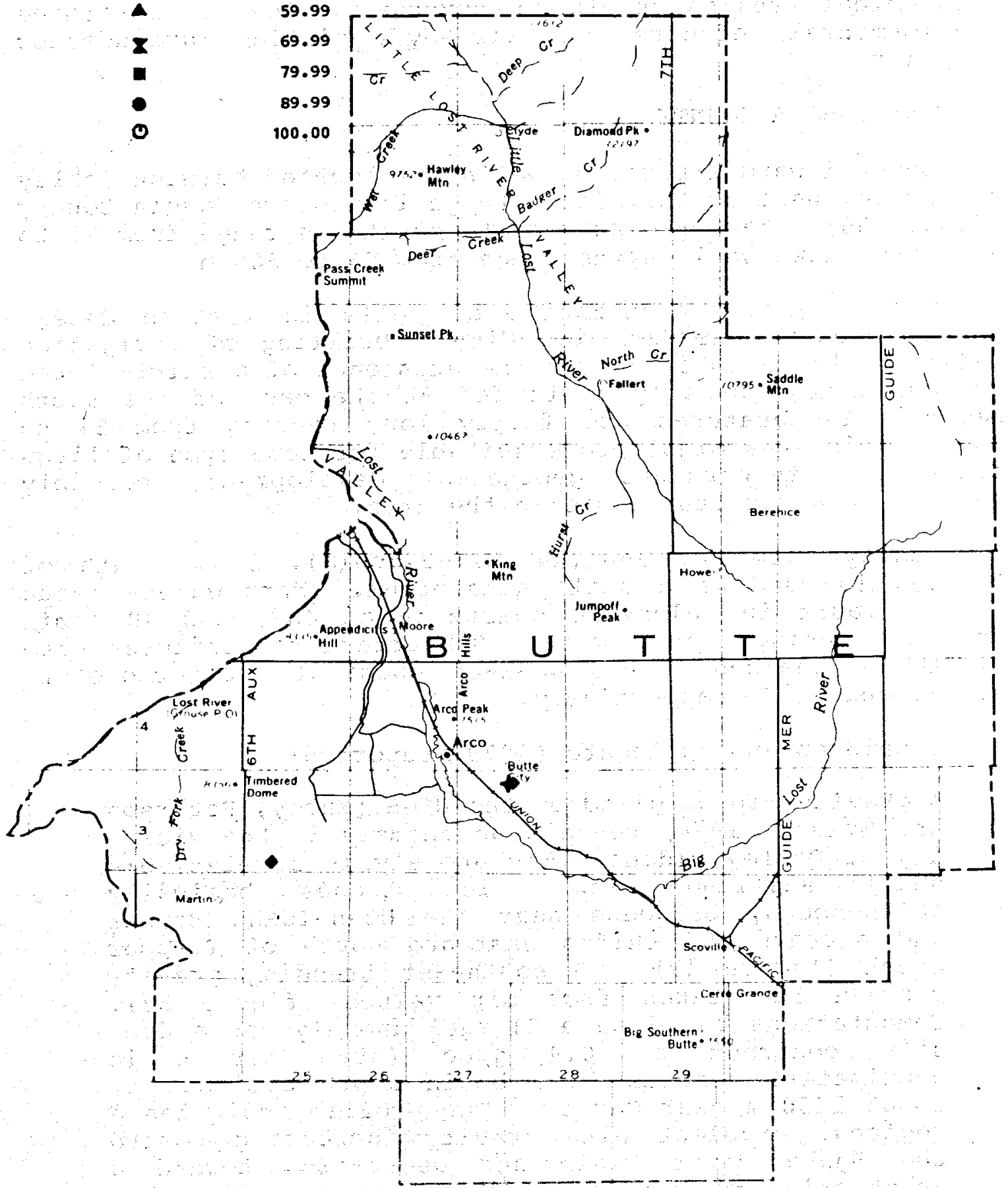

FIGURE 55. Index map of Butte County showing locations of thermal occurrences with surface temperatures of $20^{\circ} \mathrm{C}$ or higher. 
appears these thermal occurrences are structurally controlled (maybe drilled into faults along which the thermal water is rising). Any studies should be designed to delineate the faults and determine the extent of the resource along them. This could be accomplished by geophysical techniques, coupled with detailed geologic mapping, of the area around Butte City and Arco. Hydrologic and geochemical studies should be pursued in order to determine developmental effects on already existing groundwater supplies.

WESTERN CASSIA COUNTY

Several warm irrigation wells are located between Oakley and Burley west of the Albion Range in western Cassia County (figure 56). Measured surface temperatures range from 21 to $39^{\circ} \mathrm{C}$ and known well depths range from 76 to $585 \mathrm{~m}$.

The largest concentration of wells in western Cassia County occurs near Artesian City. Drilling of irrigation wells in this area indicates the existence of a fairly large thermal zone, possibly fault fed at the base of the south Hills. Temperatures are fairly low, ranging from 24 to $38^{\circ} \mathrm{C}$. This area might prove suitable for some type of large scale low temperature geothermal development, possibly related to agricultural use in the area.

Oakley Warm Springs (14S-22E-27dcbls), $5 \mathrm{~km}$ south of Oakley, is used as a small natatorium. Warm waters issue from a fault in Paleozoic quartzite at $48^{\circ} \mathrm{C}$ and $40 \mathrm{l} / \mathrm{min}$ from two springs and a well. Subsurface temperatures predicted by chalcedony and $\mathrm{Na}-\mathrm{K}-\mathrm{Ca}$ chemical geothermorneters are 89 and $92^{\circ} \mathrm{C}$, respectively.

Donaldson and Applegate (1979) reported:

A gravity map compiled by the USGS (Mabey, Peterson and wilson, 1974) reveals an anomaly in the vicinity of Oakley, Idaho. The anomaly is a relatively small amplitude low which trends basically north-south, broadens near the Utah-Idaho Border and narrows and shifts eastward north of Trapper Creek (figure 49). A southeast trending gravity profile was taken Erom map values (Eigure 57). Computations based on a $21 \mathrm{mgal}$ anomaly and a density contrast of $0.4 \mathrm{~g} / \mathrm{cc}$ (gram per cubic centimeter) results in a basin depth estimate of about $1250 \mathrm{~m}$ near Oakley. The profile indicates a regional gradient with gravity increasing toward the Snake River Plain and decreasing toward a neighboring gravity low southeast of Almo, Idaho.

The Oakley anomaly is not strongly definitive of structure and Witkind (1975) does not document 


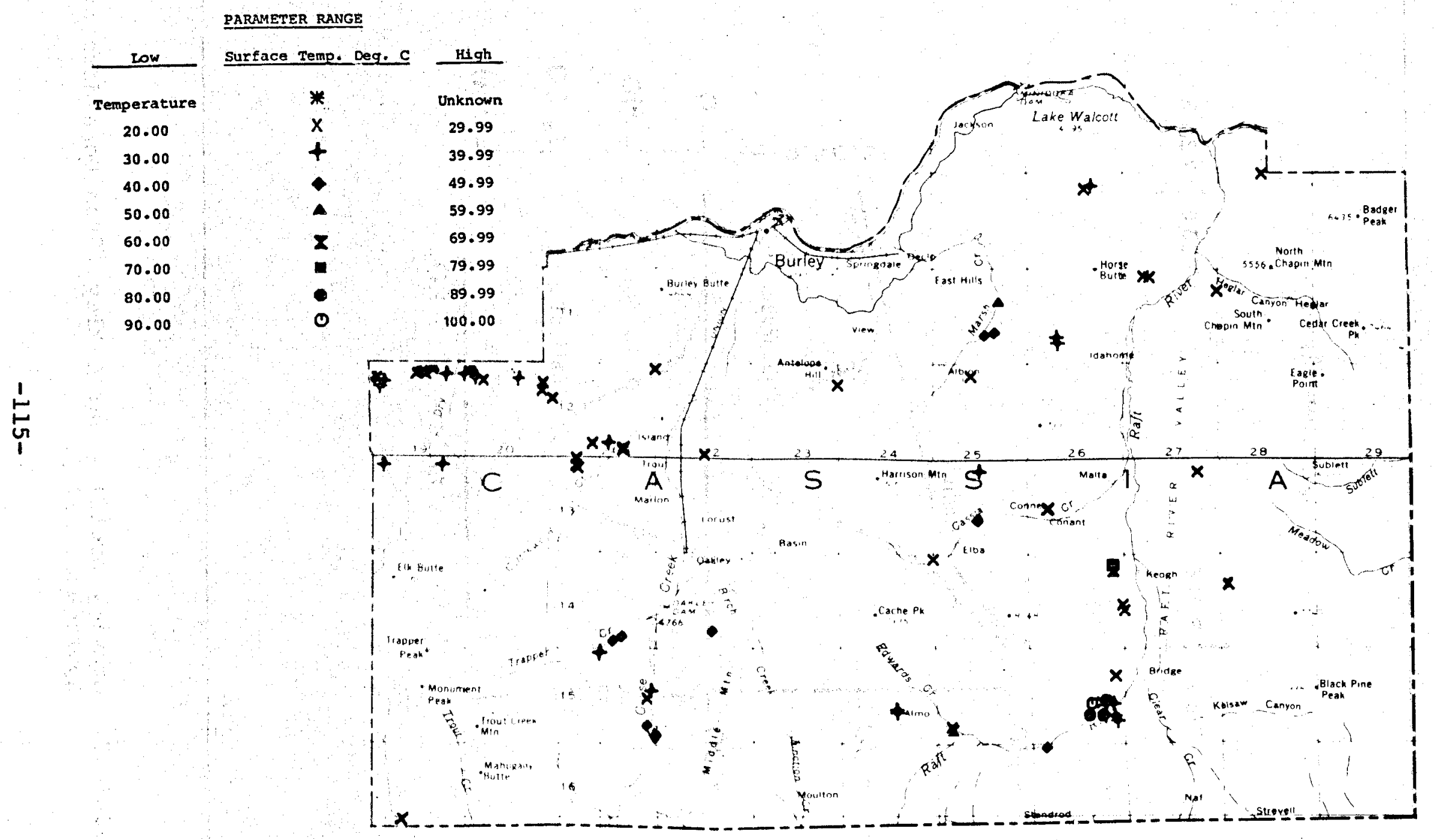

FIGURE 56. Index map of Cassia County showing locations of thermal water occurrences with surface temperatures of $20^{\circ} \mathrm{C}$ or higher. 


\section{Oakley Area}

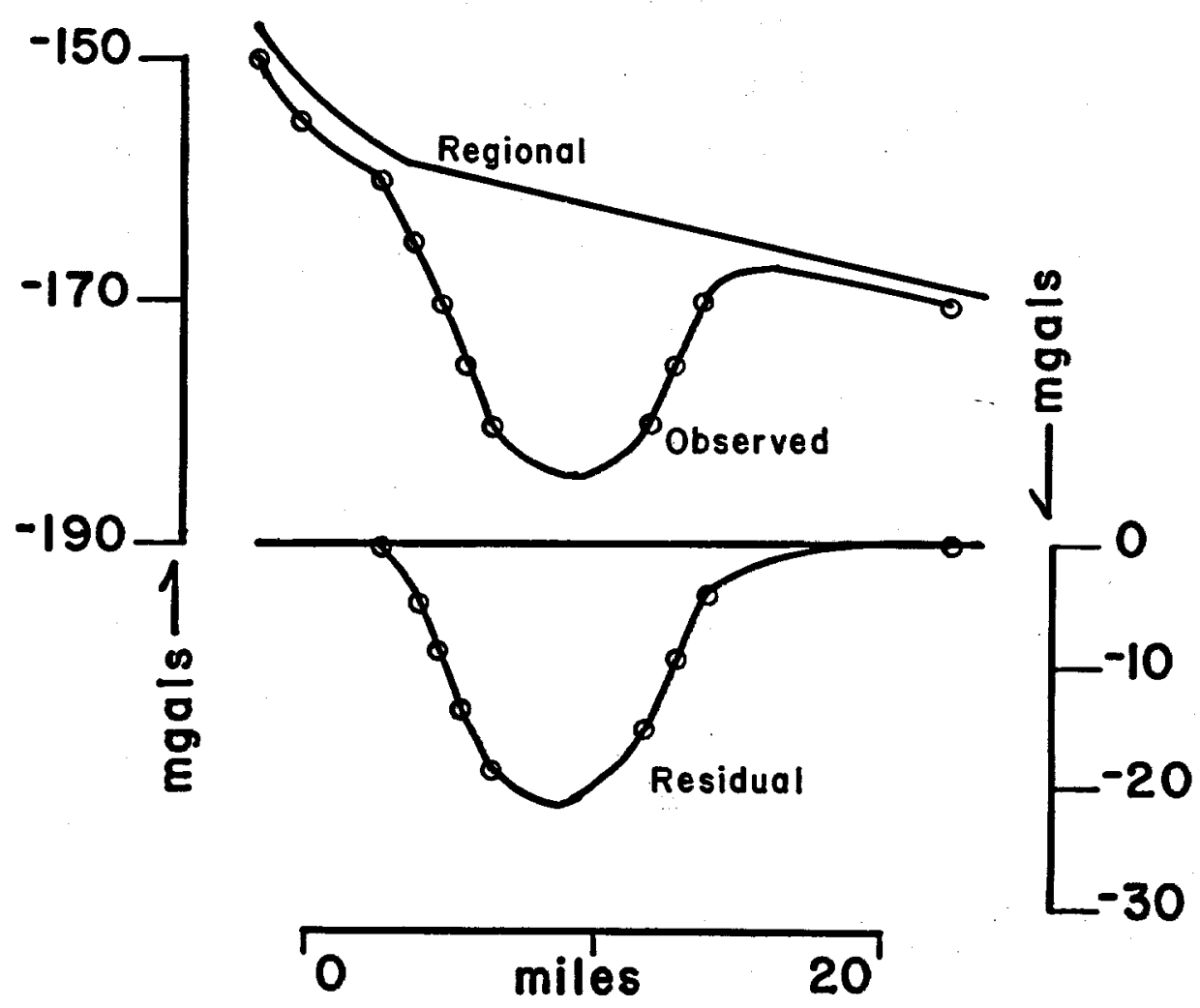

FIGURE 57. Gravity profile near Oakley (from Donaldson and Applegate, 1979). 
known or suspected active faults which would control the nose of the anomaly to the northeast. He does identify a fault suspected of being active since mid-Miocene which lies about $11 \mathrm{~km}$ west of Oakley, trends northwest and appears to control a rather linear topographic break. The position of this fault does correlate very well with a coherent distortion of gravity contours as expected for movement downward toward the basin.

While faults are not documented to define the gravity suggested structure, Day (1974) has mapped lineaments from ERTS imagery which correspond very well to the location, shape and trend of the gravity anomaly (figure 9 ).

The basin depth estimate of about $1250 \mathrm{~m}$ near Oakley is a very conservative estimate based on calculations using a Bouger approximation. This approximation is generally quite accurate where basin width is several times the basin depth and results in increasingly conservative estimates as the width to depth ratio decreases.

Assuming a $1250 \mathrm{~m}$ deep basin structure with a basement rock thermal conductivity of $6.0 \mathrm{mcal} / \mathrm{cm} /{ }^{\circ} \mathrm{C}$, a basin fill thermal conductivity of $3.0 \mathrm{mcal} / \mathrm{cm} /{ }^{\circ} \mathrm{C}$, and a heat flow of 3.0 HFU (see Brott, et al., 1976), one can calculate a predicted temperature of about $90^{\circ} \mathrm{C}$ at maximum depth (Diment, et al., 1975). This maximum temperature estimate is conservative in the same sense that the depth estimate is considered conservative. 
Table 5 shows cities, towns, and recreational home areas in central Idaho that are near known thermal water. These towns probably could make use of thermal water for space heating of schools and public buildings if sufficient flow - rates and temperatures could be obtained by drilling. The subsequent reuse of the warm water effluent through watersource heat pumps would give a greater and more economic use of a limited heat source. The hot springs near transportation lines might be used to establish small industries suitable to thermal water found in the area. In certain places (see basic data table 1) fluoride concentrations in the thermal water that exceed EPA's drinking water standard (to $2.4 \mathrm{mg} / 1$ depending on temperature) might lead to disposal problems. The areas near these towns would probably be evaluated without large capital outlays for exploration as the target areas are limited in size. In this area, those with the potential for the highest return in conventional energy savings should be evaluated first. These would include areas of largest population or of greatest industrial potential. Initial evaluations of the geothermal resource in the Boise Front area has already been conducted. Several successful exploration holes have been drilled. Other areas needing initial assessment work are Nampa-Caldwell, Twin Falls, Mountain Home, and Mountain Home Air Base. Weiser has received an initial assessment, but no drill sites have been selected. More work is needed there and near payette to select possible drill sites.

Exploration programs including detailed geophysical studies, such as gravity, magnetic, resistivity, and reflective seismic surveys, as well as hydrologic studies including isotope and additional geochemical work should be pursued in areas near known thermal water to determine structure and select drill sites. These surveys probably should be conducted by federal or state people or by private entities with federal or state assistance as these studies are expensive and small private companies have little capital to invest in such programs. Large corporations with exploration money presently are not interested in what they feel are minor energy users and will not invest money to supply energy to one or even several users. However, combined users switching to a geothermal source in several of these areas could significantly affect the present energy consumption pattern in Idaho and help Idaho toward becoming more energy self-sufficient. 


\begin{tabular}{|c|c|c|c|c|c|c|c|c|c|c|}
\hline \multirow[b]{2}{*}{ Town } & \multirow[b]{2}{*}{$\begin{array}{l}\text { CITIES AND } \\
\text { County } \\
\end{array}$} & \multirow{2}{*}{\multicolumn{2}{|c|}{$\begin{array}{c}\text { TOWNS IN THE SNAKE RIVER } \\
\begin{array}{c}\text { Spring } \\
\text { or } \\
\text { Well } \\
\text { Surface } \\
\text { Tempera- } \\
\text { ture }{ }^{2}\end{array} \\
\text { Location } \\
\end{array}$}} & \multirow{2}{*}{\multicolumn{2}{|c|}{$\begin{array}{r}\text { TABLE } \\
\text { PLAIN REGION WITHIN } 5 \\
\text { *Best } \\
\text { Est Imated } \\
\text { Subsurface } \\
\text { Temperature } o c \\
\text { Mine Maxe } \\
\text { Na-K- } \mathrm{Ca} \text { Chalcedony } \\
\end{array}$}} & \multirow{2}{*}{$\begin{array}{l}5 \\
\text { KM }(3 \text { MI }) \\
\text { Total } \\
\text { Dissolved } \\
\text { Sollids } \\
\end{array}$} & \multirow[b]{2}{*}{$\begin{array}{c}\text { Present } \\
\text { Water } \\
\text { Use } \\
\end{array}$} & \multirow[b]{2}{*}{ Population } & \multirow[b]{2}{*}{$\begin{array}{r}\text { Surface } \\
\text { Owner } \\
\end{array}$} & \multirow[b]{2}{*}{ Remarks } \\
\hline & & & & & & & & & & \\
\hline Boise & Ada & $3 N-2 E-12 c d d 1$ & 71 & 80 & 96 & 286 & Space Heating & 92,901 & Private & $\begin{array}{l}\text { One of several } \\
\text { wolis in Boise } \\
\text { area. Depth range } \\
122-430 \mathrm{me}\end{array}$ \\
\hline Buhl & Twin Falls & $9 S-14 E-36 d$ & - & - & - & - & - & 3,382 & Private & No chemical anal- \\
\hline Caldwell & Canyon & $4 N-3 W-28 a a b 1$ & 28 & 54 & 70 & 203 & $\begin{array}{l}\text { Irrigation } \\
\text { Recreation }\end{array}$ & 15,643 & $\begin{array}{l}\text { City of } \\
\text { Caldwell }\end{array}$ & Flowing welle \\
\hline $\begin{array}{l}\text { Cambr Idge } \\
\text { Emmett }\end{array}$ & $\begin{array}{l}\text { Washington } \\
\text { Gem }\end{array}$ & $\begin{array}{l}14 N-3 W-19 c b d 1 s \\
6 N-2 W-14 a c c 1\end{array}$ & $\begin{array}{l}26 \\
20\end{array}$ & 65 & -76 & 312 & $\begin{array}{l}\text { Unused } \\
\text { Domestic }\end{array}$ & $\begin{array}{r}451 \\
3,943\end{array}$ & Private & $\begin{array}{l}\text { Plans are for } \\
\text { space heating a } \\
\text { shop. No chemlcal I } \\
\text { analyses avall- } \\
\text { able. }\end{array}$ \\
\hline $\begin{array}{l}\text { Filer } \\
\text { Glenns } \\
\text { Ferry }\end{array}$ & $\begin{array}{l}\text { Twin Falls } \\
\text { Elmore }\end{array}$ & $5 s-10 E-32 b d b 1$ & $\overline{38}$ & $-\overline{67}$ & 68* & 364 & Natatorlum & $\begin{array}{l}1,420 \\
1,387\end{array}$ & $\begin{array}{l}\text { Private } \\
\text { Private }\end{array}$ & $\frac{a b l e}{-}$ \\
\hline $\begin{array}{l}\text { Hanson } \\
\text { Hollister }\end{array}$ & $\begin{array}{l}\text { Twin Falls } \\
\text { Twin Falis }\end{array}$ & $\begin{array}{l}\text { 10S-18E-26bbal } \\
12 S-17 E-31 \text { babis }\end{array}$ & $\begin{array}{r}20 \\
36\end{array}$ & 81 & 29 & 279 & $\begin{array}{l}\text { Irrigation } \\
\text { Natatorlum }\end{array}$ & $\begin{array}{r}450 \\
63\end{array}$ & $\begin{array}{l}\text { City of } \\
\text { Hollister }\end{array}$ & $\begin{array}{l}\text { Well located half- } \\
\text { way between Hanson } \\
\text { and Kimberlye }\end{array}$ \\
\hline $\begin{array}{l}\text { Homedale } \\
\text { KImberly }\end{array}$ & $\begin{array}{l}\text { Owyhee } \\
\text { Twin Falls }\end{array}$ & $10 \mathrm{~S}-18 \mathrm{E}-26 \mathrm{bbal}$ & $=$ & -- & $\overline{-}$ & $\overline{-}$ & Irrigation & $\begin{array}{l}1,601 \\
1,780\end{array}$ & $\begin{array}{l}\text { Private } \\
\text { Private }\end{array}$ & $\begin{array}{l}\text { Well located half- } \\
\text { way between Hanson } \\
\text { and Kimberly. }\end{array}$ \\
\hline $\begin{array}{l}\text { King HIII } \\
\text { Kuna }\end{array}$ & $\begin{array}{l}\text { Elmore } \\
\text { Ada }\end{array}$ & $\begin{array}{l}55-11 E-7 a c d \\
2 N-1 W-35 \mathrm{caal}\end{array}$ & $\begin{array}{l}32 \\
25\end{array}$ & 63 & $65^{*}$ & 235 & $\begin{array}{l}\text { Domestic } \\
\text { Irrigation }\end{array}$ & $\overline{941}$ & $\begin{array}{l}\text { Private } \\
\text { Private }\end{array}$ & $\begin{array}{l}96 \text { meters deep } \\
3,595 \text { lpm. }\end{array}$ \\
\hline $\begin{array}{l}\text { Melba } \\
\text { Midvale }\end{array}$ & $\begin{array}{l}\text { Canyon } \\
\text { Washington }\end{array}$ & $13 N-3 W-8 c c c 1$ & $\overline{23}$ & $\ddot{46}$ & $-\overline{68 *}$ & $\overline{318}$ & Public supply & $\begin{array}{l}221 \\
447\end{array}$ & Private & $\begin{array}{l}\text { Munjcipal } \\
\text { well. }\end{array}$ \\
\hline $\begin{array}{c}\text { Mountaln } \\
\text { Home }\end{array}$ & Elmore & $3 S-6 E-26 a d c 1$ & 23 & - & - & - & $\begin{array}{l}\text { Municlpal water } \\
\text { supply }\end{array}$ & 6,755 & $\begin{array}{l}\text { City of } \\
\text { Mountain } \\
\text { Home }\end{array}$ & $\begin{array}{l}\text { City woll } 305 \mathrm{~m} \\
\text { deep. }\end{array}$ \\
\hline $\begin{array}{l}\text { Mountaln } \\
\text { Home Air- } \\
\text { base }\end{array}$ & Elmore & $4 S-5 E-25 b b c 1$ & 24 & 47 & 62 & 114 & Irrigation & 6,000 & Private & Well $162 \mathrm{~m}$ deep. \\
\hline $\begin{array}{l}\text { Murphy } \\
\text { Nampa }\end{array}$ & $\begin{array}{l}\text { Owyhee } \\
\text { Canyon }\end{array}$ & $\ddot{-}$ & $\overline{-}$ & $\overline{-}$ & - & $\overline{-}$ & $\overline{\text { Recreation }}$ & $23, \overline{584}$ & $\begin{array}{l}\text { Private } \\
\text { City of } \\
\text { Nampa }\end{array}$ & $\begin{array}{l}\text { Well - } \\
\text { No chemical anal- } \\
\text { yses avallable. }\end{array}$ \\
\hline
\end{tabular}


Table 5. Citles and Towns In the Snake River Plain Reglon within $5 \mathrm{~km}(3 \mathrm{ml})$ of a $200^{\circ} \mathrm{Cor} H I g h e r$ Thermal Spring or Well (continued)

\begin{tabular}{|c|c|c|c|c|c|c|c|c|c|c|}
\hline Town & County & Location & $\begin{array}{l}\text { Spring } \\
\text { or } \\
\text { Well } \\
\text { Surface } \\
\text { Tempera- } \\
\text { ture } 9 \\
\end{array}$ & $\begin{array}{r}\text { Est } \\
\text { Subs } \\
\text { Temper } \\
\text { Mine } \\
\mathrm{Na}-\mathrm{K}-\mathrm{Ca}\end{array}$ & $\begin{array}{l}\text { Sest } \\
\text { imated } \\
\text { urface } \\
\text { ture oc } \\
\text { Max. } \\
\text { Chal cedony }\end{array}$ & $\begin{array}{l}\text { Total } \\
\text { Dissolved } \\
\text { Sollds } \\
\end{array}$ & $\begin{array}{c}\text { Present } \\
\text { Water } \\
\text { Use } \\
\end{array}$ & Population & $\begin{array}{c}\text { Surface } \\
\text { Owner } \\
\end{array}$ & Remarks \\
\hline Parma & Canyon & $4 N-3 W-35 a b c 1$ & 28 & 54 & 70 & - & $\begin{array}{l}\text { Municipal } \\
\text { water use }\end{array}$ & 1,879 & $\begin{array}{l}\text { City of } \\
\text { Parma }\end{array}$ & Well $46 \mathrm{~m}$ deep. \\
\hline Paul & Minldoka & $9 S-23 E-28 \mathrm{ccal}$ & 22 & - & - & - & $\begin{array}{l}\text { Municlpal } \\
\text { water use }\end{array}$ & 911 & & Well 137. m deep. \\
\hline Twin Falis & Twin Falls & $10 S-17 E-14 c d d 1$ & 29 & - & - & - & Irrigation & 23,616 & $\begin{array}{l}\text { Mun Iclpal } \\
\text { well }\end{array}$ & - \\
\hline & WashIngton & $11 \mathrm{~N}-6 \mathrm{~W}-10 \mathrm{cca}$ & 70 & 145 & $152^{* * *}$ & 197 & $\begin{array}{l}\text { Natator l um, } \\
\text { greenhouse }\end{array}$ & 4,607 & Private & $\begin{array}{l}\text { Several smal I } \\
\text { diameter wells. }\end{array}$ \\
\hline Oakley & Cassia & $14 S-22 E-7 d c b 1 S$ & 47 & 90 & 90 & 295 & Natator I um & 698 & Private & Warm spring. \\
\hline
\end{tabular}

* See first footnote, Table 4.

* Minimum temperature is chalcedony temperature. Maximum temperature is Na-K-Ca temperature.

***Minimum temperature is quartz temperature. Maximum temperature is Na-K-Ca temperature. 


\section{GEOTHERMAL POTENTIAL OF THE BASIN AND RANGE}

OF SOUTHEASTERN IDAHO

INCLUDING EASTERN CASSIA, ONEIDA, FRANKLIN, BEAR LAKE CARIBOU, BANNOCK, POWER, BINGHAM, BONNEVILLE, MADISON, JEFFERSON, SOUTHERN FREMONT, CLARK AND TETON COUNTIES

Thermal springs and wells in the Basin and Range-Central Rocky Mountain Region (figure 6) generally share several characteristics - including high dissolved solids, high $\mathrm{HCO}_{3}$ content and generally precipitation of $\mathrm{CaCO}_{3}$ in the form of travertine. This area also is endowed with certain geologic characteristics that favor the occurrence of geothermal energy .

The eastern margin of the Basin and Range province is within a long narrow curvilinear zone of earthquake activity stretching from Las Vegas, Nevada, on the south to Flathead Lake, Montana, on the north, known as the Intermountain Seismic Belt (Smith and Sbar, 1974). This zone is interpreted to be a boundary between subplates of the greater North American crustal plate, where differential movements between the Basin and Range and Colorado Plateau-Rocky Mountain provinces are taking place (Sbar and others, 1972). Plate and subplate boundaries are considered to be excellent areas for prospecting for geothermal resources. Youthful magmatic activity, areas of high heat flow, and thermal spring activity are known to occur along the Intermountain Seismic Belt. In Idaho, the approximate axis of the belt passes near preston, in Cache valley, through the Soda Springs area in Caribou County to Driggs in Teton County and into the Yellowstone Park area.

The Basin and Range province in Idaho consists predominantly of block faulted mountain ranges separated by Intermontane basins arranged in an echelon pattern. Mountain front faults are considered to be normal faults by most authorities. Most of the block fault ranges tilt eastward, and valleys have been partially filled with eroded waste rock from adjacent mountains. Rock types here differ from most of the rest of the state, since they are mostly marine limestones, dolomites, shales, siltstones, and sandstones ranging in age from precambrian through Permian, and Cretaceous, and younger land derived sediments. The rocks in general are older in the central part of the area and become increasingly younger toward the edges of the province.

Thermal spring activity is widely distributed through the Basin and Range Province, and wells have encountered 
thermal water locally. Most springs are associated with known faulting or lineaments but not necessarily with valley-mountain range boundary faults. Most springs are near drainages and are therefore at low elevations. Thermal springs and wells in southeast Idaho exhibit the highest dissolved solids of any found in Idaho, presumably reflecting the soluble nature of the marine sedimentary bedrock. Thermal springs and wells are found in areas of no known adjacent igneous activity.

Thermal springs and wells in southeastern Idaho seem to occur along suspected curvilinear zones (figure 9) similar to springs in the central part of the state. The curvilinear zones may not be quite so well defined here as in the crystalline granitic terrain of central Idaho. One zone, stretching from Bear lake Hot Springs to Blackfoot River Hot Springs near the north end of Blackfoot Reservoir, has an apparent gap between Georgetown and soda springs where no thermal springs appear. Actually, a cold water spring associated with voluminous travertine deposits does exist near the center of the gap. It is thought that this spring was once thermal.

The largest curvilinear zone, stretching from the southern Idaho border up to Big Springs in Island Park (near Yellowstone National Park), coincides with a lineament that stretches from the northern part of the Great salt Lake, somewhat discontinuously, up to at least Brockman Creek warm springs.

Discussion of the geothermal potential of this region follows on a county basis.

EASTERN CASSIA COUNTY

The best known and most studied geothermal anomaly in Idaho is in the Raft River valley (figure 56), a north trending basin and range valley in southern Idaho immediately south of the Snake River Plain. The Raft River KGRA (known geothermal resource area), was formerly known as the Frazier KGRA after C.W. Frazier who drilled the first hot water well there for irrigation and stock watering purposes. This well was drilled to a depth of $122 \mathrm{~m}$ and issued $95^{\circ} \mathrm{C}$ water. Later, another hot well $\left(92^{\circ} \mathrm{C}\right)$, was drilled on the Crank property and is presently used for greenhouse heating. Many other thermal wells exist in the Raft River valley ranging from 20 to $148^{\circ} \mathrm{C}$.

The largest variety of geothermal testing and experimentation at any single location in the world is presently underway or developing (Chappell and others, 1978, p. 83) at the Raft River site. The principal experiments have been summarized by the above authors (p. 85) as follows: 
Soil Cooling

Soil Heating Agriculture

Aquacul ture

Agriculture

Fluidized Bed Drying

Gas Air Conditioning

Component Testing

Tube \& Shell Heat Exchanger

Direct Contact Heat Exchanger

60-KW Turbine-Generator

Environmental

Reservoir Engineering

Heat Dissipation (Pond Cooling)

Supply Well Mixing Tests

Injection Testing

Aerated Geothermal Water Corrosion

Cooling Tower Chemistry of Brine as Makeup water

Sulfide Oxygen Scavenge Test

Asbestos Cement Pipe

Downhole Pump Test

500-KW Turbine-Generator Direct Contact

Many reports describing results of these experiments are available and 1 isted as the ANCR \& TREE reports in the Selected References.

Geophysical studies (Mabey and others, 1978 , p. 1,4701,478 ) have been conducted to infer the structure and general lithology underlying the valley (figures 58-60).

The thermal waters are believed to be derived from a deep fault and may be similar to other basin and range occurrences in Idaho. From several deep well tests in the Raft River valley, a certain degree of reliability has been proven relating to the chemical geothermometers. The quartz and $\mathrm{Na}-\mathrm{K}-\mathrm{Ca}$ predicted aquifer temperatures (Young \& Mitchell, 1973 and mixing models in unpublished data) agreed very closely (within $10^{\circ} \mathrm{C}$ ) with temperatures found at depth (Kunze, 1975). Indeed, the $\mathrm{Na}-\mathrm{K}-\mathrm{Ca}$ chemical geothermometer predicted temperatures almost exactly as were found. This proven reliability in the Raft River Valley gives some measure of confidence in applying the same methods to other similar areas of the state.

To date, seven deep wells have been arilled to depths of $1,525 \mathrm{~m}$ into indicated fault zones, and large quantities of thermal water near $150^{\circ} \mathrm{C}$ have been encountered. From further well tests, it appears that the geothermal system is capable of sustained production of sufficient water to run a 50 megawatt power plant, although present plans are limited to 10 megawatts. The power generation system will be a binary cycle system. 

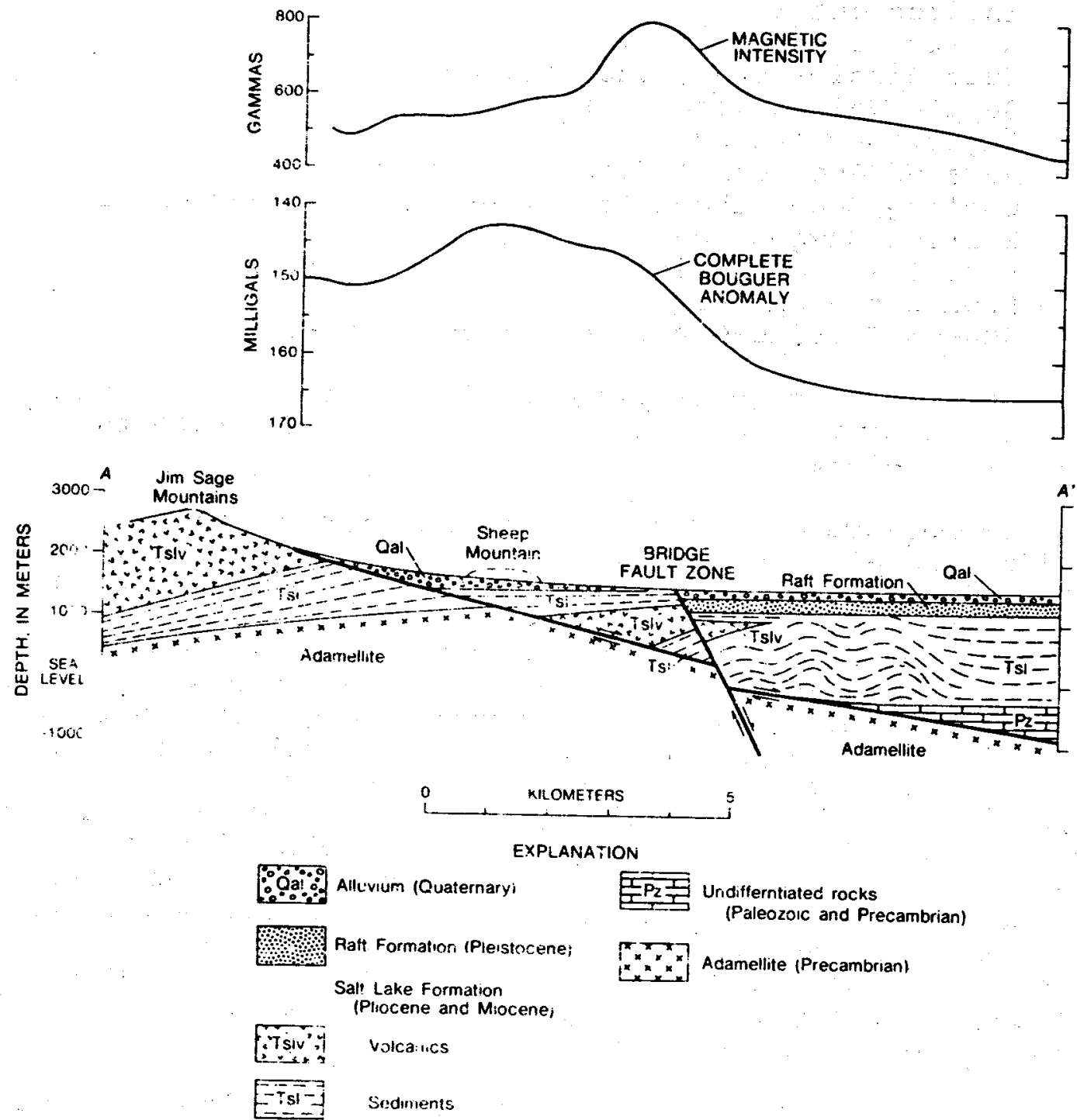

FIGURE 58. Interpreted section across the west side of the southern Raft River Valley. (From Mabey and others, 1978.) 


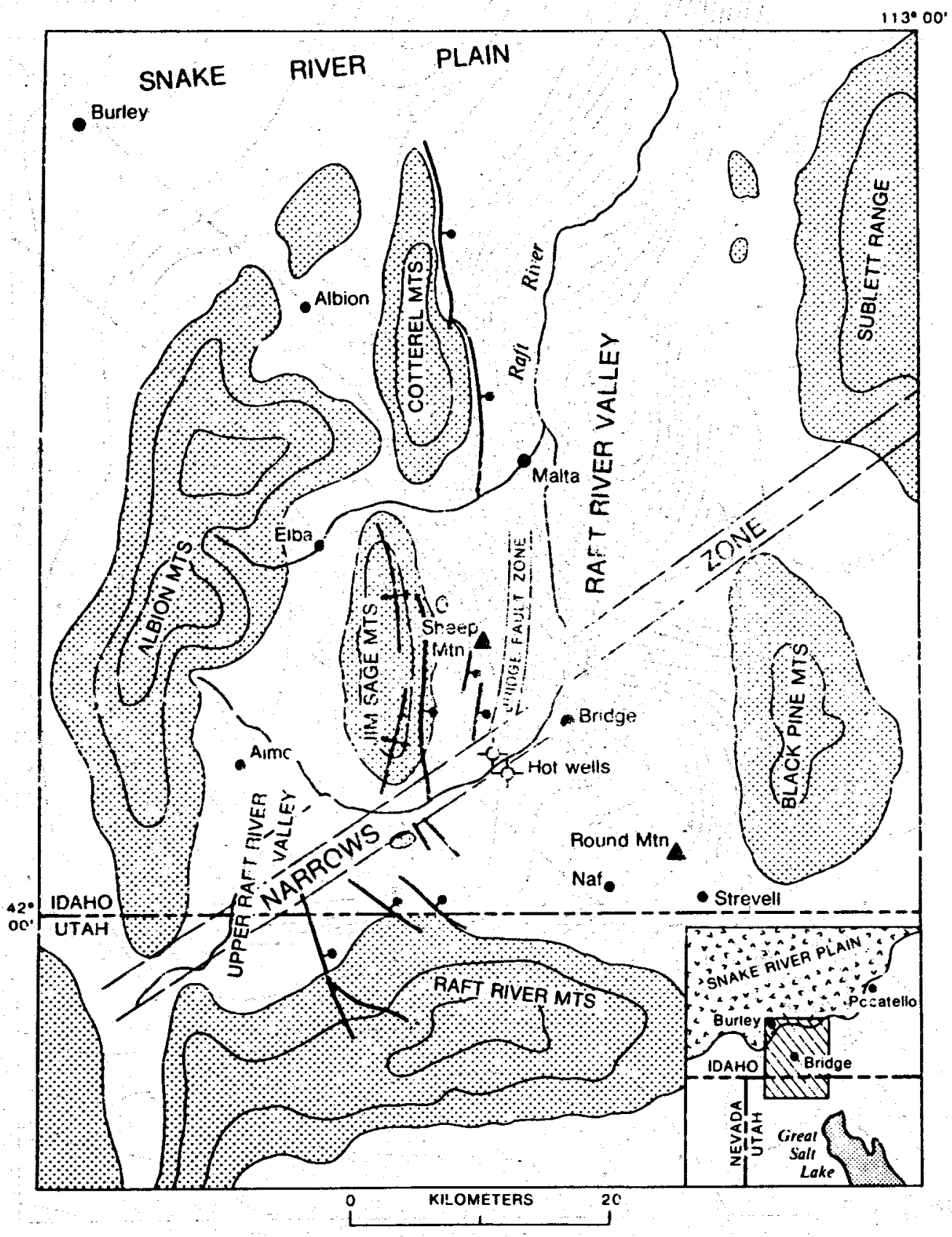

FIGURE 59. Map of the Raft River Valley region, Utah and Idaho, showing major topographic features and faults. (From Mabey and others, 1978.) 


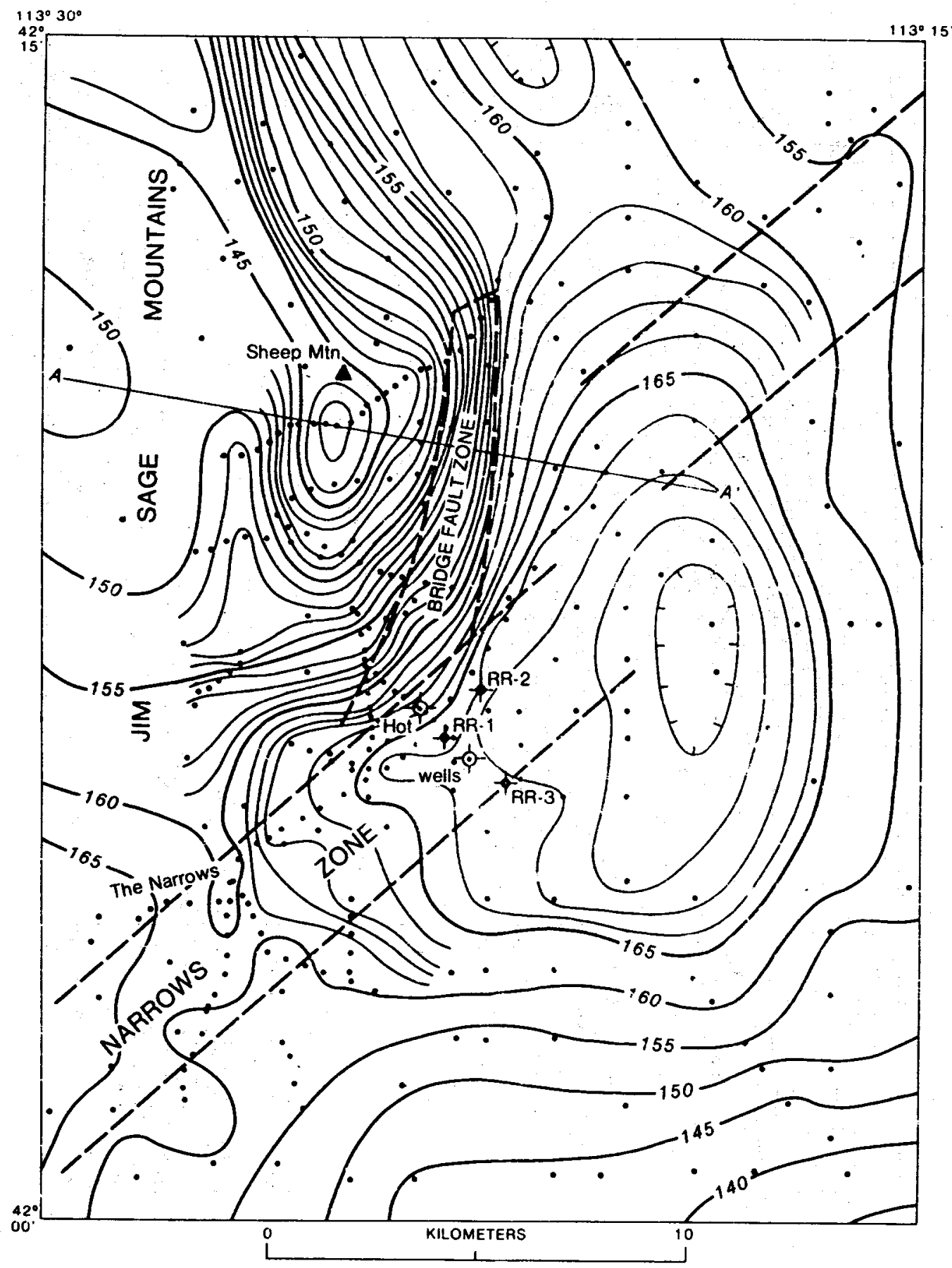

FIGURE 60. Complete Bouguer gravity anomaly map of the southern Raft River Valley. Contour interval is 1 and 5 milligals. Deep drill holes are shown and numbered. Dots are gravimeter stations. (From Mabey and others, 1978.) 
other springs and wells exist in the Raft River Valley and Cassia County, some of which are located along arcuate trends, as in north-central Idaho.

Oakley Warm Springs (14S-22E-27dcbl) located near Oakley in an adjoining valley west of Raft River issues at $47^{\circ} \mathrm{C}$ from Paleozoic quartzite and is developed as a small resort. The other wells documented in Cassia County are for irrigation or domestic uses and are in rural locations as are the springs.

ONEIDA COUNTY

Five thermal springs are located in oneida county (figure 61) in the Malad Valley. All are fairly low in surface temperature and most occur near surface drainages. Pleasantview Warm Springs (15S-35E-3aabls) issues at $25^{\circ} \mathrm{C}$ from precambrian quartzite and presently is unused. Woodruff Warm Springs (16S-38E-10bbc1S) is the warmest spring at $27^{\circ} \mathrm{C}$. Price's Hot Spring (16S-38E-23bbdls) reportèd by Ross (1971) could not be found. An unnamed spring (12S-34E-36bcbls) exists near the upper end of Malad Valley. Its surface temperature is $24^{\circ} \mathrm{C}$. Malad Warm Springs (14S-36E-27cdals) issues at $25^{\circ} \mathrm{C}$ from a travertine mound in the fairgrounds area near Malad City. This spring, being in close proximity to Malad City, appears to have the most potential for development, due to its proximity to a population center.

In addition to the thermal springs, Burnham and others (1969, p. 33) report three areas of saline groundwater in Malad valley. These saline groundwaters were: "(1) small in volume compared to recharge and groundwater in storage, (2) associated directly with deep circulation along or on the bedrock side of the boundary faults of the valley, and (3) localized in only three small areas." These saline waters might indicate that mineral rich thermal water is mixing with cold groundwaters. Indeed, the cold saline groundwaters are all found near thermal springs - one area near the eastern margin of the Malad valley from Malad City to Cherry Creek, one area near Pleasantview Warm Springs, and one near Woodruff warm Springs. If mixing is occurring, there is a good possibility that hotter water could be found by drilling near the warm springs. Careful targeting of drill holes to intersect faults at depth should be undertaken before any drilling commences. However, the chalcedony chemical geothermometer indicates aquifer temperature only a few degrees above surface temperature except at Woodruff Warm springs where aquifer temperature may be as high as $46^{\circ} \mathrm{C}$.

None of the mixing models applied to these three thermal springs in these areas are definitive (basic data table 2 , columns $T_{8}, 9,11$ ). 
PARAMETER RANGE

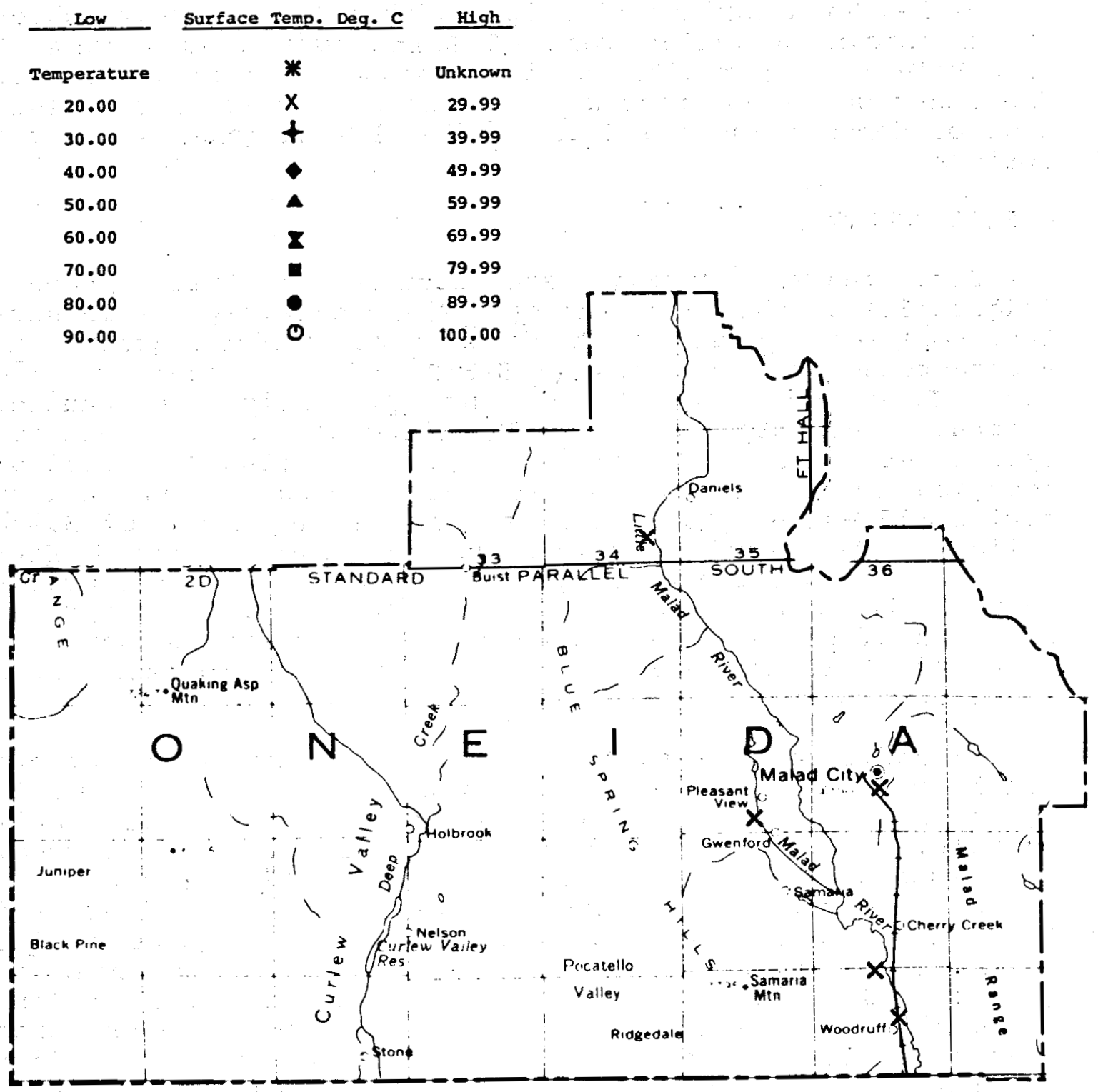

FIGURE 61. Index map of Oneida county showing locations of thermal water occurrences with surface temperatures of $20^{\circ} \mathrm{C}$ or higher. 


\section{FRANKLIN COUNTY}

Mitchell, 1976, p. 17-19, summarized the thermal water occurrences in the northern Cache Valley area as follows:

Thermal springs and wells are scattered at irregular intervals along the Bear River (figure 62). They occur in conjunction with various types of consolidated and unconsolidated sedimentary rocks including travertine, limestone, quartzite, and alluvial deposits. Thermal wells penetrate only alluvial deposits.

Most springs in the area appear to be fault related. The springs near cleveland are situated along a northwest linear trend on both sides of Bear River. On the west side, spring vents (12S-41E-30caals) issue from the bottom of circular pools 6 to $9 \mathrm{~m}$ in diameter within travertine formations. Numerous seeps and many small pools occur near the river edge. Numerous seeps and spring vents issue from a travertine bluff overlooking Bear River on the east. Much gas, thought to consist mostly of $\mathrm{CO}_{2}$, escapes from the riverbed, audible for some tens of meters.

No fresh deposits of travertine were forming near cleveland. The springs on the west side issuing from pools may even be dissolving the existing travertine deposits. The waters on the west side are much cooler $\left(35^{\circ} \mathrm{C}\right)$ than the waters from the east bluff $\left(66^{\circ} \mathrm{C}\right)$. Waters from the vents on the west side have been used for recreational purposes. Samples were taken for chemical analyses from the large pools on the west side and from several vents on the east side.

Maple Grove Hot Springs (13S-41E-7acals) are located in an area of intense local faulting near the shore of Oneida Narrows Reservoir. The numerous vents and seeps and the one large pool that make up the spring system are more or less aligned with each other. Unlike the cleveland springs, Maple Grove waters are depositing much travertine. Gas, probably $\mathrm{CO}_{2}$, is also being evolved. Several small, cold $\left(10^{\circ} \mathrm{C}\right)$ mud pots near the smaller vents at Maple Grove evolve small quantities of gas which bubbles up through the mud. The bubbling might be interpreted by a casual observer as evidence of boiling. These waters have been used for recreational purposes and also for power generation as evidenced by an old Pelton wheel found below the spring on the shore of oneida 


\section{FIGURE 62. Index map of Franklin and Bear Lake counties showing locations of thermal water occurrences with surface temperatures of $20^{\circ} \mathrm{C}$ or}

higher.

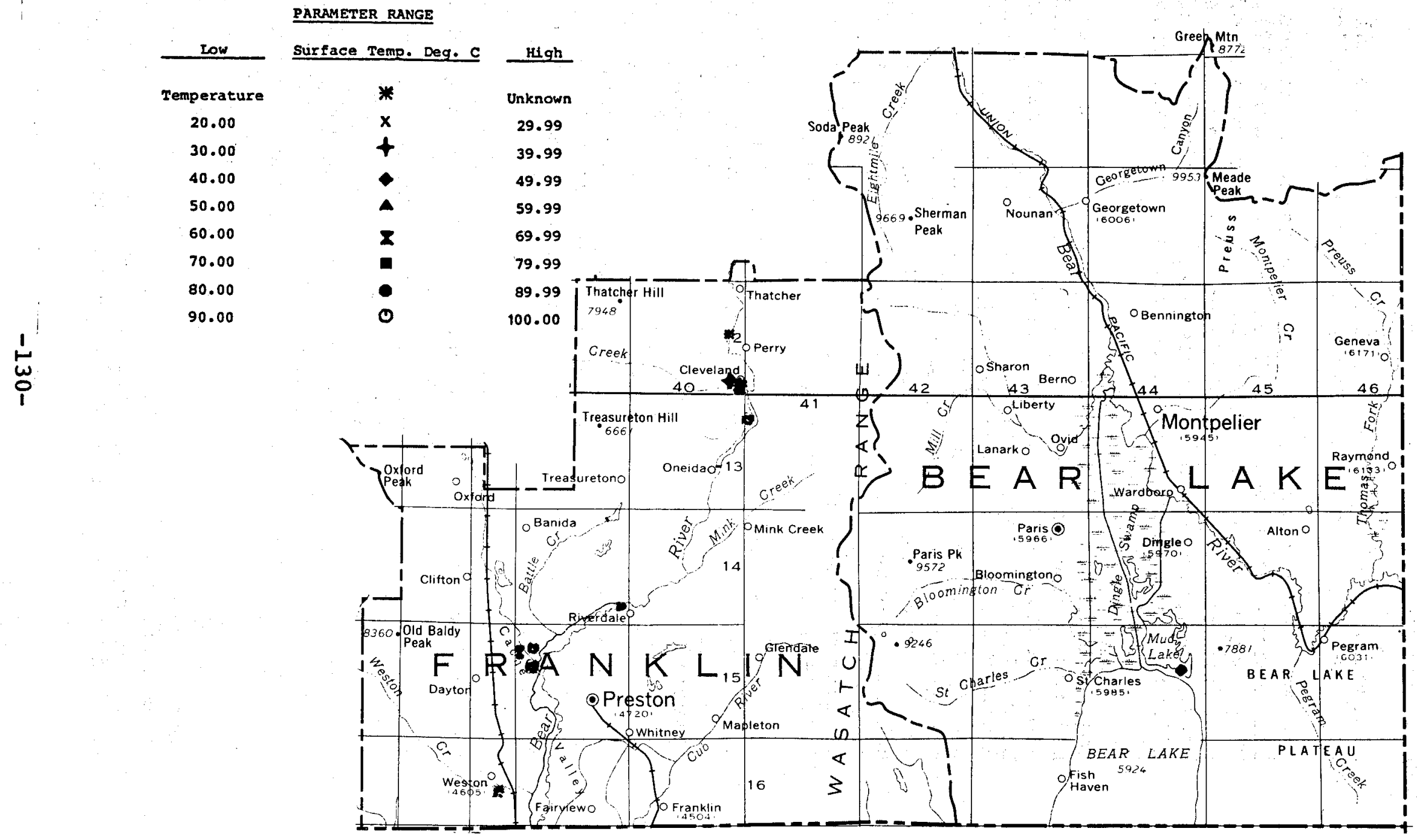


Narrows Reservoir. This may have been the first use of geothermal water for power generation in Idaho; even though the wheel was designed to make use of kinetic energy of the flowing water, rather than its enthalpy or heat content. Total installed capacity probably did not exceed 5 kilowatts (kw).

Well 14S-39E-36adal, on the Bear River flood plain at Riverdale, has a surface water temperature of $40^{\circ} \mathrm{C}$ and was reportedly drilled to a depth of 12.1 $m$. For years, water from this well has been used for beneficial purposes in a dairy operation. Rulon F. Mitchell, a resident of the area for 40 years, reports that snow in a 40-acre tract around the well would melt much more quickly than in surrounding areas.

The Clifton Hill high angle boundary faults may exist at Battle creek Hot Springs (Wayland) (15S-38E-8bdcls) and Squaw Hot Springs (15S-39E17bcdls) (Oriel and Platt, 1967; Peterson and Oriel, 1970; and Mabey, 1974, unpublished data). These faults may intersect the Mink Creek-Bear River lineament near these two hot springs (figure 63). The structural implications of this transverse lineament are unknown but it could represent a strike-slip or normal fault. The controlling structure for these two hot springs could be the intersection of the clifton Hill high angle boundary faults with the Mink Creek-Bear River(?) fault.

Battle Creek Hot springs consists of one large pool about $6 \mathrm{~m}$ in diameter, a smaller pool (probably a collapsed travertine structure), numerous vents and seeps. This spring system is located on the western edge of Bear River. Numerous vents are marked by gas bubbles in the riverbed. Travertine is actively being deposited around the pool and vents of this spring system. These waters have been used for hog carcass scalding and recreation. Samples were taken from the two pools and two smaller vents. Cold water seeps (temperature $60^{\circ} \mathrm{C}$ and total discharge $5-101 / \mathrm{m}$ ) were issuing from a clay bank just above the spring vents at Battle creek Hot springs. Other cold water seeps were issuing at approximately the same elevations as the thermal vents about $40 \mathrm{~m}$ down river from the thermal vents. The cold water may be seepage along impermeable clay layers from an irrigation canal which runs along the bottom edge of the uppermost terrace level of the river valley above the hot springs, or from irrigation water applied on farmlands above the canal. Significant quantities of cold water could be mixing with the thermal water. 
Squaw Hot Springs (15S-39E-17bcd1s) are located about $1 \mathrm{~km}$ south of Battle creek Hot Springs near the confluence of Deep Creek and Bear River. This system consists of one well, reportedly $6.7 \mathrm{~m}$ deep, four other vents and several seeps. Discharge from the well (15S-39E-17bcd1) is depositing travertine at the end of the discharge pipe sorne $30 \mathrm{~m}$ from the well head, and a small mound of travertine $1.5 \mathrm{~m}$ high and $3 \mathrm{~m}$ across the base has been formed on the edge of Deep Creek. Only minor travertine deposition or evaporative incrustation was evident at the well head itself, where water samples were taken. The other vents are now only very minor depositors of travertine with small incrustations and a few travertine-coated pebbles along discharge channels. older travertine deposits crop out in the immediate spring area, indicating prior deposition by the springs. Samples were taken from the well, from a vent situated near the road, and from another vent located near the Bear River-Deep Creek confluence. All spring vents were-evolving minor quantities of gas, probably $\mathrm{CO}_{2}$. The well being the most prolific gas evolver, gave a false appearance of vigorous boiling. These spring waters were formerly used for recreational purposes, and for heating hot houses.

Basic data table 2 lists apparent subsurface temperatures in Franklin County. Mitchell (1976) listed reasons for believing that at squaw and Battle creek hot springs, subsurface temperatures would approach $150^{\circ} \mathrm{C}$ provided quartz controlled silica in these waters. If mixing of thermal and non-thermal groundwater were taking place, temperatures could be as high as $235-245^{\circ} \mathrm{C}$. In other areas of Franklin County the chalcedony chemical geothermoneter $\left(\mathrm{T}_{4}\right.$, basic data table 2) probably gives good subsurface temperature estinates.

\section{BEAR LAKE COUNTY}

In Bear Lake County (figure 62), located in the central Rocky Mountain Province, there are only two known thermal springs presently active. Extensive travertine deposits, particularly on the west side of Bear Lake valley north of Bern, attest to much greater thermal spring activity in the past. It is not known whether the springs here ceased flowing because of cooling or to self sealing because of travertine deposition, or both. prospecting for thermal water might prove fruitful in areas of extensive travertine deposition near known faults.

Pescadero Warm Spring $(12 \mathrm{~s}-44 \mathrm{E}-7 \mathrm{bdalS})\left(26^{\circ} \mathrm{C}\right)$ is located two miles south of the Nounan-Georgetown Road near the 


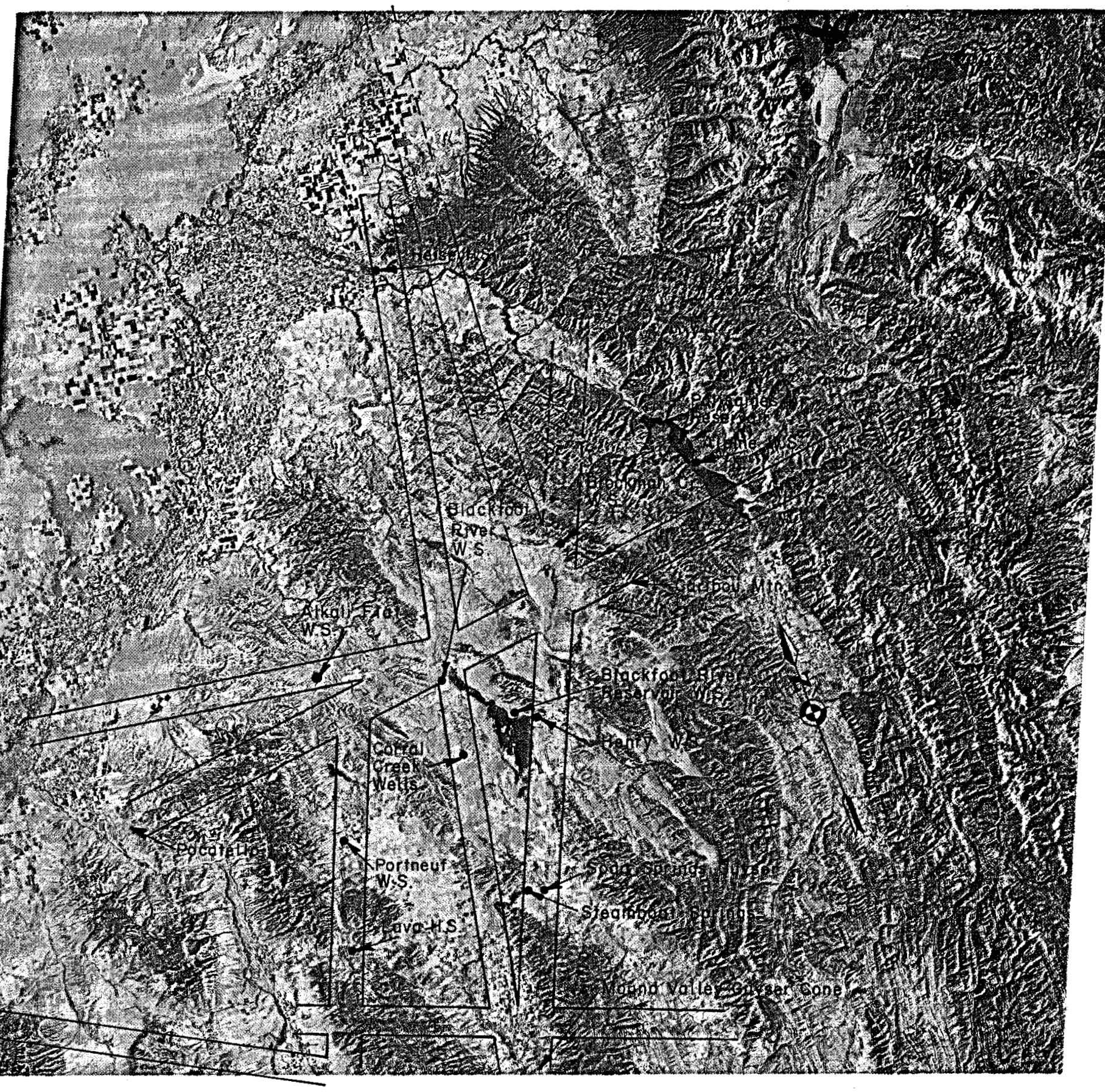

FIGURE 63. EROS false color infrared Landsat EDISE image of part of southeastern Idaho and northern Utah showing selected thermal water locations with surface temperatures above $20^{\circ} \mathrm{C}$. 


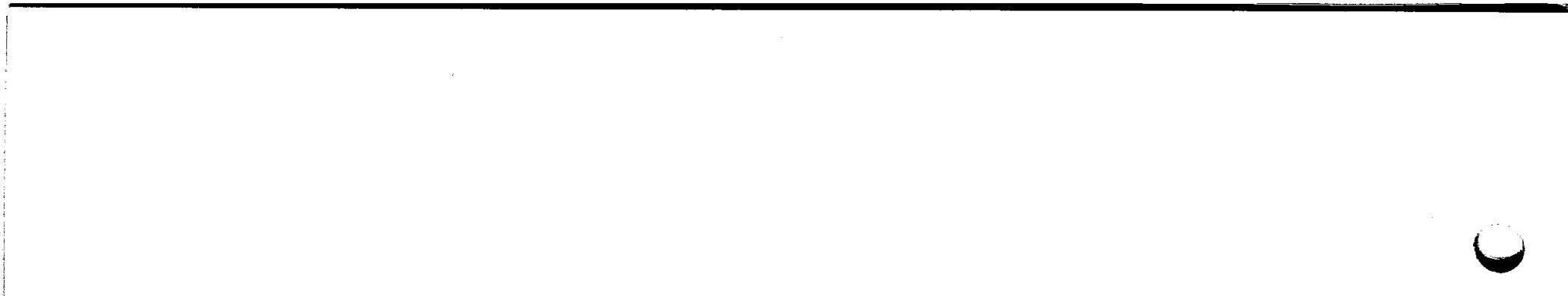


Bern-Pescadero Road on a travertine-covered bluff overlooking the Bear River. It issues at about $401 / \mathrm{min}$. It is presently used for stock water.

Bear Lake Hot Springs (15S-44E-13bcals) is a popular resort area and has been for many years. Formerly known as Joe Rich's Spring, vents issue from limestone along a fault scarp at the base of the steep slope, which forms the western edge of the Bear lake Plateau. The water issues at $48^{\circ} \mathrm{C}$. Bear Lake Hot Springs and Pescadero Warm Springs are remote from population centers in Bear Lake Valley. Maximum subsurface temperatures expected at depth may be best represented by the chalcedony equilibrium temperature at about $54^{\circ} \mathrm{C}$ (see basic data table 2 , column $T_{5}$ ). Bear Lake Hot Springs could probably support a natatorium and a greenhouse provided additional flow could be found by drilling.

Donaldson and Applegate (1979) reported that:

Gravity mapping (Mabey, Peterson and wilson, 1974) in the Bear Lake-Montpelier area of southeastern Idaho reveals steep east-west gradients suggesting a north-south striking basin and range type graben valley (figure 64). An east-west profile taken from the aforementioned map along the Idaho standard Parallel south through the Bear Lake anomaly (figure 65) defines a 21 mgal residual low. Calculations made assuming a $0.4 \mathrm{gm} / \mathrm{cm}^{3}$ density contrast between valley fill and flanking bedrock result in an estimated basin depth of about $1250 \mathrm{~m}$. Witkind (1975) defines faults along both margins of the gravity inferred graben (figure 15) which are presumed active with late quaternary beds broken. Day (1974) has mapped linears fron band $5 \mathrm{~m}$ MSS-ERTS inagery which also coincide very well with the gravity inferred graben (figure 9).

The basin depth estinate must be considered very conservative. A similar depth estinate was calculated in the Oakley area where a maximum temperature-at-depth of about $90^{\circ} \mathrm{C}$ was calculated. Given similar assumption, similar temperature estimates would be appropriate for this area.

\section{CARIBOU COUNTY}

six thermal springs and four thermal wells are known in Caribou County. They are widely scattered but principally located around the margins of the Blackfoot lava field and near the principal drainages of the Blackfoot, Bear, and Portneuf rivers (figure 66 ).

The best known thermal occurrence in Caribou county is located within the town of soda springs and is known as soda 


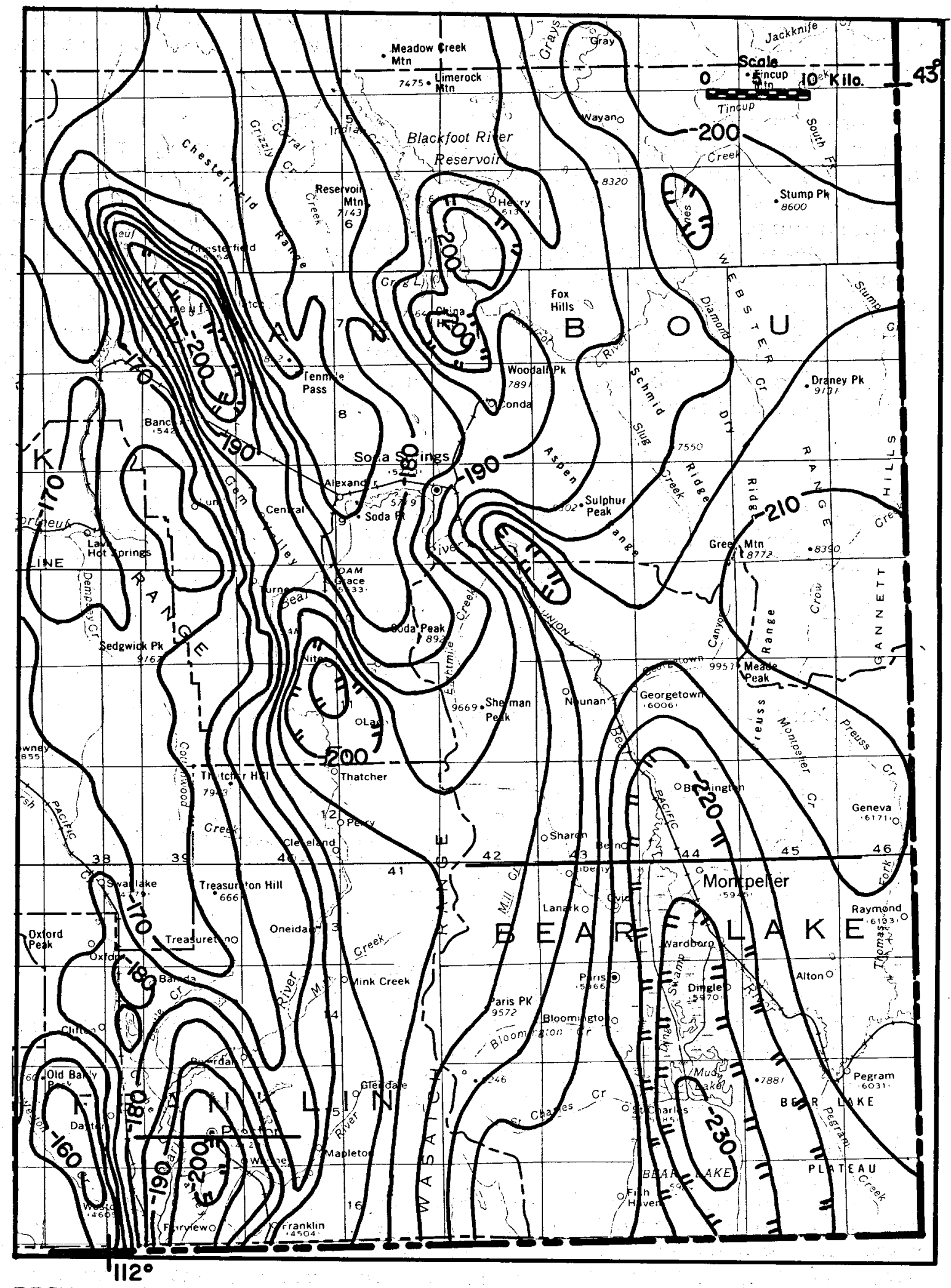

FIGURE 64. Gravity lows from Gem Valley (upper left), near Preston in Cache Valley (lower left), and near Bear Lake (lower right) (Mabey, Peterson and wilson, 1974.) Contour interval $=5$ milligals. 


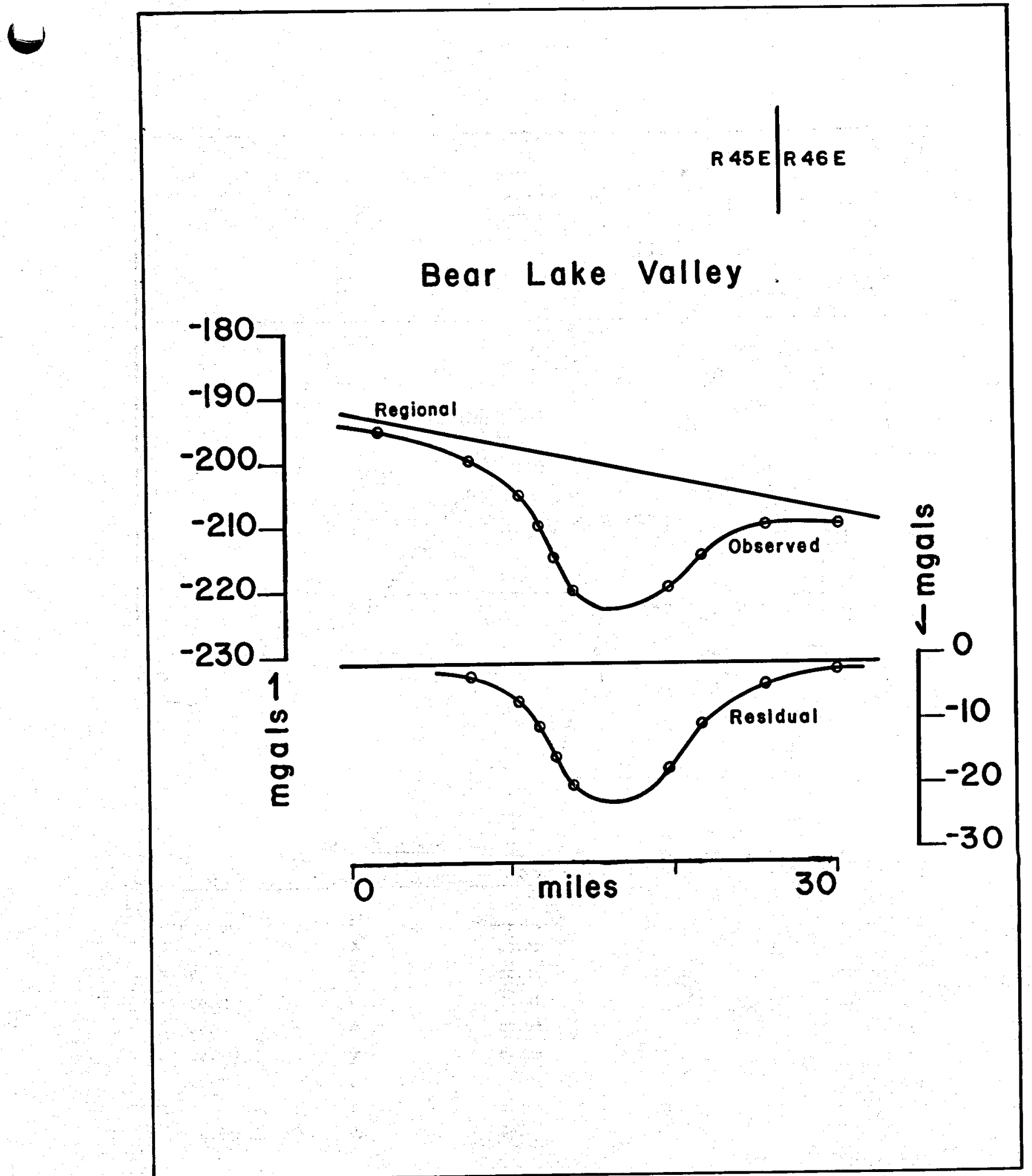

FIGURE 65. Gravity profile near Bear Lake. (From Donaldson
and Applegate, 1979.) 


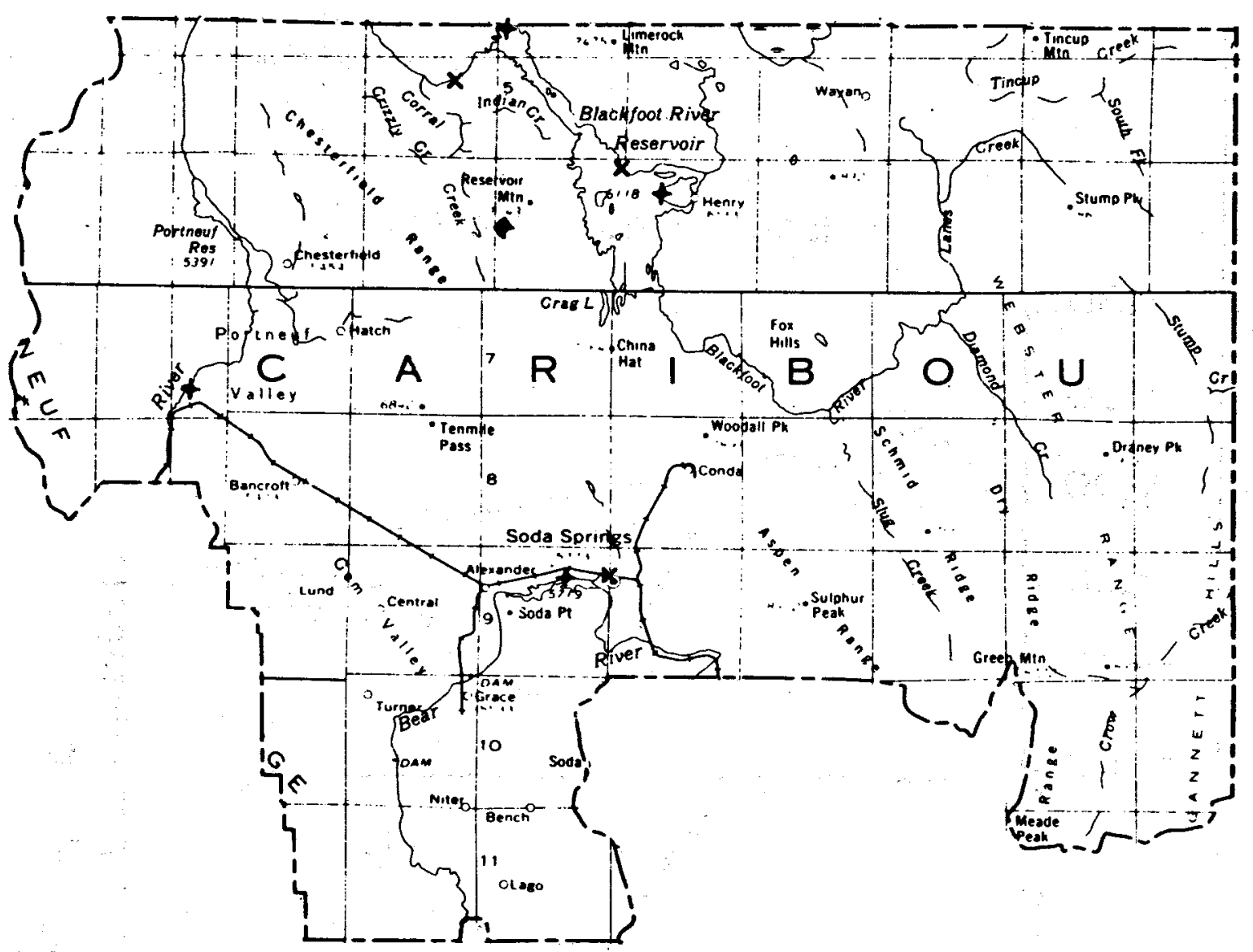

PARAMETER RANGE

\begin{tabular}{|c|c|c|}
\hline Low & Surface Temp. Deg. C & High \\
\hline Temperature & 米 & Unknown \\
\hline 20.00 & $\mathbf{x}$ & 29.99 \\
\hline 30.00 & + & 39.99 \\
\hline 40.00 & $\bullet$ & 49.99 \\
\hline 50.00 & $\Delta$ & 59.99 \\
\hline 60.00 & $\mathbf{x}$ & 69.99 \\
\hline 70.00 & $\mathbf{a}$ & 79.99 \\
\hline 80.00 & $\odot$ & 89.99 \\
\hline 90.00 & $\mathbf{0}$ & 100.00 \\
\hline
\end{tabular}

FIGURE 66. Index map of Caribou County showing locations of thermal water occurrences with surface temperatures of $20^{\circ} \mathrm{C}$ or higher. 
Springs Geyser (9S-4lE-12addl). It is actually a well drilled near a former hot spring, and geysering is caused by high pressure carbon dioxide gas rather than steam pressure generated by superheated water. Soda Springs Gyeser is now a tourist attraction erupting through automatic valves every hour (at the will of the city police) when the wind is right. It is $28^{\circ} \mathrm{C}$ at the wellhead.

A spring (6S-42E-8dbals) with a surface temperature of $21^{\circ} \mathrm{C}$ issues from a large circular travertine mound west of Henry near the shore of Blackfoot Reservoir, and another ( $6 \mathrm{~S}-4 \mathrm{lE}-1 \mathrm{adclS})$ issues at $22^{\circ} \mathrm{C}$ across the Meadow Creek arm of the reservoir. Steamboat Springs (9S-41E-10daals) issues from travertine beneath the waters of Soda point Reservoir. Blackfoot River Warm Springs (5S-40E-14bcdls) issues from travertine overlying basalt on the edge of the Blackfoot River. Its temperature is $26^{\circ} \mathrm{C}$. Another spring (7S-38E$26 \mathrm{cbdls}$ ) known in the area is on the bank of the portneuf River on the west side of the Portneuf valley. It has a temperature of $41^{\circ} \mathrm{C}$.

The Corral Creek wells $(6 \mathrm{~S}-41 \mathrm{E}-19 \mathrm{ba}$, temperature 36 to $\left.41^{\circ} \mathrm{C}\right)$ are located in an extremely faulted area. strike-slip, normal, and reverse faults were encountered when Food Machinery Corporation (FMC) drilled for phosphate in the area. The thermal water was encountered when drilling reached the Mead Peak member of the phosphoria formation. The wells were drilled near an old geyser cone.

Mitchell (1976) summarized the geothermal potential of Caribou County as follows:

Geologic evidence of geothermal activity is abundant in Caribou County. The Intermountain seismic Belt, related to plate and subplate boundaries, passes through the area. A known zone of high heat flow coincides with the seismic zone, and is manifested by numerous thermal springs. Mansfield (1927) reports a high geothermal gradient. The Pleistocene basalt flows, thought to be less than 700,000 years old, exist west and south of the Blackfoot Reservoir. possibly present is a geologically young volcanic collapse structure (caldera) or low density granitic intrusive (heat source ?). The extremely young (less than 100,000 years old) rhyolite structures (China Hat, North Cone and South Cone) exist near the center of the area surrounded by the somewhat younger basalts. Thermal spring deposits, warm springs and geyser activities are evident. All are strong geologic evidence of large-scale geothermal potential.

The audio-magnetotelluric (AMT) survey indicates that no shallow, low-conductive zone (typical of 
geothermal systems) exists to depths approaching $2 \mathrm{~km}$. This indicates the absence of geothermal reservoirs to $2 \mathrm{~km}$ depths in the survey area.

The chemical geothermometers indicate that the thermal waters of the Blackfoot Reservoir area probably have never reached high temperatures (above $50^{\circ} \mathrm{C}$ ).

Published estimates of temperature gradients suggest that the thermal springs could emerge from depths as shallow as $1,000 \mathrm{~m}$. The close association of these springs and wells with normal faults indicates that the waters are probably meteoric waters circulating to shallow depths along faults and re-emerging as thermal springs or wells. Water ascending from shallow depths may provide little information concerning any deep therma 1 system, which in this area would be the real exploration target.

The geochemistry of the thermal waters, the results of the AMT survey, and the speculative geothermal gradient and heat flow estimates from the Blackfoot Reservoir area indicate little potential for geothermal power generation from shallow depths (less than $2 \mathrm{~km}$ ). The possibility of deeper geothermal resources is, however, attested to by the favorable geologic framework. The possible deep reservoirs would not be accessible to exploration or development except by very expensive techniques such as deep resistivity, heat flow, or deep test drilling.

Heat flow measurements taken from three or four strategically placed $300 \mathrm{~m}$ deep drill holes would indicate the approximate intensity of any deep heat source in the area, and consequently may be the better and less expensive method of exploration. This activity should be deferred until other, more accessible geothermal systems in Idaho have been assessed.

Caribou County does, however, represent a unique region where prospecting for geothermal water for low temperature use might be successfully conducted by local individuals, small businessmen, or corporations who wish to make use of low temperature geothermal energy but who lack large amounts of speculative investment capital. Local water well drillers might locate hot water in areas of obvious faulting where surface deposits of travertine are found. If the extinct springs have ceased to flow 


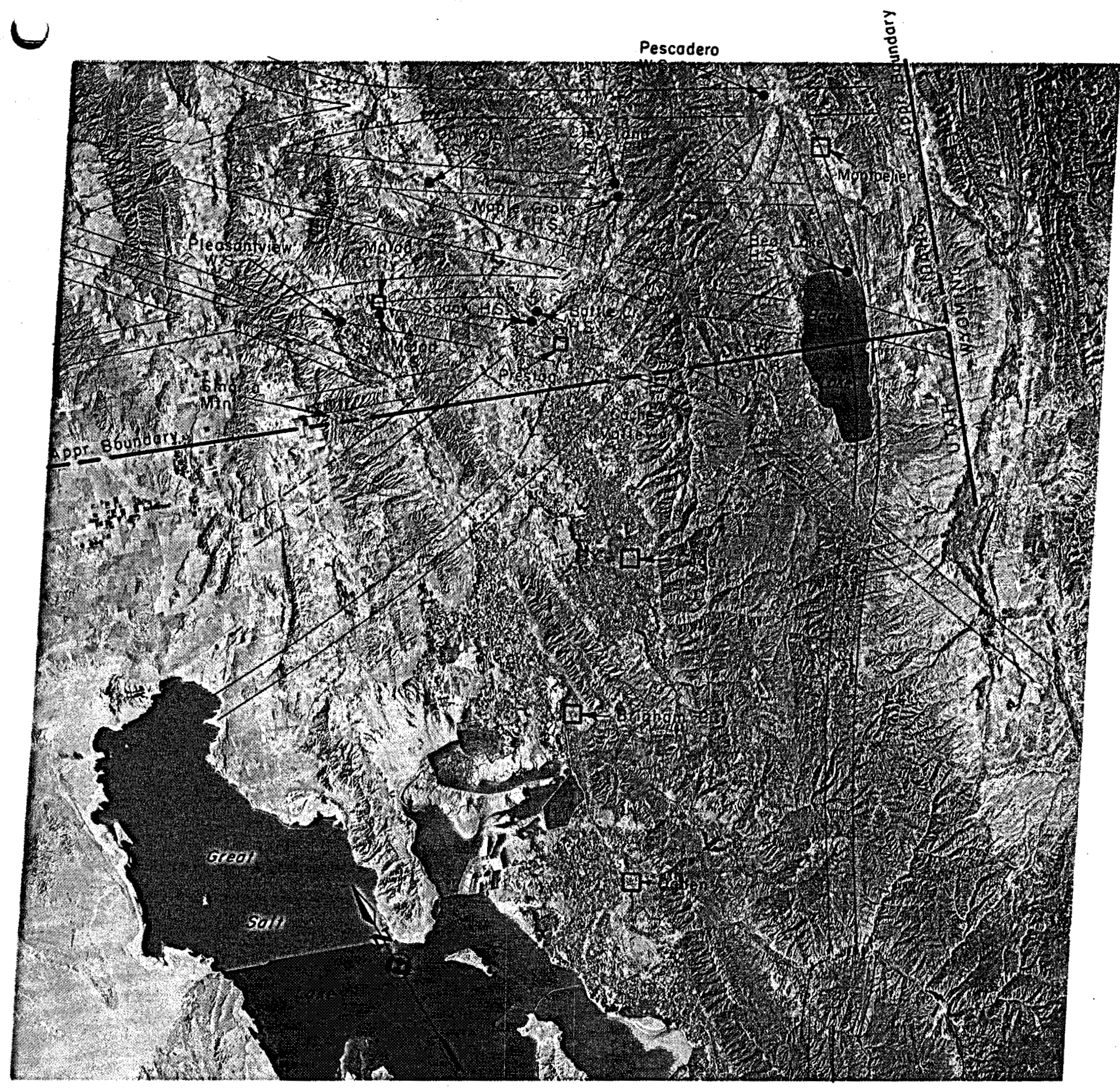

FIGURE 67. EROS false color infrared Landsat EDISE image of part of southeastern Idaho showing selected linear features and thermal water locations with surface temperatures above $20^{\circ} \mathrm{C}$. 
because of self-sealing due to $\mathrm{CaCO}_{3}$ deposition, rather than regional cooling or more arid conditions than formerly existed, substantial amounts of low temperature water (less than $75^{\circ} \mathrm{C}$ ) might be found by drilling into fault zones associated with travertine deposits. Self-reliant, enterprising individuals may even devise methods of scaling control, a potential hazard in geothermal water utilization in this area.

The moderately high dissolved solids in these waters preclude their use for irrigation purposes or stockwatering. Their low temperatures suggest uses such as mushroom growing, balneological baths, soil warming, recreational usages, warm water for winter mining operations or de-icing. Space heating for vegetable greenhouses or animal husbandry may be practical if efficient heat pumps were utilized.

The saline waters may challenge engineers who work toward their utilization. Activities related to the large-scale withdrawal and use of these waters must be very carefully monitored. Cooperation between those individuals making use of the water, as well as state and local officials, is necessary to avoid potential thermal and saline pollution, which could be a danger due to the higher temperature and salinity of these waters should large-scale withdrawal be attempted.

Figure 67 is an enhanced false-color infrared satellite image of part of southeastern Idaho showing major linear features and thermal water occurrences. Many of the thermal springs and wells are near the intersection of these major linear features. The exact nature of these features is not known but the features may represent some type of crustal fracture along which meteoric water circulates to depths where it is heated by hot rock.

An irregular, somewhat discontinuous and curved lineament can be traced on satellite images (figures 63 and 67) from the north end of the Great Salt Lake in northern Utah through Woodruff Hot Springs south of Malad, near Squaw Hot springs west of Preston, through Cleveland Hot Springs, through soda springs, through Henry Warm Springs, through Brockman Creek Warm Springs, through Fall Creek Mineral Springs, and further north, perhaps to Ashton Warm Springs. This lineament coincides with the suspected curvilinear zone revealed by thermal spring activity as shown on figure 9. Springs along this zone appear near where east-west trending lineaments intersect the curvilinear lineament or zone. 
The geothermal potential of the Blackfoot Reservoir area indicates that much of the energy requirements for the growing phosphate industry, as well as space heating for the expanding population, might be supplied by geothermal energy.

\section{BANNOCK COUNTY}

Four thermal spring areas and seven thermal wells are located in Bannock County (figure 68). The most promising areas for development are north of pocatello near Tyhee and Lava Hot Springs.

In the Tyhee area the warm water wells, drilled to depths of $177 \mathrm{~m}$, are used for irrigation, domestic, and stock water. The wells range from 20 to $41^{\circ} \mathrm{C}$ in temperature. They are more or less aligned in a northeastsouthwest direction approximately following an inferred fault through the area (Trimbel, 1976). A faint linear feature can be seen in enhanced false color satellite images of the area. The feature is consistent with the warm water well alignment and inferred fault. A magnetic high similar to one found near Heise Hot springs also exists near the wells (Corbett, 1978, oral commun.). These facts are evidence of both structural control for thermal water in the area and possible deep circulation of meteoric water along faults. Chalcedony and $\mathrm{Na}-\mathrm{K}-\mathrm{Ca}$ chemical geothermoneters give 63 and $47^{\circ} \mathrm{C}$ respectively in one well (5s-34E-26dabl) in the Tyhee area. Quartz predicts $63^{\circ} \mathrm{C}$ for the subsurface temperature in another well (basic data 2 , columns $\mathbf{T}_{1}, \mathbf{T}_{4}$, $\left.\mathrm{T}_{5}\right)$. Further work in the area should be considered to determine the attitude and exact position of the controlling structures to target drill holes to intersect the structure at predetermined depth. Gravity, magnetic, and hydrologic studies should be performed first to best determine the type of followup approaches to use in further reservoir assessment in the pocatello-Tyhee area. This area is currently being studied in greater detail. Any thermal water discovered here could be utilized for space heating and industrial uses in Pocatello.

Another area of thernal water occurrence is Lava Hot Springs where two groups of thermal springs and several wells of above normal temperatures are known. Lava Hot Springs has been a popular resort area for years boasting a state-owned health spa. Before renovation, the swimming pool contained natural thermal water; now, the water must be heated by natural gas to give a comfortable swimming temperature. The city is interested in further development of the resource, particularly for space heating.

Mcclain (1978) reported on the geothermal occurrences near Lava Hot Springs and stated: 


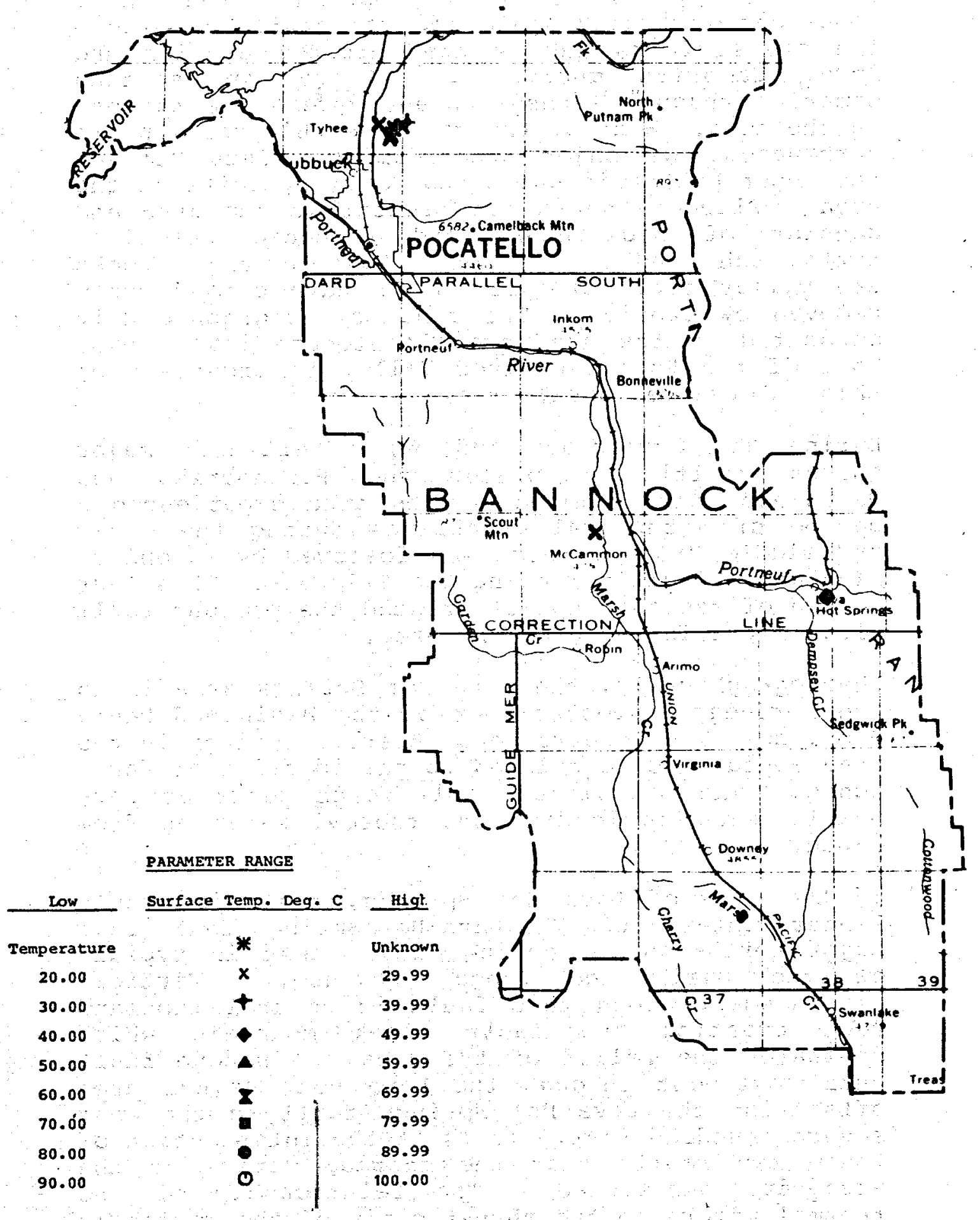

FIGURE 68. Index map of Bannock County showing locations of thermal water occurrences with surface temperatures of $20^{\circ} \mathrm{C}$ or higher. 
Geologically, the Lava Hot Springs area is a complicated stratigraphic and structural location. The oldest rocks in the area are precambrian and lower Cambrian quartzite. Units representing Cambrian through Pennsylvanian systems are present in the area. Most of the rocks in this section are carbonates. A major unconformity exists between the upper Paleozoic units and Tertiary units of the area. Pliocene units are present in the area and consist of sedimentary and volcanic breccias, tuffs, ash, and lava flows. Most of these rocks are valley fill materials which have been largely removed by erosion. The final stratigraphic unit deposited in the area are pleistocene lava flows. Most of the Portneuf River Valley is underlain by this intervalley basalt flow.

During the Cretaceous and early Tertiary, major thrust faulting displaced the precambrian and Paleozoic units eastward. The area experienced a period of structural quiescence during the early and middle Miocene which was followed by extensive high angle faulting during the Pliocene. This last period of tectonic uplift created the present fault block mountain range of the area.

Physiographically, the Lava Hot Springs area is in the northeasternmost corner of the Basin and Range Province. The occurrence of thermal springs in the area appears to be related to the location of fault zones. The brecciated fault zones serve as permeable conduits leading the thermal water up from depth.

In the city of Lava Hot springs, two major fault linears intersect. The Lava Hot Springs fault is a major north-south trending linear that is typical of the Basin and Range Province. Vertical displacement along this fault is several thousand feet creating the fault block mountain which dominates the relief of the area. A second fault cuts east-west through the Lava Hot Springs area offsetting the Lava Hot Springs fault to the east several hundred feet. It is at the intersection of these two faults that the thermal waters of the area are manifested. The relationship of the thermal waters to the thrust plain of the region is unclear.

The hot waters of the Lava Hot Springs area range in temperature from $21-68^{\circ} \mathrm{C}$. The major springs which feed the Foundation Spa are $38^{\circ} \mathrm{C}$. The presence of fault zones can be easily determined in the 
area by extensive travertine deposits. These thermal waters are most logically associated with deeper sources of thermal fluids which are circulating up through the Paleozoic units along the fault intersection.

Most of the thermal springs and wells in the area occur from the basaltic rocks which underlie the Portneuf River Valley. Several shallow wells have been dug with backhoes to depths of less than 20 feet. Hot fluids are intersected along the bottom contact of the basalts. This may indicate that thermal water of the area is rising along the fault zones and spreading horizontally along the basalt contact.

Using the sodium-potassium-calcium geothermometer, a reservoir temperature of $211^{\circ} \mathrm{C}$ has been predicted, and using silica, a temperature of $80^{\circ} \mathrm{C}$. In either case, the temperature would be sufficient for space heating. A surface temperature of $71^{\circ} \mathrm{C}$ has been reported on the bank of the portneuf River just west of the spa. Investigations are presently being undertaken to determine the feasibility of designing a district heating project. The reported flow (over $1500 \mathrm{l} / \mathrm{min}$ ) and the location appears to favor this project. A district heating project would also avoid the present apparent interference between the very shallow individual wells in towns.

- Downata Hot Springs (12s-37E-12ccd1s), a popular resort area of long standing, rises from Quaternary alluvium near Tertiary sediments. It is associated with an east-west lineament (see figure 67). It is $43^{\circ} \mathrm{C}$ at the surface. Subsurface temperatures here probably are not much higher than $46^{\circ} \mathrm{C}$, as estimated by the $\mathrm{Na}-\mathrm{K}-\mathrm{Ca}$ chemical geothermometer. These hot springs are remote enough from a large population center to exclude large scale development. Greenhouses or other agricultural uses could be made of excess water over and above the resort's needs.

One warm domestic well $\left(22^{\circ} \mathrm{C}\right)$ exists near Marsh Creek between McCammon and Inkom. It has not been sampled.

\section{POWER COUNTY}

Power County has one popular resort area, Indian Springs (8S-3lE-18dabls) (figure 69), which has been in existence for many years. It is located a few kilometers south of American Falls. Indian springs is $32^{\circ} \mathrm{C}$ and discharges 5,830 $1 / \mathrm{min}$. Maximum subsurface temperatures expected are best represented by the $\mathrm{Na}-\mathrm{K}-\mathrm{Ca}$ chemical geothermometer at $71^{\circ} \mathrm{C}$ with the quartz chemical geothermometer indicating $63^{\circ} \mathrm{C}$. 


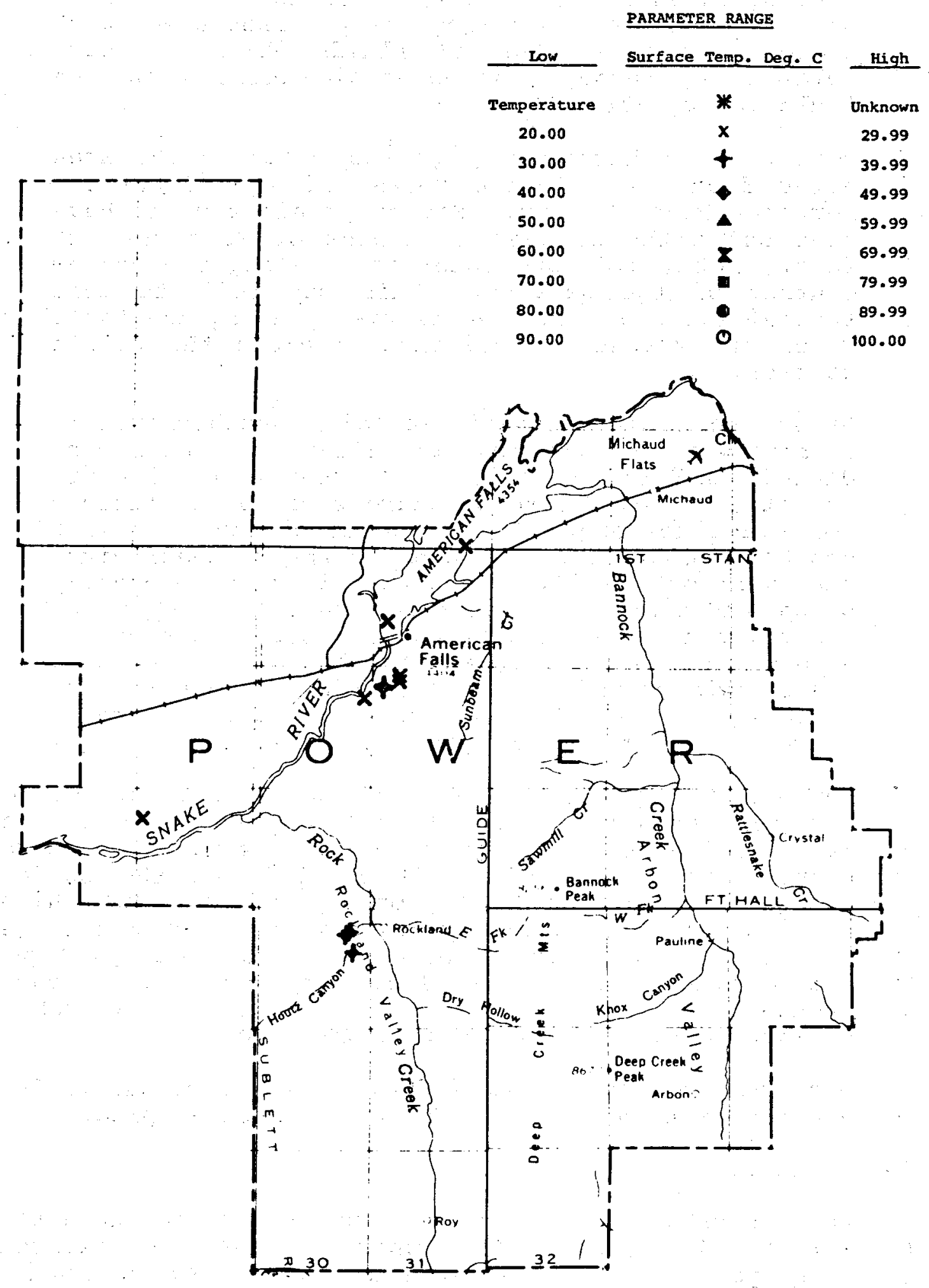

FIGURE 69. Index map of Power County showing locations of thermal water occurrences with surface temperatures of $20^{\circ} \mathrm{C}$ or higher. 
Two other springs, Rockland Warm Springs (10S-30E$13 c d c l s)$ and an unnamed spring (9S-28E-19acdls) located west of Massacre Rocks state Park on the shore of Lake Walcott, are undeveloped. Rockland Warm springs has a chemistry and surface temperature similar to Indian Springs.

Several large travertine deposits occur in Power county (figure 70). Past flows of thermal water may have deposited them. If the thermal springs ceased flowing due to self sealing from travertine deposition in spring vents, thermal water might be found by prospecting along known faults near the travertine deposits. Trimble and Carr (1976, p. 62-64) reported on the geology in the Rockland and Arbon quadrangles, Power county. They stated:

Travertine and travertine-cemented conglomerate and breccia occur at several localities in the Rockland and Arbon quadrangles. Yellowish-white travertine as much as $1.83 \mathrm{~m}$ thick overlies the Little Creek Formation in the valley of Warm creek from a point near Indian Springs to a point near the community of Neeley. An isolated exposure of travertine apparently overlies basalt of the Massacre Volcanics on the east side of the valley of Rock Creek, in the SW1/4 NEl/4 sec. 13, T.9S,, R.3lE. Several outcrops of travertine overlie alluvial pebbly silt or gravel that, in turn, rests on the Starlight Formation (1) on the north side of Rocky Hollow east of the highway between American Falls and Rockland (state Highway 37), (2) in secs. 28 and 29, T.9S., R.31E., between Rocky Hollow and spring creek and (3) along the valley of spring creek.

Travertine and travertine-cemented conglomerate and breccia are exposed in the valley of East Fork Rock Creek and in Sand Hollow and Dry Hollow in the Rockland quadrangle and are exposed in the area of Pete Lish Canyon, Howard Flat, and Warner Flat in the Arbon quadrangle. The thickest travertine deposits are adjacent to the frontal fault of the Deep Creek Mountains and to a normal fault of large displacement in the Arbon quadrangle. In Sand Hollow, travertine-cemented conglomerate immediately adjacent to the frontal fault is about $68 \mathrm{~m}$ thick and ends abruptly on the east at a breccia zone. In the valley of East Fork Rock Creek, it is more than $15 \mathrm{~m}$ thick. Travertine is found downvalley from the fault for as much as $5 \mathrm{~km}$ in some places and appears to be younger than the coarse pediment gravel in this area.

The volume of travertine-cemented breccia at the locality in the Arbon quadrangle is notable. An 


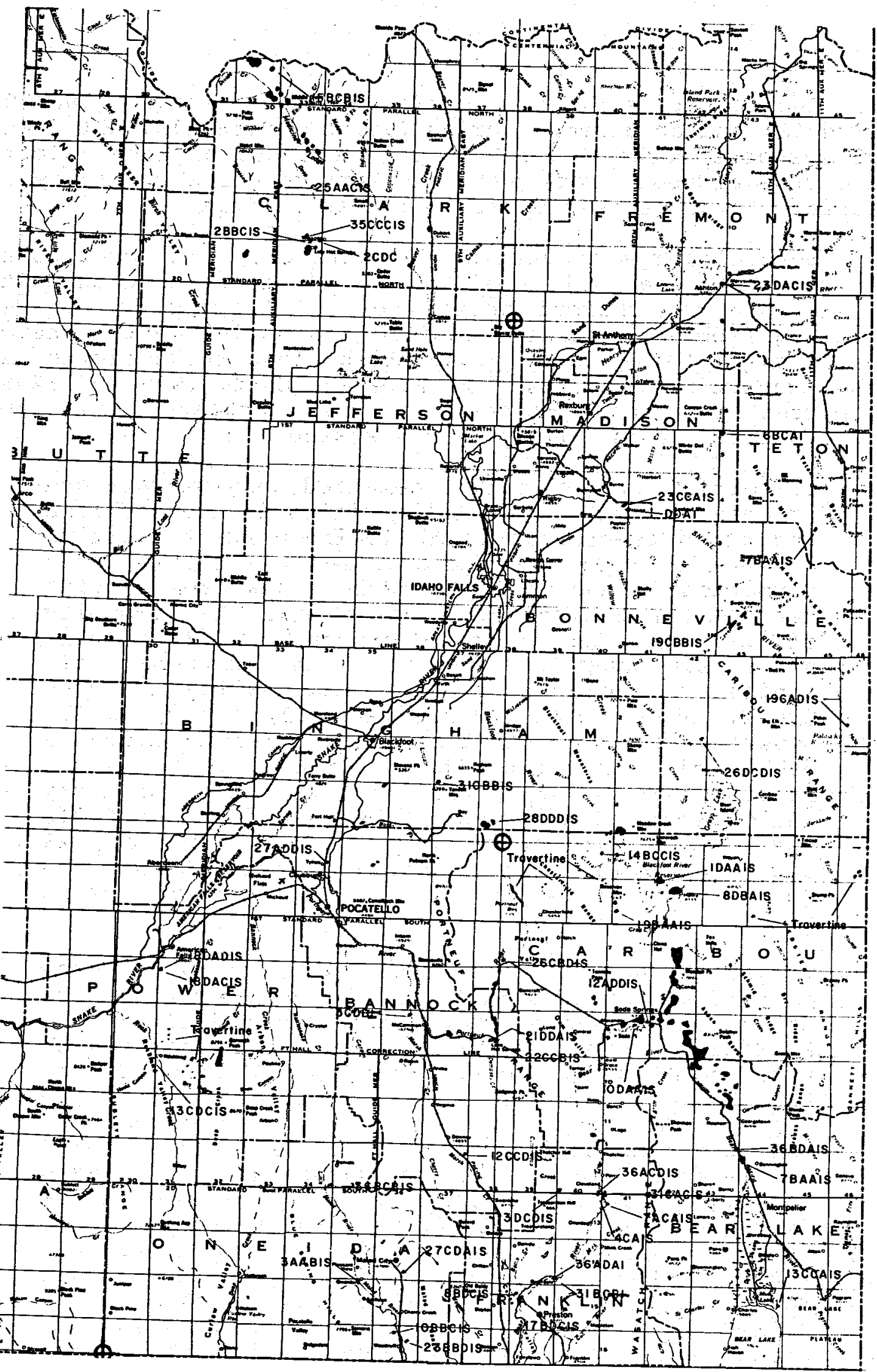

FIGURE 70. Travertine deposits and associated known springs in southeastern Idaho (modified from Bodnar and Bush, 1978). 
area more than $4 \mathrm{~km}$ long and locally more than half a mile wide between Pete Lish Canyon and warner Flat is completely covered. Locally, this deposit probably is more than $150 \mathrm{~m}$ thick. The breccia is composed mainly of fragments $0.65-1.25 \mathrm{~m}$ across of Paleozoic rocks in a travertine matrix. Travertinecemented sandstone and tuffaceous sandstone is locally interbedded with the breccia.

The common occurrences of travertine-cemented conglomerate and breccia adjacent to major faults, and the abundance of travertine near Indian springs, a hot spring apparently on a fault line, indicate that the travertine was deposited by water containing a high percentage of calcium carbonate that issued from artesian springs along the faults.

A late Pleistocene age for most of the travertine is suggested by two lines of evidence. First, the isolated exposure of travertine overlying basalt east of Rock Creek, in the SEl/4 NWI/4 sec. 13, T.9S, R.30E., contains mollusks of possible Pleistocene age (USGS Cenozoic loc. 21644). According to D.W. Taylor (written commun., 1959) the absence of extinct species tends to suggest a late Pleistocene age, but the small number of species makes even this age uncertain. The stratigraphic position, in several localities, of the travertine above gravel that probably is generally equivalent to the sunbean formation also suggests a late pleistocene age for much of the deposit. Eastward dips in the travertine cemented breccia and sandstone in the Arbon quadrangle indicate that there has been renewed tectonic movement along the major fault after deposition of the travertine. This suggests that these deposits are somewhat older than flat-lying deposits west of the frontal fault of the Deep Creek Mountains.

\section{BINGHAM COUNTX}

only two thermal springs are known in Bingham county (figure 71). Both are of low temperature. Yandall springs (3S-37E-31dbbls) is located at the base of Yandall Mountain along a fault in Paleozoic linestone. It issues from several vents at $22-32^{\circ} \mathrm{C}$. This is a fairly large spring, discharging $5,700 \mathrm{l} / \mathrm{min}$ and is used for irrigation. Dissolved solids are only $197 \mathrm{mg} / 1$. Subsurface temperature probably will not exceed $35^{\circ} \mathrm{C}$, as predicted by the chalcedony chemical geothermoneter.

Alkali Flat Warm Springs (4S-38E-28dddls) is a small seep situated in a bowl in travertine and closely resembles 
FIGURE 71. Index map of Bingham County showing locations of thermal water occurrences with surface temperatures of $20^{\circ} \mathrm{C}$ of higher.

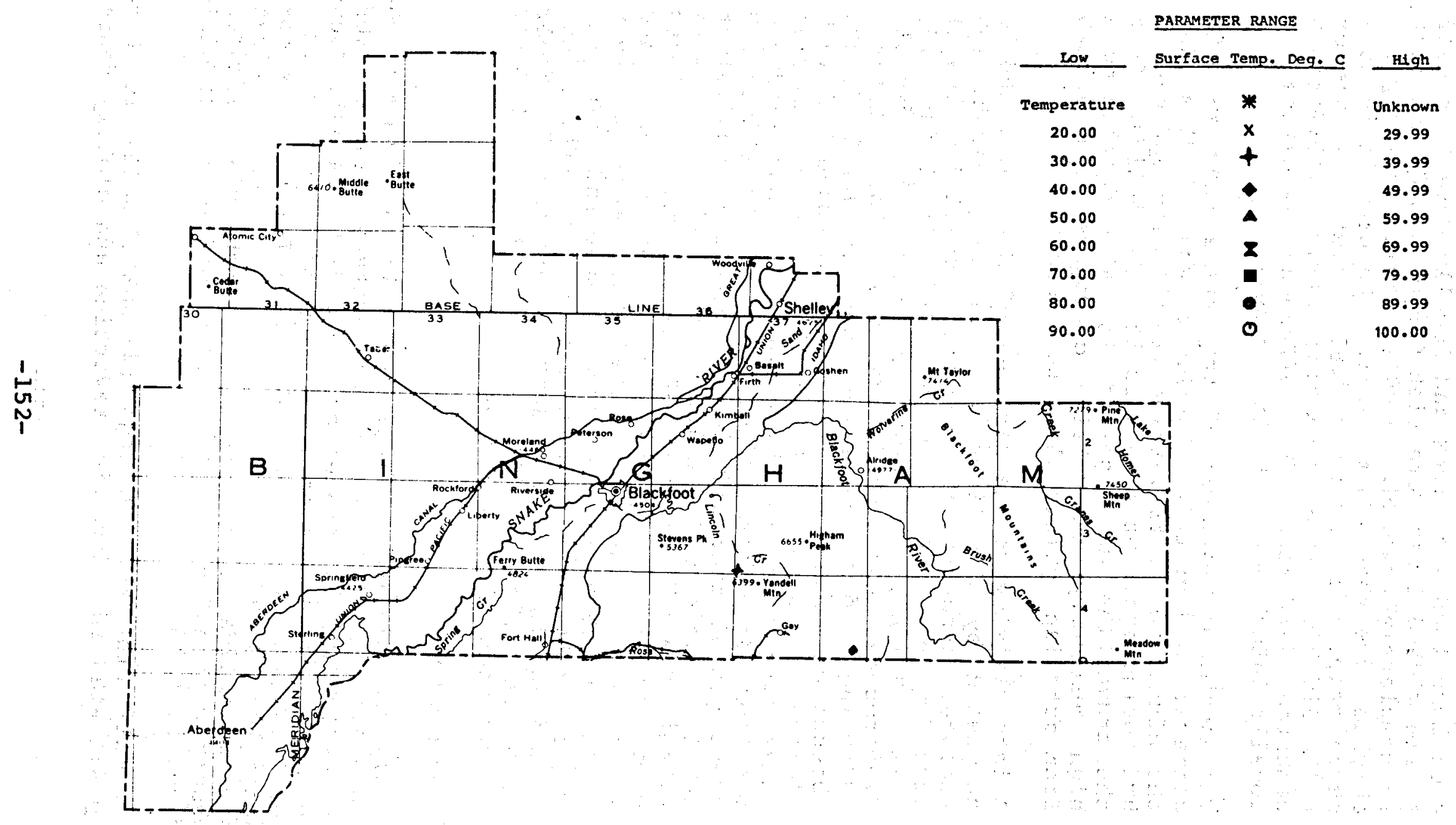


springs found in Caribou County. It has a surface temperature of $34^{\circ} \mathrm{C}$, discharges about $751 / \mathrm{min}$ and is located in the Gay Mine (phosphate) area. Thermal water in this area could possibly be used in winter mining operations. The spring is presently used for stock water. Subsurface temperatures are predicted to be about $58^{\circ} \mathrm{C}$ by the chalcedony chemical geothermometer.

Donaldson and Applegate (1979) reported that:

The preliminary Gravity Map of southern Idaho (Mabey, Peterson and Wilson, 1974) defines a prominent low about 12 miles south of Blackfoot ( $f$ igure 72). An east-northeast profile through this anomaly (figure 73 ) defines a $22.5 \mathrm{mgal}$ low which, assuming a $0.4 \mathrm{gm} / \mathrm{cm}^{3}$ density contrast, results in calculations estimating a basin depth of about $1,342 \mathrm{~m}$. A steep gravity gradient on the east side of the anomaly is very suggestive of a fault but the equi-dimensional nature of the main part of the anomaly does not suggest a preferred direction of valley strike. Witkind (1975) defines a $105 \mathrm{~km}$ long active fault which is terminated in the vicinity of the east flank of the gravity anomaly (figure 15). This fault has been recurrently active since Middle Miocene time. East of this anomaly, gravity is quite featureless and exhibits only a regional gradient of about $-.64 \mathrm{mgal} / \mathrm{km}$ eastward. Day (1974) has mapped a lineament from ERTS imagery (Eigure 9) which approximates a portion of the witkind fault but terminates before reaching the gravity anomaly. In the vicinity of the gravity anomaly, Day has mapped several northeast trending linears which parallel the trend of the eastern snake River Plain, only a short distance northward (figure 9). It is probably significant that gravity contours enclosing the main portion of the previously mentioned anomaly are distorted toward the northeast (figure 72). Gravity, mapped lineaments and a prominent fault intercuption all indicate effects of the force or forces responsible for the presence of the eastern Snake River plain and the complexity expected in the transition into this dominating structural feature.

\section{BONNEVILLE COUNTY}

Three thermal spring areas are located in Bonneville County and warm water of $20^{\circ} \mathrm{C}$ has been encountered by well drilling near Ammon west of Idaho Falls (figure 74). Alpine Warm Springs (2S-46E-19cad1s), the hottest at $37^{\circ} \mathrm{C}$, is now covered by the waters of Palisades Reservoir. A sample of 
FIGURE 72. Gravity lows south of Blackfoot (lower right) and Swan Valley (upper left) (Mabey, Peterson and Wilson, 1974).

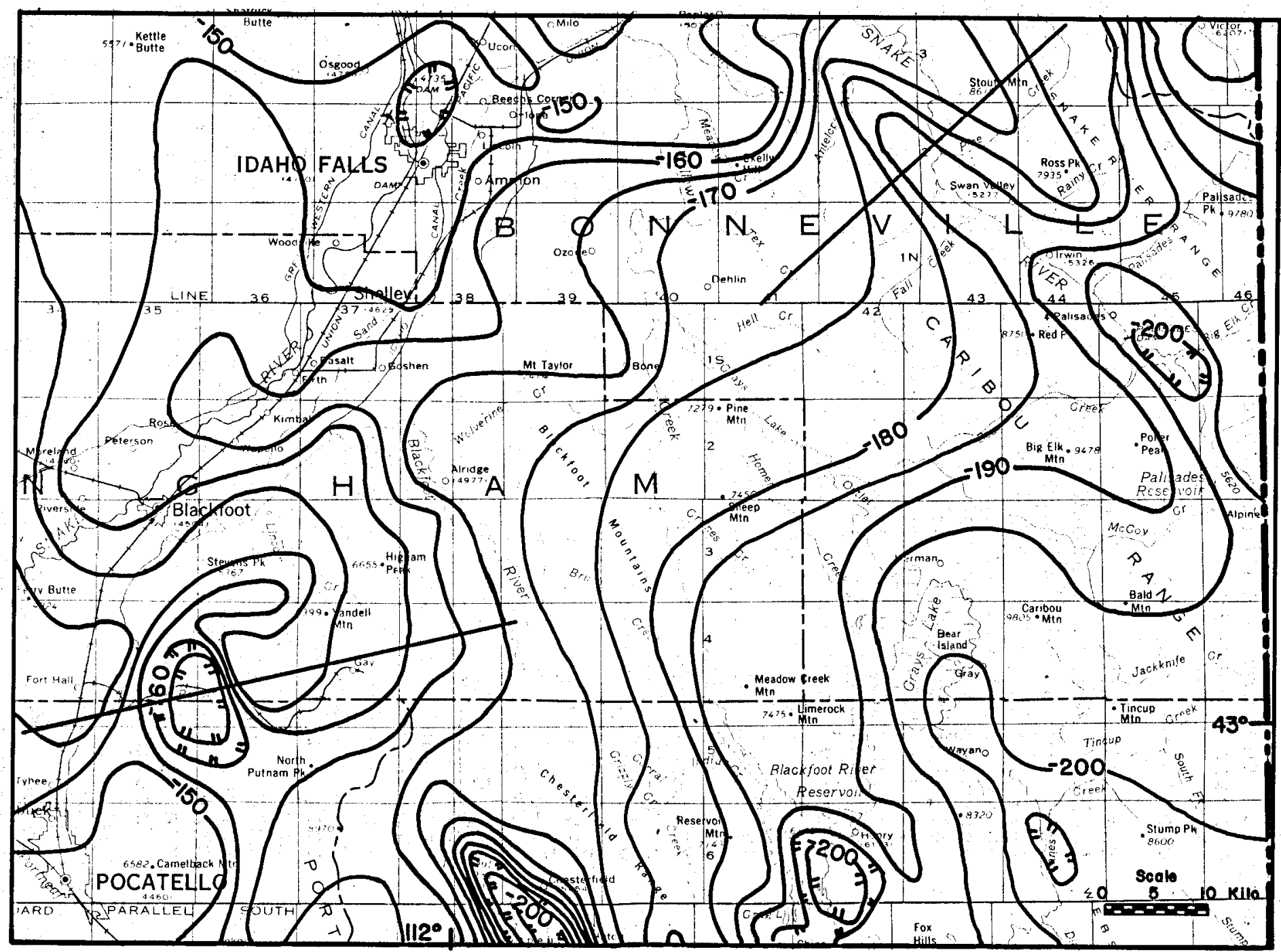




\section{BLACKFOOT - GAY MINE AREA}

R33E|R34E

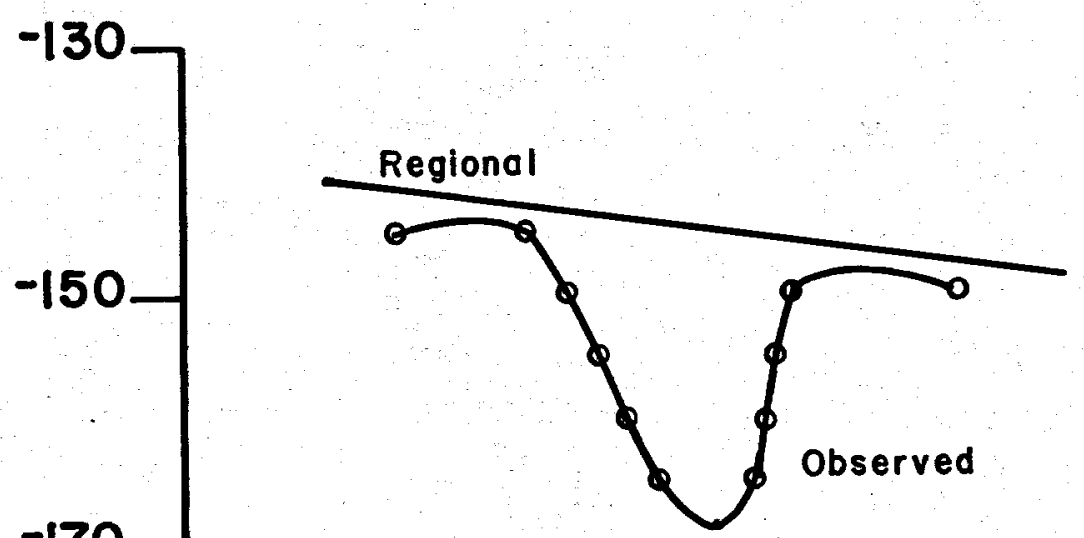

$-170$

$-190$
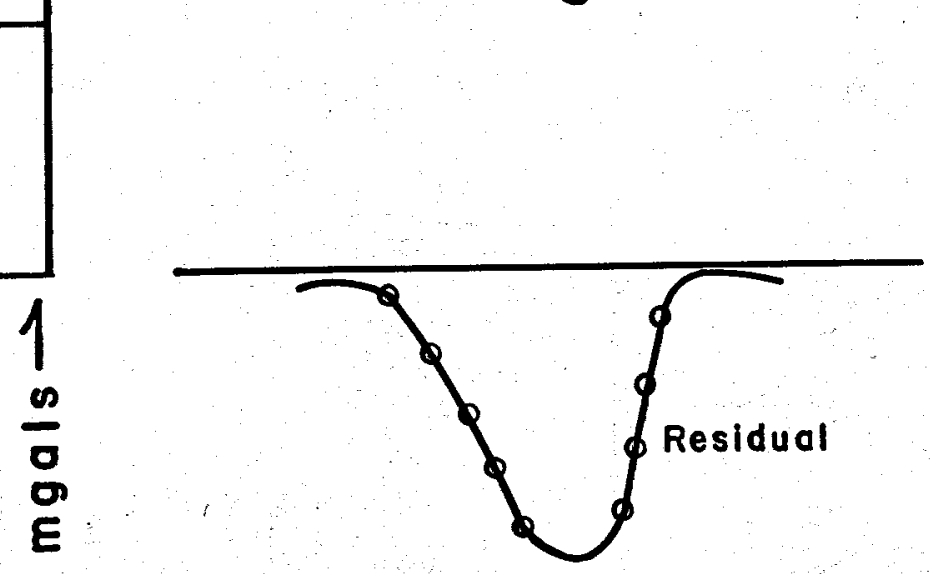

o

$\frac{\infty}{0}$

0

E

$\sqrt{1}$

0

$-10$

$-20$

30

miles

30

FIGURE 73. Gravity profile near Blackfoot. (From Donaldson and Applegate, 1979.) 
FIGURE 74. Index map of Bonneville County showing Iocations of thermal water occurrences with surface temperatures of $20^{\circ}$ or higher.

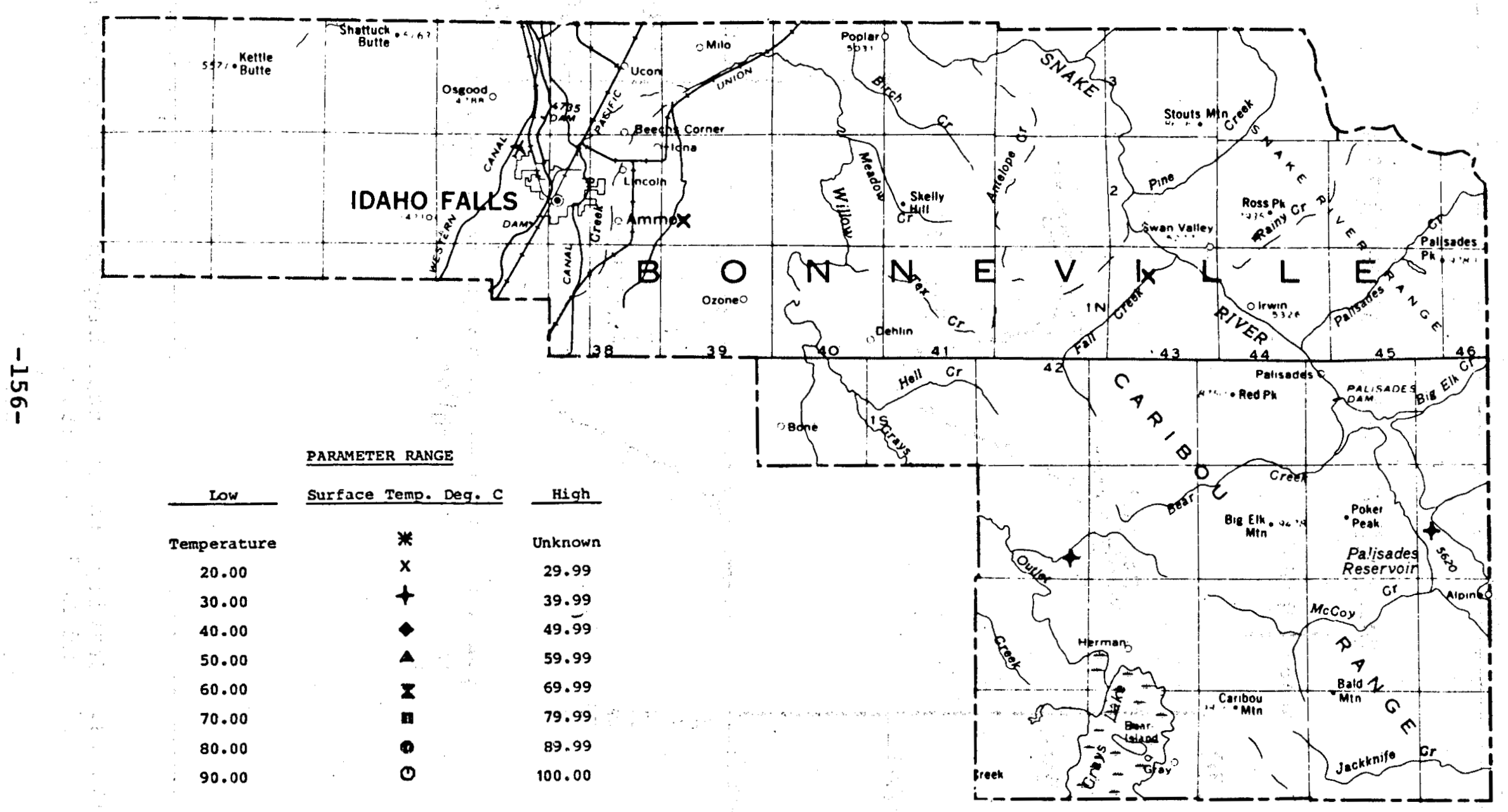


this group of springs was obtained during low water caused by the drought of 1977. Subsurface temperature here might be $61^{\circ} \mathrm{C}$ as predicted by the chalcedony chemical geothermometer.

Brockman Creek Hot Springs (2S-42E-26dcdls) is $35^{\circ} \mathrm{C}$, discharges $49 \mathrm{l} / \mathrm{min}$ and bubbles gas.

Fall Creek Mineral Springs ( $1 \mathrm{~N}-43 \mathrm{E}-9 \mathrm{cbbls})$ is the coolest thermal spring at $25^{\circ} \mathrm{C}$. It discharges water along a three-fourths mile long stretch of Fall Creek and deposits travertine in several locations. The spring appears to be fault controlled:

Subsurface temperatures in these areas are best represented by the chalcedony ( $T_{4}$, basic data table 2 ) temperature, with the exception of Fall Creek Mineral spring, where quartz $\left(T_{1}\right)$ may be the best estimated subsurface temperature. At Fall Creek, subsurface temperatures may approach $40^{\circ} \mathrm{C}$, while at Brockman Creek and Alpine Warm Springs, subsurface temperatures might be as high as 38 and $61^{\circ} \mathrm{C}$, respectively.

This area lies along what. is locally known geologically. as the Heise Alpine Trend.

\section{MADISON COUNTY}

Madison county near Rexburg and Fremont County near Newdale have been scenes of intense geothermal research activity by the DOE and the USGS. Since the destruction of Sugar City by the Teton Dam failure and flood of 1976, efforts have been aimed at finding a thermal source to heat the rebuilt town of Sugar City. The area lies along the southern margin of the eastern snake River plain in a zone of high heat flow recognized by Brott and others, 1976. Heat flow values in excess of 5 HFU extend in a northeastsouthwest zone from Rexburg to Newdale. Several thermal wells are also known here (figure 75). The $\mathrm{Na}-\mathrm{K}-\mathrm{Ca}$ chemical geothermometer predicts a shallow warm water system with temperatures that might range between 30 and $81^{\circ} \mathrm{C}$.

\section{Mabey (1978) reports:}

A caldera complex in the Rexburg area of the eastern Snake River Plain has been defined on the basis of geologic evidence provided by H.J. Prostka and G.F. Embree (written communication, 1977) and named the Rexburg caldera complex (figure 76). Geothermal resources in the Rexburg area are likely to be related directly or indirectly by this caldera complex. 
FIGURE 75. Index map of Madison and Jefferson counties showing locations of thermal water occurrences with surface temperatures of $20^{\circ} \mathrm{C}$ or higher.

\section{PARAMETER RANGE}

\begin{tabular}{cccc} 
Low & Surface Temp. Deg. $C$ & High \\
\cline { 3 - 4 } Temperature & W & \\
20.00 & $X$ & Unknown \\
30.00 & + & 29.99 \\
40.00 & - & 39.99 \\
50.00 & $\times$ & 49.99 \\
60.00 & $X$ & 59.99 \\
70.00 & - & 69.99 \\
80.00 & - & 79.99 \\
90.00 & 0 & 89.99 \\
& & 100.00
\end{tabular}
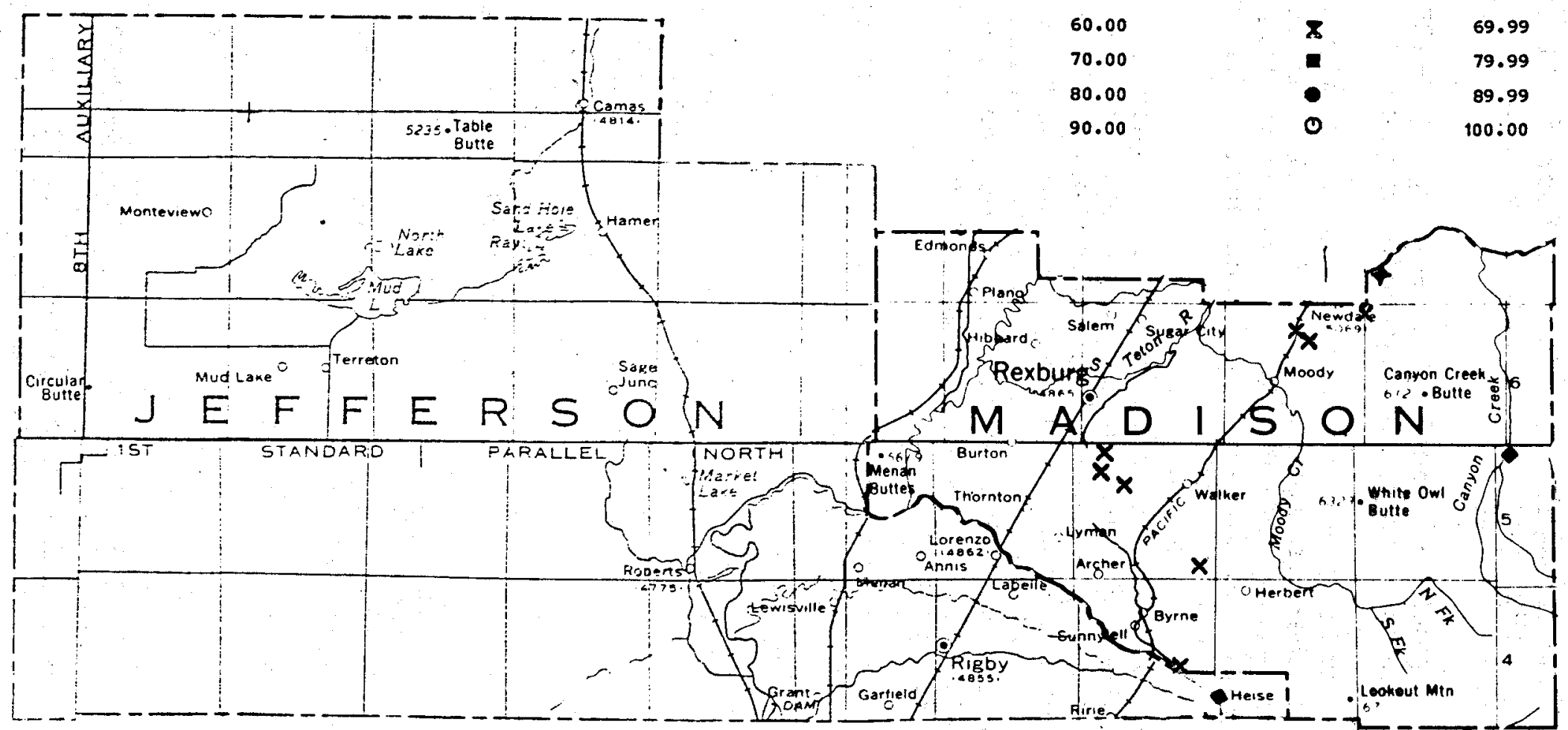


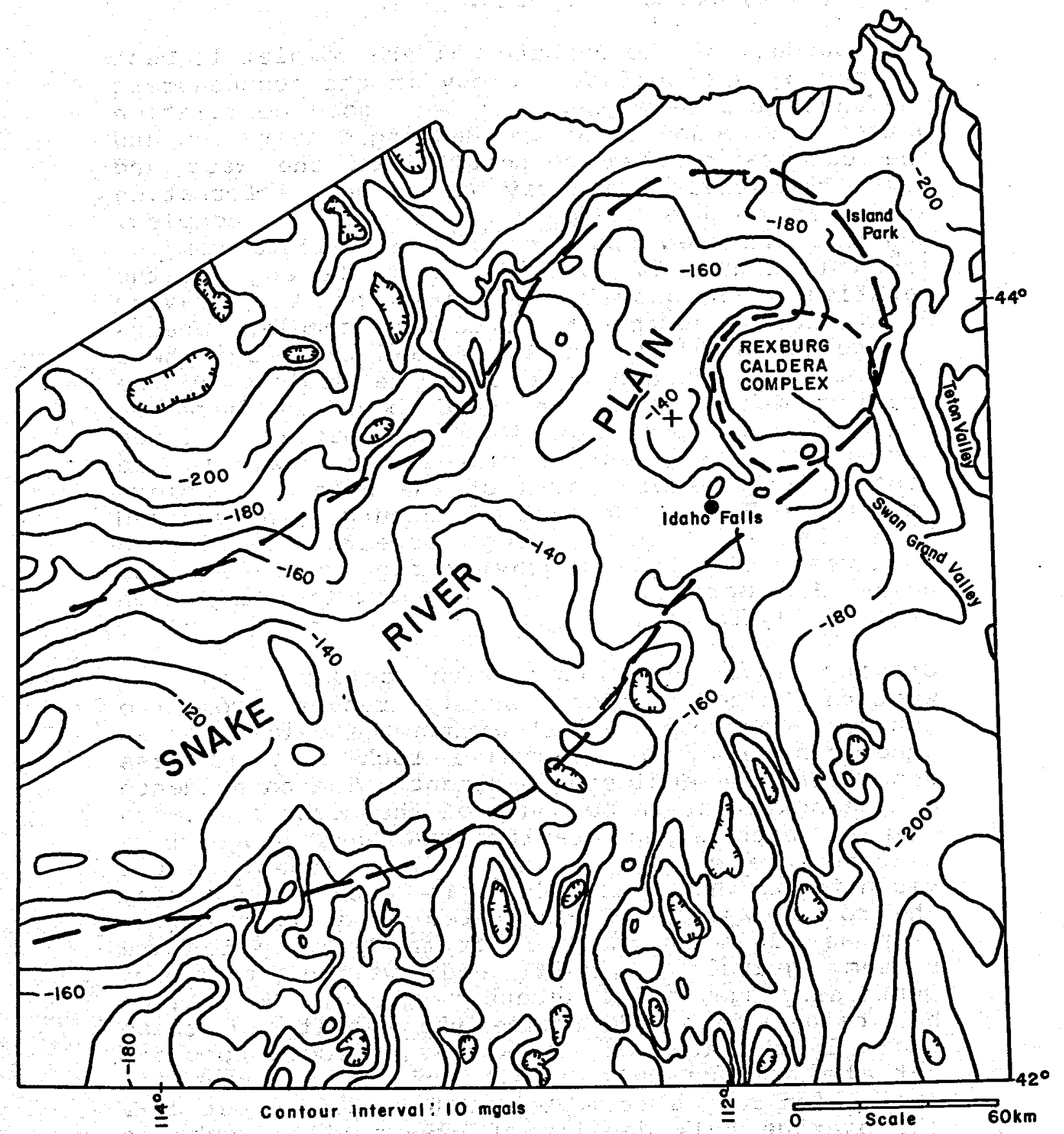

FIGURE 76. Bouguer gravity anomaly map of southeastern Idaho showing the location of the Rexburg caldera complex (from Mabey, 1978). 
A gravity map of the caldera complex (Mabey, 1978) is shown in figure 77 .

Mabey (1978) further reports:

The boundary of the Rexburg caldera complex is best defined by the surface geology in the southeastern quadrant, and here there is very good correlation between the boundary of the Rexburg gravity low and the caldera complex boundary. On the west and north the gravity data may be the best information available on the boundary of the caldera complex, and the inferred boundary of the caldera complex shown in figure 77 coincides with the edge of the negative mass anomaly indicated by the gravity data. To the northeast the caldera complex appears to overlap another depression, and the margin here is not well defined by either the geology or the gravity data. The inferred boundary here is primarily a connection of the better defined segments. The lowest gravity values occur in the eastern and western parts of the caldera complex; near Menan Buttes and east of Rexburg. The subdued high between these lows appears to be a northwestward-trending gravity high centered over Heise Hot Springs and a southwest-trending high west of Sugar City.

Gravity lows associated with calderas in the western United States usually result from two sources: low density fill within the caldera or an underlying body of intrusive rock that is less dense than the enclosing basement. The coincidence of the southwestern boundary of the Rexburg caldera complex with steep gravity gradients suggests a near-surface source, caldera fill. Except in the vicinity of the gravity high at Heise Hot Springs, the rocks exposed or penetrated by drill holes as deep as $420 \mathrm{~m}$ in the area of the gravity low are stream gravels, basalt and welded tuff of Quaternary age, and Pliocene rhyolite. No attempt has been made to determine the density of these rocks in the area of the Rexburg caldera complex, but the average bulk density of similar rocks in the region ranges from about 2.0 to $2.65 \mathrm{~g}$ per $\mathrm{cm}^{3}$. The average bulk density of pre-Tertiary rocks in the region is about $2.65 \mathrm{~g}$ per $\mathrm{cm}^{3}$. Thus a mass of the low-density Quaternary and Tertiary sedimentary and volcanic rock enclosed by pre-Tertiary rock would produce a gravity low, and this seems a probable cause of a major part of the low. Nowhere does the gravity anomaly require a deep source, although the existence of such a source smaller in 


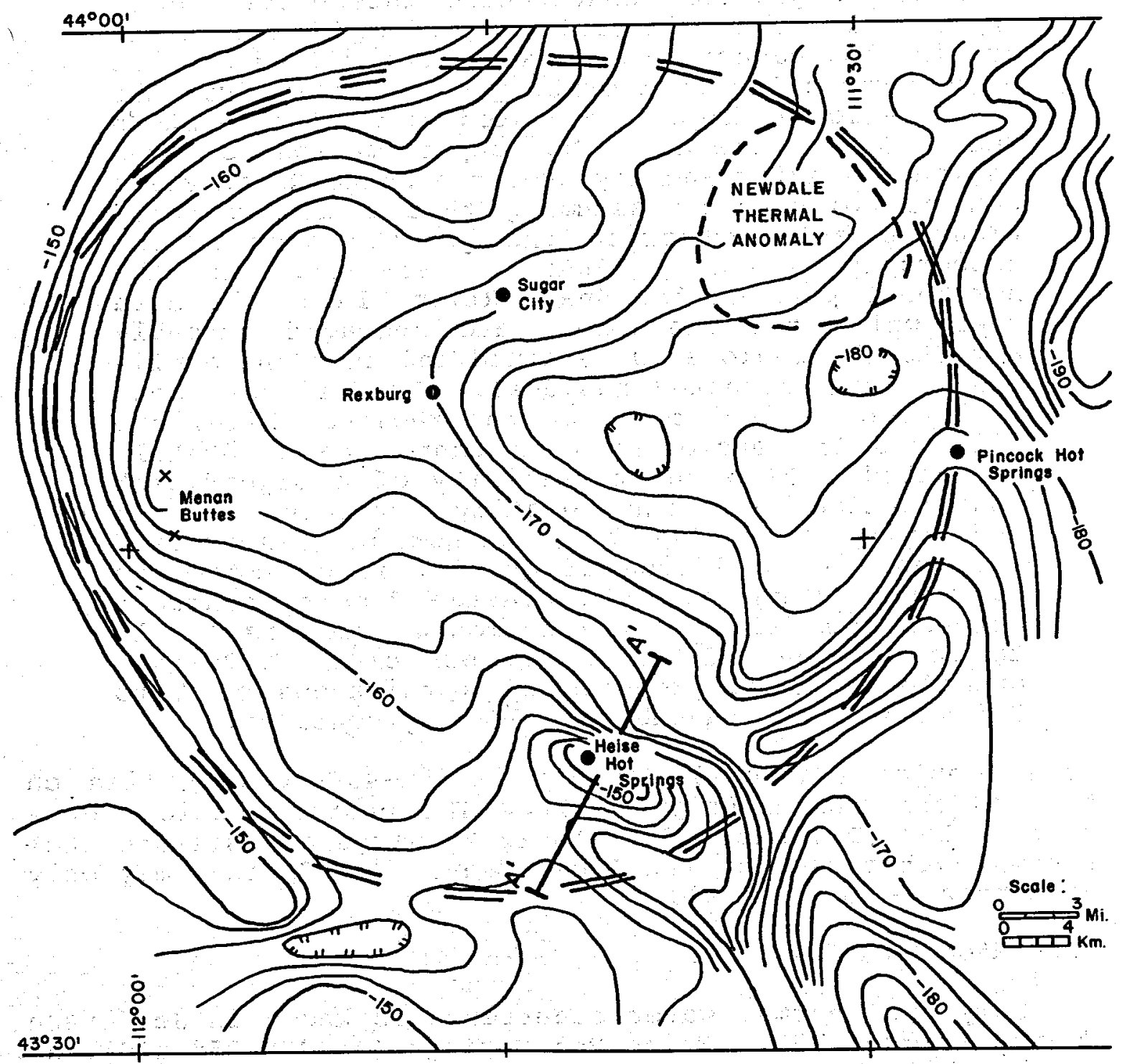

FIGURE 77. Bouguer gravity anomaly map of the Rexburg area showing the outline of the Rexburg caldera complex as inferred from the gravity data. Contour interval is 2 milligals (from Mabey, 1978). 
extent than the inferred caldera complex is not inconsistent with the gravity data.

Although the Rexburg gravity low appears in large part to reflect fill within the Rexburg caldera complex, a precise quantitative interpretation of the anomaly is not justified. The amplitude of the gravity low cannot be accurately determined because of uncertainties in isolating the anomaly from the more regional high associated with the eastern Snake River Plain. No approximation of the regional gravity anomaly over the Snake River Plain can be computed by assuming that a linear relationship exists between the gravity anomaly and topography (Mabey, 1966). However, in the northeast part of the Snake River Plain, the area over which the elevations are averaged strongly affects the regional determined and thus the amplitude of the computed residual. Even if the local low could be isolated from the regional high, the fill and the enclosing rock cannot be accurately estimated. Also the possibility of a significant contribution to the gravity anomaly by an underlying intrusive body cannot be discounted. The residual amplitude of gravity is estimated to be about 20 mgals. The average density contrast between the fill and the enclosing rock is likely to be between 0.2 and $0.5 \mathrm{~g}$ per $\mathrm{cm}^{3}$. A $20-\mathrm{mgal}$ anomaly could be produced by a thickness of $I$ to $2.5 \mathrm{~km}$ of rocks having this density contrast.

Green Canyon (Pincock) Hot Spring (5N-43E-6bcals) lies on the caldera margin (figure 77). The quartz chemical geothermometer ( $T_{1}$, basic data table 2 ) gives an estimate that thermal water feeding the Green Canyon Hot Springs may only have been as hot as $72^{\circ} \mathrm{C}$.

\section{JEFFERSON COUNTY}

Only one thermal water occurrence is known in Jefferson County (figure 75). Heise Hot Springs (4N-40E-25ddals), an established popular resort area located near the South Fork of the Snake River near the edge of the Snake River Plain, is in the extreme southeastern part of the county. Surface temperature is $49^{\circ} \mathrm{C}$. The quartz chemical geothermometer gives an estimate of a subsurface temperature of $79^{\circ} \mathrm{C}$. This spring deposits free sulfur and travertine and has a distinct sulfur odor. It issues from Tertiary silicic volcanic rocks along a northwest-trending fault. Heise lies within and near the southern margin of the Rexburg caldera on a large gravity high.

Mabey (1978) reports: 
The most prominent local gravity and magnetic anomalies are highs within the Rexburg caldera complex in the area of Heise Hot Springs (figure 77.) Although the crests of the anomalies are coincident, the extent of the anomalies are different and they cannot reflect entirely the same mass. Mesozoic sedimentary rocks overlain by Pliocene rhyolite flows and welded tuffs are exposed in the area of the anomalies. Rhyolite dikes are locally abundant. The northwest-trending Heise fault (Prostka and Hackman, 1974), which forms a southwest-facing scarp locally $300 \mathrm{~m}$ high, is parallel to and near the crest of the anomalies. The correlation between the gravity high and outcropping Mesozoic sedimentary rock suggests that the gravity anomaly reflects in large part a structural high elevating the more dense pre-Tertiary rocks. The shape and extent of the magnetic anomaly, the abundant rhyolite dikes in the area, and the indication by the magnetic gradients that the source 1 ies below the surface all suggest that a major part of the magnetic high is produced by a large buried intrusive body. Some features of the magnetic anomaly reflect the near-surface volcanic rocks.

Heise Hot springs and the warm springs to the northwest occur along the crest of the gravity and magnetic highs. The springs are in a structurally complex area where northwest-trending faults, probably related to the Basin and Range structure of Swan and Grand valleys, displace a structural high over the inferred intrusive body. Although the Heise fault forms a prominent southwest-facing scarp and the presence of the snake River against this scarp attests to recent movement of the fault, the geophysical data indicate that the Heise fault is near the crest of the structural high.

The north side of the magnetic high is an easttrending zone that coincides with a subtle east trend in the gravity anomaly contours. The zone coincides with west-trending segments of major canyons and is north of the northernmost outcrops of rhyolite. Another east-trending gravity feature is apparent about $5 \mathrm{~km}$ farther north.

About $8 \mathrm{~km}$ east of Heise Hot Springs are coincident gravity and magnetic lows (figure 78). The cause of the lows is not apparent on the geologic map of Prostka and Hackman (1974). The anomalies appear to reflect a zone in which both the density and magnetization of the underlying rocks are lower than those of the enclosing rocks. 
FIGURE 78. Residual aeromagnetic map of the area of Heise Hot springs showing the location of the gravity high at Heise Hot springs and a gravity low to the east.
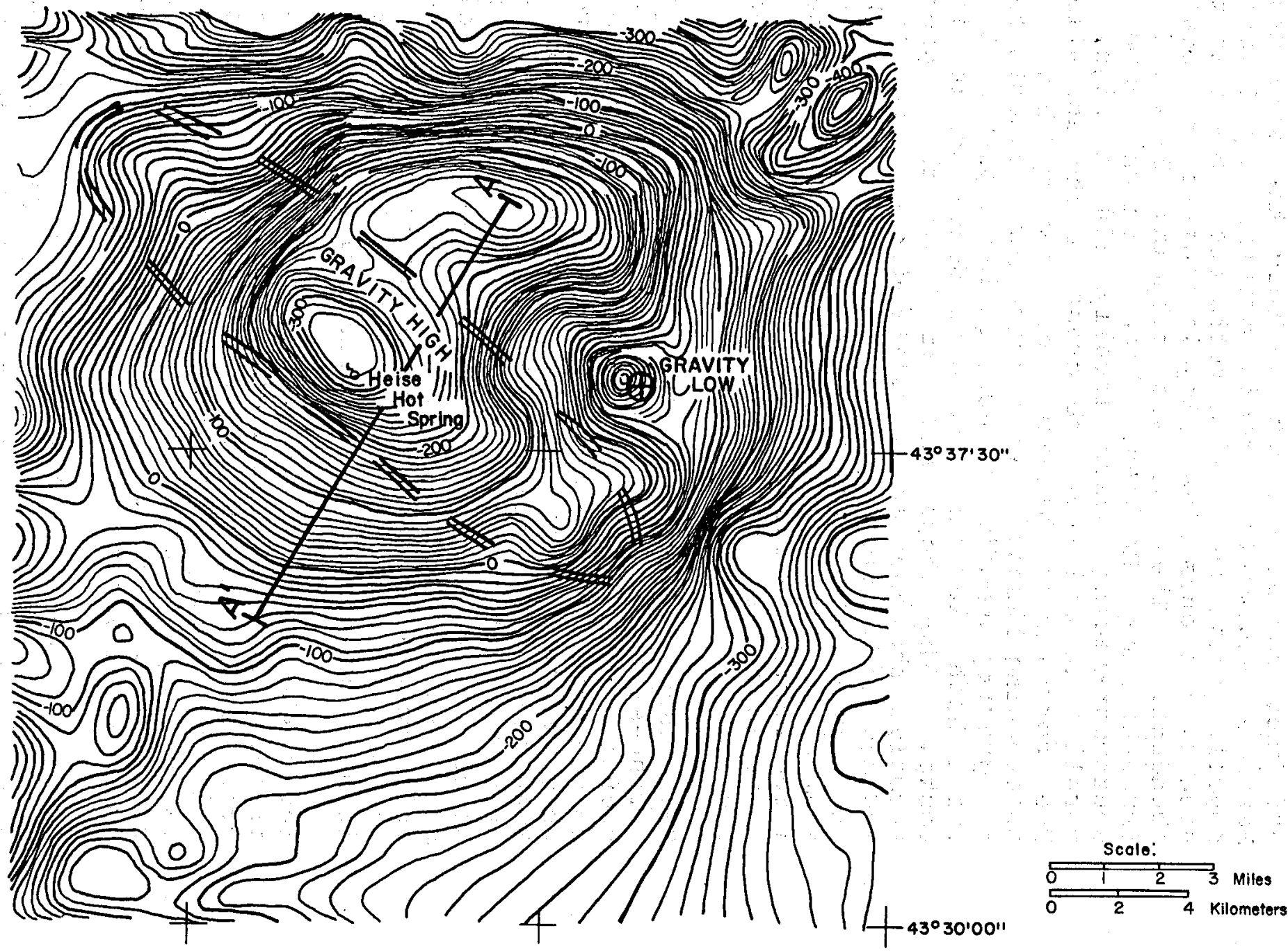
Pincock Hot Spring, on the east edge of the Rexburg caldera, lies midway betwen two flight lines about $9 \mathrm{~km}$ apart on the regional map (figure 78). Along both flight lines a magnetic high was measured opposite the hot spring. Although existing data are not adequate to define this anomaly, the data suggest a magnetic high in the area of Pincock Hot Spring.

A profile (figure 79) normal to the trend of the gravity high shows a section that would produce the major features of the gravity and magnetic fields in the vicinity of Heise Hot springs. The gravity anomaly is attributed to a high on the surface of the pre-Cenozoic rocks at Heise Hot springs and to an area of thicker Cenozoic rocks under the valley of the snake River to the southwest. The depression containing the thicker Cenozoic rocks is parallel to and within a northwestward projection of the Swan-Grand Valley trend into the Rexburg caldera complex. The magnetic anomaly has two major components: a local high at Heise Hot Springs superimposed on broader, more deeply buried source. Both components probably reflect a large body of intrusive rock with the apex near Heise Hot springs. The intrusive mass, which may be the same age as the rhyolite dikes, lies within the Rexburg caldera complex where the Swan-Grand Valley trend intersects the caldera. Magnetic anomalies suggesting a similar intrusive body occur elsewhere along the southeastern margin of the Snake River Plain, where major Basin and Range structures intersect the plain (Mabey, in press). Along the northeastern part of the profile, the magnetic anomaly appears to reflect both Cenozoic volcanic rock and the underlying intrusive body.

\section{SOUTHERN FREMONT COUNTY}

One thermal spring in southern Fremont county referred to as Ashton Warm Springs $(9 \mathrm{~N}-42 \mathrm{E}-23$ dacls $)$ is located outside the Rexburg caldera boundaries near the community of Ashton (figure 51 ). It seeps into a nearby creek at $410 \mathrm{C}$. Silica content is quite high, indicating superheated water could be obtained here. The $\mathrm{Na}-\mathrm{K}-\mathrm{Ca}$ chemical geothermometer indicates that a maximum subsurface temperature of $91^{\circ} \mathrm{C}$ may be obtained. Ashton Warm Springs is close enough to Ashton to represent a significant energy source for low temperature space heating, and uses up to low temperature blanching (figure 4) might be possible if increased flow rates and temperatures could be found through deep drilling. Geophysical and geological studies to determine structure should be pursued before any drilling in the area begins to best site a target prior to any contemplated deep holes. 

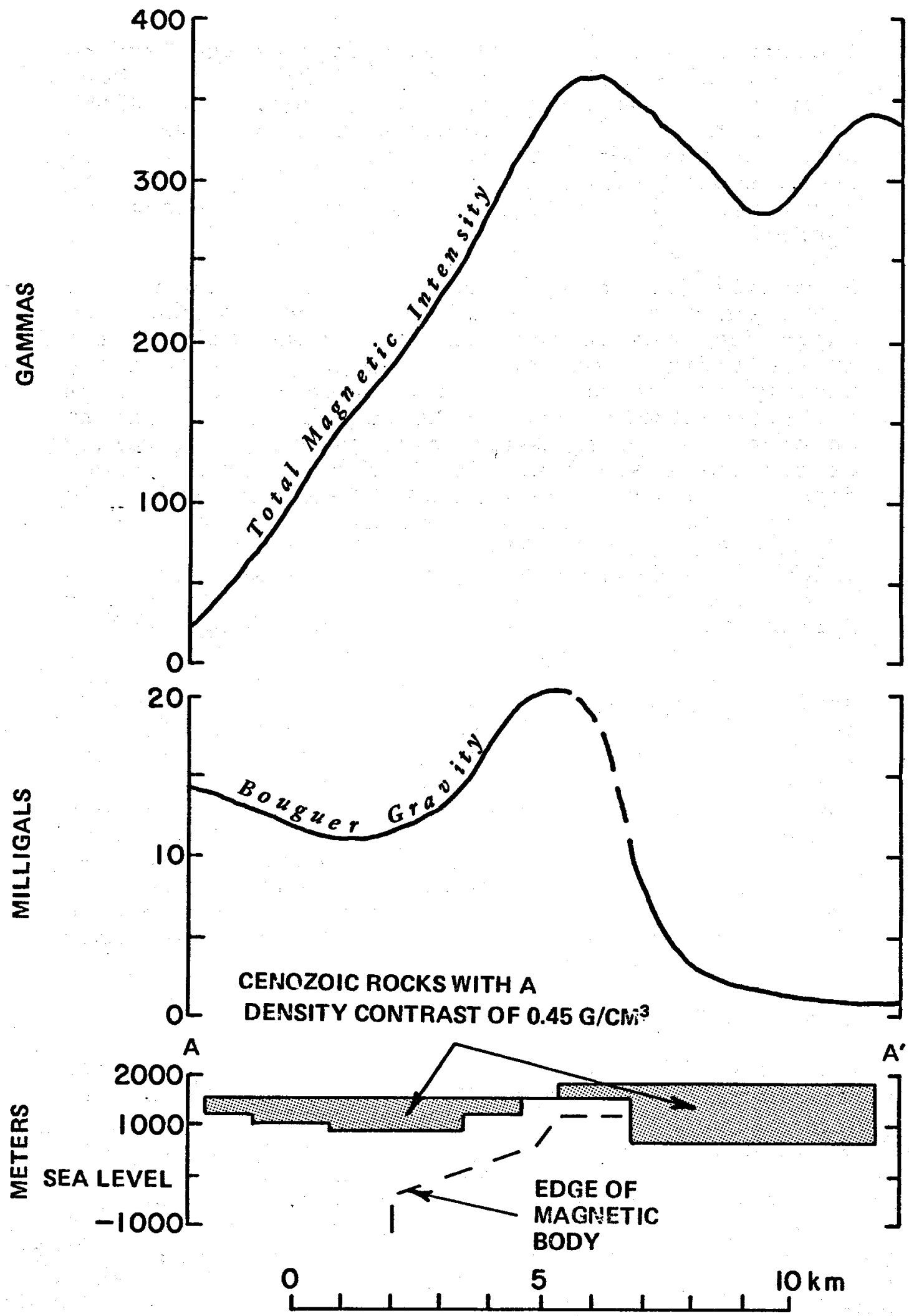

FIGURE 79. Magnetic and gravity profiles and interpreted section across the anomalies at Heise Hot Springs (from Mabey, 1978). 
Seventeen thermal wells ranging from 22 to $51^{\circ} \mathrm{C}$ exist in southern Fremont County in and around the city of Newdale $(10 \mathrm{~km}$ southeast of st. Anthony). This thermal anomaly seems to be related to the Rexburg caldera previously discussed in the sections on Madison and Jefferson counties. Further work in this area might be oriented toward determining if thermal water could possibly extend further to the northwest, toward st. Anthony.

CLARK COUNTY

Three thermal spring areas are known in clark County (figure 80 ). Liddy Hot Springs (10N-33E-35cccls) is located near where the mountain front meets the northern margin of the eastern Snake River Plain. Liddy is located on an active fault and is used presently for phosphate fertilizer processing and in a domestic laundry room. It was formerly used at the Liddy Hot Springs natatorium, which has been closed for several years. Discharge is near a ridgecrest several tens of meters above the snake River plain. It is one of the two ridgetop discharges known in Idaho. A well has been drilled near the spring site and the owner reports that water shot to the top of the $12 \mathrm{~m}$ drilling mast, so the well apparently is under some degree of shut-in pressure. Surface temperature is $51^{\circ} \mathrm{C}$. Best estimated subsurface temperature is $54^{\circ} \mathrm{C}$ by the chalcedony chemical geothermometer. The $\mathrm{Na}-\mathrm{K}-\mathrm{Ca}$ chemical geothermometer gives an estimate of $65^{\circ} \mathrm{C}$ as the probable highest temperature that might be obtained from the well.

Big Springs $(13 \mathrm{~N}-32 \mathrm{E}-15 \mathrm{bcbls})$ is located on warm Springs Creek, a tributary to Medicine Lodge Creek in the Beaverhead Mountain Range. It is $23^{\circ} \mathrm{C}$ and is not used. It discharges $140 \mathrm{l} / \mathrm{min}$. No chemical analysis is available.

Warm Springs ( $11 \mathrm{~N}-32 \mathrm{E}-25 \mathrm{aac} 1 \mathrm{~S})$ is $29^{\circ} \mathrm{C}$, discharging 3400 $1 / \mathrm{m}$ and is currently used for stock water. Chalcedony and $\mathrm{Na}-\mathrm{K}-\mathrm{Ca}$ chemical geothermorneters give an estimate of subsurface temperatures of 25 and $23^{\circ} \mathrm{C}, 4$ and $6^{\circ} \mathrm{C}$, respectively, below surface temperatures. The quartz chemical geothermometer gives an estimated subsurface temperature of $51^{\circ} \mathrm{C}$.

Clark county thermal areas apparently lie on the same thermal water structure or issue from deep rocks similar to those found on the south side of the snake River Plain, judging from the travertine deposits found in both areas (figure 70). Clark County is the only area north of the Snake River Plain where travertine deposits of large areal extent are known. Commercial quarrying operations for onyx occur here. Water quality appears to be good; dissolved solids are less than $500 \mathrm{mg} / 1$. Flouride content at Liddy Hot Springs is $6 \mathrm{mg} / 1$; however, as maximum subsurface temperatures appear to be not greater than $68^{\circ} \mathrm{C}$, 1 imited use 
FIGURE 80. Index map of Clark County showing locations of thermal water occurrences with surface temperatures of $20^{\circ} \mathrm{C}$ or higher.

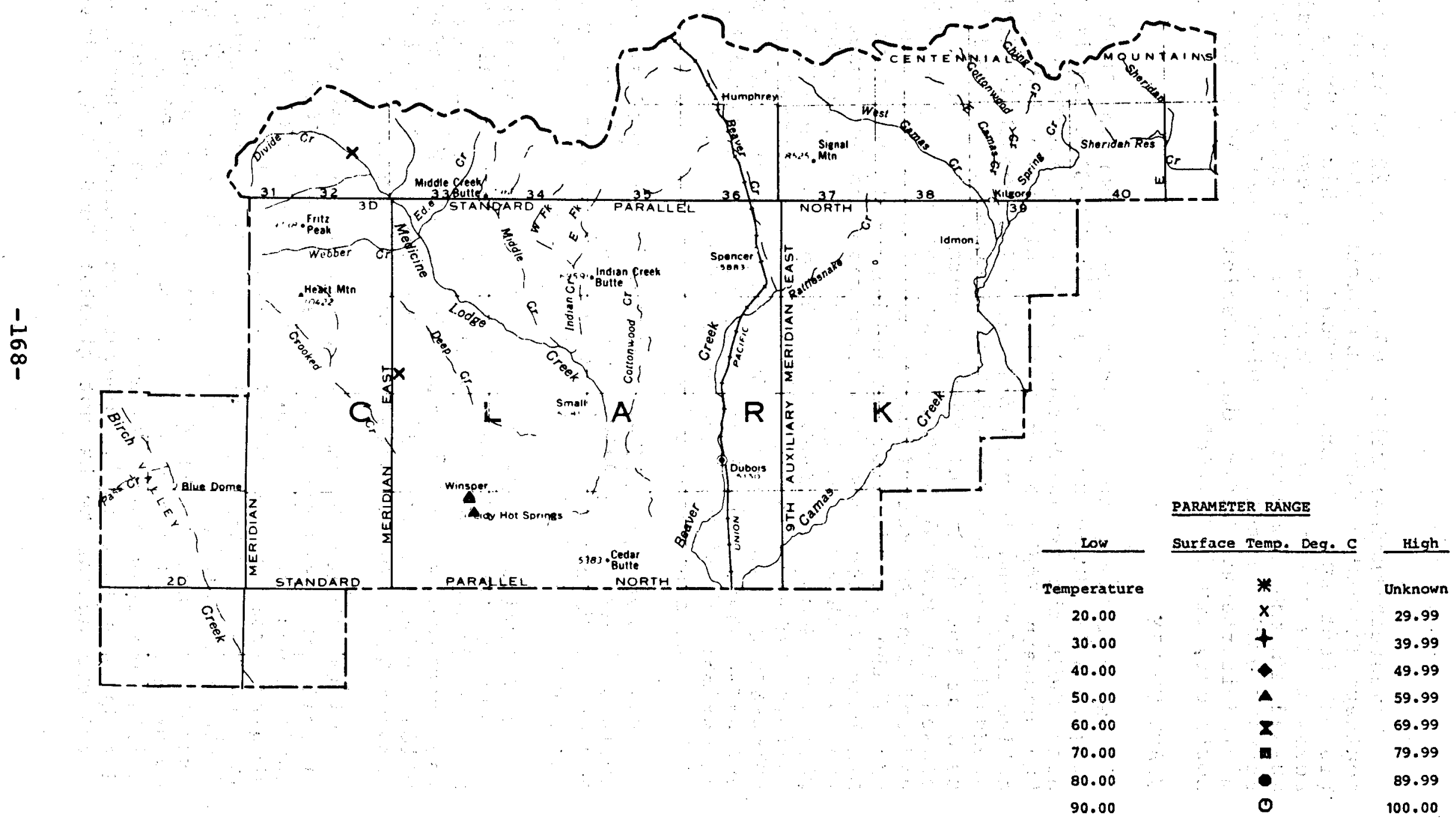


could be made of the thermal water. Uses such as animal husbandry, greenhouse, space heating, and hay and grain drying are suggested in figure 4. Other thermal water might be discovered in clark county in areas of obvious faulting near travertine deposits provided extinct springs have ceased flowing caused by self sealing from travertine deposition in the thermal water conduits.

TETON COUNTY

Only one thermal spring (13N-45E-7baals) is known in Teton county (figure 81). It is located east of victor near the western flank of the Big Hole range in the Teton Basin. It is $20^{\circ} \mathrm{C}$ at the surface. Chemical analysis is not available, so speculation on the subsurface temperature cannot be made. It discharges $950 \mathrm{I} / \mathrm{min}$ and is used for swimming. This spring is located near a thrust fault in Triassic marine sedimentary rocks near the nose of an anticline.

A thermal well (7N-43E-36aacl), $353 \mathrm{~m}$ deep, has been reported in northwestern Teton county. The reported surface temperature is $49^{\circ} \mathrm{C}$. The well was not field checked, but the well location seems to "fit" the suspected curvilinear zone outlined on figure 9. 


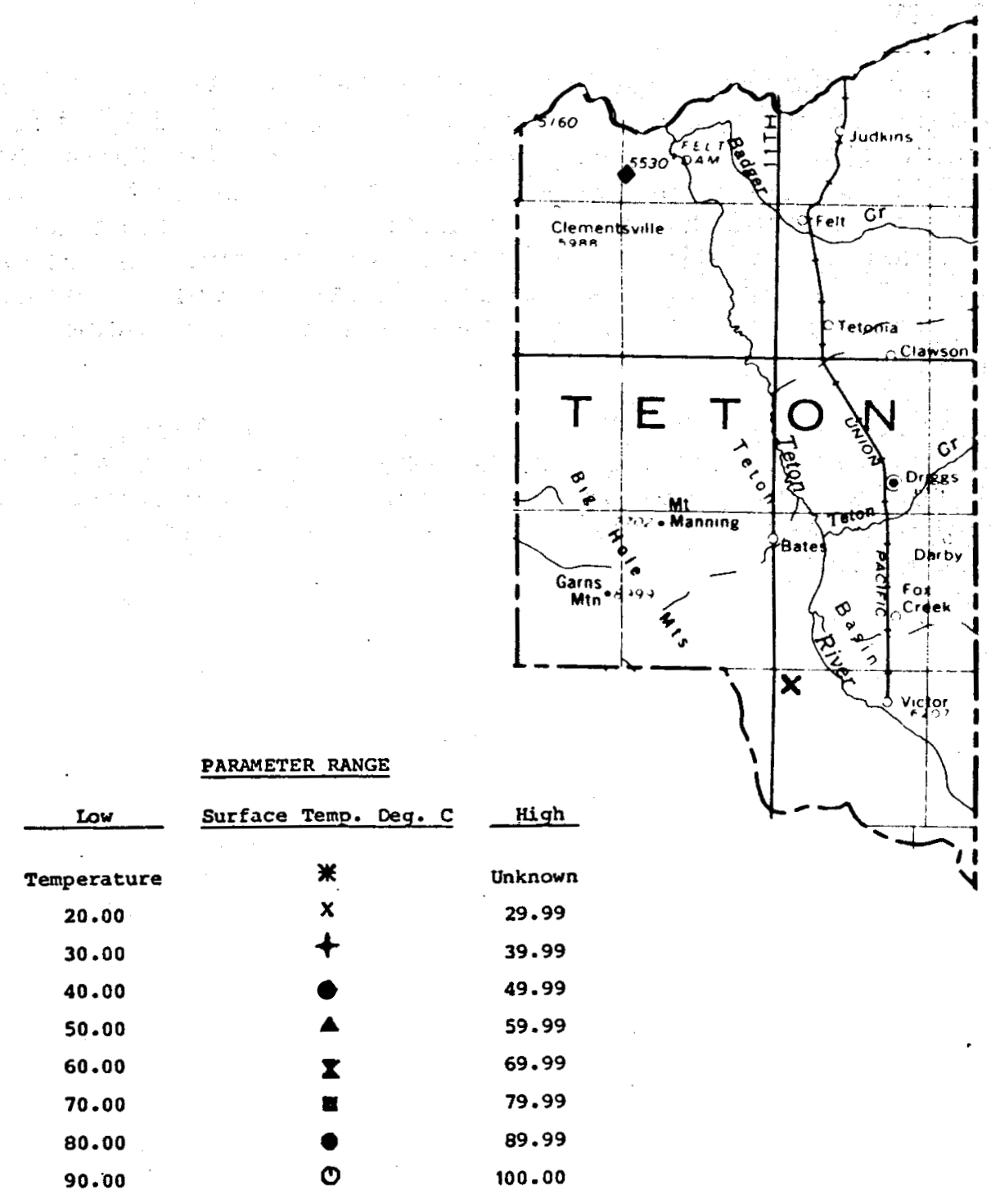

FIGURE 81. Index map of Teton County showing locations of thermal water occurrences with surface temperatures of $20^{\circ} \mathrm{C}$ or higher. 


\section{SUMMARY \\ BASIN AND RANGE \\ CENTRAL ROCKY MOUNTAIN PROVINCE \\ SOUTHEASTERN IDAHO}

Table 6 shows towns in southeastern Idaho that are near thermal water. These towns probably could be heated by geothermal water if sufficient flow rates and temperatures could be obtained by drilling. School districts could perhaps lower heating costs by developing geothermal heating. New schools or other public buildings planned could be built near thermal water locations. In certain places, as at Preston, Malad, and Soda springs, $\mathrm{CaCO}_{3}$ deposition and high dissolved solids may lead to scaling and disposal problems. In other areas, heat dissipation and objectionable gasses may pose environmental problems. Areas near towns in southeastern Idaho could be evaluated without large capital outlays for exploration as the target areas are limited in size.

Pocatello, due to its large population and industrial base, shows the most promise of the largest impact upon conventional energy supply savings by converting to geothermal energy; the potential in this area should be studied first. Gravity, magnetic, seismic refraction or resistivity studies should be able to pinpoint controlling structure and thermal water occurrence in a limited area near Tyhee, north of Pocatello. Pump tests on existing wells should be conducted to determine aquifer characteristics.

Preston may show promise of power generation. If such is the case, cascading uses could be made of thermal water effluent from the power plant. These uses range from steam electric generation to fish farming (see figure 4).

Malad, Soda Springs, Lava Hot Springs, Rexburg, and Ashton represent towns where an economical assessment of geothermal resources for space, heating of business establishments and area subdivisions could be made. Rexburg also has potential to use geothermal heat in food processing plants, as well as to heat large buildings at Ricks college. other areas may have potential and could see development as well, but assessment might be a little more difficult and costly. The engineering and economic feasibility of retrofitting the above communities for space heating could also be studied.

Wells to tap the geothermal resource would have to be carefully targeted to intersect thermal water bearing structures which, in most cases, appear to be faults. 


\begin{tabular}{|c|c|c|c|c|c|c|c|c|c|c|}
\hline \multirow[b]{2}{*}{ Town } & \multirow[b]{2}{*}{ County } & \multirow[b]{2}{*}{$\begin{array}{r}\text { D TOWNS IS } \\
\text { tIon } \\
\end{array}$} & \multirow[b]{2}{*}{$\begin{array}{l}\text { N SOUTHEAST } \\
\text { Spring } \\
\text { or } \\
\text { Well } \\
\text { Surface } \\
\text { Tempera- } \\
\text { ture oC } \\
\end{array}$} & \multirow{2}{*}{\multicolumn{2}{|c|}{$\begin{array}{c}\text { T IDAHO WITHIN } 5 \mathrm{KM} \\
\text { *Best } \\
\text { Est Imated } \\
\text { Subsurface } \\
\text { Temperature } \% \\
\end{array}$}} & \multirow{2}{*}{$\begin{array}{l}6 \\
\text { MI) OF A } \\
\text { Total } \\
\text { DIssolved } \\
\text { Solids }\end{array}$} & \multirow[b]{2}{*}{$\begin{array}{c}200^{\circ} \mathrm{OR} \text { OHIGHER } \\
\begin{array}{c}\text { Present } \\
\text { Water } \\
\text { Use }\end{array} \\
\end{array}$} & \multirow[b]{2}{*}{ Population } & \multirow[b]{2}{*}{$\begin{array}{r}\text { Surface } \\
\text { Owner } \\
\end{array}$} & \multirow[b]{2}{*}{ Remarks } \\
\hline & & & & & & & & & & \\
\hline Alblon & Cassia & $115-25 E-11 c c a 1$ & 60 & 81 & $89 * * * *$ & 372 & Irrigation & 243 & - & - \\
\hline Ammon & Bonnéville & $3 N-39 E-30 a d c 1$ & 20 & - & - & - & Domestle & 3,360 & Private & No chemica! \\
\hline Ashton & Fremont & 9S-42E-23dabls & 41 & 91 & 116 & 204 & Unused & 1,181 & Private & $\begin{array}{l}\text { Thermal spring } \\
\text { just north of }\end{array}$ \\
\hline $\begin{array}{l}\text { Lava Hot } \\
\text { Springs }\end{array}$ & Bannock & $9 S-38 E-21 d d a 1 S$ & 45 & 50 & $82^{* * *}$ & 960 & $\begin{array}{l}\text { Natator lum } \\
\text { balneologlcal } \\
\text { baths }\end{array}$ & 512 & $\begin{array}{l}\text { State of } \\
\text { Idaho }\end{array}$ & $\begin{array}{l}\text { Recreational } \\
\text { area. }\end{array}$ \\
\hline Malad & Onelda & $14 S-36 E-27 c d a 1 S$ & $5 \quad 25$ & 29 & $61 * * *$ & - & Unused & 1,848 & Private & $\begin{array}{l}\text { Spring in traver- } \\
\text { tine bowi near } \\
\text { fairgrounds. }\end{array}$ \\
\hline McCammon & Bannock & $95-36 E-3 c d b 1$ & 20 & - & - & - & Domestic & 619 & Private & $\begin{array}{l}\text { No chemical anal- } \\
\text { yses avallablo. }\end{array}$ \\
\hline Newdale & Fremont & $7 N-41 E-35 c d d 1$ & 32 & 84 & 93 & 377 & Irrigation & 285 & Clty & $\begin{array}{l}\text { Several wolls in } \\
\text { vicinity of New- }\end{array}$ \\
\hline Pocatel lo & Bannock & $5 S-34 E-26 d a b / 1$ & 41 & 47 & 62 & 718 & $\begin{array}{l}\text { Domestic \& } \\
\text { irrigation }\end{array}$ & 42,565 & Private & $\begin{array}{l}\text { Several wells } \\
\text { allgned in a NE } \\
\text { directlon. }\end{array}$ \\
\hline Preston & Frank!lin & $15 S-39 E-17 b c d 1$ & 84 & 125 & $250 * *$ & 9,830 & Unused & $3,284^{-}$ & Private & $\begin{array}{l}\text { Geothermometers } \\
\text { difficult to in- } \\
\text { terpret. }\end{array}$ \\
\hline Rexburg & Madison & $5 N-40 E-36 d d b 1$ & 26 & - & - & - & Irrigation & 9,761 & Private & $\begin{array}{l}\text { No chemlcal anal- } \\
\text { yses avallable, } \\
\text { not field checked. }\end{array}$ \\
\hline $\begin{array}{l}\text { Soda } \\
\text { Springs }\end{array}$ & Caribou & $9 S-41 E-12$ addis & 28 & 30 & 54 & 3,207 & Tour Ism & 3,487 & clty & $\begin{array}{l}\text { Really a well } \\
\text { drilled near a }\end{array}$ \\
\hline victor & Teton & $3 N-45 E-7 a b b 1$ & 20 & - & - & - & Private & 254 & Private & $\begin{array}{l}\text { No chemical anal- } \\
\text { yses avail lable. }\end{array}$ \\
\hline Weston & Franklin & $16 \mathrm{~S}-3 \mathrm{BE}-24 \mathrm{acd} 1$ & 23 & $84^{\circ}$ & 92 & 566 & irrigation & 229 & Private & $\begin{array}{l}\text { Well } 3 \mathrm{~km} \text { SE of } \\
\text { Weston. }\end{array}$ \\
\hline
\end{tabular}

\footnotetext{
* See first footnote of Table 4.

* Maximum temperature is from Na-K-Ca chemical geothermometer, minimum temperature is from quartz chemical geothermometer.

***Maximum temperature is from quartz chemlcal geothermometer, minimum temperature is from the chalcedony chemical geothermometer. ****Maximum temperature is from Na-K-Ca chemlcal geothermometer, mlinimum temperature is from the chalcedony chemical geothermometer.
} 
It has become apparent that much of the thermal water discharged through wells and springs is probably of low temperature $\left(<100^{\circ} \mathrm{C}\right)$. Much of it discharges near small towns and cities throughout southern Idaho where it could reasonably be used for space heating. Figure 82 shows locations of towns and cities in Idaho within $5 \mathrm{~km}$ of a thermal water discharge. In these areas, and to some extent in favorable rural areas, the federal 1978 Energy Tax Act has provided significant incentives for private development. These cities and towns near thermal water discharges represent approximately 30 percent of Idaho's present population.

Prior to the development of any geothermal resource, the prospective developer/user should be sure there is a necessary amount of water appropriated and a drilling permit secured from the IDWR. The subsurface ownership should be checked for ownership of the mineral rights. If not, the developer/user will need to secure a geothermal lease from the appropriate party or agency.

As found in the statewide study done for this report, most of the thermal water is associated with known faults or linear features thought to represent some type of rock fracture. Even the three main thermal aquifers presently known to have thermal water are widespread--Bruneau-Grand View, Blue Gulch-Artesian City, and Nampa-Caldwell areas may ultimately be fed through deep-seated regional fractures. Recharge to the fracture controlled systems could be anywhere along their length and interbasin groundwater transfer may be associated with those that are regional in length. More and perhaps hotter water might be discovered by exploration along faults and fractures throughout the snake River plain region. (Drill holes would have to be targeted carefully to intersect the water bearing structure at predetermined depth. Detailed knowledge of the dip, strike, and throw of faults would be needed to site the drill holes.) Reflective seismic profiling and deep electrical resistivity methods appear to be the best methods of delineating fractures containing thermal water in much of the western Snake River Plain region. A systematic program for seismic and resistivity profiling should be initiated in the Western Snake River Plain region and in areas of heavy population density in eastern Idaho, such as pocatello, Twin Falls, and Idaho Falls, to map fracture patterns, provided geologic conditions are conducive to seismic techniques in these areas. 
FIGURE 82. Index map showing known geothermal resource areas (KGRAs) and federal and state leased lands in Idaho (current to October, 1978).

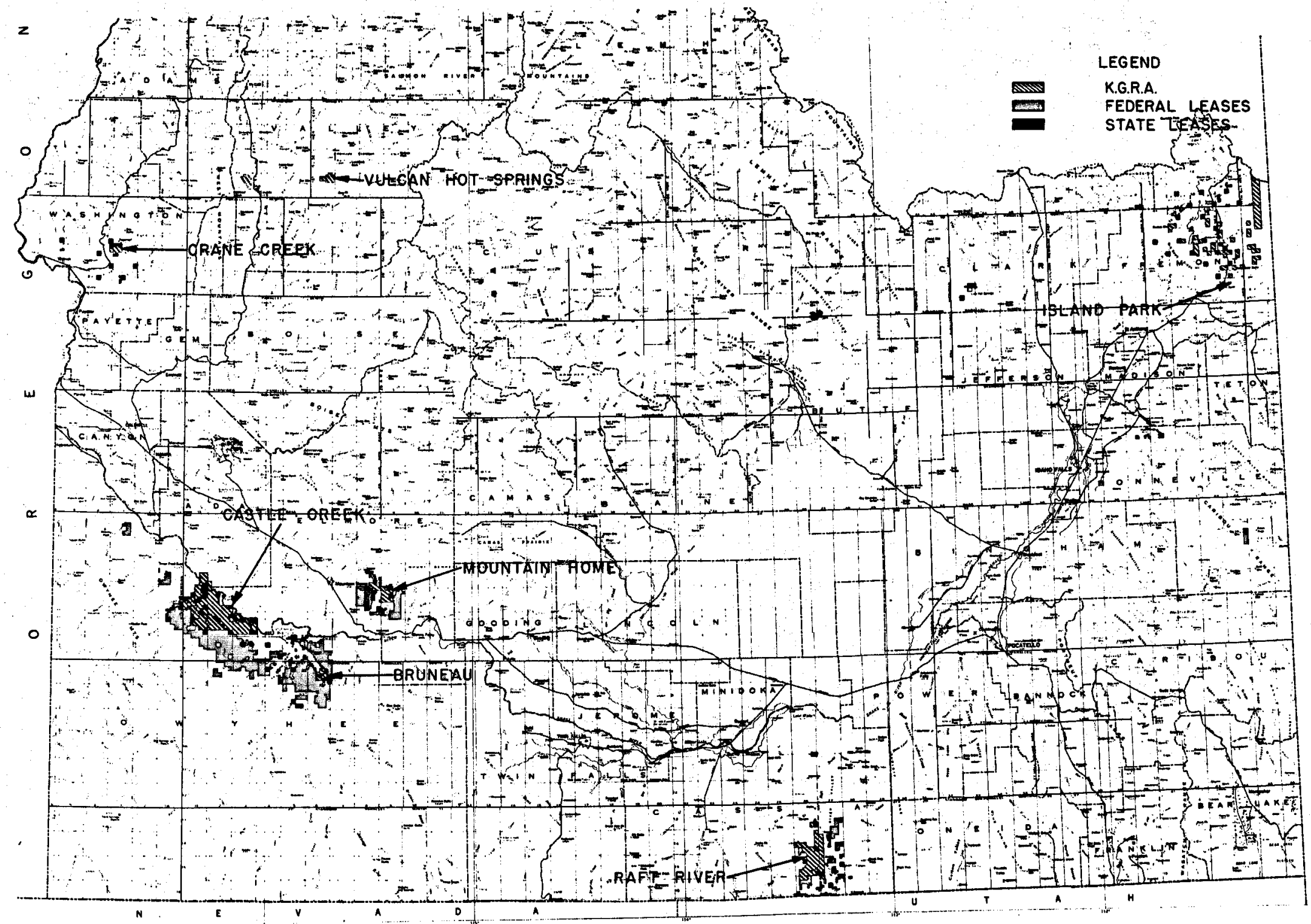


In the Western snake River Plain region, the faults and linear features associated with thermal water appear to be regional in character, some stretching the length and breadth of the plain. In the Western Snake River Plain, a systematic seismic reflection profiling program should be initiated to cover most of the plain proper where geologic conditions are favorable to seismic reflection techniques. This could be in the Nampa-Caldwell-Boise region and be extended into other areas later on. The seismic profiling could be followed by resistivity surveys of faulted and fractured areas discovered by the seismic profiling. This would provide information on deep water movement, recharge, and discharge areas. It would leave well-defined target areas for large-scale energy users to explore in greater depth.

The small towns and cities outside the Western snake River Plain could be assessed at relatively small cost as surveys could be concentrated in smaller areas.

The preceding three regional summaries give specific conclusions regarding towns that could receive the most significant and the greatest benefits from further study. 


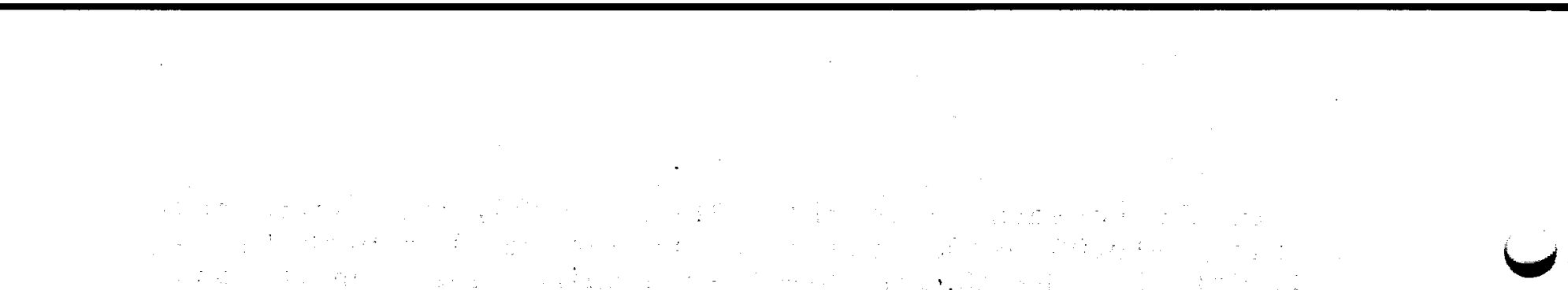


Ackerman, H.D., 1975, abs., Seismic refraction study in the Raft River geothermal area, Idaho: Soc. Explor. Geophys. Annual Int. Meeting, Abs. no. 45, p. 28.

- 1975, Velocity section in Raft River, Idaho, geothermal area from seismic refractions: U.s. Geol. Survey open file report no. 75-106.

Anderson, W.L. 1977, Intexpretation of electromagnetic soundings in the Raft River geothermal area, Idaho: U.S. Geol. Survey open file report no. 77-557.

Applegate, J.K. and Donaldson, P.R., 1975, abs., Passive and active selismic studies and the geologic structure of the Boise front, Idaho: Soc. Explor. Geophys. Annual Int. Meeting, abs, no. 45; p. 29.

- 1977, Characteristics of selected geothermal systems in Idaho, in The earth's crust, its nature and physical properties: Am. Geophys. Union, Geophysical monograph 20.

Applegate, J.K., Donaldson, P.R., Hinkley, D., and others, 1976, abs., Borehole geophysics evaluation of the Raft River geothermal reservoir, Idaho: Soc. Explor. Geophys., Annual Int. Meeting, abs. no. 45 , p. $94-95$.

Applegate, J.K., Donaldson, P.R. and Mink, L.L., 1976, abs., Geologic and seismic studies of the Boise front, Idaho, for geothermal resource evaluation: Am. Assoc. Petroleum Geologists Bull., v. 60, p. 1389.

Applegate, J.K., Donaldson, P.R., Mink, L.L., and others, 1977, An investigation of the geothermal potential of the Boise, Idaho area: U.S. Dept. of Energy, Open file report 1537 , Idaho Falls, Idaho.

Armstrong, F.C., 1953 Generalized composite stratigraphic section for the Soda springs quadrangle and adjacent areas in southeastern Idaho: in Intermountain Assoc. Petroleum Geologists 4th Ann. Field Conf., 1953: chart in pocket.

\footnotetext{
1969, Geologic map of the Soda springs quadrangle, southeastern Idaho: U.S. Geol. Survey Misc. Geol. Inv. Map 1-557, 2 sheets.

Armstrong, F.C. and Cressman, E.R., 1963, the Bannock thrust zone, southeastern Idaho: U.S. Geol. Survey Prof. Paper 374-J, 22 p.
} 
Armstrong, R.L., Leeman, W.P. and Malde, H.E., 1975, K-Ar dating, Quaternary and Neogene volcanic rocks of the Snake River Plain, Idaho: Amer. Jour. Sci., v. 275, p. 225-251.

Arnórsson, Stefán, 1970, Underground temperatures in hydrothermal areas in Iceland as deduced from the silica content of the thermal water: in Proceedings United Nations Symp. on the Development and Utilization of Geothermal Resources, Pisa, 1970, v. 2, Part 1, Geothermics, Spec. Issue 2, p. 537-541.

- 1975. Application of silica geothermometer in low temperature hydrothermal areas in Iceland: Amer. Jour. Sci., v. 275, no. 7, p. 763-784.

Austin, C.F. and Wheland, J.A., 1978, Geothermal potential at U.S. Air Force Bases: Geothermal Technology Div. Naval Weapons Center, China Lake, Ca. Civil and Environmental Engineering Development Div., Air Force Systems Command, Tyndall Air Force Base CEEDO-TR-78-47, 55 p.

Barnes, H.L., ed., 1967, Geochemistry of hydrothermal ore deposits: New York; Holt, Rinehart, and Winston, Inc., 670 p.

Bennett, E.H., 1976, Reconnaissance geology and geochemistry of the South Mountain-Juniper Mountain region, Owyhee County, Idaho: Idaho Bur. of Mines and Geology Pamph. no. 166, 110 p.

- 1977, Reconnaissance geology and geochemistry of the Blackbird Mountain-Panther Creek region, Lemhi County, Idaho: Idaho Bur. of Mines and Geology Pamph. no. 167,108 p.

Bishop, A.A., 1975, Use of geothermal water for agriculture: Aerojet Nuclear Corp., Idaho National Engineering Laboratory, U.S. Atomic Energy Commission, Idaho Operations Office, ANCR report 1221.

Bjorklund, L.J. and McGreevy, L.J., 1971, Groundwater resources of Cache Valley, Utah and Idaho: state of Utah, Dept. of Natural Resources, tech. pub. no. $36,72 \mathrm{p}$.

Bodnar, Theodore and Bush, Richard, 1978, Hot springs in the state of Idaho and associated deposits: ISU Geology Research Dept., open file report.

Bodvarsson, Gunnar, 1970, Evaluation of geothermal prospects and the objectives of geothermal exploration: Geoexploration, 8,7 .

Bond, J.G., 1963, Geology of the Clearwater embayment: Idaho Bur. of Mines and Geology Pamph. no. 128, 83 p.

- 1978, Geologic map of Idaho: Idaho Dept. of Lands, Bux. of Mines and Geology, 1 map.

Bonini, W.E., 1963, Gravity anomalies in Idaho: Idaho Bur. of Mines and Geology Pamph. no. 132, 10 p. 
Bonini, W.E. and Lavin, P.M., 1957, abs., Gravity anomalies in southern Idaho and southwestern Montana: Geol. Soc. America Bull., v. 68, p. 1702 .

Braile, L.W., Keller, G.R., Martin, W.R., et. al., 1977, abs., Crustal structure of the Columbia Plateau and Snake River Plain: Geol. Soc. America, abs. programs, vol. 9, no. 7, p. 908-909.

Bright, R.W., 1963, Plelstocene Lakes Thatcher and Bonneville, southeastern Idaho: Minnesota UnIv. (Minneapolis) Ph.D. thesis; available from University Microfilms, Inc, Ann Arbor, Mich.

Brook, C.A., Marinex, R.H., Mabey, D.R., and Swanson, J.S., 1979, Hydrothermal convection systems with reservoir temperature $\geq 90^{\circ} \mathrm{C}$, in Assessment of geothermal resources of the United states - 1978, L.J.B. Muffler, ed., U.S. Geol. Survey Circ. 790, 163 p.

Brott, C.A., Blackwell, D.D. ana Mitchell, J.C., 1975, abs., Heat flow studies of the Snake River Plain: Geol. Soc. America, abs. programs, v. 7, no. 5, p. 590-591.

- 1976, Geothermal Investigations in Idaho, Part 8, Heat flow studies of the Snake River Plain, Idaho: Idaho Dept. of Water Resources, Water Inf. Bull. no. 30,195 p.

, 1976, abs,, Heat flow study of Snake River Plain, Idaho: Amer. Assoc. Petroleum Geologists Bull., v. 60, p. 1392.

- 1978, Tectonic implications of the heat flow of the western Snake River Plain, Idaho: Geol. Soc. America Bull., v. 89 p. 16971701.

Burnhan, W.L., Harder, A.H. and Dion, N.P., 1969, Availability of groundwater for large-scale use in the Malad Valley-Bear River Basin areas of southeastern Idaho - an initial assessment: U.S. Geol. survey open file report, $40 \mathrm{p}$.

Castelin, P.M. and Chapman, Sherl, 1972, Water resources of the Big Wood River-Silver Creek area, Blalne County, Idaho: Idaho Dept. of Water Adm., Water Inf. Bull, no. 28.

Castelin, P.M. and Winner, J.E., 1976, Effects of urbanization on the watex resources of the Sun Valley-Ketchum area, Blaine County, Idaho: Idaho Dept, of Water Resources, Water Inf. Bull, no. 40.

Cater, F.W., Pinckney, D.M., Hamilton, W.B., Parker, R.L., Weldin, R.D., Close, T.J. and $\mathrm{Zilka,N.T.,} \mathrm{1973,} \mathrm{Mineral} \mathrm{resources} \mathrm{of} \mathrm{the} \mathrm{Idaho}$ Primitive Area and vicinity, Idaho: U.S. Geol. Survey Bull, 1304, $431 \mathrm{p}$.

Chappel, R.N., Griffith, J.L., Knowles, W.R, and Schulta, R.J., 1978, The multipurpose geothermal test and experimental activities at Raft 
River, Idaho: Geothermal Energy: A Novelty becomes a Resource, transactions v. 2, sec. 1, p. 83-87, Geothermal Resources Council Annu. Meeting, 25-27 July 1978.

Choate, Raoul, 1962, Geology and ore deposits of the stanley area: Idaho Bur. of Mines and Geology Pamph. no. 126, 122 p.

Cook, K.L., Halverson, M.O., Stepp, J.C. and Bery, J.W., Jr., 1964, Regional gravity survey of the northern Great Salt Lake Desert and adjacent areas in Utah, Nevada and Idaho: Geol. Soc. America Bull., v. 75, p. 715-740.

Coulter, H.W., 1956, Geology of the southeast portion of the Preston quadrangle, Idaho: Idaho Bur. of Mines and Geology Pamph. no. 107, $47 \mathrm{p}$.

Covington, H.R., Deep drilling data, Raft River geothermal area, Idaho (well no. 3, sidetract-C): U.S. Geol. Survey open file report no. 77-883.

- 1977, Deep drilling data, Raft River geothermal area, Idaho (well no. 1): U.S. Geol. Survey open file report No. 77-226.

, 1977, Deep drilling data, Raft River geothermal area, Idaho (well no. 2): U.S. Geol. Survey open file report no. 77-243.

- 1977, Deep drilling data, Raft River geothermal area, Idaho (well no. 3): U.S. Geol. Survey open file report no. 77-616.

- 1977, Deep drilling data, Raft River geothermal area, Idaho (well no. 4): U.S. Geol. Survey open file report no. 78-9l.

Cox, Allan, Dalrymple, G.B. and Doell, R.R., 1967, Reversals of the earth's magnetic field: Sci. American, v. 216, no. 2, p. 44-54.

Crosthwaite, E.G., 1957 (1958), Ground-water possibilities south of the Snake River between Twin Falls and Pocatello, Idaho: U.S. Geol. Survey Water-Supply Paper 1460 C, p. 99-145.

Crosthwaite, E.G., Mundorff, M.J. and Walker, D.H., 1970, Ground water aspects of the Lower Henry Fork region, eastern Idaho: U.S. Geol. Survey Water Supply Paper $1879 \mathrm{C}$.

Crosthwaite, E.G. and Scott, R.C., 1956, Ground-water in the North Side Pumping Division, Minidoka County, Idaho: U.S. Geol. Survey Circ. 371, $19 \mathrm{p}$.

Dart, R.H., Neill, D.T. and Whitbeck, J.F., 1975, Conceptual design and cost evaluation of organic rankine cycle electric generating plant powered by medium temperature geothermal water: Aerojet Nuclear Corp., Idaho Operations Office, ANCR report 1226. 
Davis, W.E., 1972, Mineral resources of the Salmon River breaks primitive area, Idaho, aeromagnetic survey: U.S. Geol. Survey Bull. 1353-C, p. $18-20$.

Day, N.F., 1974, Linears Map, Band 5, MSS-ERTS, Northern and Southern Idaho: Idaho Bur. of Mines and Geology open file map, 2 maps.

Diment, W.H., Urban, T.C., Sass, J.H., et al., 1975, Temperatures and heat contents based on conductive transport of heat, in Assessment of geothermal resources of the United States, 1975: U.S. Geol. Survey Cir. 726 .

Dion, N.P., 1969, Hydrologic reconnaissance of the Bear River Basin in southeastern Idaho: Idaho Dept. of water Resources, Water Inf. Bull. No. 13,66 p.

- 1974, An estimate of leakage from the Blackfoot Reservoir to Bear River Basin, southeastern Idaho: Idaho Dept. of Water Resources, Water Inf. Bull. No. 34, 24 p.

Doherty, D.M. and Nash, K.G., 1977, abs., Remote sensing identification of caldera related geologic features in the eastern Snake River Plain: Geol. Soc. America, abs. programs, v. 9, no. 6, p. 719-720.

Donaldson, P.R. and Applegate, J.K., 1975, abs., Evaluation of the geothermal potential of the Boise front, Idaho: Soc. Explor. Geophys. Annual Int. Meeting, abs., no. 45, p. 29.

, 1976, abs., Geoelectrical investigations of Boise, Idaho geothermal system: Amer. Assoc. Petroleum Geologists Bull., v. 60, p. 1397.

- 1979, Geophysical review of selected geothermal areas in southern Idaho: Geotechniques, Inc. open file report.

Donovan, L. E., 1975, Feasibiltty/conceptual design study for Boise geothermal space heating demonstration project distribution and disposal system: Aerojet Nuclear Corp., Idaho National Engineering Laboratory, U.S. Atomic Energy Commission, Idaho operations office, ANCR report 1258.

Donovan, L.E. and Richardson, A.S., 1975, Feasibility/conceptual design study for Boise geothermal space heating demonstration project building modifications: Aerojet Nuclear Corp., Idaho National Engineering Laboratory, U.s. Atomic Energy Commission, Idaho Operations Office, ANCR report 1246.

Eldridge, G. H., 1895, A geologic reconnatssance across Idaho: U.S. Geol. Survey Sixteenth Ann. report, pt. 2, 211-276.

Ellis, A. J., 1970, Quantitative interpretation of chemical characteristics of hydrothermal systems: in Proceedings United Nations Symp. 
on the Development and Utilization of Geothermal Resources, Pisa, 1970, v. 2, Part 1, Geothermics, Spec. Isssue 2, p. 516-528.

Fenneman, N.M., 1917, Physiographic division of the United States: Assoc. Am. Geographers Annals 6, p. 19-98.

- 1931, Physiography of Western United States: New York, McGraw-Hill Book Co., 534 p.

Forrester, J.D., 1956, Geology and mineral resources of the Salmon Quadrangle, Lemhi county, Idaho: Idaho Bur. of Mines and Geology Pamph. no. 106, 102 p.

Fournier, R.0., 1977. Chemical geothermometers and mixing models for geothermal systems: Geothermics, v. 5, no. 1-4, p. 41-50.

Fournier, R.O. and Potter, R.W., II, 1978, A magnesium correction for the Na-K-Ca chemical geothermometer: U.S. Geol. Survey open file report $78-986,24 \mathrm{p}$.

Fournier, R.O. and Rowe, J.J., 1966, Estimation of underground temperatures from the silica content of water from hot springs and wet steam wells: Am. Jour. Sci., v. 264, p. 685-695.

Fournier, R.O., and Truesdell A.H., 1970, Chemical indicators of subsurface temperature applied to hot waters of Yellowstone National Park, Wyo., U.S.A.: in Proceedings United Nations Symp. on the Development and Utilization of Geothermal Energy, Pisa, 1970, v. 2, Part 1, Geothermics, Spec. Issue 2; p. 529-535.

1973, An empirical Na-K-Ca geochemical thermometer for natural waters: Geochim, et. Cosmochim, Acta., v. 73, p. 1255-1275.

- 1974, Geochemical indicators of subsurface temperature, Part 2, Estimation of temperature and fracture of hot water mixed with cold: U.S. Geol. Survey Jour. of Research, v. 2, no. 3, p. 264-270.

Fournier, R.O., White, D.E. and Truesdell, A.H., 1974, Geochemical indicators of subsurface temperature, Part 1, Basic Assumptions: U.S. Geol. Survey Jour. of Research, v. 2, no. 3, p. 259-263.

Geothermal Task. Force, 1975, Idaho, Geothermal R\&D project report for period 1-1-75 to 3-31-75: Aerojet Nuclear Corp., Idaho National Engineering Laboratory, U.S. Atomic Energy Commission, Idaho Operations office, ANCR report 1222 .

1975, Geothermal R\&D project report for period 4-1-75 to 6-30-75: Aerojet Nuclear Corp., Idaho National Engineering Laboratory, U.S. Atomic Energy Commission, Idaho Operations office, ANCR report 1247. 
1975, Geothermal R\&D project report for period 7-1-75 to 9-30-75: Aerojet Nuclear Corp., Idaho National Engineering Laboratory, U.S. Atomic Energy Commission, Idaho Operations Office, ANCR report 1281.

$\therefore$ 1975, Geothermal R\&D project report for period 10-1-75 to 12-30-75: Aerojet Nuclear Corp., Idaho National Engineering Laboratory, U.S. Atomic Energy Comission, Idaho Operations Office, ANCR report 1283.

, 1976, Geothermal R\&D project report for period 1-1-76 to 3-31-76: Aerojet Nuclear Corp., Idaho National Engineering Laboratory, U.S. Atomic Energy Comission, Idaho Operations Office, ANCR report 1319.

- 1976, Geothermal R\&D project report for period 4-1-76 to 6-30-76: EG\&G Idaho, Inc., Idaho National Engineering Laboratory, Energy Research and Development Administration, Idaho Operations Office, TREE report 1008 .

Gerick, J.A. and Simmons, George, 1977, Idaho potential for industrial utilization of geothermal energy: M.S. thesis, University of Idaho, Chem. Eng. Dept., 169 p.

Gilbert, G.K., 1875, Lake Bonneville, in report upon the geographic and geologic exploration and survey west of the 100 th meridian: Washington U.S Gov't. Printing Office, v. 3.

1890. Lake Bonneville: U.S. Geol. Survey Mon. 1, 438 p.

Godwin, L.H., Haigler, L.B., Rioux, R.L., White, D.E., Muffler, L.J.P. Wayland, R.G., 1971, Classification of public lands valuable for geothermal resources: U.S. Geol. Survey Circ. 647,17 p.

Godwin, L.H. and Oberlindacher, Peter, 1967, Rev. July 1976, state of Idaho geothermal and classification map: Menlo Park, Calif., U.S. Geol. Survey Conserv. Div., Pacific Area.

Greenberg, S.A. and Price, E.W., 1957, The solubility of silica in solutions and electrolytes: Jour. Phys. Chem. 61, p. 1539-1541.

Grose, L.T., 1971, Geothermal energy: geology, exploration, and developments; Part 1: Colorado School Mines Research Inst. Min. Industries Bul1. v. 14, no. 6,14 p.

Hale, L.A., 1969, abs., Phosphate exploration using gamma-radiation logs, Dry Valley, Idaho: Mining Eng., v. 21, no. 8, p. 35 .

Hamilton, W.S., 1965, Geology and petrogenesis of the Island Park caldera of rhyolite and basalt eastern Idaho: U.S. Geol. Survey Prof. Paper $504 \mathrm{C}, \mathrm{p} . \mathrm{Cl}-\mathrm{C} 37$. 
1976, abs., Tectonic history of west-central Idaho: Geol. Soc. America, abs. programs, v. 8, no. 3, p. 378-379.

Hardy, C.T. and Williams, J.S., 1953, Geologic map of the northern Wasatch Mountains, Utah and Idaho: in Intermountain Assoc. Petroleum Geologists Guidebook 4th Ann. Field Conf., Geology of northern Utah and southeastern Idaho, 1953, pl. 1.

Harrison, J.E., Greggs, A.B. and Wells, J.D., 1974, Tectonic features of the Precambrian belt basin and their influence on post-belt structures: U.S. Geol. Survey Prof. Paper 866.

Haskett, G. R., 1976, Thermal springs and wells, lineaments and circular feature map for Idaho, U.S. Bur of Rec. map, open file.

Healy, J., 1970, Pre-investigation geological appraisal of geothermal fields: in Proceedings United Nations Symp. on the Development and Utilization of Geothermal Resources, Pisa, 1970, v. 2, Part 1, Geothermics, Spec. Issue 2, p. 571-577.

Hill, D.P., 1963, Gravity and crustal structure in the western Snake River Rlain, Idaho: Jour. Geophys. Research, v. 68 , no. 20, p. 5807-5819.

Hill, D.P., Baldwin, H.L. and Pakiser, L.C., 1961, Gravity, volcanism and deformation in the Snake River Plain, Idaho: U.S. Geol. Survey Prof. Paper 424-B, p, 248-250.

Hill, D.P. and Pakiser, L.C., 1967, Seismic-refraction study of crustal structure between the Nevada test site and Boise, Idaho: Geol. Soc. America Bull., v. 78, p. 685-704.

Holland, H.D., 1965, Some application of thermochemical data to problems of ore deposits, II. Mineral assemblages and the composition of oreforming fluids: Econ. Geology v. 60 , no. 6 , p. 1101-1165.

' 1967, Gangue minerals in hydrothermal deposits: in Geochemistry of Hydrothermal Ore Deposits, H.L. Barnes, ed., Holt, Rinehart, and winston, Inc.

Hollenbaugh, K.M. and Nichols, C.R., 1975, Geological aspects of the national potential for non-electrical utilization of geothermal resources: Aerojet Nuclear Corp., Idaho National Engineering Laboratory, U.S. Atomic Energy Commission, Idaho Operations Office, ANCR report 1213.

Hoover, D.B. and Long, C.L., 1975, Audio-magnetotelluric methods in reconnaissance geothermal explorations: Proceedings, 2nd United Nations Symp. on the Development and Use of Geothermal Resources, San Francisco, v. 2, p. 1059-1064. 
Hoovex, D.B. and Tippens, C.L., 1975, Geothexmal Investigations in Idaho, Part 2, A reconnaissance audio-magnetotelluric survey: Idaho Dept. of Water Resources, Water Inf. Bull. no. 30 , p. 53-79.

Hoover, D.B., Brougham, G.W. and Clark, J.C., 1976, Station and traverse location map, audio-magnetotelluric data $\log$ and telluric profiles for Crane Creek known geothermal resource area, Idaho: U.S. Geol. Survey open file report no. 76-409.

Hubbard, C.R., 1956, Geology and minexal resources of Nez Perce County, Idaho: Bur, of Mines and Geology, County report no. 1, 17 p.

Huttrer, G. W. and Tamm, A.H., 1977, abs., Geothermal potential of three areas in southeastern Idaho and western Wyoming: Am. Assoc. Petroleum Geologists Bull., v. 61, p. 798.

Hyde, Jay and Whelan, J.A., 1978, Field report, geothermal potential of the Mountain Home Air Force Base and Sailor Creek Air Force Range, Idaho. Appendix B, Item 8 to Air Force report CEEDO 78-47, Geothermal potential at U.S. Air Force Bases, 55 p.

Jackson, D.B., 1974, Report on direct current soundings over a geothermal prospect in the Bruneau-Grandview area, Idaho: U.S. Geol. Survey open file report no. $74-240$.

Jobin, D.A. and Schroeder, M.L., 1964. Geology of the Conant Valley quadrangle, Bonneville County, Idaho:; U.S. Geol. Survey Mineral Inv. Field Studies Map MF-277, 1 sheet.

Karlo, J.F. and Koswor, P.R., 1975, abs., Thermal overprint as a possible effect on the gravity relations of the eastern Snake River Plain, Idaho: Geol. Soc. America, abs, programs, ve 7, no, 5, p. 615-616.

Kellex, A.S., 1963, Structure and stratigraphy behind the Bannock thrust in parts of the Preston and Montpelier quadrangles, Idaho: Unpublished Columbia Univ.,. Ph.D. dissertation, 204 p.

Keller, J.G., Miller, L.G., Miners, G.L. and Richardson, A.S., 1975, Geothermal space heating of a geothermal drilling rig: Aerojet Nuclear Corp., Idaho National Engineering Laboratory, U.S. Atomic Energy Commission Idaho Operations office, ANCR report 1241.

Kettenacker, W.C., 1977, Two dimensional simulation of the Raft River geothermal reservoir and wells: EG\&G Idaho, Inc., Idaho National Engineering Laboratory, Enexgy Research and Development Administration, Idaho Operations Office, TREE report 1085.

Kharaka, Y.K. and Barns, Ivan, 1973, SOLMNEQ: Solution-mineral equilibrium computations: National Tech. Inf. Service pub. PB-215 899.82 p. 
Khattab, M.M.M., 1969, abs., Gravity and magnetic surveys of the Grouse Creek Mountains and the Raft River Mountains area and vicinity, Utah and Idaho: Diss. abs. v. 29, no. 12, part 1, p. 4720 B.

Killsgaard, T.H., Freeman, V.I. and Coffman, J.S., 1970, Mineral resources of the Sawtooth primitive area, Idaho: U.S. Geol. Survey Bull. 1319-D.

King, Clarence, 1878, Systematic geology: U.S. Geol. Explor. 40th Parallel, v. 1, p. 127-227.

Kirkham, V.R.D., 1924, Geology and oil possibilities of Bingham, Bonneville, and Caribou Counties, Idaho: Idaho Bur. of Mines and Geology Bull. 8, 108 p.

Kummell, Bernhard, 1954, Triassic stratigraphy of southeastern Idaho and adjacent areas: U.S. Geol. Survey Prof. Paper 254-H, p. 165-194.

Kunze, J.F., 1974, Program plan for FY 1974: Aerojet Nuclear Corp., National Reactor Testing Station, U.S. Atomic Energy Commission, Idaho Operations Office, ANCR report 1139.

- 1975, Idaho geothermal R\&D project report for period 1-1-75 to 3-31-75: Idaho National Engineering Laboratory, ANCR report 1222 , p. 17 .

Kunze, J.F. and Miller, I.G., 1974, Idaho geothermal R\&D project report for period 12-16-73 to 3-15-74: Aerojet Nuclear Corp., National Reactor Testing Station, U.S. Atomic Energy Comission, Idaho Operations office, ANCR report 1155.

1 1974, Idaho geothermal R\&D project report for period 7-16-74 to 9-30-74: Aerojet Nuclear Corp., Idaho National Engineering Laboratory, U.S. Atomic Energy Commission, Idaho Operations Office, ANCR report 1190.

12-31'1974, Geothermal R\&D project report for period 10-1-74 to Laboratory, U.S Jet Nuclear Corp.' Idaho National Engineering ANCR report 1208.

- 1974, Idaho geothermal R\&D project report for 3-16-74 to 7-15-74: Aerojet Nuclear Corp., National Reactor Testing Station, U.S. Atomic Energy Commission, Idaho Operations Office, ANCR report 1175.

Kunze, J.F., Miller, L.G. and Whitbeck, J.F., 1975, Moderate temperature utilization project in the Raft River Valley. Proceedings 2nd United Nations Symp. on the Development and Use of Geothermal Resources, San Francisco, v. 3, p. 1241-1245.

Kunze, J.F. and Richardson, A.S., 1975, National program definition study for the non-electrical utilization of geothermal energy: 
Aerojet Nuclear Corp., Idaho National Engineering Laboratory, U.S. Atomic Energy Commission, Idaho Operations office, ANCR report 1214.

Kunze, J.F., Richardson, A.S., Nichols, C.R. and Mink, L. L., 1975, Geothermal space heating project involving state owned buildings in Boise, Idaho: Aerojet Nuclear Corp., Idaho National Engineering Laboratory, 0.S. Atomic Energy Commission, Idaho Operations office, ANCR report 1211.

Kunze, J.F., Richardson, A.S., Hollenbaugh, K.M., Nichols, C.R. and Mink, L.L., 1975, Non-electric utilization project, Boise, Idaho: Proceedings 2nd United Nations Symp. on the Development and Use of Geothermal Resources, San Francisco, v. 3, p. 2141-2145.

Kunze, J.F., Miller, L.G., Neill, D.T. and Nichols, C. R., 1974, Proposal for a demonstration geothermal power plant in the Raft River Valley: Aerojet Nuclear Corp., National Reactor Testing Station, U.S. Atomic Energy Conmisston, Idaho Operations Office, ANCR report 1138.

Kunze, J.F. and Whitbeck, J.F., 1976, A plan for developing moderate temperature low salinity geothermal resources: Aerojet Nuclear Corp., Idaho National Engineering Laboratory, U.S. Atomic Energy Commission, Idaho Operations office, ANCR report 1318.

La Fehr, T.R., 1963, abs., Gravity and crustal structure in eastern Snake River Plain, Idaho: Am. Assoc. Petroleum Geologists Bull., v. 47. p. 1772 .

La Fehr, T.R. and Pakiser, L.C., 1962, Gravity, volcanism and crustal deformation in the eastern Snake River Plain, Idaho: U.S. Geol. Survey Prof. Paper 450D, p. 76-78.

Lindal, Baldur, 1973, Industrial and other applications of geothermal energy: - in Earth Sciences 12, Geothermal Energy, A Review of Research and Development, The Unesco Press, H.C. Armstead, ed., P. 135-147.

Lindgren, Waldemar, 1900, The gold and silver veins of silver city, Delamar, and other mining districts in Idaho: U.S. Geol. Survey Twentieth Ann. report p. 3, p. 65-256.

Livingston, D.C. and Laney, F.G., 1920, The copper deposits of the Seven Devils and adjacent districts including Heath, Hornet Creek, Hoodoo, and Deer Creek: Idaho Bur, of Mines and Geology Pamph. no. $1,105 \mathrm{p}$.

Long, C.L., O'Donnell, J.E. and Smith, B.D., 1975, abs., Geophysical studies in the Island Park caldera, Idaho: Geol. Soc. America, abs. programs, v. 7, no. 5, p. 623.

Iong, C.L., et, al., 1976, AMT station location map, Island Park KGRA, Idaho: U.S. Geol. Survey open file report no. 76-700-E. 
Mabey, D.R., 1966, Relation between Bouguer gravity anamalies and regional topography in Nevada and the eastern Snake River Plain, Idaho: U.S. Geol. Survey Prof. Paper 550-B, p. 105-110.

- 1971, Geophysical data relating to a possible Pleistocene overflow of Lake Bonneville at Gem Valley, southeastern Idaho: U.S. Geol. Survey Prof. Paper 750-B, p. 122-127.

' 1974, abs., Regional gravity and magnetic anomalies in southeastern Idaho and western Wyoming: Geol. Soc. Am. Spec. Paper 76, p. 212 .

- 1976, Interpretation of a gravity profile across the western Snake River Plain, Idaho: Geology, v. 4, no. 1, p. 53-55.

, 1978, Gravity and aeromagnetic anomalies in the Rexburg area of eastern Idaho: U.S. Geol. Survey open file report no. 78-382.

Mabey, D.R., Ackerman, H., Zohdy, A.A.R., and others, 1975, abs., Geophysical studies of a geothermal area in the southern Raft River Valley, Idaho: Geol. Soc. America, abs. programs, v. 7, no. 5, p. 624 .

Mabey, D.R. and Armstrong, F.C., 1962, Gravity and magnetic anomalies in Gem Valley, Caribou County, Idaho: U.S. Geol. Survey Prof. Paper 450-D, p. 73-75.

Mabey, D.R., Peterson, D.L. and Wilson, C.W., 1973, abs., Regional gravity and aeromagnetic studies in southern Idaho: Geol. Soc. America, abs., v. 5, no. 6, p. 494 .

- 1974, Preliminary gravity map of southern Idaho: U.S. Geol. Survey open file report no. 74-78, 1 map, scale $1: 250,000$.

, 1975, abs., Regional gravity and magnetic studies of the Snake River Plain: Geol. Soc. America, abs, programs, v. 7, no 5 , p. 624-625.

Mabey, D.R. and oriel, S.S., 1970, Gravity and magnetic anomalies in the Soda Springs region, southeastern Idaho: U.S. Geol. Survey Prof. Paper 646-E.

Mabey, D.R., Hoover, D.B., O'Donnell, J.E., and Wilson, C.W., 1978, Reconnaissance geophysical studies of the geothermal system in southern Raft River Valley, Idaho, Geophysics, v. 43, no. 7, p. 1470-1484.

Madsen, W.W. and Ingvarsson, I.J., 1975, Analysis of the binary cycle for geothermal power generation: Aerojet Nuclear Corp., Idaho National Engineering Laboratory, U.S. Atomic Energy Commission, Idaho Operations office, ANCR report 1245. 
Mahon, W.A.J., 1970, Chemistry in the exploration and exploitation of hydrothermal systems: in Proceedings United Nations Symp. on the Development and Utilization of Geothermal Resources, Pisa, 1970, v. 2, Part 2, Geothermics, Spec. Issue 2, p. 1310-1322.

Malde, H.E., 1959, Fault zone along northern boundary of western Snake River Plain, Idaho: Science, v. 130, no. 3370, p. 272.

Malde, H.E., 1965, Snake River Plain: in the Quaternary of the United States: Princeton, N.M., Princeton Univ. Press, p. 255-263, illus., tables, geol. map.

Malde, H.E., Powers, H.A. and Marshall, C.H., 1963, Reconnàissance geologic map of west-central Snake River Plain, Idaho: U.S. Geol. Survey, Misc. Geol. Inv. Map 1-373.

Maley, S.T., 1973, Handbook of mineral law (1977): Idaho Dept. of Lands Adm. \& Div, of Earth Resources, MMRC Publication, Boise, Idaho, $293 \mathrm{p}$.

Mansfleld, G. R., 1927, Geography, geology and mineral resources of part of southeastern Idaho: U.S. Geol. Survey Prof. Paper 152, 453 p.

McGreevY, L.L. and Bjorklund, L.J., 1970, Selected hydrologic data, Cache Valley, Utah and Idaho: U.S. Geol. Survey open file release (duplicated as Utah Basic-Data Release 21), 51 p.

Malain, David, 1978, Lava Hot Springs, Idaho: Geo-heat utilization center Bull. v. 14, no. 1, p. 3 .

Meinzer, O.E., 1924, Origin of the thermal springs of Nevada, Utah, and southern Idaho: Jour. Geology v. 32, no. 4, p. 295-303.

Meuschke, J.L. and Long, C.L., 1965, Aeromagnetic map of part of the Lanes Creek quadrangle, Caribou County, Idaho: U.S. Geol. Survey Geophys. Inv. Map GP-490, 1:62,500.

Millex, R.L., 1976, Corrosion Engineering in the utilization of the Raft River geothermal resource: Aerojet Nuclear Corp., Idaho National Engineering Laboratory, U.S. Atomic Energy Commission, Idaho Operations Office, ANCR report 1342 .

Mink, L.L. and Graham, D.L., 1977, Geothermal potential of the west Boise area: EG\&G Idaho, Inc., Idaho National Engineering Laboratory, Dept. of Energy, Idaho Operations Office, TREE report $1162,34 \mathrm{p}$.

Mitchell, C.M., Knowles, F.F. and Petrafeso, F.A., 1965, Aeromagnetic map of the Pocatello-soda Springs area, Bannock and Caribou Counties, Idaho: U.S. Geol. Survey Geophys. Inv. Map GP-521.

Mitchell, J.C., 1976a, Geothermal Investigations in Idaho, Part 5, Geochemistry and geologic setting of the thermal waters of the 
Northern Cache Valley area, Frankl in County, Idaho: Idaho Dept. of Water Resources, Water Inf. Bull. no. 30,47 p.

- 1976b, Geothermal Investigations in Idaho, Part 6, Geochemistry and geologic setting of the thermal and mineral waters of the Blackfoot Reservoir area, Caribou County, Idaho: Idaho Dept. of Water Resources, Water Inf. Bull. no. 30,47 p.

- 1976c, Geothermal Investigations in Idaho, Part 7, Geochemistry and geologic setting of the thermal waters of the Camas Prairie area, Blaine and Camas Counties, Idaho: Dept. of Water Resources, Water Inf. Bull. no. 30,44 p.

- 1978, Idaho Dept. of Water Resources unpublished data.

Mundorff, M.J., 1967, Ground-water in the vicinity of American Falls Reservoir, Idaho: Prepared in cooperation with the U.S. Bureau of Reclamation, Geol. Survey Water-Supply Paper 1846.

Nace, R.L., et. al., 1961, Water resources of the Raft River Basin, Idaho-Utah: U.S. Geol. Survey Water-Supply Paper 1582, 138 p.

Newcomb, R.C., 1970, Tectonic structure of the main part of the basalt of the Columbia River Group, Washington, Oregon and Idaho: U.S. Geol. Survey Misc. Inv. Map 1-587, 1 sheet.

Newton, N.C. and Corcoran, R.E., 1963, Petroleum geology of the western Snake River Basin, Oregon-Idaho: Oil and Gas Investigations no. 1, Oregon Dept. of Geology and Min. Industries, $67 \mathrm{p}$.

Nichols, C.R., Brockway, C.E. and Warnick, C.C., 1972, Geothermal watex and power resource exploration and development for Idaho: Water Resource Research Inst. Tech. Completion Prep. Project NSF-Geothermal 47-517, $48 \mathrm{p}$.

Norvitch, R.F. and Larson, A.L., 1970, A reconnaissance of water resources in the Portneuf River Basin, Idaho: Idaho Dept. of Reclamation, Water Inf. Bull. no. 16,58 p.

Oriel, S.S. and Platt, L.B., 1968, Reconnaissance geologic map of the Preston quadrangle, southeastern Idaho: U.S. Geol. Survey open file map, 2 sheets.

Pakiser, I. C., 1960, abs., Gravity in volcanic areas, California and Idaho: Joux. Geophys. Research v. 65, no. 8, p. 2515.

Pakiser, L.C. and Baldwin, H.L., 1961, Gravity, volcanism and crustal deformation in and near Yellowstone National Park: U.S. Geol. Survey Prof. Paper 424-B, p. 246-248.

Pakiser, L.C. and Hill, D.P., 1963, Crustal structure in Nevada and southern Idaho from nuclear explosions: Jour. Geophys. Research, v. 68 , no. 20 , p. 5757-5766. 
Pennington, W.D., Smith, R.B. and Trimble, H.B., 1974, A microearthquake survey of parts of the Snake River Plain and Central Idaho: Seismological Soc. Amer. Bull, v. 64, p. 307-312.

Peterson, D.L., 1974, Bouguer gravity map of part of the northern Lake Bonneville Basin, Utah and Idaho: U.S. Geol. Survey, Misc. Field Study Map, no. MF-627, gravity survey map $1: 250,000$.

1977. Principal facts for a gravity survey of Battle Creek-Squaw Creek Hot Springs and vicinity, northern Cache Valley, Idaho: U.S. Geol. Survey open file report no. 77-670.

Peterson, D.L. and Oriel, S.S., 1970, Gravity anomalles in Cache Valley, Cache and Box Elder Counties, Utah, and Bannock and Franklin Counties, Idaho: U.S. Geol. Survey Prof. Paper 700-C, pp. Cll4-C118.

Peterson, D.L. and Witkind, I.J., 1975, Preliminary results of a gravity survey of the Henry's Lake quadrangle, Idaho and Montana: Jour. Research, U.S. Geol. Survey, v. 3, no. 3, p. 223-228.

Piper, A.M., 1923, Geology and water resources of the Goose Creek Basin, Cassia County, Idaho: Idaho Bur. of Mines and Geology Bull. no. 6,48 p.

- 1925, Ground Water for irrigation on Camas Prairie, Camas and Elmore Counties, Idaho: Idaho Bur.: of Mines and Geology Pamph. no. $15,46 \mathrm{p}$.

Presser, T.S. and Barnes, Ivan, 1974, Special techniques for determining chemical properties of geothermal water: U.S. Geol. Survey Water Resource Investigations 22-74, 11 p.

Prostka, H.J. and Embree, G.F., 1978, Geology and geothermal potential of the Rexburg area, southeastern Idaho, U.S. Geol. Survey open file report no. 78-1009.

Prostka, H.J., Hackman R.J., 1974, Preliminary geologic map of the northwest $1 / 4$, Driggs 1 and $2^{\circ}$ quadrangle, southeastern Idaho: U.S. Geol. Survey open file geologic map 74-105.

Prostka, H.J. and Oriel, S.S., 1975, abs., Genetic models for Snake River Plain, Idaho: Geol. Soc. America, abs, programs, v. 7, no. 7, p. 1236 .

Ralston, D.R. and Chapman, S.L., 1968, Ground-water resources of the Mountain Home area, Elmore County, Idaho: Idaho Dept. of Reclamation, Water Inf. Bull. no, $4,63 \mathrm{p}$.

Rambo, W.L. and Blank, H.R., Jr., 1969, abs., Gravity survey of the Island Park caldera and vicinity, eastern Idaho: Geol. Soc. America Spec. Paper 121, p. 625. 
Renner, J.L., White, D.E. and Williams, D.I., 1975, Hydrothermal convection systems: in Assessment of Geothermal Resources of the United States - 1975, U.S. Geol. Survey Circ. 726, D.E. White and D.L. Williams, ed., 155 p.

Richards, R.W., 1911, Notes on lead and copper deposits in the Bear River Range, Idaho and Utah: U.S. Geol. Survey Bull, no. 470, p. 117-187.

Richards, R.W. and Mansfield, C.R., 1912, The Bannock overthrust, a major fault in southeastern Idaho and northeastern Utah: Jour. Geology, v. 20, p. 681-701.

Rightmire, C.T., Young, H.W. and Whitehead, R.L., 1976, Geothermal Investigations in Idaho, Part 4, Isotopic and geochemical analysis of water from the Bruneau-Grand View and Weiser areas, southwest Idaho: Idaho Dept. of Water Resources, Water Inf. Bull. no. 30, 28 p.

Roberts, P,A., 1975, Fish culture utilization of geothermal energy: Aerojet Nuclear Corp., Idaho National Engineering Laboratory, U.S. Atomic Energy Commission, Idaho Operations, ANCR report 1220.

Ross, S.H., 1971, Geothermal potential of Idaho: Idaho Bur. of Mines and Geology Pamph. no. 150, 72 p.., also in Proceedings, United Nations Symp. on the Development and Utilization of Geothermal Resources, Pisa, v. 2, Part 2, Geothermic Spec. Issue 2, p. 975-1008.

Rassell, I.C., 1902, Geology and water resources of the Snake River Plain of Idaho: U.S. Geol. Survey Bull. no. 199, p. 192.

Sacarto, D.M., 1976, State policies for geothermal development: National Conference of State Legislatures, Denver, Renewable Energy Resources Project, Patrick Binns, Dir., 94 p.

Savage, C.N., 1958, Geology and mineral resources of Ada and Canyon Counties: Idaho Bur. of Mines and Geology, County report 3, 94 p.

- 1962, Geomagnetics and geologic intexpretation of a map of Eastern Bonner County: Idaho Bur. of Mines and Geol. Info. Circ. no. $15,16 \cdot \mathrm{p}$.

Sbar, M.L., Barazangi, Muawia, Dorman, James, Christopher, H.S. and Smith, R.B., 1972, Tectonics of the Intermountain Seismic Belt, Western United states Micro-earthquake seismicity and composite fault plane solution: Geol. Soc. American Bull. v. 83, no. 1 .

Schmidt, D.I. and Makin, J.H., 1962, Quaternary geology of the Bellevue area in Blaine and Camas Counties, Idaho: U.S. Geol. Survey open file report no. 625 . 
Schmitt, R.C. and Spencer, S.G., 1977, Beneficial uses of geothermal energy, description and preliminary results for phase $I$ of the Raft River irrigation experiment, TREE report 1048 .

Shaffer, C.J., 1975, Geothermal steam plant modeling and power tradeoff studies: Aerojet Nuclear Corp., Idaho National Engineering Laboratory, U.S. Atomic Energy Commission, Idaho Operations Office, ANCR report 1295.

Siever, Raymond, 1962 , Silica solubility, $0-200^{\circ} \mathrm{C}$ and diagenesis of siliceous sediments: Jour. Geol. v. 70, p. 127-150.

Smith, C.L., 1966, Geology of the eastern Mount Bennett Hills, Camas, Gooding and Lincoln Counties, Idaho: Ph.D. dissertation, Univ. of Idaho, Moscow, 129 p.

Smith, R.B. and Sbar, M.L., 1974, Contemporary tectonics and seismicity of the Western United States: Geol. Soc. America Bull,, v. 85, p. 1205-1218.

Smith, R.O., 1959, Ground water resources of the middle Big wood River-Silver Creek area, Blaine County, Idaho: U.S. Geol. Survey Water-Supply Paper 1478, 64 p.

Spencer, S.G., 1975, Environmental Report - Deep geothermal test wells in the Raft River Valley: Aerojet Nuclear Corp., Idaho National Engineering Laboratory, U.S. Atomic Energy Commission, Idaho Operations Office, ANCR report 1204.

Staley, W.W. and Prater, I.S., 1945, Sulphux in Idaho: Idaho Bur. of Mines and Geology, Min. Resources report no. 2, 7 p.

Stanley, W.D., 1972, Geophysical study of unconsolidated sediments and basin structure in Cache Valley, Utah and Idaho: Geol. Soc. America Bull, v. 83 , no. 6 , p. $1817-1830$.

Stearns, H.T. and Bryan, L.L., 1925, Preliminary report on the geology and water resources of the Mud Lake Basin, Idaho: U.S. Geol. Survey Water-Supply Paper 560-D, 134 p.

Stearns, H.T., Crandall, Lynn and Steward, W.G., 1936, Records of wells on the Snake River Plain, southwestern Idaho: Water Supply Paper 775, 139 p.

-1938, Geology and ground-water resources of the Snake River Plain in southeastern Idaho: U.S. Geol. Survey water Supply Paper 774,268 p.

Stearns, N.D., Stearns, H.T. and Waring G.A., 1937, Thermal springs in the United States: U.S. Geol. Survey Water-Supply Paper 679-B, p. 59-206. 
Stephenson, G.R. and Zugel, J.F., 1967, Seismic refraction studies in watershed hydrology: Proceedings of the Fifth Annual Engineering Geology and Soils Engineering Symp., Idaho Dept. of Highways.

Stoker, R.C., 1975, Drilling plan Boise slim (2-3/8 in. diameter) holes demonstration space heating project 1975: Aerojet Nuclear Corp., Idaho National Engineering Laboratory, U.S. Atomic Energy Commission, Idaho Operations Office, ANCR report 1261.

Stoker, R.C., 1977, unpublished data, EG\&G Idaho, Inc., Idaho Falls.

Stott, L.R., 1974, A gravity survey of a late Cenozoic graben in the Wyoming-Idaho thrust belt: Masters thesis, Univ. of Michigan.

Swanberg, C.A., 1972, Vertical distribution of heat generation in the Idaho batholith: Jour. Geophys. Res., v. 77, p. 2508-2513.

Swanson, J.R., 1977, Data file geotherm: U.S. Geol. Survey open file data, Menlo Park, CA.

Swink, D.G. and Schultz, R.J., 1975, Conceptual study for utilization of an intermediate temperature geothermal resource: Aerojet Nuclear Corp., Idaho National Engineering Laboratory, v.s. Atomic Energy Commission, Idaho Operations Office, ANCR report 1260.

Torgerson, L.D. and Richardson, A.S., 1975, Feasibility review for geothermal conversion of existing $H \& V$ systems on the Boise geothermal space heating project: Aerojet Nuclear Corp., Idaho National Engineering Laboratory, U.s. Atomic Energy Commission, Idaho Operations Office, ANCR report 1256.

Trimble, D.E., 1976, Geology of the Michaud and Pocatello quadrangles, Bannock and Power Counties, Idaho: U.S. Geol. Survey Bull. 1400, p. 88 .

Trimble, D.E. and Carr, W.J., 1961, Late Quaternary history of the Snake River in the American Falls region, Idaho: Geol. Soc. America Bull, v. 72, no. p. 1739-1748.

Truesdell, A.H. and Jones, B.F., 1974, WATEQ, a computer program for calculating chemical equilibia of natural waters: Jour. Research, U.S. Geol. Survey, v. 2, no. 2, March-April, 1974, p. 233-248.

Tschanz, Charles, et. al., 1974, Mineral resources of the eastern part of the Sawtooth National Recreation Area, Custer and Blaine Counties, Idaho: U.S. Geol. Survey open file report.

Umpleby, J.B., 1915, Ore deposits in the Sawtooth quadrangle, Blaine and Custer Counties, Idaho: in Contribution to Economic Geology: U.S. Geol. Survey Bull. 580, p. 221-249.

Umpleby, J.B., Westgate, L.G. and Ross, C.P., 1930, Geology and ore deposits of the Wood River region, Idaho: U.S. Geol. Survey Bull. 814 . 
Urbin, T.C. and Diment, W.H., 1975, abs., Heat flow on the south flank of the Snake River rift: Geol. Soc. America, abs. programs, v. 7, no. 5, p. 648 .

U.S. Geological Survey, 1971, Aeromagnetic map of southwestern Idaho, scale 1,500,000: U.S. Geol. Survey open file report.

Vincent, K.R. and Applegate, J.K., 1978, A preliminary evaluation of the seismicity of southwestern Idaho and eastern oregon: Implications for geologic engineering studies: Idaho Trans. Dept., Div. of Highways, Proc, Sixteenth Annual Eng, Geol, and Soils Eng. Symp.

Walker, E.H., Dutcher, L.C., Decker S.O. and Dyer, K.L., 1979, The Raft River Basin, Idaho, Utah, As of 1966: A re-appraisal of the water resources and effects of ground-water development: U.S. Geol. Survey open file report, $116 \mathrm{p}$.

Wallace, R.W., 1972, A finite-element planer flow model of Camas Prąirie, Idaho: Univ. of Idaho Ph.D. dissertation.

Walton, W.C.. 1962, Ground-water resources of Camas Prairie, Camas and Elmore Counties, Idaho: U.S. Geol. Survey Water-Supply Paper 1609, $57 \mathrm{p}$.

Waring, G.H. (revised by R.R. Blankenship and Ray Bentall), 1965, Thermal springs of the United States and other countries of the world a sumary: U.S. Geol. Survey Prof. Paper 492, 383 p.

Warner, M.M., 1972, Geothermal resources of Idaho: in Geothermal Overviews of the Western United States, Geothermal Resources Council Special report no. 1, p. 92-98.

- 1975, special aspects of Cenozoic history of southern Idaho and their geothermal implications: in Proceedings 13th Annu. Eng. Geol. and Soils Eng. Symp. p. 247-270.

- 1975, abs., Special aspects of Cenozoic history of southern Idaho and their geothermal implications: Geol. Soc. America, abs. programs, v. 7, no. 5, p. 649-650.

Watson, K., 1975, abs., Reconnaissance geothermal exploxations at Raft River, Idaho, from thermal infrared scanning: Soc. Explor. Geophys., Annu. Int. Meeting, abs. no. 45, p. 66-67.

Wells, M.W., 1971, Heat from the earth's surface: Early development of western geothermal resources: Jour. of the West, v. 10, p. 53-71.

Whitbeck, J.R., 1974, Design concepts for flash steam systems for use with medium temperature geothermal water: Aerojet Nuclear Corp.. National Engineering Laboratory, U.S. Atomic Energy Commission, Idaho Operations office, ANCR report 1210.

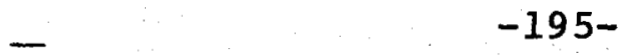


- 1975, Review and tentative selection of a working fluid use with a medium temperature $\left(300^{\circ} \mathrm{F}\right)$ geothermal resource: Aerojet Nuclear Corp., Idaho National Engineering Laboratory, U.S. Atomic Energy Commission, Idaho Operations office, ANCR report 1224 .

White, D.E., 1970, Geochemistry applied to the discovery, evaluation, and exploitation of geothermal energy resources, in Proceedings United Nations Symp. on the Development and Utilization of Geothermal Energy, Pisa, v. 1, Part 2, Geothermics, Spec. Issue 2, p. 5880 .

White, D.E., Muffler, L.J.P. and Truesdell, A.H., 1971, Vapor-dominated hydrothermal systems compared with hot water systems: Econ. Geology, v. 66 , no. 1, p. 75-97.

White D.E. and Williams, D.L., ed., 1975, Assessment of geothermal resources of the United States - 1975: U.S. Geol. Survey Circ. 726.

Willden, R., 1965, Seismic-refraction measurements of crustal structure between American Falls Reservoir, Idaho, and Flaming Gorge, Utah: U.S. Geol. Survey Prof. Paper 525-C, p. 44-50.

Williams, P.I., Mabey, D.R., Zohdy, A.A.R., Ackermann, Hans, Hoover, D.B., Pierce, K.L. and Oriel, S.S., 1975, Geology and geophysics of the southern Raft River Valley geothermal area, Idaho, U.S.A.: Proceedings, 2nd United Nations Symp. on the Development and Use of Geothermal Resources, San Francisco, v. 2, p. 1273-1282.

wilson, M.D., Applegate, J.K., Chapman, S.L. and Donaldson, P.R., 1976, Geothermal investigations of the Cascade, Idaho area: Dept. of Geology and Geophysics, Boise State University report, 44 p.

Witkind, I.J., 1975, Preliminary map showing known and suspected active faults in Idaho: U.S. Geol. Survey open file report no. 75-278.

Woolard, G.P., 1958, Areas of tectonic activity in the United States as indicated by earthquake epicenter: Trans. Am. Geophys. Union, v. 39 , no. 6 , p. 1135-1149.

Young, H.W., 1977, Reconnaissance of ground-water resources in the Mountain Home plateau area, southwest Idaho: U.S. Geol. Survey water resources investigations 77-108 open file report, 40 p.

Young, H.W., Harenburg, W.A. and Seitz, H.R., 1977, Water resources of the Weiser River Basin, west-central Idaho: Idaho Dept. of Water Resources, Water Inf. Bull. no. 44 .

Young, H.W. and Mitchell, J.C., 1973, Geothermal Investigations in Idaho, Part 1, Geochemistry and geologic setting of selected thermal waters: Idaho Dept. of Water Resource, Water Inf. Bull. no. 30 , $43 \mathrm{p}$. 
Young, H.W. and Whitehead, R.L, 1975a, Geothermal Investigations in Idaho, Part 2, An evaluation of thermal water in the Bruneau-Grand View area, southwest Idaho: Idaho Dept. of .Water Resources, Water Inf. Bull. no. 30,126 p.

, 1975b, Geothermal Investigations in Idaho, Part 3, An evaluation of thermal water in the Weiser area, Idaho: Idaho Dept. of Water Resources, Water Inf. Bull. no. 30, 35 p.

Zohdy, A.A.R., 1970, abs., mapping basaltic aquifers in southern Idaho by deep electrical soundings: Geophysics, v. 35, p. 1166.

Zohdy, A.A.R. and Bisdorf, R.J., 1976, Schlumberger soundings in the Upper Raft River and Raft River Valleys, Idaho and Utah: U.S. Geol. Survey open file report no. 76-92.

Zohdy, A.A.R., Bisdorf, R.J. and Jackson, D.B., 1978, Simple total field and Schlumberger soundings near sugar City, Idaho: U.S. Geol. Survey open file report no. 78 .

Zohdy, A.A.R., Jackson, D.B. and Bisdorf, R.J., 1975, Schlumberger soundings and total field measurements in the Raft River geothermal area, Idaho: U.S. Geol. Survey open file report no. 75-130.

, 1975, abs., Exploring the Raft River geothermal area, Idaho, with the D.C. resistivity method: Soc. Explor. Geophys. Annual Int. Meeting, abs. no. 45, p. 27-28.

Zohdy, A.A.R. and Stanley, W.D., 1972, abs., Profiles of deep electrical soundings on the Snake River Plain, Idaho: Geol. Soc. America, abs., v. 4, no. 6 , p. 423-424. 


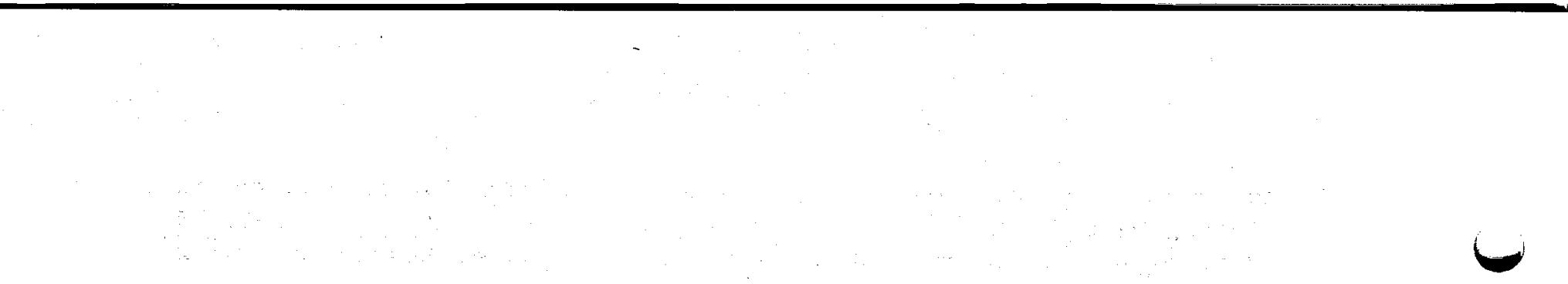




\section{APPENDIX}

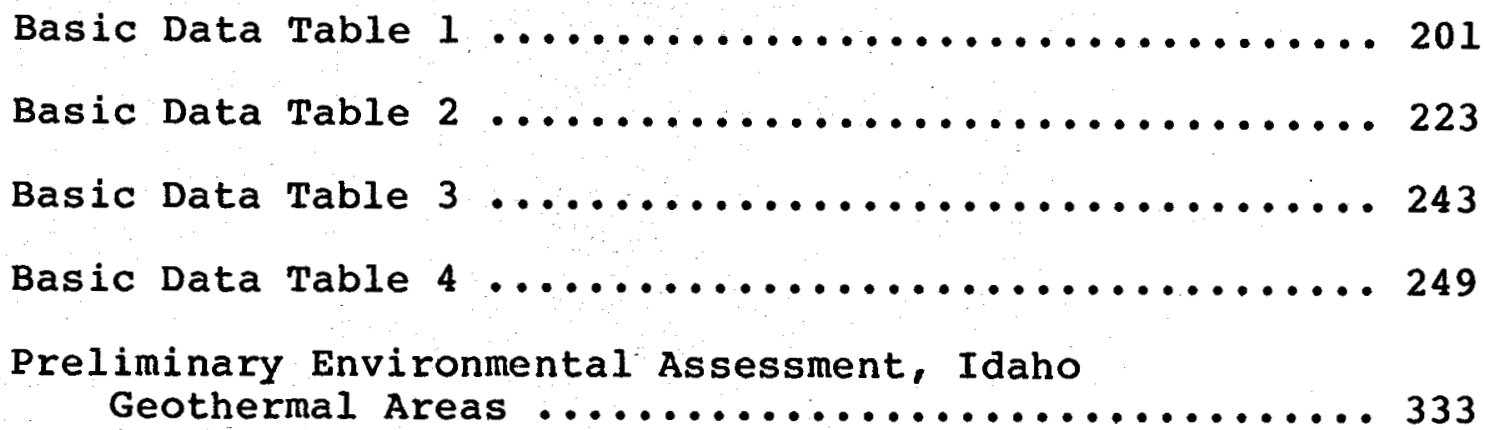

The basic data tables list information on thermal springs and wells so far as is presently known. In some instances the spring number given in the basic data tables may differ slightly from that found on the map, Geothermal Resources of Idaho, Plate 1, in pocket. The location given in the basic data tables represents a sample location while that given on the map represents that of the main discharge points. When a spring location is given in the text, it refers to the basic data tables. 


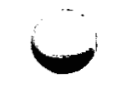

. 


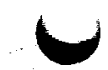

BASIC DATA TABLE 1 
Basic data table 1

CHEMICAL ANALYSES OF THERMAL WATER FROM SELECTED SPRINGS AND WELLS IN IDAHO (Chemical constitutents in milligrams per liter)

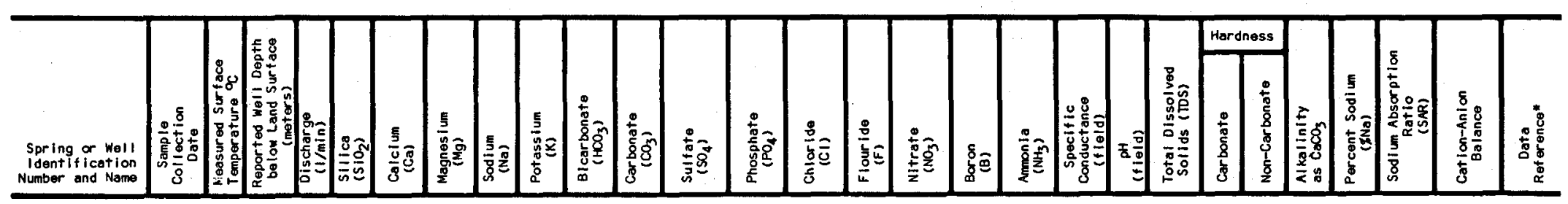

Ada county

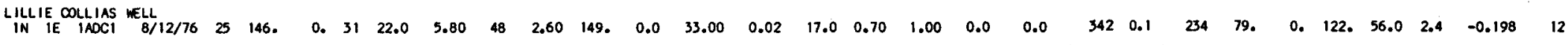

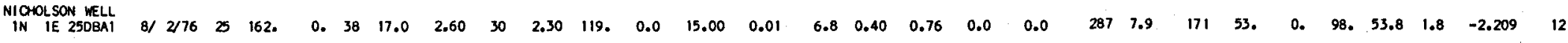

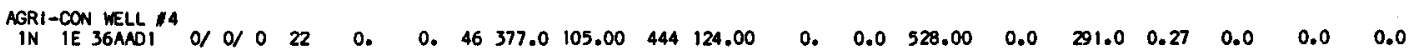

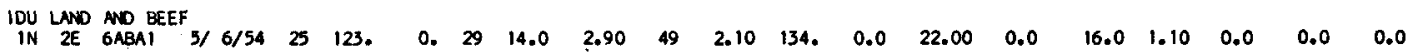
TOM BEVINS WELL
$2 \mathrm{~N}$
IE $2200 \mathrm{~B} 1$ GEORGE WIITMORE

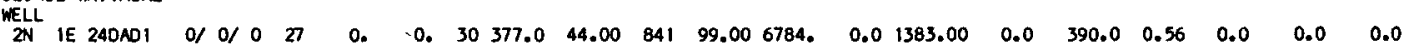

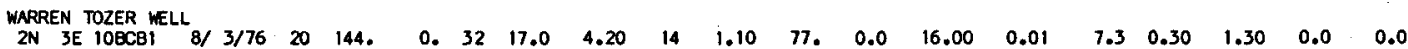
ST. TRANS. DEPT.

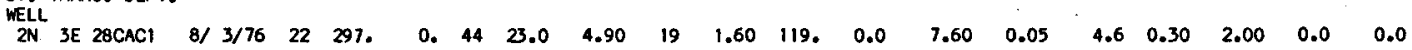
$\begin{array}{llllllllll}248 & 7.8 & 1915 & 1372 . & 1372 . & 0 . & 38.7 & 5.2 & 44.406 & 12\end{array}$

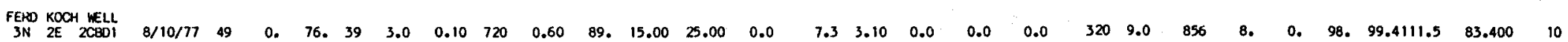

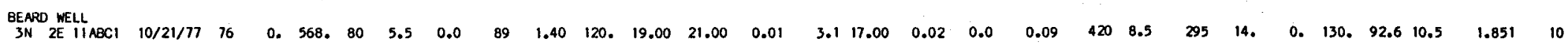
WARM SPRINGS

$\begin{array}{lllllllllllllllllllllllllllllllll}\text { WATER } & 015 T \\ 3 \mathrm{~N} & 2 E & 120001 & 5 / 31 / 72 & 75 & 122 . & 727 . & 78 & 2.0 & 0.0 & 75 & 1.30 & 141 . & 4.00 & 23.00 & 0.01 & 9.3 & 24.00 & 0.08 & 0.0 & 0.0 & 386 & 7.3 & 286 & 5 . & 0 . & 122 . & 96.1 & 14.6 & -13.543 & 3\end{array}$

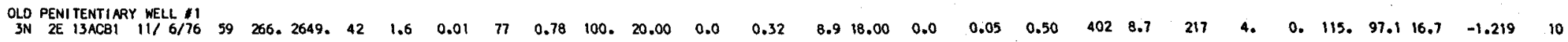
BOISE WATER

$\begin{array}{llllllllllllllllllllllllllllll}3 \mathrm{~N} & \text { WE } 36 \mathrm{ABCl} & 7 / 29 / 77 & 21 & 0 . & 0 . & 23 & 19.0 & 0.80 & 22 & 1.10 & 97 . & 0.0 & 14.00 & 0.0 & 5.9 & 0.50 & 0.28 & 0.0 & 0.03 & 204 & 7.3 & 134 & 51 . & 0 . & 79 . & 47.9 & 1.3 & -3.582 & 12\end{array}$

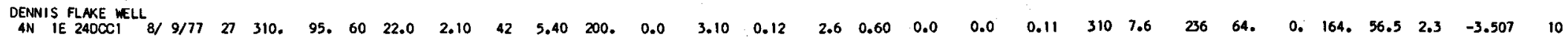

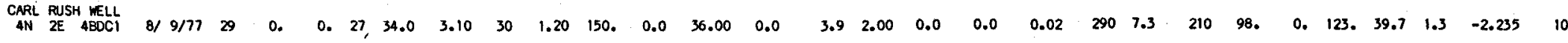
EDWARDS GREENHOUSE

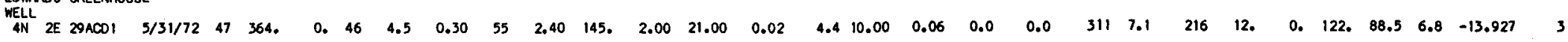




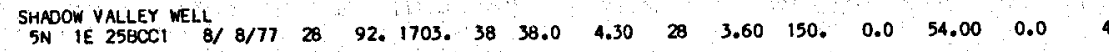

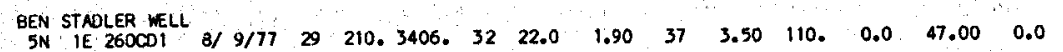

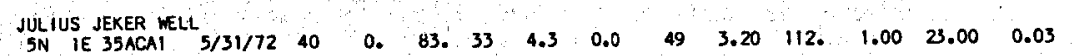

JERRY DAVIS

CLATER FURSGREN

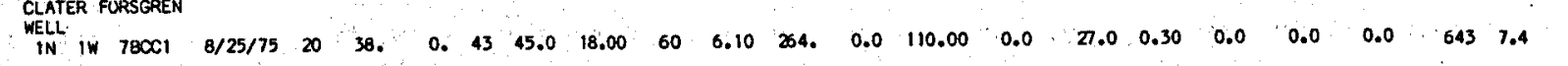

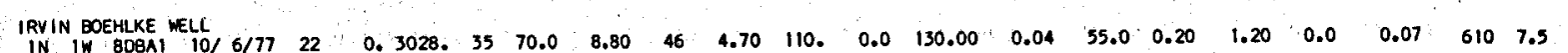

$\begin{array}{lllllllllllllllllllllll}\text { SHANE BUES WELL } & 8 / 12 / 76 & 23 & 165 & 0 . & 47 & 20.0 & 7.00 & 39 & 4.90 & 130 . & 0.0 & 37.00 & 0.01 & 15.0 & 0.30 & 1.20 & 0.0 & 0.0\end{array}$

TERRY TLUCEK

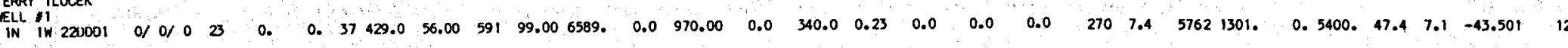

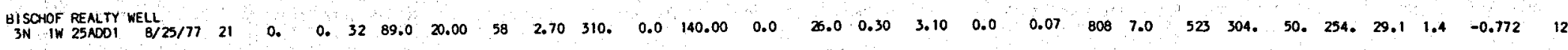

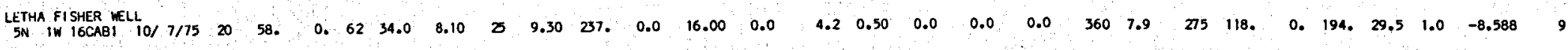

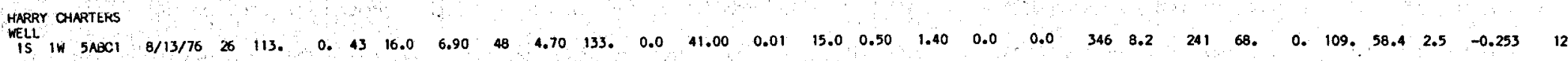

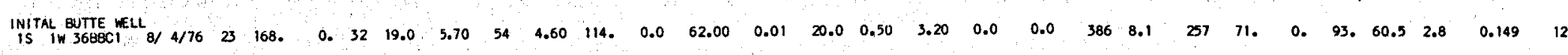

Adams County

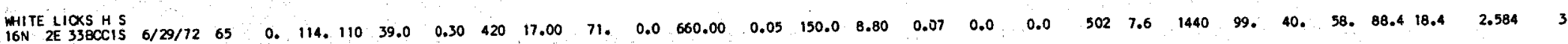

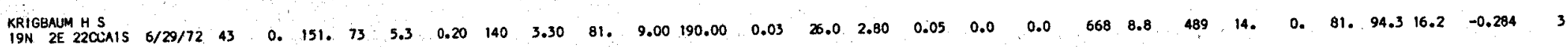

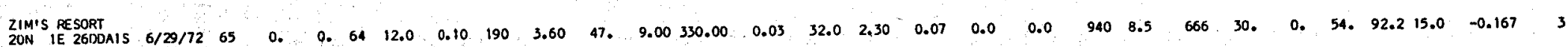

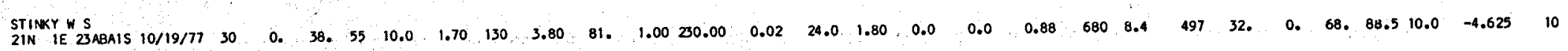

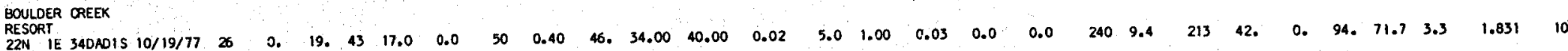

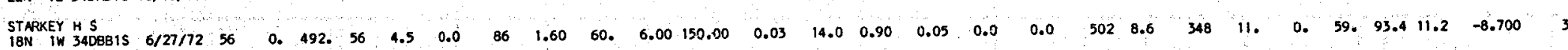

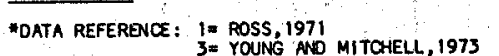

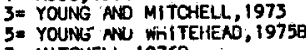
$7=$ YOUNG NU MITCHELL, 19768

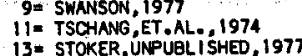

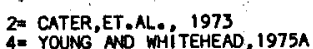

4= YOUNG MO MITGHELL, $1976 \mathrm{AT}$

$8=$ MITCELLL, $1976 C$
$10=$ MITCHELL UNPUBLISHED, 1978

10= MITCHELL,UNP
$12=$ USGS WFD FILE
$14=$ YOUNG, 1977 
Basic Data Table 1. Chemical Analyses of Thermal water from Selected Springs and Wells in Idaho (continued)

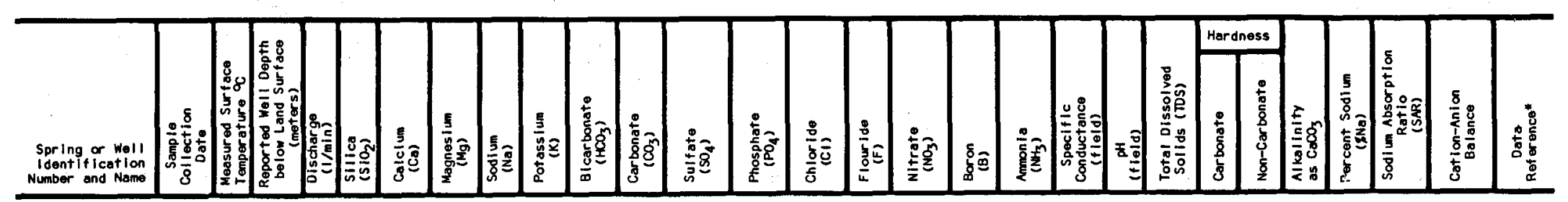

Bannock County

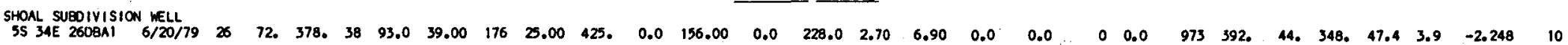

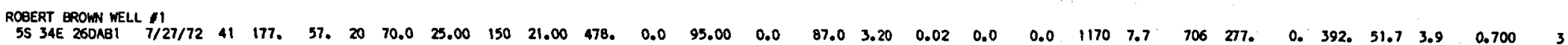

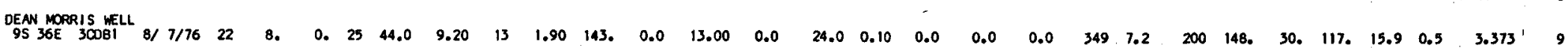

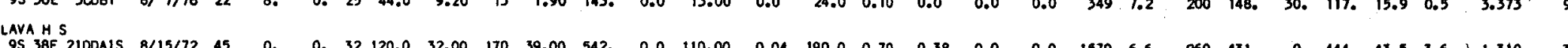

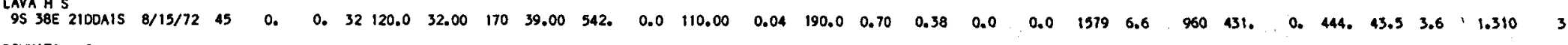

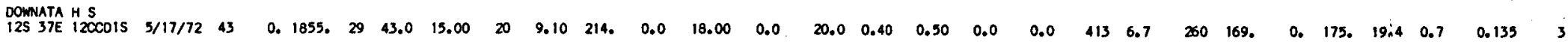
Bear Lake County

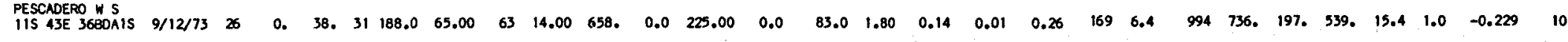

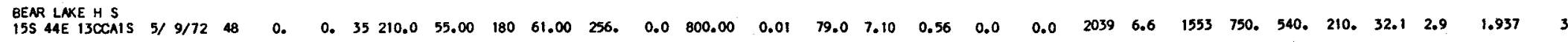
Bingham county

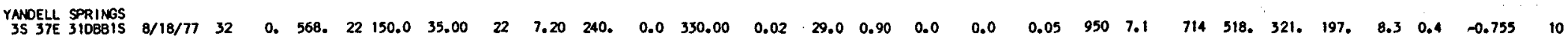

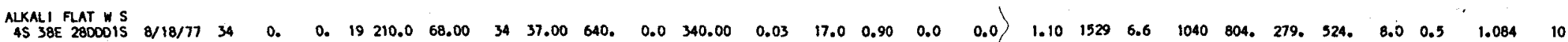
Blaine County

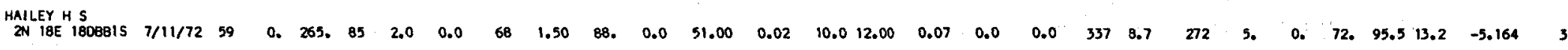

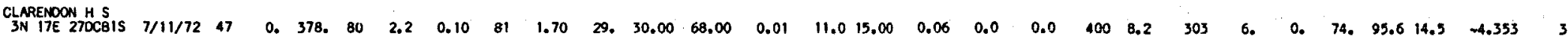

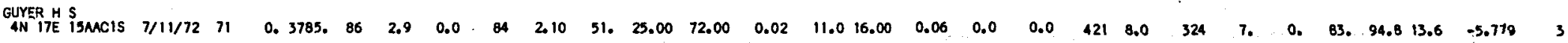

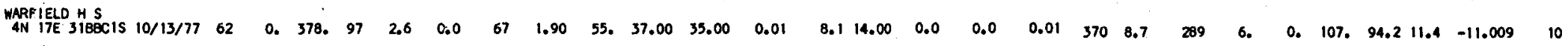

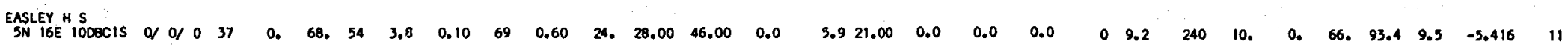

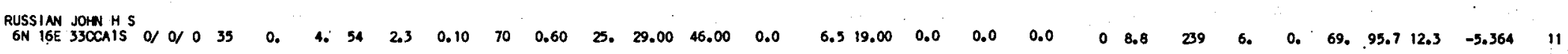

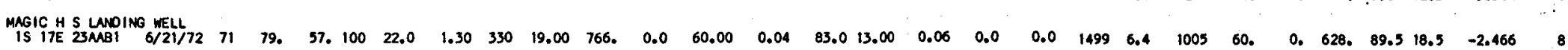




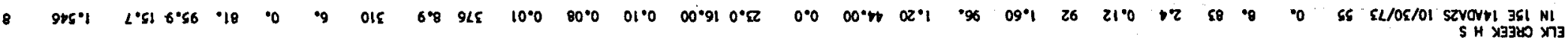

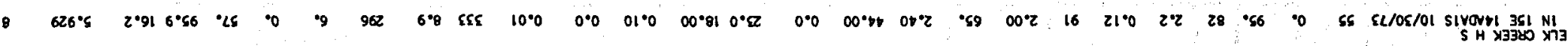

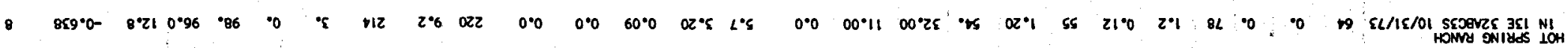

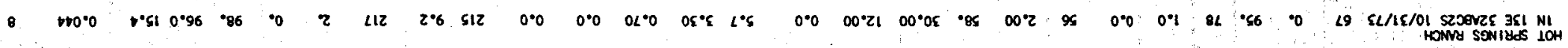
8 6iL.

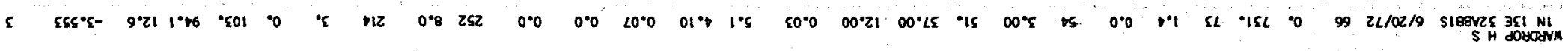
ऊұtunos seures

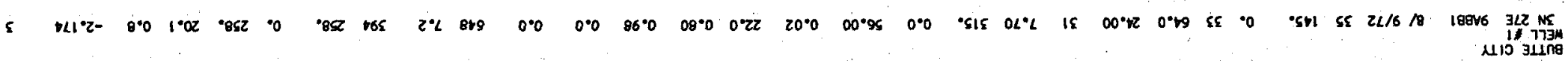

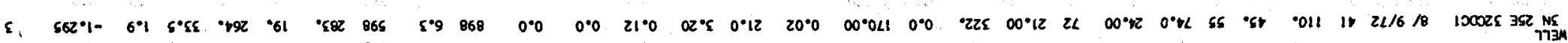

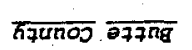

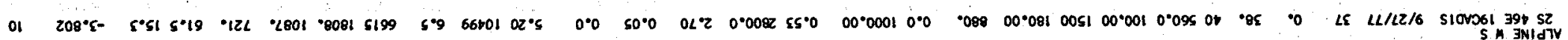

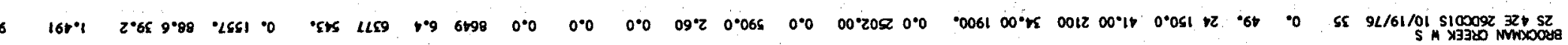

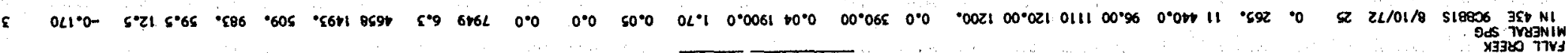

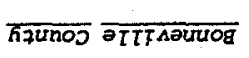

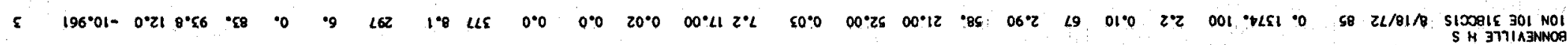

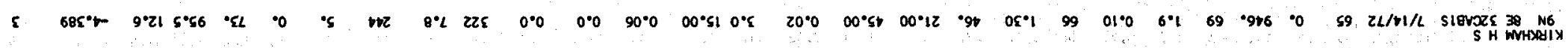

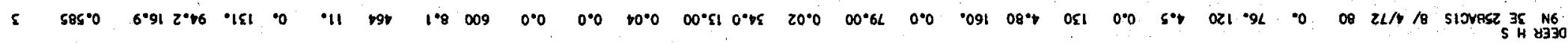

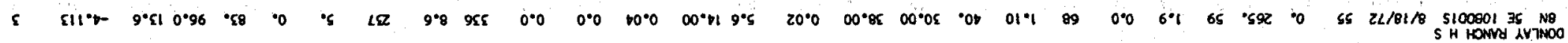

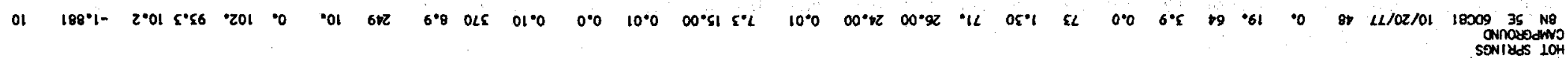

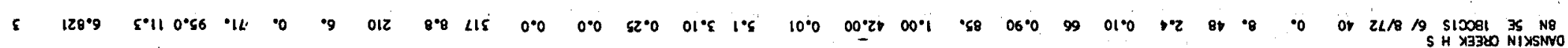

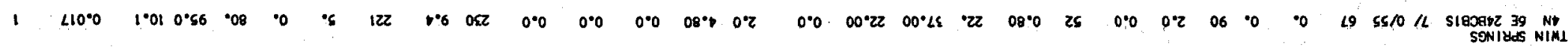

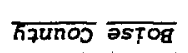

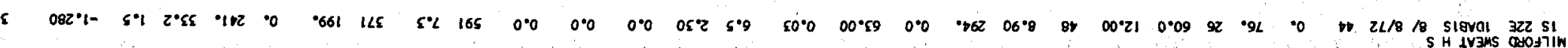

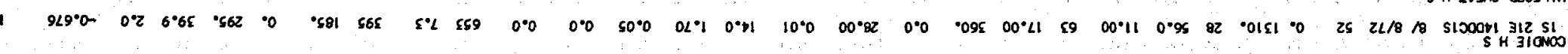

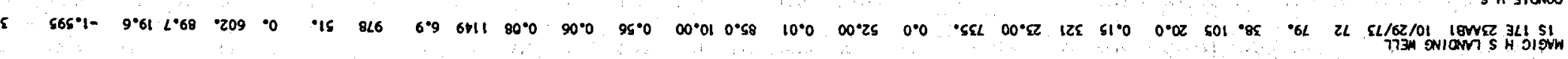


Basic Data Table 1. Chemical analyses of Thermal Water from Selected Springs and Wells in Idaho (continued)

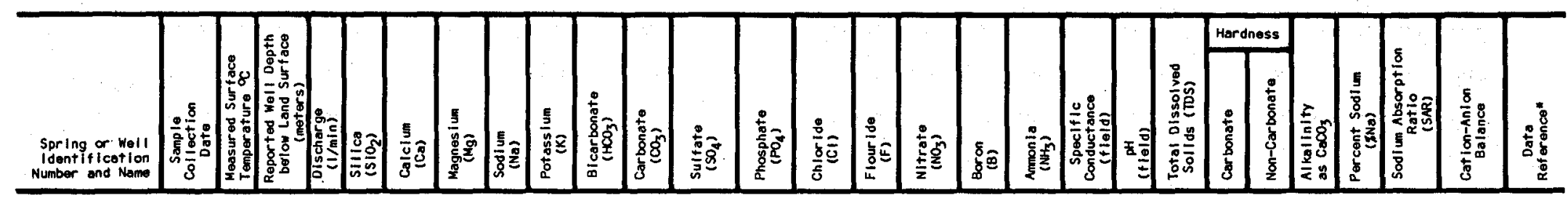

Camas Sounty (cont'd.)

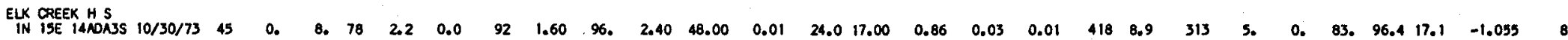

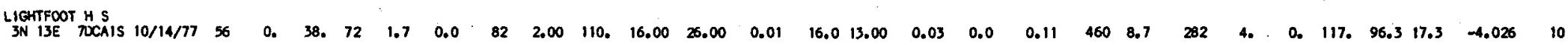

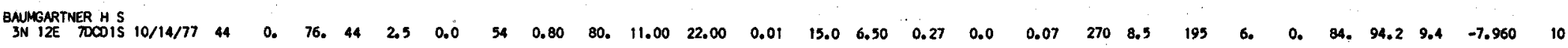

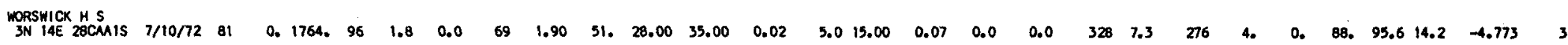

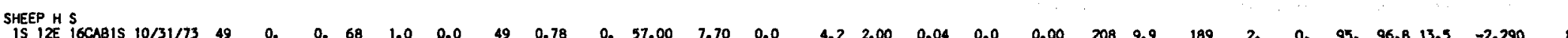

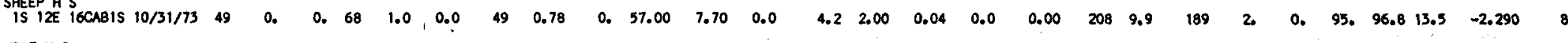

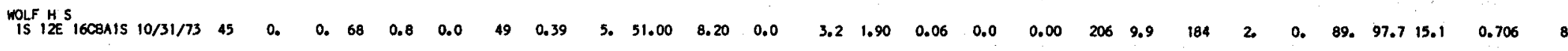

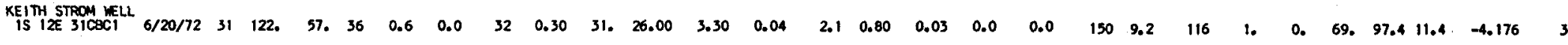

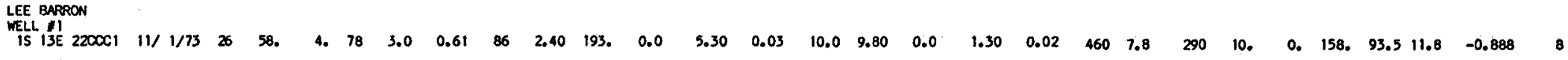

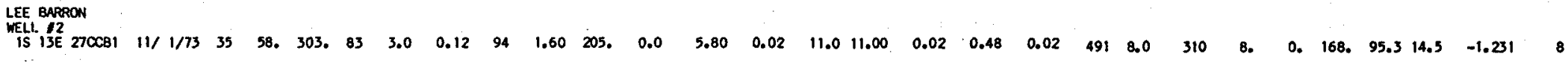
LEE BARRON

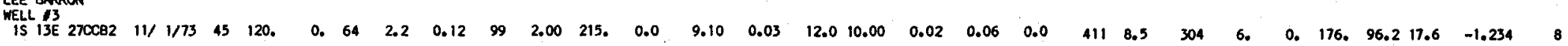

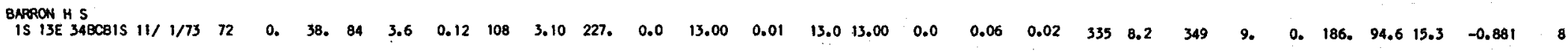
LEE BARRON

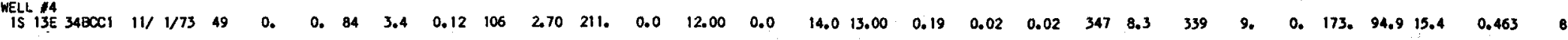

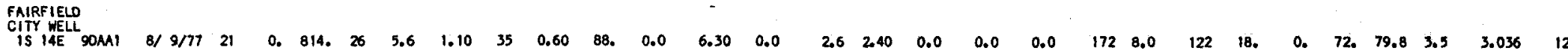

LEONARO TIEGS Canyon County

$\begin{array}{llllllllllllllllllllllllllllllllll}\text { WELL } & 11 \\ \text { IN } & 50001 & 8 / 27 / 75 & 22 & 223 . & 0 . & 28 & 45.0 & 7.80 & 37 & 3.40 & 146 . & 0.0 & 72.00 & 0.0 & 30.0 & 0.30 & 0.0 & 0.0 & 0.0 & 483 & 8.0 & 295 & 144 . & 25 . & 120 . & 35.1 & 1.3 & -2.671 & 9\end{array}$

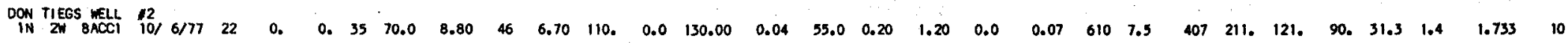

$\begin{array}{lllllllllllllllllllllllllllllll}\text { MELBA CITY WELL } & 10 / 6 / 77 & 25 & 0 . & 757 . & 42 & 9.1 & 2.30 & 88 & 3.80 & 200 . & 0.0 & 34.00 & 0.04 & 17.0 & 1.40 & 0.40 & 0.0 & 0.0 & 420 & 8.2 & 296 & 32 . & 0 . & 164 . & 83.8 & 6.7 & -0.192 & 10\end{array}$ 


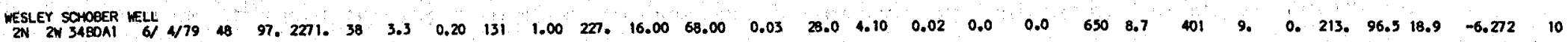
CMNNON FARMS

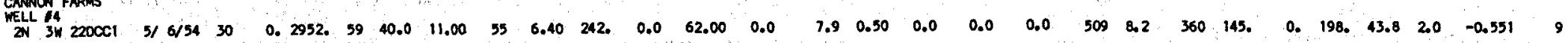

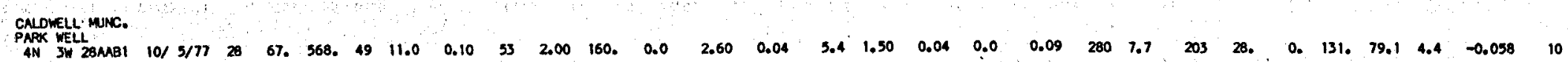

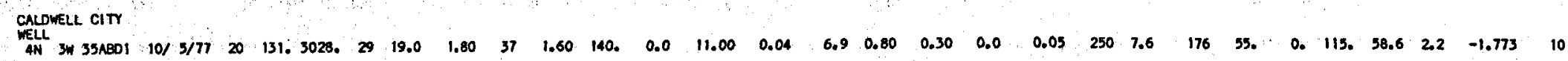

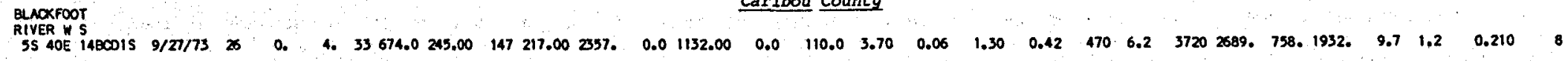

Caribou county

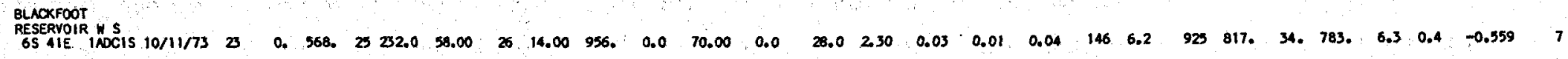

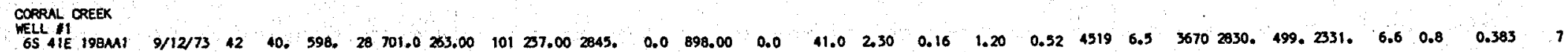

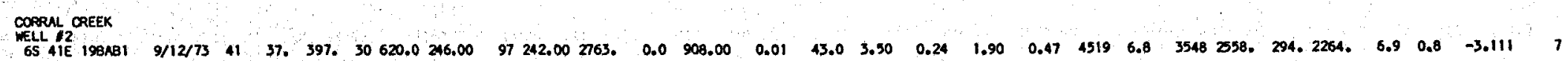
CORRAL CREEK

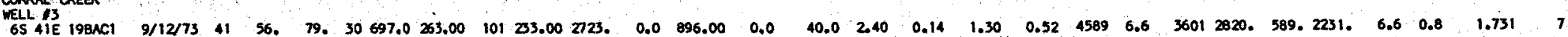
CORRN CREEK

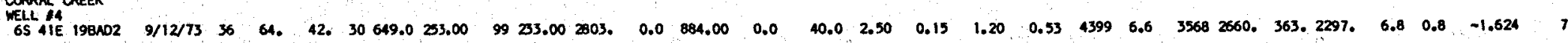

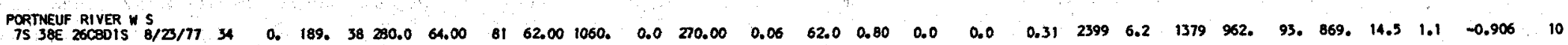

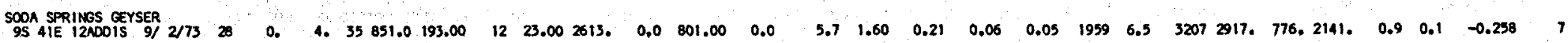
S1X S PANCH Cassia county

S1X S RANCH
WELL 11
115 25E $110 \mathrm{CA}$

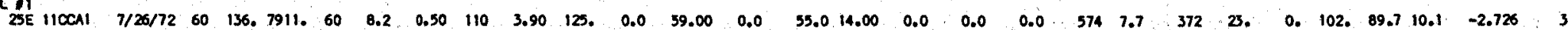
SIX S RNACH

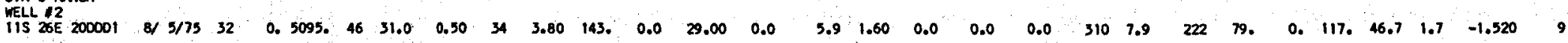

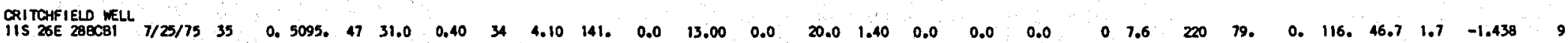
C. $\mathrm{Y}$ RNOH

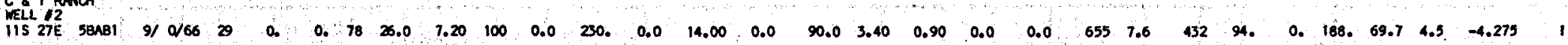

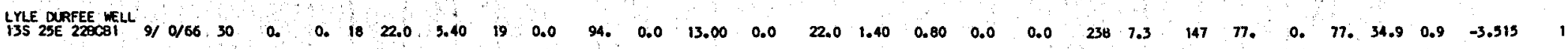

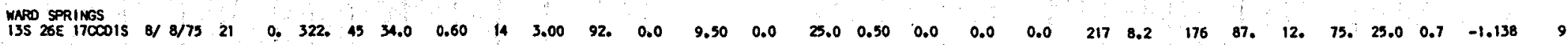

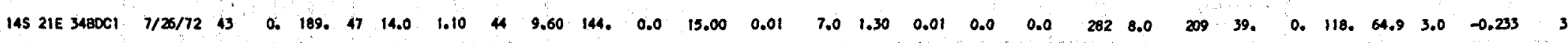

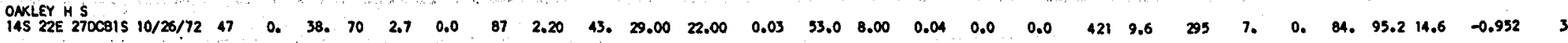


Bagic Data Table 1. Chemical Analyses of Thermal water from selected Springs and wells in Idaho (continued)

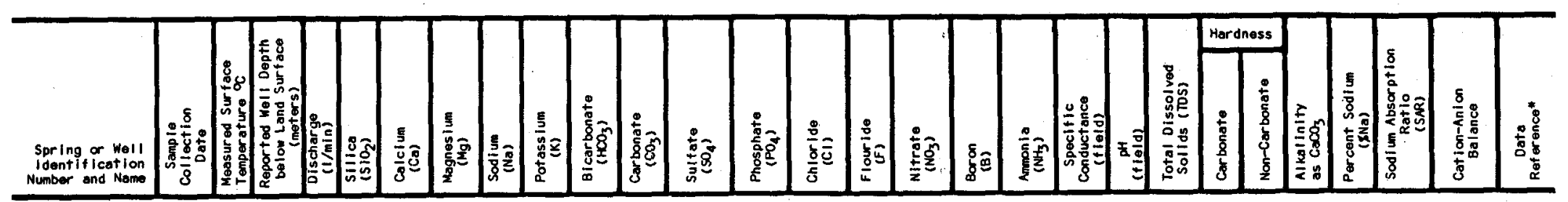

Cassia County (cont'd.)

$\begin{array}{llllllllllllllllllllllllllllll}\text { SENPS SPRING } \\ \text { 14S 25E 688BIS } & 8 / 5 / 75 & 28 & 0 . & 662 . & 22 & 29.0 & 7.50 & 15 & 3.30 & 120 . & 0.0 & 10.00 & 0.0 & 19.0 & 0.40 & 0.0 & 0.0 & 0.0 & 270 & 8.2 & 165 & 103 . & 5 . & 98, & 23.3 & 0.6 & 0.365 & 9\end{array}$

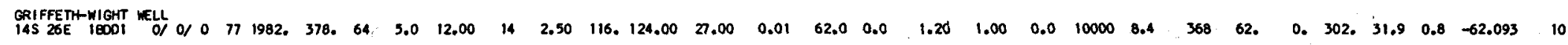

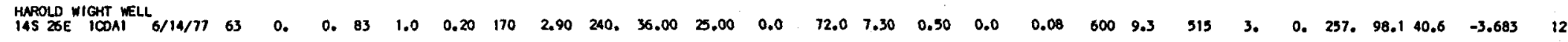
HAROLD WARO

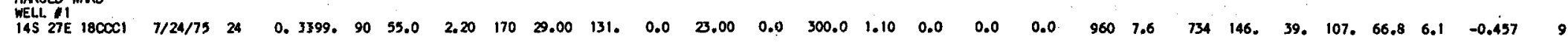
MORRIS MITOHELL

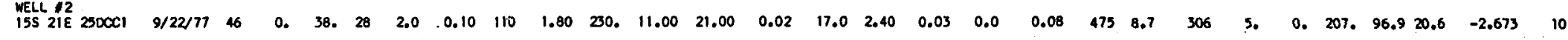

HAROLO WAPO

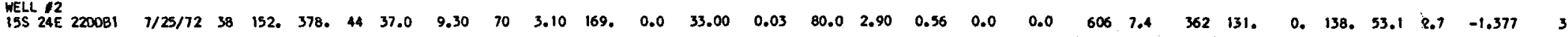

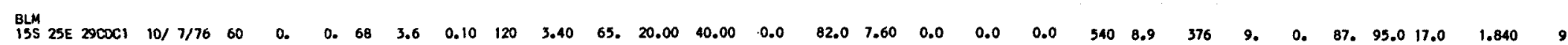

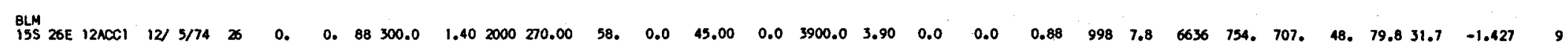

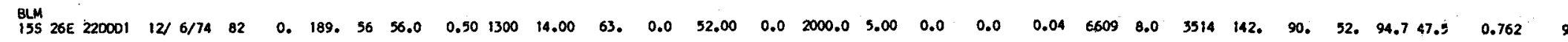

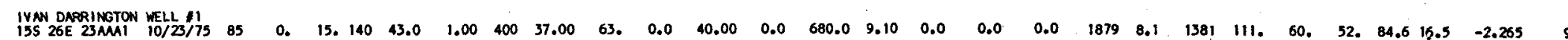

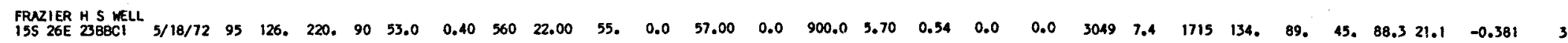

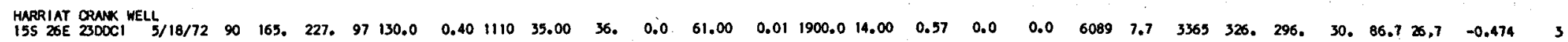

IVAN DARRINGTON

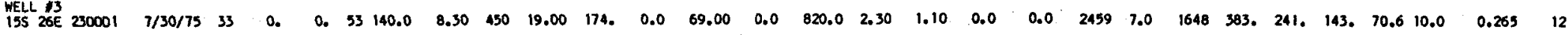

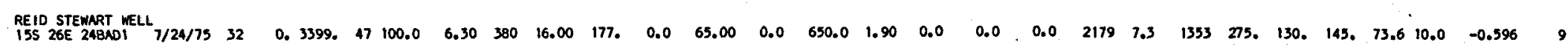

IVAN DARRINGTON

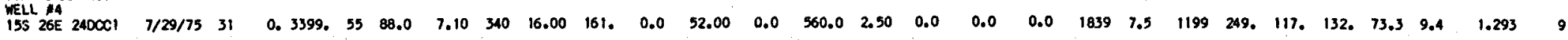

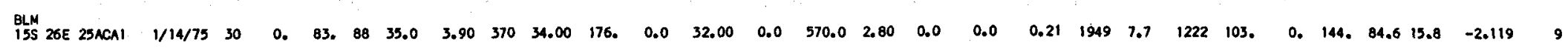

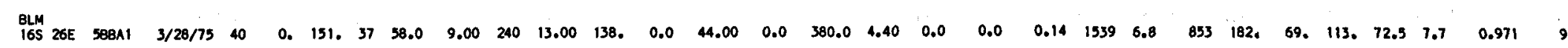




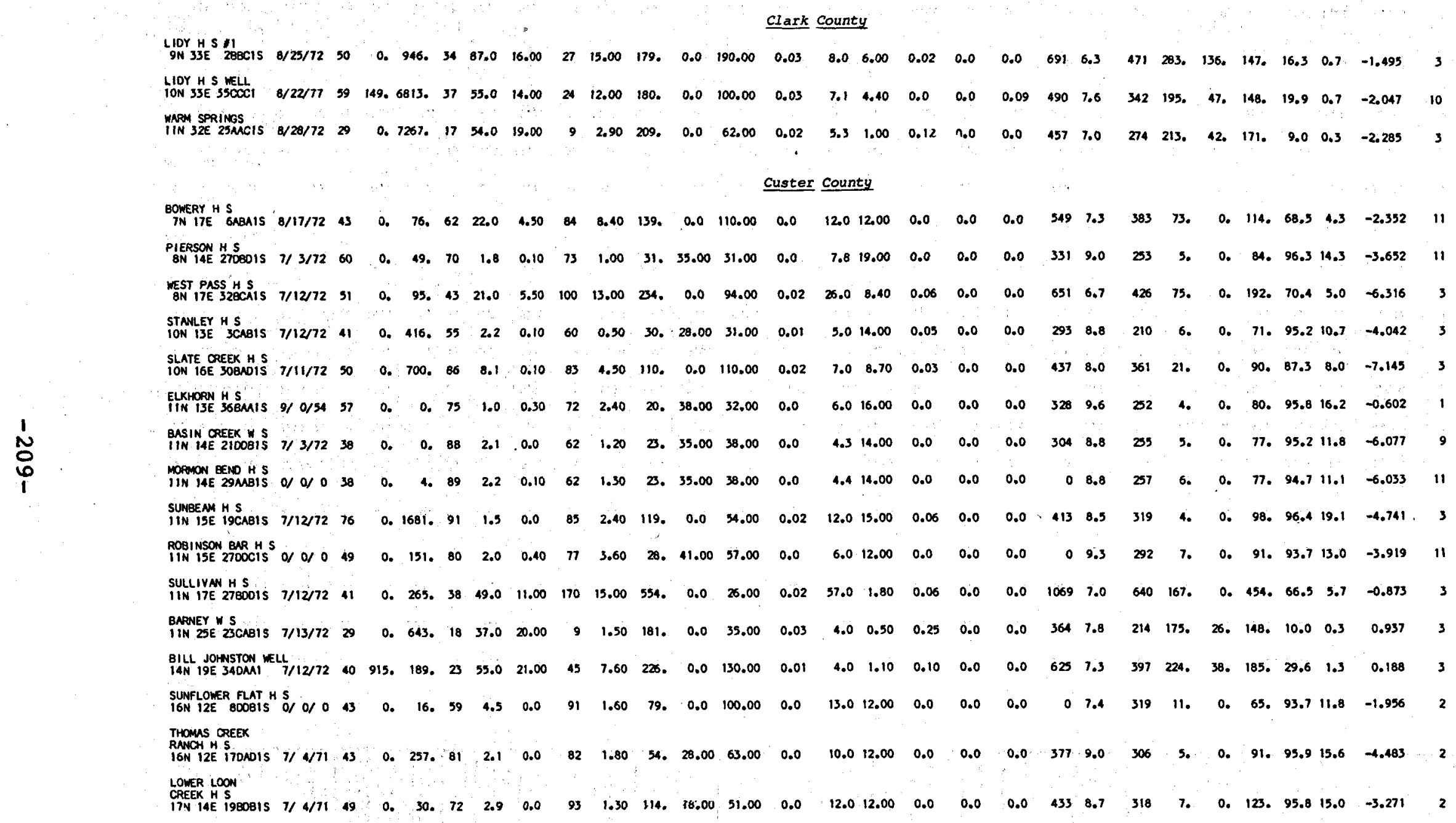

Elmore County

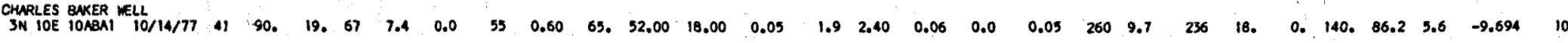

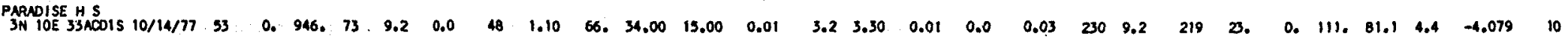


Basic Data Table 1. Chemical Analyses of Thermal water from Selected Springs and Wells in Idaho (continued)

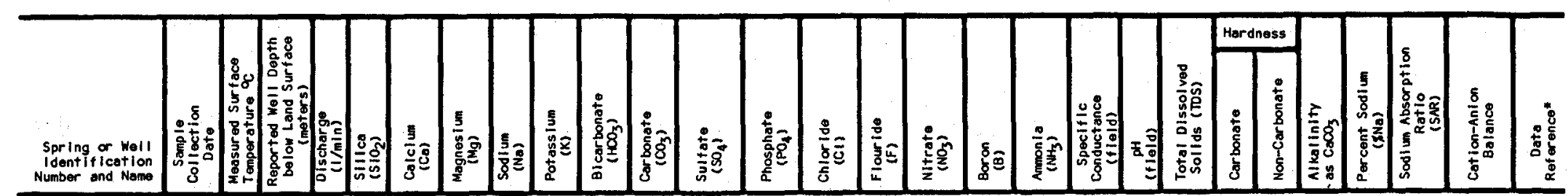

Elmore County (cont'd.)

PARAOISE

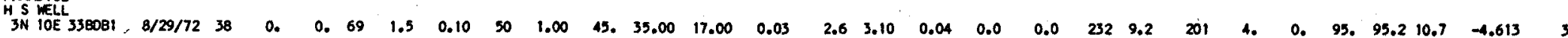

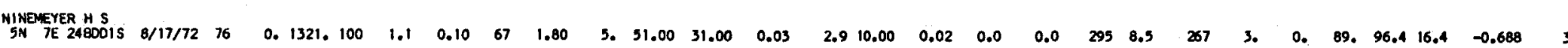

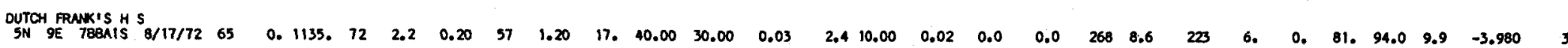

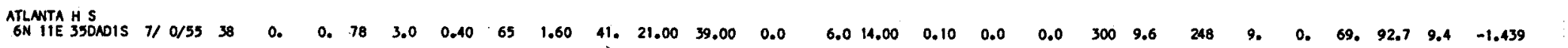

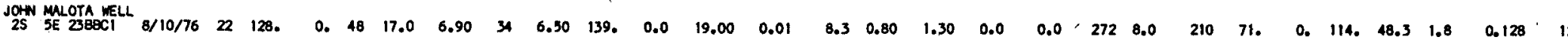
LONG TOM RWCH

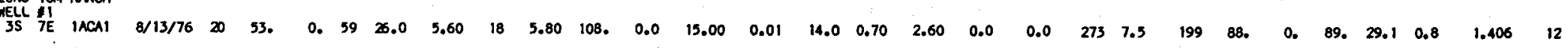

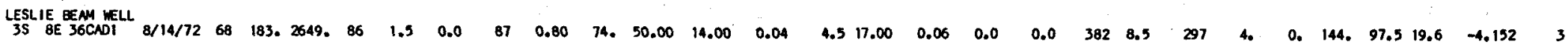

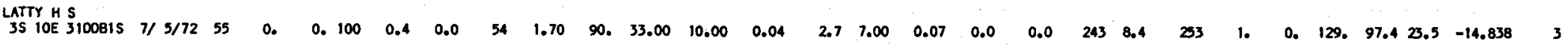

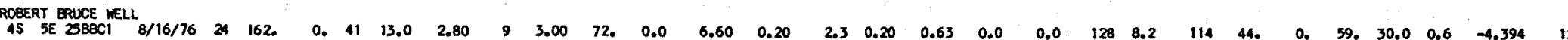

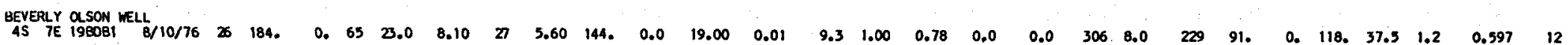
NORTHEEST

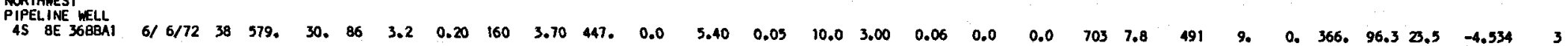

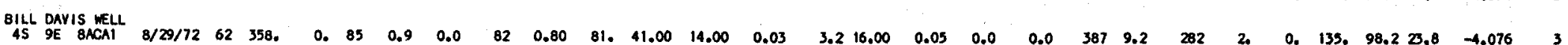

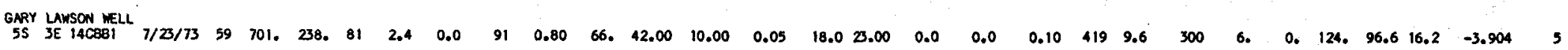

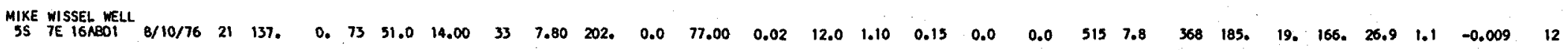

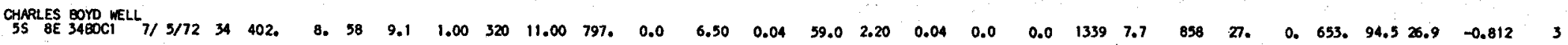
MAGIC WEST

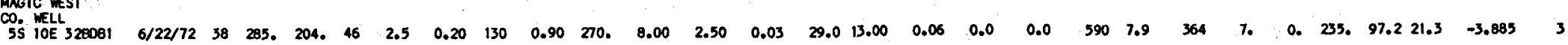
CHARLES ANOERSON

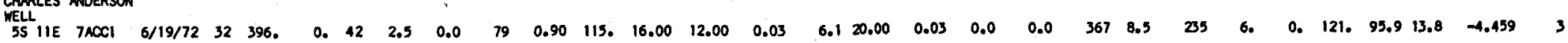




\section{Frankl in County}

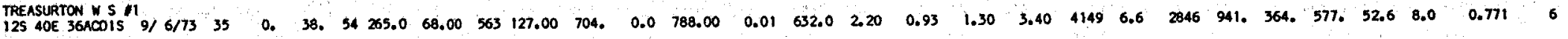

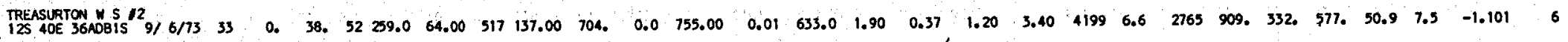

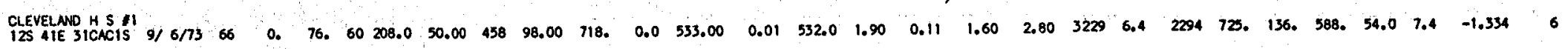

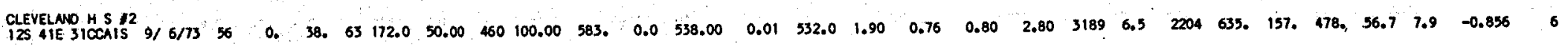

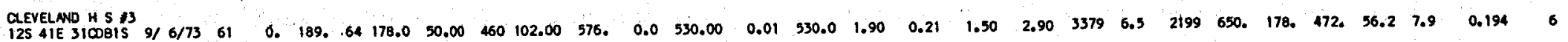

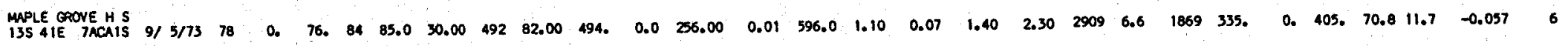

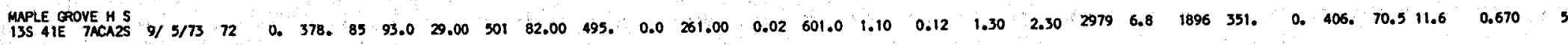

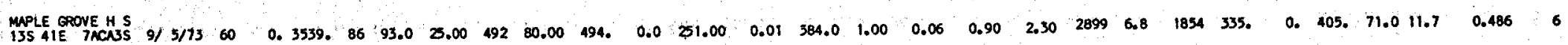

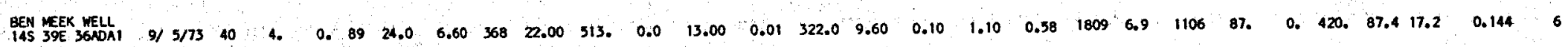

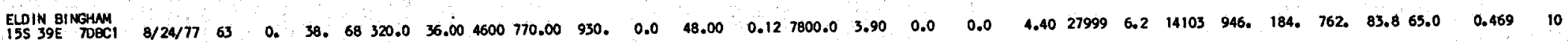

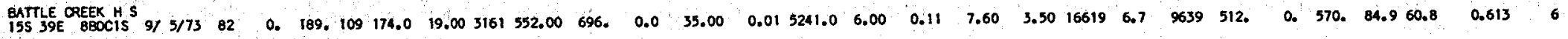

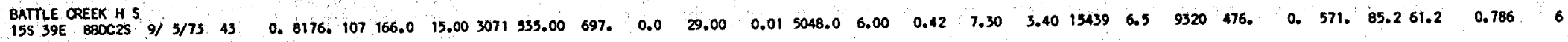

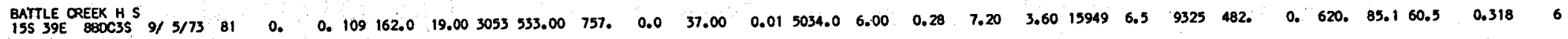

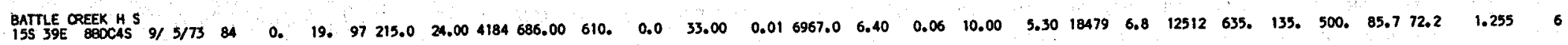

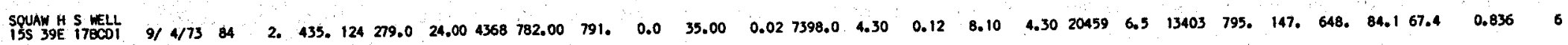

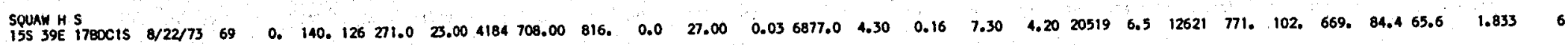

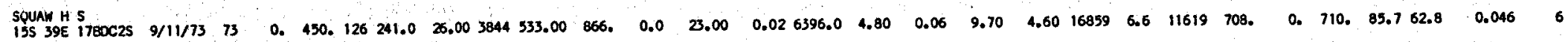

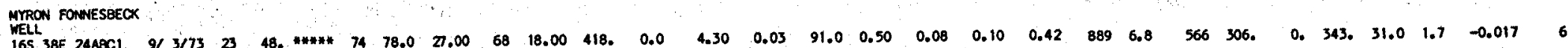
Fremont County

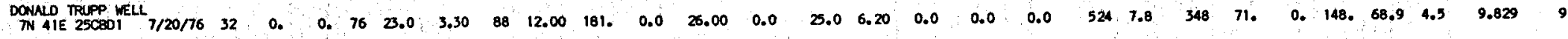

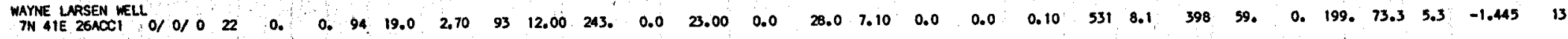

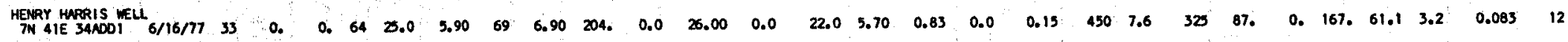

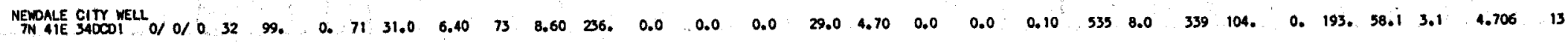

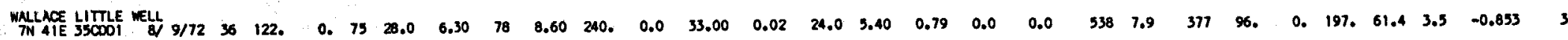


Basic Data rable 1. Chemical Analyses of Thermal water from Selected Springs and wells in Idaho (continued)

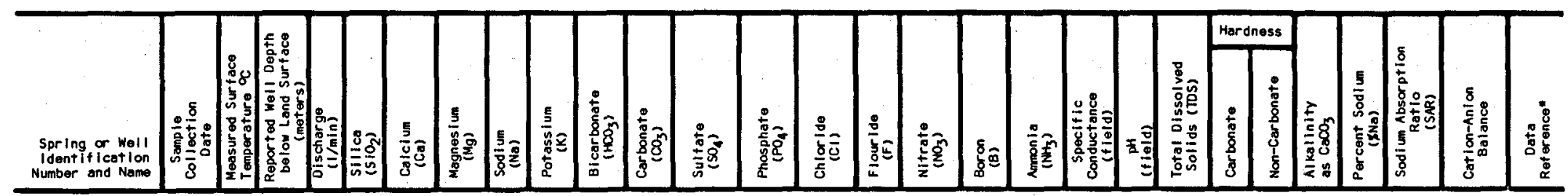

Fremont County (cont'd.)

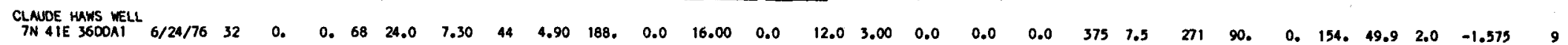

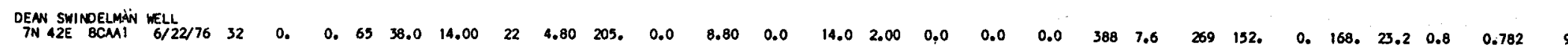

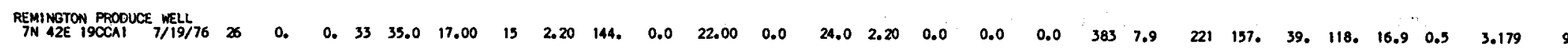

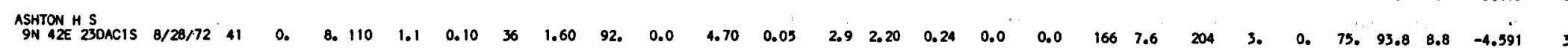

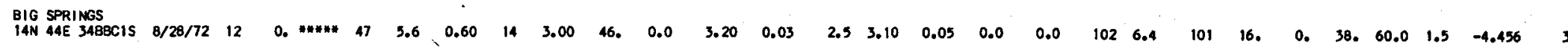
Gem County
\end{abstract}

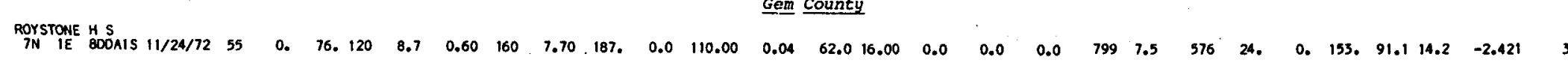

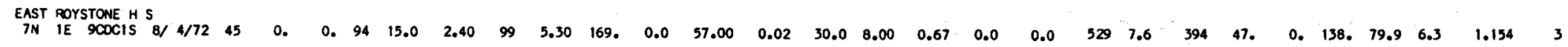
Gooding County

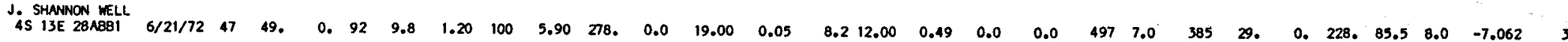

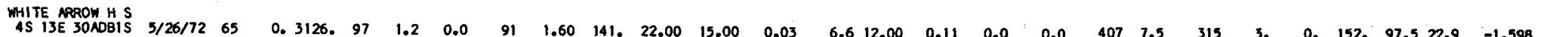

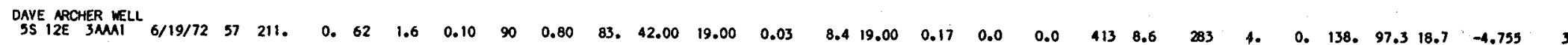

\title{
Idaho County
}

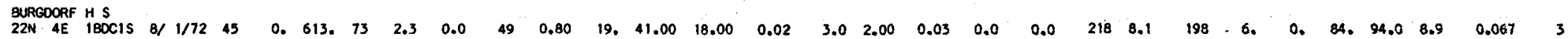

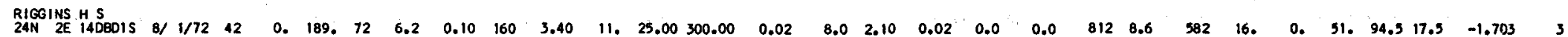

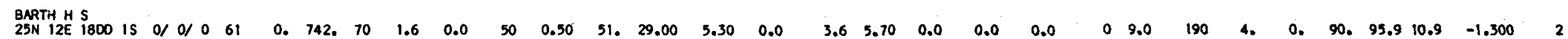
$\begin{array}{llllllllllllllllllllllllllllll}\text { RED RIVER HS } \\ 28 \mathrm{~N} \text { IOE } 300015 & 8 / 21 / 72 & 55 & 0 . & 132 . & 76 & 2.7 & 0.0 & 81 & 1.60 & 36 . & 36.00 & 44.00 & 0.01 & 4.4 & 23.00 & 0.04 & 0.0 & 0.0 & 380 & 8.6 & 286 & 7 . & 0 . & 89 . & 95.3 & 13.6 & -4.630 & 3\end{array}$

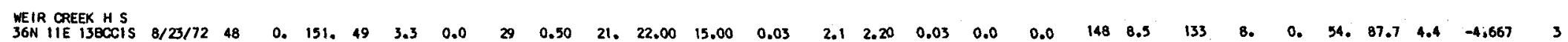

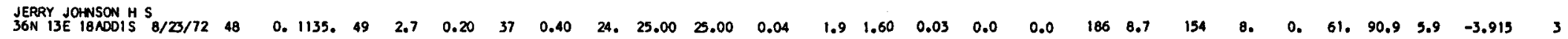




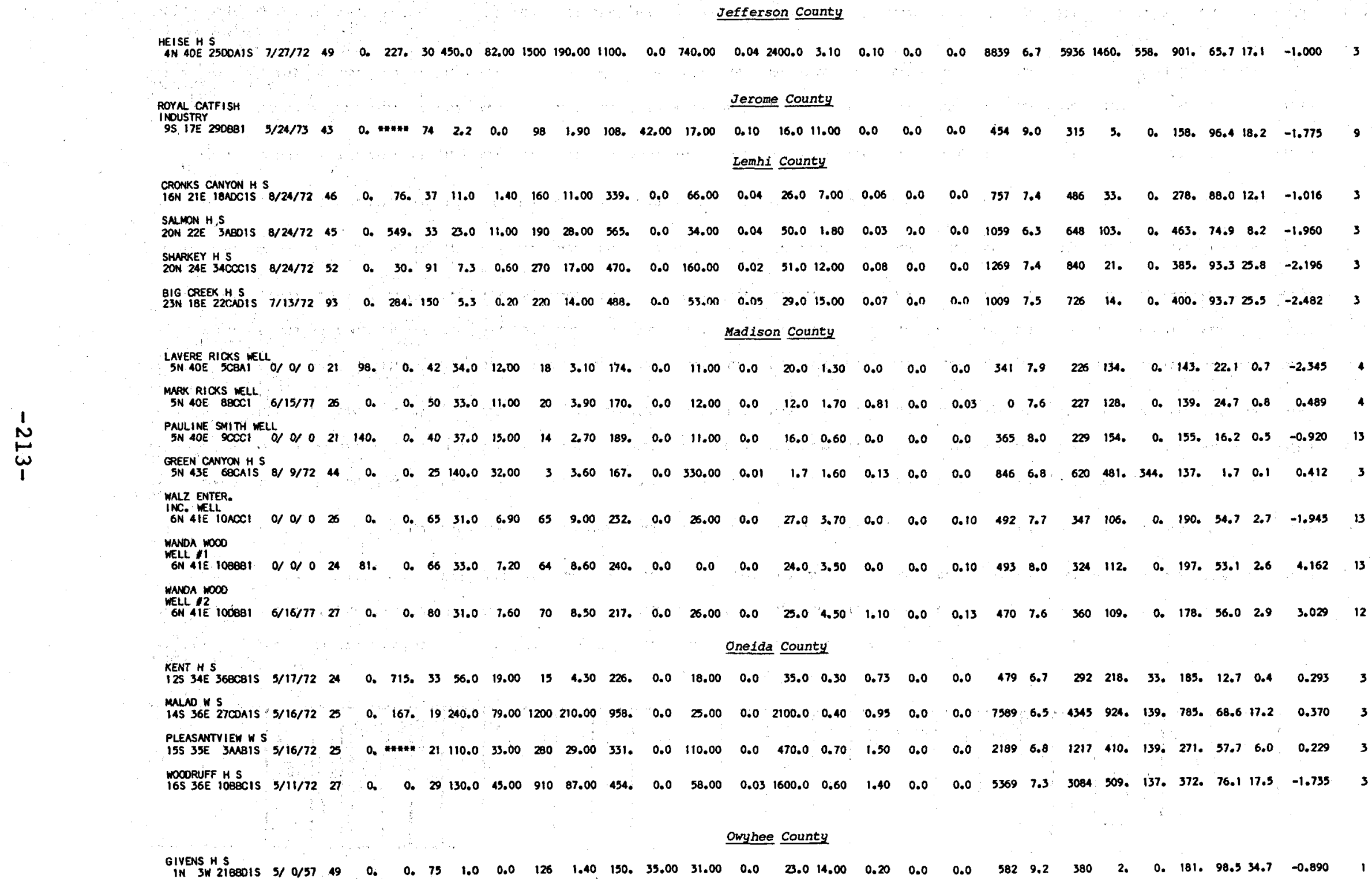


Basic Data Table 1. Chemical Analyses of Thermal water from Selected Springs and Wells in Idaho (continued)

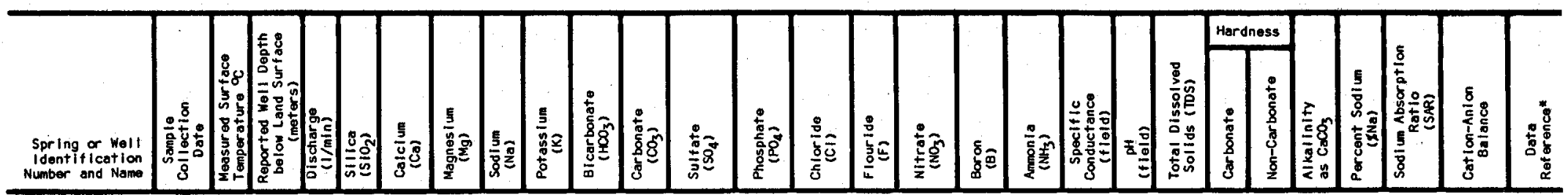

Owyhee County (cont'd.)

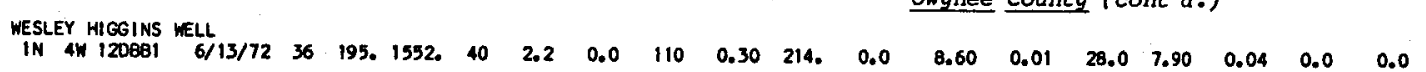

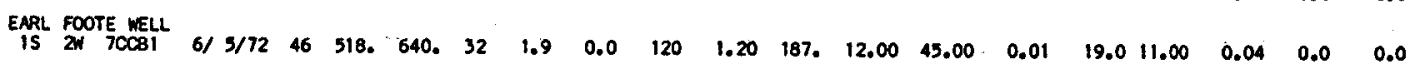

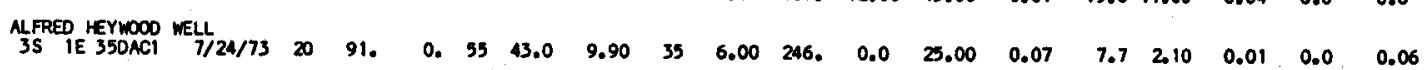
WILLIAM $C 0 \mathrm{x}$

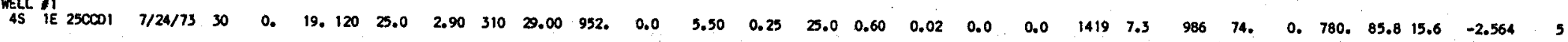
WULLIAM $\operatorname{WOX}$

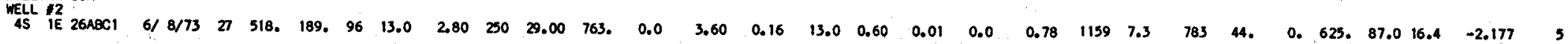

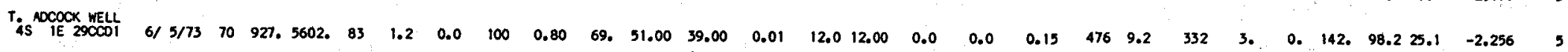

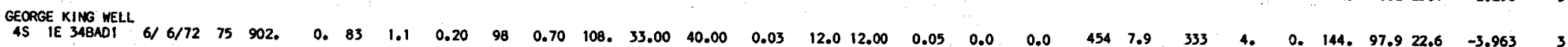
G. ORRI STENSEN

$\begin{array}{llllllllllllllllllllllllllllllllll}\text { WELL } 2 E & 2908 C 1 & 7 / 27 / 73 & 28 & 305 . & 38 . & 100 & 21.0 & 6.90 & 330 & 24.00 & 1010 & 0.0 & 4.50 & 0.0 & 31.0 & 0.30 & 0.0 & 0.0 & 0.62 & 1389 & 7.4 & 1014 & 81 . & 0 . & 828 . & 86.6 & 16.0 & -3.016 & 5\end{array}$

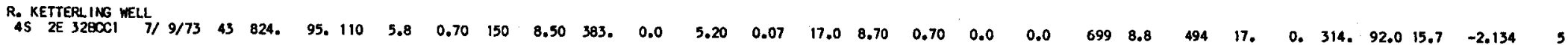

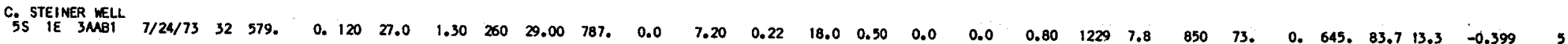

E. LAMREACE E. JOWNSTON

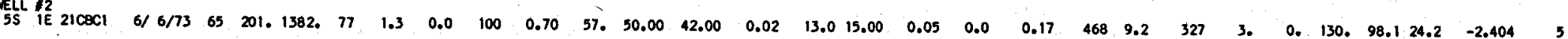
E. LAMRENCE

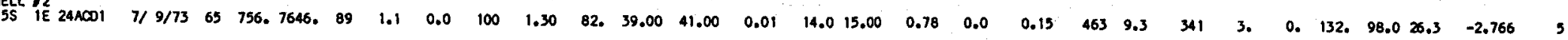
E. LARRENCE

$\begin{array}{lllllllllllllllllllllllllllll}\text { IE } 24 A 081 & 7 / 24 / 72 & 66 & 951 . & 4012, & 82 & 1.2 & 0.10 & 100 & 0.80 & 105 . & 31.00 & 45.00 & 0.23 & 13.0 & 14.00 & 0.04 & 0.0 & 0.0 & 459 & 7.9 & 338 & 3 . & 0 . & 138 . & 98.0 & 23.6 & -4.260 & 3\end{array}$

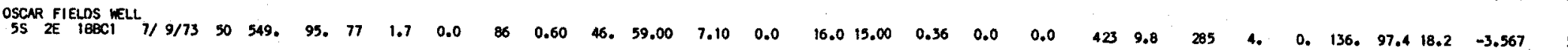
CARENCE HOPKINS

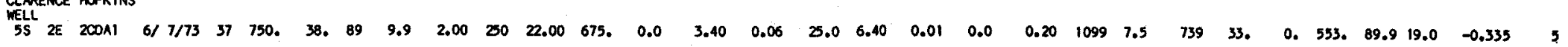




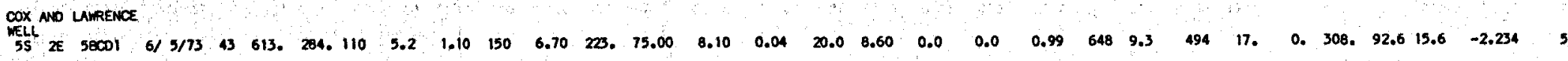

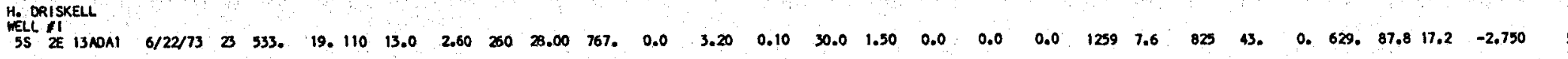

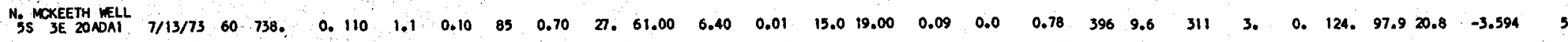

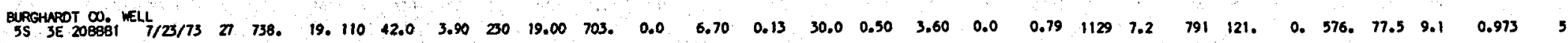

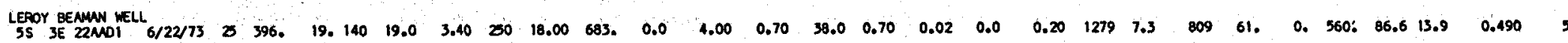

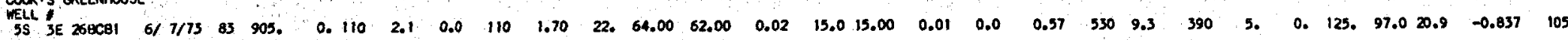
COOK'S GREENHOUSE

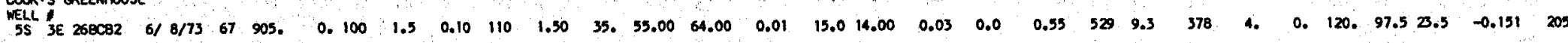

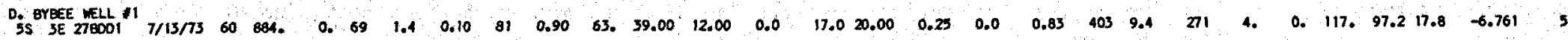

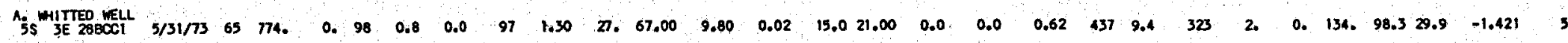

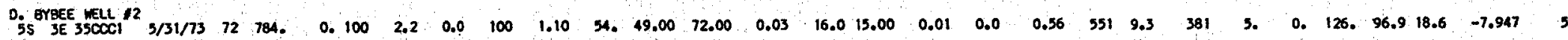

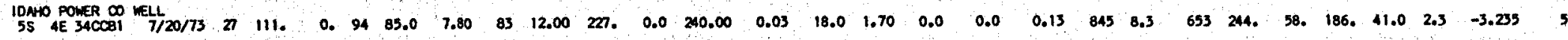

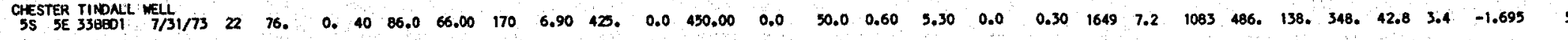

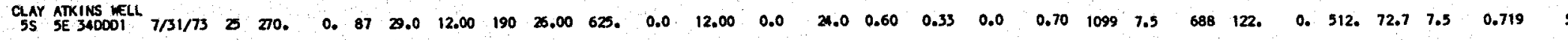

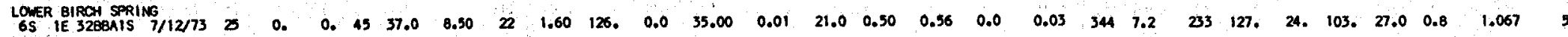

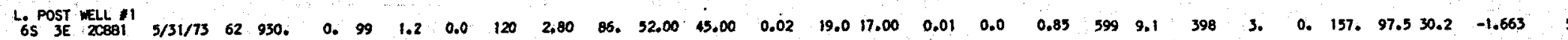

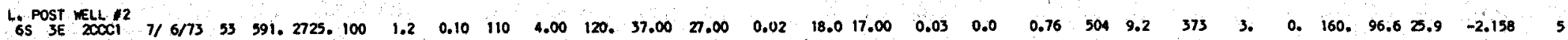

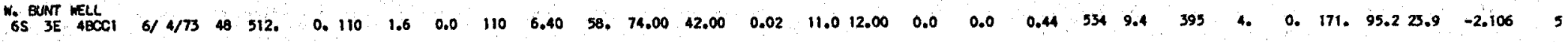

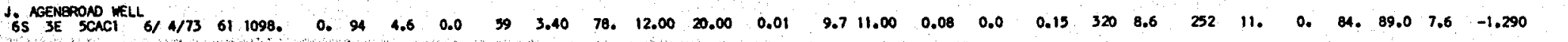

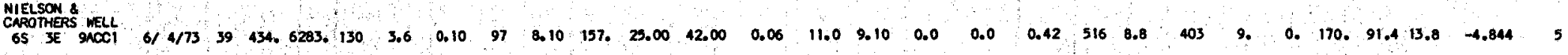
TRINGLL DAIRY

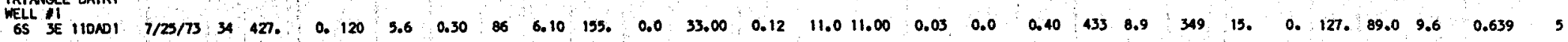
LITLE VNLCE

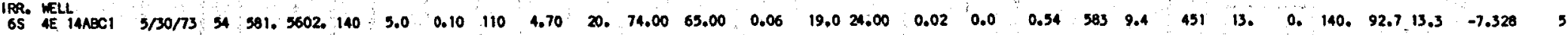

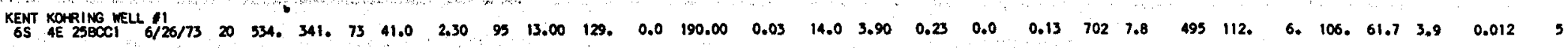


Basic Data Table 1. Chemical Analyses of Thermal water from Selected Springs and wells in Idaho (continued)

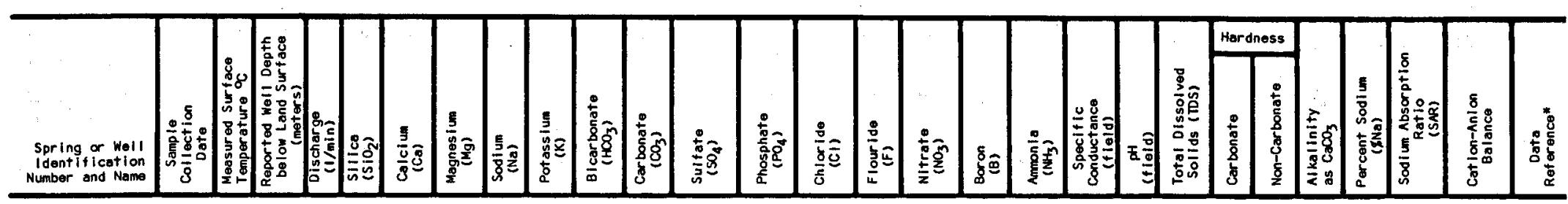

Owyhee County (cont'd.)

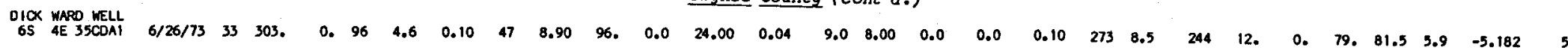

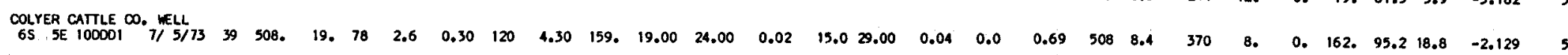
J.R.SIMPLOT

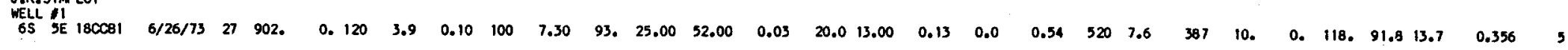
J.R.SIMPLOT

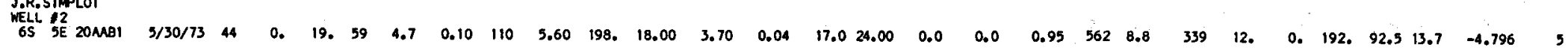
GEORGE HNTCHINSON

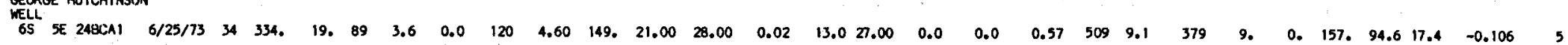

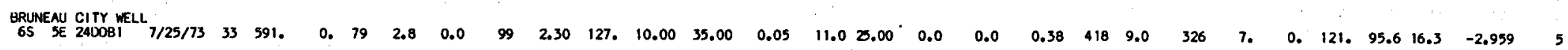

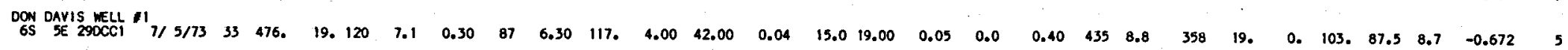
CARL $\&$ HARRY

$\begin{array}{llllllllllllllllllllllllllllll}6 S & \text { SE } 350 C A 1 & 7 / 19 / 73 & 22 & 140 . & 0 . & 73 & 38.0 & 3.30 & 54 & 8.60 & 166 . & 0.0 & 66.00 & 0.02 & 11.0 & 6.90 & 0.17 & 0.0 & 0.10 & 462 & 9.1 & 342 & 108 . & 0 . & 136 . & 49.6 & 2.3 & -0.773 & 5\end{array}$ IOAHO PARKS

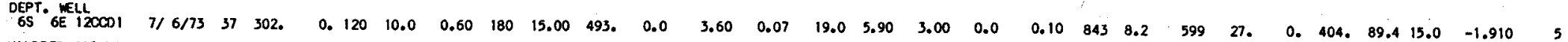
MILDRED HACMMAN

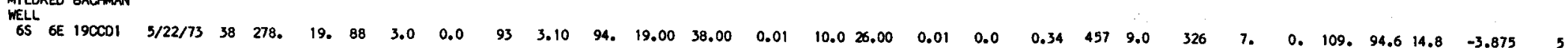
BRUNEAU CEMENTARY

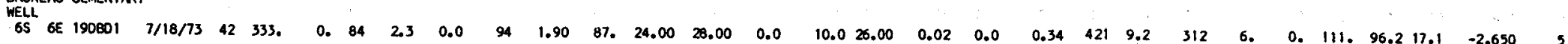

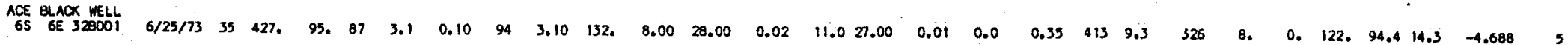

WILBUR WILSON

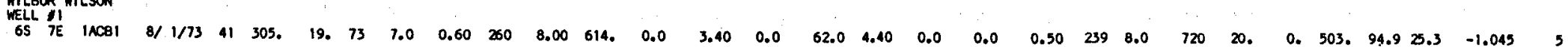
WILBUR WILSON

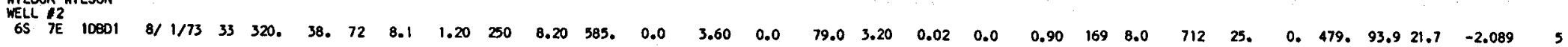

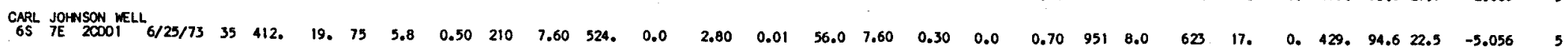

SAN DUNES
FAPS WELL
$6 S$ 
BILL BURGHART

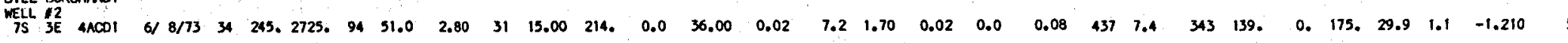

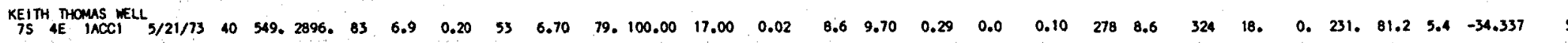
PETE MERRIC PWELL N 1 (1) PETE MERRICX

PETE MERRIC

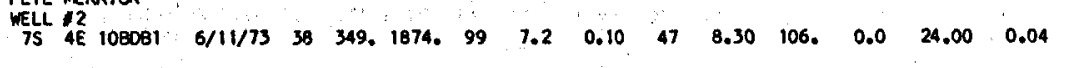

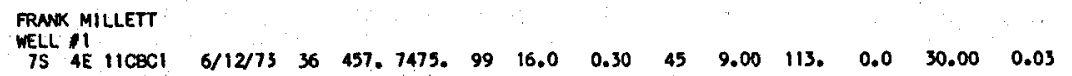

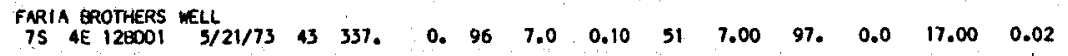

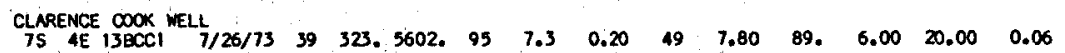

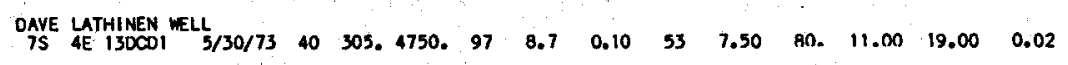
FRAN MILLETT

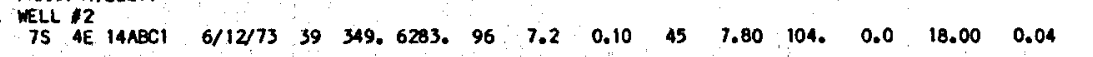

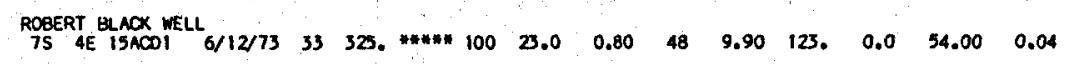

BLAINE RAMLINS

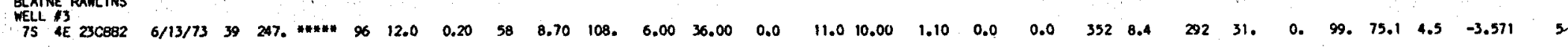

BELL PRANO

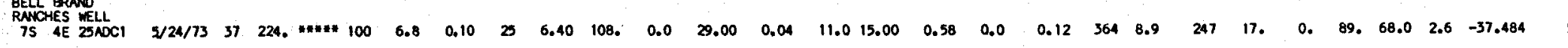
GUTHERIES

$\begin{array}{lllllllllllll}\text { RANCH WELLL } & & & & & & \end{array}$ $\begin{array}{lllllllllllllll}\text { DAVE LATHINEN WELL } & & & & & & & & & \end{array}$

$\begin{array}{llllllllllllll}\text { ACE QANCK } & & & & & & & & \end{array}$

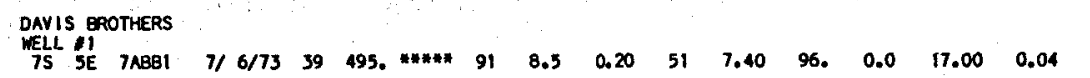

DAVIS EROTHERS

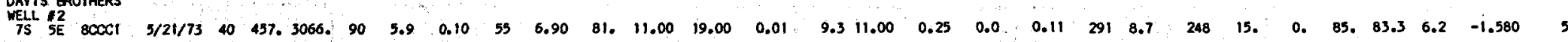

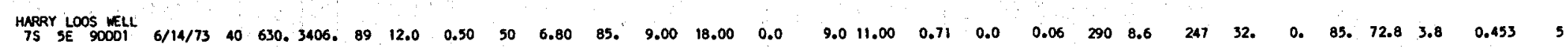

\section{ROY Divis}

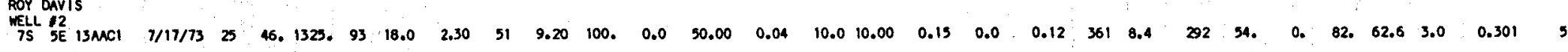

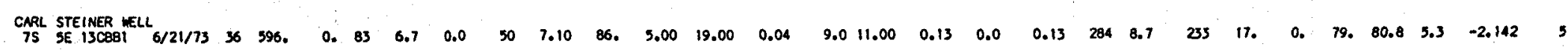

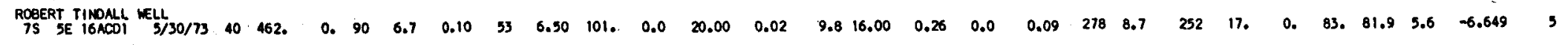


Basic Data Table 1. Chemical Analyses of Thermal water from Selected Springs and wells in Idaho (continued)

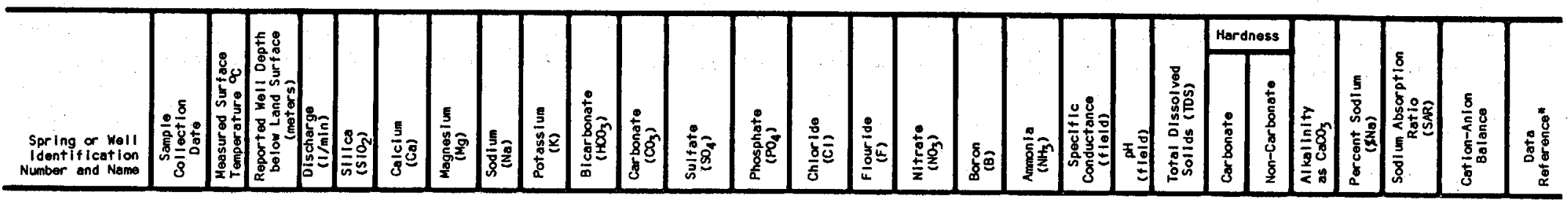

Owyhee County (cont'd.)

BELL BRND

0.0

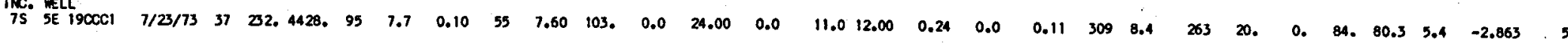

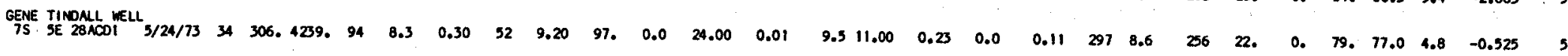

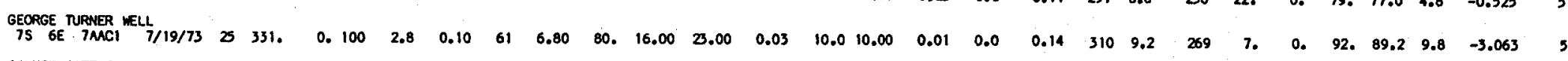
COLYER CATTLE

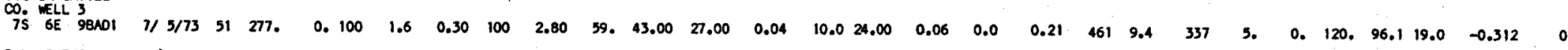
R.L. OMENS

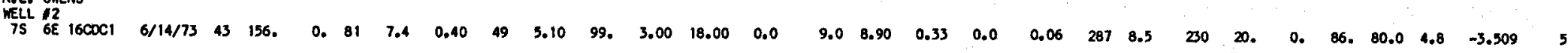
HOT SPRINGS

$\begin{array}{lllllllllllllllllllllllllllllll}\text { TS GE } 2108 C 1 & 6 / 14 / 73 & 43 & 232 . & 0 . & 82 & 5.9 & 0.30 & 54 & 4.60 & 91 . & 7.00 & 18.00 & 0.0 & 9.0 & 12.00 & 0.28 & 0.0 & 0.07 & 287 & 8.5 & 237 & 16 . & 0 . & 86 . & 84.3 & 5.9 & -4.179 & 5\end{array}$ R.L.OWENS

$\begin{array}{lllllllllllllllllllllllllllllll}\text { WS } & \text { 6E } 238881 & 11 / & 0 / 33 & 47 & 0 . & 0 . & 75 & 9.0 & 1.20 & 51 & 6.10 & 110 & 0.0 & 17.00 & 0.0 & 9.0 & 10.00 & 1.30 & 0.0 & 0.0 & 287 & 7.2 & 233 & 27 . & 0 . & 90 . & 75.9 & 4.2 & -0.854 & 1\end{array}$

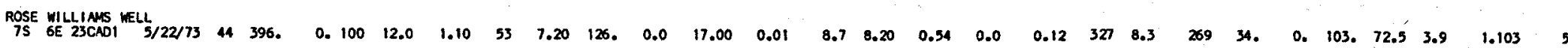
R.L. OUENS

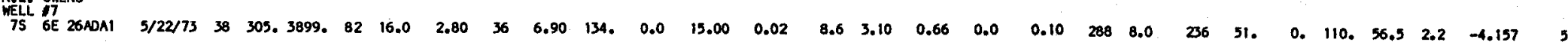

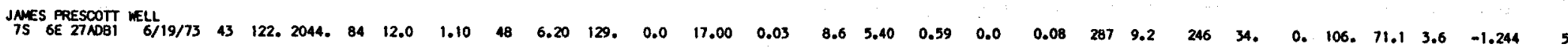

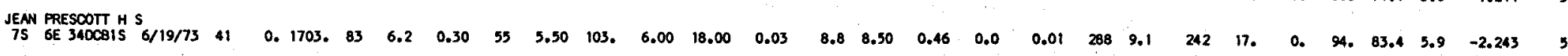

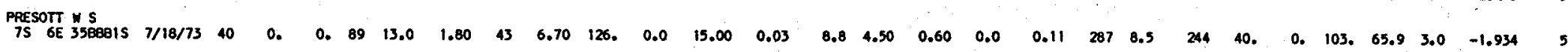

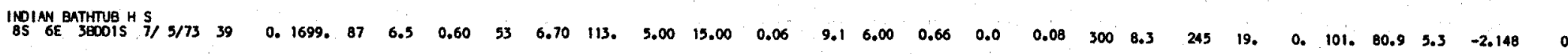

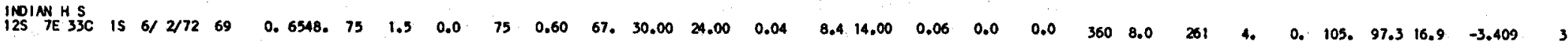

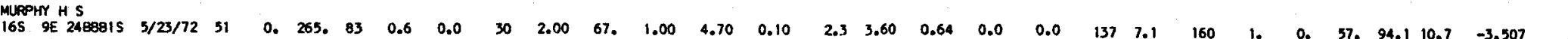

Power county

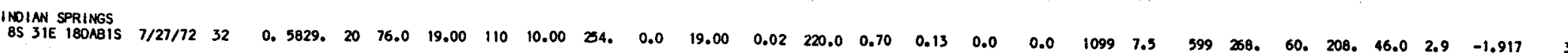




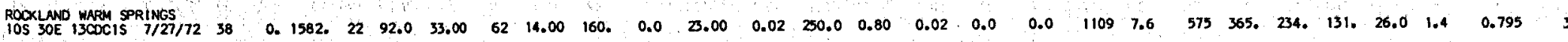

\section{rwin Falls county}

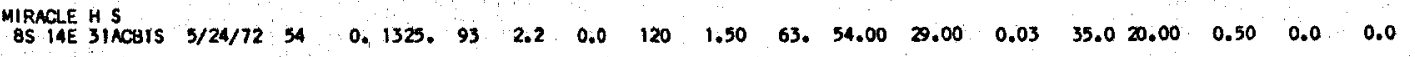

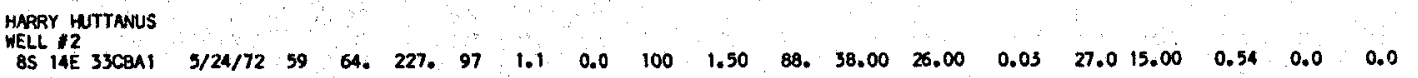

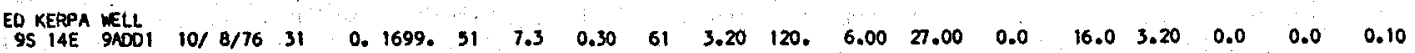
SAM HIGH NO SUNS

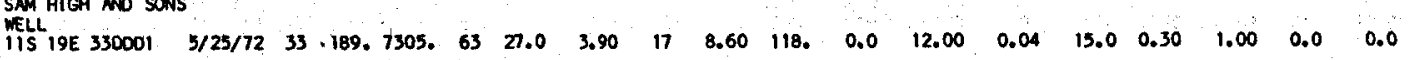
$\begin{array}{lllllllllllllllllllll}\text { Tis } 2063400 C 1 & 9 / 0 / 52 & 32 & 0 . & 0 . & 28 & 43.0 & 8.90 & 11 & 7.40 & 186 . & 0.0 & 13.00 & 0.0 & 5.0 & 0.70 & 0.60 & 0.0 & 0.0\end{array}$

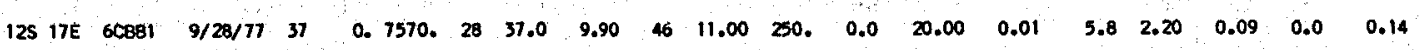

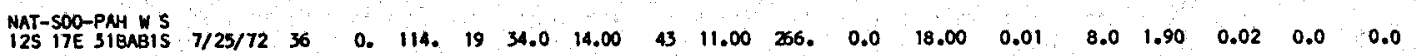

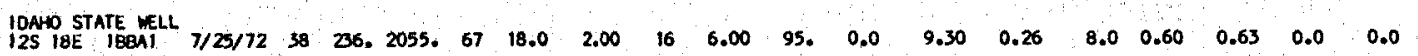
HOLLISTER VILLAGE

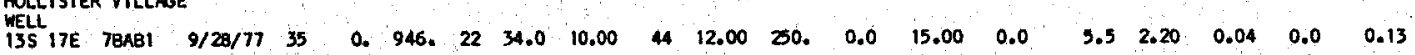

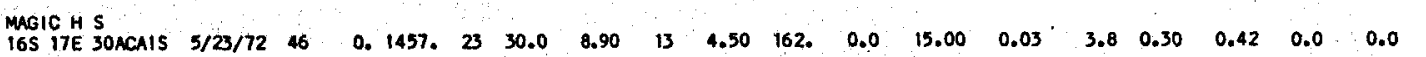
Valley County

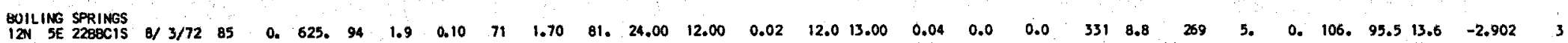
SILVER CREEK

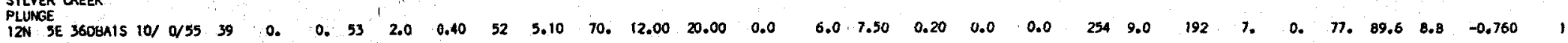

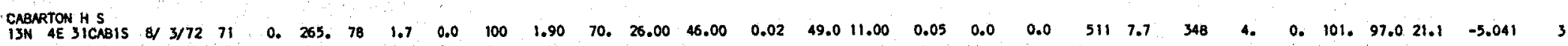

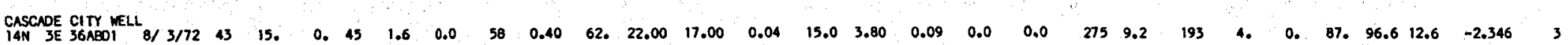

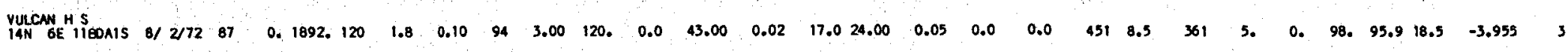

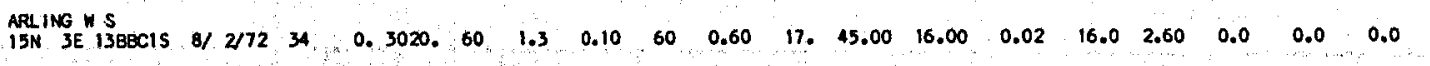

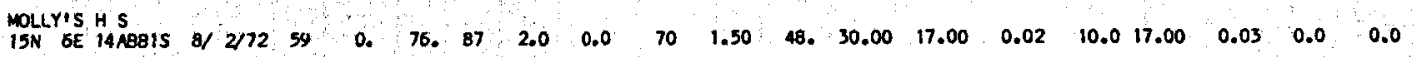

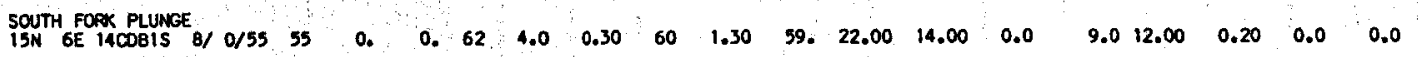

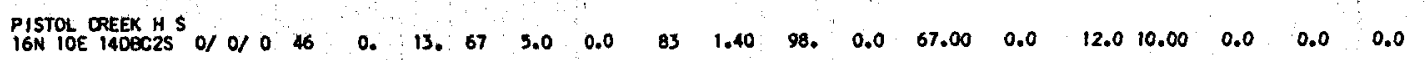

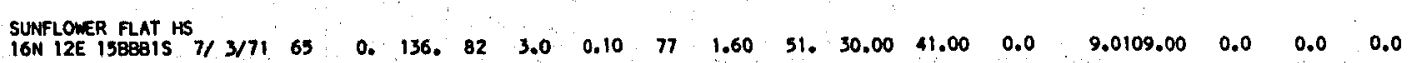

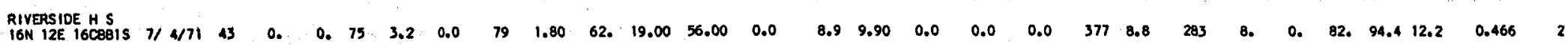

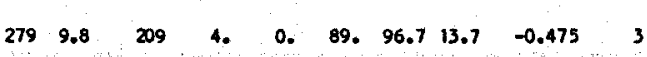
$\begin{array}{llllllllllll}326 & 7.7 \quad 258 & 5 . & 0 . & 89 . & 95.7 & 13.6 & -2.277 & 3\end{array}$ $\begin{array}{lllllllllllllll}284 & 9.3 & 213 & 11 & 0 . & 85.91 .0 & 7.8 & -0.737 & 1\end{array}$ $\begin{array}{lllllllllll}0 & 6.3 & 293 & 12 . & 0 . & 80 . & 92.7 & 10.2 & 0.241 & 2\end{array}$ $\begin{array}{llllllllllll}369 & 8.8 \quad 377 & 8 . & 0 . & 92 . & 94.4 & 11.9 & 42.244 & 12\end{array}$ 
Basic Data Table 1. Chemical Analyses of Thermal water from Selected Springs and wells in Idaho (continued)

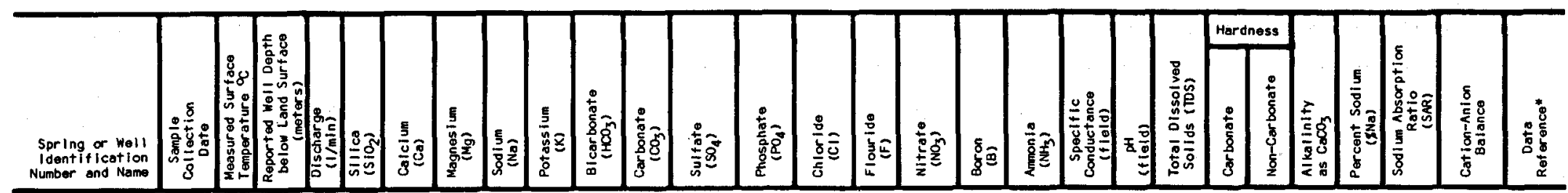

Valley County (cont'd.)

$\begin{array}{lllllllllllllllllllllllllllll}\text { HOLOOVER HSS } \\ 17 N \text { GE } 28 \text { ANIS } & 10 / 18 / 77 & 46 & 0 . & 95 . & 67 & 1.6 & 0.0 & 60 & 1.00 & 62 . & 34.00 & 9.90 & 0.01 & 9.8 & 8.90 & 0.02 & 0.0 & 0.05 & 280 & 9.0 & 222 & 4 . & 0 . & 107 . & 96.1 & 13.1 & -6.623 & 10\end{array}$

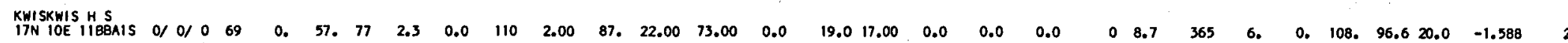

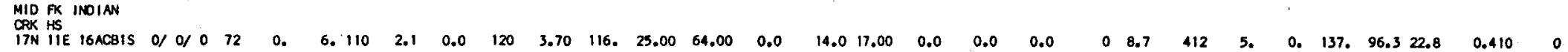

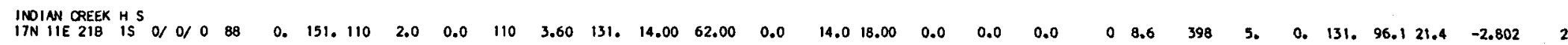

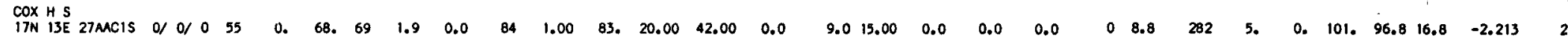

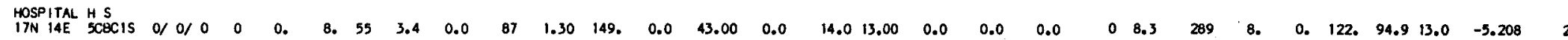

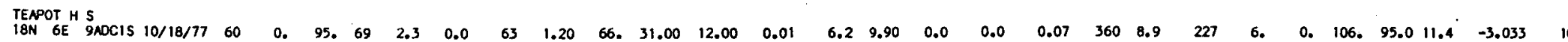

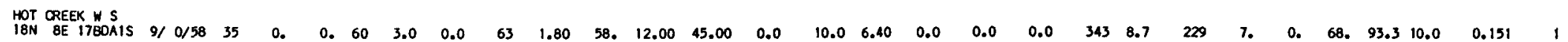
Washington county

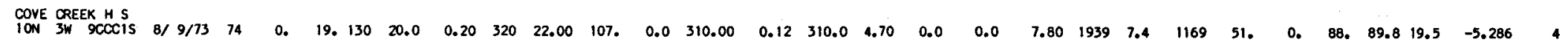

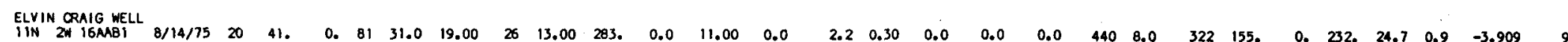

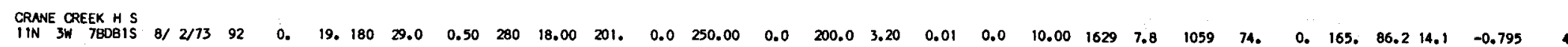

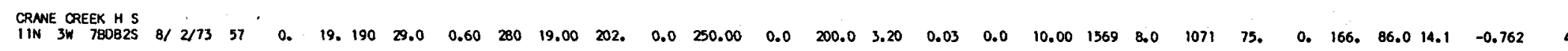

$\begin{array}{lllllllllllllllllllllllllllllll}\text { DOUGLAS MOGINNIS } \\ \text { WELLL } \\ \text { IIN SW } 208001 & 8 / 9 / 73 & 21 & 59 . & 0 . & 54 & 31.0 & 5.30 & 21 & 6.90 & 136 . & 0.0 & 25.00 & 0.0 & 6.8 & 0.50 & 1.80 & 0.0 & 0.00 & 271 & 7.2 & 219 & 99 . & 0 . & 111 . & 29.7 & 0.9 & 0.684 & 4\end{array}$

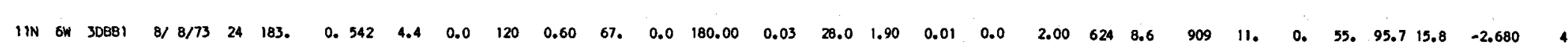

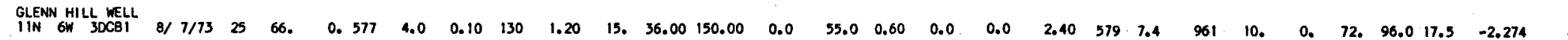

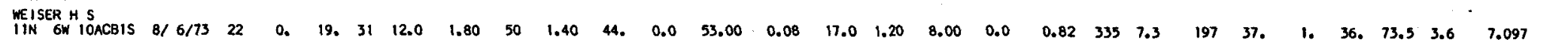
GEOSOLAR GROWERS

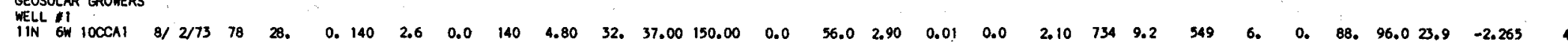





BASIC DATA TABLE 2

ESTIMATED AQUIFER TEMPERATURES, ATOMIC AND MOLAR RATIOS OF SELECTED CHEMICAL CONSTITUENTS, FREE ENERGIES OF FORMATION

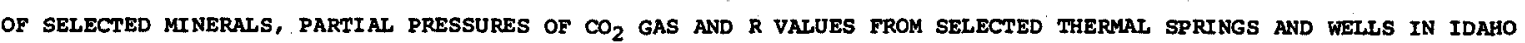

\begin{tabular}{|c|c|c|c|c|c|c|c|c|c|c|c|c|c|c|c|c|c|c|c|c|}
\hline \multirow[b]{3}{*}{$\begin{array}{c}\text { Spring/Nell } \\
\text { Ientiticotion } \\
\text { Number \& N Name }\end{array}$} & \multirow[b]{3}{*}{ 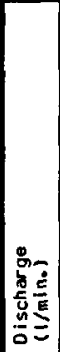 } & \multirow{3}{*}{ 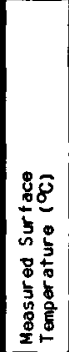 } & \multirow[b]{2}{*}{$\begin{array}{c}\text { Aquif er Temperatures and Percentage of Cold Wat or } \\
\text { Est Imated trom Gochent cal Ther mometers } \\
\text { (see tootnotes) }\end{array}$} & \multicolumn{6}{|c|}{ Atomic Ratios } & \multicolumn{6}{|c|}{ Molar Ratios } & \multicolumn{3}{|c|}{$\begin{array}{l}\text { Free Energles of } \\
\text { Formation of }\end{array}$} & \multirow{2}{*}{ 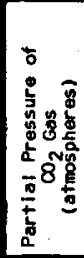 } & \multirow[b]{2}{*}{ 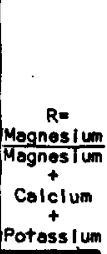 } \\
\hline & & & & 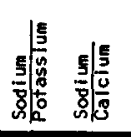 & 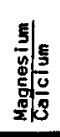 & $\frac{5}{3} \frac{5}{6}$ & 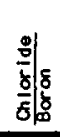 & 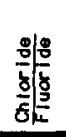 & 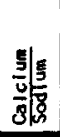 & 占兑 & 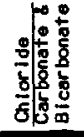 & $\frac{2}{8}$ & 送 & $\frac{\text { : }}{8}$ & 龆 & בְ & 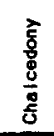 & 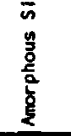 & & \\
\hline & & & $\begin{array}{lllllllllllllll}T_{1} & T_{2} & T_{3} & T_{4} & T_{5} & T_{6} & T_{7} & T_{8} & T_{9} & T_{10} & T_{11} & s_{9} s_{11}\end{array}$ & ${ }_{\mathrm{K}}^{\mathrm{N}} \quad \frac{\mathrm{Na}}{\mathrm{Ca}}$ & $\frac{M g}{C_{a}}$ & $\frac{C_{0}}{F}$ & $\frac{C I}{B}$ & $\frac{C 1}{F}$ & $\frac{C_{0}}{N_{0}}$ & $\frac{\mathrm{Ca}_{3}}{\mathrm{HCO}_{3}}$ & $\begin{array}{l}\frac{\mathrm{Cl}}{\mathrm{Co}_{3}{ }^{+}} \\
\mathrm{HCO}_{3}\end{array}$ & $\frac{\mathrm{NH}_{4}}{\mathrm{CT}}$ & $\frac{\mathrm{NH}_{4}}{\mathrm{~F}}$ & $\frac{\mathrm{C}_{1}}{\mathrm{SO}_{4}}$ & $\frac{d c o}{N o}$ & puart & cooon & $\begin{array}{l}\frac{\Delta G}{\text { mor- }} \\
\text { mous }\end{array}$ & $\mathrm{PCO}_{2}$ & $\frac{m_{g}}{M g+C^{\prime}+k}$ \\
\hline
\end{tabular}

Ade County

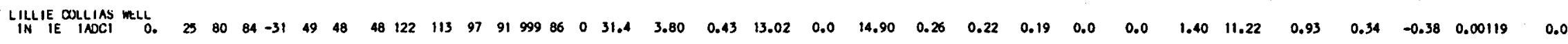

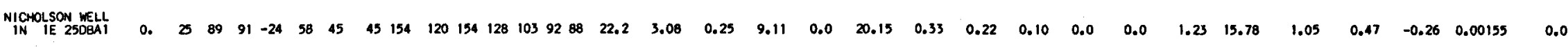

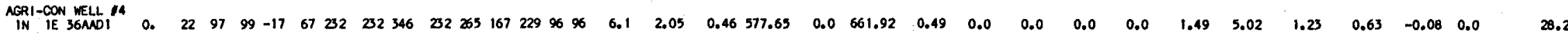

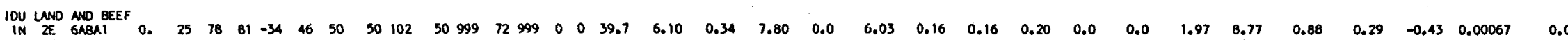

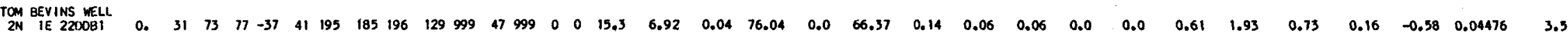
GEORGE WHITMORE GEORGE WHITMORE

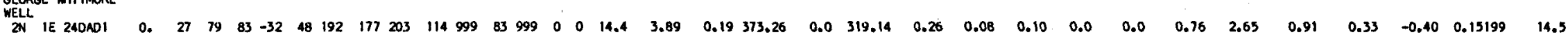

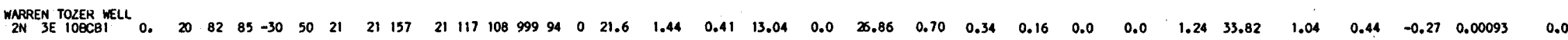
ST. TRANS. DEPT.

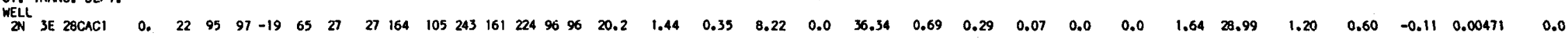

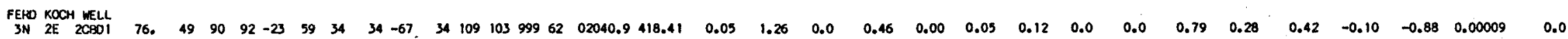

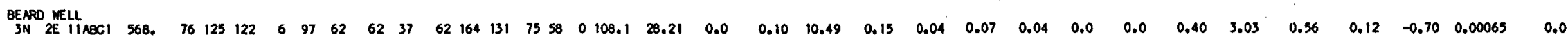
WARM SPRINGS

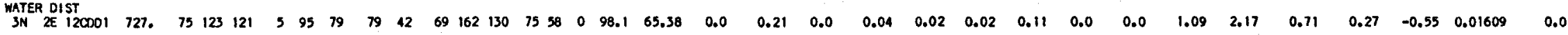

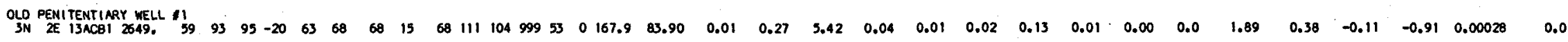
BOISE WATER

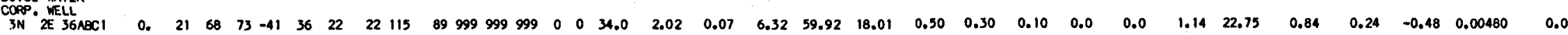

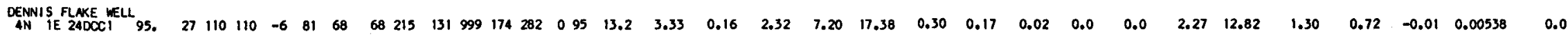

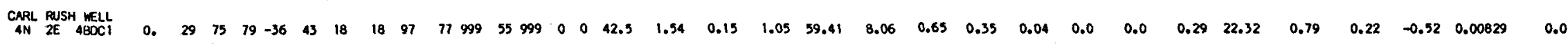
EDWARDS GREENHOUSE

$\begin{array}{lllllllllllllllllllllllllllllllllllllll}\text { AN } 2 E & 29 A C D 1 & 0 . & 47 & 97 & 99 & -17 & 67 & 78 & 78 & 104 & 91 & 126 & 117 & 91 & 70 & 56 & 39.0 & 21.31 & 0.11 & 0.24 & 0.0 & 0.21 & 0.05 & 0.05 & 0.05 & 0.0 & 0.0 & 0.57 & 4.43 & 0.82 & 0.29 & -0.48 & 0.01732 & 7.9\end{array}$

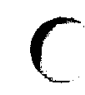


BEN STROLER WELL JULLUS JEKER WELL

JERPAY DANIS

WeEt in 7 incel

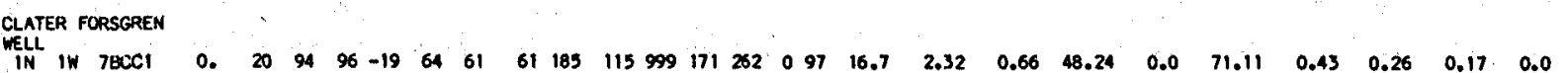

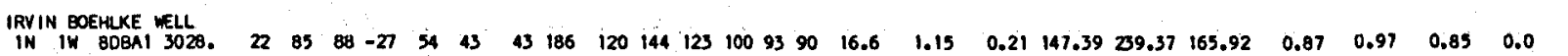

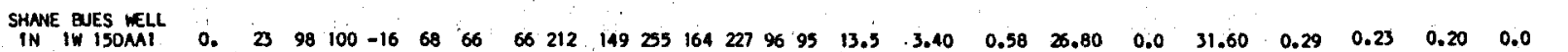
TERRY TLUCEK

in. in 220001

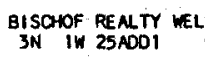

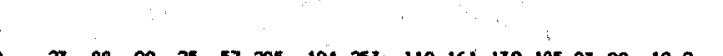

3N 16 25N001.

21. $82 \quad 85-30 \quad 50$

$27 \quad 27$

LETHA EF SHER FELLL

HARRY OHRRERS

is in SABC1

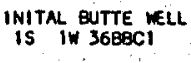

$0.2694 \quad 96-1964$

0. $23 \quad 82 \quad 85-30 \quad 50 \quad 68 \quad 68$

Adams County

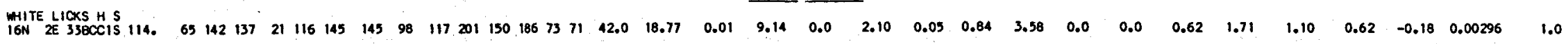

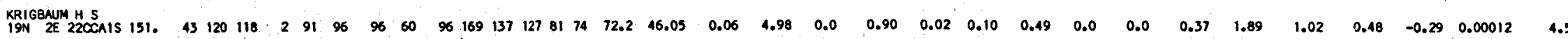

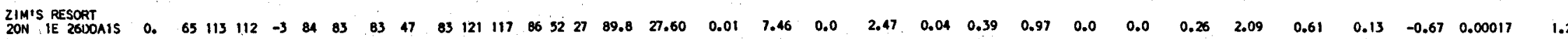

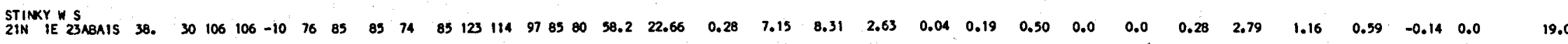
BOUDER OREEK

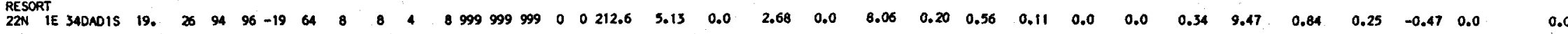

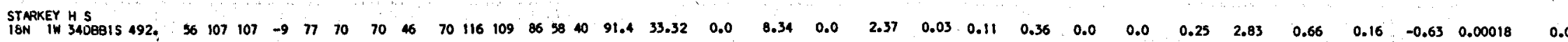
Bannock county

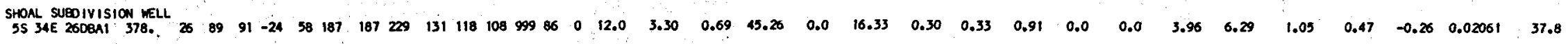

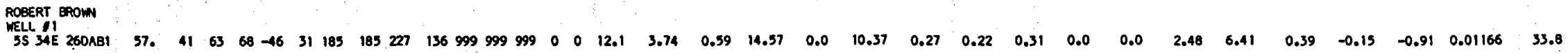

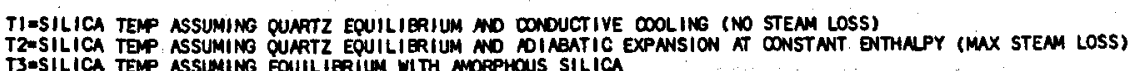

T2=SILICA TEP ASSUMING QUARTZ EQUILIRRIUM MO MOINBATIC EXPANSION AT CONST NTT ENTHNLPY (MAX STEM LOSS) TA=SILICA TEPPERATURE ASSUMING EQUILIBRIUM WITH OHNLEDONY NO CONDUCTIVE DOOLINO (NO STENM LOSS) 
Basic Data Table 2. Estimated Aquifer Temperatures, Atomic and Molar Ratios of Selected Chemical Constituents, Free Energies of Formation of Selected Minerals, Partial Pressures of $\mathrm{CO}_{2}$ Gas and $\mathrm{R}$ Values from Selected Thermal springs and wells in Idaho (continued)

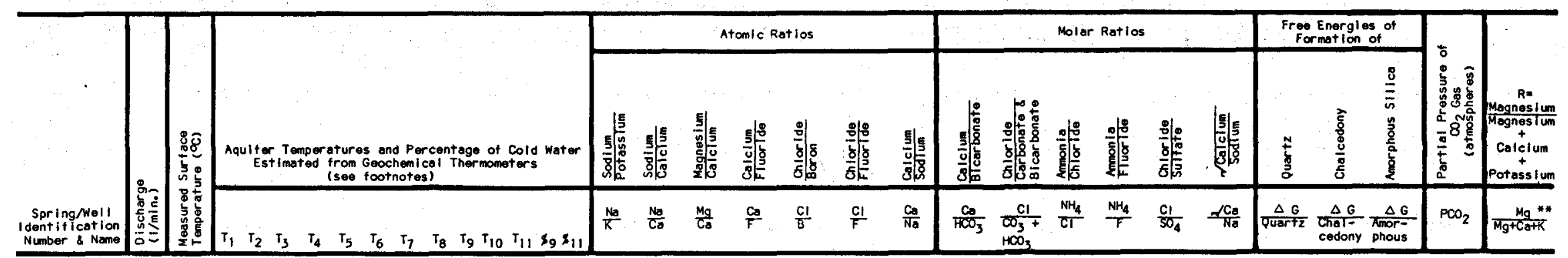

Bannock County (cont'd.)

$\begin{array}{lllllllllllllllllllllllllllllllllll}\text { DEAN MORPIS MELLL } & 0 . & 22 & 12 & 76 & -39 & 40 & 18 & 18 & 233 & 111 & 999 & 999 & 999 & 0 & 0 & 11.6 & 0.52 & 0.34 & 128.63 & 0.0 & 208.58 & 1.94 & 0.47 & 0.28 & 0.0 & 0.0 & 5.00 & 58.59 & 0.87 & 0.27 & -0.44 & 0.00884 & 0.0\end{array}$

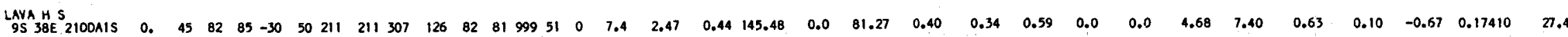

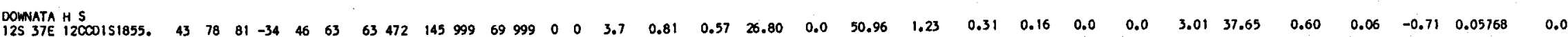

\section{Bear Lake County}

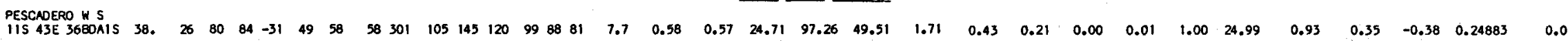

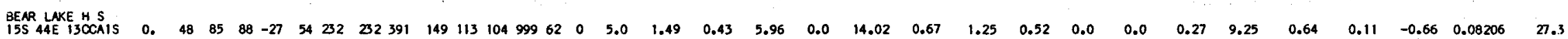

\section{Bingham County}

$\begin{array}{lllllllllllllllllllllllllllllllll}\text { YANOELL SPRINGS } \\ \text { 3S 37E 310881S 568. } & 32 & 67 & 72 & -43 & 35 & 34 & 34 & 382 & 134 & 999 & 80 & 999 & 0 & 0 & 5.2 & 0.26 & 0.38 & 17.27 & 176.70 & 79.01 & 3.91 & 0.95 & 0.20 & 0.0 & 0.0 & 0.24 & 63.93 & 0.62 & 0.05 & -0.69 & 0.02025 & 0.0\end{array}$

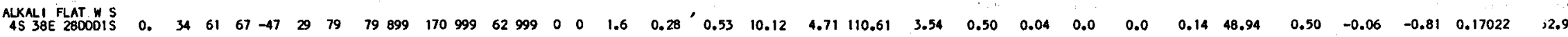

\section{Blaine county}

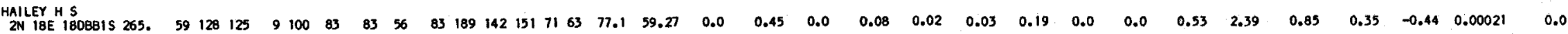

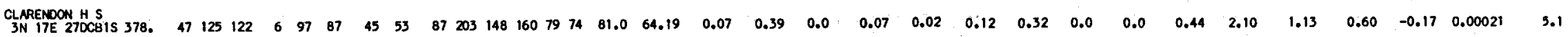

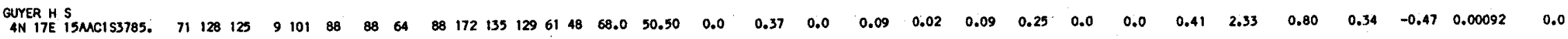

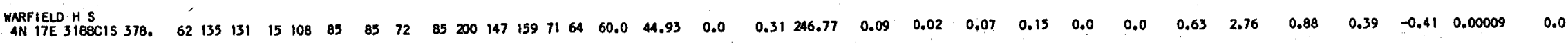

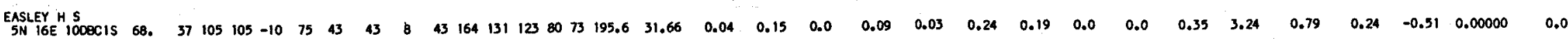

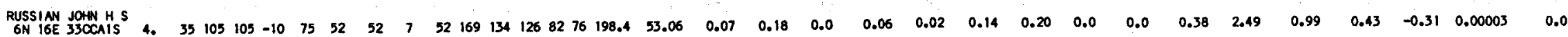

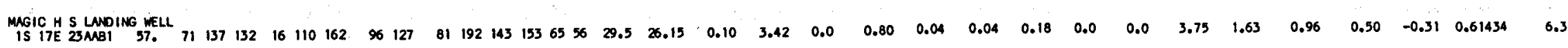

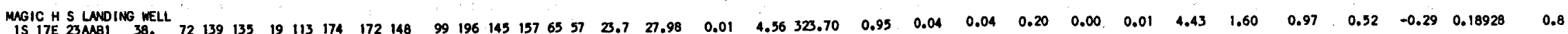

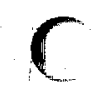




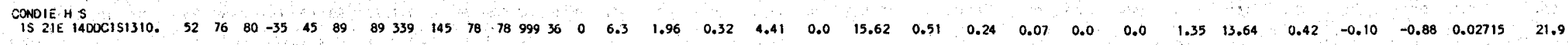

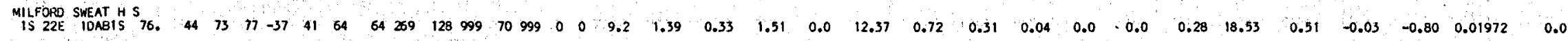

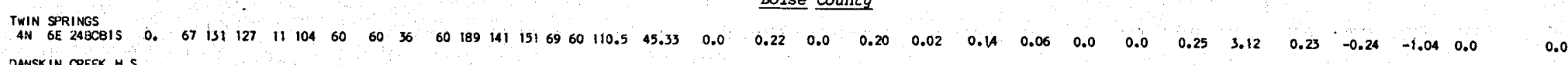

Boise county

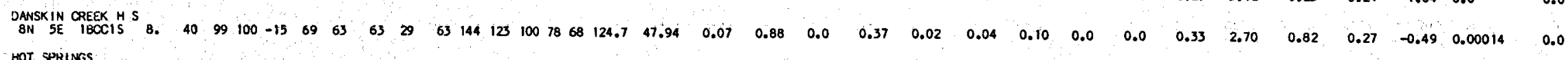
HoT spinings

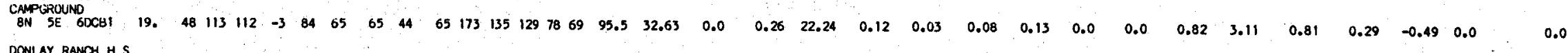

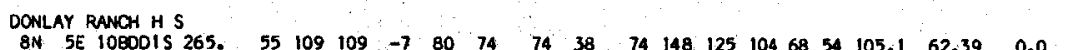

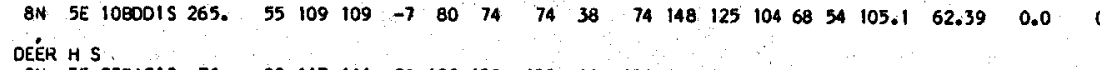

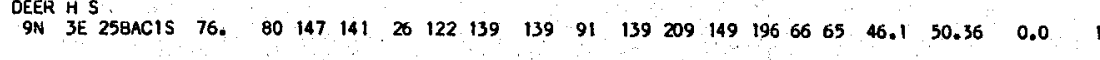

$\begin{array}{llllllll}0.0 & 0.16 & 0.02 & 0.04 & 0.36 & 0.0 & 0.0\end{array}$

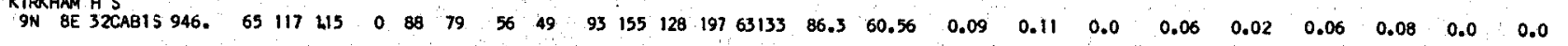

BONNEVILLE H S

$\begin{array}{lllll}0.07 \quad 0.23 & 0.0 & 0.06 \\ 0 & & 0 & 0\end{array}$

FAL CXEEK

Bonneville County

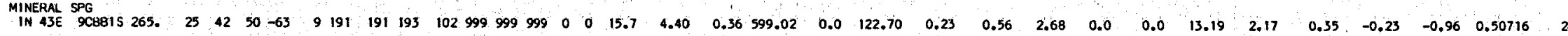

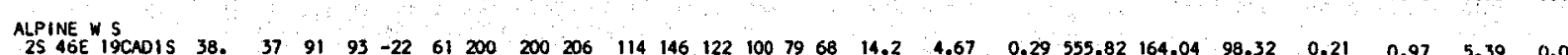

LEWIS ROTHWELL

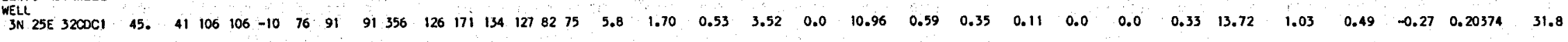
BUTTE CITY

WN 271 SABB

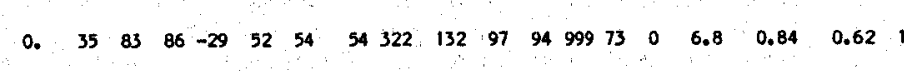

\section{Camas County}

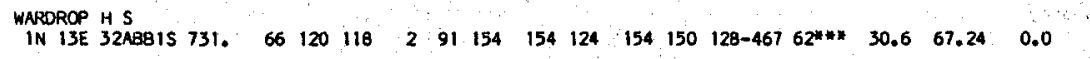

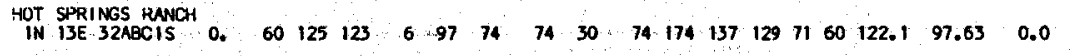

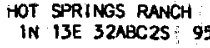

$\begin{array}{lllllllllll}0.67 & 0.0 & 0.16 & 0.01 & 0.04 & 0.10 & 0.0 & 0.0 & 1.15 & 2.52\end{array}$

$\begin{array}{llllllllllllllll}0.83 & 434.13 & 0.13 & 0.01 & 0.03 & 0.12 & 0.0 & 0.0 & 1.40 & 2.05\end{array}$

$\begin{array}{lllllllllllllll}0.93 & 0.0 & 0.14 & 0.01 & 0.03 & 0.11 & 0.0 & 0.0 & 1.29 & 2.05\end{array}$

JabC3s

IN $15 E$ IANOA

ELK CREEK HS

ELK CREEK $H S$

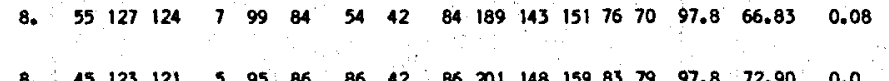

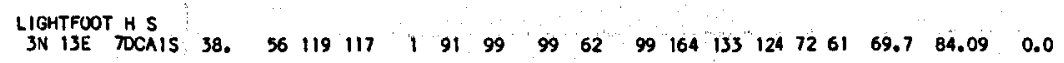

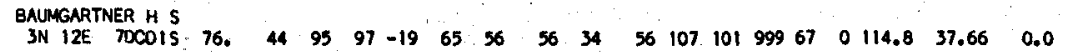

$\begin{array}{llllllll}0.95 & 0.0 & 0.18 & 0.01 & 0.03 & 0.11 & 0.0\end{array}$

$1.40 \quad 2.29$

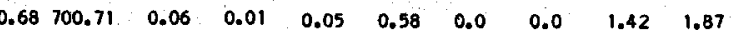

$\begin{array}{lllllllllll}0.77 & 500.50 & 0.07 & 0.01 & 0.04 & 0.40 & 0.01 & 0.01 & 1.42 & 1.93\end{array}$

$\begin{array}{lllllllllll}0.76 & 522.26 & 0.06 & 0.01 & 0.03 & 0.41 & 0.00 & 0.00 & 1.35 & 1.85\end{array}$

$\begin{array}{llllllllll}0.66 & 44.31 & 0.06 & 0.01 & 0.02 & 0.21 & 0.0 & 0.0 & 1.57 & 1.83\end{array}$

$\begin{array}{llllllllll}1.24 & 65.28 & 0.18 & 0.03 & 0.05 & 0.28 & 0.0 & 0.0 & 1.85 & 3.36\end{array}$

$\begin{array}{lllll}0.77 & 0.30 & -0.50 & 0.00091 \quad 0.0\end{array}$

$\begin{array}{lllllll}0.51 & 0.02 & -0.78 & 0.0 & 0.0\end{array}$

$\begin{array}{llllllllll}0.32 & -0.15 & -0.95 & 0.00000 & 0.0\end{array}$

$\begin{array}{lllll}0.39 & -0.08 & -0.89 & 0.0 & 9.8\end{array}$

$\begin{array}{llllll}0.81 & 0.31 & -0.48 & 0.00006 & 5.8\end{array}$

$\begin{array}{llll}0.82 & 0.32 & -0.47 & 0.00012\end{array}$

$\begin{array}{lllll}0.99 & 0.45 & -0.32 & 0.00011\end{array}$

$\begin{array}{llll}0.80 & 0.30 & -0.49 & 0.0\end{array}$

$\begin{array}{llll}0.80 & 0.27 & -0.50 & 0.0\end{array}$ 
Basic Data Table 2. Estimated Aquifer Temperatures, Atomic and Molar Ratios of Selected Chemical Constituents, Free Energies of Formation of Selected Minerals, Partial Pressures of $\mathrm{CO}_{2}$ Gas and $\mathrm{R}$ Values from Selected Thermal springs and Wells in Idaho (continued)

\begin{tabular}{|c|c|c|c|c|c|c|c|c|c|c|c|c|c|c|c|c|c|c|c|c|}
\hline & & & & & & tomic & tios & & & & & Molor & Ratios & & & $\begin{array}{r}\text { Free } \\
\text { Fo }\end{array}$ & $\begin{array}{l}\text { Enorg } \\
\text { rmation }\end{array}$ & & & \\
\hline & & $\frac{8}{85}$ & 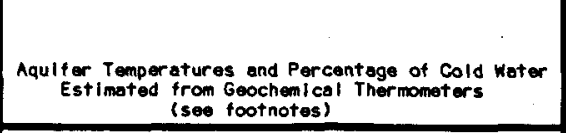 & 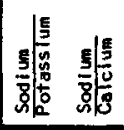 & 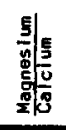 & $\frac{5}{3} \frac{5}{\frac{5}{6}}$ & 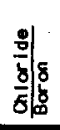 & $\frac{8}{\frac{8}{6}}$ & 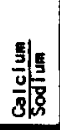 & 氛 & 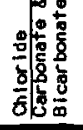 & $\frac{0}{20}$ & 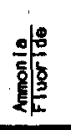 & 就能 & 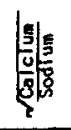 & $\frac{1}{3}$ & $\begin{array}{l}\frac{1}{8} \\
\frac{0}{0} \\
\frac{0}{0} \\
\frac{5}{5}\end{array}$ & 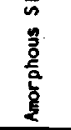 & 年 & $\begin{array}{l}\text { Mogneslum } \\
\text { Mognesium } \\
+ \\
\text { Calium } \\
+ \\
\text { Potessium }\end{array}$ \\
\hline $\begin{array}{l}\text { Spring Nell } \\
\text { identification } \\
\text { Number \& Neme }\end{array}$ & 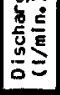 & 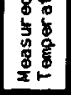 & $\begin{array}{llllllllllllll}T_{1} & T_{2} & T_{3} & T_{4} & T_{5} & T_{6} & T_{7} & T_{8} & T_{9} & T_{10} & T_{11} & s_{9} x_{11}\end{array}$ & $\frac{N_{0}}{K} \quad \frac{N_{0}}{C_{0}}$ & $\frac{\mathrm{Mg}}{\mathrm{C}_{0}}$ & $\frac{C_{0}}{F}$ & $\frac{a t}{b}$ & $\frac{C I}{F}$ & $\frac{\infty}{N a}$ & $\frac{c_{0}}{H \infty_{3}}$ & $\frac{C 1}{\infty_{3}+}$ & $\frac{N+4}{C T}$ & $\frac{N+H_{4}}{F}$ & $\frac{\mathrm{Cl}}{\mathrm{SO}_{4}}$ & $\frac{d c a}{N a}$ & $\frac{\Delta G}{\text { puartz }}$ & 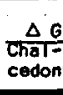 & $\begin{array}{l}\frac{\Delta 6}{\text { Kmor- }} \\
\text { phous }\end{array}$ & $\mathrm{PCO}_{2}$ & $\frac{\mathrm{Mg}_{\mathrm{g}}^{* *}}{\mathrm{Mg}+C+\mathrm{K}}$ \\
\hline
\end{tabular}

\section{Camas County (cont'd.)}

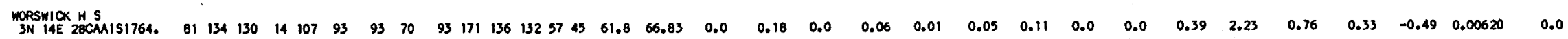

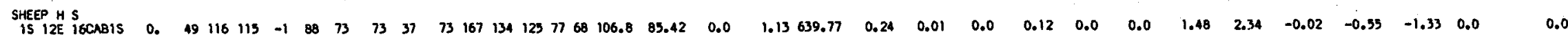

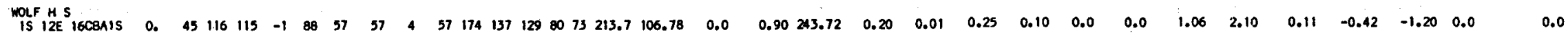

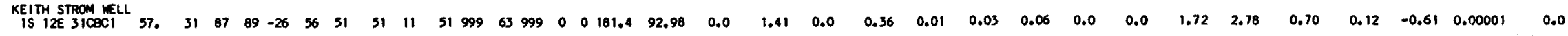

N LEE BARRON

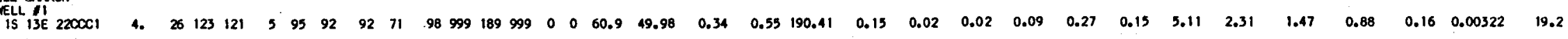
LEE GAPRON

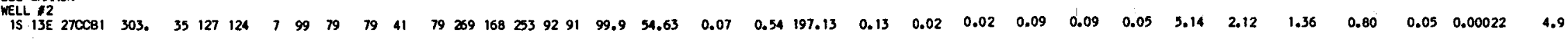
LEF BARRON

$\begin{array}{lllllllllllllllllllllllllllllllll} & & & \end{array}$

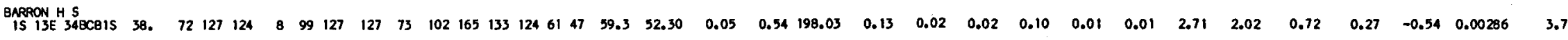

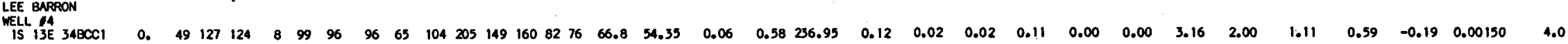
FAIRFIELD

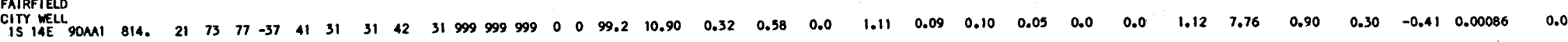

LEONARD TIEGS

Canyon County

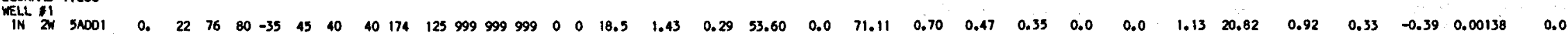

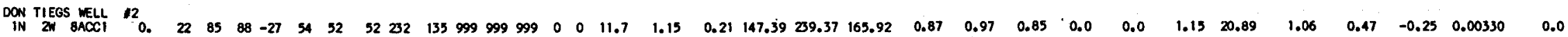

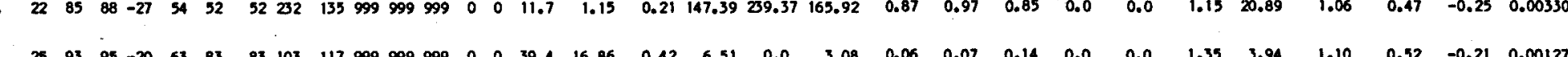

MELBA CITY WELL

$0.0 \quad 1.35 \quad 3.94$

MESLEY SOHOBER NELL

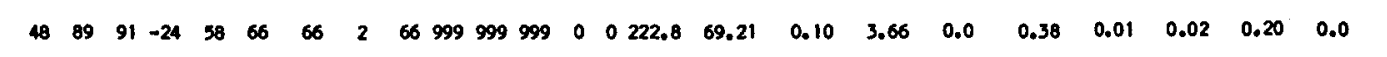

CANNON FARMS

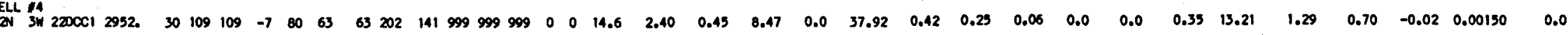

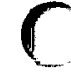


CALOWELL MUNC.

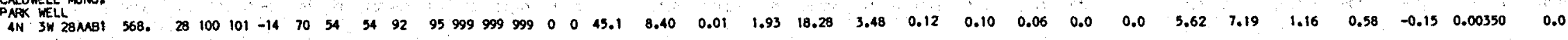
CALDUELL CITH

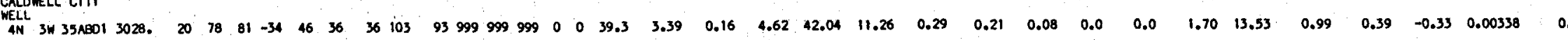

\section{Caribou Count}

SAOKFOOT

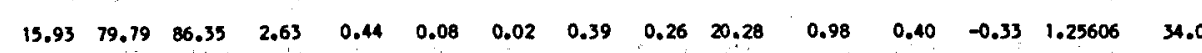

RIVA 40 SOE

BLACXFOOT

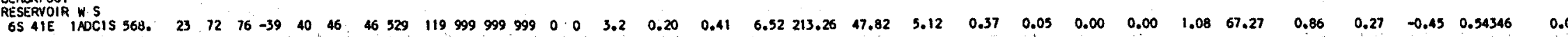

CORERA OREEK

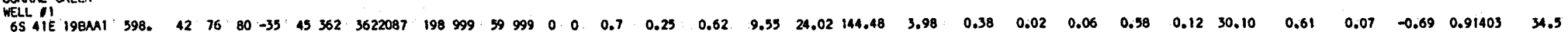
CORRAL CREEK

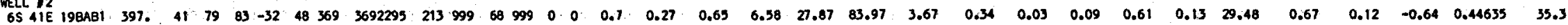
CORRR CREEK

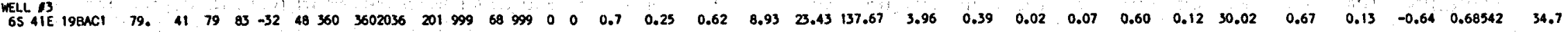
COAPR OREEK

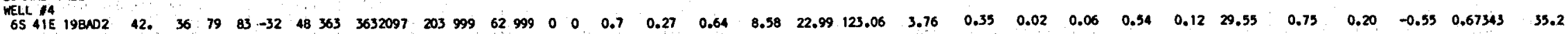

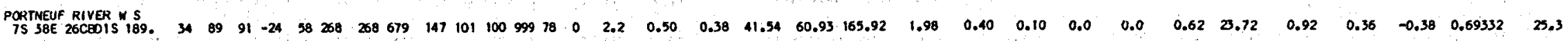

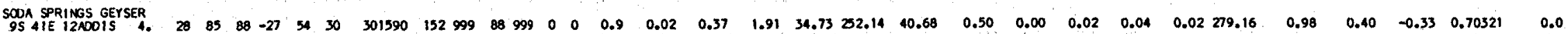

\section{SIX S RUNaH}

\section{Cassia county}

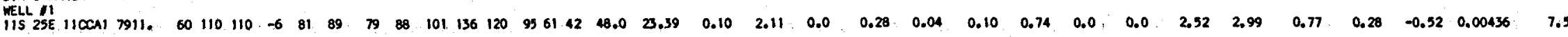
Six S RUNCH

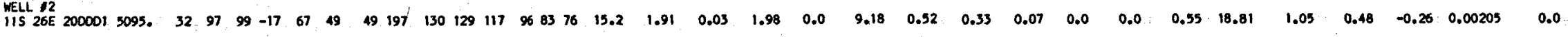

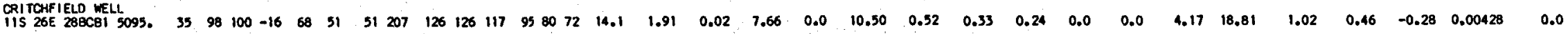

C\& Y RANCH

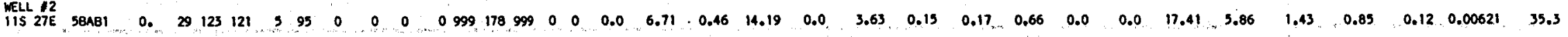

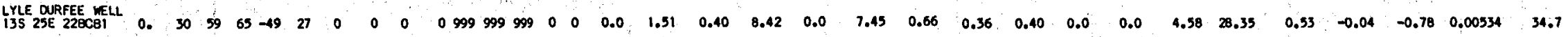

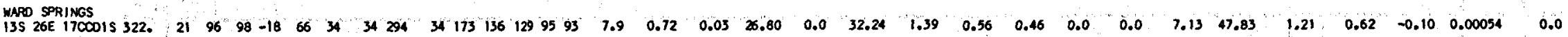

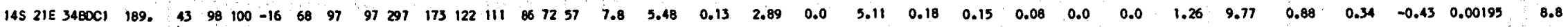

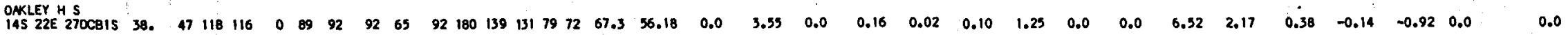

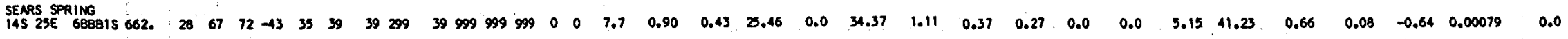

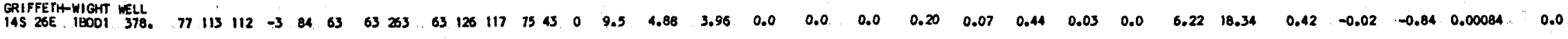

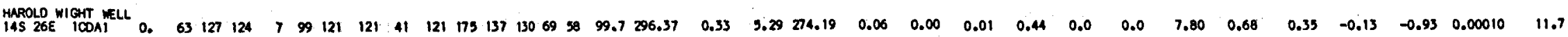


Basic Data Table 2. Estimated Aquifer Temperatures, Atomic and Molar Ratios of Selected Chemical Constituents, Free Energies of Formation

of Selected Minerals, Partial Pressures of $\mathrm{CO}_{2}$ Gas and $\mathrm{R}$ values from Selected Thermal Springs and Wells in Idaho (continued)

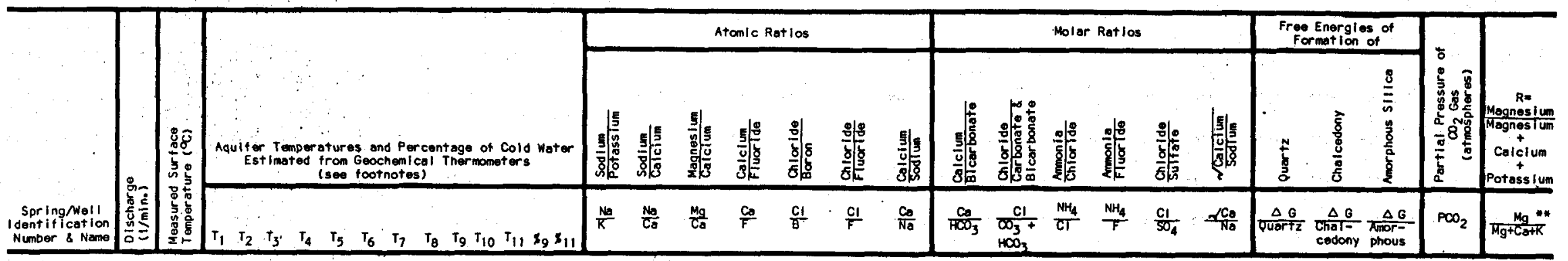

HAROLO WARD

Cassia county (cont'd.)

$\begin{array}{llllllllllllllllllllllllllllllllllll}145278 & 180061 & 3399 . & 24 & 131 & 127 & \text { i1 } & 104 & 201 & 180 & 256 & 165.999 & 213 & 999 & 0 & 0 & 10.0 & 5.39 & 0.07 & 146.17 & 0.0 & 23.70 & 0.19 & 0.64 & 3.88 & 0.0 & 0.0 & 35.32 & 5.01 & 1.59 & 1.00 & 0.28 & 0.00317 & 4.9\end{array}$ MOKRIS MITCHELL

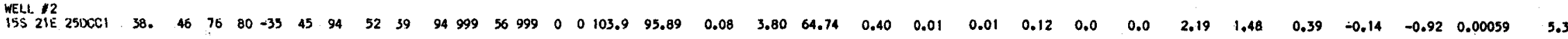
HAROLO WARO

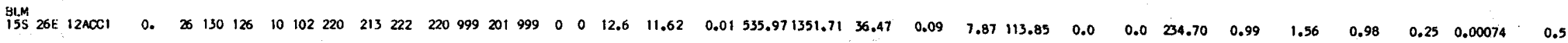

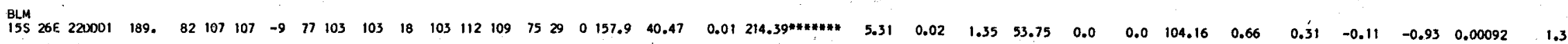

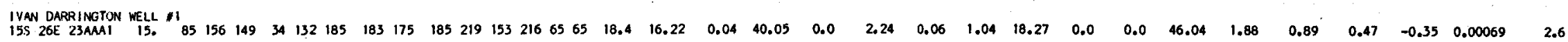

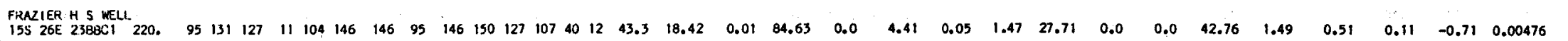

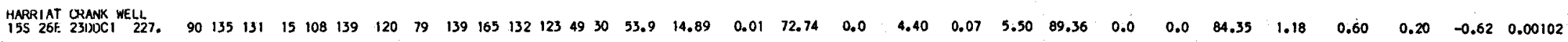
IVAN DARRINGTON

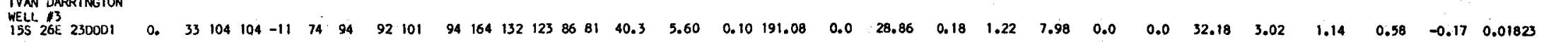

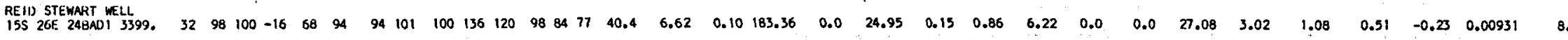

IVAN DARRINGTUN

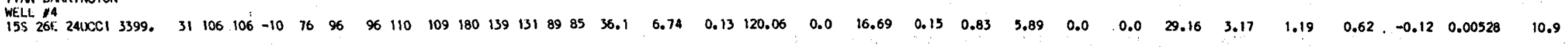

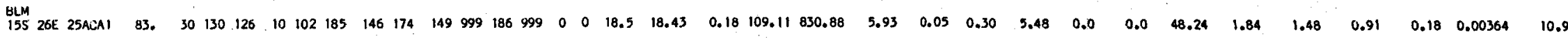

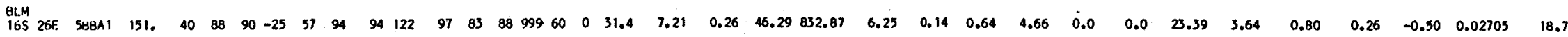

\section{Clark County}

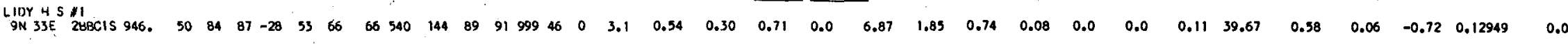

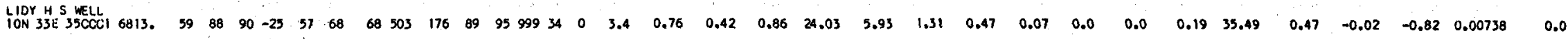




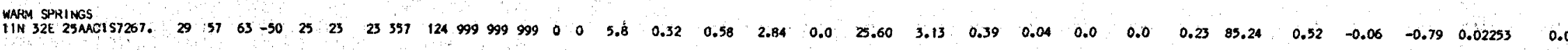
custer county

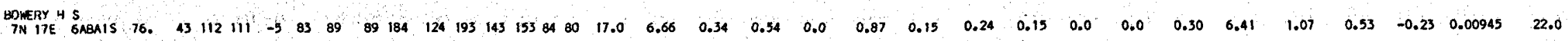

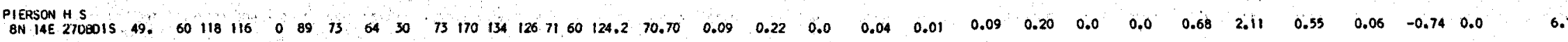

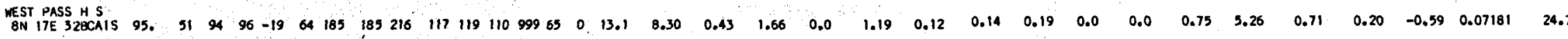

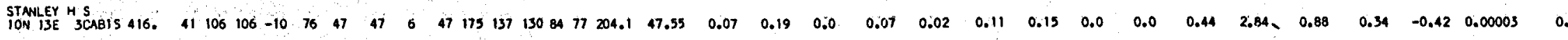

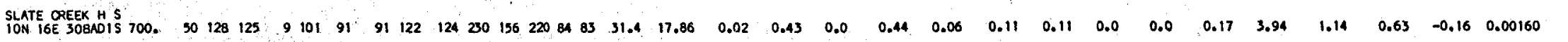

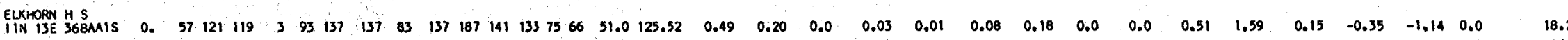

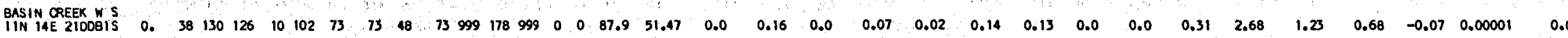

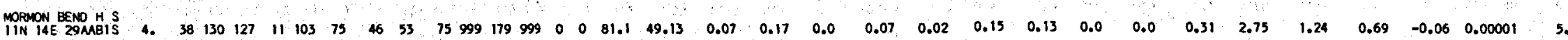

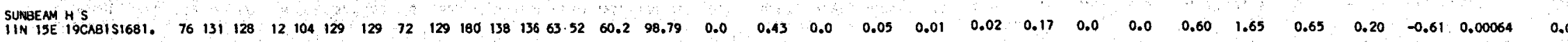

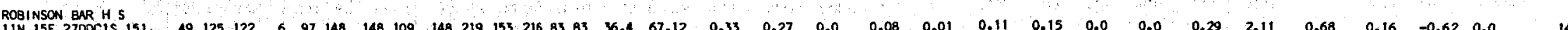

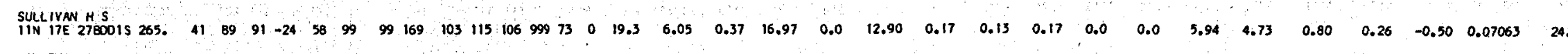

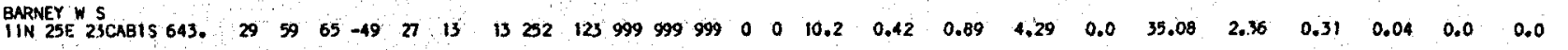

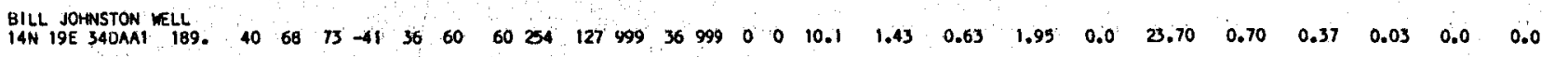

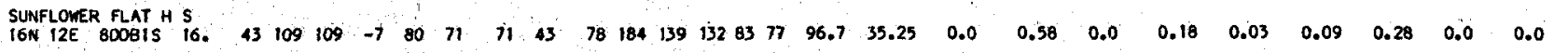
THOMAS OREEX

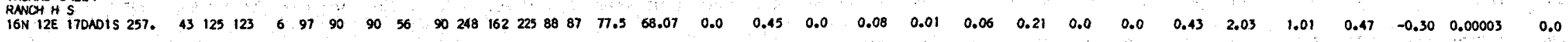




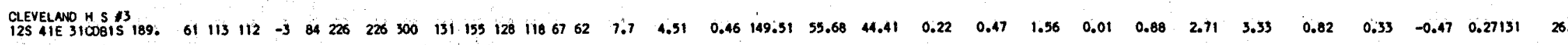

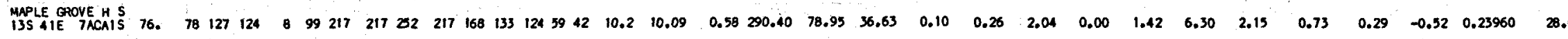

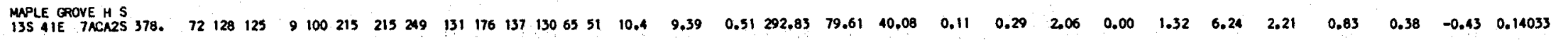

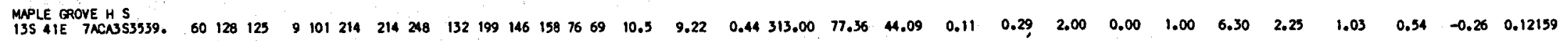

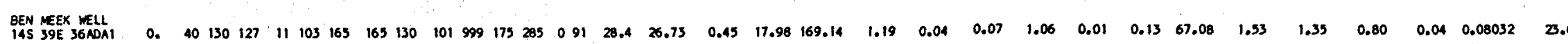

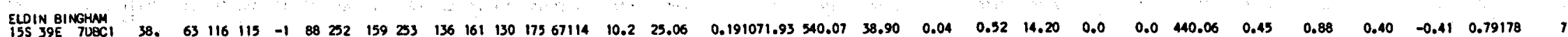

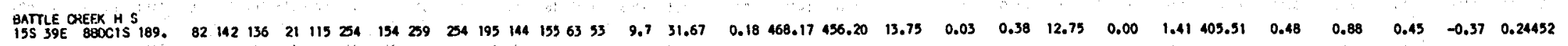

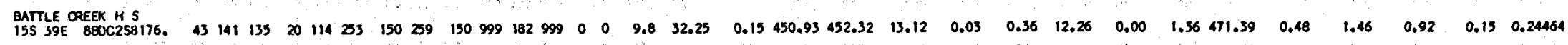

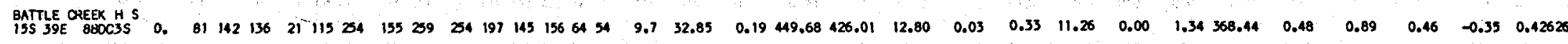

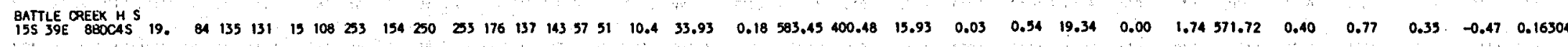

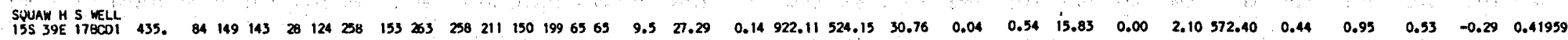

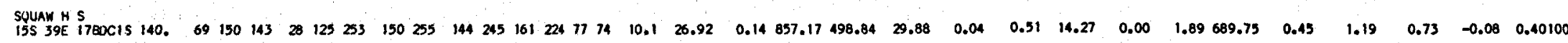

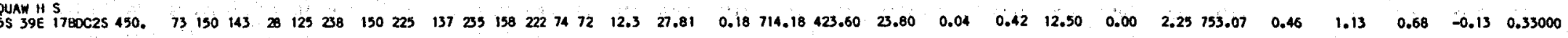
MYRON FONNESBECX

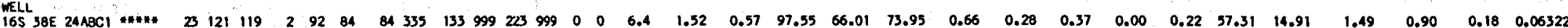

Fremont County

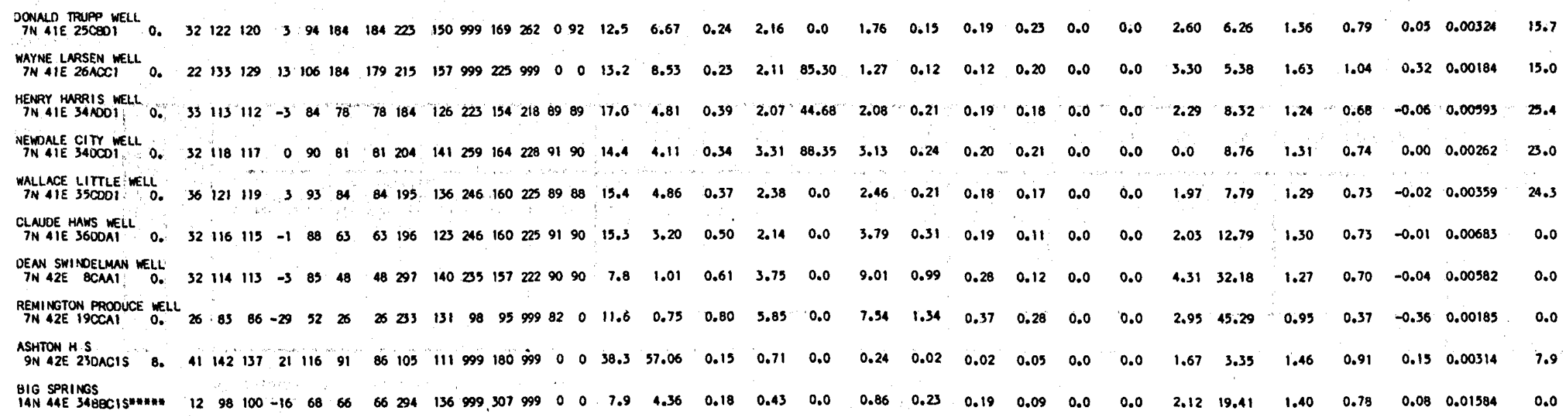


Basic Data Table 2. Estimated Aquifer Temperatures, Atomic and Molar Ratios of Selected Chemical Constituents, Free Energies of Formation of Selected Minerals, Partial pressures of $\mathrm{CO}_{2}$ Gas and $\mathrm{R}$ Values from Selected Thermal springs and wells in Idaho (continued)

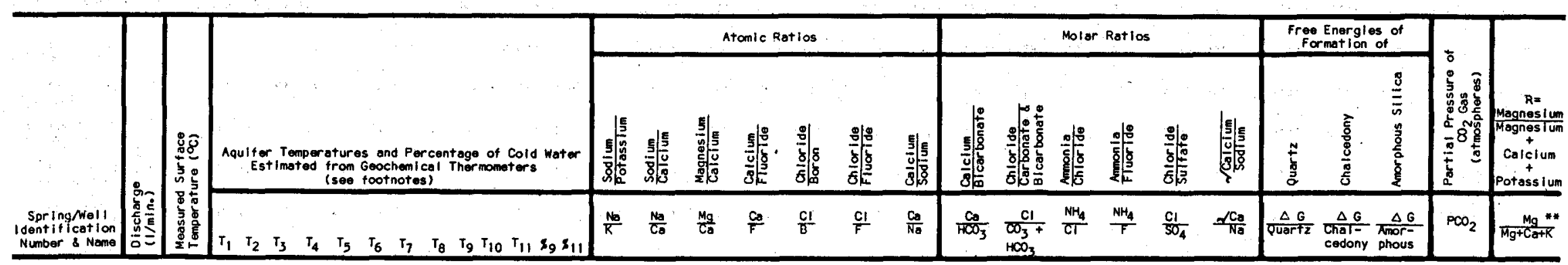

Gem county

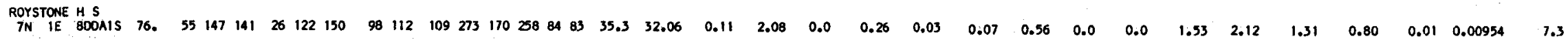

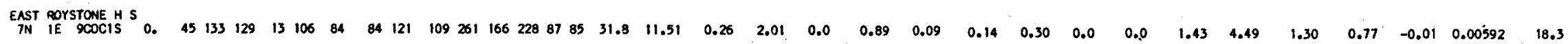

\section{Gooding County}

J. SHANNON MELL

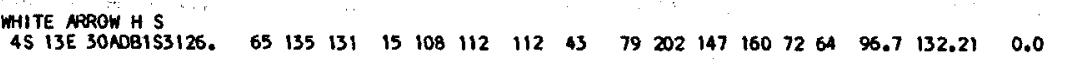

DAVE ARCMER MELL

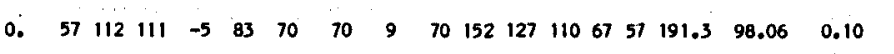

\section{Idaho County}

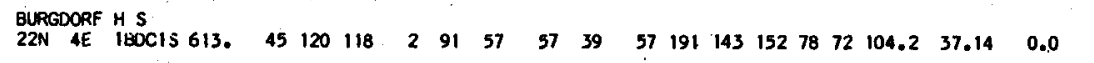

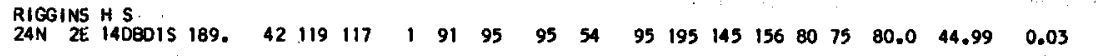

$\begin{array}{lllllllllllllll}0.80 & 0.0 & 0.55 & 0.03 & 0.18 & 0.08 & 0.0 & 0.0 & 0.45 & 3.55 & 1.11 & 0.58 & -0.19 & 0.00017 & 0.0\end{array}$

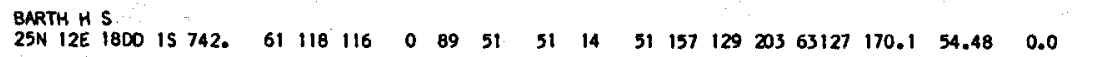
$\begin{array}{lllllllllllllll}2.04 & 0.0 & 1.40 & 0.02 & 0.86 & 0.38 & 0.0 & 0.0 & 0.07 & 1.79 & 1.08 & 0.54 & -0.22 & 0.0 & 2.0\end{array}$

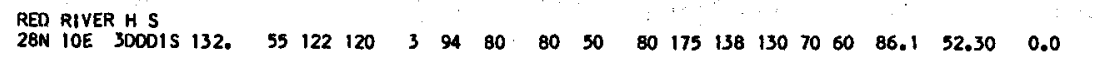
WEIR OREEX H.S

$\begin{array}{llllllllllllll}0.34 & 0.0 & 0.13 & 0.02 & 0.05 & 0.08 & 0.0 & 0.0 & 1.84 & 2.91 & 0.53 & 0.05 & -0.75 & 0.00002\end{array}$ $\begin{array}{llllllllllllll}0.10 & 0.0 & 0.06 & 0.02 & 0.11 & 0.10 & 0.0 & 0.0 & 0.27 & 2.33 & 0.88 & 0.38 & -0.41 & 0.00008\end{array}$

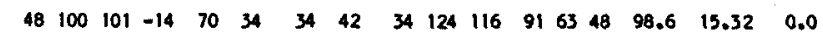
$0.51 \quad 0.0 \quad 0.11$

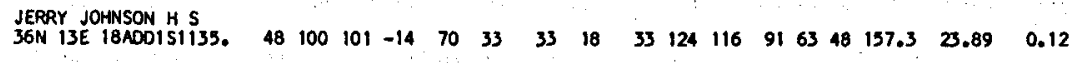

\section{Jefferson County}

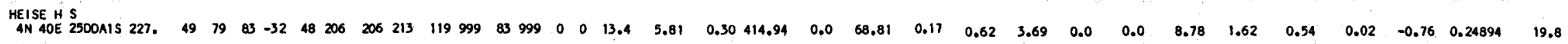
ROYAL CATFISH

Jerome County

INOUSTRY 290881

$\begin{array}{llllllllllllll}0.78 & 0.0 & 0.09 & 0.01 & 0.03 & 0.18 & 0.0 & 0.0 & 2.55 & 1.74 & 0.95 & 0.41 & -0.35 & 0.00010\end{array}$ 
Lemhi $\underline{\text { County }}$

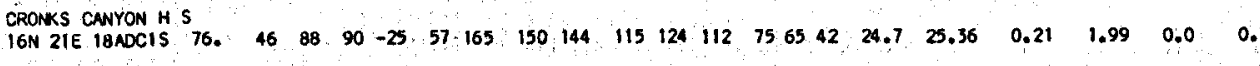

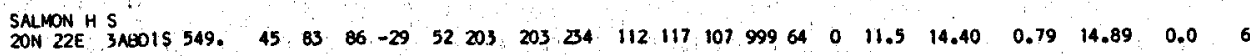

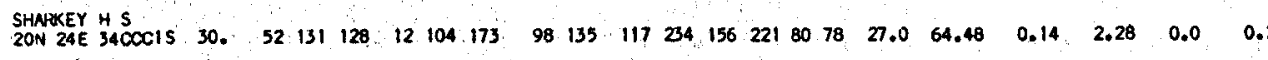

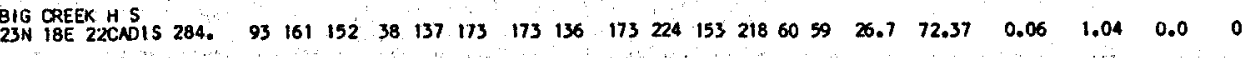

\section{Madison County}

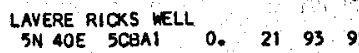

MARK RICKS WELL
5N $40 E$ SBCOI

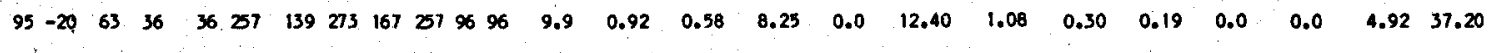

PAULINE SMITH WELL

0. $26101102-14$ iो

GREE CANYON HS

WALZ ENTER.

INC. WELL 4 WIEACCI

WANDA WOOG

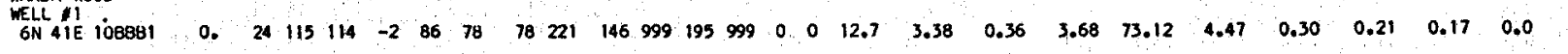

WANDA WOOD

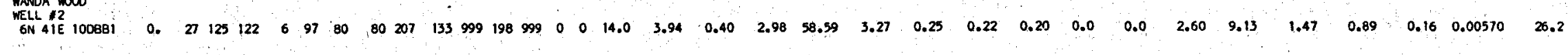

\section{Oneida county}

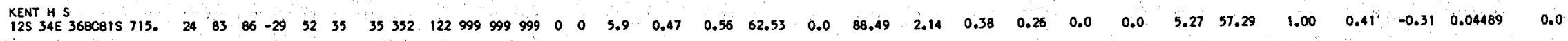

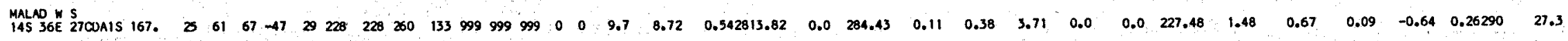

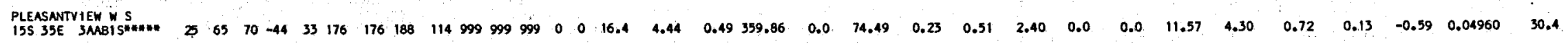

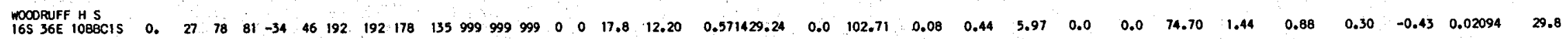
Owyhee county

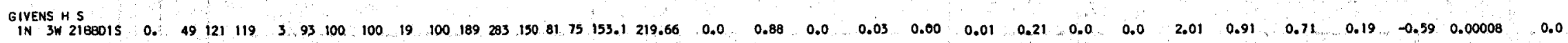

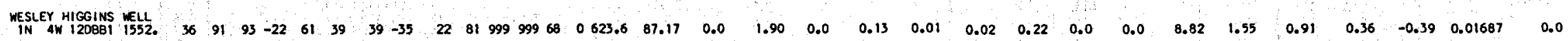

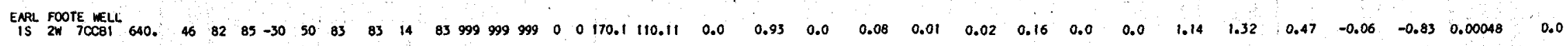

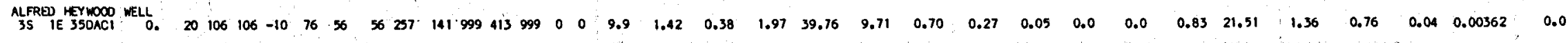

WLLLIMM

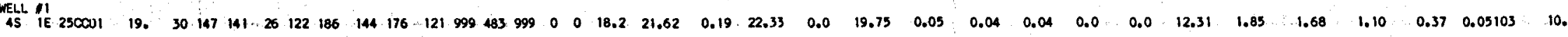
WELLIN

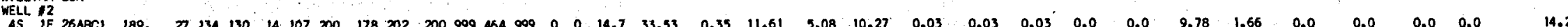


Basic Data Table 2. Estimated Aquifer Temperatures, Atomic and Molar Ratios of Selected Chemical Constituents, Free Energies of Formation of Selected Minerals, Partial Pressures of $\mathrm{CO}_{2}$ Gas and $\mathrm{R}$ Values from Selected Thermal Springs and wells in Idaho (continued)

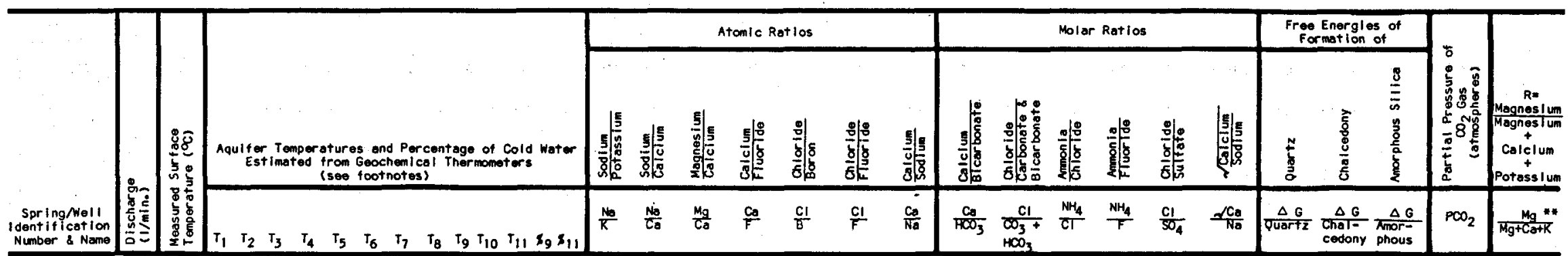

Owyhee County (cont'd.).

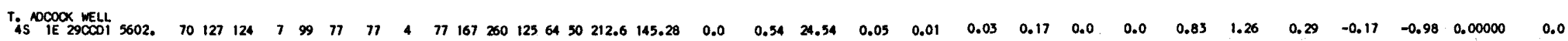
$\begin{array}{llllllllllllllllllllllllllllllllllllllll}\text { GEORGE KING WELLL } & 0 . & 75 & 127 & 124 & 7 & 99 & 75 & 75 & 0 & 75 & 161 & 253 & 75 & 59 & 0 & 238.1 & 155.32 & 0.30 & 0.54 & 0.0 & 0.04 & 0.01 & 0.02 & 0.14 & 0.0 & 0.0 & 0.81 & 1.23 & 1.78 & 1.15 & 0.46 & 0.00003 & 18.4\end{array}$ G. OHRISTENSEN

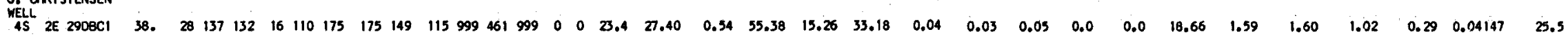

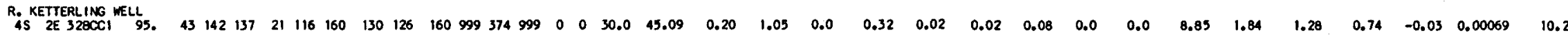

C. STEINER MELL

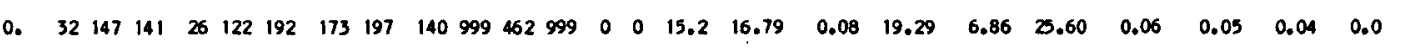

E. LAURENCE

ES JOHSTON

E. JOLLWNTON

ES IE 21 CACI

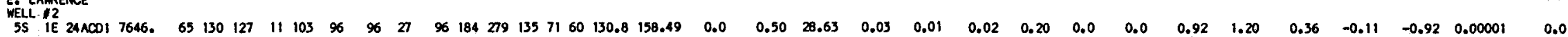

E. LAURENCE

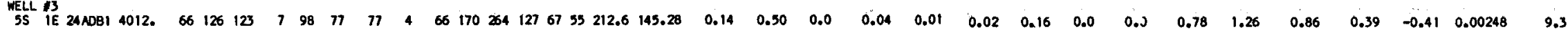

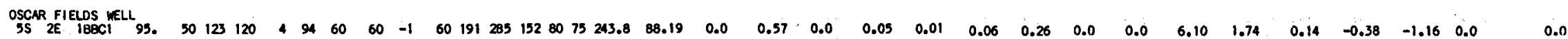

CLARENCE HOPKINS

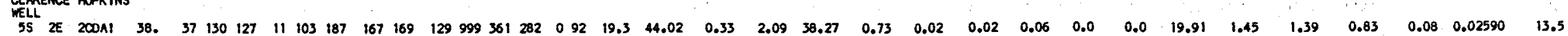
COX NO LAMRENCE

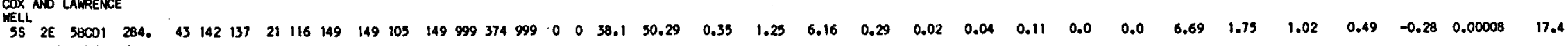

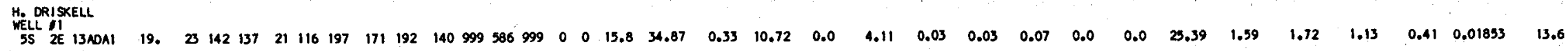

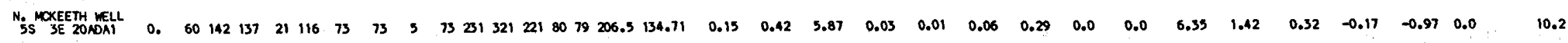

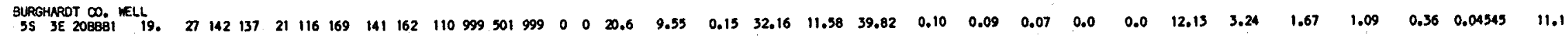

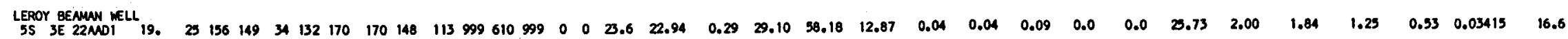


COOK'S GREEN+OUSE

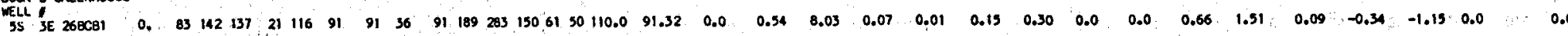
DOX's GREENHOUSE

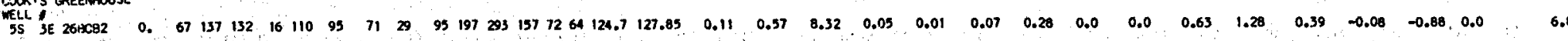

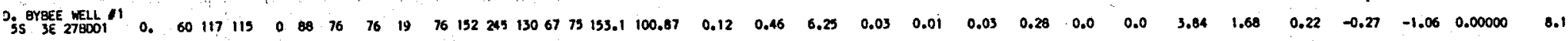

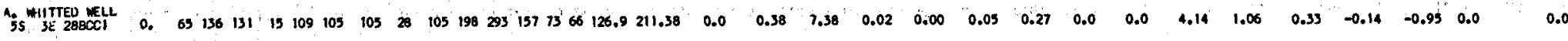

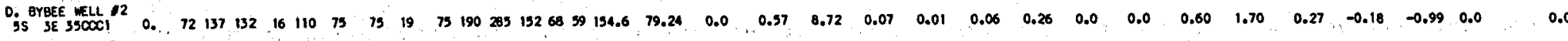

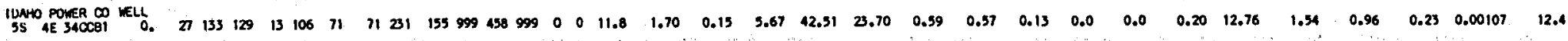

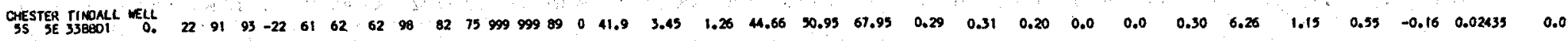

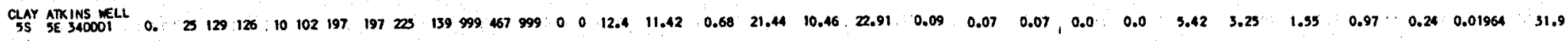

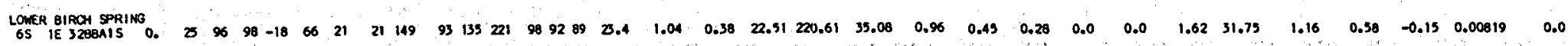

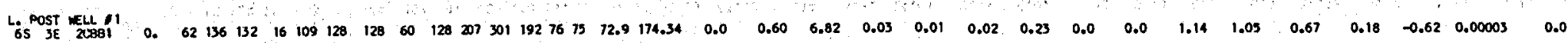

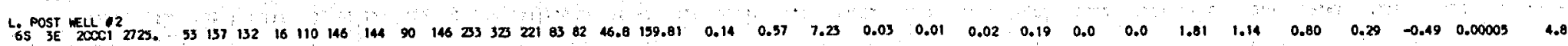

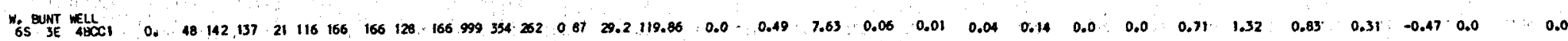

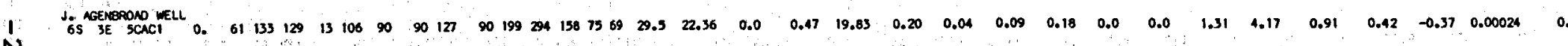

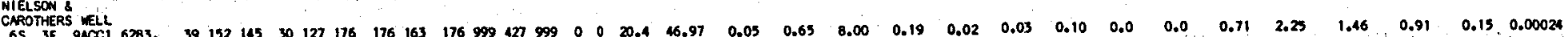

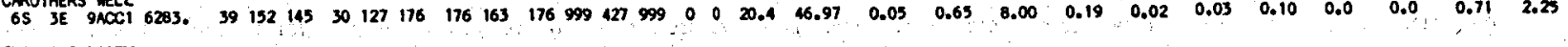
TRINGLE DAIRY

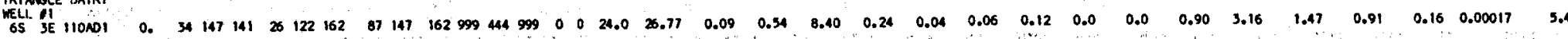

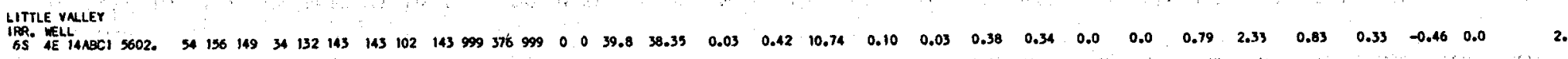

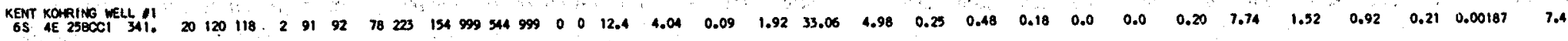

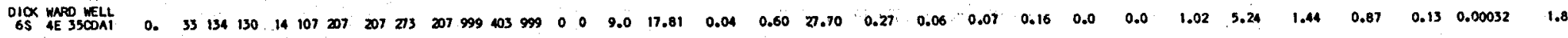

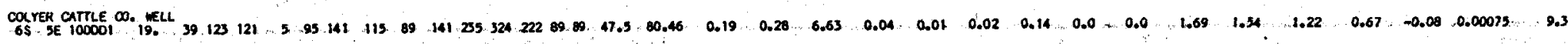

J.R.SIIMPLOT

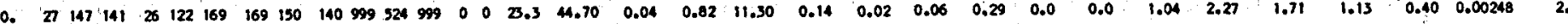

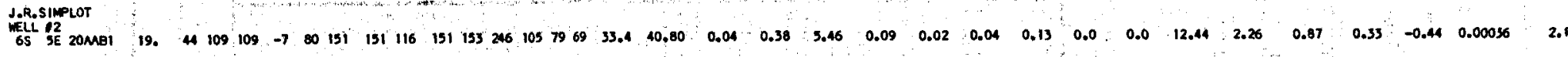

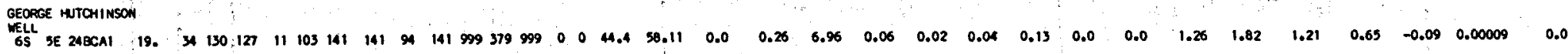

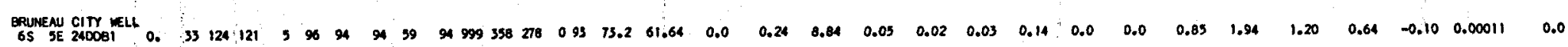

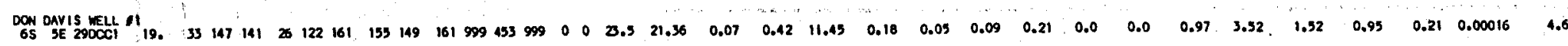

CNRE $B$ MARPY

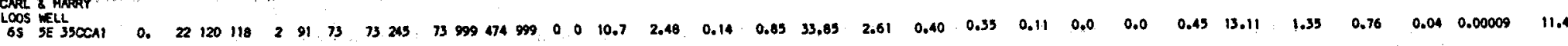


Basic Data Tabie 2. Estimated Aquifer Temperatures, Atomic and Molar Ratios of Selected Chemical Constituents, Free Energies of Formation

of Selected Minerals, Partial Pressures of $\mathrm{CO}_{2}$ Gas and $\mathrm{R}$ Values from Selected Thermal Springs and Wells in Idaho (continued)

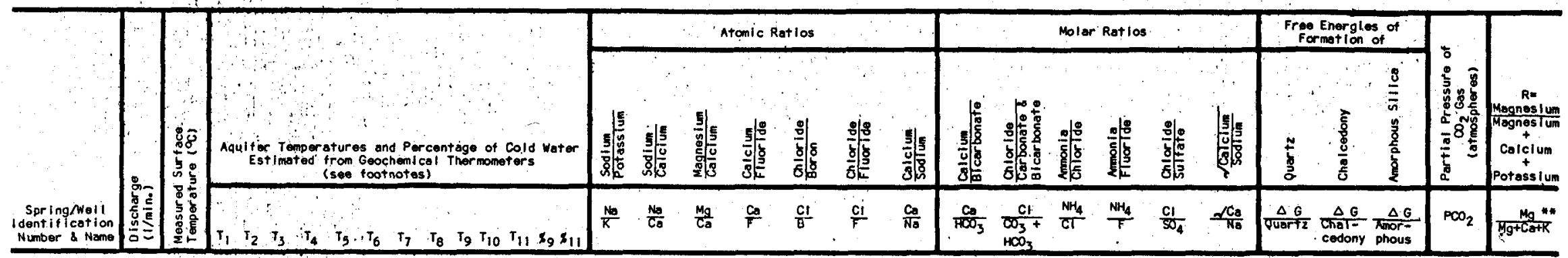

Owyhee County (cont'd.)

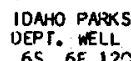

MILORED BACHMAN

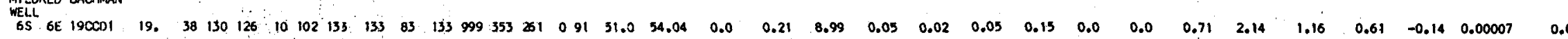
BRUNEN CEMENTARY

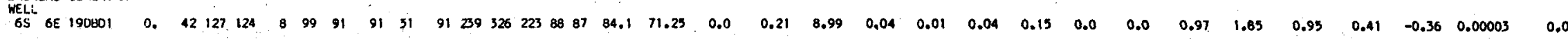

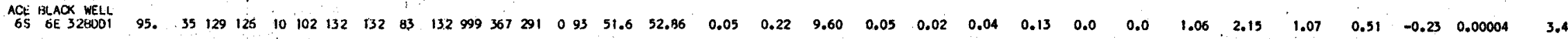

WIBEUR WILSON

WES

WILBUR WILSON

WELL. 28 ,

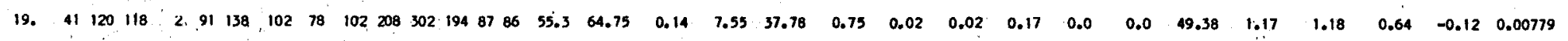

CARL. JOHNSON WELI

$\begin{array}{lllllllllllllllllllllllllllllllllllll}33 & 119 & 111 & 1 & 91 & 139 & 139 & 82 & 104 & 351 & 336 & 226 & 93 & 92 & 51.9 & 53.81 & 0.24 & 13.23 & 26.77 & 1.20 & 0.02 & 0.02 & 0.23 & 0.0 & 0.0 & 59.43 & 1.31 & 1.30 & 0.74 & -0.00 & 0.00657\end{array}$

SAND TE 200 DUNES

SAND DUNES
FAR TELL
GS

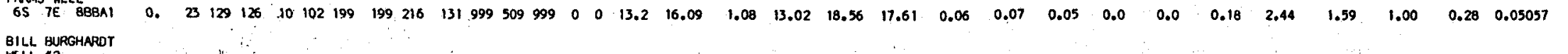

75 SE AACDI 272

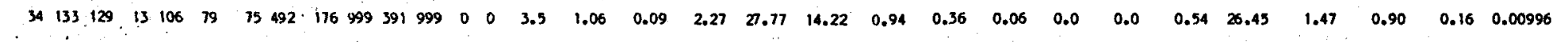

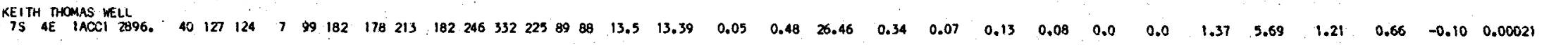

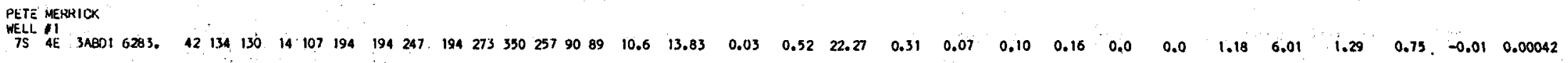
PETE MERRICK

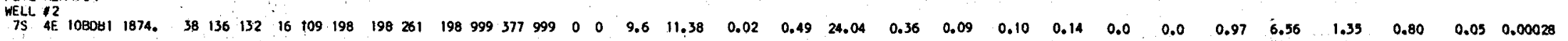
FRANK MILLETT

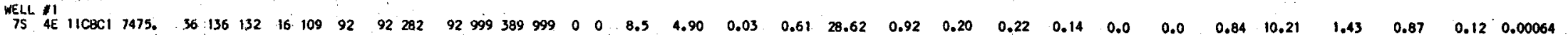
FARIA BROTHERS WELL

$\begin{array}{llllllllllllllllllllllllllllllllllll}43 & 134 & 130 & 14 & 107 & 186 & 186 & 224 & 186 & 270 & 348 & 254 & 89 & 89 & 12.4 & 12.70 & 0.02 & 0.52 & 25.85 & 0.38 & 0.08 & 0.11 & 0.15 & 0.0 & 0.0 & 1.34 & 5.96 & 1.22 & 0.69 & -0.08 & 0.00020\end{array}$

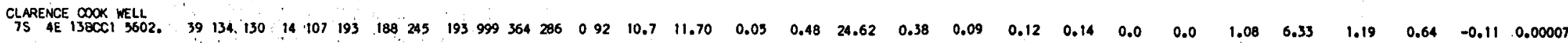
0

8.2

13.9 


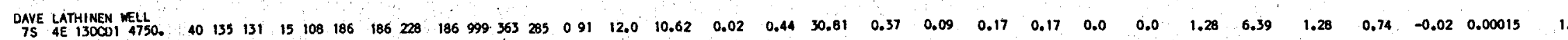

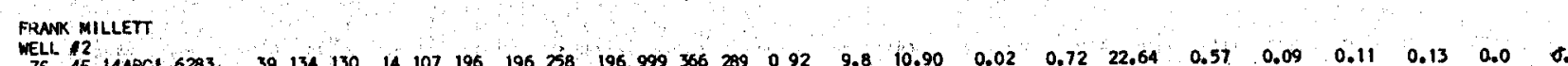

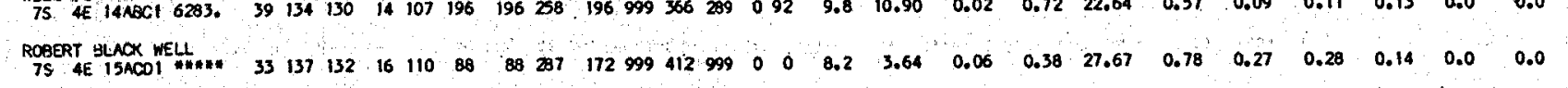

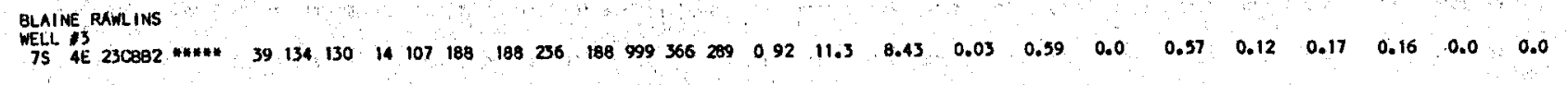

BELL BRAN

75 AE 25 CUTHERIES
RNCH WELL

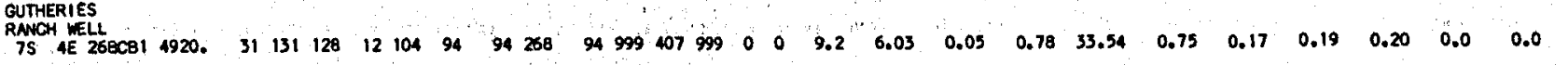

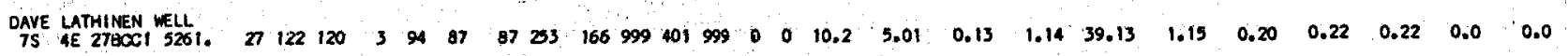

AcE Bunox.

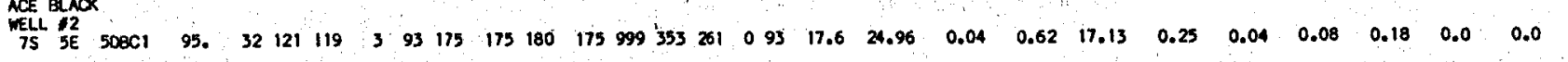
DAVIS BROTHERS

DELIS PROTHERS

75 DE 7 MaBt

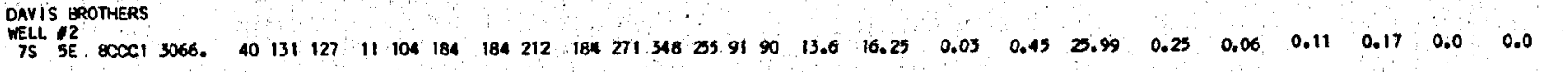

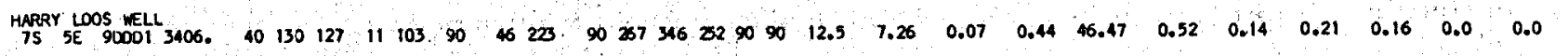

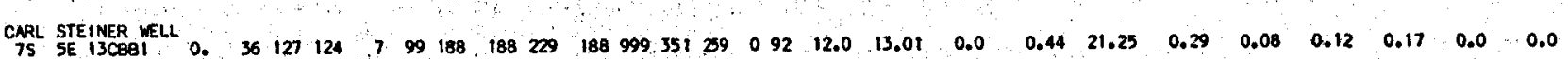

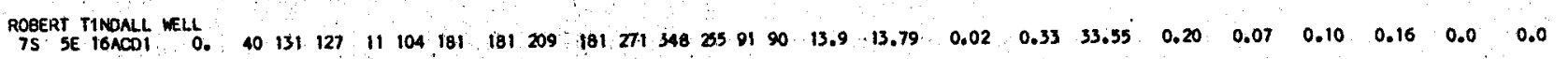

BELL Dano

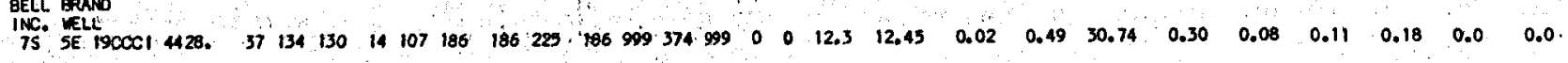

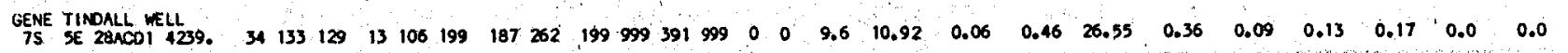

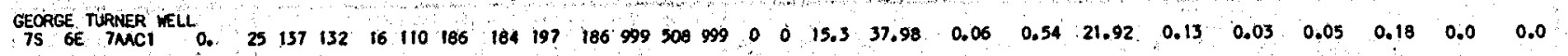

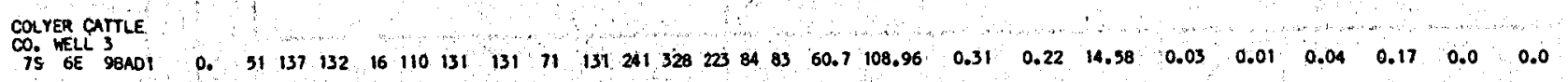

R.L. OWENS

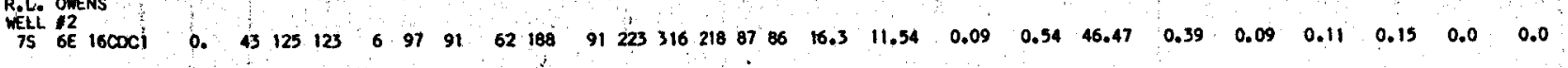

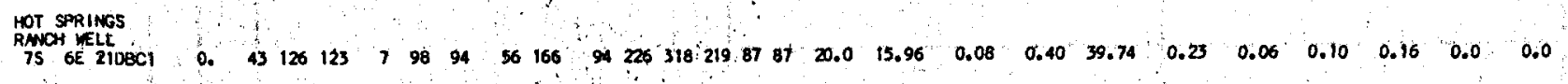

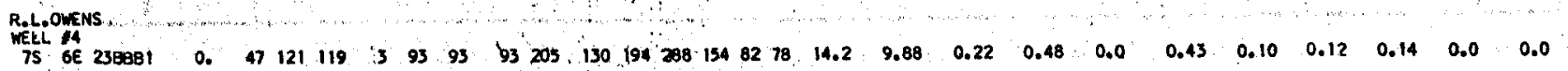

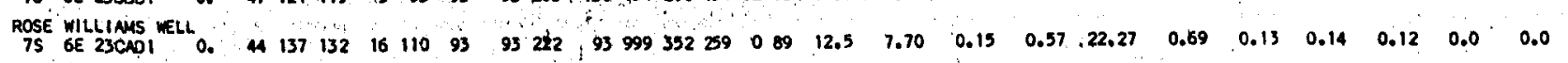

Retri: OWEens:

$\begin{array}{llllllll}1.22 & 6.85 & 1.32 & 0.71 & 0.01 & 0.00028 & 1.5\end{array}$

$0.50 \quad 11.47$

$\begin{array}{lllll}1.50 & 0.94 & 0.20 & 0.00139\end{array}$

4.5

75 6E 2600

$\begin{array}{llllllllllll}99 & 8.9 & 3.92 & 0.29 & 1.49 & 26.46 & 2.45 & 0.25 & 0.18 & 0.11 & 0.0 & 0.0\end{array}$

1.0311 .98

$1.48 \quad 9.20$

$1.35 \quad 9.99$

$0.54 \quad 3.82$

$1.56 \quad 6.56$

$1.33 \quad 5.07$

1.357 .96

$0.54: 9.55$

$1.28 \quad 5.94$

$1.33 \quad 3.61$

$1.24 \quad 5.79$

$1.07 \quad 6.36$

$1.18 \quad 3.15$

$1.00 \quad 1.45$

$1.35: .6 .38$

$1.35,5.17$

$1.43 \quad 6.76$

$1.39 \cdot 7.31$

$1.55 \quad 12.76$

$\begin{array}{llll}.30 & 0.75 & -0.00 & 0.00012\end{array}$

$\begin{array}{llll}1.47 & 0.90 & 0.16 & 0.00070\end{array}$

$\begin{array}{llllll}1.43 & 0.85 & 0.12 & 0.00114\end{array}$

$1.19 \quad 0.62 \quad-0.11 \quad 0.00007$

$\begin{array}{llll}1.30 & 0.75 & -0.00 & 0.00034\end{array}$

$\begin{array}{lllll}1.24 & 0.69 & -0.07 & 0.00016\end{array}$

$\begin{array}{lllll}1.25 & 0.71 & -0.05 & 0.00022\end{array}$

$\begin{array}{lllll}1.56 & 0.97 & 0.25 & 0.00038\end{array}$

$\begin{array}{lllll}1.26 & 0.70 & -0.05 & 0.00017\end{array}$

$\begin{array}{llllll}1.24 & 0.69 & -0.07 & 0.00021\end{array}$

$\begin{array}{llll}1.38 & 0.82 & 0.07 & 0.00046\end{array}$

$\begin{array}{lllllllll}1.39 & 0.83 & 0.09 & 0.00024\end{array}$

$\begin{array}{llllll}1.44 & 0.85 & 0.13 & 0.00003\end{array}$

$\begin{array}{llllll}0.69 & 0.18 & -0.61 & 0.0\end{array}$

$\begin{array}{lllll}1.16 & 0.62 & -0.14 & 0.00037\end{array}$

$\begin{array}{llll}1.17 & 0.63 & -0.14 & 0.00034\end{array}$

$\begin{array}{llll}1.13 & .0 .60 & -0.17 & 0.01035\end{array}$

$\begin{array}{lllll}1.31 & 0.77 & 0.00 & 0.00080\end{array}$

10.4

$\begin{array}{lllll}1.30 & 0.75 & -0.00 & 0.00166 & 19.1\end{array}$ 
Basic Data Table 2. Estimated Aquifer Temperatures, Atomic and Molar Ratios of Selected Chemical Conatituents, Free Energles of Formation
of Selected MInerals, Partial Preseures of $\mathrm{CO}_{2}$ Gas and $\mathrm{R}$ Values from Selected Thermal Springs and Wolls in Idaho (continued)

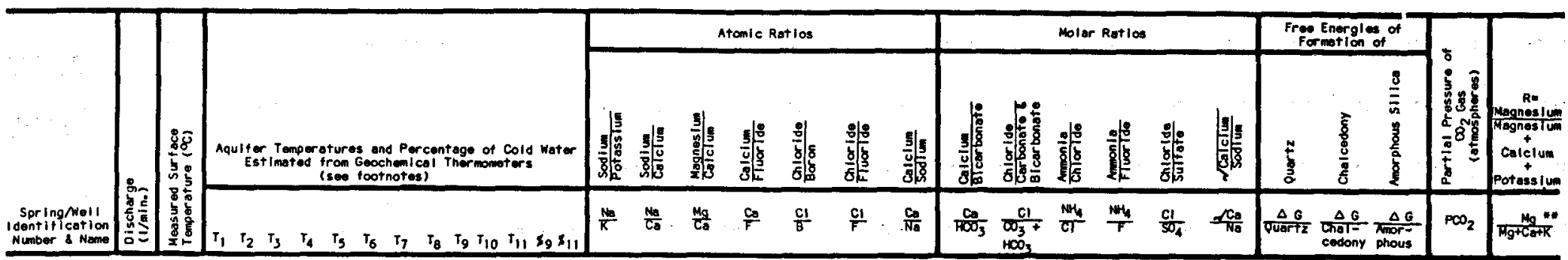

Owyhee county (cont'd.

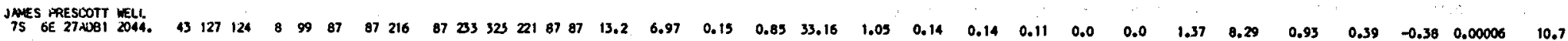

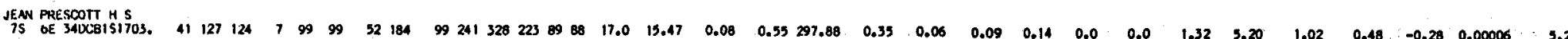

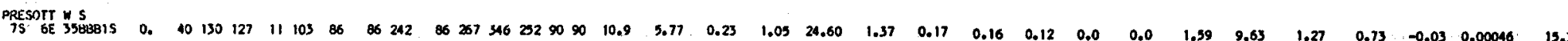

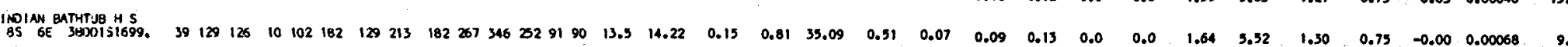

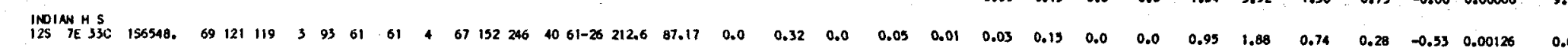

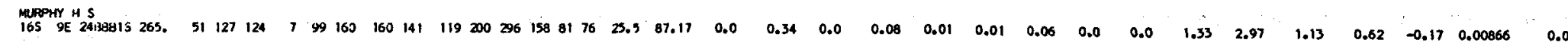

\section{Power county}

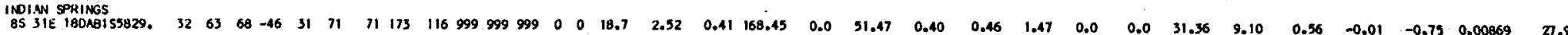

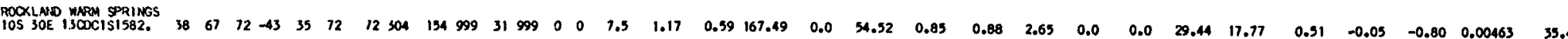

Twin Falls County

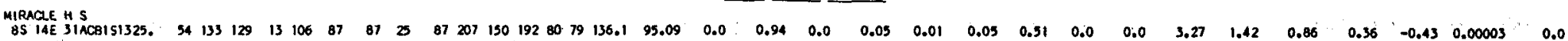

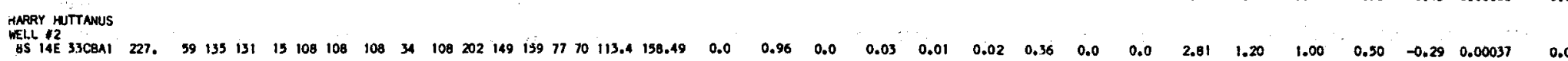

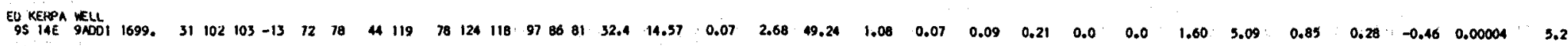
SMM HIIGH NOO SONS

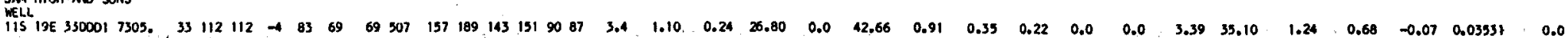

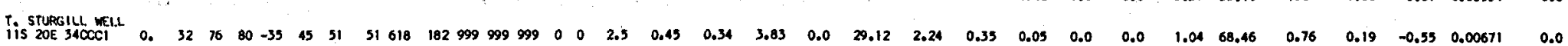

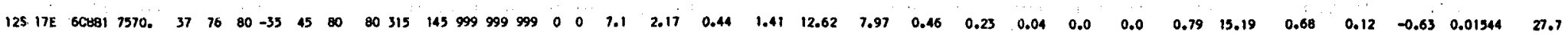

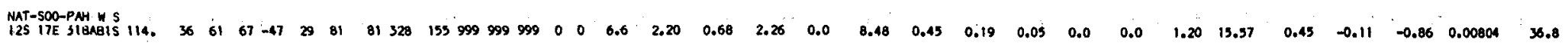




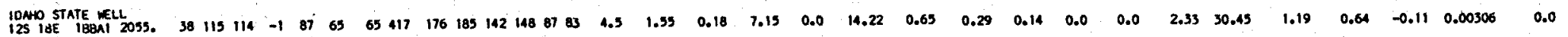
HOLLISTER VILLAGE:

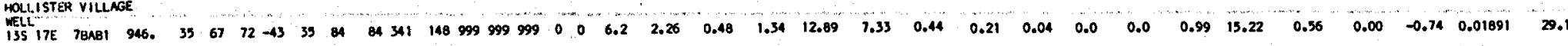

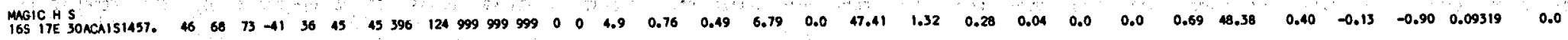

\section{Valley county}

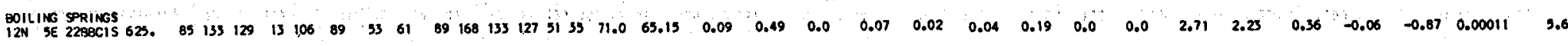

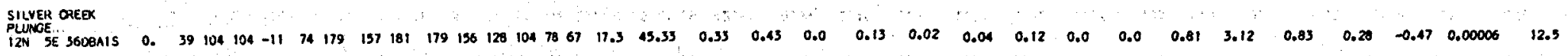

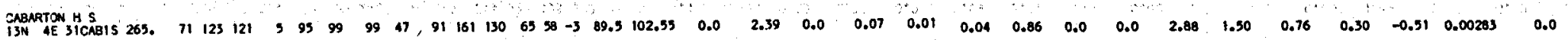

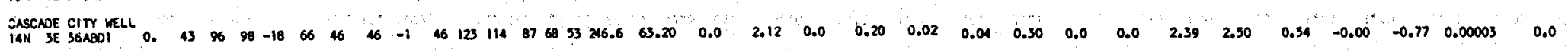

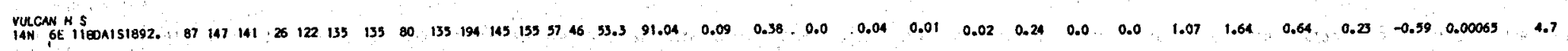

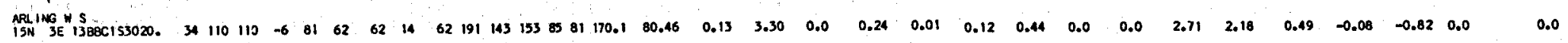

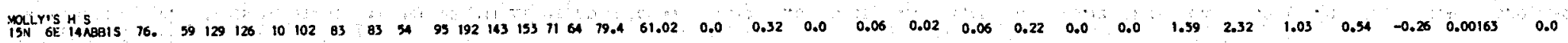

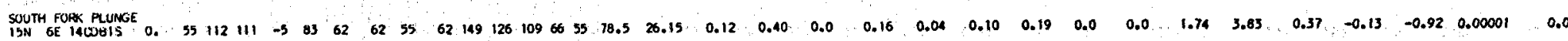

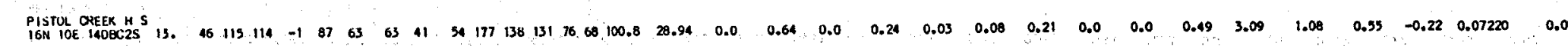

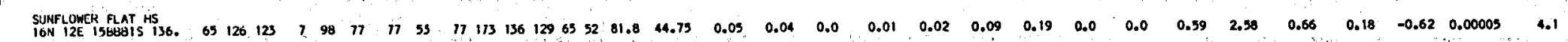

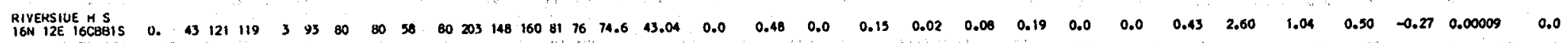

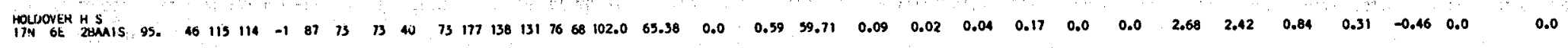

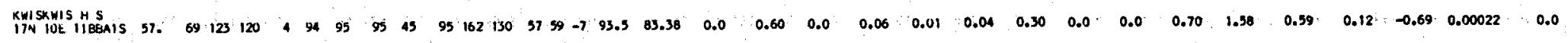

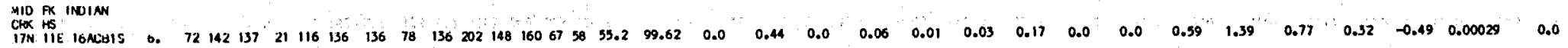

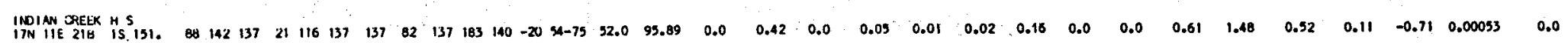

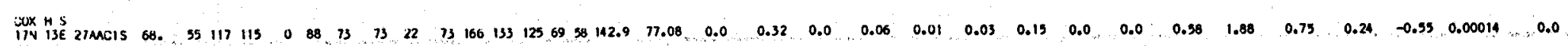

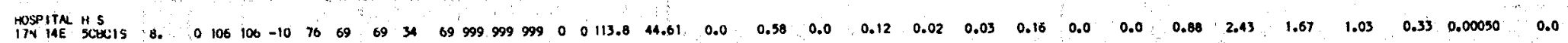

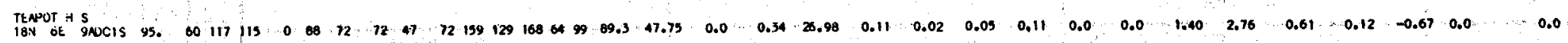

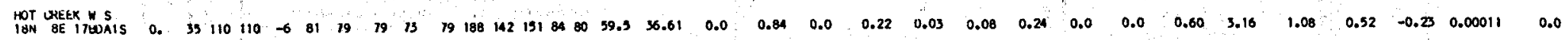

\section{Washington County}

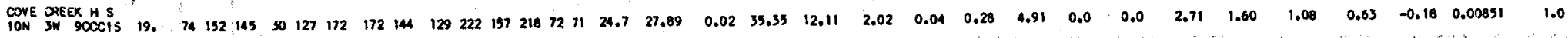

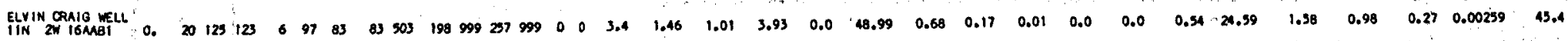


Basic Data Table 2. Estimated Aquifer Temperatures, Atomic and Molar Ratios of Selected Chemical Constituents, Pree Energies of Formation of Selected Minerals, Partial pressures of $\mathrm{CO}_{2}$ Gas and $\mathrm{R}$ Values from Selected Thermal Springs and wells in Idaho (continued)

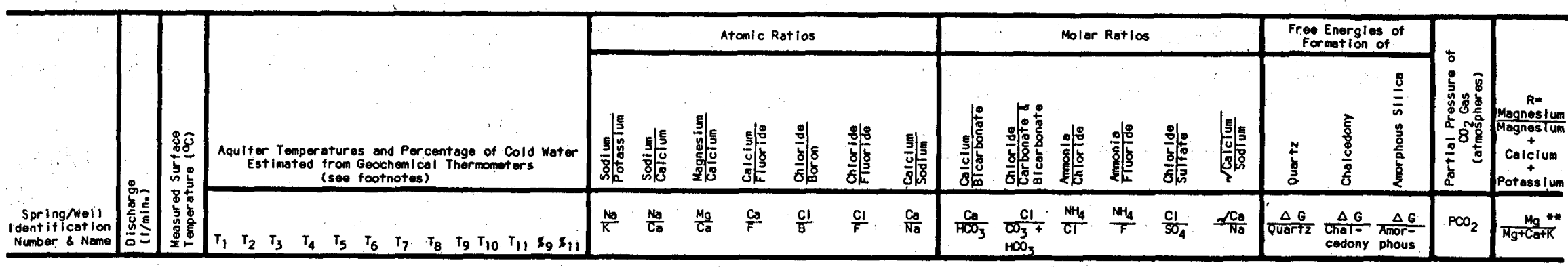

Washington county (cont'd.)

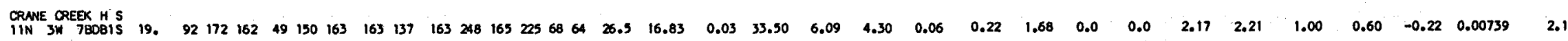

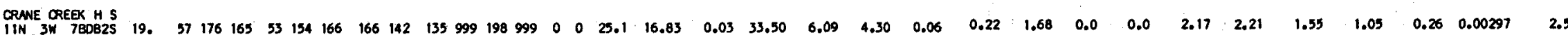
DOUGLAS MCGINNIS

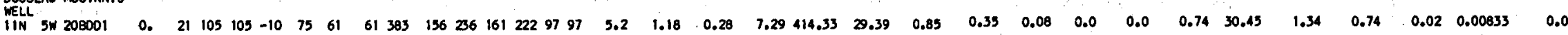

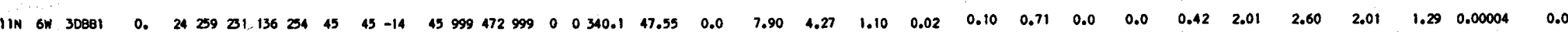

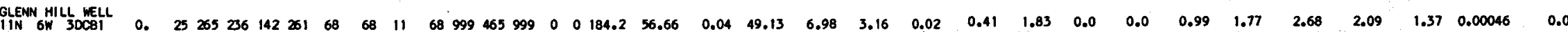

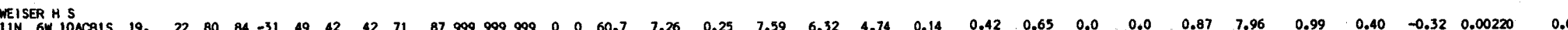
GEOSOLAR GROWERS

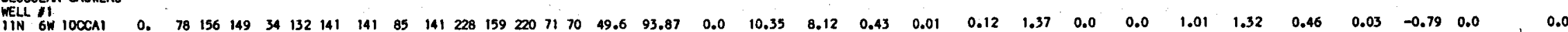
GEOSOLAR GROWERS

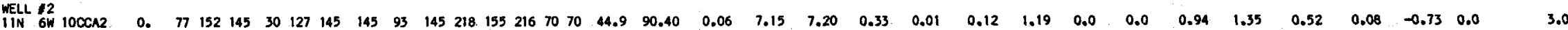
GEOSOLAR EROWERS

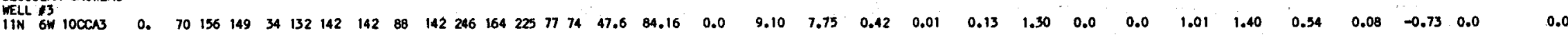

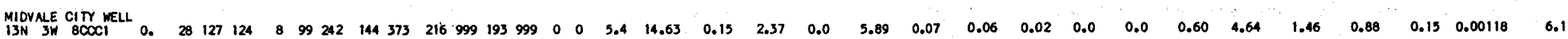

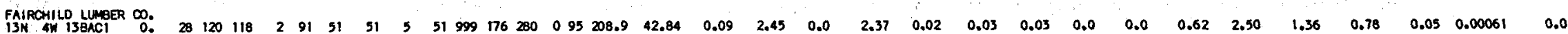

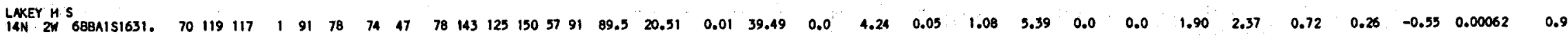

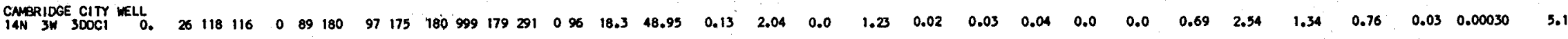

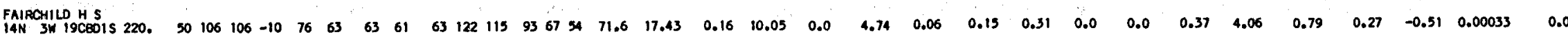



BNSTC Dara rasase 3

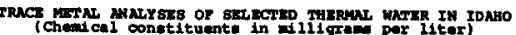

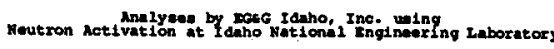

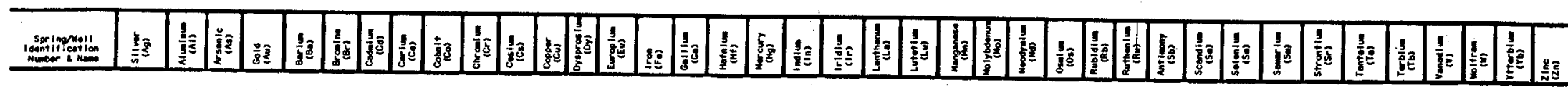

\section{Ade county}

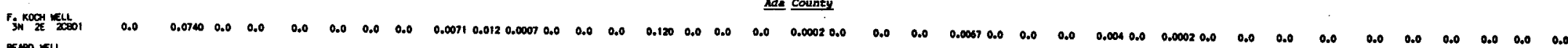

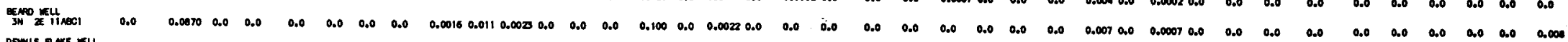

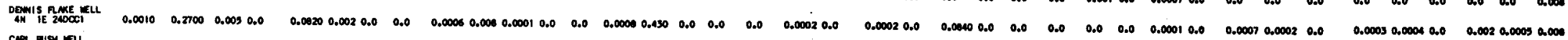

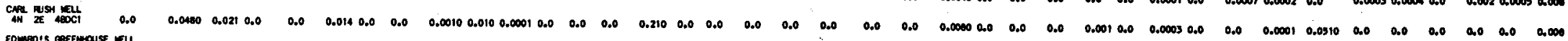

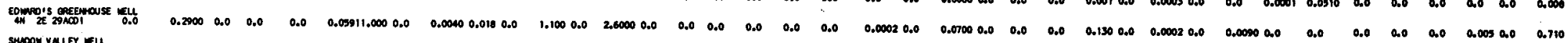

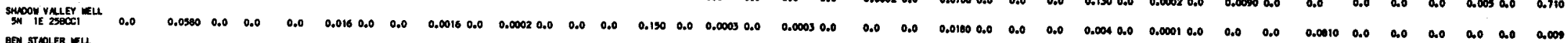

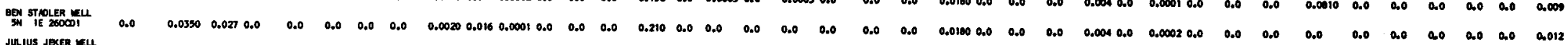

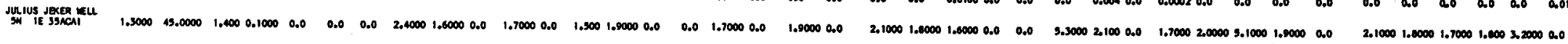

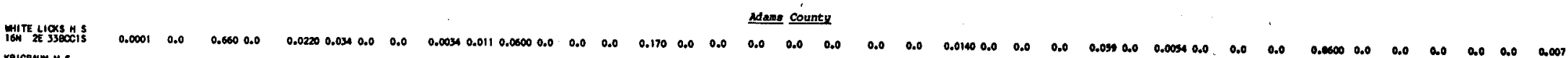

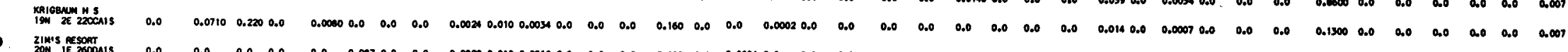

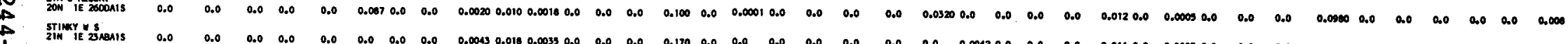

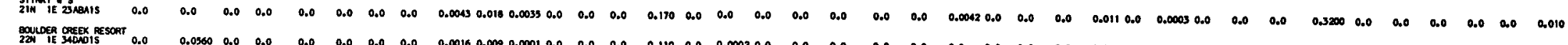

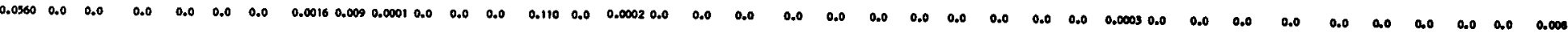

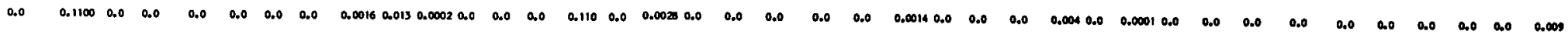

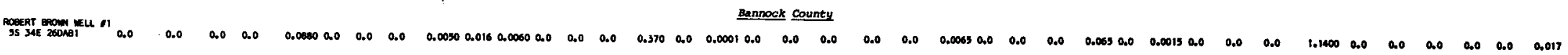

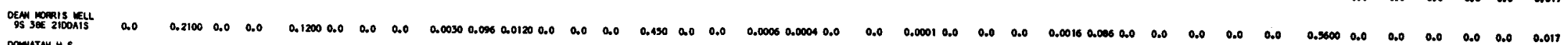

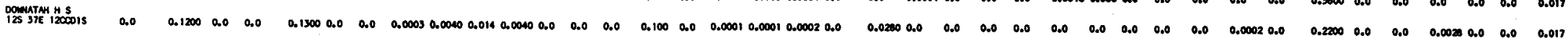

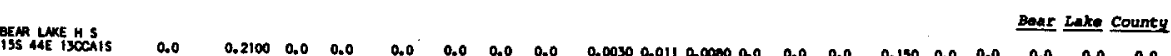

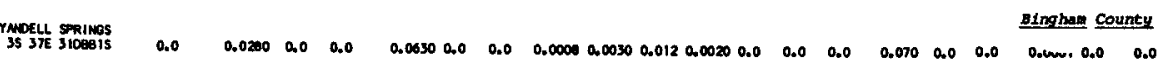

$\begin{array}{llllllllllllllllllllllll}0.0 .0 & 0.0 & 0.0 \mathrm{~m} & 0.0 & 0.0 & 0.0 & 0.0 & 0.0 & 0.0 & 0.0 & 0.0 & 0.013 & 0.0 & 0.0001 & 0.0011 & 0.0 & 0.0 & 1.2000 & 0.0 & 0.0 & 0.0 & 0.0 & 0.0 & 0.011\end{array}$

Muler HS

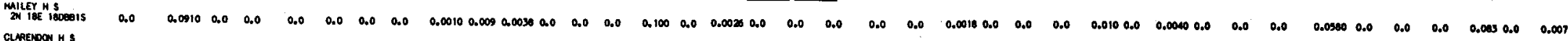

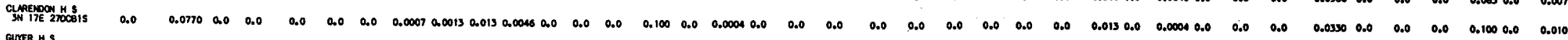

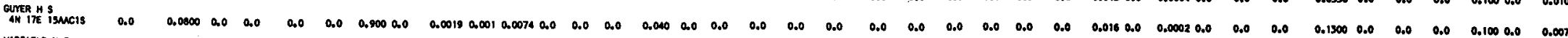

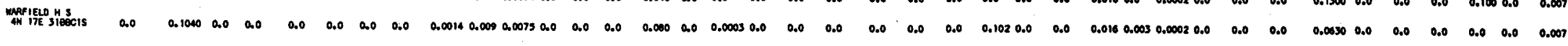




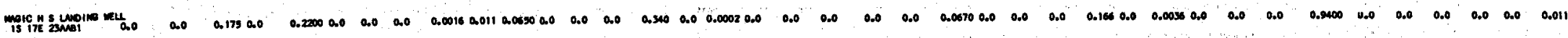

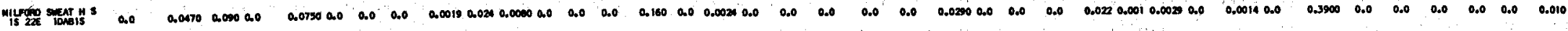

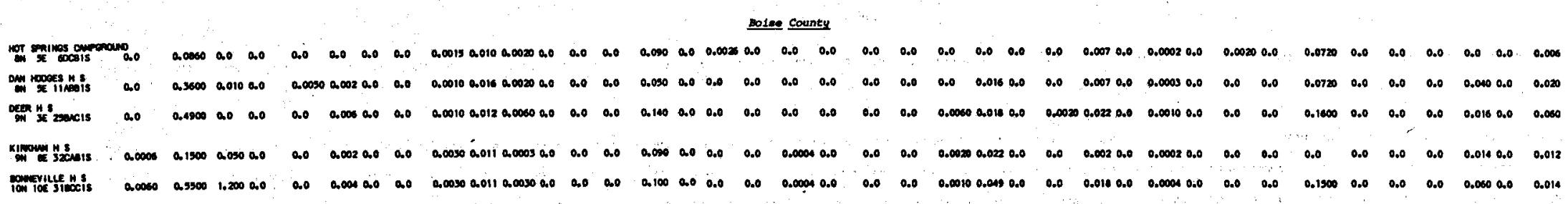

\section{Bonnerlule countr}

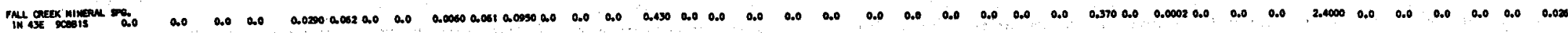

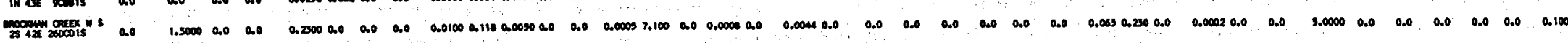

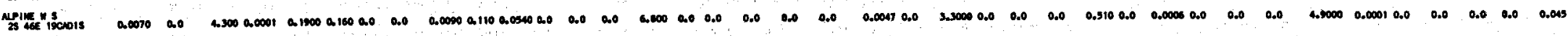

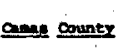

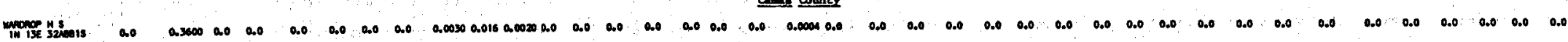

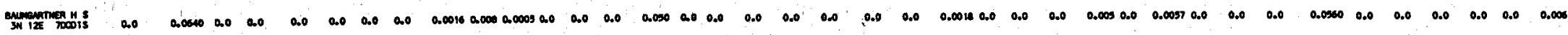

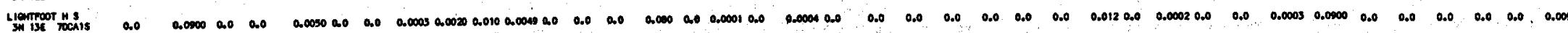

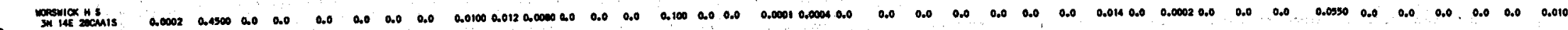

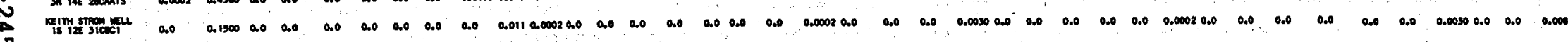

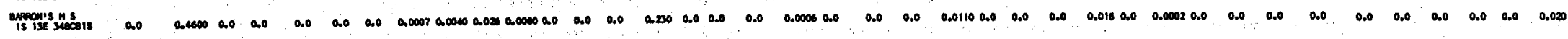

\section{Cenyon county}

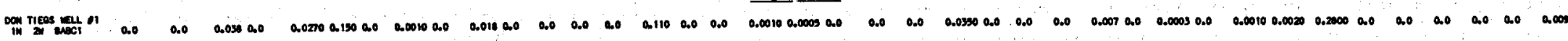

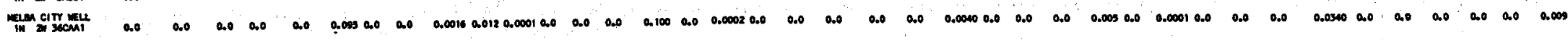

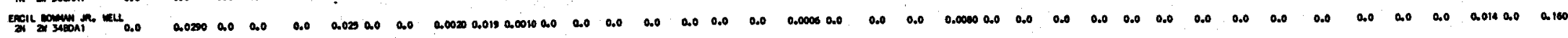

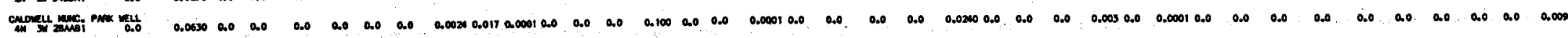

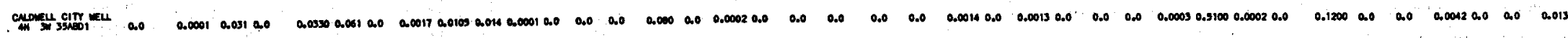

\section{Caribou county}

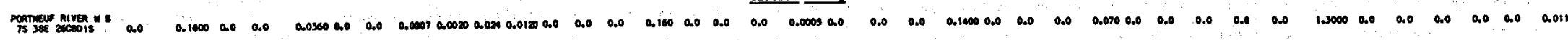

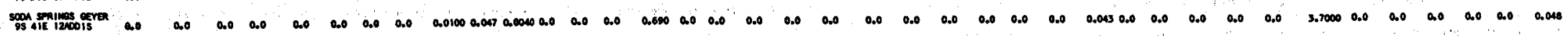

\section{canese County}

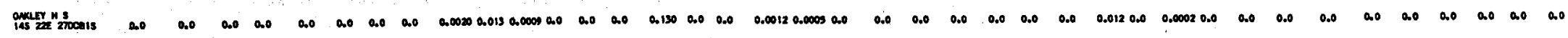

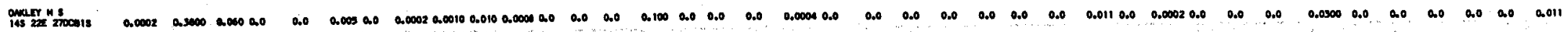

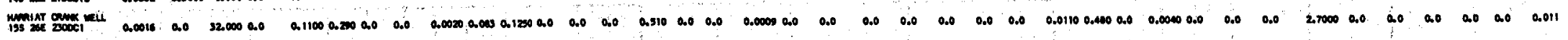

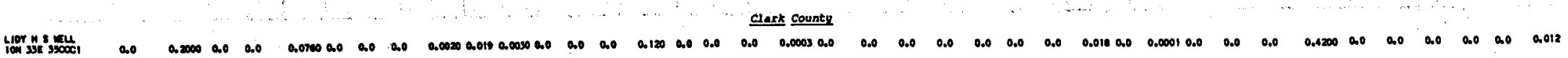




\begin{tabular}{|c|c|c|c|c|c|c|c|c|c|c|c|c|c|c|c|c|c|c|c|c|c|c|c|c|c|c|c|c|c|c|c|c|c|c|c|c|c|}
\hline 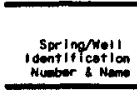 & $\frac{b}{\bar{n}} \bar{z}$ & \begin{tabular}{|l}
$\frac{5}{\frac{2}{2}}$ \\
$\frac{2}{2}$ \\
\end{tabular} & $\frac{2}{2}$ & $\frac{9}{8} \frac{3}{3}$ & $\frac{5}{5}$ & $\begin{array}{l}2 \\
0 \\
0 \\
0\end{array}$ & $\frac{5}{5}$ & $\frac{3}{3} \bar{g}$ & $\frac{5}{8}$ & 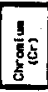 & $\frac{5}{3}$ & & $\frac{9}{8}=$ & 8 & \begin{tabular}{l|l}
$\mathrm{s}$ \\
8
\end{tabular} & $\begin{array}{l}\frac{3}{3} \\
\frac{5}{5}\end{array}$ & $\begin{array}{ll} \\
5\end{array}$ & 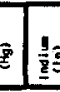 & 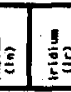 & 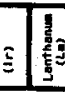 & {$\left[\begin{array}{l}5 \\
5\end{array}\right.$} & 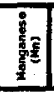 & 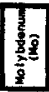 & $\frac{3}{3}$ & $\frac{8}{8}$ & 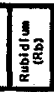 & 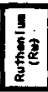 & 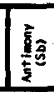 & $\mid \frac{5}{5}$ & 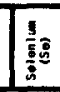 & 5 & 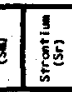 & 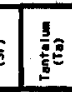 & 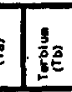 & 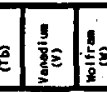 & 列 & 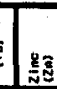 \\
\hline
\end{tabular}

\section{custer county}

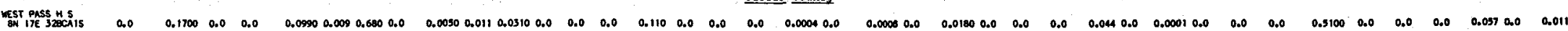

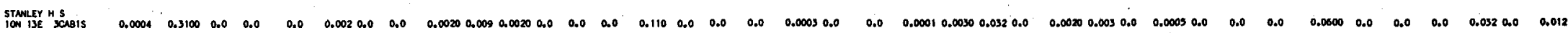

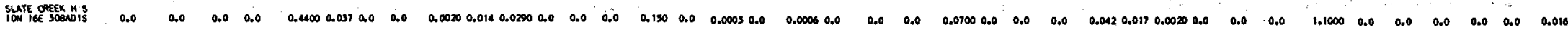

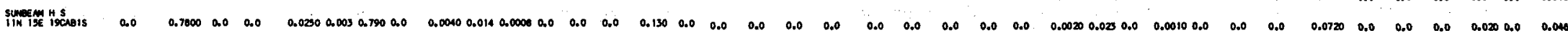

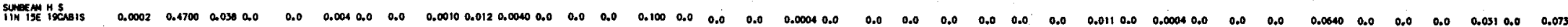

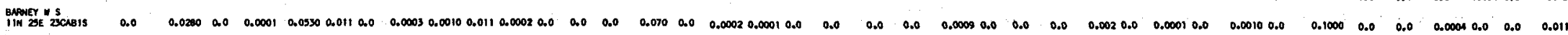

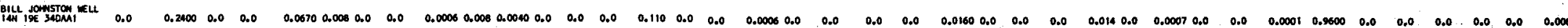

\footnotetext{
Blmore county
}

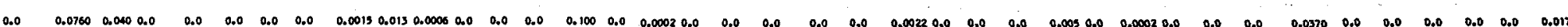

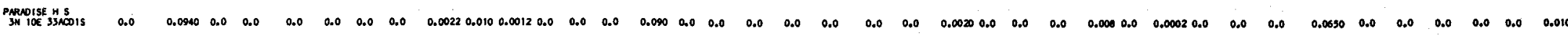

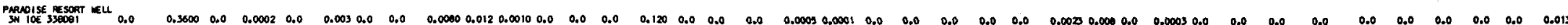

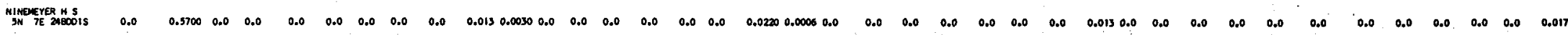

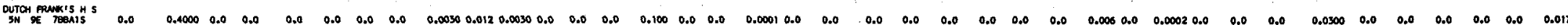

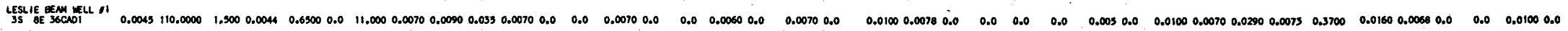

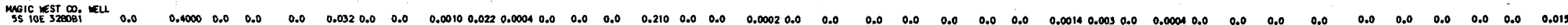

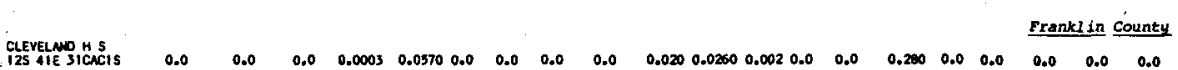

$\begin{array}{llllllllllllllllllllllllll}0.0 & 0.0 & 0.0 & 0.0 & 0.0 & 0.0 & 0.0 & 0.0700 & 0.0 & 0.0 & 0.0 & 0.140 & 0.0 & 0.0004 & 0.0 & 0.0 & 0.0 & 1.0000 & 0.0 & 0.0 & 0.0 & 0.0 & 0.0 & 0.012\end{array}$

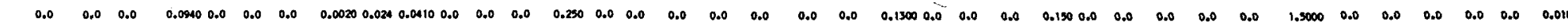

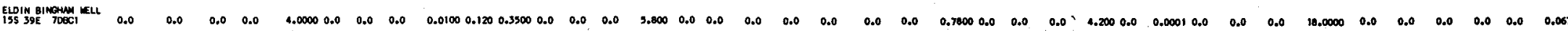

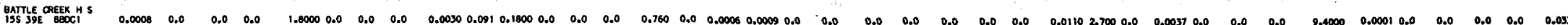

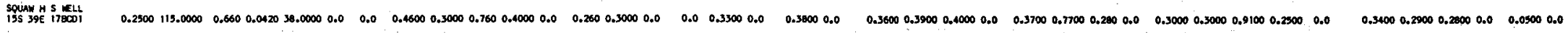

NEDONE GIT HEL

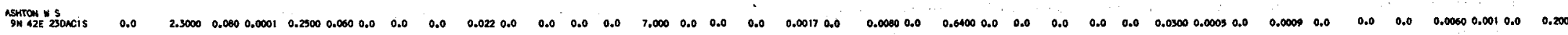

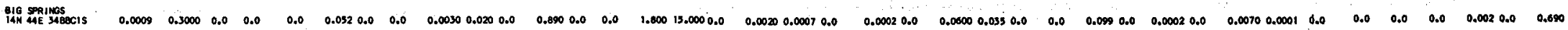

$$
\text { Gem county }
$$

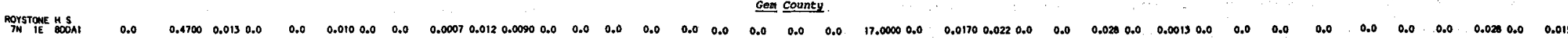

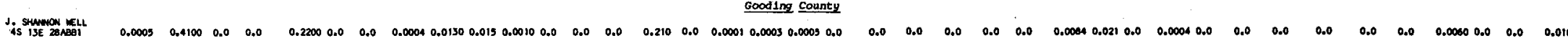

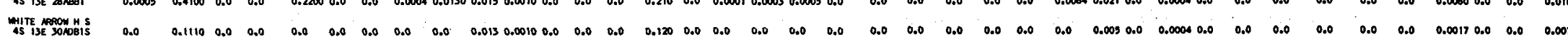

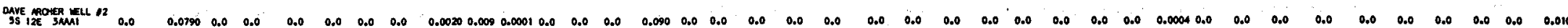


Idara county

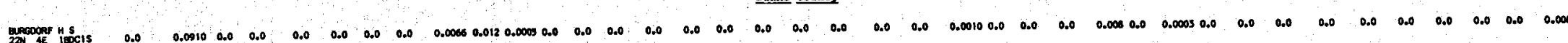

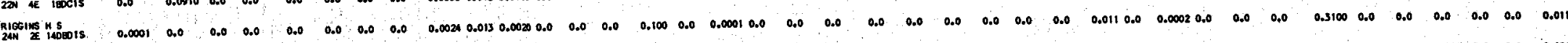

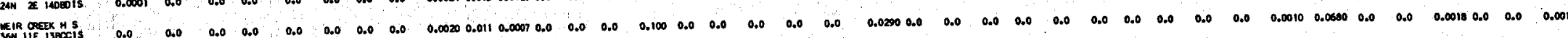

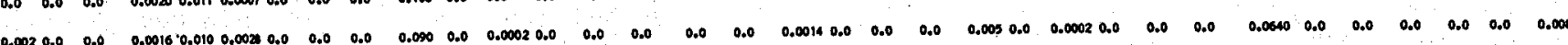

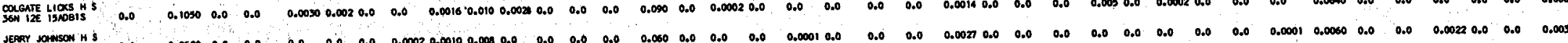

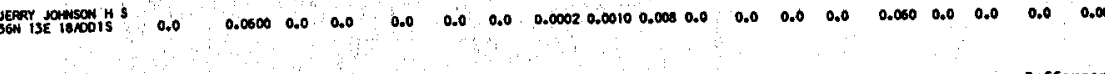

Jefferron county

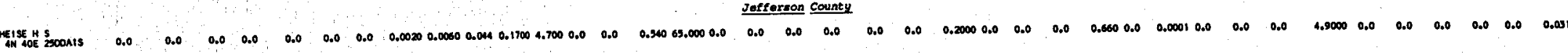
Lamhi county

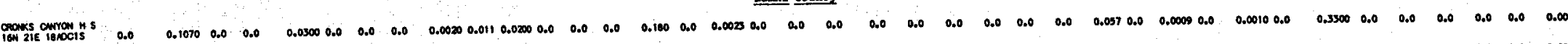

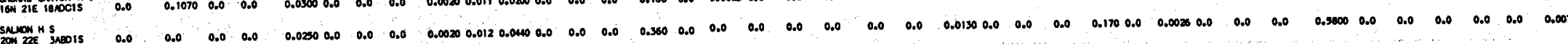

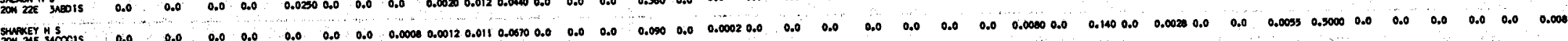

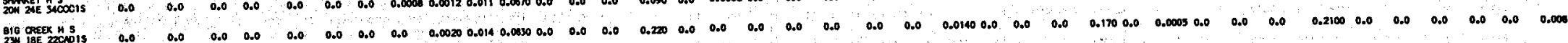

\section{Oreida County}

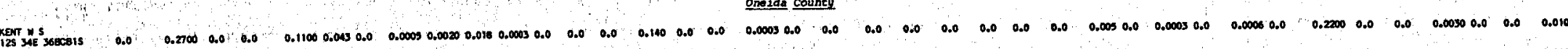

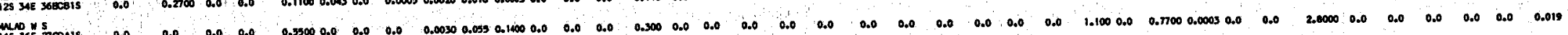

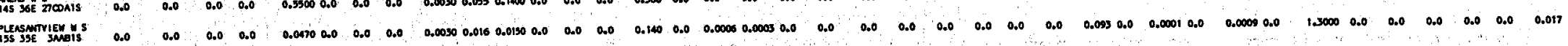

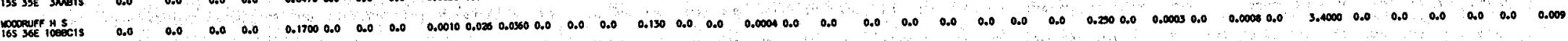
onyhee county

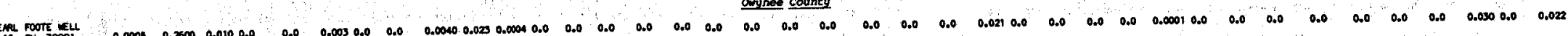

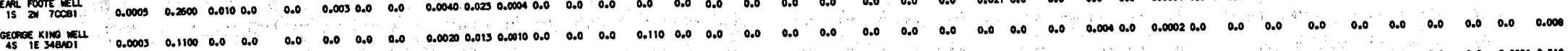

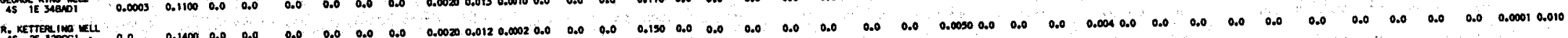

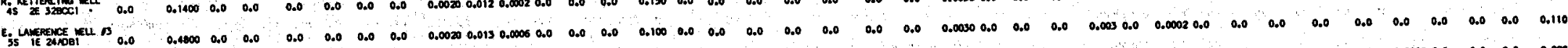

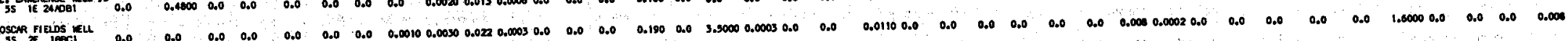

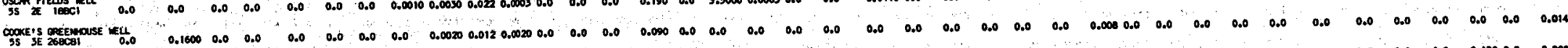

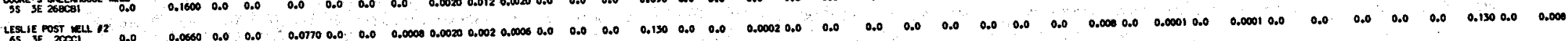

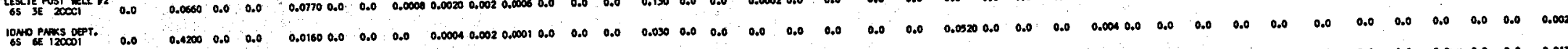

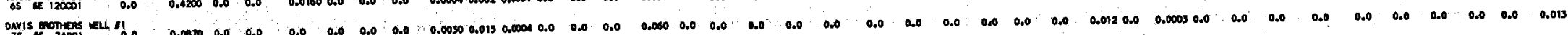

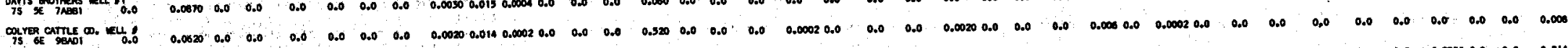

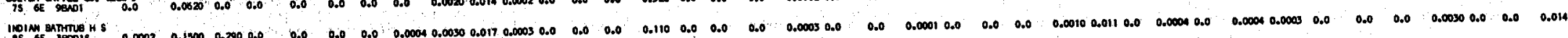

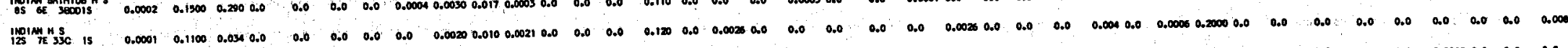

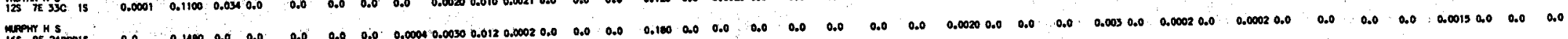
power county

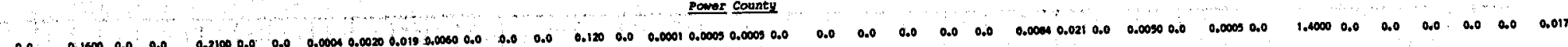
an wion no sons reu

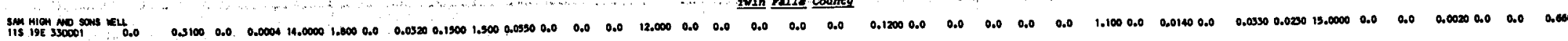




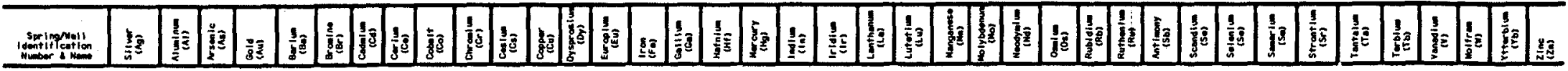

win relses county (cont'd.)

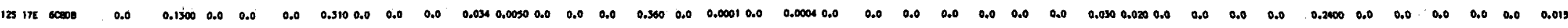

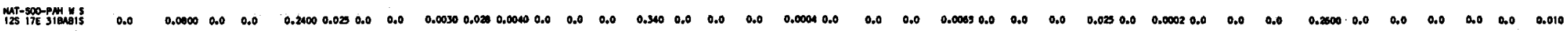

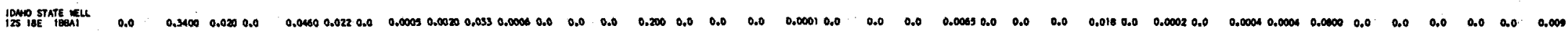

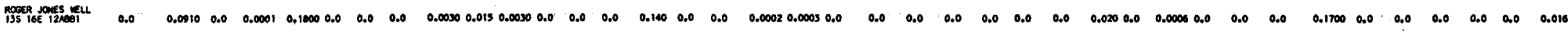

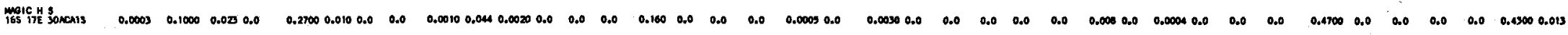

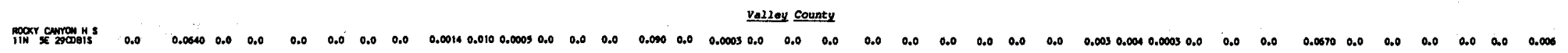

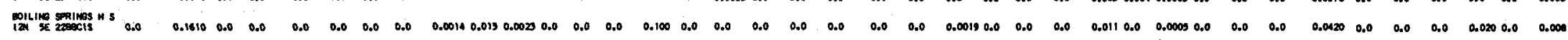

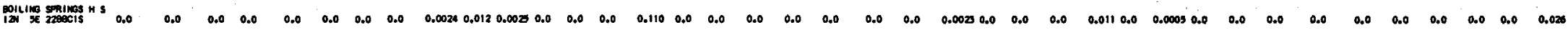

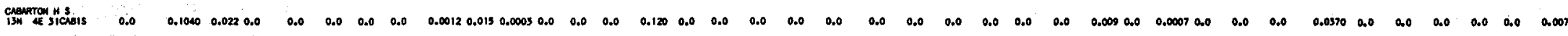

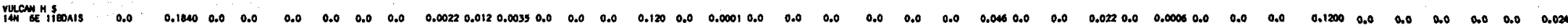

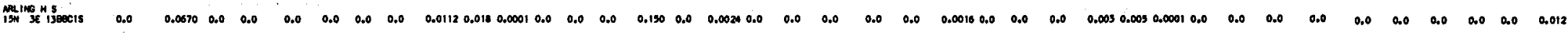

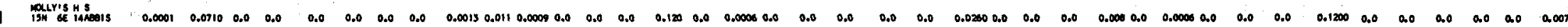

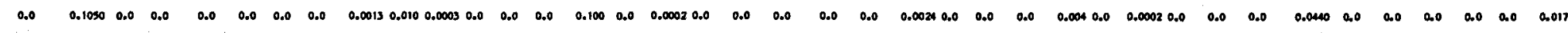

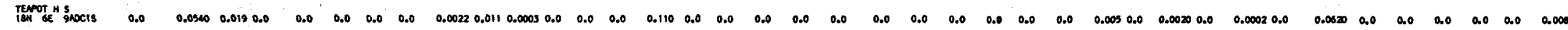

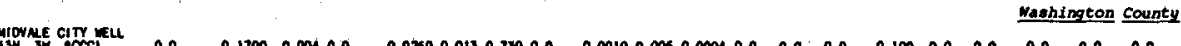

$\begin{array}{lllllllllllllllllllllllll}0.100 & 0.0 & 0.0 & 0.0 & 0.0 & 0.0 & 0.0 & 0.0 & 0.0030 & 0.0 & 0.0 & 0.0 & 0.027 & 0.0 & 0.0 & 0.0 & 0.0 & 0.0 & 0.0 & 0.0 & 0.0 & 0.0 & 0.0 & 0.0 & 0.010\end{array}$

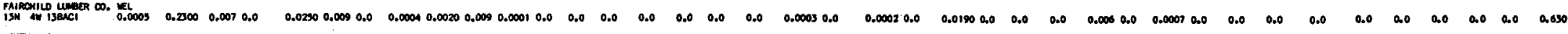

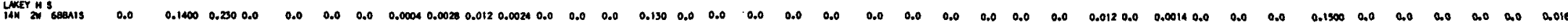

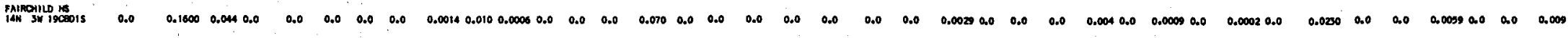



BASTC DATA TABLE 4

LOCATION, GEOLOGIC ENVI RONMENT, PRESENT USE AND POTENTI AL USE OF THERMAL SPRINGS AND WELLS IN IDAHO

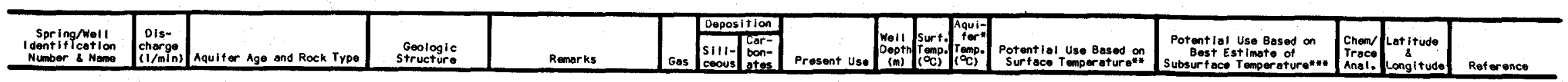

Ada county

WULLIE DULIAS

PLIOCENE MO PLEI STUCENE
SEOMMENTS

15 PLIOCENE MO PLEISTOCENE
SEUIMENTS

PLIOCENE MD PLEI STOCENE
SEO IMENTS

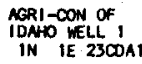

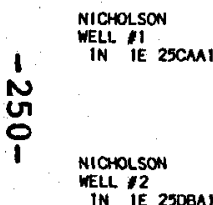

PLIOCENE MO PLEISTOCENE
SEDIMENTS ND BASALTIC LAVA

PLIOCENE ND PLEISTOCENE
SEDIMNNTS

AGRI-CON OF
IDNO MELL 2
IN IE 2500C1

12870 PLIOCENE NO PLEI STOCENE
SEDPMENTS

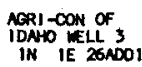

PLIOCENE NO PLEISTOCENE
SEDIMENTS

BETH DESHAZO WELL IIJS5 PLOCENE NO PLEISTOCENE
IN IE 33 SWDI

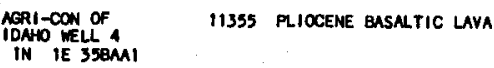

FLoro EDWNeOS
WELL
IN IE 358081

PL IOCENE MD PLEI STOCENE
SEDIMENTS
DRILLER'S LOG AVAILABLE

IRPIGATION

1462648 BIOOEGRADATION

LAUNORY USES

vOMESTIC

99 25 MEATING MO COOLING WITH

IRRIGATION

13324 CATFISH FNOMING

STOCX WATERING 140 Z 2 MEAING MD COOLNG WITH

IRRIGATION

1612345 CATFISH FAPMING

MUSHROCOM CROWING

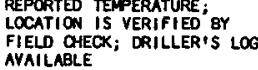

DRILLER'S LOG AVAILABLE

DRILLer's LOG AYAILABLE

DRILLER'S LOG AVALLABLE

DRILLER'S LOG AVAILABLE

121

MEATING MO DOLLING WITH
HEAT PUPP

IPRIGATION
YES $\begin{aligned} & 43.4543 \\ & 116.2782\end{aligned}$

43.4493
116.2739 SAVAGE, 1958

43.4034
116.3036 SAYAGE, 1950

43.3929
116.2840

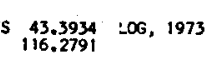

43.3941 SAVAGE, 1958
116.2862

43.3868
116.2839 SAYAGE, 1958

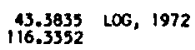

$43.3850 \quad L 06,1969$
116.3034

43.3861 SAVAGE, 1958
116.3129 


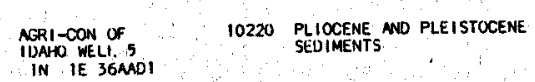

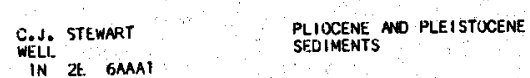

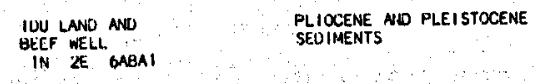

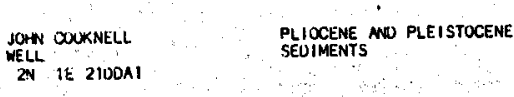

TOM BEVANS
WEL
ZN

崩

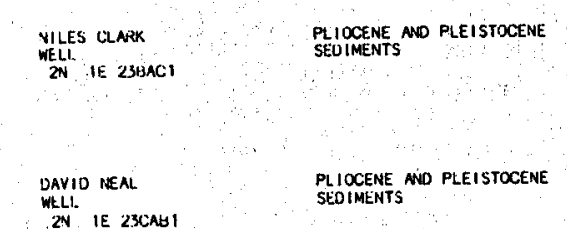

AL CLIFFUed

WEL IE 230OA

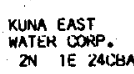

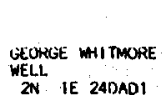

PLIOCENE NU PLEI ISTOCENE
SEUIMENTS

2N. IE 24DAO

CHARLES BAIR
WELL IE
2N

2649 PLIOCENE MO PLEISTOCENE
SEO MENTS
DQILeg's log avallable

PLOCENE MNO PLE ISTOCENE
SEOMENTS

PLIOCENE, NO PLEISTUCENE
SEOMMENTS
IRPIGATION

DOMESTIC

oomestic

DOMESTIC

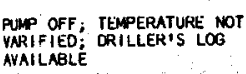

REPOREED TEMPERATURE; NOT
WN USE

ORILLER'S LOG AVAILABLE
$13524 \quad 67$ DE-ICING ROADHAY

IRRIGATION

APPLE OEHTORATION

$11732 \ldots$ CATFISH FARMING

1232450 CATFISH FAPMINO

3523 DE-IGING HIGHWAYS

24 DE-ICING SIDEWALKS

11724 DE-ICING RONDWAYS

25 CATFISH FAPMINO

voMESTIC

DOMESTIC

9324

UNUSED

DOMESTIC
DE-ICING SIOEWALKS

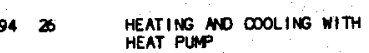

27 FERMENTATION

11527 SHRIMP MNO TROPICAL FISH
YES 113.3931 SAYAGE, 1958

43.4586
116.2538

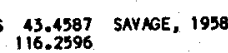

43.4919
116.3347 SAYAGE, 1930

YES $\begin{gathered}\text { 43.4921 SAVAGE, } 1958 \\ 116.3183\end{gathered}$

43.5000
116.3076

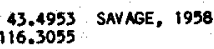

${ }_{116.2953}^{43.4902}$ SAVAGE, 1958

43.4941 SAVAGE, 1958
116.2887 .

YES $\begin{gathered}43.4934 \\ 116.2740\end{gathered}$

43.4882 SAVAGE, 1958
116.3008

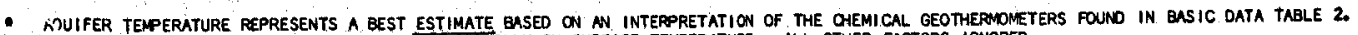

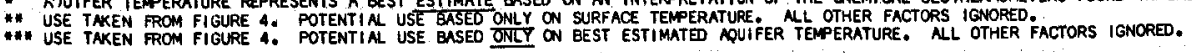


Basic Data Table 4. Location, Geologic Environment, Present Use and Potential Use of Thermal Springs and wells in Idaho (continued)

\begin{tabular}{|c|c|c|c|c|c|c|c|c|c|c|c|c|}
\hline $\begin{array}{c}\text { Spring/Noll } \\
\text { doentificotion } \\
\text { Number \& Nome }\end{array}$ & 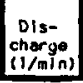 & Aquif er Ago and Rock Type & $\begin{array}{c}\text { Geologic } \\
\text { Structure }\end{array}$ & Remarks & Gas & 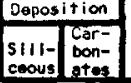 & Present Usa & 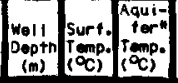 & $\begin{array}{l}\text { Potent las Use Based on } \\
\text { Surf toce T Temperatur oft" }\end{array}$ & 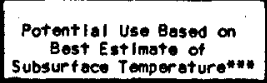 & $\begin{array}{l}\text { chend } \\
\text { Troce. } \\
\text { Anat. }\end{array}$ & $\begin{array}{l}\text { Lattitude } \\
\text { Langltude } \\
\text { Longla }\end{array}$ \\
\hline
\end{tabular}

Ada county (cont'd.)

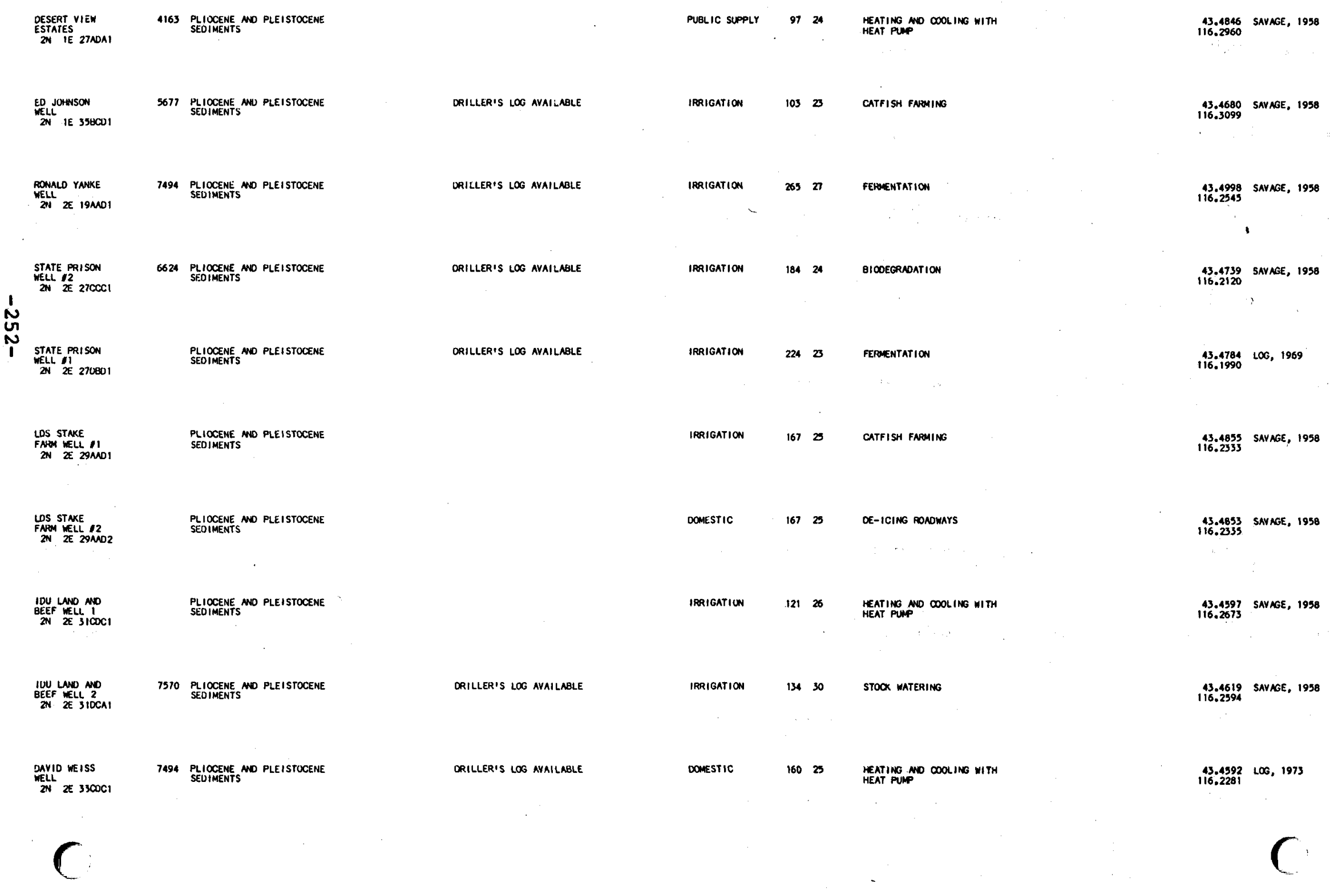




\begin{tabular}{|c|c|c|c|c|c|c|c|c|}
\hline 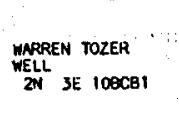 & $\begin{array}{l}\text { PLIOCEEE MO PLE ISTOCENE } \\
\text { SEOMGNTS }\end{array}$ & 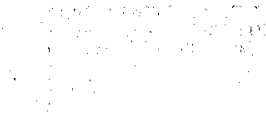 & $\begin{array}{l}\text { IRRIGATION MO } \\
\text { DOMESTIC }\end{array}$ & $143 x$ & 021 & FISH FNAMUING & CATFISH FAPMING & 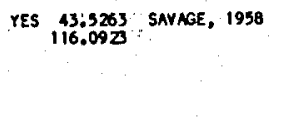 \\
\hline 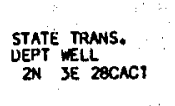 & 227 PLOCENE MO PLE ISTOCENE & 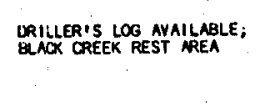 & Domestic & 2972 & 222 & $\begin{array}{l}\text { REATING NO DOL LNG WITH } \\
\text { HETT PUMP }\end{array}$ & PEPAENTATION & 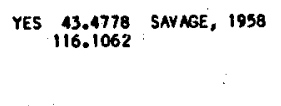 \\
\hline 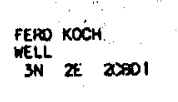 & $\begin{array}{l}\text { 302. PLIOCENE NO PLE I STOCENE } \\
\text { SEDOMENTS }\end{array}$ & DRILLR'S LOG AVAILABLE & Dowestic. & 3485 & $30 \quad 39$ & GRAIN-HAY DRYING & SPACE HEATING & 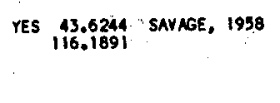 \\
\hline 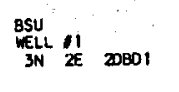 & & 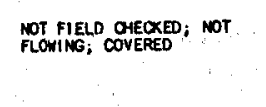 & $\begin{array}{l}\text { GEOTHERMLL } \\
\text { RESERPOA }\end{array}$ & 862 & 28 & DE-IGING SIDEMACKS & & $\begin{array}{l}43.6107 \\
116.1708\end{array}$ \\
\hline $\begin{array}{l}\text { GNOEE CIT } \\
\text { WEEL } \\
\text { SN } \approx \text { SOCAI }\end{array}$ & DOS PLIOCENE NO PLEISTOCENE & 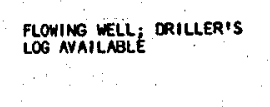 & PUGLIC SUPPLY & 2472 & 20 & $\therefore$ & & $\begin{array}{l}43.6208 \text { SAVAGE, } 1958 \\
116.2385\end{array}$ \\
\hline 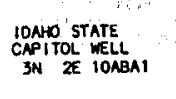 & $\begin{array}{l}\text { 113S PLOOCEN MO PLE ISTOCENE } \\
\text { SEOOMENTS }\end{array}$ & ORILLR''S LOG AVALLABLE & $\begin{array}{l}\text { DOMESTIC MO } \\
\text { SPRINKLING }\end{array}$ & 327 & 40 & SPACE HEATING & & $\begin{array}{l}.43 .6180 \\
1160.1984 \\
1100,1962\end{array}$ \\
\hline 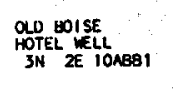 & & 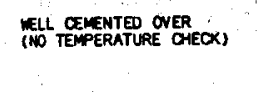 & unusEo & & 4 & & & $\begin{array}{l}73.6176 \\
116.2010\end{array}$ \\
\hline 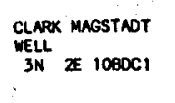 & 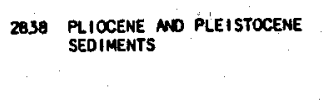 & DRILLER'S LOC, AVAILABLE. & $\begin{array}{l}\text { COMERCINL } \\
\text { LAHORY }\end{array}$ & 192 & 24. & $\begin{array}{l}\text { HETING MO DOLLNG WITH } \\
\text { HEAT PUPP }\end{array}$ & & $\begin{array}{l}43.61199 \text { SANAGE, } 1958 \\
116.2059\end{array}$ \\
\hline 每 & 367. & COUERED & $\begin{array}{l}\text { EEOTHERenL } \\
\text { EESERPOH }\end{array}$ & 1985 & 56,97 & SEEDLING ONIFERS & BANOHNG & YES, $\begin{array}{l}43.8165 \\
116.1821\end{array}$ \\
\hline 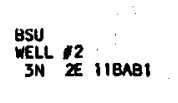 & & Not FLOMING & 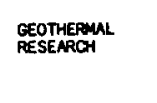 & 391 & 7 & LANORY USES & & $\begin{array}{l}143.1881 \\
116.1833\end{array}$ \\
\hline 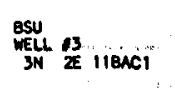 & 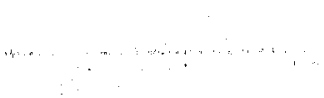 & MELL HAS BEEN COVEREO & 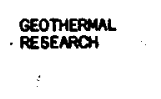 & & 74 & PPLE DEMTPRATION & & $\begin{aligned} 43.6164 \\
-116.8697\end{aligned}$ \\
\hline 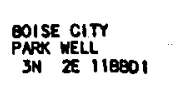 & $\begin{array}{l}\text { 2271 PLOCENE NO PLEISTOCENE } \\
\text { SEDMMENTS }\end{array}$ & DRILLER'S LOG AVAILAOLE & IRRIGATION & .174 & $\infty$ & BIOOEGRAOATION & & 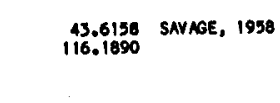 \\
\hline
\end{tabular}


Basic Data Table 4. Location, Geologic Environment, Present Use and Potential Use of Thermal Springs and wells in Idaho (continued)

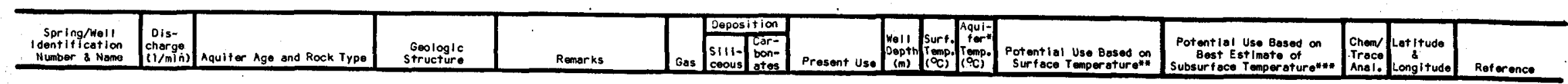

Ada County (cont'd.)

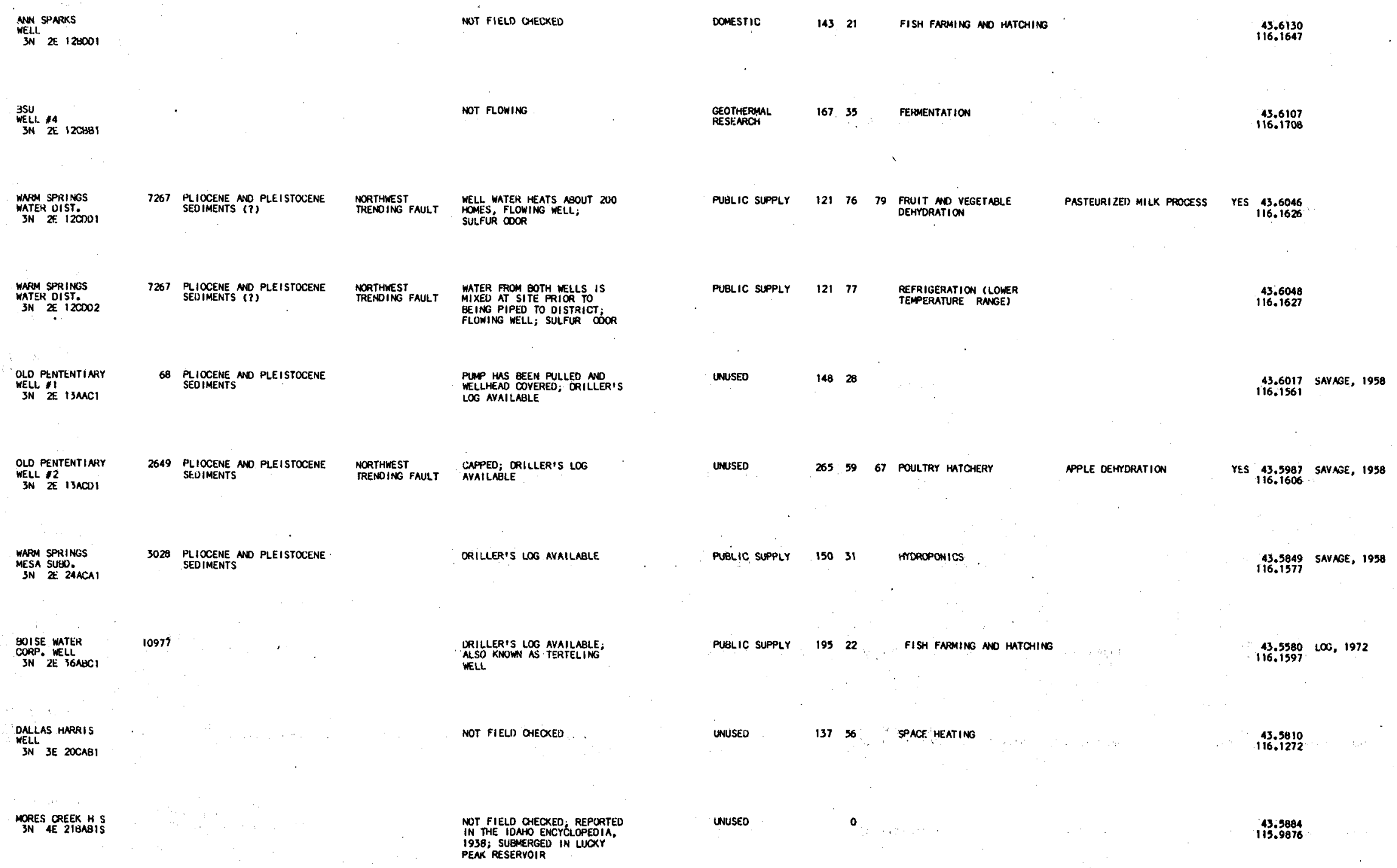




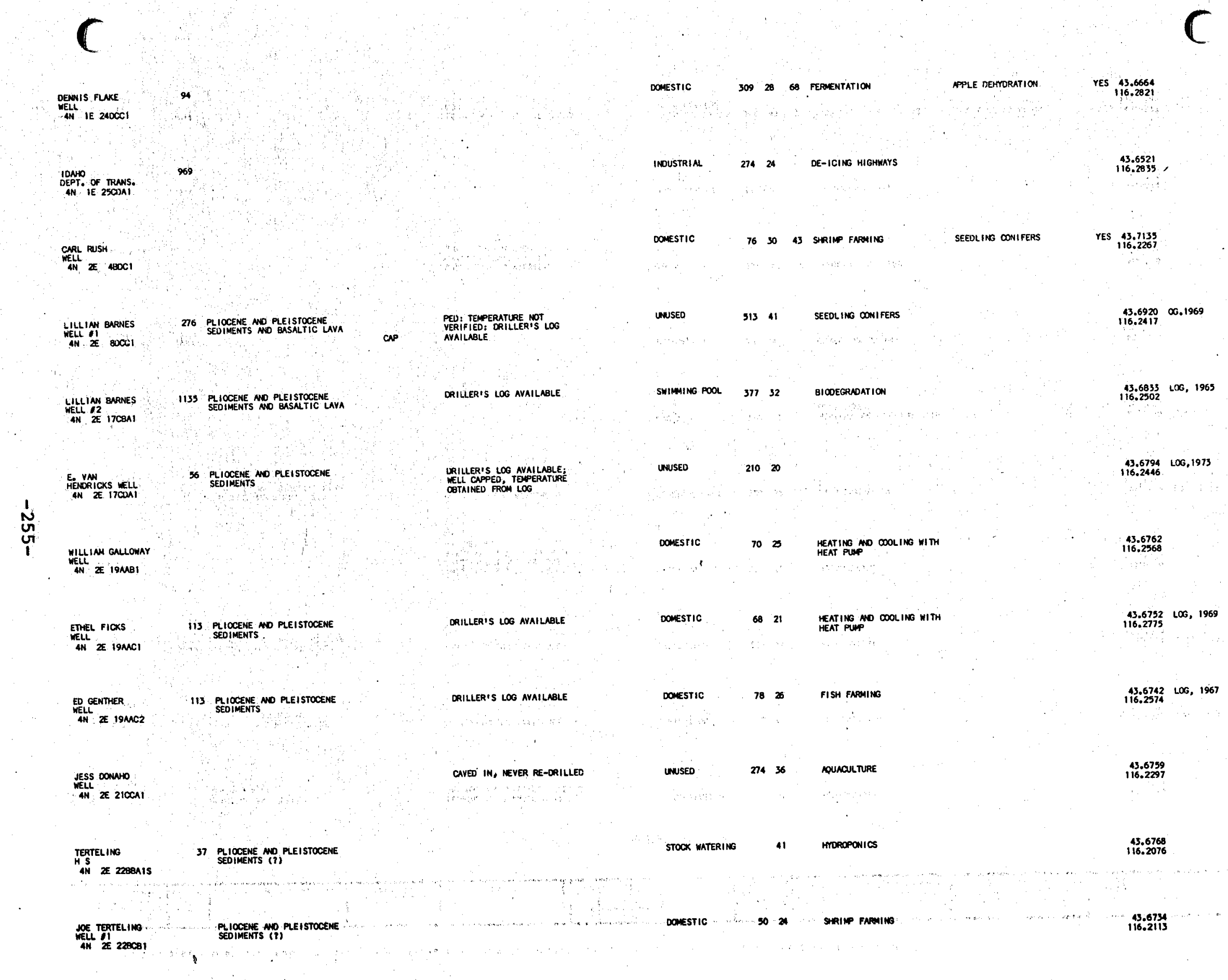


Basic Data Table 4. Location, Geologic Environment, Present Use and Potential Use of Thermal Springs and well. in Idaho (continued)

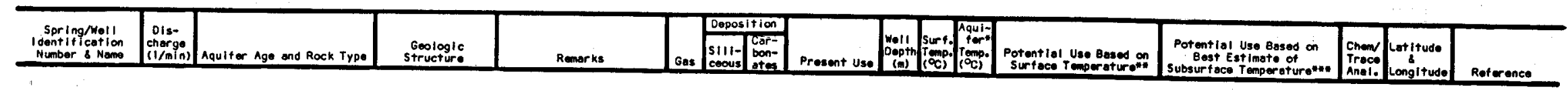

Ada County (cont'd.)

JOE TERTELING PLIOCENE MO PLEISTOCENE
MELL
AN ZE 22HSOI

WEL $\$ 3$ TE $22 \mathrm{CHOH}$

PLIOCENE NO PLEISTOCENE
SEOMENTS OERKLINING

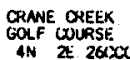

COA9 PLIOCENE MO PIEISTOCENE
SEDIMENTS NO GASALTIC LANA

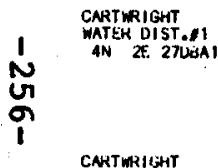

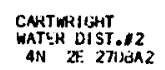

PLIOCENE MOP PLEISTOCENE
SE:IIMENTS NW BASALTIL LAVA

CNRTWRIGHT
WATER DIST.,13
AN 2E 270BA3

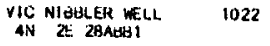

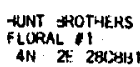

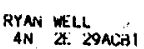

1430

EDWANO'S
GREENHOUSE WELL
4N 2 I 29AEDI
FLOWIGG OLLO MATER NEXT TO

DRILLER'S LOG AVALLABLE

DRILLER'S LOG AVAILABLE

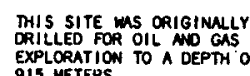

DRI LLER'S LOG AVAILABLE

$\therefore \cdot$

SO KNOWN AS MILSTENO

FLORAL; FLOWING WEELL
SLIGHT' SULFUR DOOR

FLOWING WELL; SLIGHT SULFUR
SPACE IEATING

16744 MQUAOULTURE

IRRIGATION

18243 PEPMENTATION

IPRIGATION

22521 FISH HATOANO

PUaLIC SUPPLY

21332

MQUACULTURE

PUBLIC SUPPLY 22832 BIOOEGRNATION

oomestic

15232 HEATING MO DOOLING WITH

IRRIGATION

39648 GRAIN-HAY DRYING

CREENHOUSE

38147 SEEDLING CONIFERS

SPACE HeATING

33546

GRAINHAYY DRYING

GREENHOUSE NO
SPACE HEATHNG

PRUNE DEHYRATION
135.6710

$\begin{aligned} & 43.6695 \\ & 116.2107\end{aligned} 100,1968$

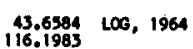

$\frac{13.6596}{116.6994}$

$\frac{43.6349}{116.6994} 100,1976$

116.05998

$\frac{143.6516}{116.2212}$

193.6556

1.43.6614

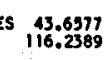




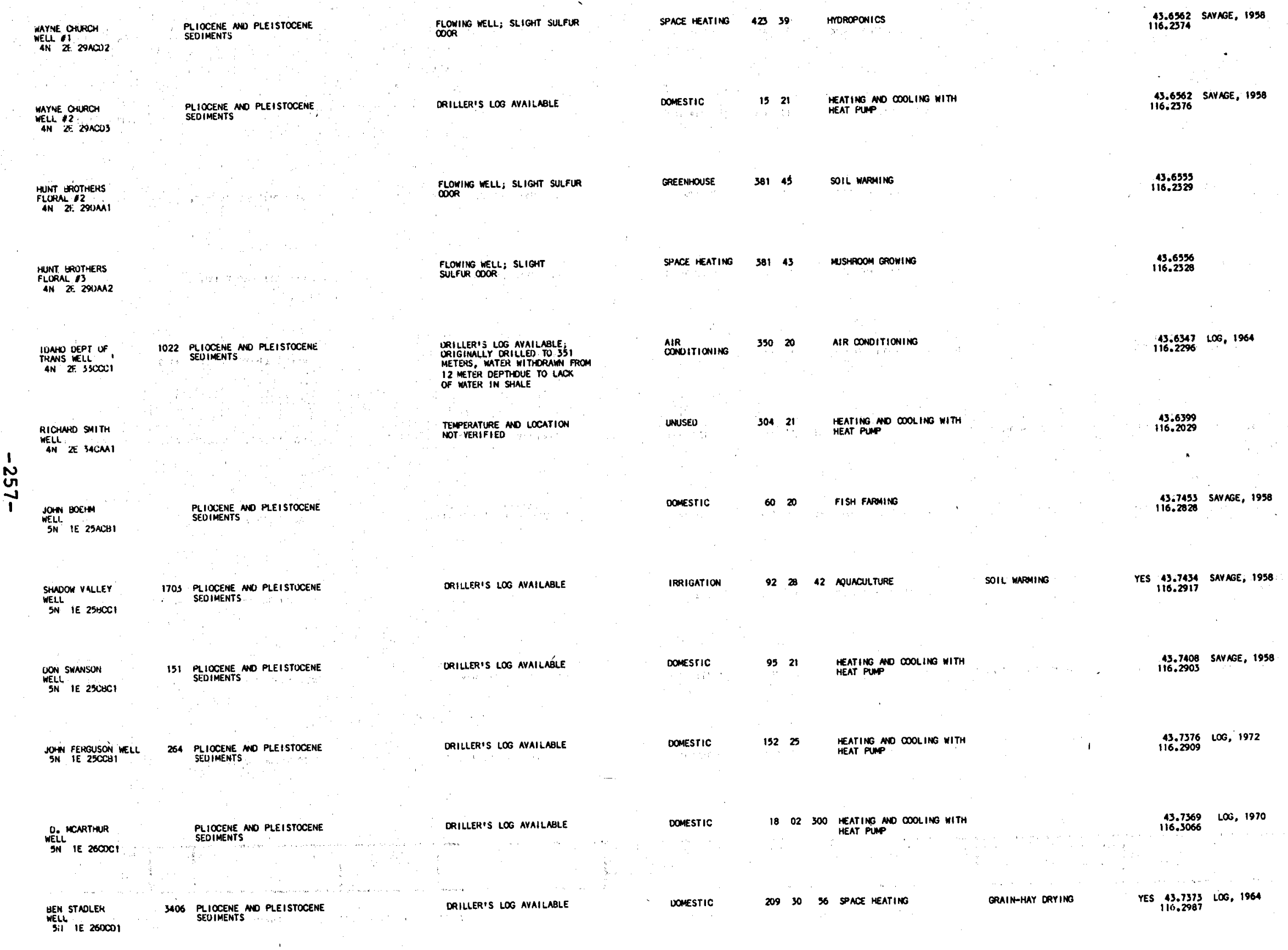


Basic Data Table 4. Location, Geologie Environment, Present Use and Potential Use of Thermal Springs and wells in Idaho (continued)

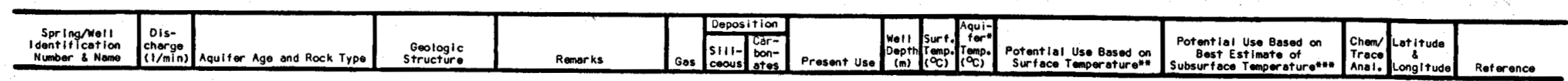

Ada County (cont'd.)

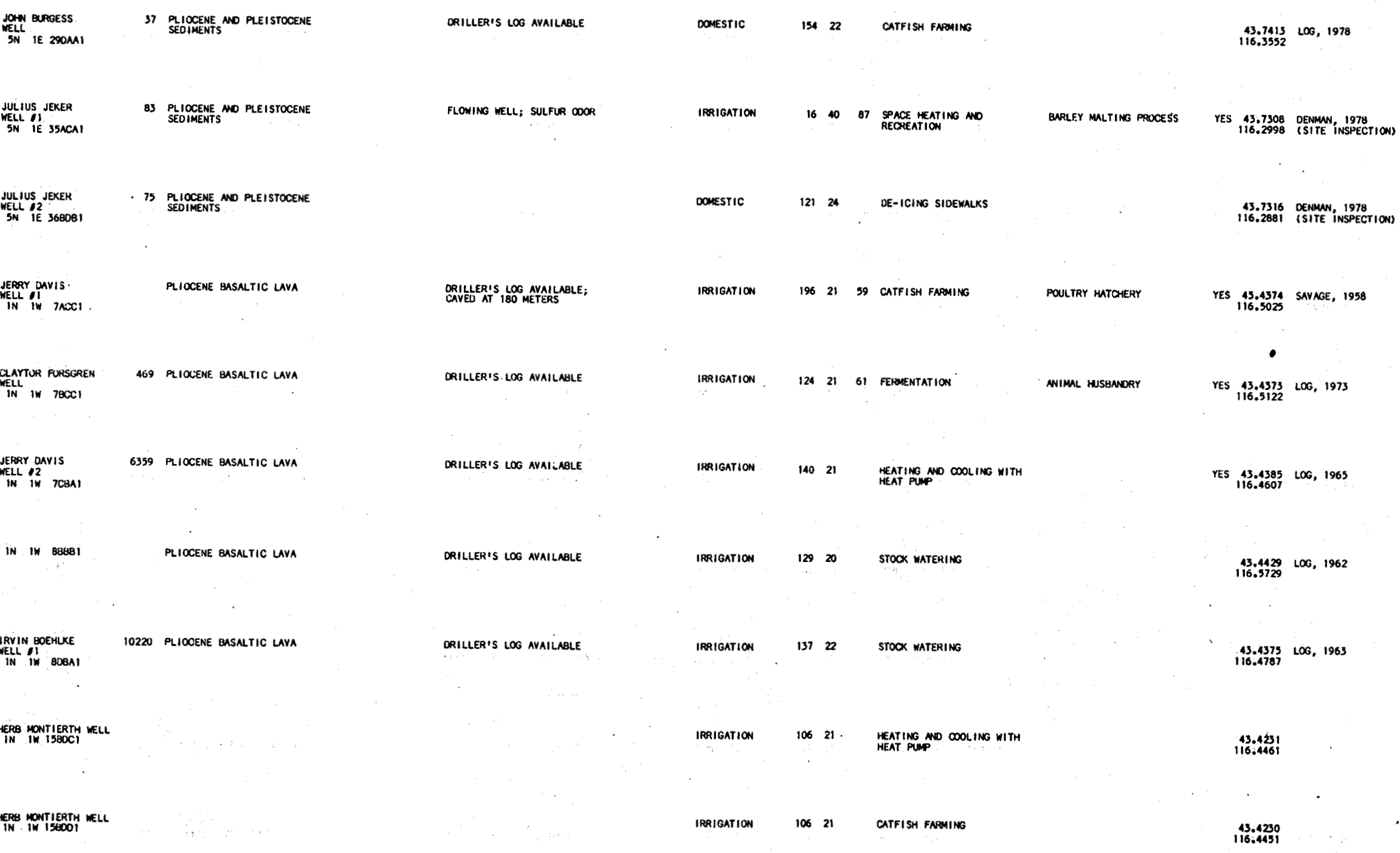


IRVIN BOEHLKE
WELL 2
IN

pliocene Basaltic LaVA

DRILLER'S LOG AVAILABLE

JRVIN BOEHLKE

IN II 17CAd!

LLOYO NOE WELC

PLIOCENE NND PLE I STOCENE
SEOMMENTS

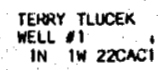

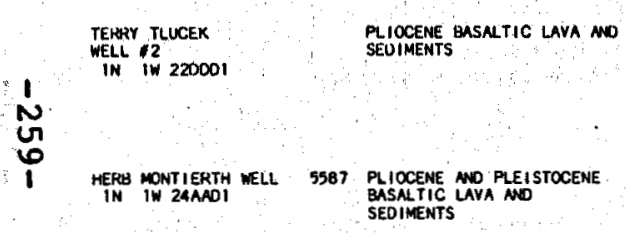

TERPY TUUCEK
WLLL
IN

4542 PLIOCENE NO PLEISTOCENE
SEOMENTS NO BASALTIC LAVA

LLOY NOE

PLIOCENE MD PLEISTOCENE
SEDMENTS ND BASALTIC LAVA

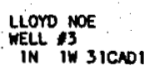

PLIOCENE MO PLEISTOCENE
SEDIMENTS

MIKE YNOENGERO

WELL AW 32MEI

KENETH FORREY
WEL II 34 INOC1
RILLER's LOG AYAiLABLE

DRILLER'S LOG AVAILABLE

DRILLER'S LOG AVAILABLE

ORILLER'S LOG AVAILABLE

TEMPERATURE NOT YARIFIED

DRILLER'S LOG AVAILABLE
IRRIGATION

12322 CATFISH FAPMING

IRRIGATION

DOMESTIC

IFRIGATION

10521

HEATING ND COOL ING WITH

IRRIGATION

$106 \quad 27$ 57 CATFISH FNPMING

IRRIGATION

1112

DE-ICING RONOMATS

IRRIGATIOON

111 2

STOOX WATERING

imigation

1092

CATFISH FAPMING

IRRIGATION

11824 DE-IGING RONDWAYS

DOMESTIC

216

Domestic

106 27. BIOOEGROATION
116.4330

43.4262
116.4784 L06, 1963

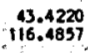

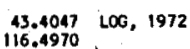

4.35 .4047

geAINHAYY DRYING

YES $\begin{aligned} & 43.4019 \\ & 116.4339\end{aligned}$ LOO, 1964

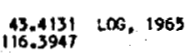

$\begin{array}{r}43.3998 \\ 116.4526\end{array} 206,1976$

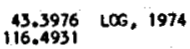

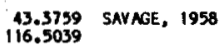

115.98970

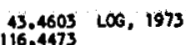


Basic Data Table 4. Location, Geologic Environment, Present Use and Potential Use of Thermal Springs and wells in Idaho (continued)

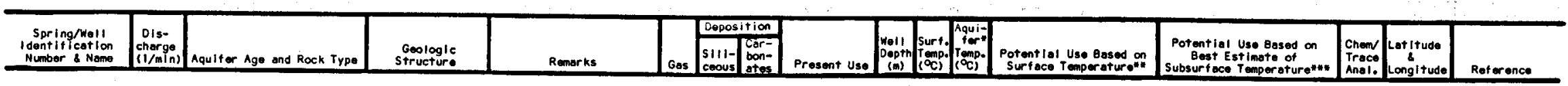

Ada County (cont'd.)

\begin{tabular}{|c|c|c|c|c|c|c|c|c|c|c|}
\hline 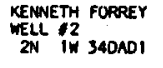 & & $\begin{array}{l}\text { PLLOCENE MO PLEISTOCENE } \\
\text { SEOMENTS NO BSALTIC UANA }\end{array}$ & DRILLER'S LOG AYAILABLE & IPRIGATION & 107 & 20 & CATFISH FNPWINO & & $\begin{array}{l}43.4645 \\
116.4328\end{array}$ & Los. 1967 \\
\hline $\begin{array}{l}\text { SMM GABIOLA } \\
\text { WELL IN IN } \\
\text { IN } 35 \mathrm{CMN}\end{array}$ & 3996 & $\begin{array}{l}\text { PLIOCENE MO PLEISTOCEEE } \\
\text { SEOIMENTS MO EASALTIC LAYA }\end{array}$ & DRILLER'S LOG AYAILABLE & IRRIGATION & 96 & 23 & $\begin{array}{l}\text { REATING NO OOLLING WITH } \\
\text { MEAT PUNP }\end{array}$ & & $\begin{array}{l}13.4622 \\
116.4246\end{array}$ & 200,1958 \\
\hline 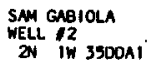 & & & & IRRIGATION & 146 & 22 & FEIMENTATION & & $\begin{array}{l}43.4660 \\
116.4140\end{array}$ & \\
\hline $\begin{array}{l}\text { BISOHOF REALTY } \\
\text { 3N IW 25NOOI }\end{array}$ & & $\begin{array}{l}\text { PLIOCENE ND PLEISTOCENE } \\
\text { SEDIMENTS }\end{array}$ & $\begin{array}{l}\text { DRRLLER'S LOG AVAILABLE; } \\
\text { NBNOONED }\end{array}$ & Domestic & 68 & $21 \quad 27$ & CATFISH FNRMING & BIOOEGRAATION & YES $\begin{array}{l}43.5685 \\
116.3940\end{array}$ & Los, 1970 \\
\hline $\begin{array}{l}\text { CLIFFOFO SMITH } \\
\text { WEL IW BADCI }\end{array}$ & & $\begin{array}{l}\text { PLIOCENE NO PLEISTOCENE } \\
\text { SEDIMENTS }\end{array}$ & DRILLER'S LOG AVAILAELE & DOMESTIC & 152 & 28 & NQUACULTURE & & $\begin{array}{l}43.7875 \\
116.4747\end{array}$ & SAYAGE, 1958 \\
\hline $\begin{array}{l}\text { DEE RACHILLA } \\
\text { WELL IW BNOO1 }\end{array}$ & 52 & $\begin{array}{l}\text { PLIOCENE MNO PLEISTOCENE } \\
\text { SEDIMENTS }\end{array}$ & DRILLER'S LOQ AVAILAELE & Domestic & 106 & 21 & $\begin{array}{l}\text { MEATING MO DOOLING WITH } \\
\text { HEAT PUUPP }\end{array}$ & & $\begin{array}{r}43.7888 \\
116.4726\end{array}$ & Lox, 1971 \\
\hline $\begin{array}{l}\text { DAVID TRAYLOR } \\
\text { WELL IW SCAOT } \\
\text { SN }\end{array}$ & & $\begin{array}{l}\text { PLIOCENE ND PLEISTOCENE } \\
\text { SEDIMENTS }\end{array}$ & DRILLER'S LOG AVAILABLE & Domestic & 119 & 20 & BIODEGRAOATION & & $\begin{array}{l}43.7826 \\
116.3149\end{array}$ & Los, 1972 \\
\hline $\begin{array}{l}\text { 81LL LEACH } \\
\text { WELL } \\
\text { SN NW } 90001\end{array}$ & & $\begin{array}{l}\text { PLIOCENE MO PLEISTOCENE } \\
\text { SED IMENTS }\end{array}$ & ORILLER'S LOG AVAILABLE & DOMESTIC & 137 & o & HTOROPOWICS & & $\begin{array}{l}43.7835 \\
116.4620\end{array}$ & LOG, 1967 \\
\hline $\begin{array}{l}\text { LETHA FISHER } \\
\text { WELL IN 16CABI } \\
\text { SN }\end{array}$ & & $\begin{array}{l}\text { PLLOCENE ND PLEISTOCENE } \\
\text { SEDIMENTS }\end{array}$ & DRILLER'S LOG AVAILABLE & DONESTIC & 191 & $21 \quad 70$ & $\begin{array}{l}\text { GROUNO-MATER HEAT PUAP } \\
\text { FOR HEATING MO DOLING }\end{array}$ & ONION DEHYPRATION & YES ${ }_{116.4625}^{43.7701}$ & $L 06,1963$ \\
\hline $\begin{array}{l}\text { HWRPY OANTERS } \\
\text { WELL IN SABCI } \\
\text { IS IN }\end{array}$ & 13627 & PLIOCEME BASALTIC LAYA & DRILLER'S LOG AYAILABLE & IRRIGATION & 112 & $26 \quad 71$ & CATFISH FARMING & PASTEURIZED MILK PROCESS & $\begin{array}{ll}\text { YES } \\
113.36 .4618\end{array}$ & Los, 1969 \\
\hline
\end{tabular}




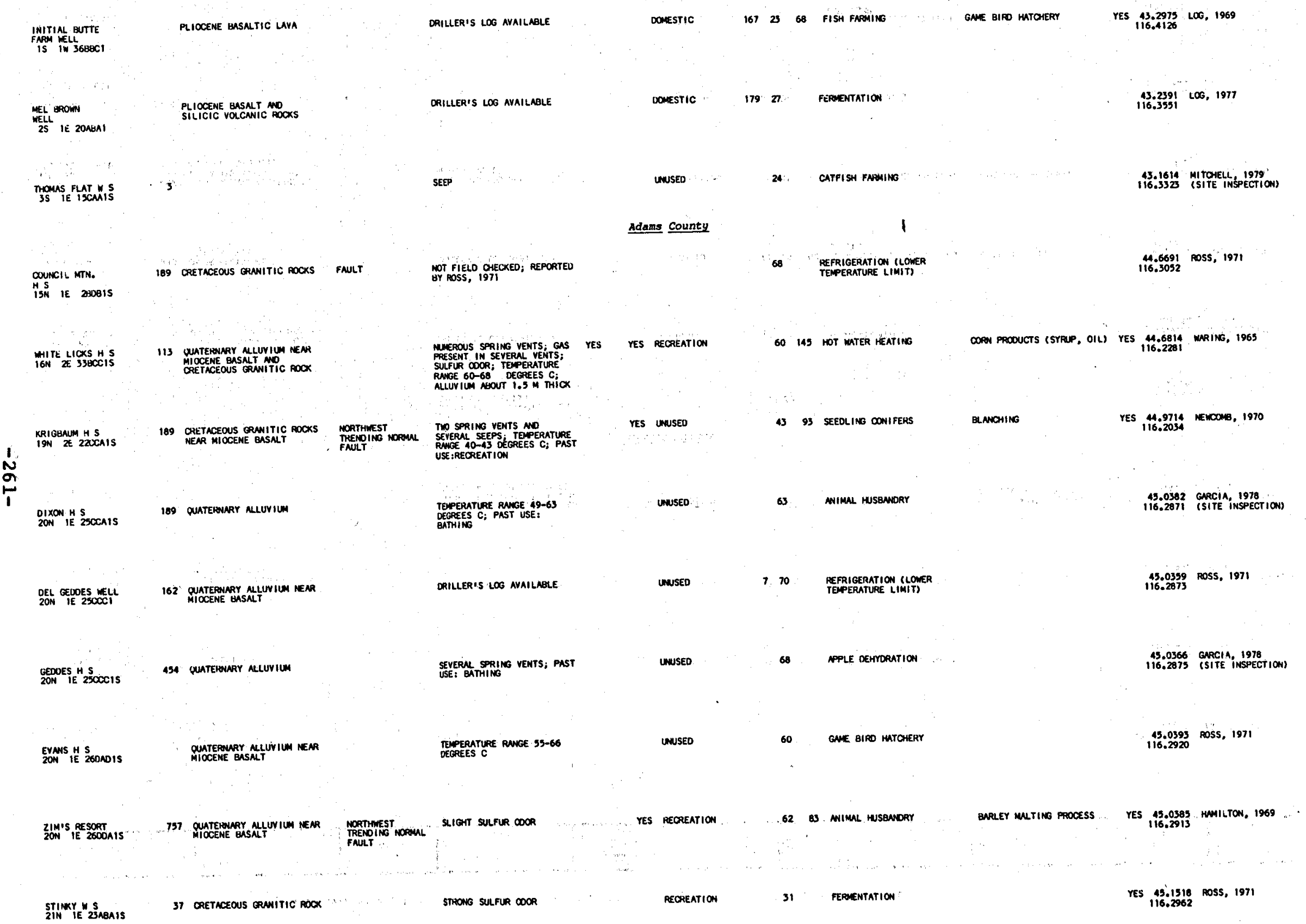


Basic Data Table 4. Location, Geologic Environment, Present Use and Potential Use of Thermal Springs and Wells in Idaho (continued)

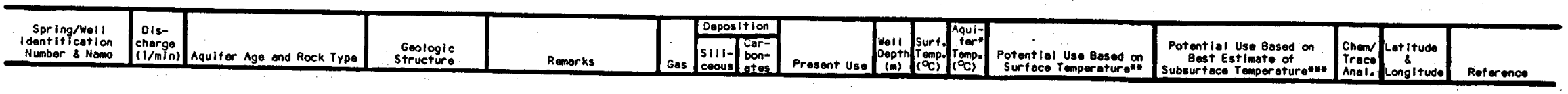

Adams County (cont'd.)

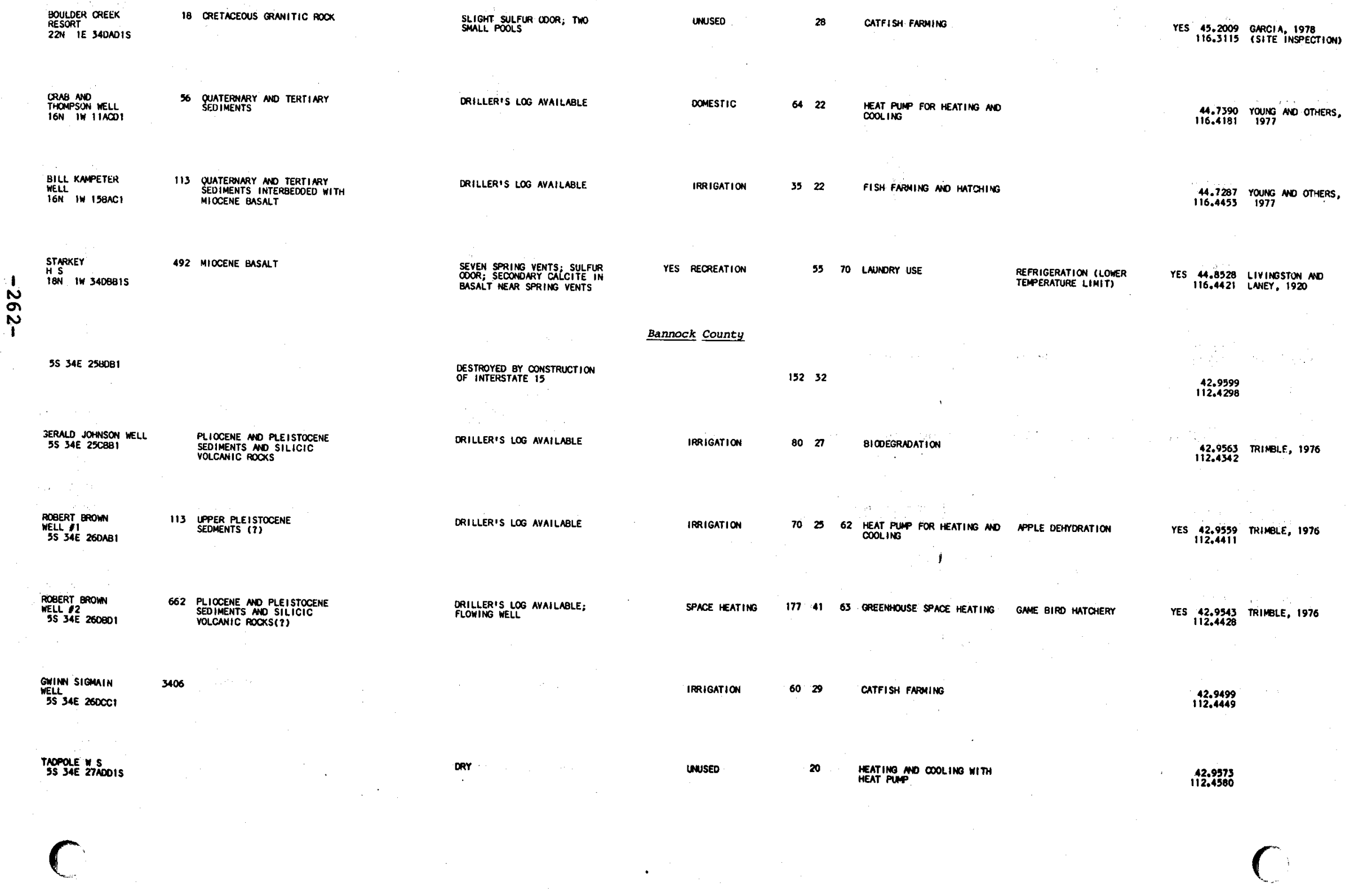


DEN MORRIS

DOMESTIC

$2422 \quad 40$ CATFISH FAPMING

SOIL WARMING

VES $\underset{12.6642}{112356}$

LANA 5 s

PRLEOZOIC OURRTZITE MO FAULT
YOUNGER TRAVERTINE

MUMEROUS SPRING VENTS
EXENSTIVETRAVETINE
DEPOSITION

reS

TES RECREATION

TES REGREATION

LAVA HS

PALEOZOIC QURTTZITE

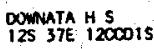

1854 QUATERANRY RLLUUIUN NEAR
TERIINAY SEDIMENTS

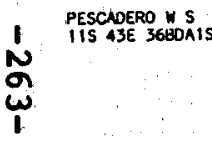

31. PRLEOZOIC LIMESTOWE

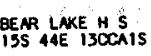

PALEOZOIC LIMESTONE

NORTH TRENOING

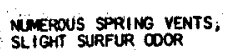

YMNOELL SPRINGS W S S671. PRE-TERTINAY LLMESTOWE

TEPERATURE RMGE $18-32$
DEGRES $C$

MLKNLI FUATS WS

37. TUFA IN QUATEROART NLLUVIUM

$\underset{\text { HAILEY H S }}{\text { 2N ISE I8DBQIS }}$

264 PALEOZOIC LIMESTONE

CLAPEOON H S
BQANOCK-SHOSHONE TRIBE,

YES

Blaine county

MUERRUS SORING VENTS; YES YES UNUSED
SULFUR ODOR STERERATURE RANGE 42-52
HIAMATHA HOTEL MO POO

SULFUR OOOR, MMERPOUS
RECREATION

Bear Lake County

MOROPONIC

and

69 CATFISH FNeming

GRAIN-HAY DRYING

ES 111.37378 viow, 1969

res PECREATION

48 Sh GRAinthaY DRY ING

HOT EED MEATING

YES $\underset{111.2640}{\$ 1.1148}$ DIOW, 1969

Bingham County

IRRIGATIOI

3235 AQUAOULTURE

BIOOEGRAOATION

YES 113.1143 poss, 1971

SPACE MEATING

Y 1123.0377 Ross, 1971
55. B3 SEEOLING DONIFERS

52. B7, SPACE HEATING
BLANOHNO
YES $\begin{aligned} & \text { 42.6205 STENONS ND } \\ & 112.0082 \text { OTHERS, } 1938\end{aligned}$

YES $\begin{aligned} & 42.6198 \\ & 112,0053\end{aligned}$

YES $\begin{aligned} & 42.3877 \\ & 12.0851 \text { NORNITCH, NO }\end{aligned}$ 
Basic Data Table 4. Location, Geologic Environment, Present Use and potential Use of Thermal Springs and walls in Idaho (continued)

\begin{tabular}{|c|c|c|c|c|c|c|c|c|c|c|c|c|c|}
\hline $\begin{array}{c}\text { Spring/Noll } \\
\text { Iolantiflcation } \\
\text { Number \& Name } \\
\end{array}$ & $\begin{array}{l}\text { Dis- } \\
\text { enserge } \\
\text { ens/min }\end{array}$ & Aquilfer Age ond Rock Type & $\begin{array}{l}\text { Geologle } \\
\text { Strueture }\end{array}$ & Remorks & Gas & 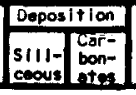 & Prosent Uso & 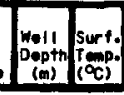 & 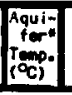 & $\begin{array}{l}\text { Potemtlal Use Basod on } \\
\text { Surtece Temporeturent }\end{array}$ & 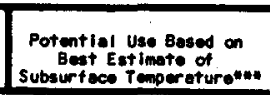 & $\begin{array}{l}\text { cheow } \\
\text { Tracec } \\
\text { Anal. }\end{array}$ & 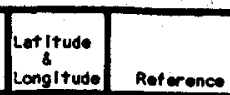 \\
\hline
\end{tabular}

Blaine county (cont'd.)

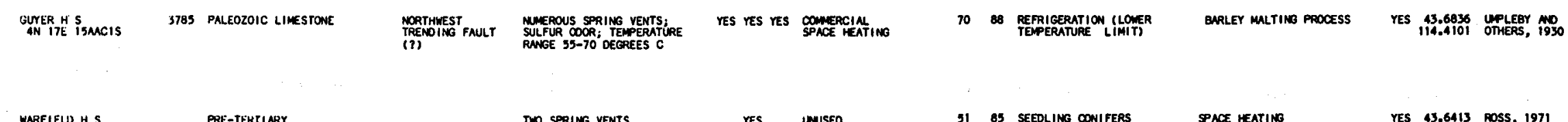

\begin{tabular}{|c|c|c|c|c|c|c|c|c|c|c|c|c|}
\hline $\begin{array}{l}\text { MARFIELD HS } \\
\text { WN IJE SIBOCIS }\end{array}$ & & $\begin{array}{l}\text { PRE-TERTIARY } \\
\text { UEIFFERENTIATEU HOCKS }\end{array}$ & TWO SPRING VENTS & $n$ & & UNUSEO & si & 3185 & SEEDLING OONIFERS & SPACE HEATING & YES 113.6413 & ROSs, 1971 \\
\hline $\begin{array}{l}\text { EASLEV "SS } \\
\text { SN ISE IOUBCIS }\end{array}$ & 189 & 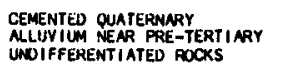 & SIX SPRING VENTS & & & SWIMUING POOL & 3 & $38 \quad 43$ & MTOROPONIICS & SOIL WNPENA & VES 113.77995 & ROSS, 1971 \\
\hline 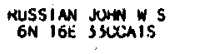 & 3 & WATERNARY ALIIUVIUM & SEEPING MORE THW RLOWING & re & & UNUSED & 3 & $38 \quad 32$ & Mpuncuiruture & MUSHROOM GPOWING & YES, 134.80522 & Ross, 1971 \\
\hline 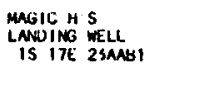 & 56 & QUATENANAY SEUIMENTS (I) & 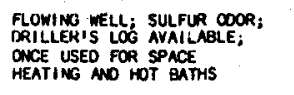 & & YES & unUSEO & 797 & 174 & $\begin{array}{l}\text { REFRIGERATION LUOWER } \\
\text { TEPERUTURE LIMIT) }\end{array}$ & ORY QEENING & VES 113.32899 & $\operatorname{sMl} 1 \mathrm{TH}, 1959$ \\
\hline 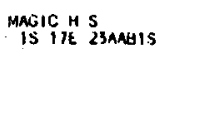 & 1514 & SUATEHNNEY NLLUVIUM (?) & 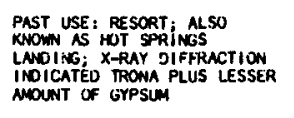 & & res & unesED & 7 & 73 & BALNEOLOGICAL BATHS & & 114.3989 & SMitTh, 1959 \\
\hline $\begin{array}{l}\text { CHANLES LNRKIN WELL } \\
\text { IS ZOE ISOCAT }\end{array}$ & 2271 & QUATERNABY MLLUVIUM & DRILLER'S LOG AVAILABLE & & & IRRIGATION & 303 & 38 & HMOROPONICS & & $\begin{array}{l}43.3320 \\
114.0836\end{array}$ & $\begin{array}{l}\text { CASTELN NO } \\
\text { OHPMN, } 1972\end{array}$ \\
\hline 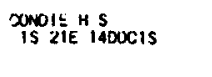 & 1309 & $\begin{array}{l}\text { WUATERANAY MLLIYYIUM NEAN } \\
\text { PLEISTOCENE BSSALT }\end{array}$ & $\begin{array}{l}X \text { X-AY DIFFRACTION MULYYSIS } \\
\text { INOICATED CALCIUM CABBONATE }\end{array}$ & YES & YES & IRPIGATION & 5 & 5189 & GRAIN MO HAY DRYING & QuNOHNG & YES $\begin{array}{c}43.3270 \\
113.9178\end{array}$ & $\begin{array}{l}\text { STEARNS NOD } \\
\text { OTHERS, } 1938\end{array}$ \\
\hline $\begin{array}{l}\text { MILFOFU SWEAT } 4 S \\
\text { IS 22E: IUAASIS }\end{array}$ & 75 & 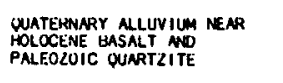 & TWO SPRING VENTS & res & YES & IRRIGATION & & 1464 & HYDRCPONICS & APPLE DEHTORATION & VES $\begin{array}{c}13.3630 \\
113.7794\end{array}$ & Ross, 1971 \\
\hline 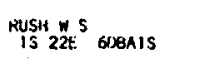 & & WUATERNARY ALLIIVIUM & & & & unusEo & & 22 & FISH FNPOMING & & $\begin{array}{l}13.3669 \\
113.8643\end{array}$ & $\begin{array}{l}\text { EOONER NO EUSH, } \\
1978\end{array}$ \\
\hline
\end{tabular}




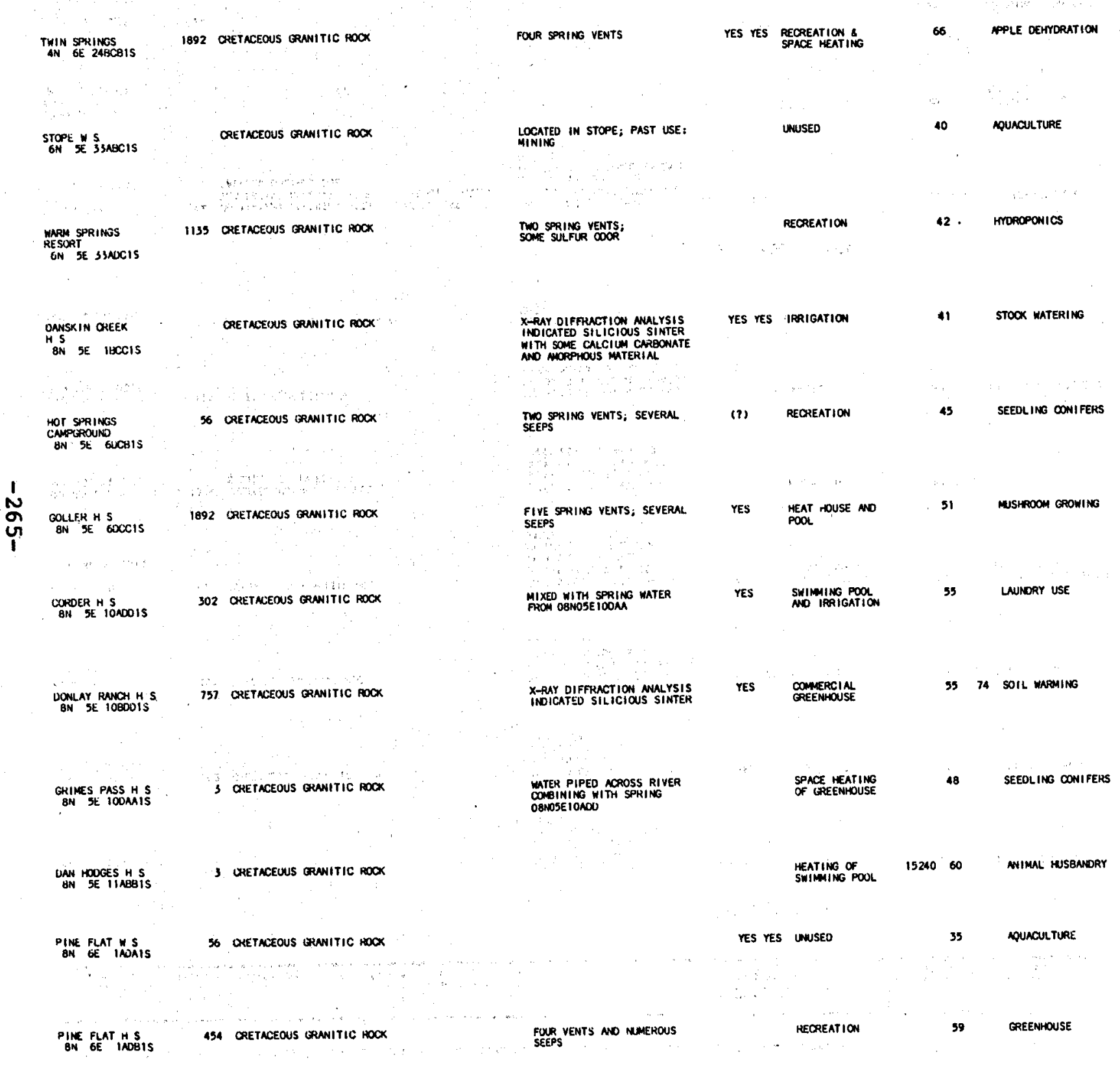

\section{Bolse county}

YES 133.6705 Ross, 1971

43.8192
115.8682
IOWNSON, 1978
(SITE (ISPECGION)

113.8162 Ross, 1971

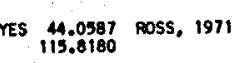

VES 14.05500 RoSs, 1971

$144: 09532$ ross, 1971

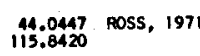

ONION DERTORATION

YES, 41.0439 poss, 1971

115.8423 Ross, 1971

115.0286 . 9055,1971

144.0620045 Ross, 1971

114.06869 ross, 1971 
Basic Data Table 4. Location, Geologie Environment, Present Use and Potential Use of Thermal Springs and walls in Idaho (continued)

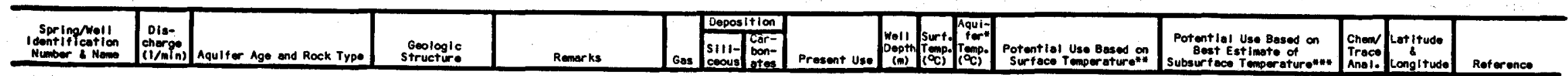

Boise County (cont'd.)

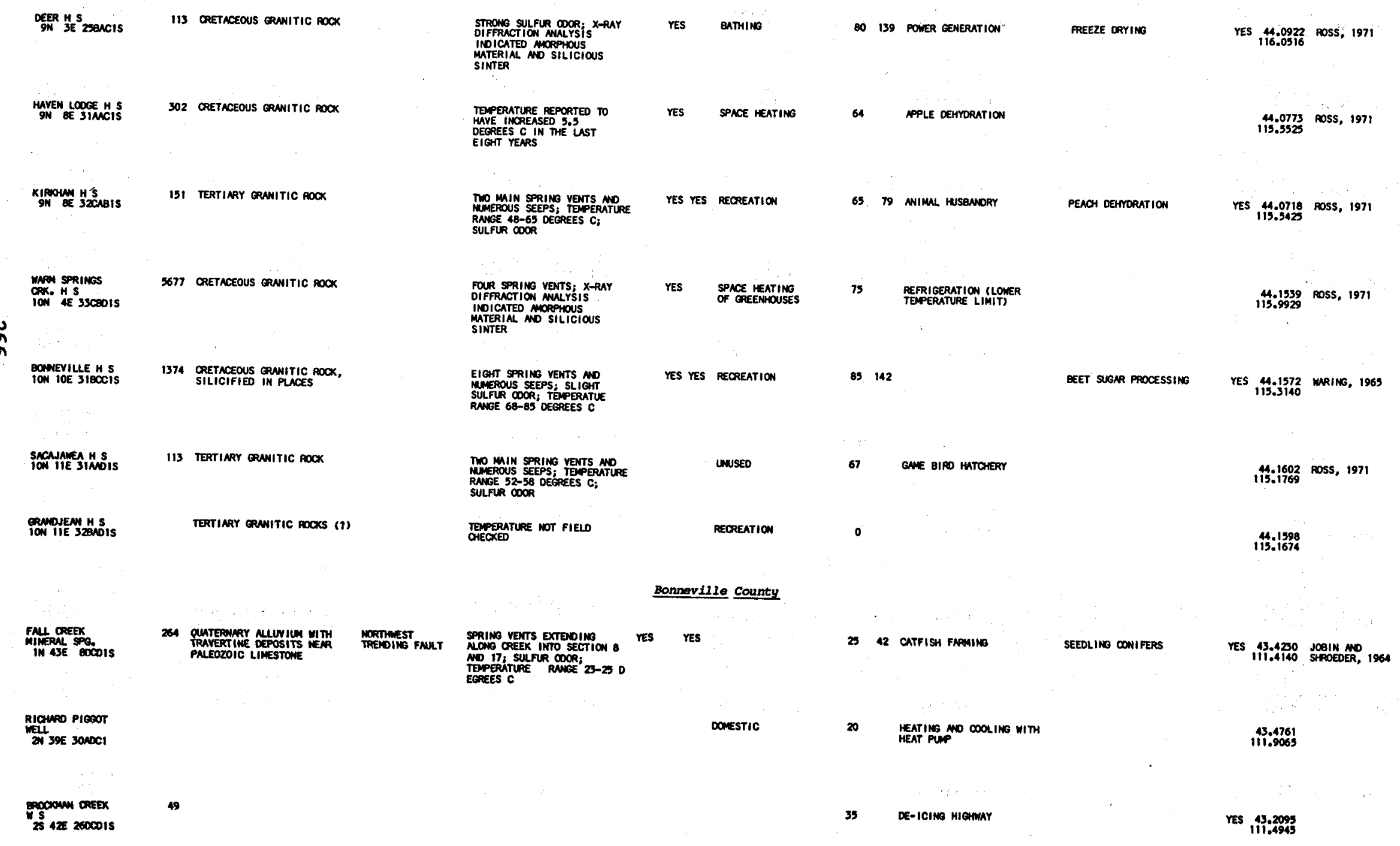




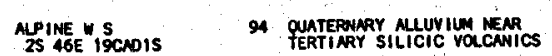

LEWIS ROTHWEL MELL PLEISTOCENE AASNT

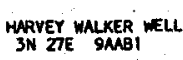

BUTE CITY WELL

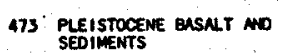

BUTrE CIT MELL

473 PEE ISTOCENE EASNT NO
SEODKENTS

$\stackrel{1}{1}$

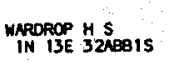

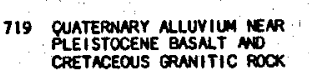

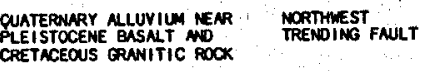

ELK OREER HS
IN $15 E$ T140ANS

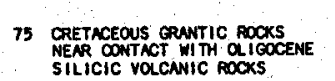

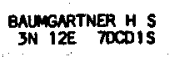

75 CRETACEOUS GRNITIC ROOKS

LIOATFoor. HS

189 CRETACEOUS ORNITIC ROOKS

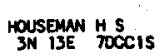

PAEISH S S

\footnotetext{
10. TRETIRY DIKES IN
}

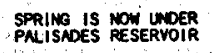

3761 BIOOEGRAOATION

APPLE DEMPRATION

YES 43.2265 ross, 1971

Butte county
ORILLER'S LOG AVAILABLE

NOT FIELD OAECXED

ORILLRRS LOG ANAILABLE;

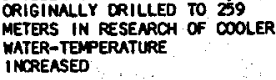

STOOK MATERING

109 4S 76 GREENHOUSE NO SOIL

STOCX WATERING

18240

PUBLIC SUPPLY

PUBLIC SIPPL

FEAEENATION

Camas County

Domestic

MUEROUS SPRING VENTS
TEAPRARTURE RMGE $60-67$
OEGEEES C; ALSO KNOW AS

FIYE SRENG VENTS NO TMEROUS SEEPS:
DECRERT C

SLIGT SULFUR COOR

SEVERA SPRING VENTS;

UNUSED

UNUSED

inuseo
BIOEEgrnoATIOA

Gapagation (LONER
TEPERATURE LIMIT)

YES 13.5401 MYTCHELL MO

43.6093
113.2884

YES $\begin{aligned} & 43.6007 \\ & 113.2436 \text { MITCHELL, MOO }\end{aligned}$

43.6086 MITCHELL MO
113.244 YOUNG, 1973 $\therefore$

43.3832 MLITON, 1962
114.9319
.

YES 133.4232 WALTOW, 1962

YES 133.6025 ROSS, 1971

YES 33.6054 GARCIA, 1978
114.9492 (SITE INSPECTION)

$\mathbf{4 3 . 6 0 2 3}$
114.9516

43.5762 ross, 1971
114.8299 
Basic Data Table 4. Location, Geologic Environment, Present Use and Potential Use of Thermal Springs and wells in Idaho (continued)

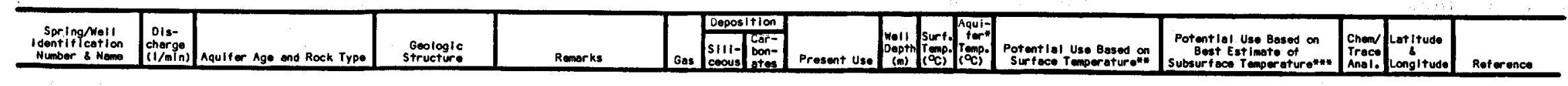

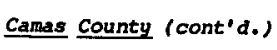

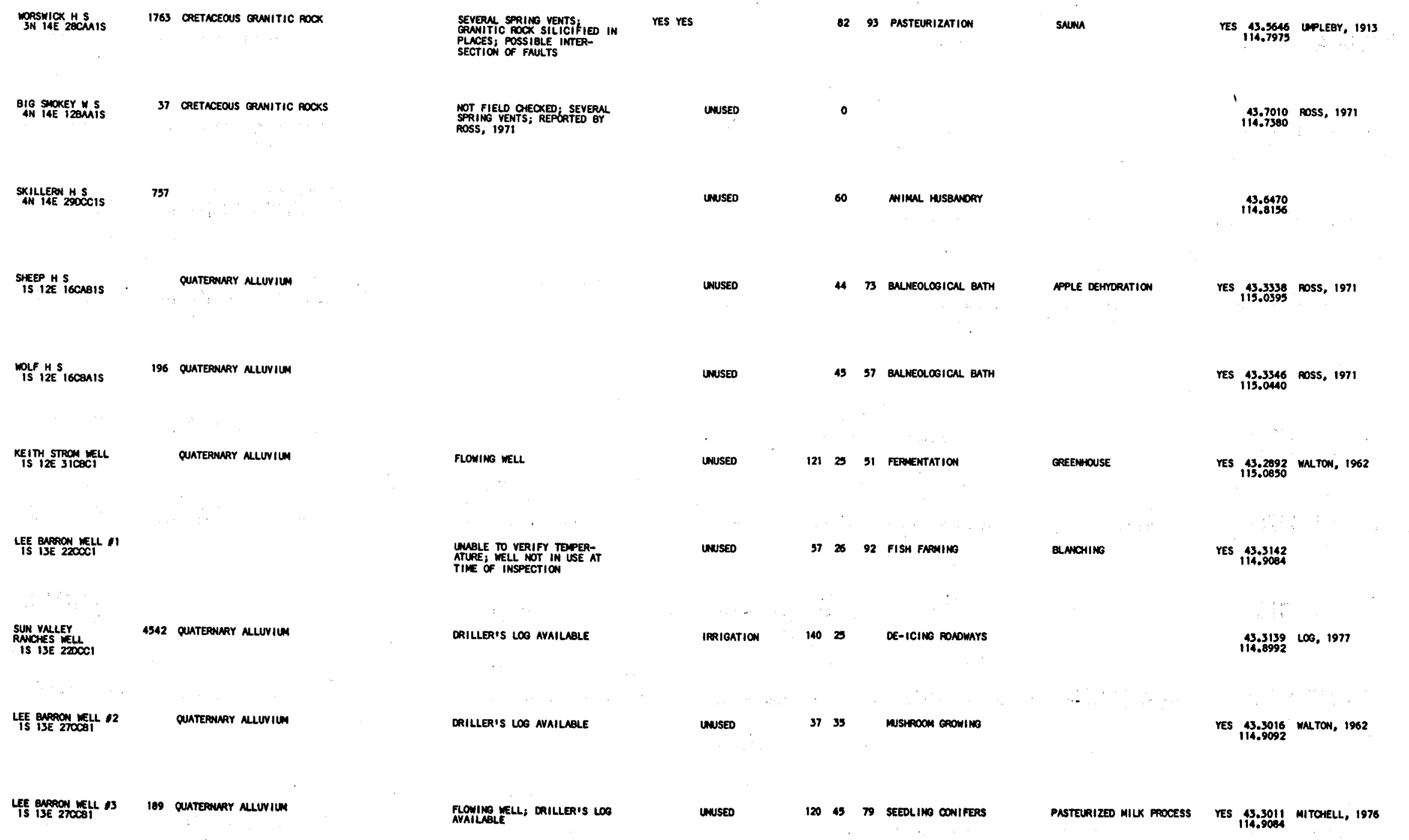

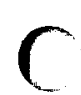




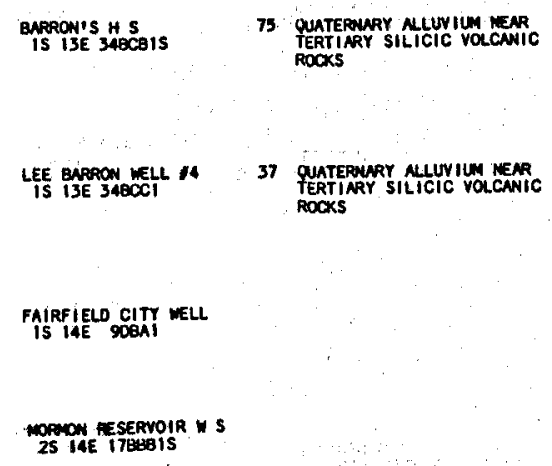

75 PUIOCEES MO PLEI ISTOCENE
Donestic

7595 ochropation

MEATING

\section{OBDILER'S LOO AYALANGLE
FLOTNGG WELL}

NOT FIELD CMECXED

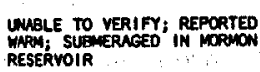

ORILLER'S LOS AYAILABLE

\section{Nor}

DRILLER'S LOG AVAILABLE

OOSERYAIION YGLL; DRILLR'S

ORILLER'S LOG AYALLARL

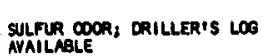

IRRIGATION

IRRIGATIOI

IRPIGATION

canyon county

IRRIGATION

IRRIGATION

IRRIGATIOA

132 CSS CATFISH FAPMINO

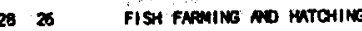

137 21 MEATING MO DOL ING WITH

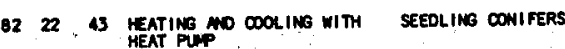

17322 FISH PNOMING no mutoming res 43.2399 Ross, 1971

Yes 13.92921 poss, 1971

res 143.3493

$\frac{135.2549}{114.6293}$
43.4512
116.5776

RES 113.4524 SANAGE, 1958 43.4503
116.6069 SANAEE, 1938

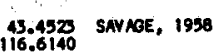

YES 1136.4014 SANASE, 1958

YES 43.4379 SAMAGE, 1958 133.4454 SARMEE, 1998 
Basic Data Table 4. Location, Geologic Environment, Present Use and Potential use of Thermal Springs and wello in Idaho (continued)

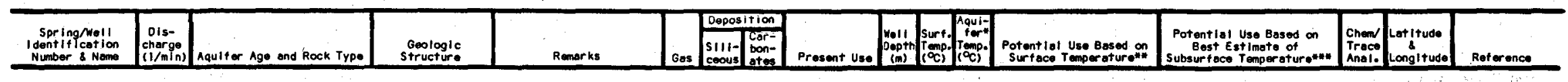

Canyon county (cont'd.)

MPK MVRER $\quad 3706$ PLLOCENE, NO PLEISTOCENE

STEVE TIEGS PLIOCENE MO PLEISTOCENE

J. SHERRL JOANSTON 1703 PLIOCEEE NO PLE ISTOCENE
SEDIMENTS
IN 2W 20NOI

$\stackrel{1}{1}$

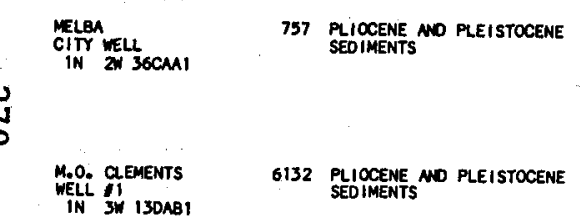

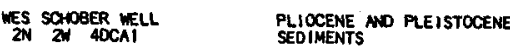

JOWN TUCKER WELLL
2N 2049 PLLCACENE NO PLEISTOCENE
SEDIMENTS

DALE GETER WELL

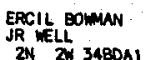

2649 PLIOCENE NO PLEISTOCENE
SEDIMENTS

$\underset{2 N}{\text { JAY NEIOER }}$

PLIOCENE MO PLEISTOCENE
SEDIKENTS
IRRIGATION

15222 MEATINO MO DOOLINO WITH

DRILLER'S LOG AVAILABLE

ORILLER'S LOG AYAILABLE

DRILLER'S LOG AVAILABLE

NORTHWEST
TREMOING FAULT SULFUR OOOR; DRILLER'S LOG
NYALLABLE

NORTHWEST
TRENOING FAULT DRILLER'S LOG AVAILABLE
II)
IRRIGATION

12120 MEATING WO DOLING WITH

IRRIGATION

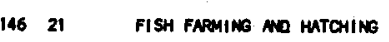

PUBLIC SUPPLY

182. 21 FISH FAPMing no miching

IRRIGATIOA

183 20. MEATING MNO DOOLING WITH

IPRIGATION

11222 FISH FNOMING NO HUTCHNG

IRRIGATION

184 27 REATING MO DOUING WITH

oOMEstic

20 repmentation

IRRIGATION

9649 ERLNELLOSICN BATHS

IRRIGATION

9729 DE-ICING RONDAYS
43.4586 SAYMEE, 1958
116.5141

45.4175 SAYAGE, 1930
116.6000

43.4063 SAYAGE, 1958
116.5548

YES $\begin{gathered}43.3780 \\ 116.5250\end{gathered}$

c 116.4235 SAYAEE, 1958

43.5349
116.5776

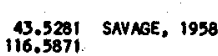

43.4809 DEMUN, 1979
116.5808 (SITE INSPECTION)

YES $\begin{aligned} & 33.4698 \\ & 116.5629\end{aligned}$

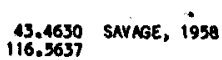




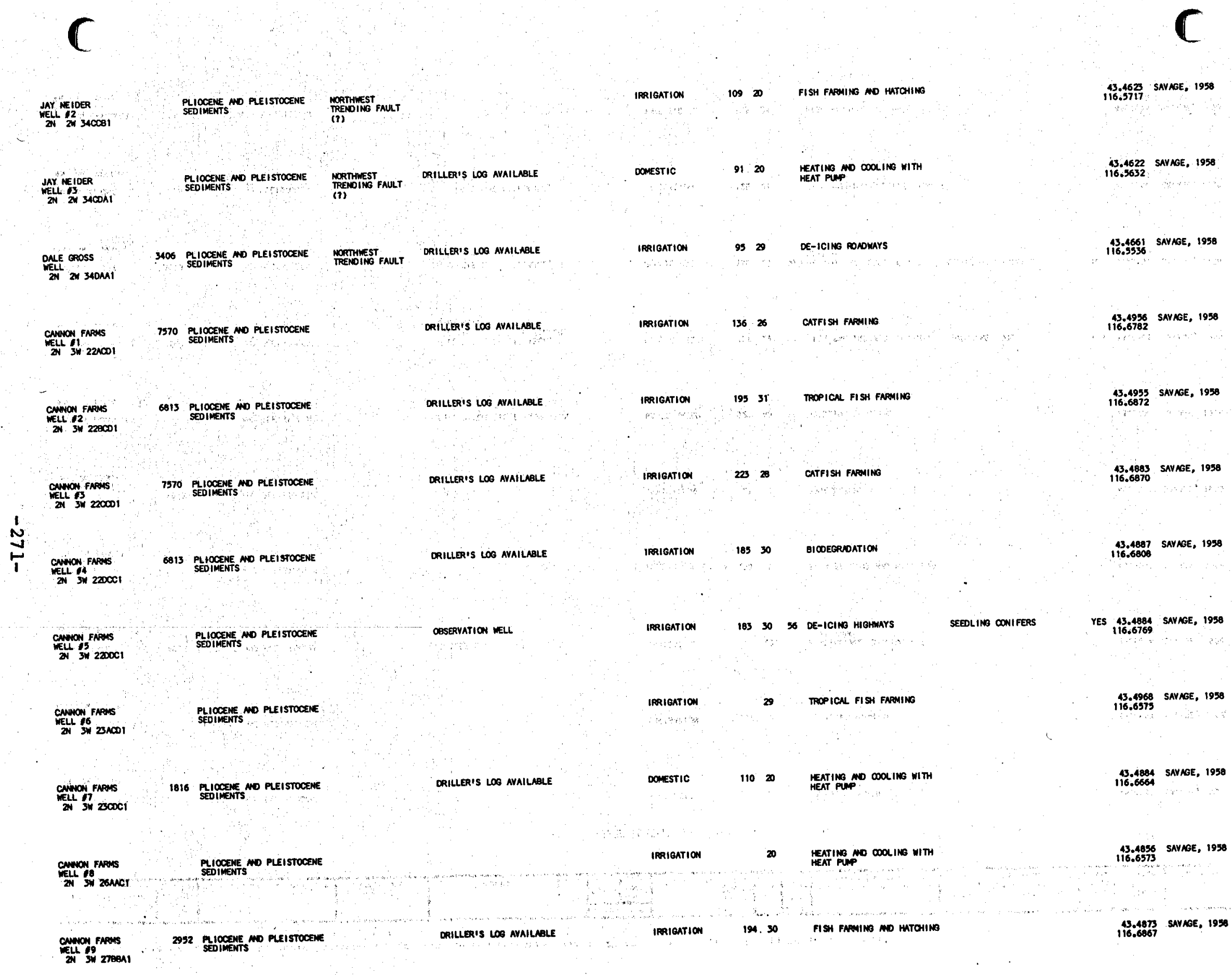


Basle Data Table 4. Location, Goologic Environment, Present Use and Potential Use of Thermal springa and wells in Idaho (continued)

\begin{tabular}{|c|c|c|c|c|c|c|c|c|c|c|c|c|}
\hline $\begin{array}{c}\text { Spring Moll } \\
\text { Iountiflcation } \\
\text { Number \& Nomo }\end{array}$ & 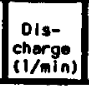 & Aqulfer Age and Rock Type & $\begin{array}{l}\text { Geologle } \\
\text { structure }\end{array}$ & Romarks & Gos: & 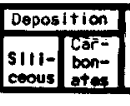 & Prosent Use & 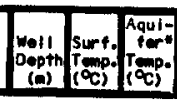 & $\begin{array}{l}\text { Potantiol Uso based on } \\
\text { Surf tece T mperatureft }\end{array}$ & 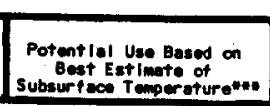 & $\begin{array}{l}\text { Chaw } \\
\text { Troces } \\
\text { Anol. }\end{array}$ & $\begin{array}{l}\text { Lertitude } \\
\text { Longitude }\end{array}$ \\
\hline
\end{tabular}

Canyon county (cont'd.)

OESERT SUN FNPENS PLIOCENE, ND PLEISTOCENE

OHAPLES PENTLERS PLIOCENE ND PLEISTOCENE
WEL

iDAHO STATE

SCOOOLHOSP.

4086 PLIOCENE MD PLEISTOCENE
SEOIMENTS

$\stackrel{1}{N}$

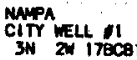

PLIOCEEE MO PLEISTOCENE
SEDIMENTS.

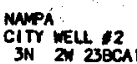

1892 PLIOCEEE ND PLEI STOCENE
SEDIMENTS

SIMPLOT FEDLOT

cromeil innc.

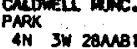

CALONELL CITY
WELL
AN 3N 3SNBO1

GEORBE WRIGT

WELL AW 40001

RUSSELL FIVECOCT

WN AN 30001

PLIOCENE NO PLEISTOCENE
SEDIMENTS

367 PLIOCENE MO PLEISTOCENE
SEOIMENTS

3020 PLLOCENE MO PLEISTOCENE
SEDINENTS

\section{PLIOCENE MO PLEISTOCENE}

IFRIGATION

ORILLER'S LOS AVAILABLE

ORILLER'S LOS AYAILABLE;
FLOHING WELL

ORILERIS LOG AYILALEE
RRESTIN FLON; BACK FILLE
TO 67 METESS

DRILLER'S LOG AVAILABLE;
FLOWING WELL

IPRIGATIOI

DOMESTIC
15529 CATFISH FAPNIMG

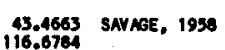

43.4657 SAYAGE, 1950.
116.6625

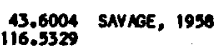

43.6002
116.6113 SAYAGE, 1958

43.5853 SAVAGE, 1958
116.5487

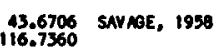

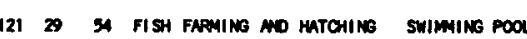

YES $\begin{gathered}43.6624 \\ 116.6963\end{gathered}$

TES $\begin{aligned} & 43,6433 \\ & 116.6309\end{aligned}$ SAYNAE, 1950

13.7059 SAYAGE, 1958
116.0209

43.7113 SAYAGE, 1938
116.0376 


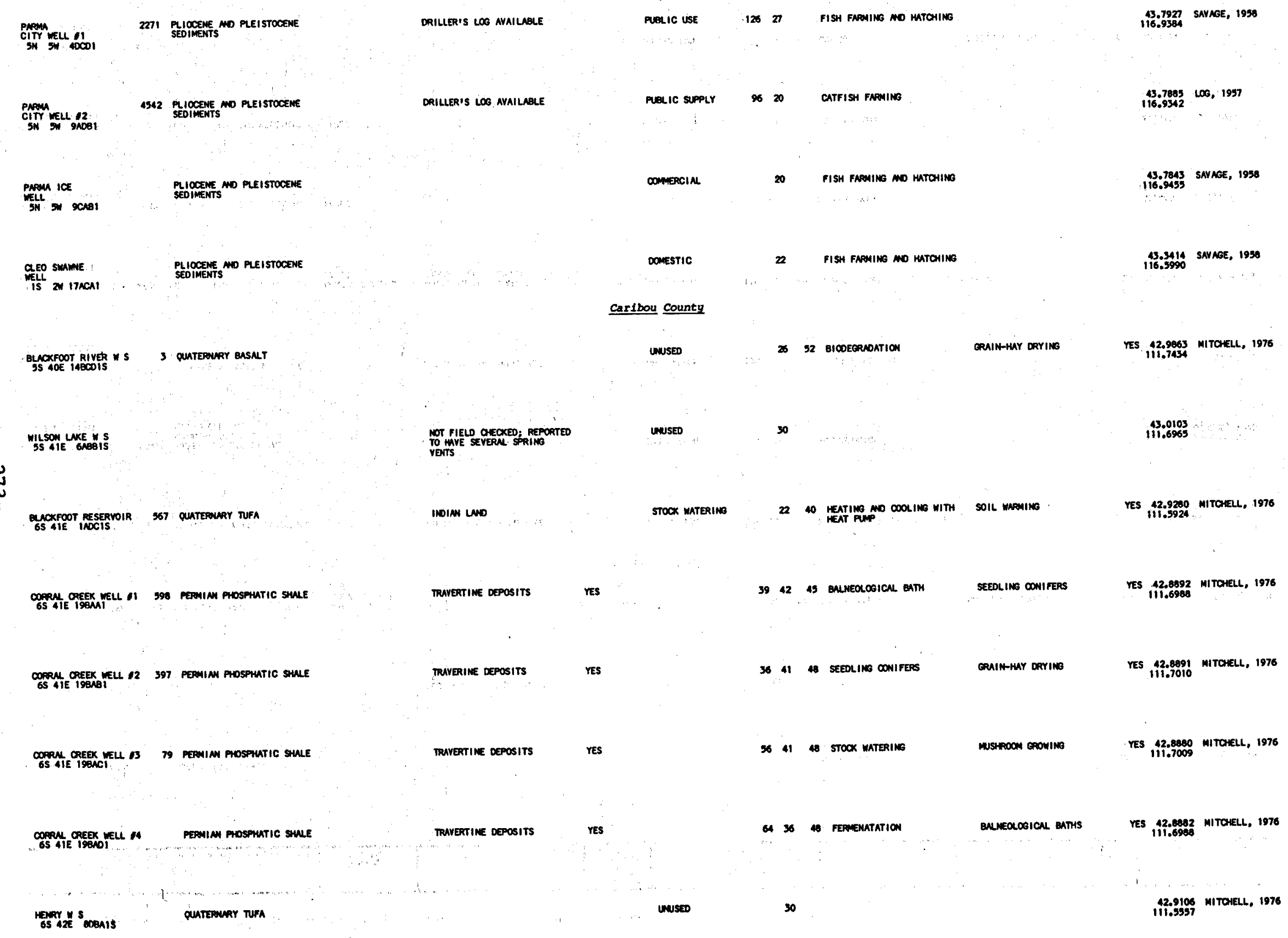


Basic data rable 4. Location, Geologic Environment, Present Use and Potential Use of Thermal springs and wells in Idaho (continued)

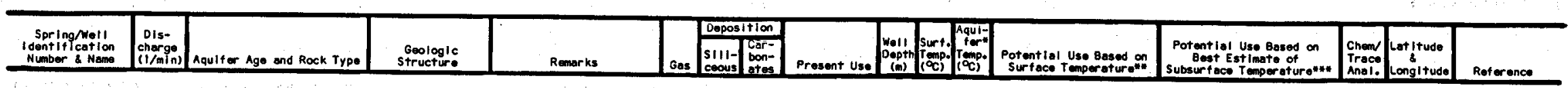

Caribou county (cont'd.)

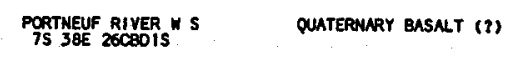

STENGOAT SPRIMGS
9S 4 IOTMIS

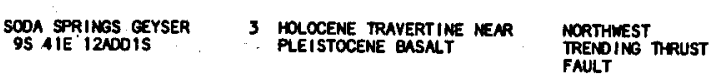

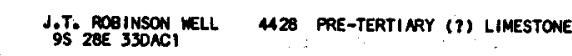

$\stackrel{1}{N}$

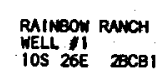

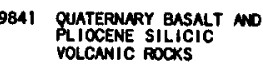

RAINBON RANCH
WEEL 22
IOS 26E 2CBA

PLIOCENE SILIGIC VOLCWIC
ROCKS

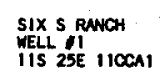

408 PPECAMGRIN QUNRTZITE

FORTH TRENOING

MRSH OREEK H S
IIS $25 E$ 22COC1S

37 PLIOCENE SILICIC VOLCANIC FAULT
ROCKS

MARSH GULLY HS

37 PLIOCENE SILIGIC VOLCNNIC FAULT
ROCKS

S1X S RANOH
WELL 22
1152600001

4220

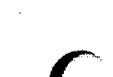

ORILLER'S LOG AVAILABLE;
FLWING WELL; SULFUR DOOR

SUGMERGED IN SOOA POINT

rES

Cassia county

DRILLER'S LOG AVAILABLE

DRILLER'S LOG AVAILAELE

DRILLER'S LOG AVAILABLE

IRRIGATION

YES YES IRRIGATION

UNUSED

40 SOIL MNRMING

UNUSED

11 SOIL MNPMING

IRRIGATION

31

28 Fermentation

24937 imoropowics

136 . $55 \quad 89$ LNMORY USES

3349 aqunaulture
34

259 25 FISH FNeming ho mitaring

19024 CATFISH FNOMING

SNUMA

GRAIN-HAY DRYING

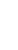

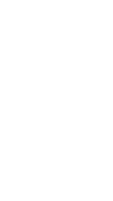

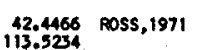

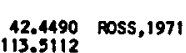

SEEDL ING CONI FERS

YES $\begin{array}{r}42.4454 \\ 113.4338\end{array}$

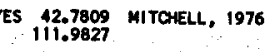

12.6594

YES $\begin{gathered}42.6570 \\ 111.6040\end{gathered}$

42.3961. MUKKR MO
113.1788 OTHERS, 1970

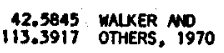

42.5816. VON LINOEAN, 1978
113.3999
(SITE INSPECTI IOW)

42.4766 CROSTHMAITE, 1957
113.5068 
(

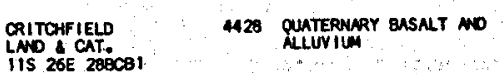

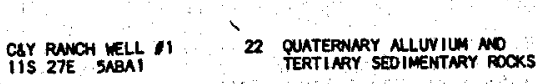

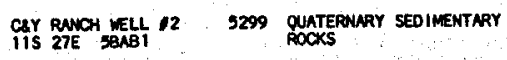

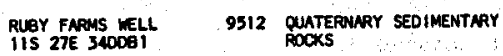

STOKER WULN

IIS $28 E 310001$

un

Ois. JoHESOW WELL

22 TERTIMAY SEOIMENTARY ROOXS

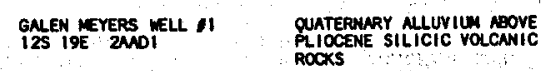

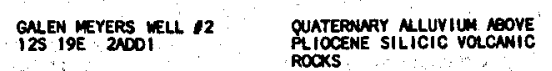

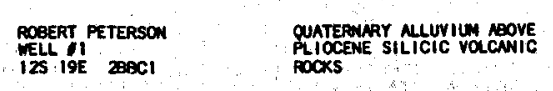

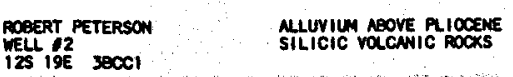

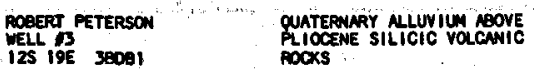

PATIIN DRILLER'S LOG
AYALAABLE

DRILLER'S LOG AYAILABLE

IRRIGATION

24 PERANTATION

DOOESTIC AND
STOC WHTERING

IFRIGATION

$$
29835 \text { MQUNOLLTURE }
$$

IRRIGATION

2737 moroponics

IRRIGATION 320 zI

IFRIGATION

27427 BIOOEGPNOATION

ipaigation

21327 PISH FAOMING MO MATOXING
MUSHROOM GROWING

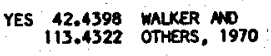

42.5009 WALKER NO
113.3185 OTHER, 1970

YES $\begin{gathered}42.5017 \text { MAUKER AND } \\ 113.3238 \text { OTHERS, } 1970\end{gathered}$

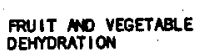

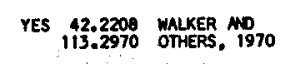

113.4255 Ross, 1971

年2:41393

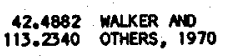

12.3273
114.1960

$\frac{42.4101}{114.1915}$ Ross, 1971

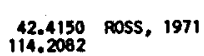

$\underset{114.4106}{11.2285}$ Ross, 1971

114.4128 Moss, 1971 
Baelc Data Table 4. Location, Geologie Environment, Present Use and Potentlal use of Thermal Springs and wells in Idaho (continued)

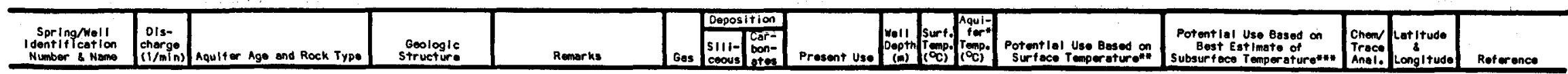

Cassia County (cont'd.)

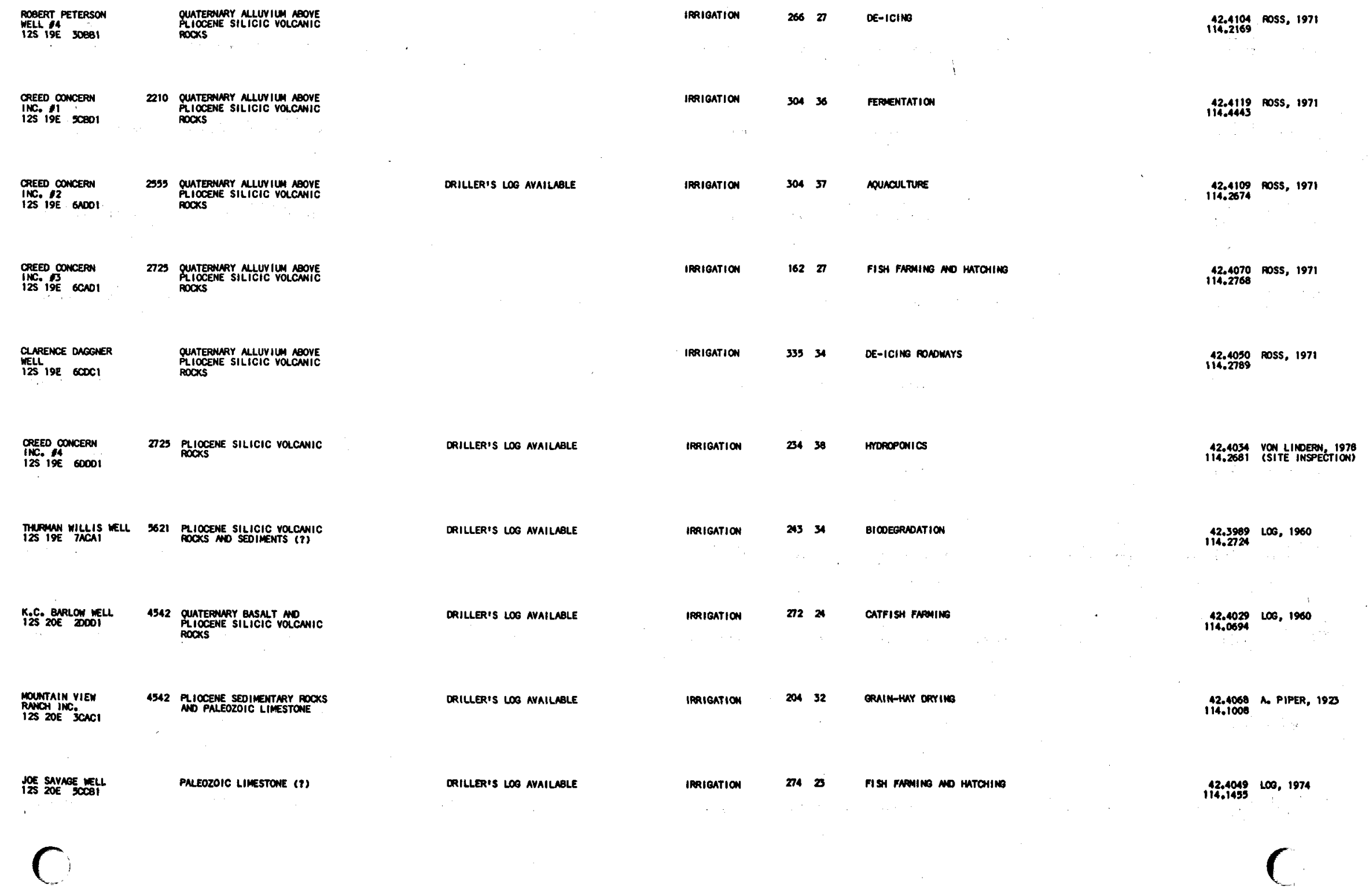




\begin{tabular}{|c|c|c|c|c|c|}
\hline 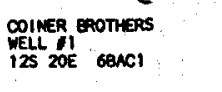 & 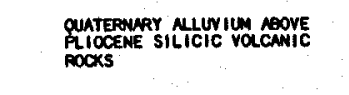 & DrILLR'S LOG AYAILABLE & $\begin{array}{l}\text { SPACE METING } \\
\text { MO IRRIGATION }\end{array}$ & 13741 & SEEDLINB COOIIFERS \\
\hline 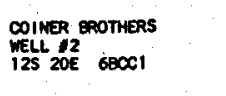 & 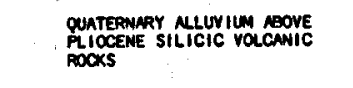 & $\cdots$ & IRPIGATION & 19837 & BICOEGRNAATION \\
\hline $\begin{array}{l}\text { MAROD SAYYGE, MELL } \\
125200 \text { COAC1 }\end{array}$ & 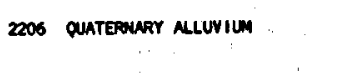 & & IRRIGATIOON & 2032 & 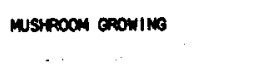 \\
\hline 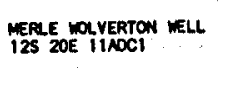 & 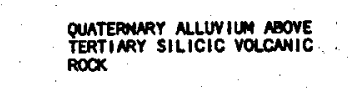 & & imsiantion & 43720 & 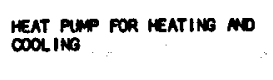 \\
\hline 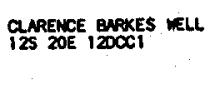 & 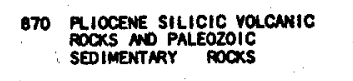 & DRILLER'S LOO AVAILARER & IFPIGATION & 33720 & CATFISH FNOUING \\
\hline 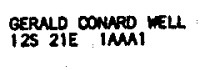 & $\begin{array}{l}\text { Muocene Silicic volcanlic } \\
\text { RDCSS }\end{array}$ & DRILLR'S LOG AYALLBLLE & IPRAGATION & 30627 & 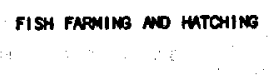 \\
\hline 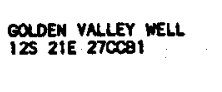 & 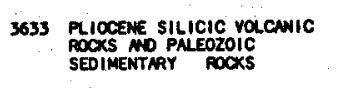 & DRILLER'S LOG AVAILLREE & IRRIBATIOON & 58539 & mropoponics \\
\hline 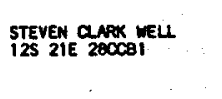 & 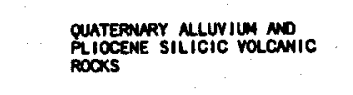 & DRILLRR'S LOG AYAILABLE & IRPIGATIOAN & 34821 & CATFISH FNPQMING \\
\hline 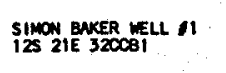 & 6813 PAEOZOIC SEDIMETHAYY ROCXS & DRILLR'S'S LOG AVAILABLE & 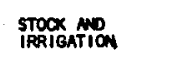 & 7621 & 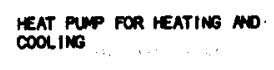 \\
\hline 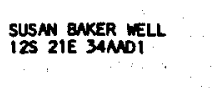 & 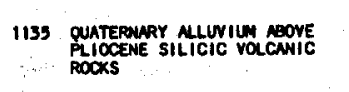 & DRILER'S LOS AVAILLALE & IPRIGATION & 49926 & CAFFISH PReming \\
\hline 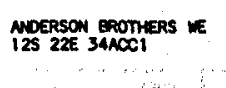 & 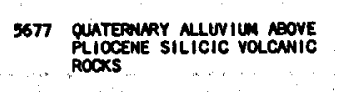 & DRILLR'S LOO AVAILBSLE & IRPIGATION & 34224 & CATFISH FNMMING \\
\hline 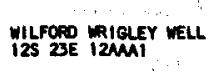 & 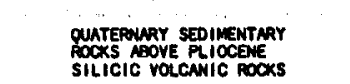 & DRILLER'S LOQ AVAILALE & STOCX WATER INO & 17922 & 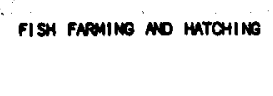 \\
\hline
\end{tabular}

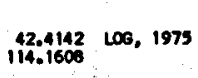

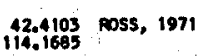

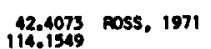

122.3997 ross, 1971.

112.305857 L06, 1976

${ }_{113.0932}^{20.4158,200,1988}$

172.3979 1000,1975

122.3791 1006,1975

12.33536 Lo6, 1962

12.2535s noss, 1971

12.23370 1306,1997

12.4009 100,1962 
Basic pata Table 4. Location, Geologic Environment. Present Use and Potential Use of Thermal Springs and wells in Idaho (continued)

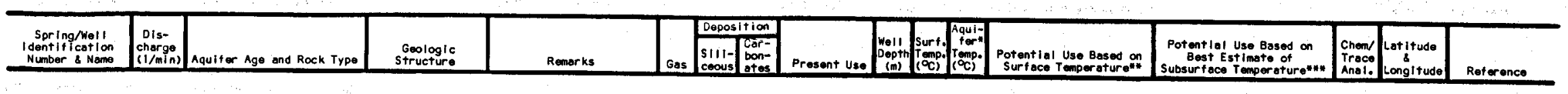

Cassia County (cont'd.)

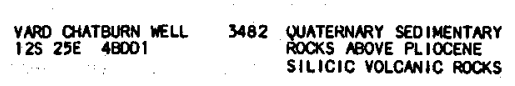

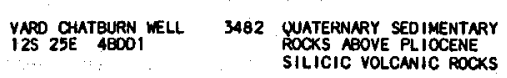

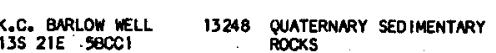

SIMON BAKER WELL 12
ISS $21 E$ GMOI

$\stackrel{1}{1}$

681 QUATERNMRY MLLUVIUM

LYLE DURFEE WELL
IIS $25 E .223 C B 1$

FAULT (?)

18 PRE-TERTIARY

FAULT

RICE SPRING
135265 17COBIS

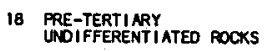

LESTER THOOPSON WELL
I3S 27 . 2 NOC1

PALEOZOIC SEDIMENTARY ROCKS

NELSON MELL
14S 21 E $34 \mathrm{MCI}$

3406 PRE-TERTIARY
WOIFFERENTIATED ROCKS

$14521 E 348001$

189 PLIOCENE SILICIC VOLCANIC
ROCKS

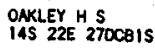

37 PRE-TERTIARY QUARTZITE

IRRIGATION

IRRIGATION

IRRIGATION

IRRIGATION

SLIGHT SULFUR COOR

IRRIGATION

$191 \quad 29$

HEATING NO DOOLING WITH
HEAT PUIP

213 23 FISH FAPMING MO HUTOHING

104 22 CATFISH FARHING

15632 AQUNCULTURE

20 34 CATFISH FNPAING

MUNACULTURE

IPRIGATION

22 HEAT PUNP FOR HEATING MO

DRILLER'S LOG AVAILABLE

FLOWING WELL; SULFUR ODOR

YES UNUSED

SANMA

RECREATION
$40 \quad 97$ iropoponics

$336 \quad 26$ FISH FAPMING NO HATOHING

29943 STOCX WATERING

4892 grain-HAY DRY ING
BLAOHING
112.4087 LOG, 1953

$140,0245206,1961$

42.3259
184.0291

YES $\underset{113.3500}{42.3209}$ ROSS, 1971

YES $\begin{gathered}42.2850 \\ 113.4463\end{gathered}$

113.4448 Ross, 1971

$\sqrt{42.3215}$ LOG, 1958

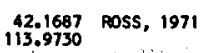

YES $\begin{array}{r}42.1648 \text { PIPER, } 1923 \\ 113.9838\end{array}$

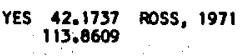




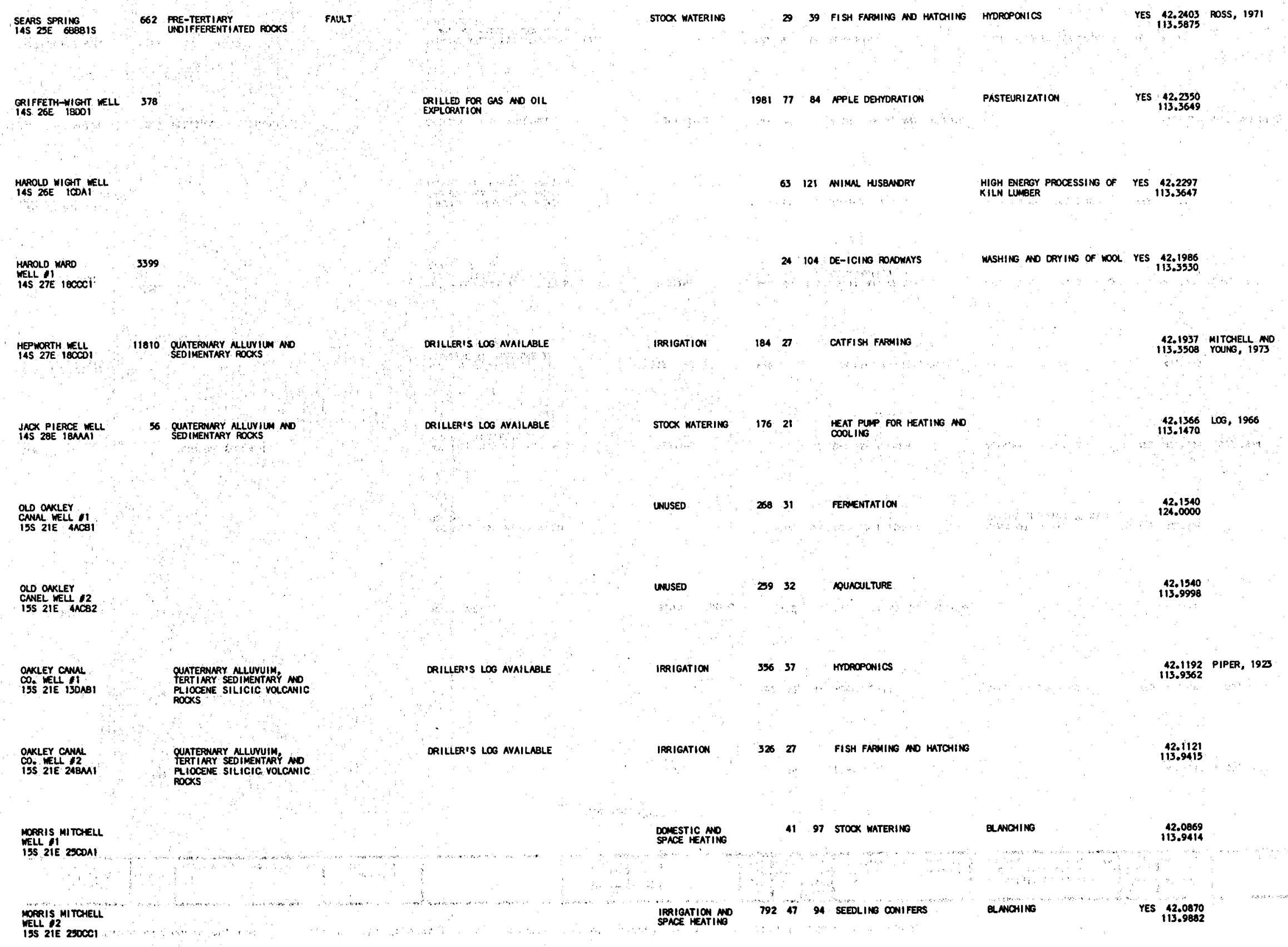


Bhile Data rable 4. Location, Geologic Environment, Present Use and Potential Use of Thermal springs and wells in Idaho (continued)

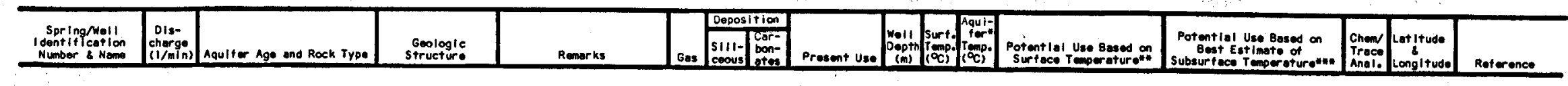

Cassia county (cont'd.)

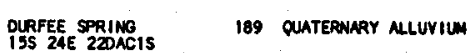

MEROLO MNOS. 378 QUATERANRY ALLUVIUM

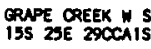

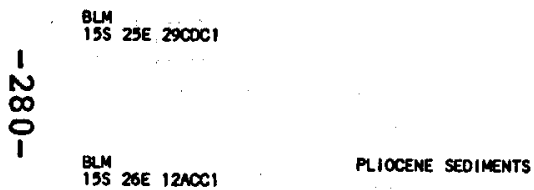

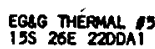

155 26E 220001

1892

IVN ONERINGTO

IVN OARRINGTON

MELL 268 23NSO1

RRNIER HS KELL
ISS ZOE ZOECI
200 PLEISTOCENE SEOINENTS

219
unUSED

DOMESTIC

$132 \quad 32 \quad 47$ MQUNCULTURE

STOCK MATERINO

MRSH MREA

MOT FIELD OHECXEO FOR THIS

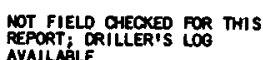

RAFT RIVER PROJECT,
- SURFACE TEPERATURE IS

123 DEGREES

NOT FIELO OEEKED FOR THIS

SURFACE ERPERATURE REACHES
140 DEGRES C ATTER BEING PIMPED FOR A PERTOO OO TIME

ORILLER'S LOG AVAILABLE

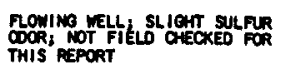

39

DE-ICING

TESTING

TESTING

1476

TESTING

IFRIGATIOA

12893146 BLAMOINO
42.1015
113.6319

SEEDL ING CONIFERS

YES 112.0991 ROSS, 1971

\subsection{9}

SO 128 POULTAY MUTCHERY

CEPPORATION MO

YES $\begin{gathered}12.0820 \\ 113.5623\end{gathered}$

2530 CATFISH FAPMING

MLFALFA DEMTORATIOON

YES $\underset{113.13350}{41.3620}$ Los, 1974

CNWING NO PRESERV INO

1420.093

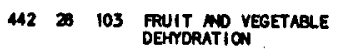

IMSHING NO DRYING of WOL YES 122.0971 LOO, 1974

65 149 PASTEURIZATION

BEET SUAR PROCESSING

YES 113.3737

109 28 FISH FAPMino no mutahing 113.13702 MCE NO OTHERS,

DOFN PRDOUCTS (SYRUP, OIL) VES $\begin{array}{r}12.1079 \\ 113.3910\end{array}$ 


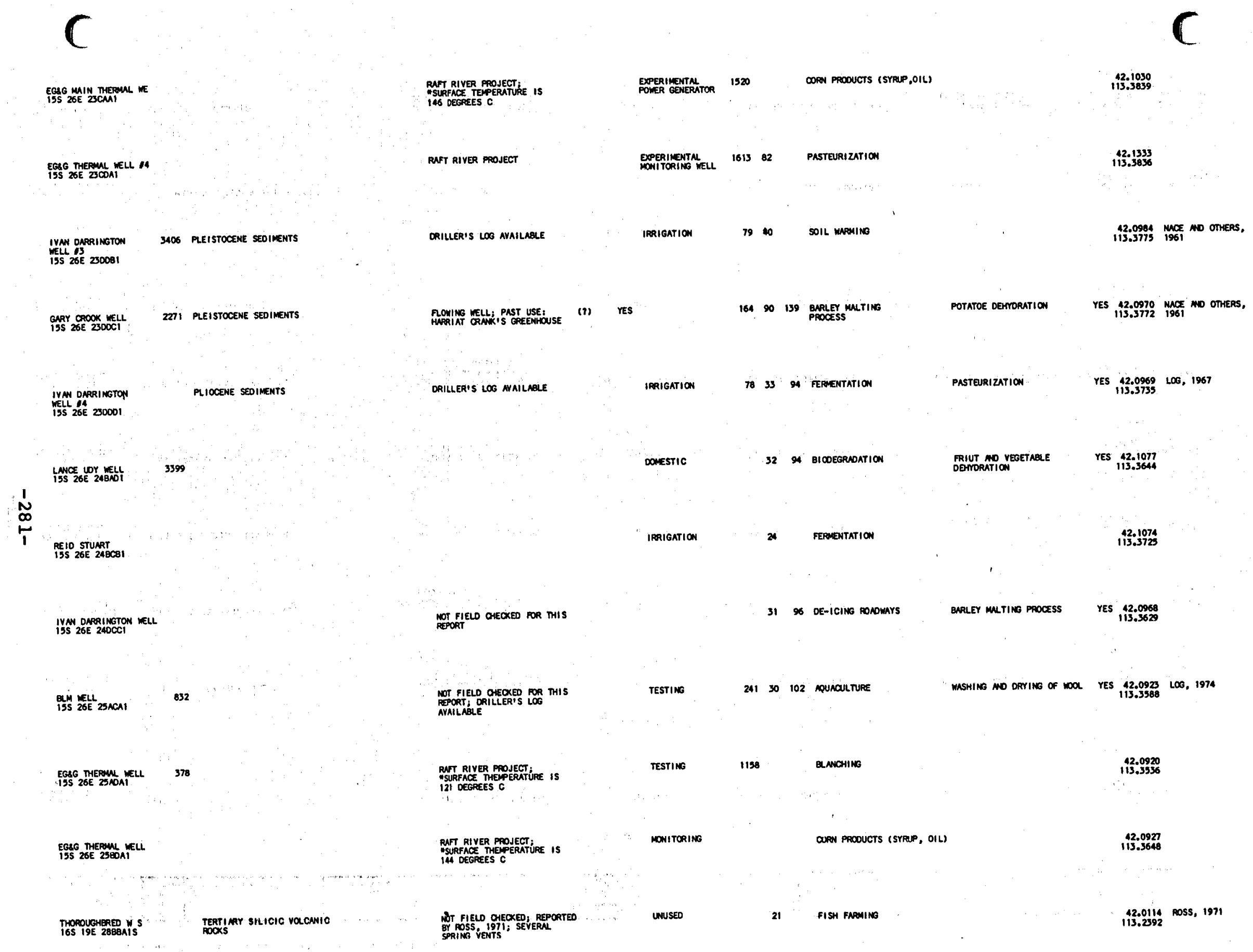


Basie Data Table 4. Location, Geologle Environment, Present Use and Potential Use of Thermal Springs and wells in Idaho (continued)

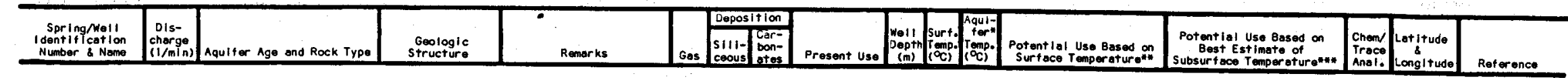

Cassia County (cont'd.)

\section{QUMM WELL
165 26E
SBBA \\ 1514}

$\operatorname{liOY}_{33 E}^{H} S \operatorname{Sil}$

946 PRE-TERTINRY LIMESTONE

WILSON BROS. WELL 3785 PRE-TERTI ARY LIMESTONE

1
$N$
$\infty$ i

LIOY H 5 S 2000

189 PRE-TERTI NRY LIMESTONE

WAPM SPRINGS

3406 PRE-TERTI NRY LIMESTONE

BIG SPRINGS
I3N $32 E$ 15ECB1S

189 PRE-TERTINRY LIMESTONE

PIERSON H
BN 14E 2708015

416 QUNRTZ MONZONITE
NOT FIED OAEXED FOR THIS
REFORT DRILLER'S LOG
AVAILBLE.

TESTING

clark County

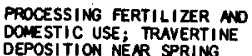
DEPOSI TION NERR SPRING

PROCESSING FERTLLIER ND
DOUESTINC USE; PAST USE:
RECREATION

PROCESSING FERTILIZER NO
DONESTIC USE

PROCESSING FERTIL IZER NO
OOMESTIC USE

TWO SPRING VENTS X X-FAY
OIFFRACTION ANAYYSIS
INO ICATED TRAVRTINE

UnUSED

Custer County

Not FIELD OMEOKed

TEMPERTURE RNAGE $37-43$
DEGRES C; TWO SPRING VENTS
UnUSED

UNUSED
854094 SOIL WAPMING

Q.ANOIING

YES $\begin{aligned} & 42.0671 \\ & 133.466\end{aligned}$
5166 HAY DRYING

21350 SPACE HEATING

$125 \quad 58 \quad 68$ GREENHOUSE

31 LANDOY USES

2957 CATFISH FNPMING

23

FISH FAPMING WO HMTONING
PPPLE DERropation

114.13316 poss, 1971

REFRGERTION (LOWER
LEPERATURE
LIMIT)
$\mathbf{1 1 2 . 1 4 5 3 2}$

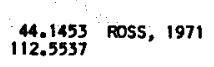

GREENHOUSE SPACE HEATING YES $\begin{gathered}41.2565 \\ 112.6391\end{gathered}$

41.4538 .
112.6958
43 S9EOLING CONIFERS

4373 BRLMEOLOGICAL BATH
Q., NGOANG

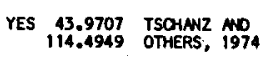

REFRIGERATION (LOWER
YES $\begin{aligned} & \text { 43.9903 TSOHNZ NO } \\ & 114.7999 \\ & \text { OTHERS, } 1974\end{aligned}$ 


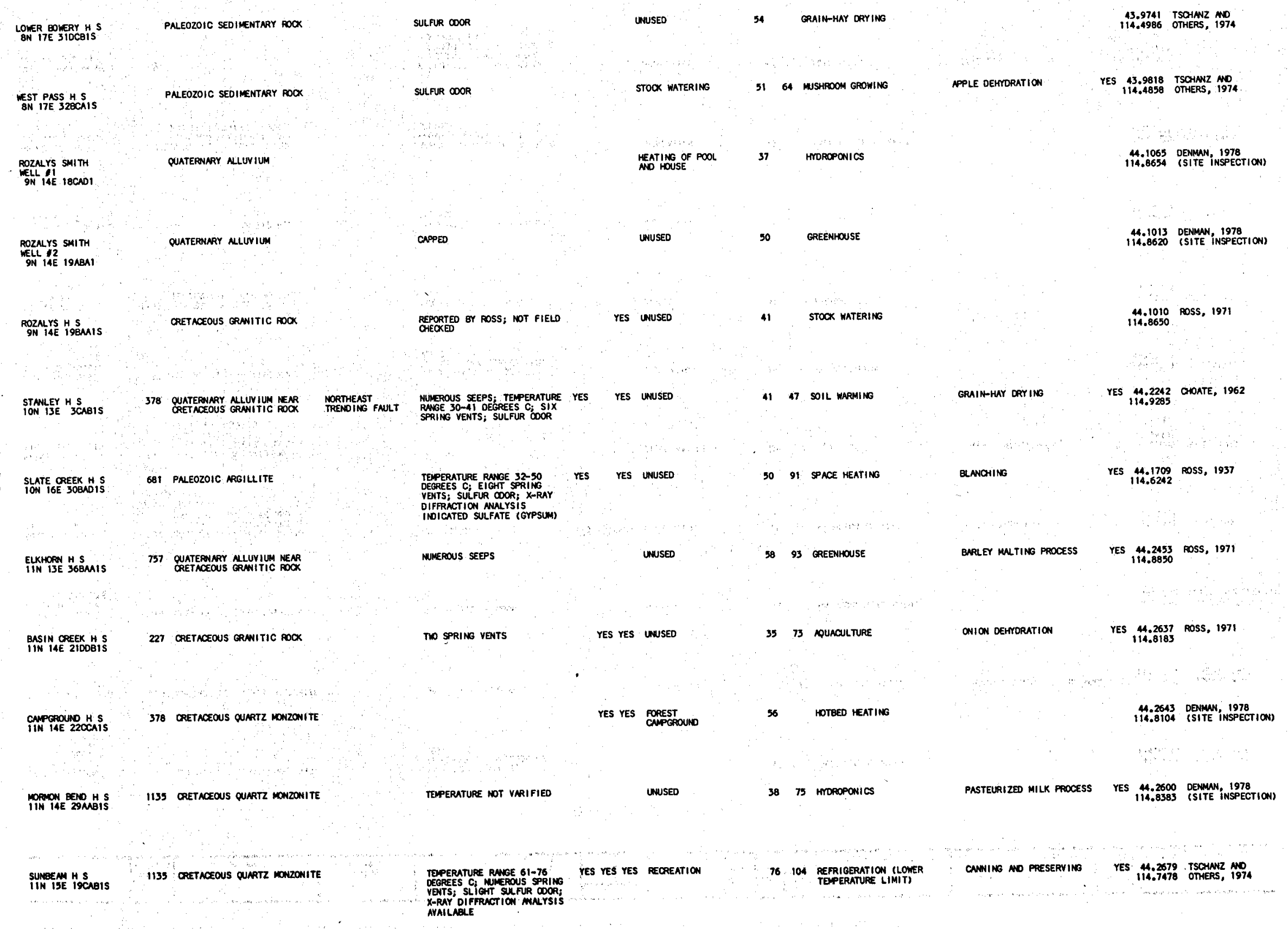


Basic Data Table 4. Location, Geologie Environment, Present Use and Potential Use of Thermal springs and wells in Idaho (continued)

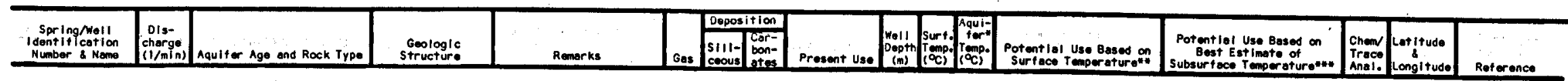

Custer County (cont'd.)

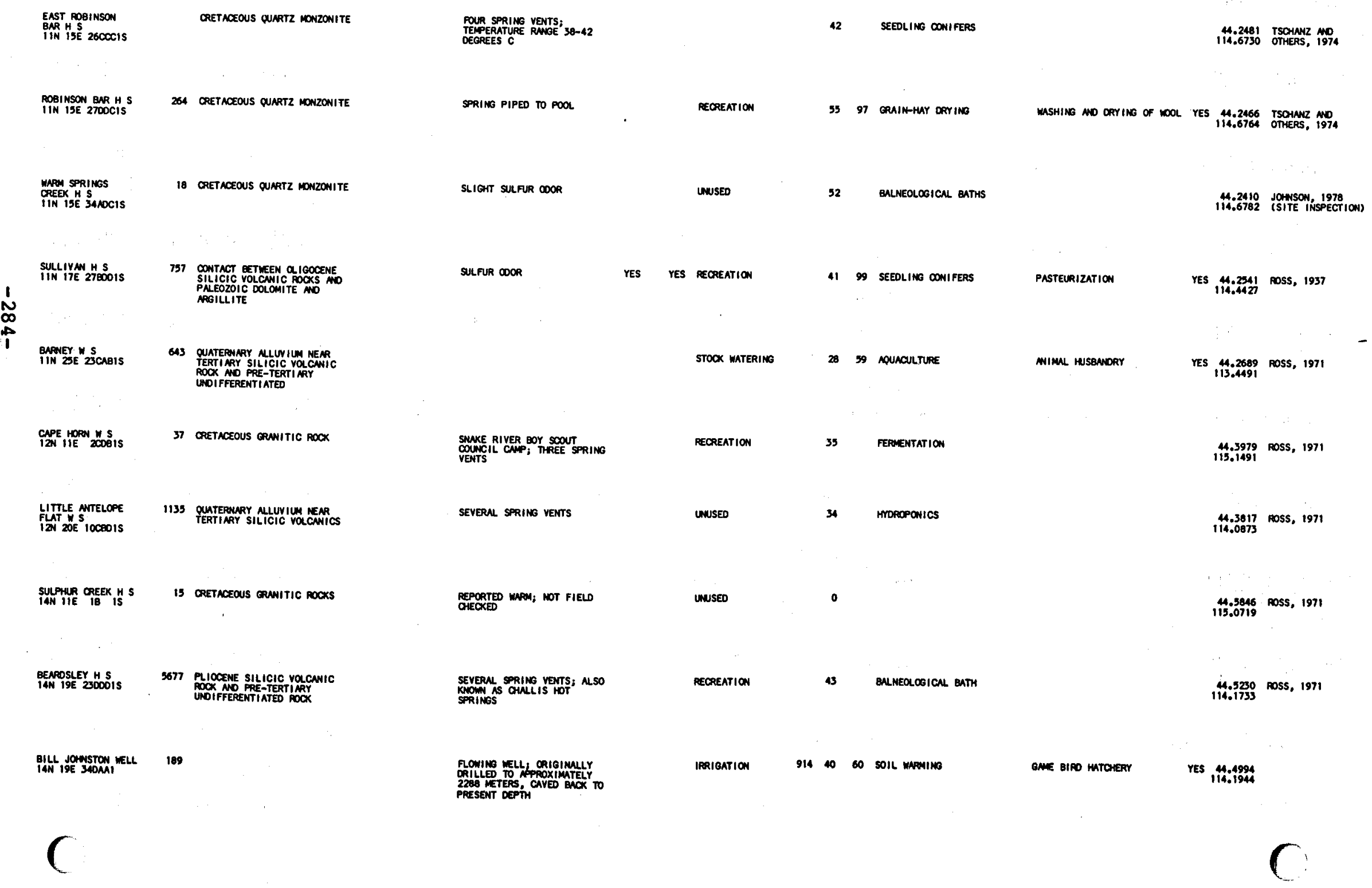


C

\begin{tabular}{|c|c|c|c|c|c|c|c|}
\hline $\begin{array}{l}\text { OWEN CABIN HS } \\
\text { ISN IAE JONDCIS }\end{array}$ & 94 REE-TERTIARY & SULFur ODOR & unsed & s6 & Nustreoon Growns & & 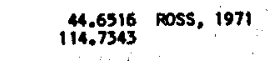 \\
\hline 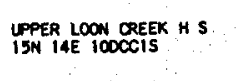 & 18 PRE-TERTILAY & 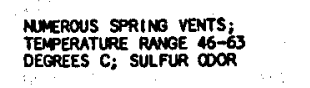 & UNUSED & 63 & CREEMHOUSE & & 14.654787 Ross, 1971 \\
\hline 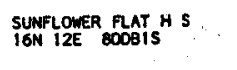 & & 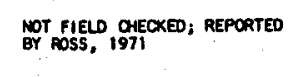 & UnSEED & 437 & 1 SEDDLING CONIFERS & $\begin{array}{l}\text { REPIOERATION LLOUER } \\
\text { TEP ERATURE LIMITT) }\end{array}$ & res 114.73319 \\
\hline 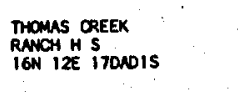 & 257 TERTINAY GRNITIC ROOKS & $\begin{array}{l}\text { NOT FIED , OAECXED; REPORTED } \\
\text { BY FOSS, 1971 }\end{array}$ & unNesD & $43 \times$ & D SRMEOLGICAL BATHS & amaring & Yes, ${ }_{1,4.7212}^{\text {M.:0150 }}$ ROSs, 1971 \\
\hline 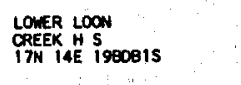 & 30 TERTIARY OWWITIC ROCXS & $\begin{array}{l}\text { NOT FIELD OAECXE; REPQRTED } \\
\text { BY FOSS }\end{array}$ & Inused & 497 & IS SPAEE HEATINO & PPLE OEHOPRATION & 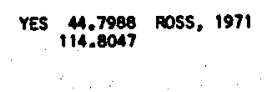 \\
\hline & & & Elmore County & & & & \\
\hline LNOAH & $\therefore$ & $\begin{array}{l}\text { WD SPEING EENTS NO } \\
\text { SEVERR SEEPS }\end{array}$ & YES SPREE HEATING & 60 & GNE BIDO MUTARERY & & $\begin{array}{l}73.5413 \\
115.2817\end{array}$ \\
\hline $\begin{array}{l}\text { BRIDGE H S } \\
\text { 2N } 10 \mathrm{SACAIS}\end{array}$ & 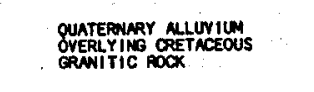 & 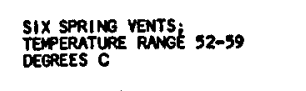 & res & 99 & OREENHOUSE & & 135.5398 Ross, 1971 \\
\hline 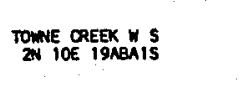 & & & & 24 & 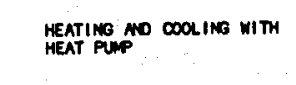 & & , 43.49968 \\
\hline 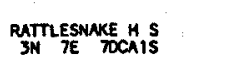 & & NOT FIELO OAECXDD & unsed & 56 & gerenntouse & & $\begin{array}{l}43.6093 \\
115.6636\end{array}$ \\
\hline $\begin{array}{l}\text { OWRZES gQKER MELL } \\
\text { 3N OOE IOABAI }\end{array}$ & 26 CRETiCEOUS CRNITIC ROCXS & 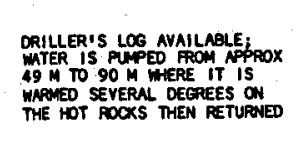 & SPACE HEATING & 8943 & SEEDLING CONIFERS & & YES $\begin{array}{c}43.6150 \\
115.2484\end{array}$ \\
\hline 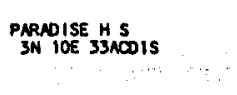 & 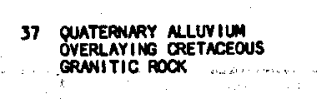 & & $\begin{array}{l}\text { YES SPNCE HEATING } \\
\vdots\end{array}$ & 32 & 73 LNMORY USE & ONION DEMORORTION & YES $\begin{array}{l}43.5577 \text { Ross, } 1971 \\
115.2670\end{array}$ \\
\hline 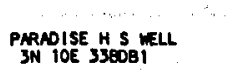 & IS ORETACEOUS ORMITIC ROXS & 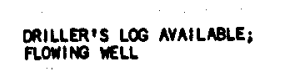 & UnUSED & 3730 & Hropocorowios & & . 153.5546 Ross, 1971 \\
\hline
\end{tabular}


Basic Data Tabie 4. Location, Geologic Environment, Present Use and Potential Use of Thermal Springs and Wells in Idaho (continued)

\begin{tabular}{|c|c|c|c|c|c|c|c|c|c|c|c|c|c|}
\hline 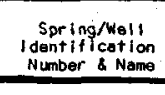 & $\begin{array}{l}\text { ors- } \\
\text { charge } \\
(1 / \text { min })\end{array}$ & Aquifer Age and Rock Type & $\begin{array}{c}\text { Geologle } \\
\text { structure }\end{array}$ & Renarks & Gos & 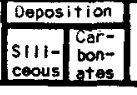 & Prosent Use & 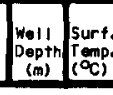 & 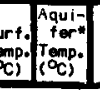 & $\begin{array}{l}\text { Potent lol Use Bosed on } \\
\text { Surf ace Temperature"* }\end{array}$ & 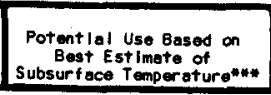 & $\begin{array}{l}\text { chem } \\
\text { Treace } \\
\text { Anat. }\end{array}$ & $\begin{array}{l}\text { Latitude } \\
\text { Loituse } \\
\text { Langitude }\end{array}$ \\
\hline
\end{tabular}

E1more County (cont'd.)

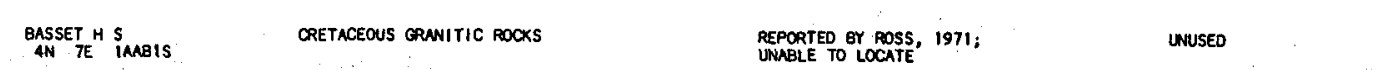

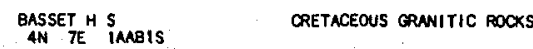

REPORTED GY ROSS, 1971:
UNABLE TO LOCATE

${ }_{4 N}^{\text {REEO }}{ }_{7 E}{ }_{7 N}$ NOCIS

18 CRETACEOUS GRANITIC ROCKS

SHEEP OREEK
BRINGE S S SRETACEOUS GRANITIC ROCKS
AN TE HCBBIS

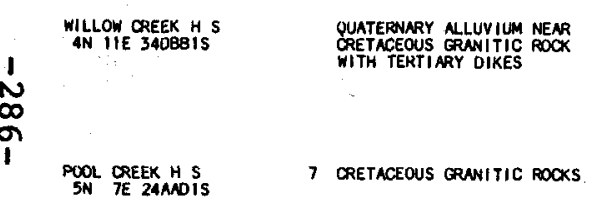

NIMEMEYER HS S 1321 CRETACEOUS GRNITIC ROCKS

VMUGH SPRING
SN 7 TE 260 ARIS

SMMTH CABIN HS S
SN TE 34 SCEBIS

$\underset{S N}{\text { LOFTUS HES }}$ STDEAIS

151 CRETACEOUS GRANITIC ROCKS

ERON CREEK HS
SN SE 1000015

757 CRETACEOUS GRANITIC ROCK

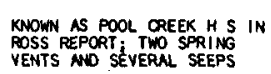

UNUSED

TWO SPRING VENTS; MINIMAL
OEPOSIIION OF SILICIOWS
SINTER

THREE SPRING VENTS NO
MUERORS SEEPS

SONE SEEPAGE

TEMERATURE RANGE 65-75
DEGRESS C; THIRTEEN SPRING
VENTS

TEMPERATURE RANGE 58-68
DEREES $C_{;}$THREE SPRING
VENTS

FOUR SPRING VENTS

TEMERATURE RANGE 47-54
DEGRES C; TWO SPRTNG VENTS

YES YES BATHING
0

41 STOOK MATERING

61 GMUE BIFD HATCHERY

55 GREENHOUSE

42 SOIL MARMING

76 I26 PASTEURIZED MILK PROCESS SUGARBEET PULP DEHYORATION YES $\begin{array}{r}43.7553 \\ 115.5709\end{array}$ WARING, 1965

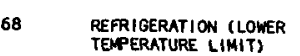

59. MIMAL HUSBANDRY

34 GRAN-HAY DRYING

so MUSHROOM GROWING
43.7175
115.5620

115.6607 Ross, 1971

115.6556 Ross, 1971

43.6372 Ross, 1971
115.1295

43.7595 Ross, 1971
115.5602

43.7243 ROSS, 1971
115.6041

43.7242
115.6040

115.6041 Ross, 1971

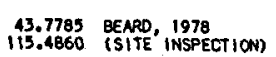




\begin{tabular}{|c|c|c|c|c|c|c|c|c|c|c|}
\hline 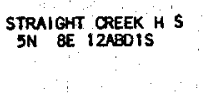 & & 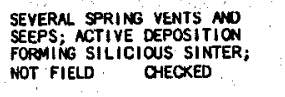 & YES & UNUSED & & 62 & APPLE DEHTDRATION & & $\begin{aligned} 43.7882 \\
115.4444\end{aligned}$ & \\
\hline$\underset{S N}{\text { GRWITE OREEK H }}$ S & 75 CRETHCEOUS GRANITIC ROCK & $\begin{array}{l}\text { FOUR SPRING YENTS NO } \\
\text { SEVERN SEEPS }\end{array}$ & YES & unused. & & ss & GREENHOUSES & & $\begin{array}{l}43.8033 \\
115.4006\end{array}$ & $\begin{array}{l}\text { OEAPD, } 1978 \\
\text { (SITE INSPECTION) }\end{array}$ \\
\hline $\begin{array}{l}\text { DUTCH RRANK'S H S } \\
\text { SN TE TBBAIS }\end{array}$ & 1135 CRETACEOUS GUWITIC ROCK & 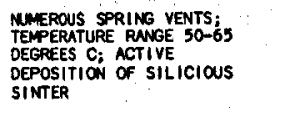 & YES YES YES & unuseo & & 65,72 & APPLE DEHTORATION & $\begin{array}{l}\text { REFRIGERATION (LOWER } \\
\text { TEMPERAURE LLMIT). }\end{array}$ & VES 113.7894 & WARING, 1965 \\
\hline $\begin{array}{l}\text { WEATHERGY MHLLL WELL } \\
\text { GN } 9 E 35 A C A T\end{array}$ & CRETACEOUS ORNITIC ROOX, & $\begin{array}{l}\text { FLOWING WELL; DEPTH } \\
\text { REPORTED BY ROSS, } 1971 \\
\end{array}$ & & RECREATION & 533 & 30 & FEPMENTATION & & $\begin{array}{l}43.8170 \\
115.3545\end{array}$ & ROSs, 1971 \\
\hline $\begin{array}{l}\text { WEATHEREY H. S } \\
\text { GN } 10 E \text { SOCOBB IS }\end{array}$ & 189 CRETACEOUS GPUNITIC ROCK & SEEPAGE TPEE SPRING & & UNusED: & & 45 & GRAIN-HAY DRYING & & $\begin{array}{l}43.8259 \\
115.3271\end{array}$ & ROSS, 1971 \\
\hline $\begin{array}{l}\text { OUEENS RIVER HS } \\
\text { GW IIE } 300 B 15\end{array}$ & & NOT PELD CHECKED; REPORTD & & $\therefore$ & & 0 & 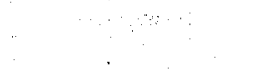 & & $\begin{array}{l}43.8314 \\
115.1915\end{array}$ & \\
\hline $\begin{array}{l}\text { ATLNNTA HS } \\
\text { GN IIE } 350 \text { SDIS }\end{array}$ & 378 CRETACEOUS GRANITIC POCK & 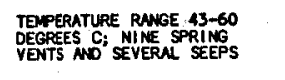 & YES & UNUSEO . & & 6076 & $\begin{array}{l}\text { RERIEERRATION (LOWER } \\
\text { TOPERATURE LLMIT) }\end{array}$ & & $\begin{array}{l}43.8116 \\
115.1093\end{array}$ & ROSS, 1971 \\
\hline $\begin{array}{l}\text { OHATANOOGA H S } \\
\text { GN IIE } 350 B B I S\end{array}$ & 37 CRETACEOUS GRWITIC ROCK & $\begin{array}{l}\text { SEVERU SPRING VENTS MO } \\
\text { NRMEROUS SEEPS }\end{array}$ & & UNUSED & & $50 \ldots$ & LAUNDRY USES & & $\begin{array}{l}43.8130 \\
115.1157\end{array}$ & Ross, 1971 \\
\hline $\begin{array}{l}\text { LEG IT CREEK H S } \\
\text { GN I2E 33BCBIS }\end{array}$ & $\begin{array}{l}\text { ORETACEOUS ORNITIC ROOX } \\
(3)\end{array}$ & 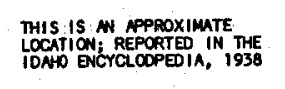 & & UNUSED : & & 0 & & & $\begin{array}{l}43.8169 \\
115.0459\end{array}$ & \\
\hline $\begin{array}{l}816 \text { D RANCH WEL } \\
25 \text { AE } 288001\end{array}$ & $\begin{array}{l}\text { 9463 PEEISTOCENE BASALTIC LAVA } \\
\text { NO SED IMENTS }\end{array}$ & DRILLER'S LOG AVAILABLE & & IRRIGATION & 365 & 27 & DE-ICING & & $\begin{array}{l}43.2223 \\
115.9866\end{array}$ & YOUNG, 1977 \\
\hline $\begin{array}{l}\text { FRED HICKEY WELL } \\
2 S \text { SE } 11 N D O 1\end{array}$ & $\begin{array}{l}7210 \text { PLEI STOCENE RASN.TIC LAVA } \\
\text { ND SEDIMENTS }\end{array}$ & DRILLER'S LOS AVAILABLE & & IRRIGATION & 182 & 22 & FISH FNPOMHNG & & $\begin{array}{l}13.2663 \\
115.8188\end{array}$ & rounc, 1977 \\
\hline $\begin{array}{l}\text { OMRLES COE WELL } \\
25.5 E \text { 22MO1 }\end{array}$ & S67 PLEISTOCENE EASALTIC LAVA & 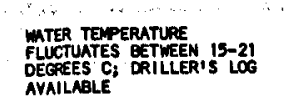 & & DOMESTIC & 132 & 21 & $\begin{array}{l}\text { KEATING MO DOOLING WITH } \\
\text { HEAT PUPP }\end{array}$ & & $\begin{array}{l}43.2406 \\
115.0376\end{array}$ & 6106,1977 \\
\hline
\end{tabular}


Basic Data Table 4. Location, Geologic Environment, Present Use and potential Use of Thermal Springs and Wells in Idaho (continued)

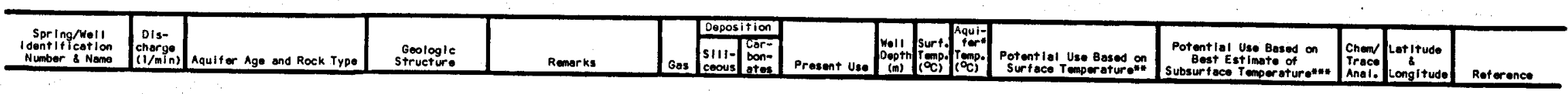

Elmore county (cont'd.)

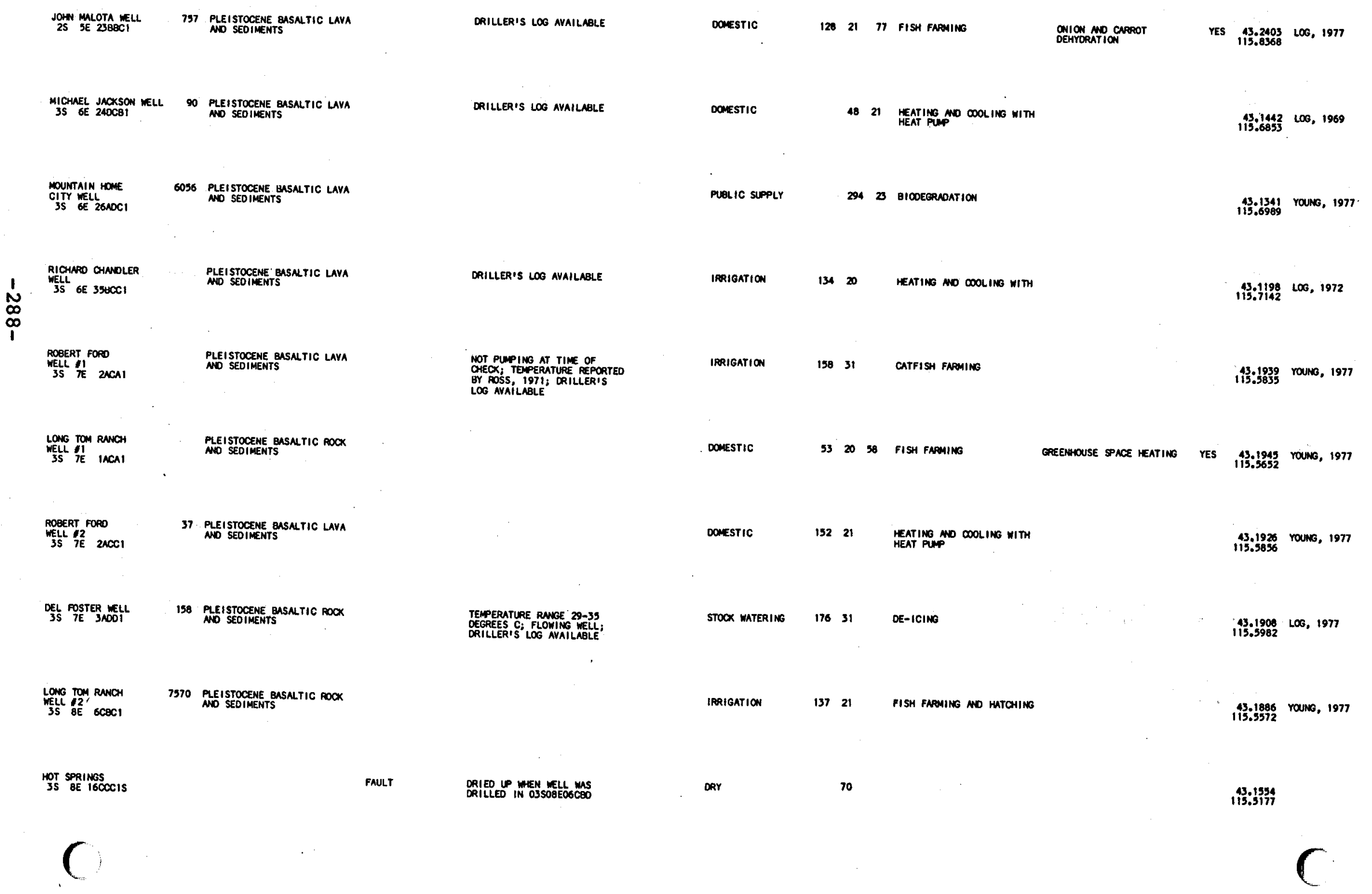


LESLIE BEMM

2744 PLIOCENE MD PLEISTOCENE
SED MENTS

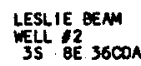

113 PLIOCENE NO PLEISTOCENE

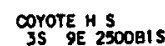

283 PLIOCENE SILICIC VOLCNIC

LATTY H S
SS IOE $3100 B 15$

$\underset{\text { PLOK }}{\text { PLIOENE SILICIC VOLCNIIC }}$

JOW DOENRON MELL 7570 PLEI STOCENE BASATIC LAVA
AE $32 A C C I$
NO SEDIMENTS

1
0
0
0

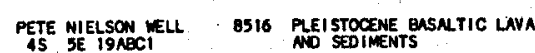

PLEISTOCENE EASNTIIC LAVA
NO SEDINENTS

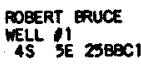

SB13 PLEISTOCENE BASALTIC LAVA
NO SEDIMENTS

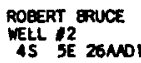

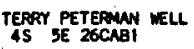

45 PLEISTOCENE BNSNTIC UVA
NO SEDIENTS

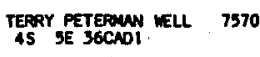

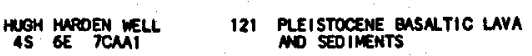

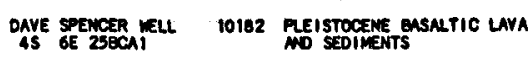

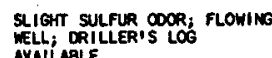

SLIGHT SULPUR COOR; FLOWING

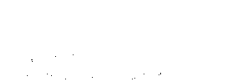

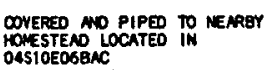

ORILLER'S LOG AVAILAELE

Driller's Log avallarle

OESERYAT ION WELL FOR
GSONO WATER LEVES:
DRILLERIS LOG ANAILABLE

DRILLER'S LOS AYAILABLE

ORILLER'S LOO AVAILABLE

ORILLERIS LoO AYAILARE.
IRRIGATION

1826771 MPPLE DEHroRation

STOCK MATERING 17836 FERMENTATION

unver

IRRIGATION

IRRIGATION

24 21 REATING NO COOLING WITH

IFAgATION

147 20 FISH FNOMUNG

IFRIGATION

$\cdot$

IRRIGATION

BagATION

$122 \quad 21$

IRPIGATION

24

FePEentation

DONESTIC

16322 KEATING NO DOLING WITH

iprigation
MEATING MO COLING WITH
RERIGERATION (LOMER
TERPRATURE LIMIT)

YES 113.1155 D1ON MO ORIFFIN,

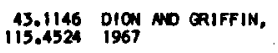

43.1292 JOHSON, 1978 JON)
115.3397 (SITE IISPECTION)

YES $\begin{aligned} & 45.1159 \\ & 115: 3054 \text { JOWSOW 1978 } \\ & \text { (SITE INSPECTION) }\end{aligned}$

43.0350 LoO, 1976
116.0061

13.0668 rouns, 1977

YES $\begin{gathered}43.0531 \\ 115.6150\end{gathered}$ L06, 1967

43.0518
115.8160 rouns, 1971

43.04713
115.8293

115.8065

113.78604 L00, 1977

115.6921 Lo6, 1967 
Basic Data Table 4. Location, Geologic Environment, Present Use and potential Use of Thermal Springs and wells in Idaho (continued)

\begin{tabular}{|c|c|c|c|c|c|c|c|c|c|c|c|c|}
\hline $\begin{array}{c}\text { Spping/woll } \\
\text { Ident ification } \\
\text { Number \& Nome } \\
\end{array}$ & \begin{tabular}{|c|c|}
$\begin{array}{c}\text { ols- } \\
\text { charge } \\
(1, \min )\end{array}$ \\
\end{tabular} & Aquiter Age and Rock Type & $\begin{array}{r}\text { Geologle } \\
\text { Structure } \\
\end{array}$ & Remarks & Ges & \begin{tabular}{|l|l|} 
Deposition \\
SIII- & Car- \\
boon- \\
coous
\end{tabular} & Present Use & 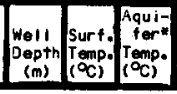 & $\begin{array}{l}\text { Potential Use Based on } \\
\text { Surtace Temperature }\end{array}$ & $\begin{array}{l}\text { Potential Use Bosed on } \\
\text { Best Est mote of } \\
\text { Subsurt tace Temperature*** }\end{array}$ & $\begin{array}{l}\text { Chem/ } \\
\text { Irace } \\
\text { Anal. }\end{array}$ & $\begin{array}{l}\text { Lat ltude } \\
8 \\
\text { Longitude }\end{array}$ \\
\hline
\end{tabular}

Elmore county (cont'd.)

FRAN LUTZ WELL "I
4S 6E 310001

PRMN LUTZ WELL I2 1022 PLEISTOCENE EASNRTIC LAVA

RALPH MOORE WELL
$4 S$ 6E 358001

RLPH YRAZABRL WELL 10220

$\mathfrak{O}_{1}^{1}$

BEVERLY OSON WELL

TS GOM GILL WELL 18926 PLIOCENE ND PLEISTOCENE

PACPFIC NW
PPELINE WELL
45. BE 368BA1

OILL DAVIS WELL 19926 PLIOCENE NO PLEISTOCENE

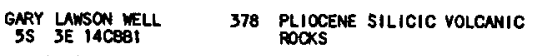

MIKE MISSEL WELL OI
DRILLER'S LOG AVAILABLE

DRILLER'S LOG AVAILABLE

DRILLER'S LOG AVAILABLE

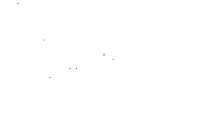

HLER'S LOG AVAILABLE,

USED AS COLLNT FOR TURBINE
DRILLER'S LOG AVALALELE

ORILER'S LOG AVAILABLE;
FLOWING WELL

SULFUR ODOR; FLOWING WELL
IRRIGATION

14921 MEATING NO COOI ING WITH

IRRIGATION

IRRIGATIOI

IRRIGATIOI

IRRIGATION

IRRIGATION

INDUSTRY

IRRIGATIOA

IRRIGATION

12420 HEAING NO COOLINO WITH

38043101 SWIIMING POOLS

DONESTIC

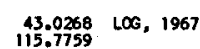

115.7746 13.0268, 1969

$115.7119606,1972$

43.0967
115.6339

YES $\begin{array}{r}43.0647 \\ 115.6698\end{array}$

115.4465 LOS, 1961

WASHING NO DRY ING Of WOL YES 113.0377 RRLSTON MO

PASTEURIZATION

YES 133.0923 RNSTRON MD

BLANOHING

YES $\begin{aligned} & \text { 42.9894 } \\ & 116.0762\end{aligned}$

\subsection{6}




\begin{tabular}{|c|c|c|c|c|c|c|c|c|c|}
\hline 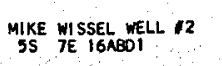 & $\begin{array}{l}\text { PLIOCEEE NO PLE ISTOCENE } \\
\text { SEDIMENTS }\end{array}$ & & DoMESTIC & 13720 & 60 & FISH PNBSHING & PQULTRYY HATOAERY & YES $\begin{array}{l}42.9947 \\
115.6244\end{array}$ & rounc, 1977 \\
\hline 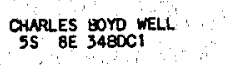 & $\begin{array}{l}\text { PUOCENE NO PLEISTOCENE } \\
\text { SEOIGENTS }\end{array}$ & ORY; REPORTED IEIPERATURE & & 3 & & RQunaUtTuRE & & $\begin{array}{l}42.9465 \\
15.4934\end{array}$ & rank, 1973 \\
\hline 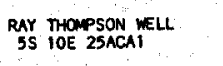 & $\begin{array}{l}\text { 49 PLIOCENE AN PLE ISTOCENE } \\
\text { SED MMENTS }\end{array}$ & DRILLER'S LOG AVA LABLEE & DOMESTIC & 1442 & & $\begin{array}{l}\text { KEATNG ND COOL ING WITH } \\
\text { HEAT PUNP }\end{array}$ & & $\begin{array}{l}142.9625 \\
153.2098\end{array}$ & Los, 1973 \\
\hline $\begin{array}{l}\text { DNNIEL HUTCHER KELL } \\
\text { SS IOE } 2800 C 1\end{array}$ & 378 PLE ISOCENE SEDIIENTS & $\begin{array}{l}\text { SIGHT SULURR COOR; FLOWING } \\
\text { ELLT }\end{array}$ & DOMESTIC & 30432 & & ImPropowios & & $\begin{array}{l}42.25917 \\
115.2770\end{array}$ & $\begin{array}{l}\text { RASSTOW NO } \\
\text { OHPMN, } 1968\end{array}$ \\
\hline 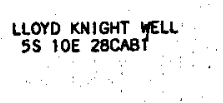 & 75 PLEI STOCENE SEDDMENTS & 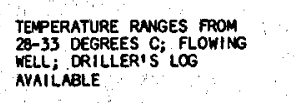 & DOMESTIC & 3353 & & CATFISH FNPMING & & $\begin{array}{l}122.9594 \\
15.2763\end{array}$ & LoG, 1969 \\
\hline 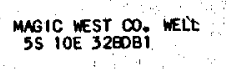 & $\begin{array}{l}\text { PLIOCENE AW PLEISTOCENE } \\
\text { SEOMENTS }\end{array}$ & & RECREATION & 2843 & 68 & Hropoponics & NPPLE DERORARTION & 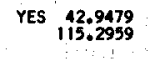 & $\begin{array}{l}\text { RuSTON MD } \\
\text { OANPMN, } \\
1968\end{array}$ \\
\hline 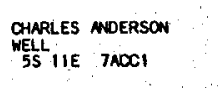 & & & DOMESTIC & 3963 & 64 & CATFI ISH FNAMING & AIIMUL HUSBANORY & YES $\begin{array}{l}43.0034 \\
115: 1926\end{array}$ & \\
\hline 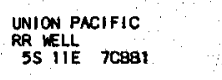 & $\begin{array}{l}\text { 189. PLIOCENE MO PLE ISTOCENE } \\
\text { SEOIMENTS }\end{array}$ & DRILLER'S LOS AVAILARLE & Donestic & 932 & & FISH FNPEMING & & $\begin{array}{l}.43 .0027 \\
115.2023\end{array}$ & ross, 1971 \\
\hline $\begin{array}{l}\text { ROONEY RUEERRY WELL } \\
\text { SS IIE } 1 B \text { BNA }\end{array}$ & 45 & FOWNG WELL & DOMESTIC & 1322 & & $\begin{array}{l}\text { MEATING NO DOLING WITH } \\
\text { HETT PUNPF }\end{array}$ & & $\begin{array}{l}142.934 \\
115.1959\end{array}$ & \\
\hline 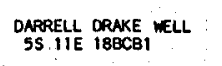 & 18 PLEI ITOCENE SEDIMENTS: & ORILLER'S LOG AVALLABLE & DOMESTIC & 732 & & CATFISH FNPUING & & $\begin{array}{l}42.9908 \\
15.2010\end{array}$ & $\angle 06,1969$ \\
\hline 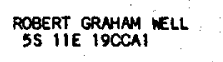 & 11 PLEI STOCENE SEDIIENTS & DRRLLER'S LOG AVAILABLEE & DOMESTIC & 1302 & & FISH FNPAMING & & $\begin{array}{l}42.9655 \\
115.2001\end{array}$ & LoG, 1974 \\
\hline 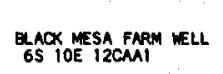 & is PLIOCENE MNO RLE ISTOCENE & DRILLER'S LOS AVAALABLE & DOMESTIC & & & CATFISH FNPUINGS & & $\begin{array}{l}142.9147 \\
115: 2147\end{array}$ & $\mathrm{~L}$ \\
\hline
\end{tabular}


Basic Data Table 4. Location, Geologic Environment, Present Use and Potential Use of Thermal Springs and Wells in Idaho (continued)

\begin{tabular}{|c|c|c|c|c|c|c|c|c|c|c|c|c|}
\hline $\begin{array}{c}\text { Spring/Woll } \\
\text { doentification } \\
\text { Number \& Name } \\
\end{array}$ & \begin{tabular}{|c|c|} 
ois- \\
chargo \\
$(1 / \mathrm{min})$
\end{tabular} & Aqulfer Age and Rock Type & $\begin{array}{r}\text { Geologic } \\
\text { Structure }\end{array}$ & Remorks & Gas $\left|\begin{array}{l}\text { Deposition } \\
\text { Sili- } \\
\text { silis } \\
\text { coous } \\
\text { bon- } \\
\text { ateat }\end{array}\right|$ & Present Uso & 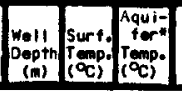 & $\begin{array}{l}\text { Potant lal Uaso Based on } \\
\text { Surface Temperatur of }\end{array}$ & 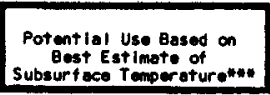 & $\begin{array}{l}\text { Cheon } \\
\text { Treace } \\
\text { Ansi. }\end{array}$ & $\begin{array}{l}\text { Lotitude } \\
\text { Longl tude }\end{array}$ & Reterence \\
\hline
\end{tabular}

Frankl in county

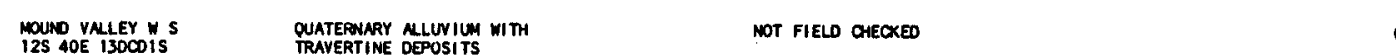

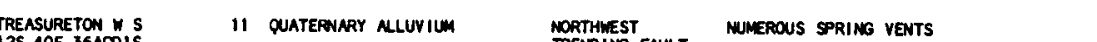

$\stackrel{1}{1}$

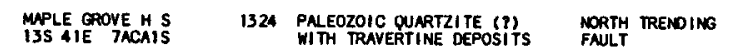

BEN MEEK WELL
IAS 395 36RA

RAY BAFRINGTON WELL 246 SUATEPNARY NLLUVIUM
14S 40 E 31 BCBI

ELPIN BINGHMM NELL 37 QUATERNARY NLLUVIUM
I5S 39 TOECI

SARTLE OREEK

SQUAN S SWELL

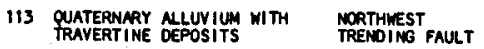

YES YES
3575 nquacultupe

S6 B1 RPUHT NOP YEGETARLE

35 MQUACULTURE

YES $\underset{\text { PELTON WHER }}{\text { POWLL }}$

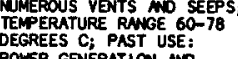
POER GGNERATION NO
RECREATION; SULFUR OOOR

6 on 149 pasteurizing
SLIGHT SULFUR DOOR

DRILLER'S LOG AVAILABLE

STOOX MATERING

2240 SOIL WARMING

63 se ANIMAL HUSEMORT

84142 BLANOHINO

1244103 SEEDLING CONIFERS

CANIING NO PRESERVING

YES 117:16566 DIOW, 1969

${ }_{111: 8366}^{42.1651} 100,1977$

ANCHINC

POTATOE DEHTORATIO

YES 1 Ai:11331 DIOW, 1969

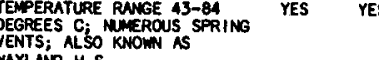

DORN PROOUCTS (STARCH,

YES 42.1191 O1ON, 1969

C 


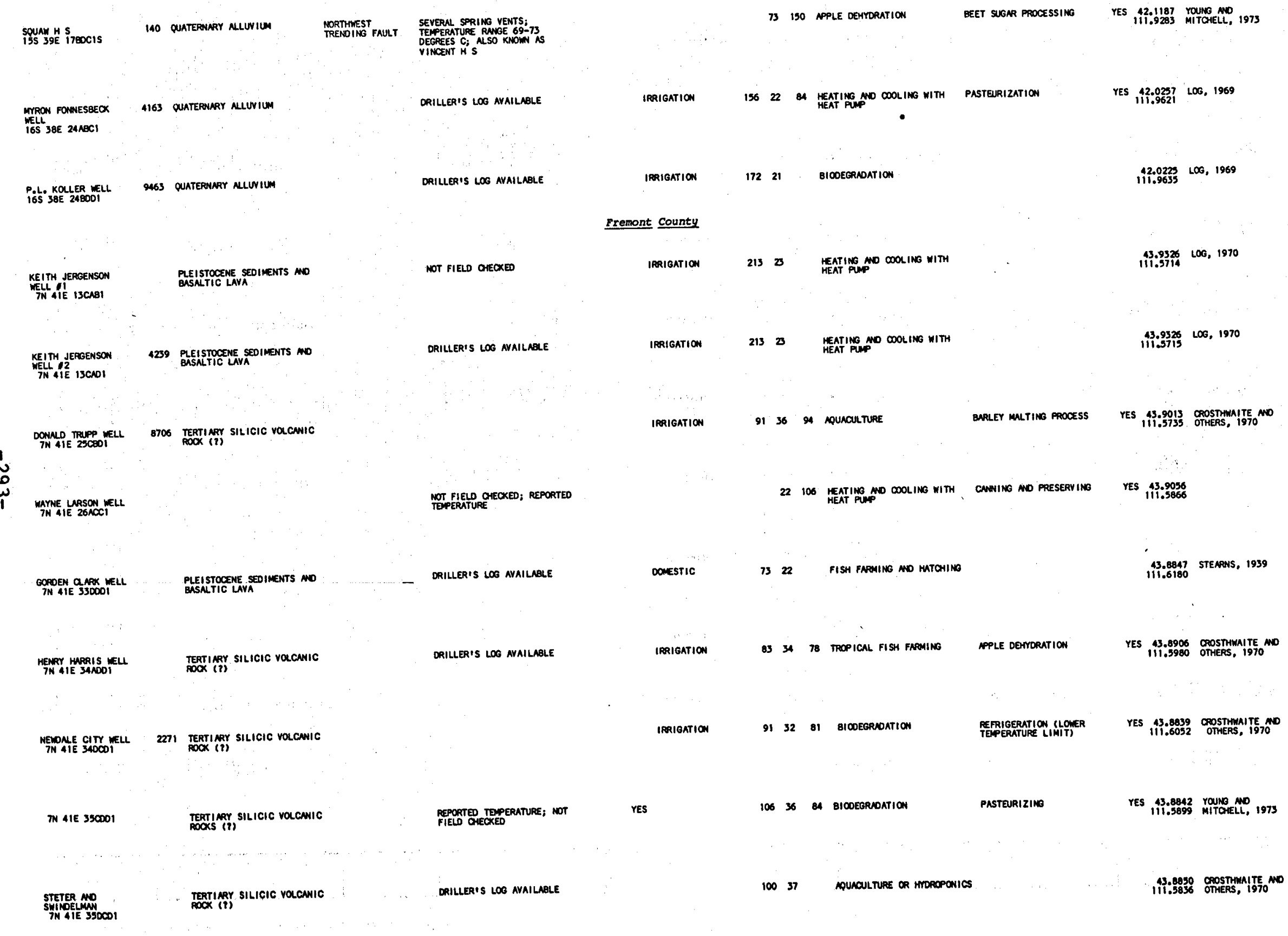


Basic Data Table 4. Location, Geologic Environment, Present Use and potential Use of Thermal springs and wells in Idaho (continued)

\begin{tabular}{|c|c|c|c|c|c|c|c|c|c|c|c|c|c|}
\hline $\begin{array}{r}\text { SprIng/wall } \\
\text { identif Icotion } \\
\text { Number \& Namo } \\
\end{array}$ & \begin{tabular}{|l|}
$\begin{array}{c}\text { Dis- } \\
\text { charye } \\
(1, \min )\end{array}$ \\
\end{tabular} & Aquifer Age and Rock Type & $\begin{array}{c}\text { Soologic } \\
\text { structure }\end{array}$ & Remarks. & Gas & \begin{tabular}{|l|l|} 
Deposition \\
Sill- & cart- \\
coous & bon- \\
ates \\
\end{tabular} & Present Use & 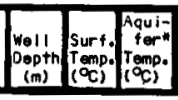 & $\begin{array}{l}\text { Potent Ial Use Based on } \\
\text { Surf ace Temper ofur of* }\end{array}$ & 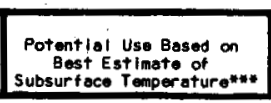 & \begin{tabular}{|c|} 
Chem \\
Trace \\
Anat I.
\end{tabular} \mid & $\begin{array}{l}\text { Lotitude } \\
\text { Longltuda } \\
\text { Longlud }\end{array}$ & Reter \\
\hline
\end{tabular}

Fremont County (cont'd.)

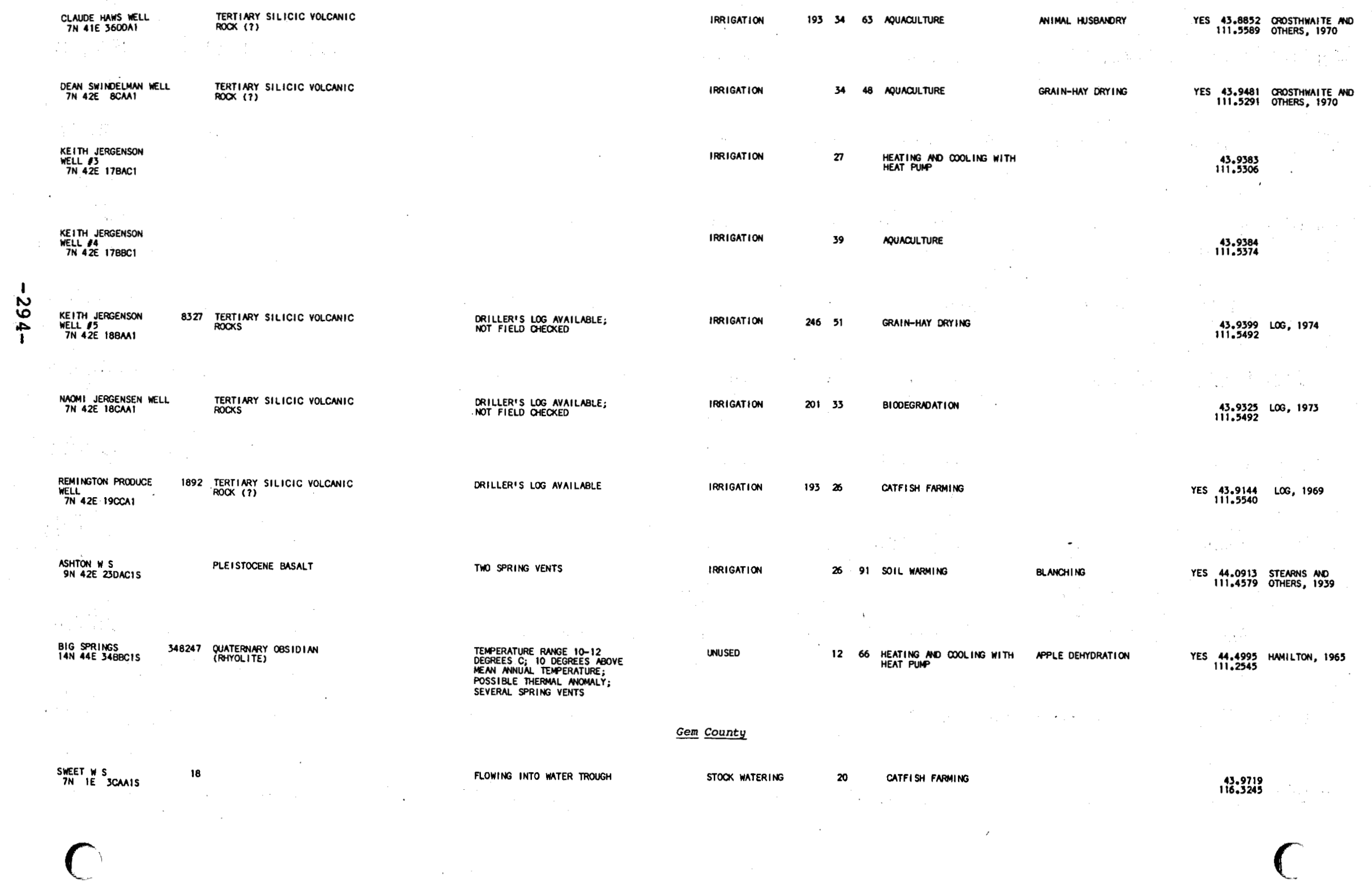




\begin{tabular}{|c|c|}
\hline ROYSTONE HS & $\begin{array}{l}189 \text { OUATEANAYY ALUVIUM MEAR } \\
\text { MOCENE BASALT }\end{array}$ \\
\hline 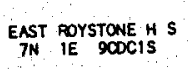 & 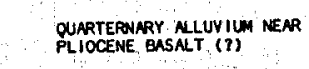 \\
\hline 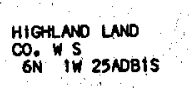 & 3 QUATERENYY NO TERT IRPY \\
\hline $\begin{array}{l}\text { DONALD, JENSEN } \\
\text { WEL II 26NAAI } \\
\text { GN IW }\end{array}$ & $\begin{array}{l}\text { 75 PLIOCENE MO PLEI STOCENE } \\
\text { SEOMENTS }\end{array}$ \\
\hline 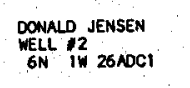 & $\begin{array}{l}75 \text { PLOCENE, NO PLEI ISTOCENE } \\
\text { SEOIENTS }\end{array}$ \\
\hline $\begin{array}{l}\text { PNL CRAMK } \\
\text { SELL } 2 W 140 B C 1 \\
\text { GN }\end{array}$ & $\begin{array}{l}\text { PLIOCENE NO PLE STOCENE } \\
\text { SEOOMENSS }\end{array}$ \\
\hline 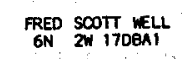 & 757 PLE ISTOCENE SEOMENTS \\
\hline $2 M B$ & 189 PLEISTOCENE SEDIMENTS \\
\hline
\end{tabular}

FANLTEO BASAT SULFUR COOR; FIVE SPRRING

NOT FIED OAEXED; REPORTED
TEPERATURE

SEEPAGE, TEYPERRTURE MY ME
LESS THW NEASURED

DRILLER's log AVAILABLE

MUTER HON MILKX APPERMNOE;
ORRLER'S LOG AVALABLE

YERY SAMLOW WELL
ORILRR'S LOE AVALLABLE

ORILLER'S LOG AVAILARLE

SLIGHT SULFLR ODOR

TSOMNWE HS
4S $12 E$ 3SMAIS

PLIOCENE BASATT

DAVE RPCHER
WELL II
WS 12 3SCNOI

140 PLIOCEAE RASALT MO
SEDIMENTS

Jis ISE 20 NEBO

PLEISTOCENE BASALT

HOT SOLPVR LNEE
4S IIE 290015

302 QUATERNARY QRSAT
DOMESTIC

54 24 HEATING MO DOLLNG MITH

$\begin{array}{lll}11 & 21 \\ \text { MEATING MNO DOOLING WITH }\end{array}$

Gooding county

TRPESATURE REPPRTED BY

UNuSED

STOCX WATERING

STOOX MATERING

DOMESTIC

IBRIGATION

DOMESTIC

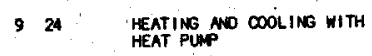

DRY

DRILLER'S LOG AVAILABLE;

DOMESTIC

16845 STOOX WATERING

ROWNAG; NREA COVERED WITH
SPRRINGS

YES DOMESTIC NO

5033 LNUNDYY USE

NO VISABLE FON, SPRING
IS SUBOUEOUS
YES UNUSED
27 FISH FNPMING
SUGAR BEET PROCESSING

YES 116.95359 NEWCOMN, 1970

$\mathbf{4}$
$\mathbf{1 1 6 . 9 5 2 9} .3468$

16.3955 Ross, 1971

43.8325 SAYNGE, 1973
116.4137

43.8304
116.4155

43.8547
116.5406 L06, 1977

43.8572
116.5970.

43.8789 SAVNGE, 1973
116.6359

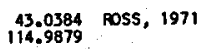

43.0289 STEAPNS MO
114.9980 OTHERS, 1938

YES $\begin{aligned} & \text { 43.0534 STENRNS MD } \\ & 114.9160 \text { OTHERS, } 1938\end{aligned}$

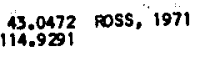


Basic Data Table 4. Location, Geologic Environment, Present Use and potential Use of Thermal Springs and wells in reaho (continued)

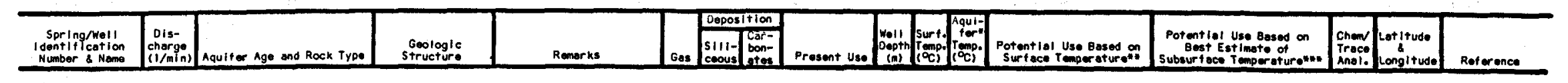

Gooding County (cont'd.)

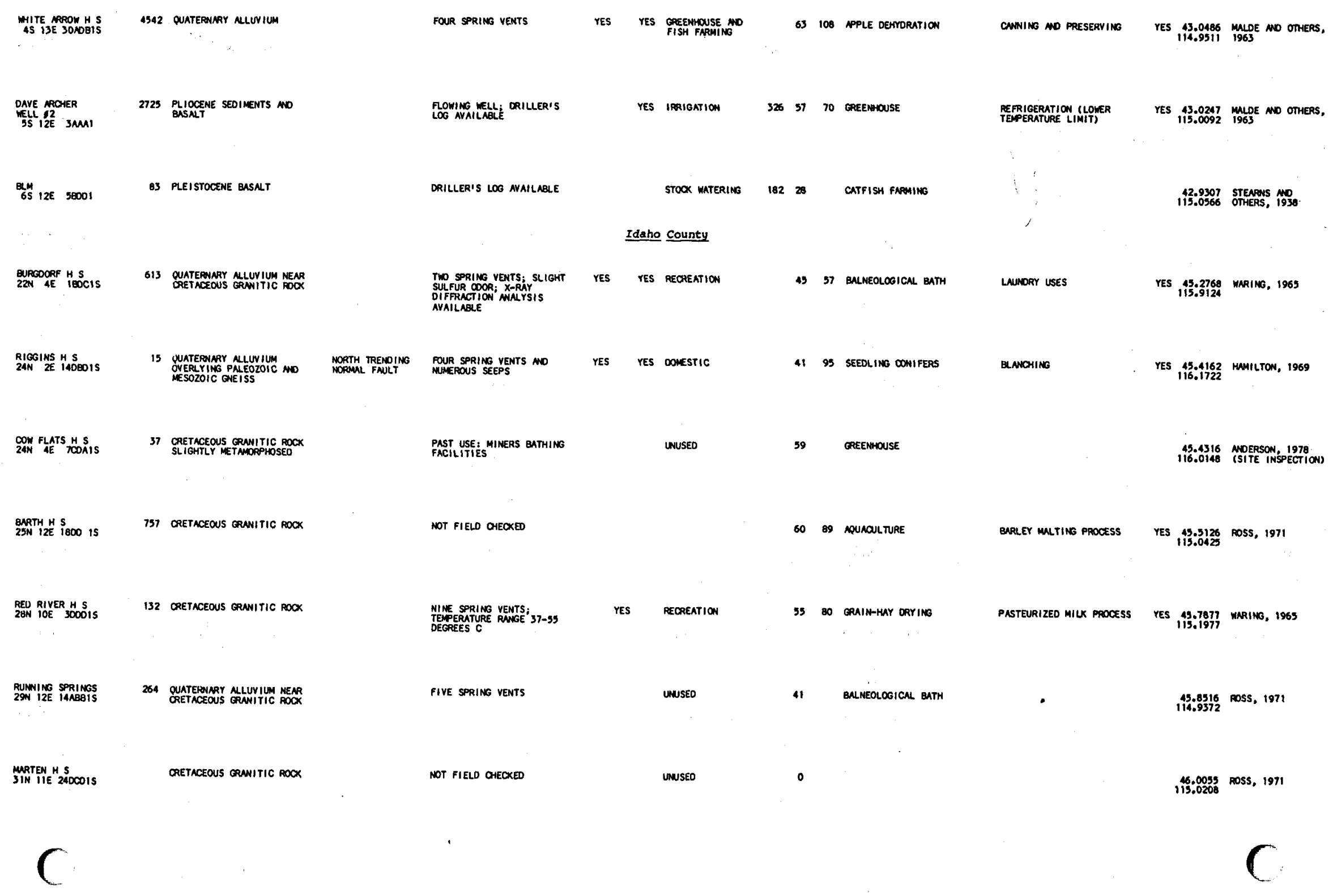


STUPRT $_{\text {S2N }} \mathrm{S}$ S

CRETACEOUS GRNITIC ROCX

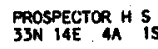

CRETACEOUS CRANITIC ROCK

STANEV HS
SWN IOE
GCAMIS

113 ORETACEOUS GRWITIC ROCX

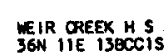

227. CRETACEOUS GRANITIC ROCK

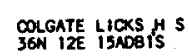

189 CRETACEOUS GRANITIC FOCX

LITTE JER IERY JOANISON

GETACEOUS GRNITIC ROCX

ஸ̃

JEER JOANSOW HS
36N IJE IISODOIS

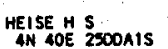

227 TERTINRY SILICIC VOLCWIIC

ROYN CATFISH

10523 PLIOCENE BASNTIIC LUYA

9S ITE 290NOI

.

FOSTER RANOH H S
ISN ISE TOOCIS

18

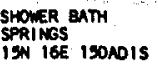

YES UNUSED

SIX SPRING VENTS
TERRATURE RANGE 44-47
DEGREES C

SEVERRL SPRING VENTS

TDO SPRING VENTS:
IEPERANURE RNGE 30-41
OEGREES C

TEPERUTURE RANGE $41-48$
DERGEES $C_{j}$ EIGHT SPRING
VENTS

YES

Jefferson County

TOO SPRING VENTS; EXTENSIVE
RANERTINE EEPSSITION

TES RECREATION

Jerome county

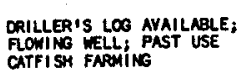

UNUSED

Lemhit county

SULFUR COOR; NGERPOUS
SPRING VENTS TEEPERATURE
RMGE 42-57 DEGREES C

unused

so RQMAULTURE

47 TO LANORY USE
37 GREENHOUSE

16.1382 poss. 1971

46.2390
114.7073

115.2575 ROSS, 1971

REFIGERTION CLOWER
TEPERATURE LIMITI)

YES $\begin{gathered}16.0635 \\ 115.0350\end{gathered}$

41 MUSHOOOM GROWING

114.96388 ROSs, 1971

$114: 07463$

4870 SEEDL ING CONIFERS

APPLE DEMPRATION

VES 116.4629 MRRING, 1969

4979 GRAN-HAY DRYING

PASTEURIZEO MILK PROCESS

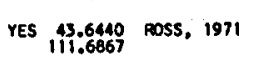

YES $\begin{aligned} & 42.6133 \\ & 114.4878\end{aligned}$

114.65610

114.6279 . 19055,1971 
Basic Data Table 4. Location, Geologic Environment, Present Use and Potential Use of Thermal Springs and Wells in Idaho (continued)

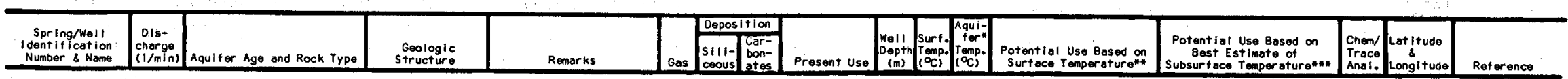

Lemhi County (cont'd.)

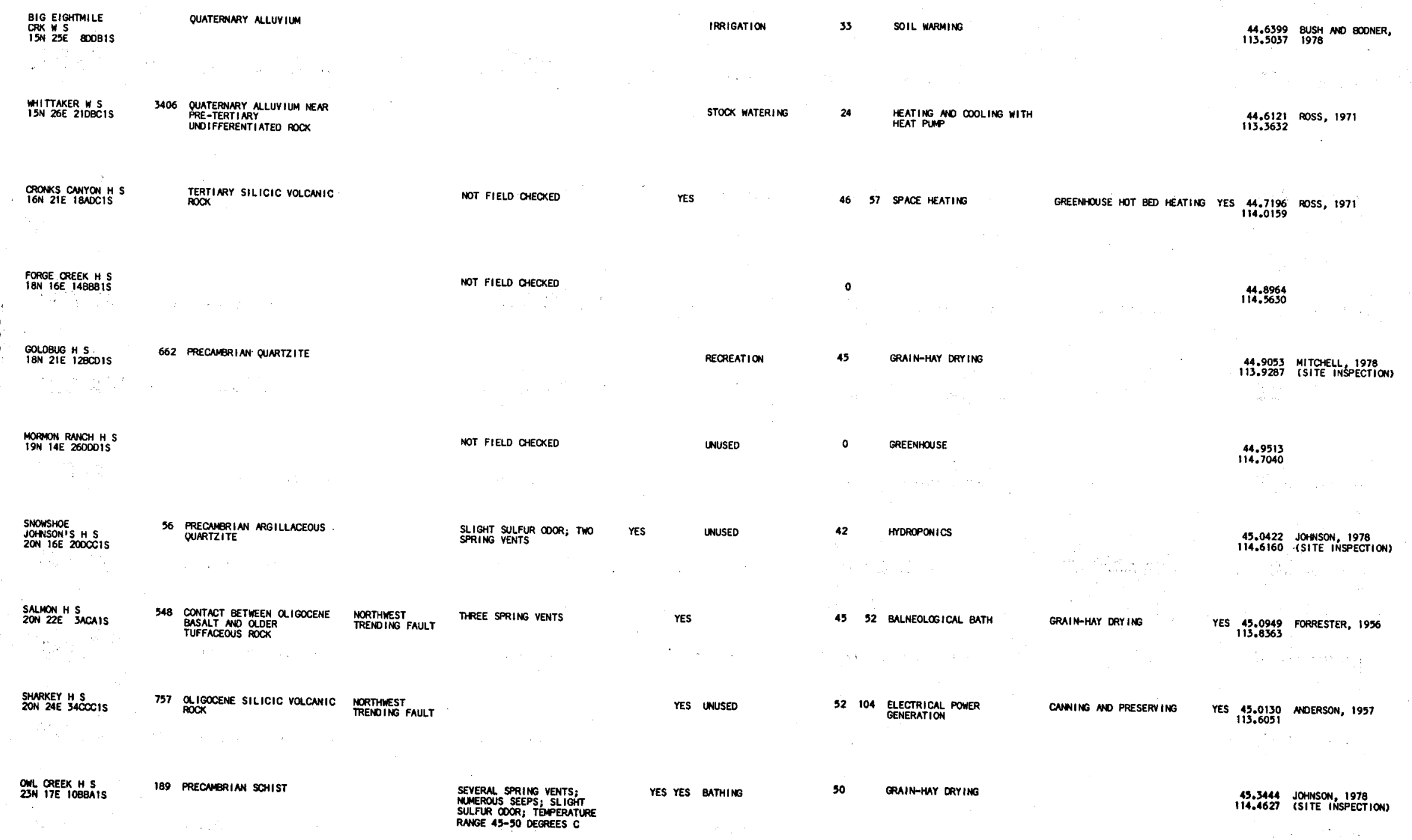




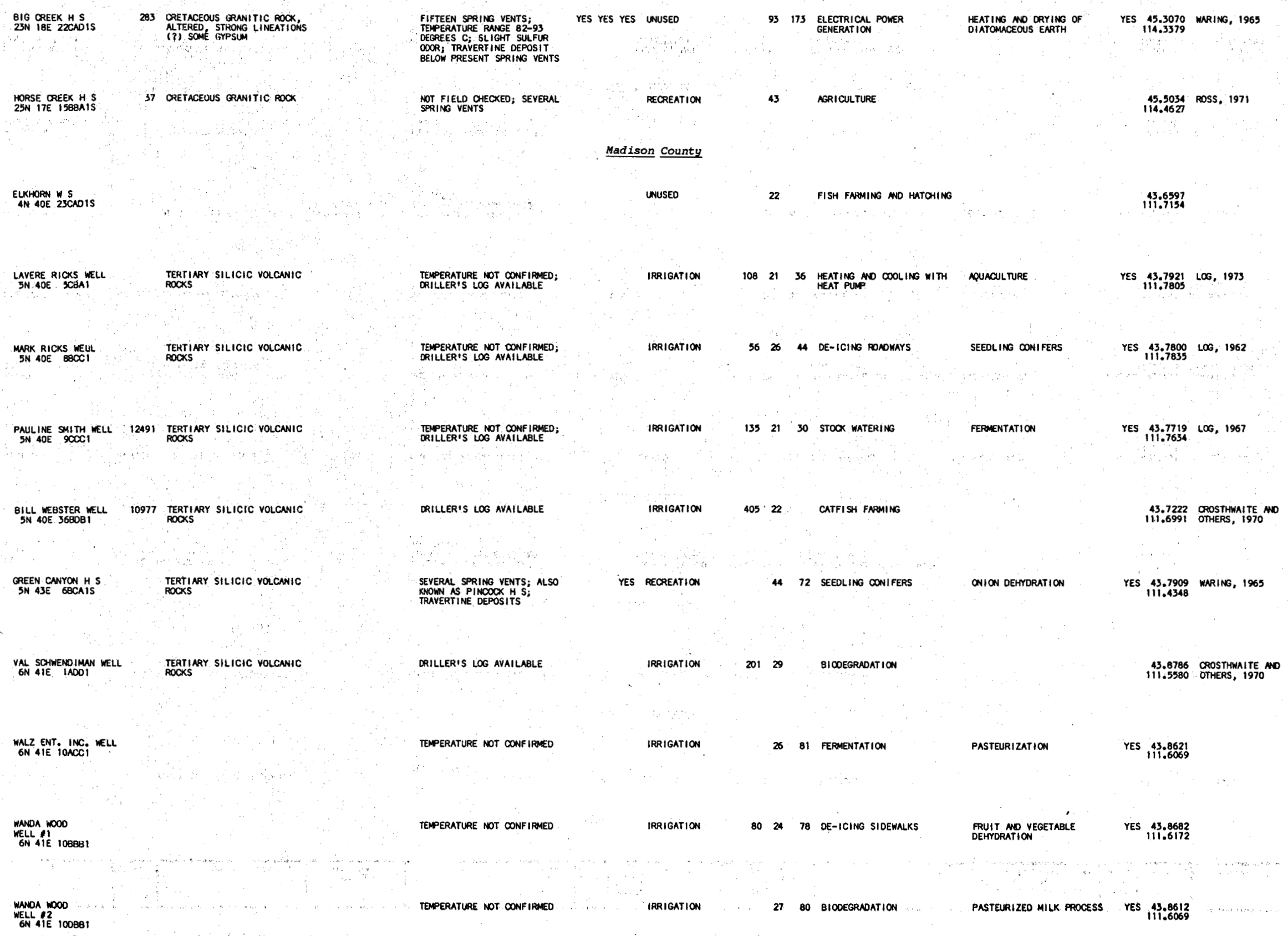


Basic Data Table 4. Location, Geologic Environment, Present Use and Potential use of Thermal Springs and Walls in Idaho (continued)

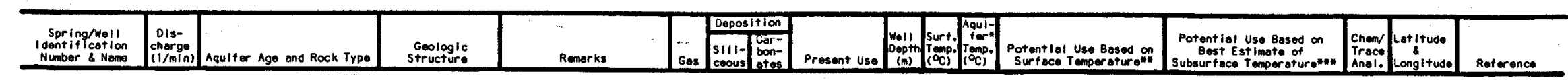

Madison county (cont'd.)

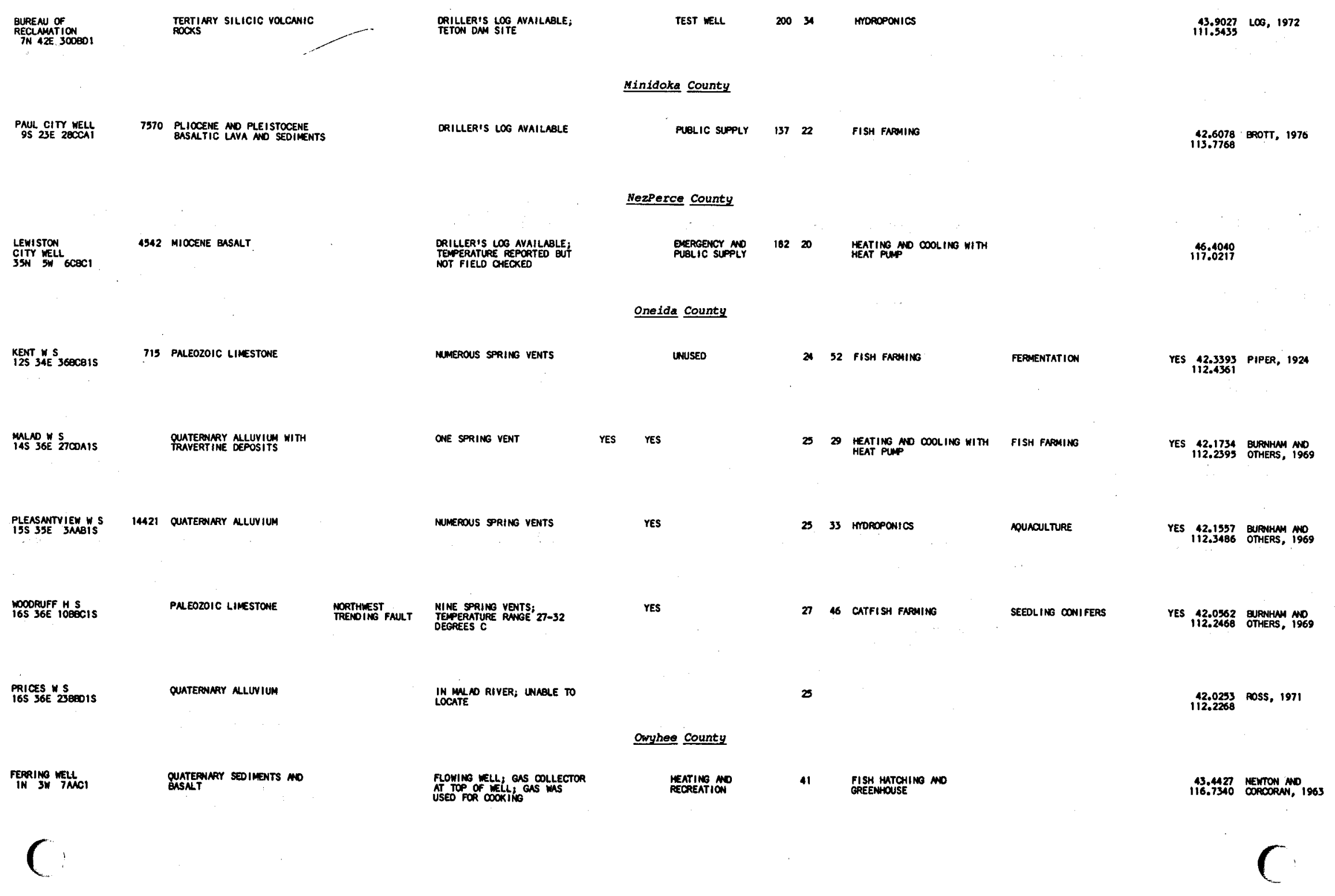




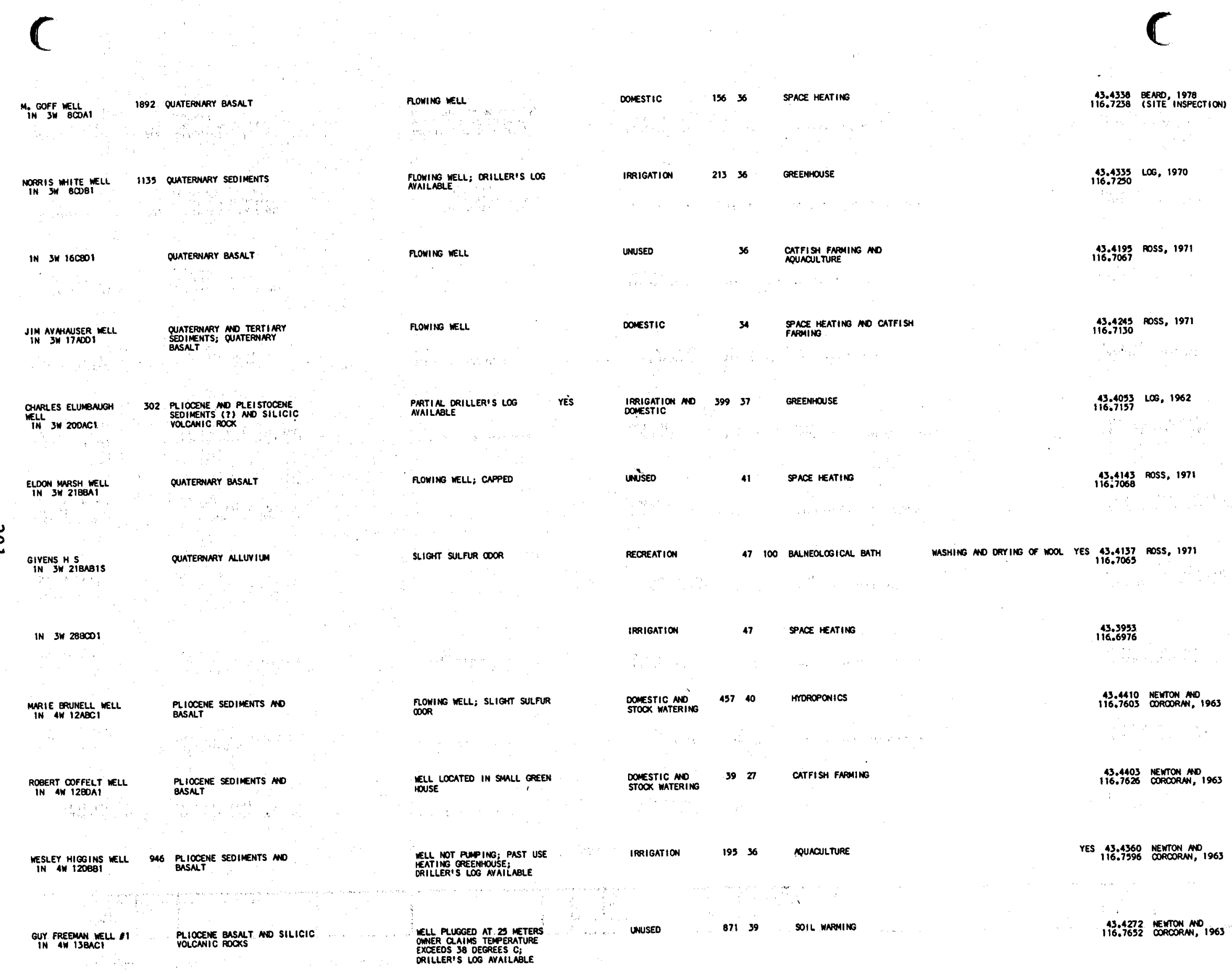


Basic Data Table 4. Location, Geologic Environment, Present Use and Potential use of Thermal Springs and wells in Idaho (continued)

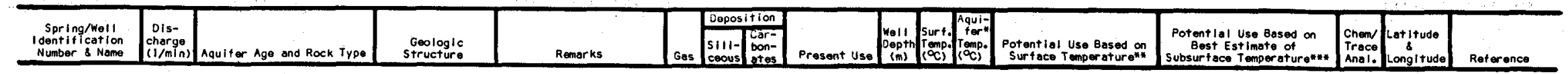

Owyhee County (cont'd.)

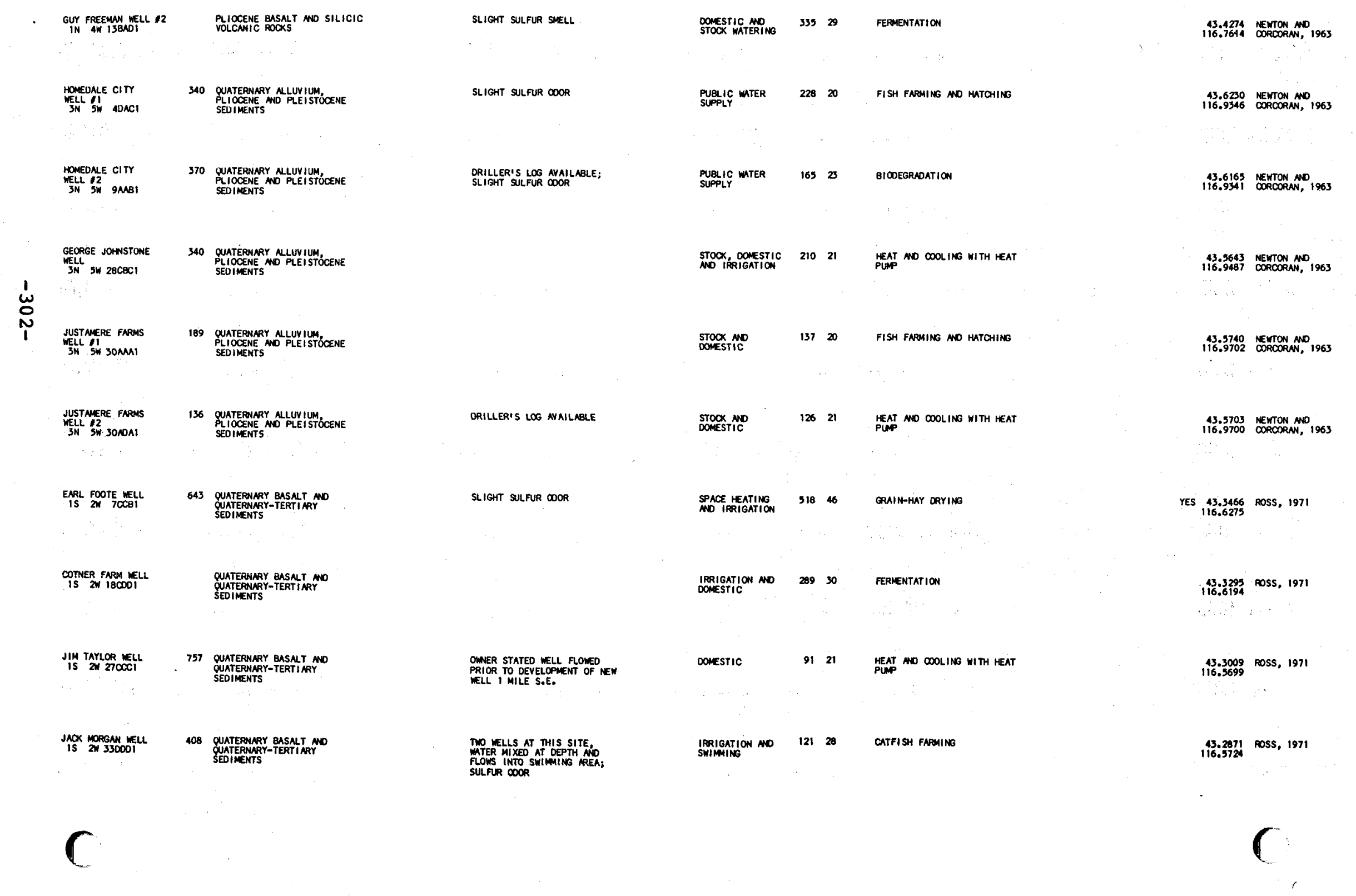




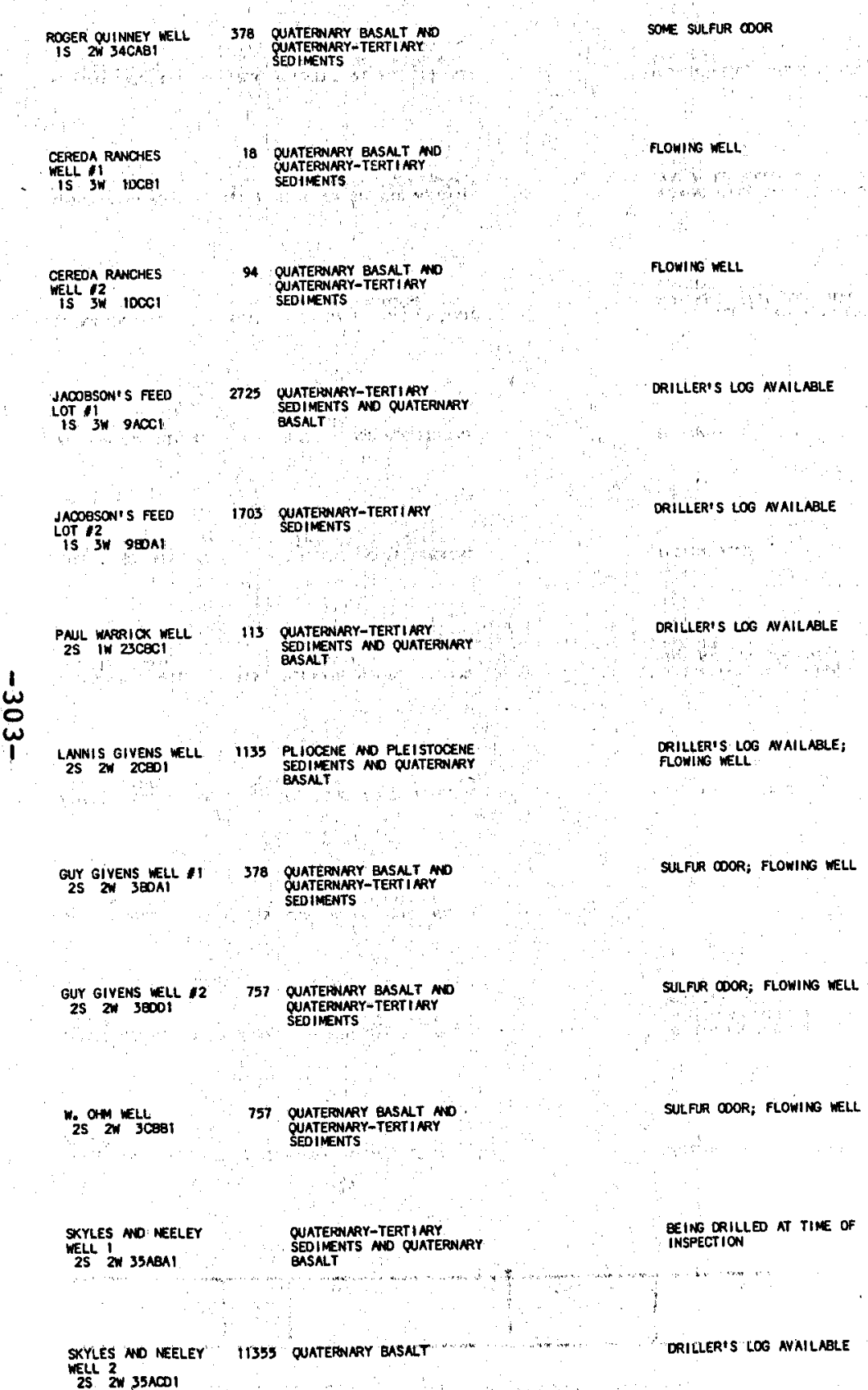

Donestic
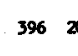

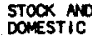

365 . 40 GEENHOUSE

IRRIGATION

27436 FEPMENTATION

STOOX MATERING

182

BIOOEGRADATION

stoox

16737 SPACE HEATING

Domestic

22130 DE-ICING HIGHAY

26038 SPACE HEATING

STOOX WATERING

$27438 \quad$ MTROPONICS

STOOK MATERING

274.43 SEEDL ING ONIIFERS

IRPIGATION

$27436 \quad$ NQUACULTURE

IRRIGATION

$335 \quad 25$

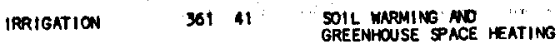

116.56645 Ross, 1971

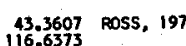

13.3585 ROSS. 1971
116.6392

$\underset{116.6975}{43.3523} 100,1968$

43.3533
116.7005

43.2329
116.432

${ }_{13.5463}^{43.2752}$ Lo6, 1953

116.5624 Ross, 1971

116.5625 Ross, 1971

43.2779 poss, 1971
116.5696

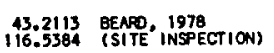

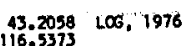


Basic Data Table 4. Location, Geologic Environment, Present Use and Potential tre of Thermal Springs and wells in Idaho (continued)

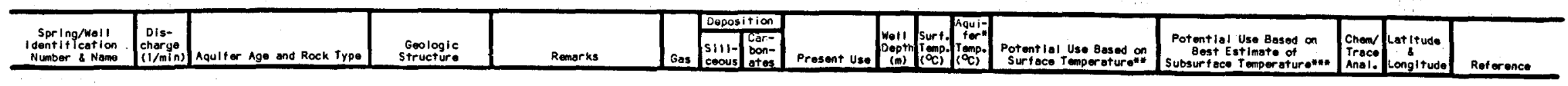

Owyhes County (cont'd.)

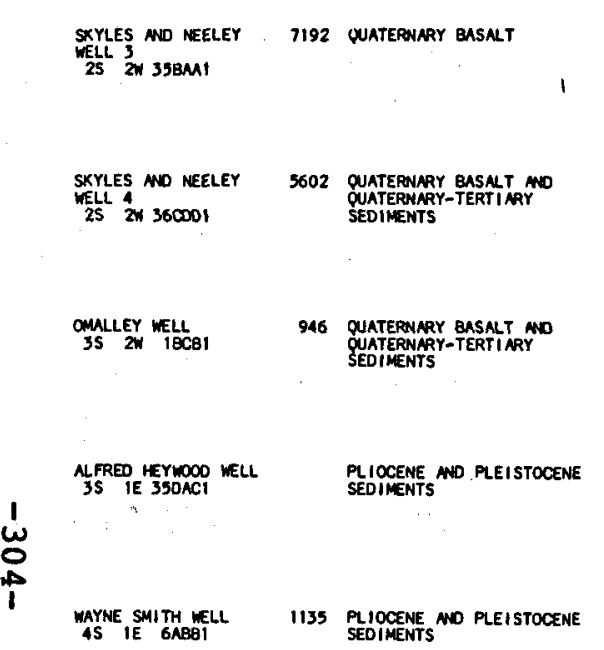

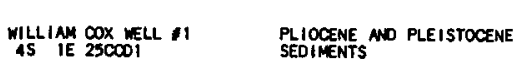

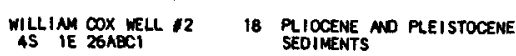

Tis NiE 2900001

6813 TERTIARY SILICIC VOLCNIC
POOSN NOPLOCENE
SEOIMENTS

GEORGE KING WELL
AS IE 34112 TERT

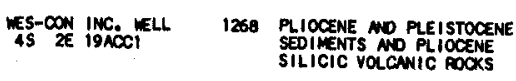

DRILLER'S LOG AVAILABLE

TO OE ORILLED DEEPER;
WMTER TESPERTUURE HIGHER WIEN FLOWING

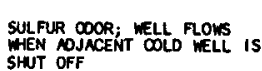

FLOWING MELL

PLOWING WELL

ROHING WELL, DRILLER'S LOS
AAALABE; PAST USE: HOG
SCALDING

FLOMING WELL; ORILLER'S LOG
AVAILABLE, SULFUR OOOR

YES IRRIGATION

FIONING MELL; ORILLER'S LOS
AVALLALE

IPRIGATION

IRRIGATION

IRRIGATION

unuseo

IRRIGATION

$$
\text { IPRIGATION }
$$

$637 \quad 32$

FEPMENTATION

36023 FISH FARMING NO HATOHING

$121 \quad 24$

CATFISH FAMMING

9120 MEATING MO DOLING WITH

STOOK MATERING

32

FERMENTATION

310 27 CATFISH FAPOING

926 68 APLE DEHTORATION

90876

PASTEURIZED MILK PROCESS

RARELY USED
958
SEEDLING OONIFENS
, 16.52131 LOS, 1970

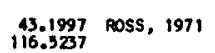

$\frac{43.1943}{116.5311}$ - Ross, 1971

YES $\begin{aligned} & 43.1176 \text { YOUNG NO } \\ & 116.2970 \text { WIIEHENO, } 1979\end{aligned}$

116.3839 2055,1971

YES $\begin{gathered}43.0412 \\ 116.2890 \\ \text { YOUNG NO } \\ \text { WHITEHENO, }\end{gathered}$

YES $\begin{aligned} & 43.0521 \\ & 116.3016 \\ & \text { YOUNG NO } \\ & W+1 \text { TEHENO, }\end{aligned}$

VES $\begin{aligned} 43.0400 \\ 116.3692\end{aligned}$

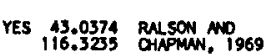

43.0656
116.2622

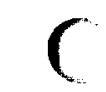




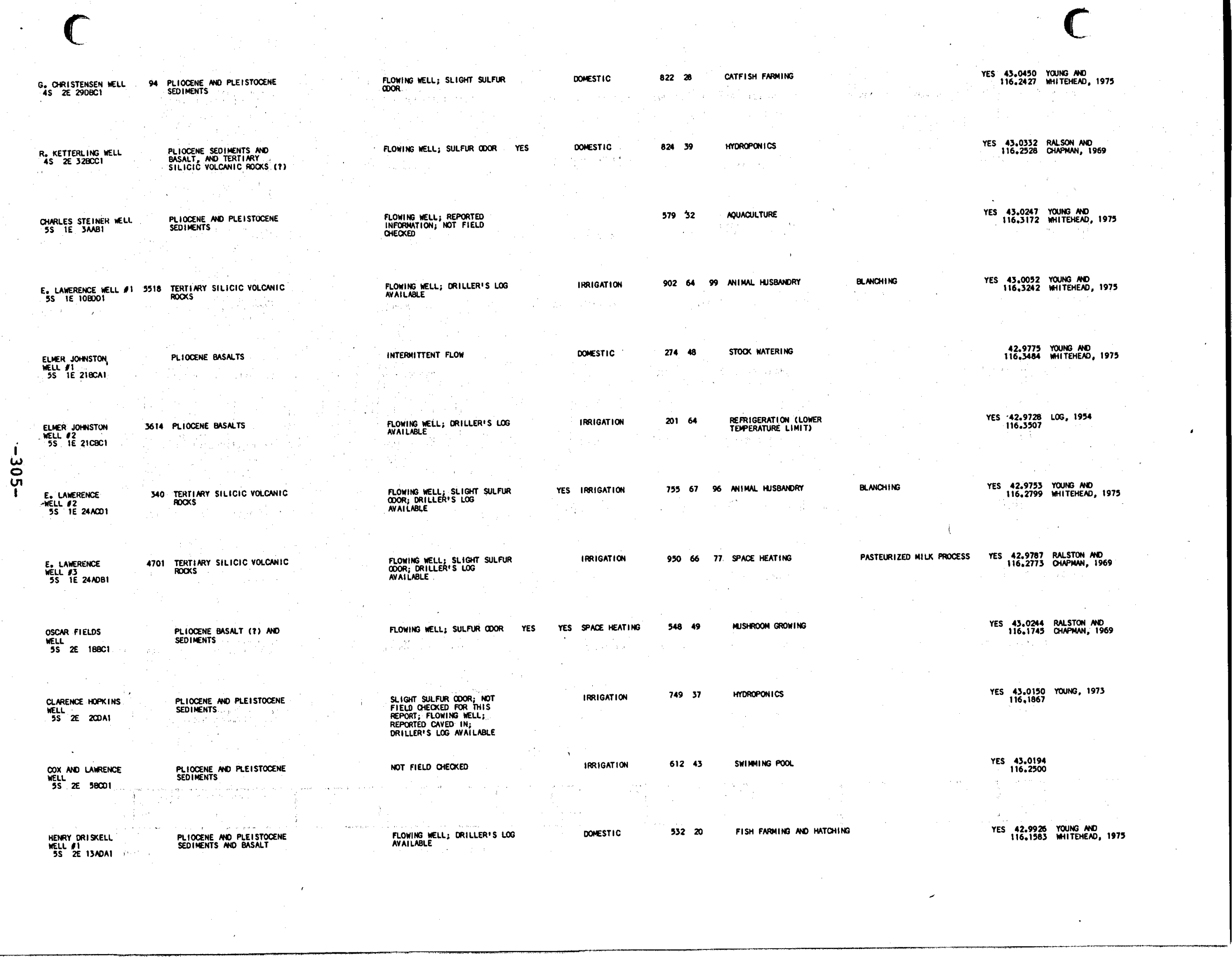


Basic Data Table 4. Location, Geologic Environment, Present Use and Potential Use of Thermal Springs and Wells in Idaho (continued)

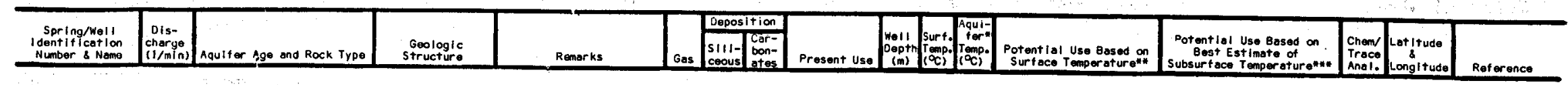

Owryhee County (cont'd.)

\begin{tabular}{|c|c|c|c|c|c|c|c|c|c|c|c|}
\hline $\begin{array}{l}\text { MENY ORI SKELL } \\
\text { WELL } \\
\text { WS } 2 E \text { 2SNDAI }\end{array}$ & & $\begin{array}{l}\text { PLIOCENE NO PLEISTOCENE } \\
\text { SEOIMENTS NO BASMT ( }(?)\end{array}$ & 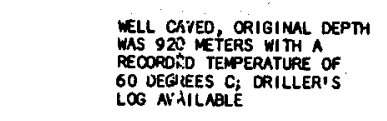 & & DOMESTIC & 45 & 21 & MIMAL HUSBNORY & & $\begin{array}{l}42.9646 \\
116.1563\end{array}$ & $\begin{array}{c}100,1965 \\
\cdots\end{array}$ \\
\hline $\begin{array}{l}\text { NORRIS MCKEETH WELL } \\
\text { SS } 3 \text { ZONAAI }\end{array}$ & 1957 & $\begin{array}{l}\text { PLIOCENE MO PLEISTOCENE } \\
\text { SEDIMENTS NO BASNT ( }(?)\end{array}$ & $\begin{array}{l}\text { FOWHAK MELL; ORILLER' S } \\
\text { LOG AHALLABLE; SULFUR OOOR }\end{array}$ & & $\begin{array}{l}\text { MEATING HONE } \\
\text { \& OUTEUILDINGS }\end{array}$ & 737 & 59 & GNE BIFO HUTCHING & & YES $\begin{array}{l}42.9973 \\
116.1167\end{array}$ & Lo6, 1959 \\
\hline $\begin{array}{l}\text { BURGHNPDT } D . \\
\text { WEL } \\
\text { SS } 3 E 208881\end{array}$ & 7 & $\begin{array}{l}\text { PLIOCENE ANO PLEISTOCENE } \\
\text { SEUIMENTS }\end{array}$ & FLowtNG wE!:L & & STOCX MATERING & & 27 & CATFISH FNEMING & & YES $\begin{array}{r}42.9820 \\
116.1358\end{array}$ & $\begin{array}{l}\text { YOWNG NND } \\
\text { YWHTEHEND, }\end{array}$ \\
\hline 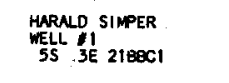 & 37 & $\begin{array}{l}\text { TERTINAY STLICIC VOLCANIC } \\
\text { ROOKS }(2)\end{array}$ & FLOWING WELL & & Dovestic & 609 & $\mathbf{n 2}$ & PUEAT MO OOOLING WITH HEAT & & $\begin{array}{l}42.9796 \\
116.1153\end{array}$ & \\
\hline 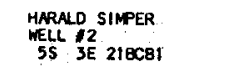 & & $\begin{array}{l}\text { TERTINRY SILLCIC VOLCANIC } \\
\text { ROOSS (?) }\end{array}$ & FLOWINS WELL & & oonestic & 609 & 27 & CATFISH FARMING & & $\begin{array}{l}12.9782 \\
116,1144\end{array}$ & \\
\hline $\begin{array}{l}\text { LEROY BEAMWN KELL } \\
\text { SS JE 22MDI }\end{array}$ & & $\begin{array}{l}\text { PLLOCENE AD PLEISTOCENE } \\
\text { SEDIMENTS }\end{array}$ & FLOWING WELL & & & 396 & 2 & DE-ICING RONDWAYS & & VES $\begin{array}{l}42.9811 \\
116.0765\end{array}$ & 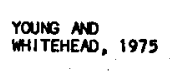 \\
\hline 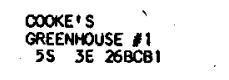 & 1059 & $\begin{array}{l}\text { PLIOCENE SILICIC VOLCANIC } \\
\text { POCXS NO PLIOCENE BSALT }\end{array}$ & FLOWING WELL & YES $(\eta)$ YES & GREENHOUSE & 905 & $85 \quad 116$ & BNRLEY MRLTING PROCESS & $\begin{array}{l}\text { HIGH ENERGY PROCESSING OF } \\
\text { KILN UURERR }\end{array}$ & YES $\begin{array}{c}\begin{array}{c}42.9639 \\
116.0756\end{array} \\
\end{array}$ & YOUNG, 1972 \\
\hline 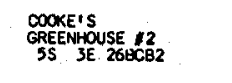 & 1741 & $\begin{array}{l}\text { PLIOCENE SILLCIC VOLCANIC } \\
\text { POOKS NDO PLIOCENE EASALTS } \\
\text { (2). }\end{array}$ & FLOWING WELL & YES & IRRIGATION & 905 & 67 & $\begin{array}{l}\text { REFIGERATION (LLOER } \\
\text { TEPPERAURE LIMIT) }\end{array}$ & & VES $\begin{array}{l}42.9639 \\
116.0750\end{array}$ & rounc, 1973 \\
\hline 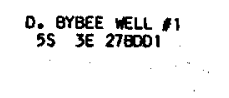 & & $\begin{array}{l}\text { PLIOCENE SILICIC VOLCANIC } \\
\text { OOOXS AO PLIOCENE BASNLT }\end{array}$ & FLOWING MELL & & AIR & 883 & 60 & GREENHOUSE & & 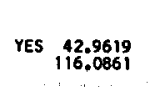 & $\begin{array}{l}\text { YOUNG AOD } \\
\text { WHITEHEAO, } 1973\end{array}$ \\
\hline 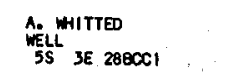 & & $\begin{array}{l}\text { TERTINEY SILLCIC VOLCANIC } \\
\text { ROOKS MD PLIOCENE BASAT }\end{array}$ & $\begin{array}{l}\text { FLOWIAG WELL; DRILLER'S } \\
\text { LOG AVAILABLE }\end{array}$ & & IRRIGATION & 774 & $64 \quad 109$ & НОTВED HEATING & CANNII & YES $\underset{116.1141}{42.9612}$ & 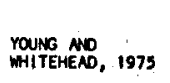 \\
\hline
\end{tabular}




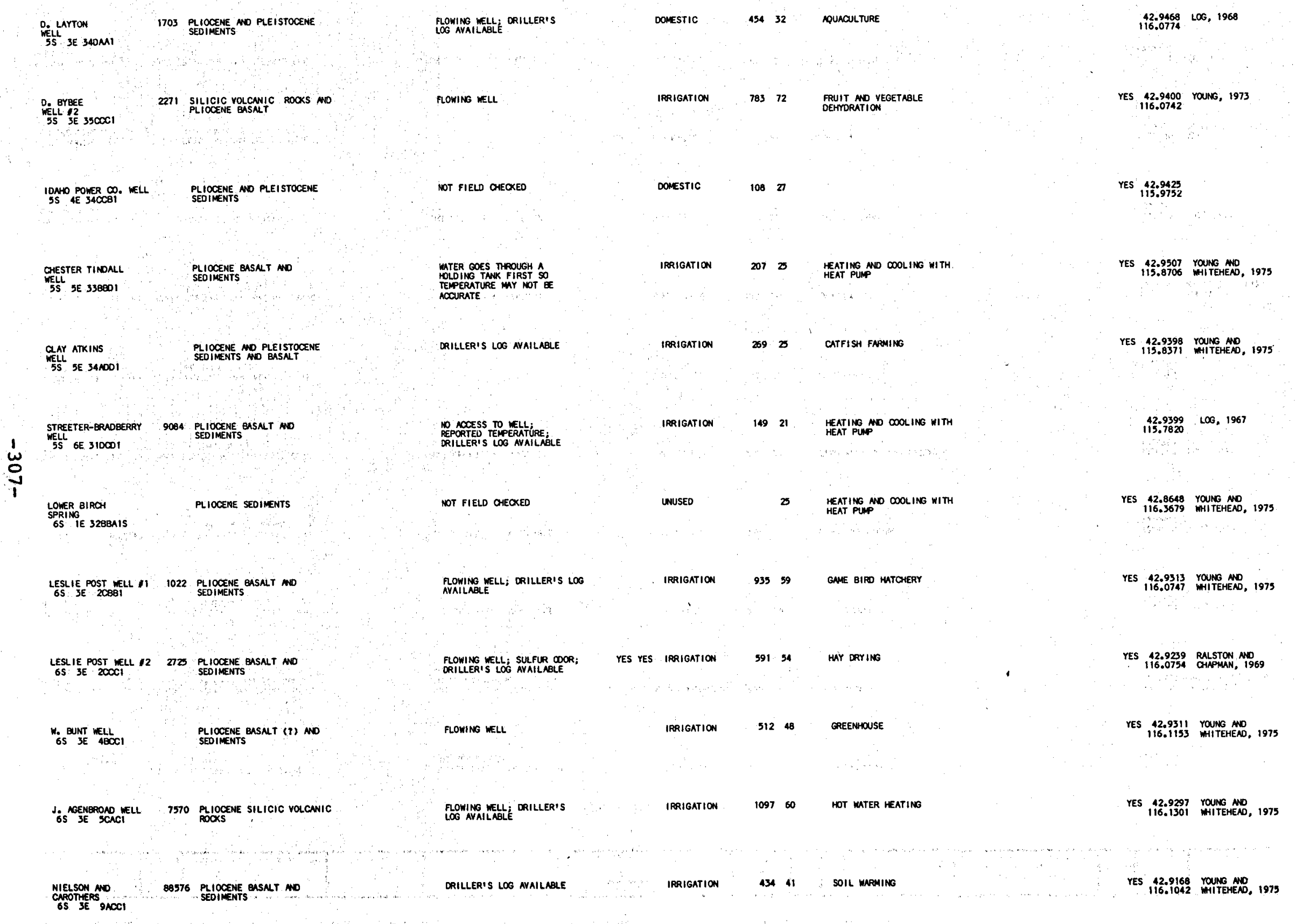


Basic Data Table 4. Location, Geologic Environment, Present Use and potential use of Thermal Springs and wells in Idaho (continued)

\begin{tabular}{|c|c|c|c|c|c|c|c|c|c|c|c|c|c|}
\hline $\begin{array}{c}\text { Spring/woll } \\
\text { Ienitiftcation } \\
\text { Number \& Name }\end{array}$ & 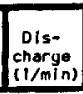 & Aquifer Age and Rock Type & $\begin{array}{c}\text { Geologic } \\
\text { structure }\end{array}$ & Remarks & Gos & \begin{tabular}{|l|} 
Deposition \\
sill- \\
cotor- \\
con- \\
stes \\
\end{tabular} & Prosent Uso & 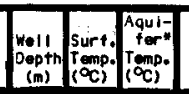 & $\begin{array}{l}\text { Potential Use Based on } \\
\text { Surface Temperature ont" }\end{array}$ & 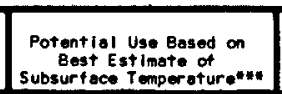 & $\begin{array}{l}\text { Chempl } \\
\text { Trace: } \\
\text { Anal. }\end{array}$ & $\mid \begin{array}{l}\text { Lat itude } \\
\text { Lugl } \\
\text { Longitude }\end{array}$ & Roterence \\
\hline
\end{tabular}

Owyhee Courity (cont'd.)

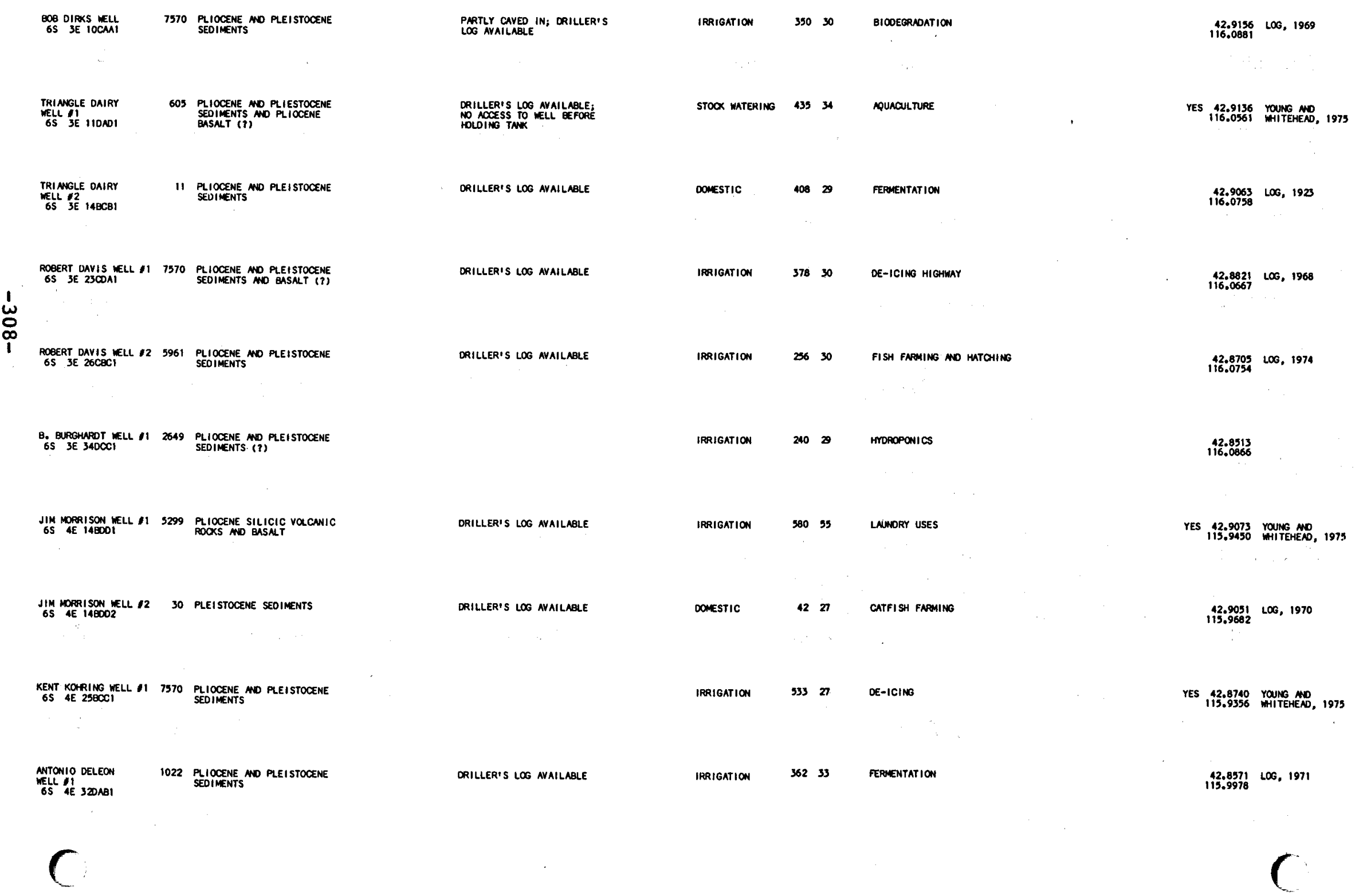




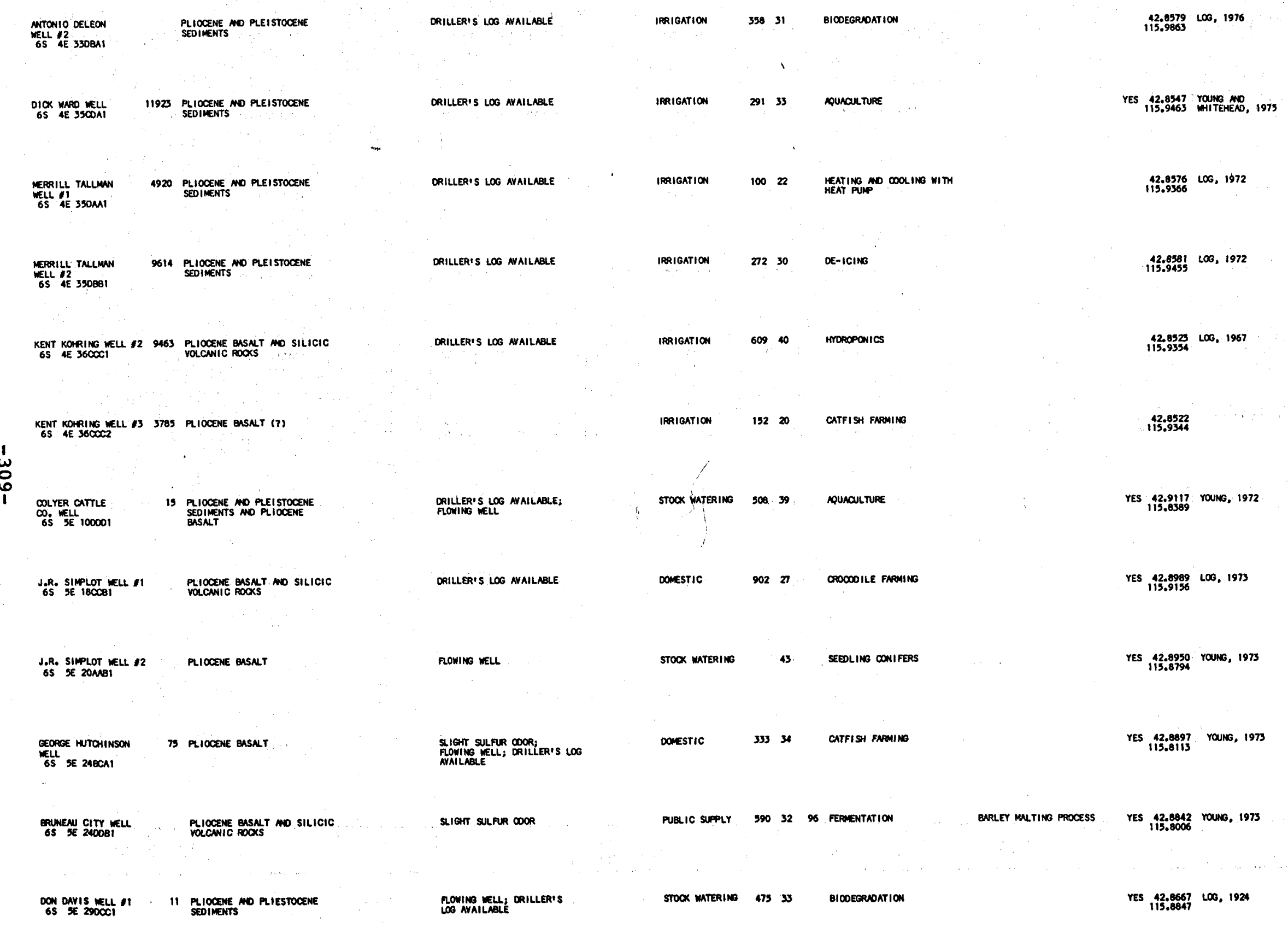


Basic Data Table 4. Location, Geologic Environment, Present Use and Potential Use of Thermal Springs and Wells in Idaho (continued)

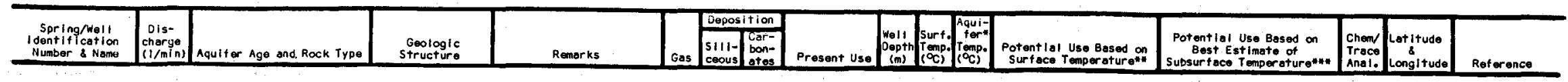

Owyhee County (cont'd.)

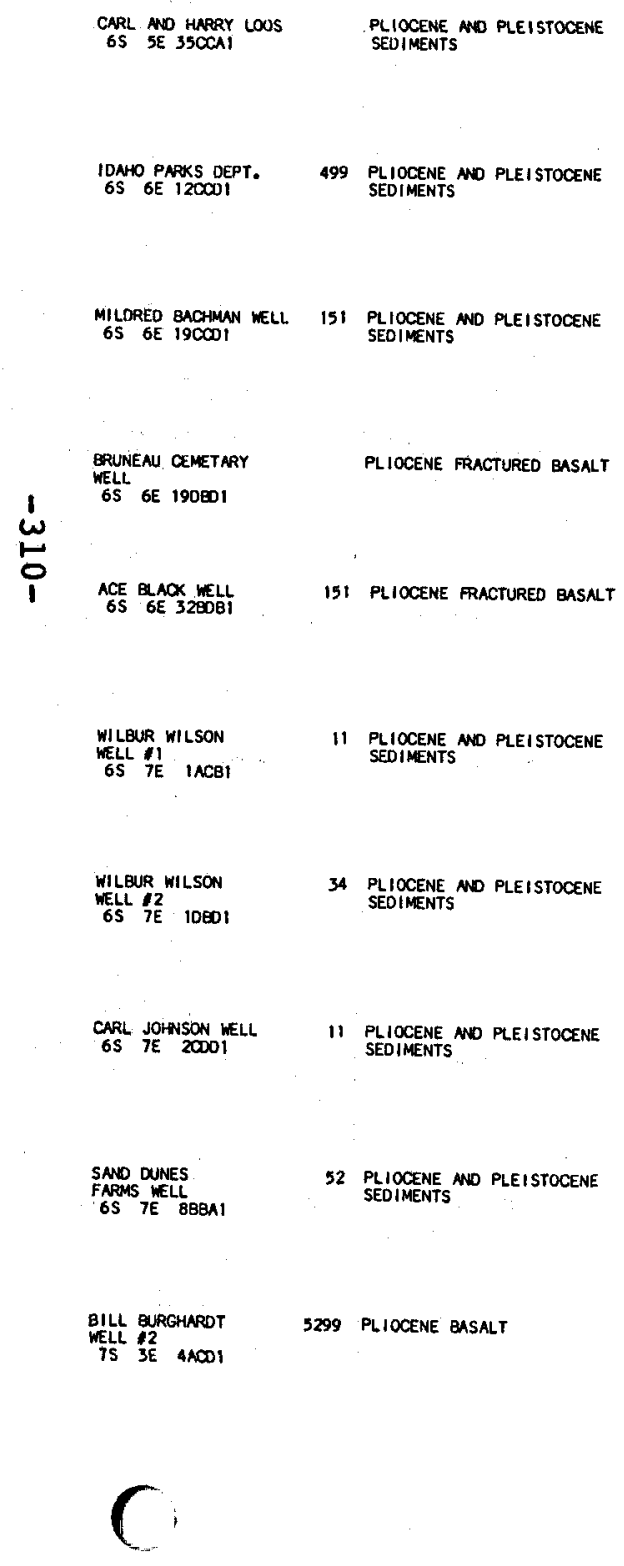

IRRIGATION

$140 \quad 22$ MEAT ND DOOLING WITH HEAT

ORILLER'S LOG AVAILABLE

FLOWING MELL; DRILLR'S
LOG ANAILABLE

ORILLER'S LOG AVAILABLE;
SULFUR DOOR

${ }_{\text {ROOR }}^{\text {RLWG MELL; SLIGHT SULFUR }}$

FLOWING WELL

FLOWING WELL

oriller's log avallaele

DRILLER'S LOG AVALLABLE; WEPTH, WATER IS REPORTED TO
IRRIGATION

$301 \quad 37$

MQUACULTURE

DOMESTIC

$278 \quad 38$

HTROPONICS

IPRIGATION

41042

SWIMUING Poors

STOOX MATERING

427. 35

FERMENTATION

DOMESTIC

30442 NQUNCULLTIRE

STOCK WATERI

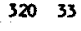

MDROPONICS

DOMESTIC

411. 35

BLOOEGRANTION

DONESTIC

11123 CATFISH FNPMING

IRRIGATION

24529 DE-IGING HIGHWAY
VES 115.8547 YOUNG, 1973

YES $\begin{array}{r}42.9108 \text { LOS, } 1968 \\ 115.6939\end{array}$

YES $\underset{115.7925}{42.8820}$ LOG, 1926

YES $\begin{array}{r}42.8856 \\ 115.7819\end{array}$ YounG, 1973

YES $\begin{array}{r}42.8600 \\ 115.7683\end{array}$

YES $\begin{aligned} & 42.9342 \text { YOUNG ND } \\ & 115.5678 \text { MIITEHEND, } 1974\end{aligned}$

YES $\begin{aligned} & 42.9283 \\ & 115.5639 \\ & \text { YOUNG MO } \\ & \text { WIIITHEAD, } 1974\end{aligned}$

VES 112.9249 YOUNG, 1973

YES $\begin{aligned} & 42.9217 \text { YOUNG ANO } \\ & 115.6528\end{aligned}$

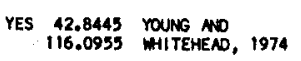


MILEER MASTRE, 1570

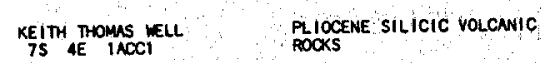

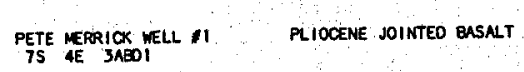

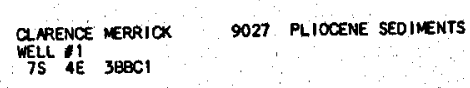

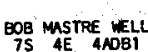

PLIOCENE BASNT

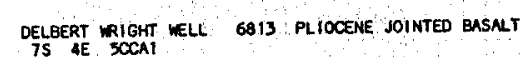

$\stackrel{\stackrel{w}{5}}{\mathfrak{t}}$

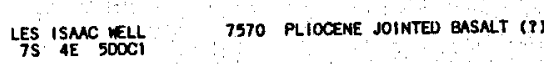

PETE WERRIXX MELL 12 PLIOCENE JOINTED BASAT

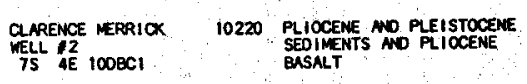

$\underset{75}{\text { PANL QEERUM WELL }} 2549$

TREMK MILETT

11923 P PIOCENE SILICIC VOLCNIC

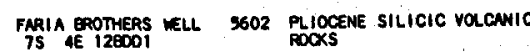

IRRIGAIION

249 39. Hropoponics

42.8310
116.0402

LOWING WELL

IFRIGATION

548 . 40 STOX WATERING

IRRIGATION

34842 SWIMAING POOLS

ORILLER'S LOG AVAILABLE

ORILLER'S LOG AVAILABLE

31630 MUACULTIRE

IREsGation

277.

DE-ICING

DRILLER'S LOO AYAILABLE

DRILLER'S LOG AVAILABLE

DRILLER'S LOG AYAILAELE

RLOMNO WEUL, ORILLER'S
LOG AVAILABLE
YES $\underset{115.9228}{42.842}$ rounG, 1973

YES $\begin{array}{r}42.8486 \\ 115.9566\end{array}$

$\underset{12.08486}{115.9729}$ Lo0, 1966

$42.8462 \quad 106,1974$
115.9761

42.8400
116.0083

115.89775

YES $\underset{115.9682}{42.8322}$ YoUNG, 1973

125.82617 LOG, 1965

12.8205

YES $\begin{gathered}42.8361 \\ 115.9533\end{gathered}$

YES $\begin{aligned} & 42.8306 \\ & 115.9238\end{aligned}$ 
Bacic Data Table 4. Location, Geologic Environment, Present Use and Potential Use of Thermal Springs and wells in Idaho (continued)

\begin{tabular}{|c|c|c|c|c|c|c|c|c|c|c|c|c|c|}
\hline 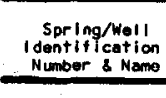 & $\begin{array}{l}\text { ols- } \\
\text { charye } \\
\text { charming }\end{array}$ & Aqulfer Age and Rock Type & $\begin{array}{r}\text { Geologic } \\
\text { Structure }\end{array}$ & Remarks & Gos & 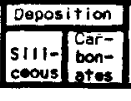 & Prosent Use & 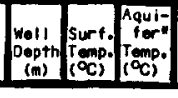 & $\begin{array}{l}\text { Potontisl Use Based on } \\
\text { Surf oce Temperature*t* }\end{array}$ & 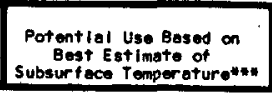 & 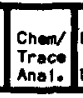 & $\begin{array}{l}\text { Latitude } \\
\text { Longitude }\end{array}$ & Reference \\
\hline
\end{tabular}

Owyhee County (cont'd.)

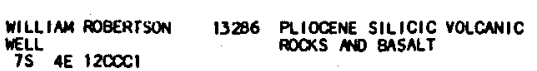

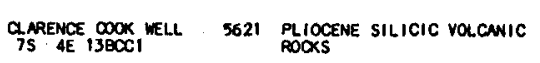

OANE LANTINEN, NELL 3785 PLIOCENE SILICIC VOLCANIC
75 POCKS

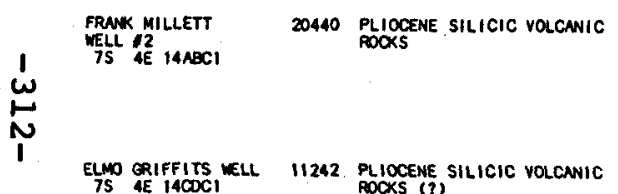

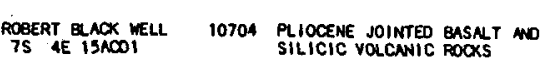

DANINE RRM INS WELL PLIOCENE SILICIC VOLCANIC
7S AE 22ACBI

Ci RUSSEL WELL. 16276 PLIOCENE SILICIC VOLCNNIC

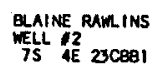

151 PLIOCENE SULICIC VOLCANIC
ROOKS NWO BASALT

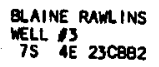

15141 PLIOCENE SILICIC VOLCANIC
POOXS NO JOINTE BASLLT
ORILLER'S LOG AVAILABLE;
FLOWING WELL

TOTM DEPTH IS UNKNOW,
WELL WAS DEEPENEO

DRILLER'S LOG AVAILABLE;
FLOWING WELL

DRILLER'S LOG AVAILABLE

DRILLER'S LOG AYAILABLE

ORILLER'S LOG AVAILABLE

ORILLER'S Log AYAILARLE

DRILLER'S LOG AVAILARLE

DRILLER'S LOG AVAILABLE

ORILLER'S LOG AVAILABLE

$$
\text { IPRIGATION }
$$

$274 \quad 43$

SEEDLING CONI FERS

IRRIGATION

32339 SOIL WNPMING

IRRIGATION

304 STOCX WATERING

IRRIGATION

34939 MOUACULTURE

IRRIGATION

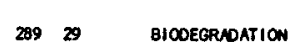

IRRIGATION

32433

FERMENTATION

IRRIGATION

30438 SHRINP FAPUING

IRRIGATION

$$
243 \text { 41 GREEMHOUSE }
$$

Domestic

$$
10835 \text { RQunculture }
$$

IRRIGATION
24639 perpentation $\frac{12.8224}{115,9334} 100,1960$

YES $\begin{gathered}42.8153 \\ 115.9336\end{gathered}$ roung, 1973

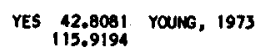

YES $\begin{gathered}42.8189 \\ 115.9433\end{gathered}$ YOUNG, 1973

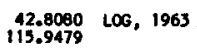

YES $\begin{aligned} & 42.8153 \\ & 115.9606\end{aligned}$ rounc, 1973

$\underset{115.9615}{42.9028}$ Lo6, 1966

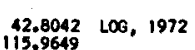

42.7999 YOUNG ANO
115.9310 WHITEHENO, 1975

VES 12.7994 YOUNG AD, 1975

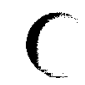


C

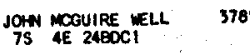

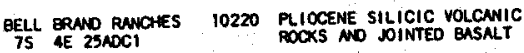

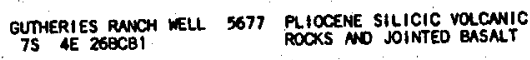

DANE LANTIMEE WEL 775 PLLOCENE SILICIC VOCANIC

DOW DAVIS IELL, $_{\text {SE }} 12$

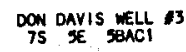

$\stackrel{b}{\omega}$

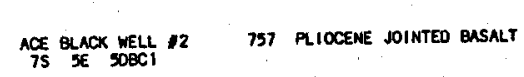

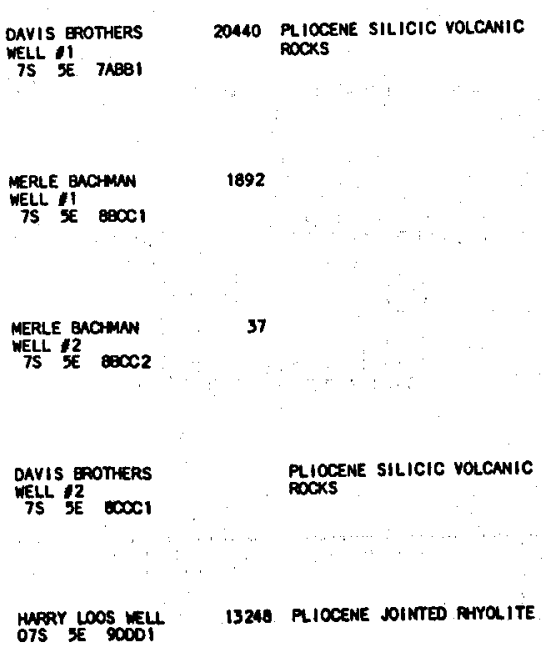

WO LONGER A RLOWING WELL

IRRIGATION

21932

DE-IGING PONOMAYS

DRILLER'S LOG AYAILABLE

ORILLER'S LOG AVAILABLE

IRRIGATIO

22436 BLOOEGADATION

IRRIGATION

25431

DE-ICING HIGHAYS

IRRIGATION

427 27 KEATING MO DOLLING WITH

ORILLER'S LOG AVAILABLE;
FLONINO WELL

ORILLER'S LOG AVAILABLE,
FLOWING WELL

FLOWING WELL

FLOWING WELL

DRILLER'S LOG AVAILABLE;
FLOWNG WELL

ROMING MELL; ORILLER'S LOS
NAALAALE
unusEd

23 CATFISH FAPMING

20. MEATING MO DOLING WITH

IRRIGATION

73332 MUNOULTURE

IRPIGATION

49539 impropowics

IRRIGATION

39640 RQUACLLTURE

IRRIGATION

21326 FERMENTATION

IRRIGATION

$45740 \quad 501 L$ WPOM1NG

IPRIGATION
42.8021
115.9286

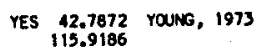

YES $\begin{gathered}42.7881 \\ 115.9528\end{gathered}$ rounc, 1973

VES $\begin{gathered}42.7860 \\ 113.9725\end{gathered}$ rouns, 1973

42.8504
115.8869

113.8694

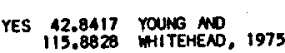

YES $\begin{gathered}42.8367 \\ 115.9044\end{gathered}$ roung, 1972

42.8306
115.8928

115.0934

YES $\begin{gathered}42.8239 \\ 115.8936\end{gathered}$ Youns, 1973

YES 112.0228 YOUNG, 1973 
Basic Data Table 4. Location, Geologic Environment, Present Use and Potential Use of Thermal Springs and Wells in Idaho (continued)

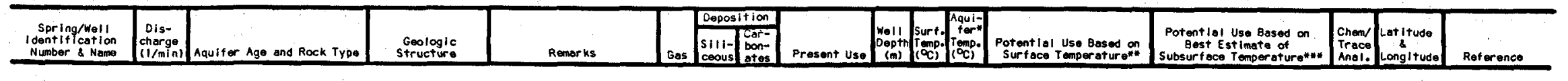

Owyhee county (cont'd.)

\begin{tabular}{|c|c|c|c|c|c|c|c|c|c|}
\hline $\begin{array}{l}\text { ROY DAVIS WELLII } \\
7 S \text { SE 13MAII }\end{array}$ & 4542 & $\begin{array}{l}\text { PLIOCENE NO PLEISTOCENE } \\
\text { SEO(MENTS (?) }\end{array}$ & $\begin{array}{l}\text { THIS WELL WAS ORIGIMULLY } \\
\text { A27 MEESES DEEP, BUT MAS } \\
\text { CAVED TO ITS PRESENT DEPTH }\end{array}$ & IRPIGATION & 106 & 23 & $\begin{array}{l}\text { MEATING MO DOLING WITH } \\
\text { HEAT PUIPP }\end{array}$ & $\begin{array}{l}42.8207 \\
115.7979\end{array}$ & \\
\hline ROY OAVIS WELL 12 & & $\begin{array}{l}\text { PLIOCENE NO PLEISTOCENE } \\
\text { SEOIMENTS }\end{array}$ & $\begin{array}{l}\text { PARTINL DRILLER'S LOG } \\
\text { AVAILABLE }\end{array}$ & IRRIGATION & 121 & 25 & DE-ICING HIGHMAYS & YES $\begin{array}{r}42.8194 \\
115.8011\end{array}$ & YOUNG, 1973 \\
\hline $\begin{array}{l}\text { CAPL STEINER WELL } \\
7 S \text { SE } 1 \text { SCBB! }\end{array}$ & 11355 & PLIOCENE FRACTURED BASALT & ORILLER'S LOG AVAILABLE & IRRIGATION & 595 & 36 & HYOROPOWICS & YES $\begin{array}{l}42.8147 \\
115.8158\end{array}$ & WHITEHENO, 1973 \\
\hline $\begin{array}{l}\text { ROBERT TINDALL MELL } \\
\text { TS SE TSCOI }\end{array}$ & 15141 & $\begin{array}{l}\text { PLIOCENE SILLCIC VOLCANIC } \\
\text { ROCKS ND SEDIMENTS }\end{array}$ & ORILLER'S LOG AVAILABLE & IRRIGATION & 461 & 39 & STOQX WATERING & YES $\begin{array}{r}42.8144 \\
115.8606\end{array}$ & roukg, 1973 \\
\hline 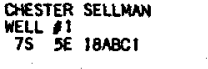 & 378 & $\begin{array}{l}\text { PLIOCEEE NO PLEISTOCENE } \\
\text { SEDIMENTS (i) }\end{array}$ & FLOWING WELL & IRRIGATION & & 30 & BIOOEGRADATIOW & $\begin{array}{l}42.8186 \\
115.9041\end{array}$ & $\begin{array}{l}\text { BEARD, } 1978 \\
\text { (SITE' INSPECTION) }\end{array}$ \\
\hline 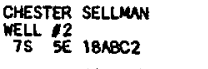 & 3596 & $\begin{array}{l}\text { PLIOCENE NO PLEISTOCENE } \\
\text { SEDDMENTS NO PL IOCENE } \\
\text { BASALT }\end{array}$ & $\begin{array}{l}\text { FLOWING WELL; DRILLER'S } \\
\text { LOG AVAILABLE }\end{array}$ & IRRIGATION & 173 & 34 & TROPICAL FISH & $\begin{array}{l}\$ 2.8197 \\
115.9034\end{array}$ & LOG, 1967 \\
\hline 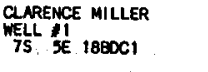 & 2838 & $\begin{array}{l}\text { PL LOCENE MO PLE ISTOCENE } \\
\text { SEOMENTS NO. RLIOCENE } \\
\text { BASALT }\end{array}$ & $\begin{array}{l}\text { FLOWING WELL, DRILLER'S } \\
\text { LOG AVALARELE }\end{array}$ & DOMESTIC & 157 & 37 & HTOROPONICS & $\begin{array}{l}42.8150 \\
115.9078\end{array}$ & LOC, 1951 \\
\hline 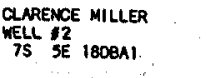 & 5299 & $\begin{array}{l}\text { PLIOCENE MO PLEISTOCENE } \\
\text { SEDIMENTS ND PLIOCENE } \\
\text { BASALT }\end{array}$ & $\begin{array}{l}\text { ORILLER'S LOG AVAILABLE; } \\
\text { FLOWING MELL }\end{array}$ & IPRIGATION & 285 & 41 & SOIL. WARMING & $\begin{array}{l}42.8145 \\
115.9016\end{array}$ & L06, 1976 \\
\hline $\begin{array}{l}\text { BELL ERAND INC. NELL } \\
75 \text { SE } 1960 C 1\end{array}$ & 4428 & $\begin{array}{l}\text { PLIOCENE SILICIC VOLCANIC } \\
\text { ROCKS }\end{array}$ & DRILLERIS LOG AVAILABLE & IRRIGATION & 231 & 36 & BIOOEGRANATION & YES $\begin{array}{r}42.7936 \\
115.9133\end{array}$ & GRHAM, 1966 \\
\hline $\begin{array}{l}\text { GENE TINDNLL WELL } \\
7 S \text { SEACDI }\end{array}$ & & $\begin{array}{l}\text { PLIOCENE BASNT NO SILICIC } \\
\text { VOLCANIC ROCKS }\end{array}$ & ORILLER'S LOG AVAILABLE & IRRIGATION & 305 & 34 & FERMENTATION & 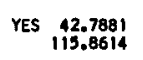 & roung, 1973 \\
\hline
\end{tabular}

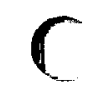


COLYER CATLE
CO. WELL T

378 PLIOCENE BASALT

$7 \$$ GE 4 QNO 1

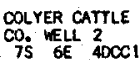

RON PROW WELL
75 GE

4920 PCIOCENE ANO PLEISTOCENE
SEDIMENTS

GEORGE TURNER WELL
PS GE TACECIE ND PLEI ISTOCENE

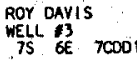

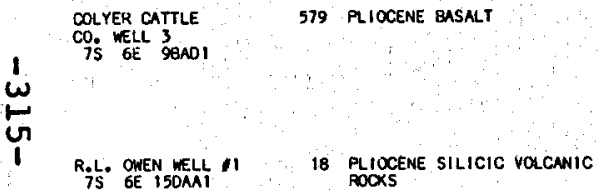

RoL. OMEN WELL 12 9463 PLIOCENE JOINTED BASAL

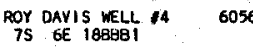

HOT SPRINGS
RANCH WELL
75 , WE $210 B C 1$

PLIOCENE JOINTED BASALT

RiL. OWEN WELL $13 \quad 757$

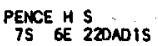

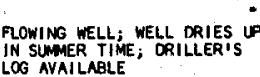

FLOWING WELL

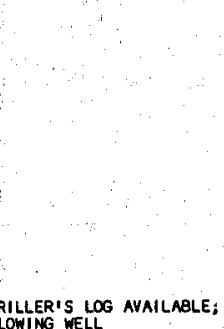

FLOWING WELL; ORILLER'S
LOG AVAILABLE

ORILLER'S LOG AVALABLE;
RLOWNG WELT; TWO WELLS'
THIS SITE

MELL WAS BEING ORILLD AT
TME OF INSPECTON MND MAS
REPORTEO TO BE DOOLING WITH

MRSH AREA
IRRIGATION

DOMESTIC

DOMESTIC

33125

DOMESTIC

271 so GRAN-HAY DRY ING

STOCK WATERINO

68527 REATING ND DOLLING WITH

IRRIGATIO

15642 SOIL MAPMING

iRRIGATION

121

FISH FARMING

IRRIGATION

\section{SEEDLING WNIFERS}

15547 GRAIN-HAY DRYING

UNSED
115.8404 ROSs, 197

42.8385
15.7450

42.8511
115.7874 LOG, 1959

YES $\begin{gathered}42.8334 \\ 115.7813\end{gathered}$

42.8225
115.7866

YES 42.8342 roung, 1972

42.8155
115.7207 L06, 1969

YES $\begin{gathered}42.8081 \\ 115.7514\end{gathered}$ YOUNG, 1973

115:-28935

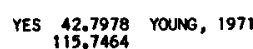

145.73930

115.7199 
Basic Data Table 4. Location, Geologic Environment, Present Use and Potential Use of Thermal Springs and Wells in Idaho (continued)

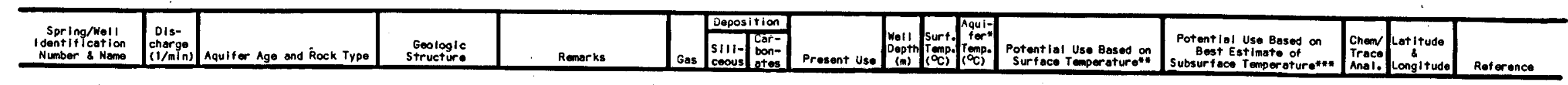

Owyhee County (cont'd.)

\begin{tabular}{|c|c|c|c|c|c|c|c|c|}
\hline $\begin{array}{l}\text { BAT HOT SPRINGS } \\
75 \text { GE } 2208915\end{array}$ & 378 & $\begin{array}{l}\text { PLLOCENE SILICIC VOLCANIC } \\
\text { ROOKS (i) }\end{array}$ & & IFRIGATION & & BALNEOLOGICNL EATH & $\begin{array}{r}12.7997 \\
115.7267\end{array}$ & Ross, 1971 \\
\hline R,L. OUEN WELL M & 7570 & $\begin{array}{l}\text { PLLIOCENE SILICIC VOLCANIC } \\
\text { ROCXS }\end{array}$ & $\begin{array}{l}\text { ORILLER'S LOG AVAILABLE; } \\
\text { FLOWENG WELL }\end{array}$ & IRPIGATION & 429 & SEEDLING ONI FERS & YES $\begin{array}{c}42.8067 \\
115.7170\end{array}$ & Young, 1973 \\
\hline$R_{i j}{ }^{L}$. OWEN $238 B E 2$ & 13248 & $\begin{array}{l}\text { PPLOCENE SILICIC VLOCANIC } \\
\text { ROCKS (I) }\end{array}$ & & IPRIGATION & 243 & NQUAOULTURE & $\begin{array}{l}42.8067 \\
115.7166\end{array}$ & \\
\hline${ }_{7 S}^{W L L I N M}$ RE ROSE WELLL & 3406 & $\begin{array}{l}\text { PLIOCENE SILICIC VOLCNIC } \\
\text { ROCKS }\end{array}$ & FLOWING WELL & IRRIGATION & 396 & SWIIMING POOLS & YES $\begin{array}{l}42.7975 \\
115.7083\end{array}$ & YOUNG, 1973 \\
\hline Rit. OWEN WELL & 2271 & & FLOWING MELL & IPRIGATION & & GRAIN-HAY DRY ING & $\begin{array}{r}42.7965 \\
115.7132\end{array}$ & \\
\hline $\begin{array}{l}\text { ANGEL BILBOA } \\
\text { WELLL } \\
75 \text { GE } 230 \mathrm{COCB}\end{array}$ & 5677 & $\begin{array}{l}\text { PLLOCENE SILICIC VOLCANIC } \\
\text { OOCKS NO BASALT (?) }\end{array}$ & $\begin{array}{l}\text { FLOWING MELL; DRILLER'S LOG } \\
\text { AYAILAELE }\end{array}$ & IRRIGATION & 313 & SOIL UARMING & $\begin{array}{r}42.7962 \\
115.7070\end{array}$ & LoG, 1966 \\
\hline R.L. OWEN WELLL & 4920 & $\begin{array}{l}\text { PLIOCENE SILLCIC VOLCANIC } \\
\text { ROCKS NO BSALT }(3)\end{array}$ & FLOWING WELL & IRRIGATION & 304 & IMPROPONICS & YES $\begin{array}{l}42.7876 \\
115.7006\end{array}$ & $\begin{array}{l}\text { YOUNG ND } \\
\text { YHITEHEN, } 1979\end{array}$ \\
\hline R.L. OWEN OEE & 3406 & $\begin{array}{l}\text { PLIOCENE SILICIC VOLCANIC } \\
\text { POCKS (i) }\end{array}$ & & IRRIGATION & . & MUNONLTURE & $\begin{array}{l}\$ 2.7920 \\
113.7084\end{array}$ & \\
\hline RoL. OWEN WELL 19 & & $\begin{array}{l}\text { PLIOCENE SILICIC VOLCNIC } \\
\text { POCKS (I) }\end{array}$ & & IRRIGATION & & PEPAENTATION & $\begin{array}{r}42.7919 \\
115.7080\end{array}$ & \\
\hline RiL. OWEN WELL 110 & 340 & $\begin{array}{l}\text { TERTINAY SILICIC YOLCANIC } \\
\text { BOKS (I) NO PRIOCENE } \\
\text { BASALT (I) }\end{array}$ & FLOWING WELL & IRRIGATION & & BICOEGRNOATION & $\begin{array}{l}42.7582 \\
15.07071\end{array}$ & \\
\hline
\end{tabular}




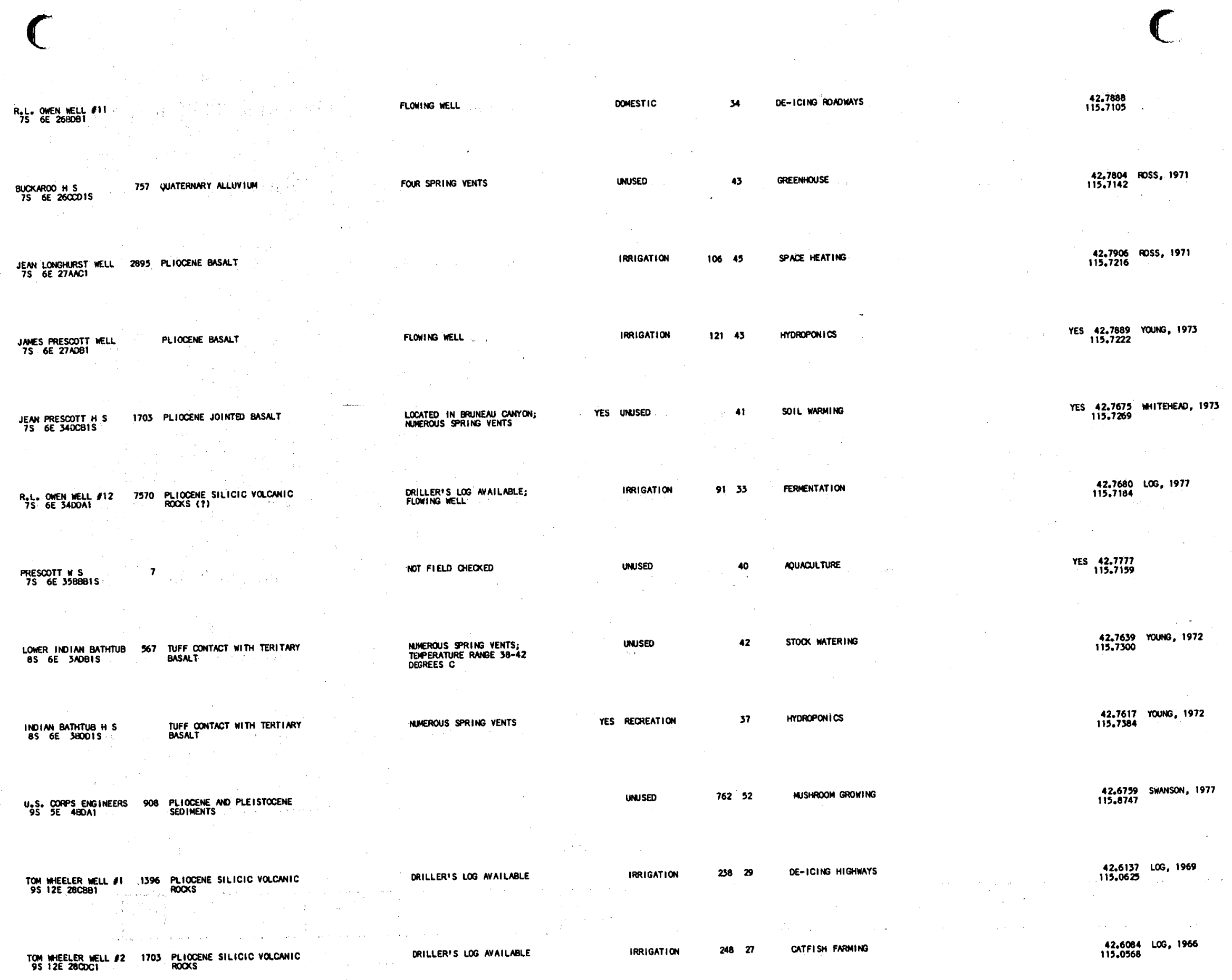


Basic Data Table 4. Location, Geologic Environment, Present Use and Potential Use of Thermal Springs and wells in Idaho (continued)

\begin{tabular}{|c|c|c|c|c|c|c|c|c|c|c|c|c|c|c|}
\hline $\begin{array}{r}\text { Spring/Well } \\
\text { Iantificotion } \\
\text { dumber \& N Nome } \\
\end{array}$ & $\begin{array}{c}\text { ois- } \\
\text { chorge } \\
11 / m i n)\end{array}$ & Aquifer Age and Rock Type & $\begin{array}{r}\text { Goologic } \\
\text { structure } \\
\end{array}$ & Remerks & Gas & \begin{tabular}{|l|l|} 
Deposition \\
sl1i- & $\begin{array}{c}\text { car- } \\
\text { coon- } \\
\text { cotes }\end{array}$ \\
\end{tabular} & Present Use & 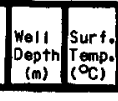 & 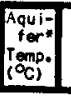 & $\begin{array}{c}\text { Potentlal Use Based on } \\
\text { Surface Temperature }\end{array}$ & 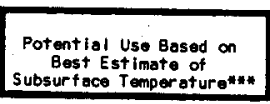 & $\begin{array}{l}\text { Chem/ } \\
\text { Troco: } \\
\text { Anal. }\end{array} \mid$ & Latitude & Reterence \\
\hline
\end{tabular}

owyhee county (cont'd.)

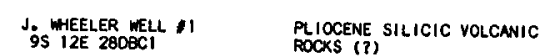

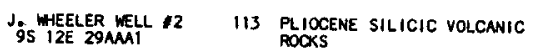

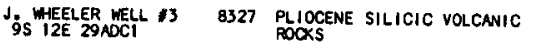

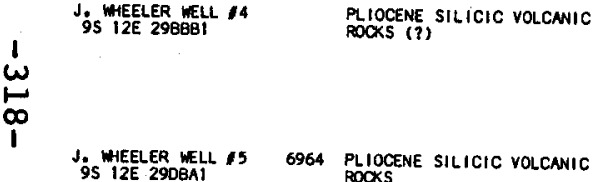

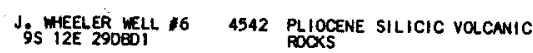

INOINNH
I2S $7 E$ S3C IS

A. KRPMER KELL
I2S IOE I2COCI

5677 PLIOCENE SILICIC VOLCANIC
ROCKS

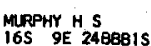

PLIOCENE GASALT NO SILICIC
VOLCANIC ROCKS

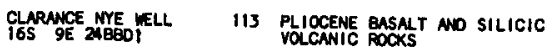

IRRIGATION

24835 MUACULTURE

ORILLER'S LOG AVAILABLE

DRILLER'S LOG AVAILABLE

DRILLER'S LOG AVAILABLE

ORILLER'S LOG AVAILABLE

NOT FIELD OHECXED

DRILLER'S LOG AVAILABLE

TWO SPRING VENTS

DRILLER'S LOB AVAILABLE

IRRIGATION

IRRIGATION

IRRIGATION

IRRIGATION

IRRIGATION

19031 FERMENTATION

IPRIGATION

IRRIGATION

DOMESTIC
17722 FISH FARMERING

16130 CATFISH FARMING

14728 TROPICAL FISH FAPMING

$170 \quad 30$ CATFISH FNPMING

71 93 REFIGERATION (LOMER

152.24 KEATING MDD DOOLING WITH

5299 MUSHROOM GROWING

BARLEY MLITING PROCESS

YES $\begin{gathered}12.0314 \\ 115.3658\end{gathered}$ ROSs, 1971
114.56951 L06, 1963

iti.6125

1152.6210 Lo6, 1977

42.5158 LOG, 1967
115.0688

42.6215
115.0815

$\underset{115.0694}{42.6146} \operatorname{LOC}, 1968$

42.6126
115.0696 LOG, 1971

42.3335
115.6500

$12.0362200,1973$
9125 HEATING MO DOOLING WITH 
Payette County

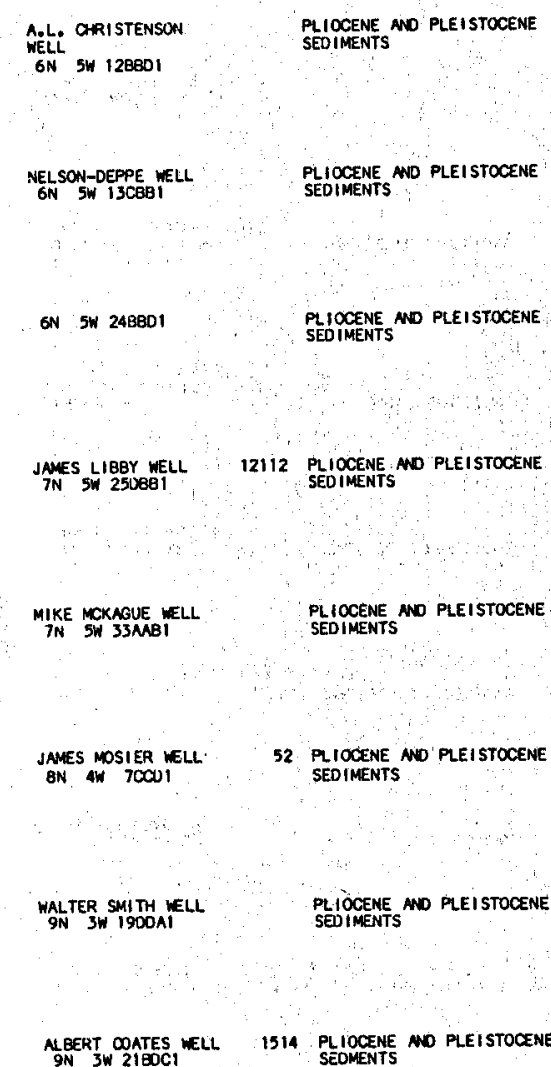

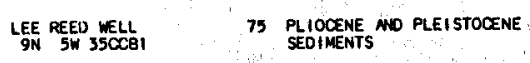

FALLS IRRIGATION
OIST.
DRILLER'S LOG AVAILABLE

DRILLER'S LOG AYAILABLE

DRILLER'S LOG AVAILAELE

DRILLERIS LOG AVAILABLE

DRIILER'S LOG AVAILABLE;
FLOHENG WELL

DRILLER'S LOG AVAILABLE

NOT FIELD OEEXED
IRRIGATION

14323 CATFISH FARMING

DOMESTIC

10822 CATFISH FRPMINO

IRRIGATION

24 OE-ICING RONOMAYS

IRRIGATION

$10720 \quad \begin{aligned} & \text { HEAT PUNP FOR MEATING MO } \\ & \text { COOLING }\end{aligned}$

DOMESTIC $60 \quad 20 \quad$ CATFISH FARMING

DOMESTIC

3520 FISH FNRMING MND MatOAING

STOCX MATERING

29 FEREENTATION

IRRIGATION

$\begin{array}{lll}112 & 25 \\ \text { HEAT PUIP }\end{array}$

DOMESTIC

9920 CATFISH FNPMING

Power county

UNUSED

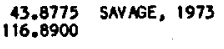

43.8568 SAYAGE, 1973
116.8923

43.8495
116.8883

43.9153 SAVAGE, 1973
116.8819

43.9090 SAVAGE, 1973
116.9373

44.0402 SAVAGE, 1973
116.8681

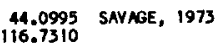

44.1032 SAYAGE, 1973
116.7050

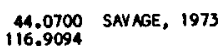

$\frac{42.8294}{12.79947} 100,1954$ 
Basic Data Table 4. Location, Geologie Environment, Present Use and Potential Use of thermal Springs and Wells in Idaho (continued)

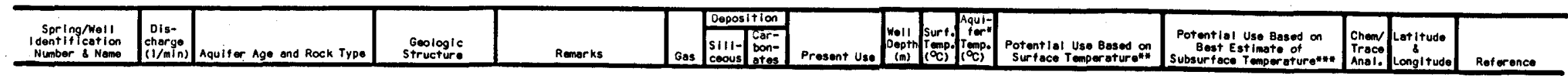

Power County (cont'd.)

TONHO POMER ON. MELL 7359 PLIESTOCENE NLUUIVIUM (1)

EMIL MAYER WELLL

4239 DUATERNAYY NLLUIUM MN

$\operatorname{muX}_{\text {BS MAYER WELLL }}$ 3IE 17 MAAI

PALEOZOIC LIMESTONE

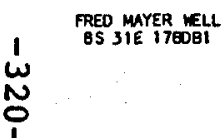

INOIN SPRINGS
BS $31 E$ 18OABIS

PNEOZOIC LIMESTONE

INOINHW
BSIE IBOACIS

PNEOZOIC LIMESTONE

O.M. THOREHILL WEL
BS $31 E$ 18DACI

1135 PNEEOZIC LIMESTONE

LAKE MULCOTT WS

ROCKLND
105300
$13 C D C 1 S$

PALEOZOIC LIMESTONE

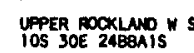

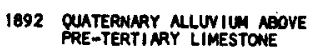

USEE ONIY IN THE MINTER;
DEILLER'S LOG ANAILABLE

DRILLER's Log AVAILABLE

ORILLER'S Log AVAILABLE

DRILLER'S LOS AYAILABLE

NORTHMEST
TRENONGG FNULT SEVEN SPRING VENTS

NORTHWEST
TRENOING FAULT FLOWING WELL

NOT FEELD OHECKED
SUEWERGEO IN LNKE MLCOTT

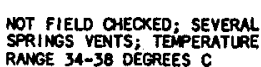

NOT FIELD OAECCED; REPORTED
QY FOSS, 1971
INOUSTRIAL.

$182 \quad 24$ DE-ICING RONOMAYS

IRRIGATION

$187 \quad 22$ MEATING MO DOLING WITH

IFRIGATION

11725 CATFISH FARMING

IRRIGATION

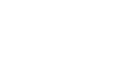

YES recreation

YES IRRIGATION

IRRIGATION

unseso

38 SOIL WXPMING $\stackrel{42.7723}{412.8698} 100,1957$

$\begin{aligned} & 42.7160 \\ & 112.8903\end{aligned} 106,1959$

42.73351 RRINGLE MO CRR,
112.8563 1976

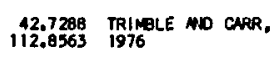

NIMAL HUSBANDRY

YES $\begin{aligned} & 42.7234 \\ & 112.8722\end{aligned}$

42.7236
12.8712 Foss, 1971

$\frac{42.7239}{112.6723}$ poss, 1971

42.6246
113.1069

MPLE DEHTDRATION

YES $\underset{12.5469}{12.8987}$ ROSS, 1971

42.9438
112.9026

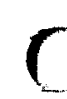




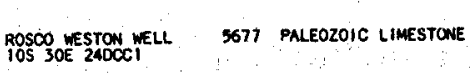

TAYLOR SPRINGS
3N ASE TBMIS

46. TR1ASSIC MRRINE SEDIMENTS
NEAR THRUST FAULT

OP MEET WELL

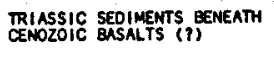

$\stackrel{1}{N}$

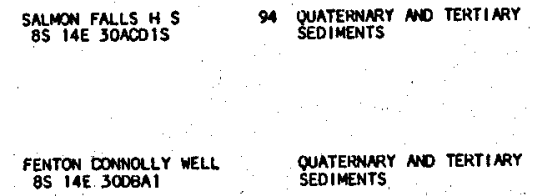

MIRACEE HS
BS 14E 3 IACBIS

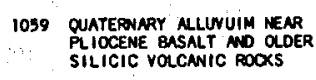

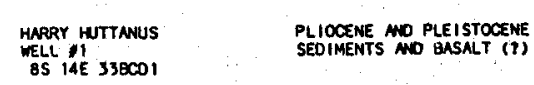

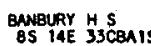

QUATERNARY MO TERTIMRY
SEOIMENTS

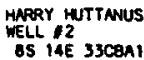

PLIOCENE MO PLEISTOCENE
SEDIMENTS NWO BASALT (?)

MELLY HUTTANUS

MELL IA 33 SCBA2
DRILLER'S LOG AVAILABLE

IPRIGATION

18438

troRopowics

reton county

IRRIGATION

20 FISH FNRMING

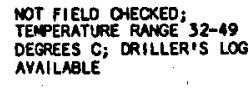

IPRIGATION

33549 GRAIN-HAY DRYING

Twin Falls county

WELL MAS ORILLED NEXT TO N
EXISTING HOT SPRING

PECREATION

121

res

(3) RECREATION

67

PPLE DEMTPRATION

Domestic

63 GREENHOUSE

NSO KNOWN AS HOT SULPHUR
SPRINGS

TES RECHEATION

$55 \quad 87$ EALNEOLOGICAL BATH

res RECreAtion

$8249^{\circ}$ SEEDLING CONI FERS

COMERCINLLY OEYELOPED

teS RECREATION

MUSHROOM GROWING

TES RECREATION

$74 \quad 37 \quad 108$ LNUNORY USES

YES HEATING OF POOL 64 37 SPACE HEATING
PASTEURIZATIOA

112.8948 LOS, 1975

43.6066 MITOHELL, 1978
111.8980

$111.3223 \quad 106,1969$

42.7060
114.8572

42.7040
114.8563

42.7016 YON LINOEFA, 1978
114.8557 (SITE INSPECETION)

YES $\begin{aligned} & 42.6920 \\ & 114.8392 \\ & 1972\end{aligned}$

42.6890 STEARNS MO
114.8258 OTHERS, 1938

42.6880
114.8256

CANING ANO PRESERV ING

YES $\begin{array}{rl}42.6684 & \text { STERNS } \\ 114.8287 & \text { OTHERS, } \\ 1938 & 938\end{array}$

42.6691 STEAPNS MO
114.8262 OTHERS, 
Basic Data Table 4. Location, Geologic Environment, Present Use and Potential Use of Thermal Springs and wells in Idaho (continued)

\begin{tabular}{|c|c|c|c|c|c|c|c|c|c|c|c|c|c|c|}
\hline $\begin{array}{l}\text { Spring/well } \\
\text { sentificotion } \\
\text { Number \& Nome }\end{array}$ & \begin{tabular}{|l} 
Dis- \\
charge \\
$(1 / \mathrm{m} \ln n$
\end{tabular} \mid & Aquiter Age and Rock Type & $\begin{array}{c}\text { Geologic } \\
\text { structure }\end{array}$ & Remarks & & 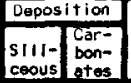 & Present Use & 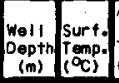 & 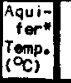 & $\begin{array}{l}\text { Potent lal USe Based on } \\
\text { Surf ace Tomper sture }\end{array}$ & 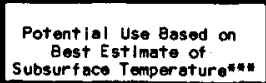 & $\begin{array}{l}\text { Cheon } \\
\text { Trace } \\
\text { Anai. }\end{array}$ & $\left|\begin{array}{c}\text { Lotitude } \\
8 \\
\text { Longl tude }\end{array}\right|$ & Reference \\
\hline
\end{tabular}

Twin Falls county (cont:d.)

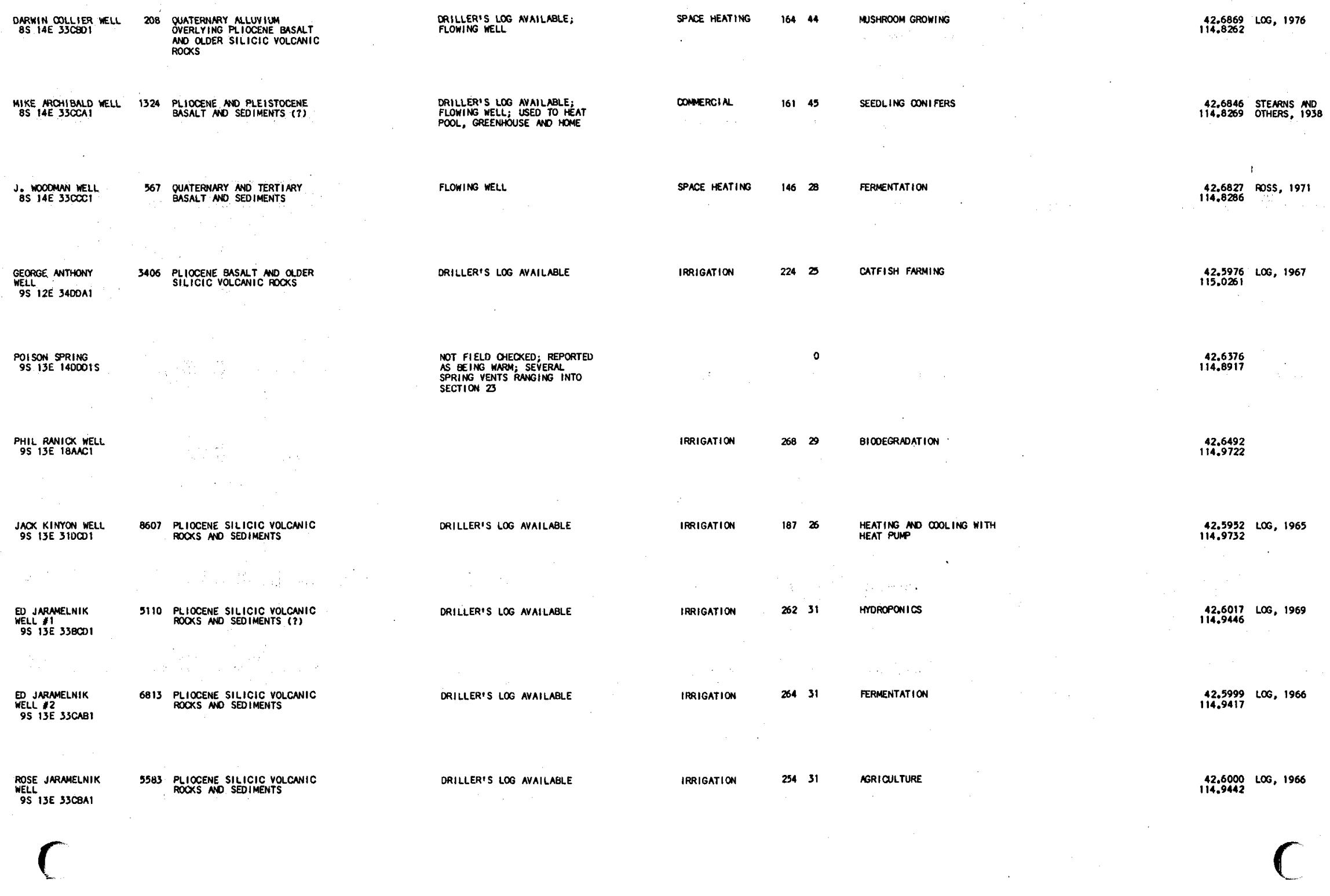




\begin{tabular}{|c|c|c|c|c|c|c|c|c|c|c|}
\hline $\begin{array}{l}\text { DICK KASTER } \\
\text { WELL } \\
\text { 9S 14E } 4 B 0 C 1\end{array}$ & 1135 & $\begin{array}{l}\text { PLLOCENE BASALT ND } \\
\text { SEDMENTS }\end{array}$ & $\begin{array}{l}\text { ORILER'S LOO AVALLABLE; } \\
\text { FOWNNG WELL }\end{array}$ & DOMESTIC & 1144 & 46 & GRAIN-HAY DRYING & & $\begin{array}{l}.42 .5744 \\
114.8244\end{array}$ & Lo6, 1975 \\
\hline $\begin{array}{l}\text { LEO RAY } \\
\text { WELL N } \\
\text { WS } 14 \text { : }\end{array}$ & 11355 & $\begin{array}{l}\text { PLLOCENE BASNT MO } \\
\text { SEDIMENTS }\end{array}$ & $\begin{array}{l}\text { DRILLER'S LOG AVAILABLE; } \\
\text { RLOWING WELL }\end{array}$ & CATFISH FNPMING & 2303 & 34. & HYOROPOWICS & & $\begin{array}{l}42.6682 \\
114.8239\end{array}$ & LOG, 1973 \\
\hline $\begin{array}{l}\text { LEO RAY } \\
\text { WELL } 12 \\
9 S \quad 14 E \text { ACDOO }\end{array}$ & 5671 & $\begin{array}{l}\text { PLIOCENE BASNT MO } \\
\text { SEDIMENTS }\end{array}$ & DRILLER'S LOG AVAILABLE & CATFISH FABMING & 167 & 37 & FISH FNPMING & & $\begin{array}{l}2.6670 \\
114.8221\end{array}$ & Lo6, 1973 \\
\hline $\begin{array}{l}\text { ED KEPPA } \\
\text { WELL } \\
\text { 9S 14E } \text { 9NDOI }\end{array}$ & 11333 & 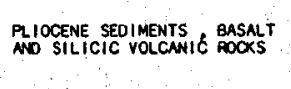 & $\begin{array}{l}\text { DRLLLER'S LOG AVALLABLE; } \\
\text { FLOWING WELL. }\end{array}$ & STOCK WATERING & 228 & 3378 & SOIL WAPMING & PASTEURIZED MILK PROCESS & YES $\begin{array}{r}42.5602 \\
114.8114\end{array}$ & LOG, 1973 \\
\hline $\begin{array}{l}\text { KENNETM HARBAST } \\
\text { WELLL } 14 \text { : } 90002\end{array}$ & $22 n$ & $\begin{array}{l}\text { PLIOCENE SEDIMENTS NDD } \\
\text { BASALT }\end{array}$ & $\begin{array}{l}\text { ORILLER'S LOOG AVAILABLE; } \\
\text { FOOWING WELL }\end{array}$ & DOMESTIC & 161 & 33 & NQUACSLTURE & & $\begin{array}{r}42.6606 \\
114.8126\end{array}$ & 100,1971 \\
\hline $\begin{array}{l}\text { ROBERT LUNTEY WEL } \\
9 S \text { 14E, } 9 A 003\end{array}$ & 1514 & $\begin{array}{l}\text { PLIOCENE GASAT ND } \\
\text { SLLICIC VOLCANIC ROCKS }\end{array}$ & 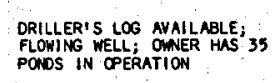 & $\begin{array}{l}\text { TROPICAL FISH } \\
\text { TEST PPOJECT }\end{array}$ & 259 & 32 & SHRIMP FARMING & & $\begin{array}{r}42.6597 \\
114.8124\end{array}$ & LoG, 1974 \\
\hline $\begin{array}{l}\text { WESLEY REYNOLDS } \\
\text { WELLL } \\
9 S \text { IAE } 10 B C C I\end{array}$ & 3785 & PLIOCENE SEDIMENTARY ROOXS & $\begin{array}{l}\text { ORILER'S LOG AVALLARE } \\
\text { FLOWNG WEOL }\end{array}$ & FISH FARMING & 184 & 33 & PERMENTATION & & $\begin{array}{l}42.6593 \\
114.8099\end{array}$ & LoG, 1971 \\
\hline 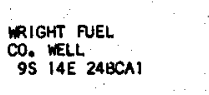 & 36 & $\begin{array}{l}\text { CUATERNARY NO TERTIARY } \\
\text { BASALT ANO SEDIMENTS }\end{array}$ & $\begin{array}{l}\text { ORILLER'S LOS AVILABLE; } \\
\text { FLWWING WELL }\end{array}$ & DOMESTIC & .42 & 24 & 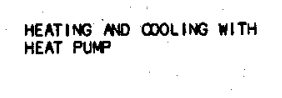 & & $\begin{array}{r}42.6333 \\
114.7688\end{array}$ & Los, 1977 \\
\hline BSH CIT WEAL " & & $\begin{array}{l}\text { PLIOCENE BASALT AOD } \\
\text { SHLICIC VOLCANIC ROOKS (n) }\end{array}$ & & PUBLIC SUPPLY & 274 & 30 & CATFISH FARMING & & $\begin{array}{l}12.5988 \\
114.7560\end{array}$ & \\
\hline $\begin{array}{l}\text { GREEN GIANT CANNING } \\
\text { 9S } 15 E 31 \mathrm{CBB} \text {. }\end{array}$ & $\$ 186$ & $\begin{array}{l}\text { GUATEROARY ND TERT IARY } \\
\text { GASALT NO SEDIMENTS }\end{array}$ & DRILLER'S LOG AVAILAOLE & $\begin{array}{l}\text { COMMERICAL } \\
\text { CANING }\end{array}$ & 196 & 20 & $\begin{array}{l}\text { HEATING NNO COLLING WITH } \\
\text { HEAT PUIPP }\end{array}$ & & $\begin{array}{r}42.6006 \\
114.7497\end{array}$ & Los, 1960 \\
\hline $\begin{array}{l}\text { BUHL CITY } \\
\text { WELL } \\
\text { 9S ISE } 310 c 81\end{array}$ & 2876 & $\begin{array}{l}\text { PLIOCENE EASALT NO COERR } \\
\text { SILICIC YOLCNIC ROCKS ( })\end{array}$ & DRILLER'S LOG AVAILABLE & PUBLIC SUPPLY & 322 & 32 & BIOOEGRNOATION & & $\begin{array}{r}42.5962 \\
114.7508\end{array}$ & LoG, 1961 \\
\hline 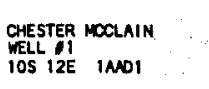 & 4542 & $\begin{array}{l}\text { QUATEFNARY MO TERTINAY } \\
\text { BASALT MO SEDIMENTS ( })\end{array}$ & & IRRIGATION & 152 & $\mathbf{2 6}$ & FISH FARMING NO HATCHING & & $\begin{array}{l}12.5909 \\
114.9874\end{array}$ & \\
\hline
\end{tabular}


Basic Data Table 4. Location, Geologic Environment, Present Use and Potential use of Thermal Springs and wells in Idaho (continued)

\begin{tabular}{|c|c|c|c|c|c|c|c|c|c|c|c|c|}
\hline 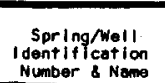 & $\left.\mid \begin{array}{c}\text { Ols- } \\
\text { charge } \\
\text { (1/min }\end{array}\right]$ & Aquifer Age and Rock Type & $\begin{array}{l}\text { Geologle } \\
\text { structure }\end{array}$ & Remarks & 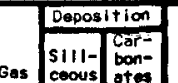 & Present Uso & 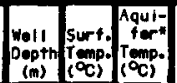 & $\begin{array}{l}\text { Potential Use Based on } \\
\text { Surf ece T Tempereatur oft. }\end{array}$ & 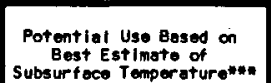 & $\begin{array}{l}\text { Chem } \\
\text { Treaces } \\
\text { Anoi. }\end{array}$ & $\begin{array}{l}\text { Latlitude } \\
\text { Longitude }\end{array}$ & Reterence \\
\hline
\end{tabular}

Iwin Falls county (cont'd.)

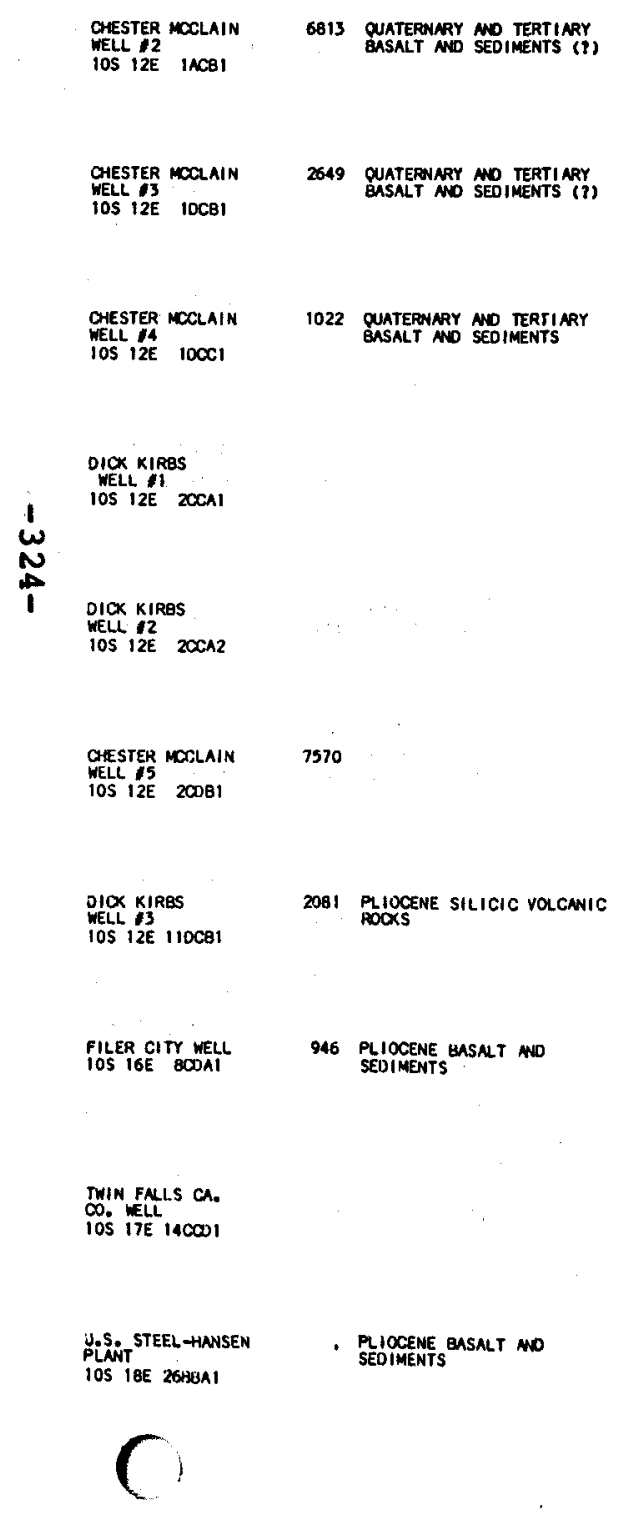

IRRIGATION

152 FISH FAPMING

12.59968

IPRIGATION

152 25 HEATING MO COLING WITH

142.5910

DRILLER'S LOG AYAILABLE

IRRIGATION

135 25 MEATING MO DOLLNG MITH

114.99933 LOG, 1953

IRRIGATION 152 Z

${ }_{1130.0209}^{42.513}$

IFPIGATION 152 25 STOOK MATERIMG

192.5822

IRRIGATION

15220 HEATING MO DOOLING WITH

1925:08128

DRILLER's LOG AvalLabLe

IPrigation

14723 FISH FNRMING

115:060756 LOG, 1961

ORIGINALYY USED GY FILR
SOOOOL WHIOH HUS GEEN
OEMOL ISHED

RECREATION

237 Z FERMENTATION

114260655 Lo6, 1963

IRBIGATION

365 \& BOOEGRAATION

12.5.4387

DRILLER'S LOG AVAILABLE

DOMESTIC

12120 MEATING MO DOOLING WITH

12:3538 1406,1964 


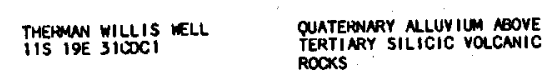

DEN KIDO WELL *2
IIS 196310001

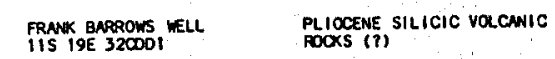

W
U

J. WOONSON OREED
WeLLL
115 19E 330001

PLIOCEENE SILICIC VOLCNIC
ROCKS

IS 19E 33000

SAM HISH NO
SONS ELLL
IIS $19 E 330001$

7305 QUATEPANRY ALLUYILM NBONE
IRRTIAYY SILICIC VOLCNIC
POOSS

RAY STANGER \&
SOYS ELLLL
IIS $195 \mathrm{EECO} 1$

QUATEPNARY ALUV IIUM ABOOE
TERTINAY SILICIC VOCONIC
ROOKS

THEOOORE STUREILL

WELL 20 E $3400 \mathrm{CO}$

PETE SNLIZER KELL
PES IGE $36 C A O I$

12S ITE GCESI
IRRIGATION

$67 \quad 34$ MQUNCULTURE

IRRIGATION

$32 \quad 31$ RUMaUtTURE

37 is HMPRPOONICS

NOT FIELD OAECXED
NOT FIELO OHEXXED
$350 \quad 2 B$ BLOOEGRNATION

15629 HTOROPONICS

28 CATFISH FAPMING

31231 BHOOEgRNOATION

1883369 SHAINP FAPUING

26 FISH FARMING no hutahing

GRAIN-HAY DRY ING
42.4176
114.2775

42.4177
114.2678

114.22809 Ross, 1971

114.2383 Lo6, 1955

YES $\begin{aligned} & 42.4176 \\ & 114.2289\end{aligned}$

114.2066 ROSS, 1971

YES 122.4175

1142.3362 
Basic Data Table 4. Location, Geologic Environment, Present Use and Potential Use of Thermal Springs and wells in Idaho (continued)

\begin{tabular}{|c|c|c|c|c|c|c|c|c|c|c|c|c|c|}
\hline 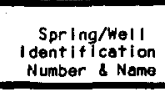 & $\begin{array}{c}\text { Dis- } \\
\text { chorgeg } \\
(1 / \text { min })\end{array}$ & Aguit or Age and Rock Type & $\begin{array}{r}\text { Geologlc } \\
\text { Structure }\end{array}$ & Remarks & Gas & \begin{tabular}{|l|l|} 
Deposition \\
sil1- \\
cort- \\
coous \\
botes \\
\end{tabular} & Present Use & 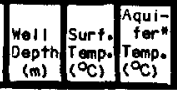 & $\begin{array}{l}\text { Potent lal Use Based on } \\
\text { Surf ace Tomperaturet* }\end{array}$ & \begin{tabular}{|} 
Potent 101 Use Bosed on \\
sest Est imate of \\
Subsurf oce T Tmperature*** \\
\end{tabular} & $\left|\begin{array}{l}\text { Chem/ } \\
\text { Treco } \\
\text { Anal. }\end{array}\right|$ & $\mid \begin{array}{l}\text { Lat! ltude } \\
8 \\
\text { Longltude }\end{array}$ & Reference \\
\hline
\end{tabular}

Twin Falls County (cont'd.)

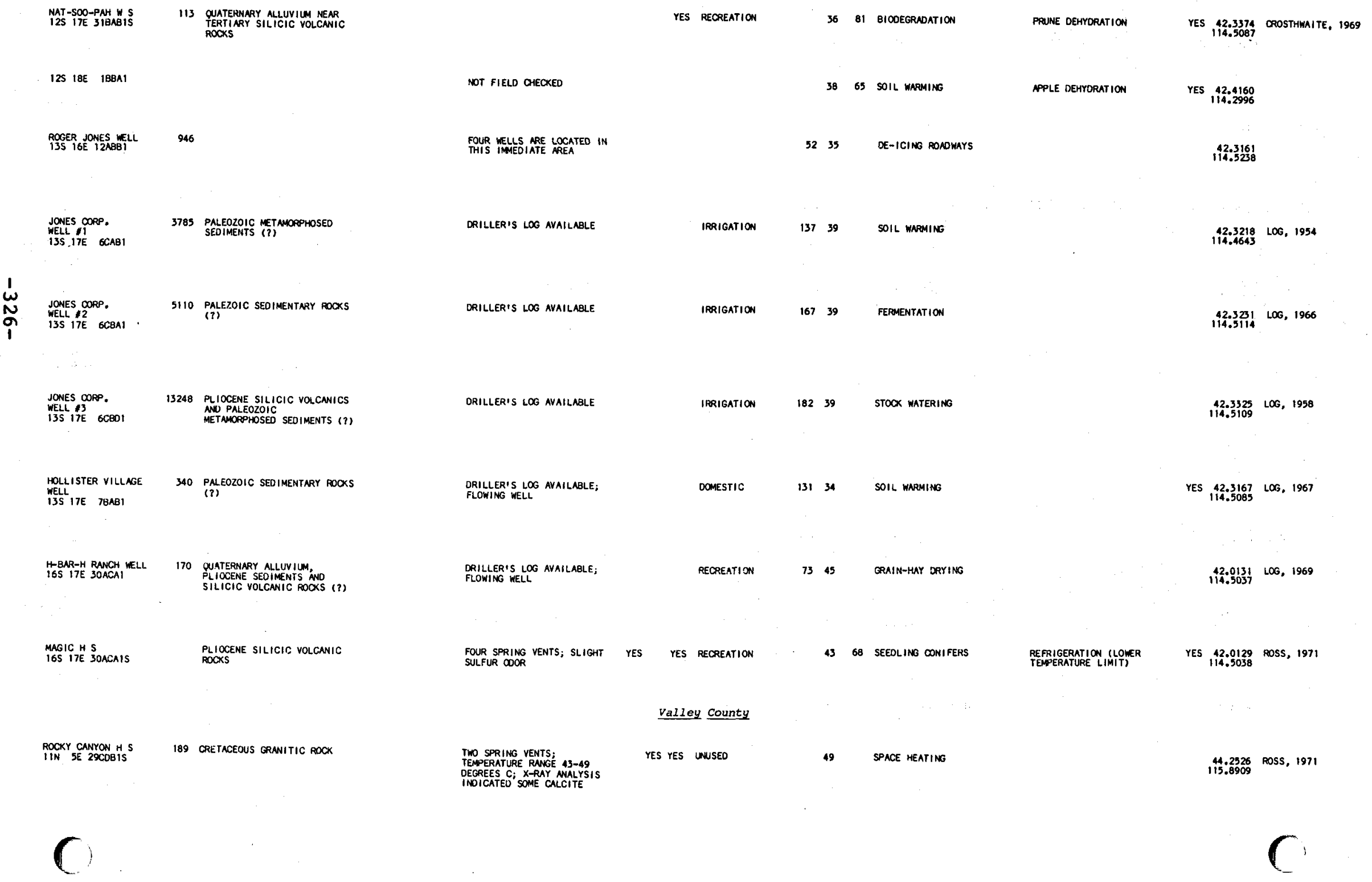




\begin{tabular}{|c|c|c|c|c|c|c|c|c|c|}
\hline $\begin{array}{l}\text { GOAT YS } \\
\text { I2N SEE DASIS }\end{array}$ & CRETAEEOUS GRNITIC ROCX & & 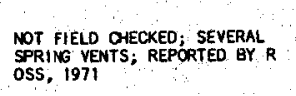 & & IRPIGATION & 0 & 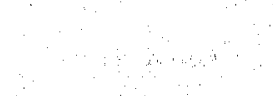 & & 445.3999 Ross, 1971 \\
\hline $\begin{array}{l}\text { DASH OREEK W S } \\
\text { IZN SE. } 1000 \mathrm{CIS}\end{array}$ & CRETACEOUS ORNITIC AOCX. & & 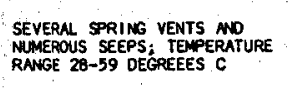 & Yes & IPRIGATION & 99 & NIMR: HSENORY & & $\begin{array}{l}44.3819 \\
115.8411\end{array}$ \\
\hline 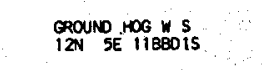 & COETACEOUS GRNITIC ROOX & & $\begin{array}{l}\text { NOT FIED OHECEE; SEVERRA } \\
\text { SPRRIIS VENTS }\end{array}$ & & unvsed & 38 & MOROPPONICS & & 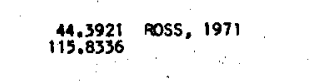 \\
\hline 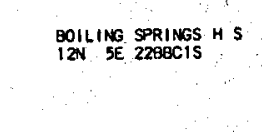 & 624 COETACEOUS GRNITIC ROCK & $\begin{array}{l}\text { MORTHEAST } \\
\text { TRENOING FAULT }\end{array}$ & 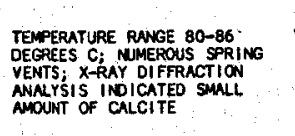 & YES YES YES & IPRIGATION & 85 & g9 pasteverization & BRRLEY MLLTING PROCESS & 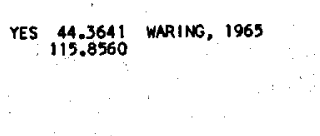 \\
\hline 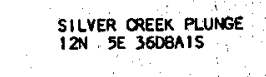 & ORETACEOUS GRNITIC ROCK & & 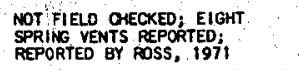 & & IRPIGATION & 39 & 74 SOIL WNEMING & $\begin{array}{l}\text { REFAIGERATION (LONER } \\
\text { TEMPERAURE LIMIT) }\end{array}$ & YES $\begin{array}{c}44.3297 \\
115.8021\end{array}$ \\
\hline $\begin{array}{l}\text { BEVVIDERE H S } \\
\text { IIS BE IISADIS }\end{array}$ & 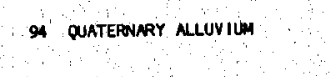 & & & YES & RECREATION & 44 & SPACE HEAT ING & & 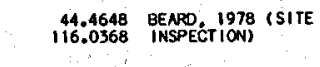 \\
\hline $\begin{array}{l}\text { CABNTON HA } \\
\text { IIN AE } 31 \text { SCBBIS }\end{array}$ & 227 CRETACEOUS GRNITIC ROCX & $\begin{array}{l}\text { NoRTHEST } \\
\text { RENOING FNULT }\end{array}$ & 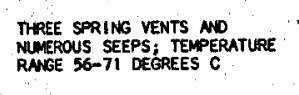 & YES YES & unuser & $" 1$ & $\begin{array}{l}99 \text { RERERERATION (LOAER } \\
\text { TEPEERATURE LIMIT) }\end{array}$ & a.MOHING & YES $\begin{array}{c}44,4160 \\
116.0313\end{array}$ NEWCOMB, 1970 \\
\hline $\begin{array}{l}\text { gULL OREEK HS } \\
\text { ISN } \\
\text { GE } 290 A B \text { IS }\end{array}$ & 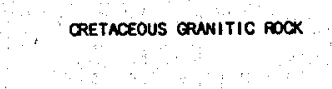 & & 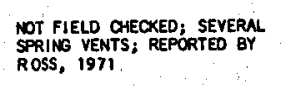 & & & 0 & & & 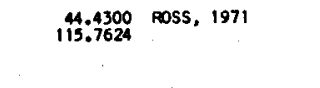 \\
\hline 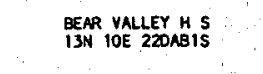 & ORETACEOUS CRANTIC ROCX & & $\begin{array}{l}\text { NOT FIELD OAECKED; REPORTEO } \\
\text { BY ROSS, } 1971\end{array}$ & & INUSED & 0 & & & 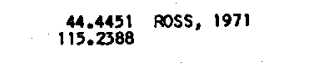 \\
\hline $\begin{array}{l}\text { CASCANE RESERVOIR } \\
\text { IAN } 3 E \text { SA is }\end{array}$ & & & 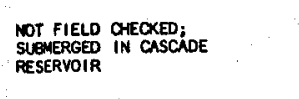 & & & 。 & & & $\begin{array}{l}44.5829 \\
116.1124\end{array}$ \\
\hline 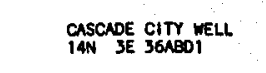 & 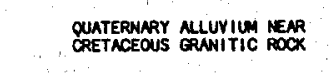 & $\begin{array}{l}\text { MORTAEST } \\
\text { TREDOONG FAULT }\end{array}$ & & res & $S$ PUBLIC SUPPLY & 1542 & 46 SEEOLING OONIFERS & SOIL WNEMING & 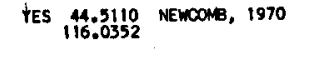 \\
\hline $\begin{array}{l}\text { VULCN HS } \\
\text { IAN } 6 \text { GE IIBOANS }\end{array}$ & 2271 ORETACEOUS GRNITIC ROOX & & 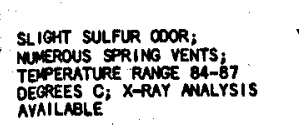 & & S. RERERATION & 8 & 147 ELANOHING & BEET SUONR PROCESSING & 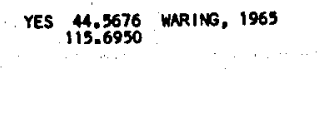 \\
\hline
\end{tabular}


Basic Data Table 4. Location, Geologic Environment, Present Use and Potential Use of Thermal Springs and Wells in Iaaho (continued)

\begin{tabular}{|c|c|c|c|c|c|c|c|c|c|c|c|c|c|c|}
\hline $\begin{array}{c}\text { Spring/well } \\
\text { Iontificeation } \\
\text { Number \& Nome } \\
\end{array}$ & $\begin{array}{c}\text { Dist } \\
\text { ohorge } \\
(1 / \mathrm{min})\end{array}$ & Aquiler Age and Rock Type & $\begin{array}{c}\text { Geologic } \\
\text { structure }\end{array}$ & Remerks & Gas & \begin{tabular}{|l|l|} 
Deposition \\
s $111-$ & car- \\
coous- & bon- \\
ceotes & \\
\end{tabular} & Presont Use & $\mid \begin{array}{c}\text { Well } \\
\text { Wepth } \\
\text { Dept } \\
(m)\end{array}$ & 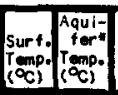 & 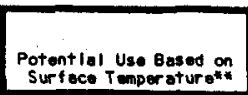 & 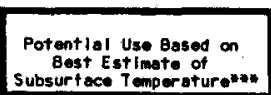 & $\begin{array}{l}\text { Chemv } \\
\text { Trece } \\
\text { Anal. }\end{array}$ & \begin{tabular}{|l} 
Latitude \\
gude \\
Longitude
\end{tabular} & Reference \\
\hline
\end{tabular}

Valley county (cont'd.)

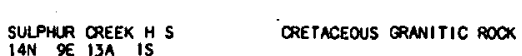

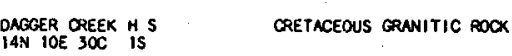

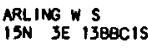

227 QUATERANAY ALUUYUY NENA MIOCENE BASALT WNO NEN
CRETACEOUS GRANITIC ROOX

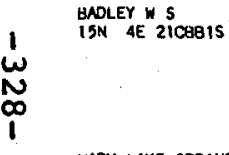

WNPOA LAKE SPRINGS
ISN 6E 13ACAIS

MOLLY'S HS
ISN 6E 1AABS1S

283 OXETACEOUS GRANITIC ROCK

SOUTH FOAK PLLNGE
ISN 6 TE 14COB1S

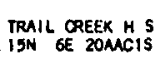

227 ORETACEOUS GRNITIC ROCK

SHEEPEATEH H S
I5N TOE 243BB

gOLO FOWX H.S
$16 \mathrm{~N}$ 4E $350 \mathrm{CB1S}$

378 PERTACEOUS gaNITIC
ROCK-BRECCIATED

227 CRETACEOUS GRANITIC ROCX
NOT FIELD OHECKED; REPORTED
BY ROSS, 1971

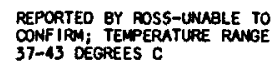

SULFUR OOOR

SUQMERGEU IN WWPO LAKE;
THREE SPRING VENTS PEPORTED

YES

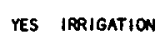

UNUSED

TEMPERATURE RAMGE 52-59
DEFGESE $C_{\text {; }}$ SEVERAL SRRING
VENTS

REPORTED TEMPERATURE; NOT
FIELD OHECKED

RECREATION

UNUSEO

NoT FIELO OHECKED

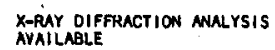

0

43 SEDDLING OONIFERS

3262 SPACE HEATING

38

MUACULTURE

59 as GAME BIFO MUTCHERY

62 MUSHROOM GROWINO

so

GRIN-HAY DRYING

33 SEEULING COWIFERS
115.3009 Poss, 1971

115.2946 Ross, 1971

NIMAL HUSEMORY

YES 11.6404 NEWCOME, 1970

115.92097 ROSs, 1971

115.6709

YES $\begin{gathered}44.6423 \\ 115.6926\end{gathered}$ WNRING, 1965

YES 114.6315

41.5263
115.7492

115.62786

415.6756 ross, 1971
115.9427 


\begin{tabular}{|c|c|}
\hline 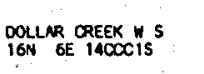 & 18 ORETACEOUS GRNITIC ROOK \\
\hline 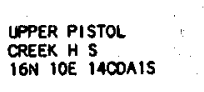 & CRETACEOUS CRNITIC ROOX \\
\hline 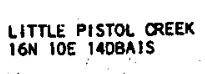 & ORETACEOUS ORNITIC POCX \\
\hline 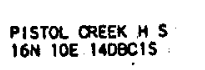 & $\begin{array}{l}\text { OREACEOUS GRNAITIC ROCK } \\
\text { WITH TERTIAYY OIKES }\end{array}$ \\
\hline 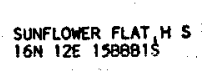 & ORETACEOUS GRANITIC ROCX \\
\hline $\begin{array}{l}\text { RIYERSIOE H S } \\
\text { ISW } 12 E \text { IOCBEIS }\end{array}$ & 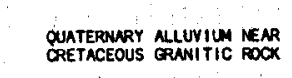 \\
\hline & ORETACEOUS ORANITIC ROOK \\
\hline
\end{tabular}

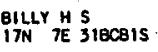

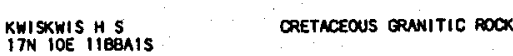

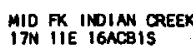

CRETACEOUS GRANITIC ROCX

ITHN ORERK

cox H.s

TERTINRY GRNITIC ROCX
WusEd

NOT FIELD OHECKEO

NOT FIELD OHECXED

NOT FIEL OHEOXED; REPORTEO
TEMPERATURE

NOT FIELO OAECKED; REFORTED
TEPERATRE
NOT FIELO OHECXED; REPORTED

NOT FIELD OHECKED; REPORTED
BY FOSS, 1971

NOT FEELD OECXED; REPORTED
INFOPMATION

NOT FIELD OAECKED; REPORTED
INFOOMTTION

UWUSED

UNUSED

unseE

UNUSED

unUSED

unUSED

UNUSED

UNUSED

unused

NOT FIELD OEECXE; REPORTED
BY ROSS, 1971

UNUSED
20 FISH FNPUING

o

0

4663 SOIL MPBMING

6577 NPPLE DEHYDRATION

39 BO GNE BIRQ HRTOHERY

47 MUSHROOM GROWING

$\circ$

$69 \quad 95$ ANIMNL HUSBNORY

72142 PPLE DEHTORATION

80 142 aRtey MRLTING Process

POTATOE DEHYRRATIO

Q.ANOIING
55 I3 GRAIN-HAY DRYING

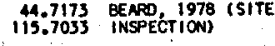

115.7109 poss, 1971

115.7229 Poss, 1971

44.7207 CARTER NO OTHERS
$115.2072 \quad 1973$

YES $\begin{aligned} & 44.7255 \\ & 114.9928 \\ & 1973\end{aligned}$

YES 145.7214 CNATEN NO OTHERS

YES $\underset{115.6967}{\mathbf{4} .8467}$ POSS. 1971

\section{4:56.702}

YES 1415.23151 ROSS, 1971

YES $\underset{115.1229}{14.8129}$ ROSS, 1971

YES $\begin{gathered}44.7988 \\ 115.1289\end{gathered}$
VES 114.7850 Foss, 1971 
Basic Data Table 4. Location, Geologic Environment, Present Use and Potential use of Thermal Springs and wells in Idaho (continued)

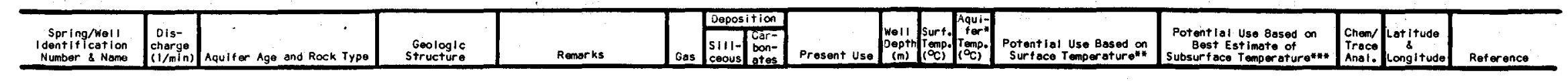

Valley County (cont'd.)

HOSPITAL HS S TIS TAE SCHCIS
ITN TIARY ORANITIC ROOK

TEAPOT H S S

56 CRETACEOUS GRNITIIC ROCX

HOT CREEK W
IBN BE 1 TEOAIS

37 CRETACEOUS GRNITIC ROCK

LICK CREEK W 5
2ON $5 E$ 15OAB IS

15 CRETACEOUS GQNITIC ROCK

$\stackrel{1}{\omega}$

\section{SHEEP CREEK HS \\ 378 QUATERNARY ALLUYIUM NEAR
RRETACEOUS GQNITIC ROCK}

$\underset{2 I N}{\text { SECESH }} 110$ IS

378 CRETACEOUS GRANITIC ROCK

COVE OREEKHS
ION SW SCOCIS

ELVIN CRAIG WELL
IIN 2W 16977 MIOCENE BASMLT

PHIL SOULEN WELL
I1N 271 27NDBI

ORANE CREEK HS

MORTHEEST
NOT FIELD OHECKED; REPORTEO
BY ROSS, 1971

SULFUR COOR

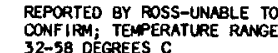

REPORTED BY ROSS-LMABLE TO
CONFIRM

YES

REOREATION

UNUSED

unuseo

RECREATION

3679 DE-ICING

33 nQUACULTURE

58 BALNEOLOGICAL BATHS

Washington County

unused

$35 \quad 172$ HOTBED HEATING

IRRIGATION

134 21 BS FISH HATOHING

DRILLER'S Log ayailable

IRPIGATION

15025 DE-ICING

14172 APPLE DEHYoration
REFRIGERTI ION (LOWER
TEMPERATURE LIMII)

YES $\begin{array}{r}44.8361 \\ 114,7904\end{array}$

YES $\begin{aligned} & 44.9137 \\ & 115.7215\end{aligned}$

PASTEURIZED MILK PROCESS YES $\begin{aligned} & 4.89996 \\ & 15.50045\end{aligned}$

45.0697 ROSS, 1971
115.8258

115.56006 Ross, 1971

45.1699 Ross, 1971
$115: 8072$

SCOSE RAYON

PASTEURIZATION

YES 114.5947 YOUNG NO OTHERS,

44.2628 YOUNG NO OTHERS,
116.5545
1977

DRYING OF FISH IEN
YES 114.2112

YES $\begin{array}{ll}416.3064 \\ 116.7455\end{array}$ NEWCONG, 1970 


\begin{tabular}{|c|c|c|c|c|c|c|c|c|c|c|c|c|}
\hline $\begin{array}{l}\text { WILLIAM RRUMETT } \\
\text { WELL AW 330BAI }\end{array}$ & 946 & $\begin{array}{l}\text { OUATERNARY MO TERTIARY } \\
\text { SEDIMENTS }\end{array}$ & $\begin{array}{l}\text { NORTH TRENDING } \\
\text { FAULT }\end{array}$ & $\begin{array}{l}\text { FOWNGG WELL; ORILLER'S LOG } \\
\text { ANALARE; NOT FIELO } \\
\text { OHECED }\end{array}$ & & 424 & 38 & & AQUROULTURE & & $\begin{array}{l}44.2448 \\
116.8169\end{array}$ & $L 06,1967$ \\
\hline $\begin{array}{l}\text { DOUGLAS MOGINNIS } \\
\text { WELL SW } 208001 \\
\text { IIN SW }\end{array}$ & 113 & $\begin{array}{l}\text { PLIOCENE NO PLEISTOCENE } \\
\text { SEDIMENTS }\end{array}$ & & DRILLER'S LOG AVAILABLE & STOOX MATERING & 59 & 21 & 6t & CATFISH FARMING & WIMAL HUSBANDRY & $\begin{array}{c}\text { YES } \begin{array}{c}44.2759 \\
116.9624\end{array} \\
:\end{array}$ & $L 06,1964$ \\
\hline $11 \mathrm{~N}$ OW $30 \mathrm{BB}$ & & & & NOT FIELD CHEXXD & & 182 & 24 & 45 & & SEEDLING CONI FERS & YES ${ }_{117: 0412}^{44.3177}$ & \\
\hline $\begin{array}{l}\text { GLENN HILL WELL } \\
\text { IIN GW 3OCQ1 }\end{array}$ & 189 & $\begin{array}{l}\text { PLIOCENE MO PLEISTOCENE } \\
\text { SEOIMENTS; MIOCENE QASALT } \\
\text { (1) }\end{array}$ & & & UNUSED & 60 & 28 & 68 & FERMENTATION & APLE DEHYDRATION & YES, 144.03143 & $\begin{array}{l}\text { YOUNG NO OTHERS, } \\
1977\end{array}$ \\
\hline $\begin{array}{l}\text { WEISER H S } \\
\text { IIN GW YOACAI'S }\end{array}$ & 18 & $\begin{array}{l}\text { PLIOCEEE NO PLELSTOCENE } \\
\text { SEUIMENTS; MIOCENE BNSALT }\end{array}$ & & MINLY SEEPAGE & & & 22 & 42 & FISH FARMING & MOROPONICS & YES $\begin{array}{r}44.3065 \\
117.0420\end{array}$ & $\begin{array}{l}\text { YounG ND OTHERS, } \\
1977\end{array}$ \\
\hline $\begin{array}{l}\text { GEOSOLAR GROWERS } \\
\text { WELL II IOCCA1. } \\
\text { WIN OW IOCCI }\end{array}$ & 5677 & MIOCENE BASNT & & 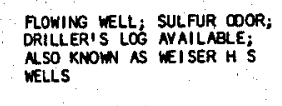 & RECREATION & 121 & 70 & 140 & $\begin{array}{l}\text { REPRIGERATION (LOWER } \\
\text { TEPERAURE LIMTT) }\end{array}$ & POTATOE DEHYDRATION & YES $\underset{117.0496}{44.2899}$ & NEMOOME, 1970 \\
\hline $\begin{array}{l}\text { GEOSOLAR GROWERS } \\
\text { WELL 'Z } \\
\text { IIN GW 1OCCAZ }\end{array}$ & 75 & MIOCENE BASNLT & & $\begin{array}{l}\text { ROWING NELL; SULFUR OOOR } \\
\text {. }\end{array}$ & RECREATION & 31 & 71 & 145 & APPLE DEHYORATION & CORN PROOUCTS (SYRAP, OIL) & YES 117.0497 & NEWCOMB, 1970 \\
\hline $\begin{array}{l}\text { GEOSOLAR CROMERS } \\
\text { WELL B } \\
\text { WIN } \quad \text { GW 10CCN3 }\end{array}$ & 37 & MIOCENE BASNAT & & FLOMING MELL; SULFUR COOR & RECREATION & $\therefore$ & 76 & 156 & ANIMUL HUSBANORY & BEET SUGM PROCESS & $\begin{array}{l}14.2994 \\
117: 0488\end{array}$ & NEMCOME, 1970 \\
\hline 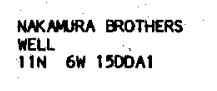 & 1249 & $\begin{array}{l}\text { PLIOCENE MO PLEI STOCENE } \\
\text { SEDIMENTS }\end{array}$ & & $\begin{array}{l}\text { DRILLER'S LOG AYALLABLE; } \\
\text { FLWWNG WELL; SULFUR DOOR }\end{array}$ & IPRIGATION & 92 & 30 & & AQUACULTURE & & $\begin{array}{l}14.2857 \\
117.0334\end{array}$ & LoG, 1977 \\
\hline 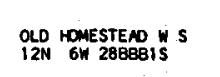 & & & & & UNUSED & 6 & 0 & & FISH, FNPMING & & $\begin{array}{l}44.3535 \\
177.0713\end{array}$ & \\
\hline 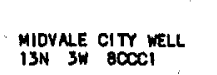 & 7570 & $\begin{array}{l}\text { MIOCENE ENSNT, OUATERNAFY } \\
\text { NO TERTINRY SEDIMENTS }\end{array}$ & 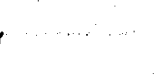 & $\begin{array}{l}\text { DRILLER'S LOS AVAILABLE; } \\
\text { RTWING WWLL }\end{array}$ & - PUELIC SUPPLY & 203 & 20 & & HTDROPOWICS & MSHING NO DRYIN & - YES ${ }_{116.7319}^{44.4716}$ & 6. WLKER, 1964 \\
\hline
\end{tabular}


Basic Data Table 4, Location, Geologic Environment, Present Use and Potential Use of Thermal springs and wells in Idaho (continued)

\begin{tabular}{|c|c|c|c|c|c|c|c|c|c|c|c|c|c|c|}
\hline $\begin{array}{c}\text { Spring/Mal } \\
\text { doentificotion } \\
\text { Number \& Nome } \\
\end{array}$ & \begin{tabular}{|c|}
$\begin{array}{c}\text { Dis- } \\
\text { chararge } \\
\text { (1i/mind }\end{array}$ \\
\end{tabular} & Aquifer Age and Rock Type & $\begin{array}{r}\text { Goologic } \\
\text { Structure } \\
\end{array}$ & Remerks & Gos & \begin{tabular}{|l|l|} 
Deposition \\
S111- & Car- \\
bon- \\
cooustes \\
ates
\end{tabular} & Presont Use & 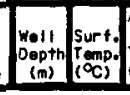 & 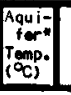 & $\begin{array}{l}\text { Potent ial Use Based on } \\
\text { Surf oce Tempersturoth }\end{array}$ & 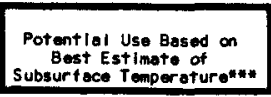 & \begin{tabular}{|l} 
chemm \\
Treace \\
Anal.
\end{tabular} & $\mid \begin{array}{c}\text { Lot } 1 \text { tude } \\
8 \\
\text { Longitude }\end{array}$ & Ref erence \\
\hline
\end{tabular}

Washington County (cont'd.)

\begin{tabular}{|c|c|c|c|c|c|c|c|c|c|c|c|c|}
\hline $\begin{array}{l}\text { FAIROHILO LUMBER } \\
\text { Co: } \\
\text { BSA AW ISBACI }\end{array}$ & 151 & MIOCENE BASALT & FLOWING WELL & & IRRIGATION & 416 & 25 & 31 & FISH FARMING & GRAIN-HAY DRYING & YES 114.46605 & MALER ND SISCD, \\
\hline LNEFY & 378 & $\begin{array}{l}\text { QUATERNARY NLLUVIUM NEAR } \\
\text { MIOCENE BASALT }\end{array}$ & $\begin{array}{l}\text { MUMEROUS SPRING YENTS; } \\
\text { TEPERRATURE 63-70 DEGREES C } \\
\text { SULFUR DOOR }\end{array}$ & YES & SPACE HEATHNG & & 70 & 78 & APPLE DEHYDRATION & PASTEURIZZE MILK PROCESS & YES $\underset{116.6304}{44.5860}$ & MEWCONB, 1970 \\
\hline 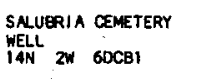 & 1135 & $\begin{array}{l}\text { PLIOCENE ND PLEI STOCENE } \\
\text { SEOIMENTS }\end{array}$ & DRILLER'S LOG AVAILABLE & & IRRIGATION & 56 & 23 & & FISH FAPMING & & $\begin{array}{l}.44 .5738 \\
116.6218\end{array}$ & Lo6, 1977 \\
\hline $\begin{array}{l}\text { CMBBRIDGE CITY WELL } \\
14 \mathrm{~N} 3 \mathrm{~W} \text { 30UCI }\end{array}$ & 1514 & MIOCENE BASNLT & $\begin{array}{l}\text { FROWING WELL; DRILLERIS LOG } \\
\text { AYAILABLE }\end{array}$ & & PUBLIC SUPPLY & 283 & 26 & & & & YES $\begin{array}{l}44.5728 \\
116.6778\end{array}$ & NEWCOMB, 1970 \\
\hline 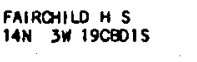 & 378 & $\begin{array}{l}\text { WUATEPNARY NLLUVIUM NEAR } \\
\text { MIOCENE EASALT }\end{array}$ & & YES & unUSED & & 32 & 63 & BRLNEOLOGICNL BATHS & PPLE DEHYORATION & YES 114.5313 & NENCONA, 1970 \\
\hline $\begin{array}{l}\text { KEPMNIT WIGGINS WELL } \\
\text { ISN 3E 100BCI }\end{array}$ & 151 & $\begin{array}{l}\text { PLLOCENE MO PLEI STOCENE } \\
\text { SEOMENENS MIOCEN } \\
\text { E HASALT }\end{array}$ & DRILLER'S LOG AVAILABLE & & DOMESTIC & 91 & 21 & & FISH MATOHING & & .94 .6477 & Los, 1977 \\
\hline
\end{tabular}




\author{
PRELIMINARY ENVIRONMENTAL ASSESSMENT
}

IDAHO GEOTHERMAL RESOURCE AREAS

by
S.G. Spencer
and

J. F. Suliivan

EG\&G Idaho, Inc.

Idaho Falls, Idaho

a 


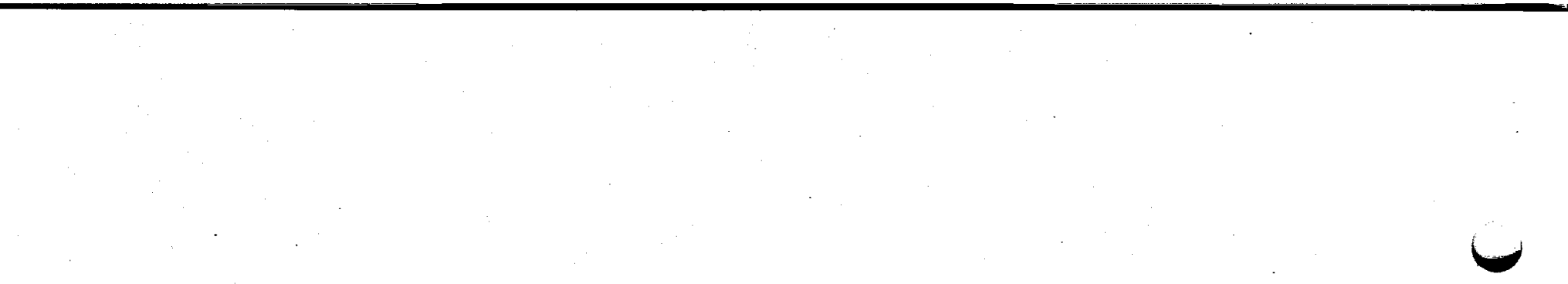

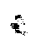

$\mathcal{U}$ 
I. Introduction $\ldots \ldots \ldots \ldots \ldots \ldots \ldots \ldots \ldots \ldots \ldots \ldots \ldots \ldots \ldots 33$

II. Description of Potential Activity ........... 339

III. Description of Existing Environment .......... 341

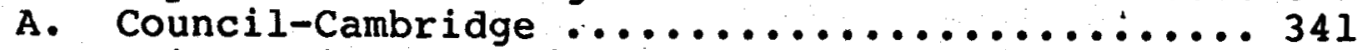

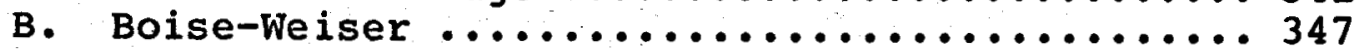

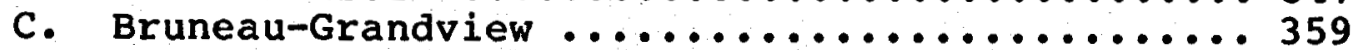

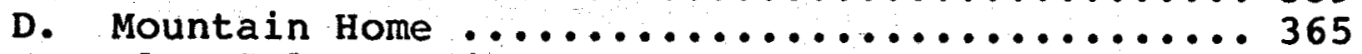

E. Blue Gulch, Twin Falls, and Artesian City .... 372

F. Pocatello ........................... 378

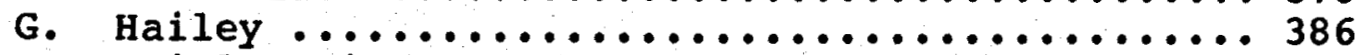

IV. Potential Envi ronmental Impacts ............. 392

A. Air Quality ......................... 392

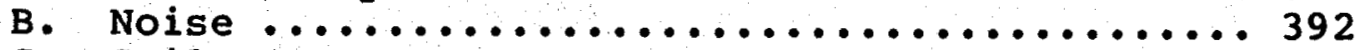

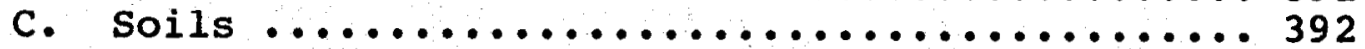

D. Water Resources ....................... 392

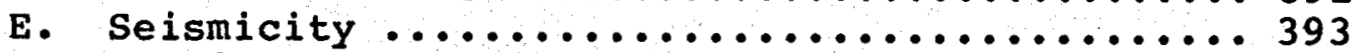

F. Subsidence ......................... 393

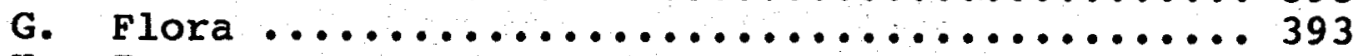

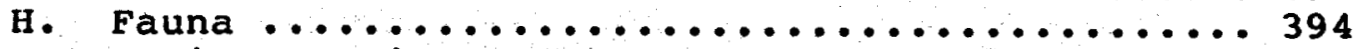

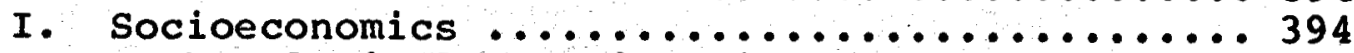

J. Archaeological and Historical ............ 394

References .......................... 395 


\section{INTRODUCTION}

This preliminary environmental assessment was prepared to address the major environmental concerns in nine areas in Idaho. (figure I-1) with significant geothermal resource potential. This assessment is brief and is not intended to provide a comprehensive environmental analysis of each area; instead, it has been compiled to provide preliminary environmental information as a companion to resource data for these areas. The nine areas addressed are:

\section{A. COUNCIL-CAMBRIDGE}

An area encompassing approximately 96,000 ha (hectares) in the Weiser River drainage of western central Idaho.

B. BOISE-WEISER

An area approximately encompassing 460,000 ha in western Idaho, including parts of Washington, Payette, Gem, Canyon and Ada counties.

\section{BRUNEAU-GRAND VIEW}

An area of approximately 186,000 ha just south of the Snake River in Owyhee County in southwest Idaho.

D. MOUNTAIN HOME

Approximately 54,000 ha surrounding the city of Mountain Home in southwest Idaho.

\section{E. BLUE GULCH, TWIN FALLS, AND ARTESIAN CITY}

Three areas encompassing $38,000,13,000$, and 10,000 ha, respectively, south of the snake River in southcentral Idaho.

F POCATELLO

An area of approximately 11,000 ha north and west of the city of Pocatello in southeastern Idaho.

\section{G. HAILEY}

An area encompassing 16,000 ha in Blaine county in central Idaho. 
STATE OF IDAHO

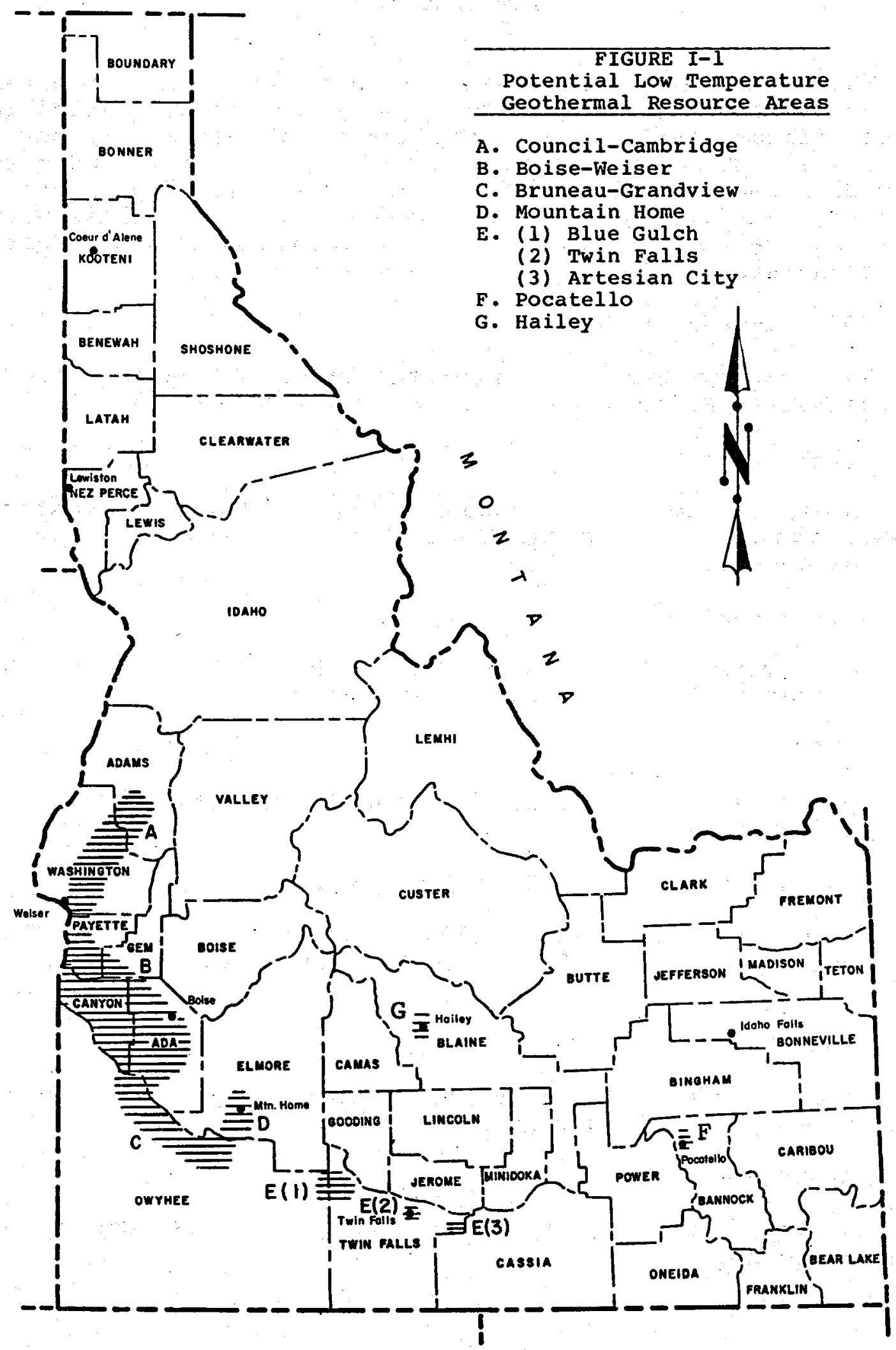




\section{DESCRIPTION OF POTENTIAL ACTIVITY}

Geothermal developments currently underway include expansion of the space heating system in Boise and the drilling of wells in Twin Falls for space heating at the College of Southern Idaho. Development in the other areas under consideration is limited; however, enough interest has been expressed in developing the resources in these areas that it can be assumed that geothermal activity will increase.

Nearly all resources identified in the areas under consideration are low to moderate temperature resources below $50^{\circ} \mathrm{C}$ (Celsius). These can be developed for a variety of direct uses, including greenhouses, space heating and cooling, pasteurization, food processing, aquaculture, and animal, rearing. In each of these processes, the geothermal fluid replaces the water-boiler systems or the heating systems and thus no major change in system design is required.

Wells drilled to provide geothermal fluids for direct use processes will generally range from less than $100 \mathrm{~m}$ (meters) in depth to over $1200 \mathrm{~m}$ deep, depending on the location and temperature of the resource. State regulations require that such wells be drilled by a licensed driller under a permit and that they be cased and cemented to preclude contamination of shallow groundwater supplies. Where higher temperatures may be encountered, blowout prevention equipment is required.

Less than 0.5 ha of land is generally cleared and graded for a drilling pad. Small reserve pits may be excavated to contain fluids encountered during drilling. When mud is used to drill the wells, mud tanks or lined mud pits are generally used as reservoirs for the mud circulation system. Access roads to move drilling equipment to the drill site are usually one-lane, ditched for drainage, and gravelled.

In addition to the drill rig, office trailers, equipment storage sheds, pipe racks, generators, and fuel tanks may be moved onto the site. All of these facilities are portable and are on location only during drilling and testing of the well. Portable sanitary facilities and water supply may also be provided.

Upon completion of the well, a wellhead is installed and connected to a supply pipeline or ditch. Geothermal pipelines are generally insulated and buried to prevent large heat losses during transport. 
Disposal of the geothermal fluids downstream of the processes will vary. Currently used methods of disposal include injection, discharge to a surface water source (including irrigation canals) and cycling through other uses (including domestic water supply). The disposal method chosen depends on the quality of the geothermal fluids, local regulations, the type of process, and economic considerations. 
III. DESCRIPTION OF EXISTING ENVIRONMENT

\section{A. COUNCIL-CAMBRIDGE}

1. Physical Environment

\section{a. Climate}

The climatic conditions of the Council-Cambridge area are generally influenced by predominant lows in the winter and highs in the summer. As a result, heavy winter snows and spring rains are usual, while summers are hot and dry. Precipitation ranges from $64 \mathrm{~cm}$ (centimeter) at Council in the Weiser valley to over $115 \mathrm{~cm}$ in the surrounding mountains. Eight percent of the precipitation falls primarily as snow in the period from October through April. Frequent chinook storms in December and January result in rapid melting of the snowpack and subsequent erosion damage. Temperatures at Council range from -32 to $43^{\circ} \mathrm{C}$ with the annual temperature averaging ${ }^{\circ} \mathrm{C}$. There are approximately 138 frost-free days annually in the valleys of the We iser basin (USFS, 1975).

\section{b. Air Quality}

In general, the air quality in the area is good, with the average background level of particulates estimated at less than $15 \mu \mathrm{g} / \mathrm{m}^{3}$ (micrograms per cubic meter). Sources of pollution include sawmills at Council, slash burning, road dust, vehicle emissions on Highway 95 , rock-crushing, and campfices. In general, pollutants are readily dissipated. However, frequent inversions in the fall during slash burning combine to hold smoke in the upper valleys.

\section{c. Land Resources}

\section{(1) Topography}

The Council-Cambridge area is located in the Wallowa-Seven Devils section of the Columbia Plateau physiographic province. North-south trending block mountains and structurally-controlled landscapes are typical. The Weiser basin is very irregular with rolling profiles in

1 the valleys. The main feature in the area of interest is the valley of the weiser River, which trends south from the Seven Devils Mountains to the river's confluence with the Snake River at Weiser. The valley is bounded on the east by the West Mountain block. On the west, the Cuddy Mountains separate the valley from the canyon of the snake River. Elevations range from $820 \mathrm{~m}$ at Midvale in the south to 2480 $m$ on Council Mountain in the northeast corner of the area. 


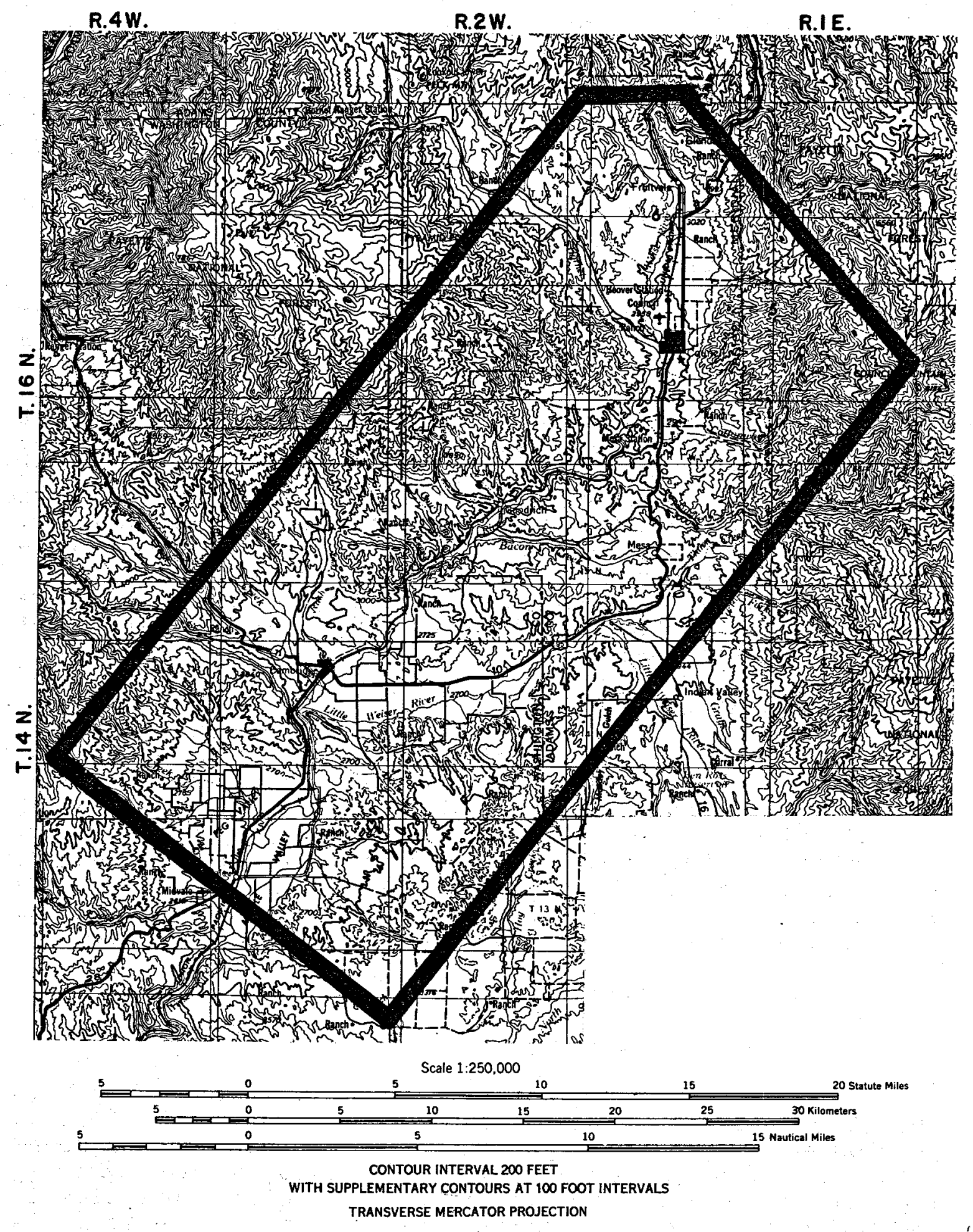

A. Council-Cambridge Study Area 
Plateau basalt flows of the Columbia River formation are the most extensive rock type in the area. These basalts are usually weakly weathered and moderately to well-fractured. Granitics of the Idaho Batholith occur in scattered exposures in the area. In the valleys of the Weiser River and its tributaries, the basalts are overlain by colluvium, fanglomerates, stream and lake deposits, and alluvium. A significant area of glaciation and associated glacial debris is located on Council Mountain in the northeast corner of the area. Primary faulting in the area occurs perpendicular to the Weiser Valley.

\section{(3) Soils}

The primary parent material of soils in the Council-Cambridge area is the Columbia River basalts. These soils are generally fine to medium-textured loams and silt loams ranging in depth from $76 \mathrm{~cm}$ to $127 \mathrm{~cm}$. Productivity is relatively high and erosion hazards are moderate to low. Soils overlying the granitics are much less extensive, coarse-textured loams and sandy loams with moderately low productivity. The erosion potential in these latter soils is moderate to high, while the basaltic soils are generally stable. Mineral fertility is high in most soils. Caliche and relatively high salinity occur in the soils overlying the lacustrine deposits on foothill slopes.

\section{d. Water Resources}

\section{(1) Surface Water}

The primary stream in the area of interest is the weiser River, which drains $1567 \mathrm{~km}^{2}$ (square kilometer) above the gaging station at Cambridge. The discharge at this station averages $19 \mathrm{~m}^{3} / \mathrm{s}$ (cubic meter per second) and ranged from a maximum of $286 \mathrm{~m}^{3} / \mathrm{s}$ on $12 / 22 / 55$ to a minimum of $0.23 \mathrm{~m}^{3} / \mathrm{s}$ on $11 / 16 / 58$. The source of water in the basin is snowmelt. Because of the irregularity of the basin, more than 60 percent of the annual runoff is contributed by tributaries on the east-side of the basin. Warm temperatures and rainstorms produce significant runoff in the winter and spring. In the 1974-1975 water year, 80 percent of the total flow of the river occurred in the period from March through June, with an average discharge during May of nearly $80 \mathrm{~m}^{3} / \mathrm{s}$. Total suspended solids during the same period ranged from $22 \mathrm{mg} / 1$ (mililigram per liter) to $229 \mathrm{mg} / 1$. Measurements of daily sediment discharge were 247 metric tons in February, 1316 metric tons in May, and 21 metric tons in July. The average quality of the river near Cambridge in 1974 and 1975 is shown in table A-1. 


\begin{tabular}{lllr}
\hline & \multicolumn{2}{c}{ TABLE A-1 } \\
& QUALITY OF WEISER RIVER \\
$(\mathrm{mg} / 1)$
\end{tabular}

Flow in the river is regulated to some extent by the Lost Valley Reservoir, $92 \mathrm{~km}$ upstream from the mouth, and by other smaller reservoirs. Diversions above Cambridge are used to irrigate about 5000 ha.. Downstream, water is used for irrigation in the lower weiser valley and for power production on the Snake River (USFS, 1975).

\section{(2) Groundwater}

Groundwater in the upper weiser basin occurs primarly in the Columbia River basalts under both water table and artesian conditions. Some water occurs in the thin layers of sand and gravel sediments in the valley bottoms around Cambridge. Depth to water in irrigation and domestic wells in the area ranges from $0.06 \mathrm{~m}$ to $34 \mathrm{~m}$. The average quality of water produced from these wells is shown in table A-2. Domestic and stock water supplies are generally derived from individual wells and springs. Industrial water use is limited to the timber industry and is primarily obtained from surface water with some supplemental groundwater.

\begin{tabular}{lccc}
\hline & $\begin{array}{c}\text { TABLE A-2 } \\
\text { GROUNDWATER QUALITY } \\
(\mathrm{mg} / 1)\end{array}$ & \\
\hline $\mathrm{Ca}$ & 16 & $\mathrm{HCO}_{3}$ & 143 \\
$\mathrm{~K}$ & 7.7 & $\mathrm{SO}_{4}^{\mathrm{m}}$ & 17 \\
$\mathrm{Mg}$ & 6 & $\mathrm{TDS}$ & 210 \\
$\mathrm{Na}$ & 29 & $\mathrm{pH}$ & 7.6 \\
$\mathrm{Cl}^{-}$ & 2.8 & & \\
$\mathrm{~F}$ & 0.4 & & \\
\hline
\end{tabular}




\section{Natural Environment}

\section{a. Flora}

The vegetation in the Council-Cambridge area can be divided into two basic types, based on elevation. At lower elevations there are scattered stands of ponderosa pine (Pinus ponderosa), with bluegrasses (Poa secunda), bluebunch wheatgrass (Agropyron spicatum), and Idaho fescue (Festuca sp.). Big sage (Artemisia tridentata) is common and primary forbs include phlox (phlox sp.), asters (Aster sp.), and western yarrow (Achillea sp.). Some rocky areas support only sparse grasses and forbs. At higher elevations in the mountains east of Council, ponderosa pine predominates. The understory is much heavier and is composed of species such as snowberry (Symphoricarpos albus), chokeberry (Pontentialla virginiana), and ninebark (Physocarpus sp.). Forbs includes asters, horsemint (Monarda sp.), geranium (Geranium sp.), and buckwheat (Fagopyrum sp.). Douglas fir (Pseudotsuga taxifolia) is common and becomes dominant above $1500 \mathrm{~m}$. Western larch (Larix occidentalis) is scattered amongst the douglas fir and Engelmann spruce (Picea engelmannii) occurs along creek bottoms in the mountains. A few whitebark pine (Pinus sp.) grow on top of Council Mountain (USFS, 1975)

\section{b. Fauna}

Although detailed inventories have not been taken, surveys of fauna in the area have identified 81 species of birds, 32 species of mammals, and 15 species of reptiles and amphibians. This diversity is primarily due to the variety of cover types and the range of elevations. Although big game is not abundant, some mule deer (Odocoileus hemionus), elk (Cervus canadensis), and numerous black bear (Ursua americanus) inhabit the mountain area. In one season, 53 black bear were tagged on the Middle Fork of the Weiser. Council Mountain is the most important mule deer habitat in the area. Coyote (Canis latrans), red fox (Vulpes fulva), muskrat (Ondatra zibethica), badger (Taxidea taxus) raccon (Procyon lotor), and skunk (Mephitis mephitis) are common.. Small mammals include Columbian ground squirrel (Citellus columbianus), golden-mantled ground squirrel (Citellus lateralis), yellowpine chipmunk (Eutamias amoenus), and snowshoe hare (Lepus americanus). Common reptiles and amphibians are western rattlesnake (Cortalus viridis), leopard frog (Rana pipiens), and bullfrog (Rana catesbeiana). In addition to a large variety of passerines, several species of hawks (Buteo sp.), golden eagles (Aquila chrysaetos), and bald eagles (Halliaeetus leucocephalus) are found throughout the area. Blue grouse (Dendragapus obscurus) and ruffed grouse (Bonasa umbellus) are abundant (USFS, 1975). 


\section{c. Aquatics}

The Idaho Department of Fish and Game classes the streams in the area as good to excellent. There is a fair trout fishery in the three forks of the weiser River and these streams are stocked several times a year. Game $f i s h$ include rainbow (Salmo gairdneri), brook trout (Salvelinus fontinalis), a few cutthroat (Salmo clarki), and Dolly Varden (Salvelinus malma). A significant number of nongame $f$ ish are found in the lower weiser River.

\section{Cultural Environment}

a. Land Use

Nearly all land in the area of interest is privately owned. Approximately 9500 ha in the northeast corner of the area are controlled by the U.S. Forest Service, and parcels of land under the jurisdiction of the state and BLM are scattered through the area. Primary land uses include farming along the Weiser River, timber harvest, range, and recreation. The area was seriously overgrazed in the late $1800^{\prime} \mathrm{s}$, but careful range management and range restoration have resulted in much of the land being considered an important range resource. At one time, Council was the center of extensive apple orchards, but water shortages, low prices and increased costs have resulted in a decline.

\section{b. Socioeconomics and Demography}

The area of interest includes parts of both Washington and Adams counties. The combined population of these counties is $11,800(1976)$. The population density of Adams County is 0.9 people $/ \mathrm{km}^{2}$, less than half the density of Washington county. The larger communities in the area and their 1970 populations are Council (899), Cambridge (383), and Midvale (176). The unemployment rate in Adams County in 1976 averaged 13.6 percent and that in Washington County averaged 8.6 percent. Primary contributors to the total employment in each county include farm proprietors, manufacturing, state and local, and trade. Per capita income in the area is 90 percent of the state average and 74 percent of the national average.

\section{c. Archaeologic and Historical}

Council Valley was an important meeting place for the NezPerce and Shoshone tribes, the valleys providing $a$ winter retreat and the mountains excellent hunting. Little is known of early occupation of the area, although the potential for prehistoric occupation in the valley areas is good. Both Council and Cambridge were settled in the $1870^{\prime} \mathrm{s}$. Council grew rapidly as a result of mining activity 
in the Seven Devils. Cattle and sheep grazing were well established by 1880 , and the subsequent overgrazing of the area resulted in heavy soil loss in the lowlands in the early $1900^{\prime} \mathrm{s}$.

\section{d. Aes thetic Values}

The study area is composed of both mountains and valleys. The mountainous regions are utilized for recreational purposes such as backpacking, hunting, and fishing, while the valleys are fairly well developed. Two national forests are touched by the area: Boise and Payette, both of great recreational value.

B . BOISE-WEISER

1. Physical Environment

a. Climate

Limited climatological data are available for selected sampling locations within the Weiser-Boise study area (National Oceanic Atmospheric Administration, 1977). These are summarized as follows:

(1) Weiser - located in the uppermost part of the study region in Washington county. The average annual temperature is $10.6^{\circ} \mathrm{C}$, with January and July averaging -2.5 and $23.3^{\circ} \mathrm{C}$, respectively. Rainfall averages $29 \mathrm{~cm} / \mathrm{yr}$ with July and January averaging 0.28 and $4.39 \mathrm{~cm}$, respectively. Relative humidity peaks at $40-50$ percent in summer and $70-80$ percent in winter.

(2) Payette - located in the northwest of the study region in Payette county. The average annual temperature is $10.8{ }^{\circ} \mathrm{C}$, with January and July averaging -2.2 and $23.6^{\circ} \mathrm{C}$, respectively. Rainfall averages $28.3 \mathrm{~cm} / \mathrm{yr}$ with July and January averaging 0.33 and $3.96 \mathrm{~cm}$, respectively.

(3) Caldwe11 - located in Canyon County in the midale of the study area. Average annual temperature is $10.7^{\circ} \mathrm{C}$ with January and July averaging -1.5 and $23.2^{\circ} \mathrm{C}$, respectively. Rainfall averages $28.3 \mathrm{~cm} / \mathrm{yr}_{\mathrm{r}}$ with July and January averaging 0.33 and $3.96 \mathrm{~cm}$, respectively.

(4) Boise - located in Ada county in the eastern portion of the study area. Average annual temperature is $10.6^{\circ} \mathrm{C}$ with January and July averaging -1.5 and $23.3^{\circ} \mathrm{C}$, respectively. Rainfall averages $29.2 \mathrm{~cm} / \mathrm{yr}$ with July and January averaging 0.38 and $3.73 \mathrm{~cm}$, respectively.

The climate is therefore characterized by hot dry summers. snowfall is a major contributor to the total precipitation, 


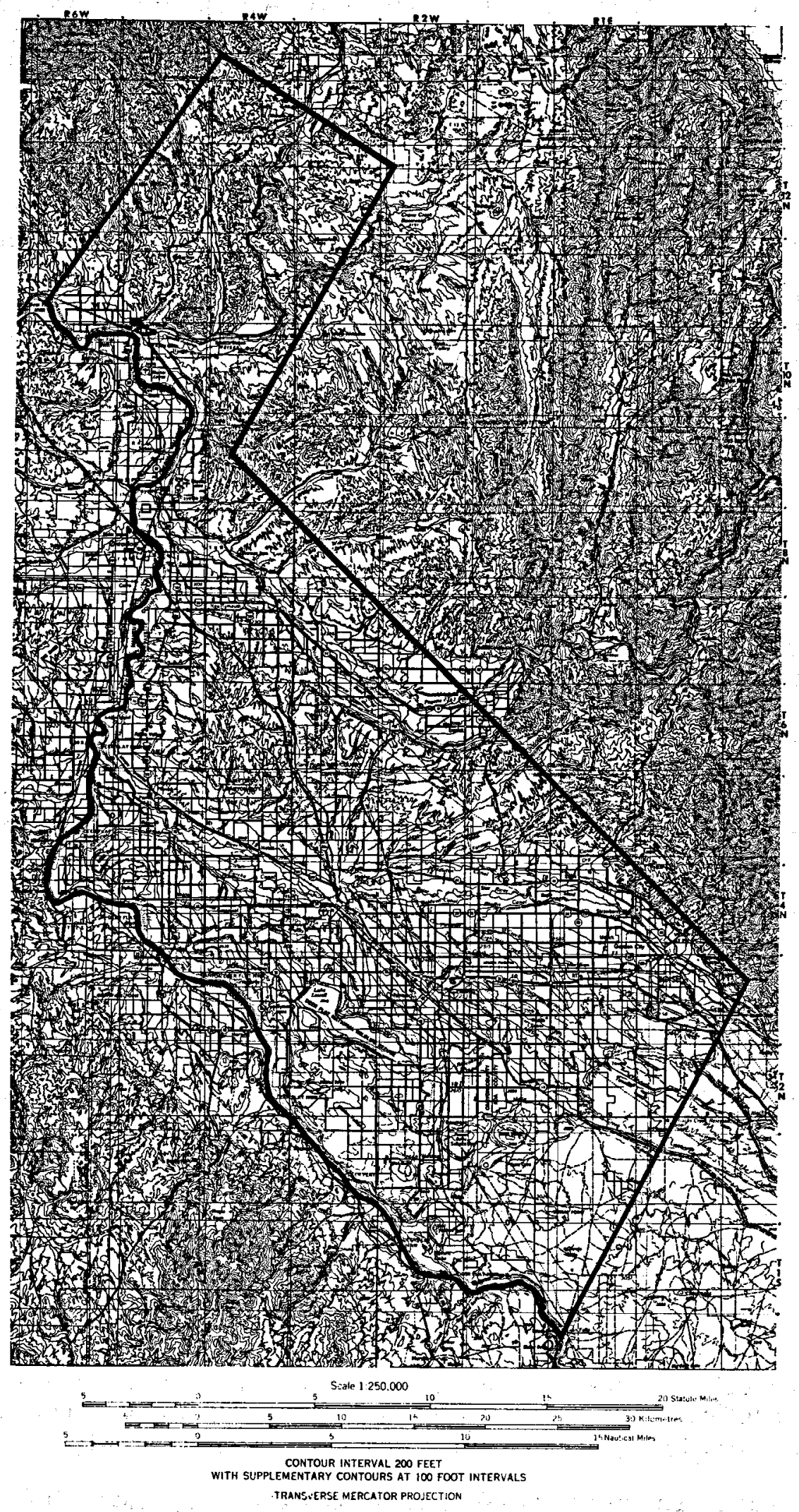

B. Boise-Weiser study Area 
notably at the higher elevations. The dry grassland climate provides well-defined seasonal characteristics.

\section{b. Air Quality}

Air masses from the Pacific reach the study area but are considerably modified over that distance point. Their influence contributes mildly to periods of cloudy or stormy winter weather. Air pollution is not a major problem in the area as a whole, however, the Boise region experiences intermittent temperature inversions which effectively trap particulates and gasses at low levels, thus creating stagnant air masses. The Metropolitan Boise Intrastate Region (including Boise, Nampa, and Caldwell) violates secondary air quality standards for particulate matter (U.S. EPA, 1972). Sources are fuel combustion and industrial process losses, primarily asphalt and ready-mix concrete operations. Additionally, dust from agricultural lands contributes to the particulate load during certain seasons.

The Boise area is the only portion of Idaho to experience significant emissions from aircraft or automobiles. Reduced visibility is a consequence of such air quality degradation during severe temperature inversions (Ada Council of Government).

\section{c. Land Resources}

\section{(1) Topography}

The Boise-Weiser study area is located on the western border of the state and includes portions of Ada, Canyon, Gem, Payette, and Washington counties. The Boise Mountains border the east side of the region while Oregon borders the west side. The snake River forms the southern boundary and the Council-Cambridge study area is adjacent on the northern border. Elevations in Ada county range from $822 \mathrm{~m}$ on the valley floor to $1890 \mathrm{~m}$ on the ridge crest.

The Boise-Caldwell area is of lower elevation than the eastern portion of the snake River Plain. The topography is generally flat with thick lake and stream sediments interbedded with basalt flows. The lower Boise and Payette River basins are included in the area (BLM, 1976).

\section{(2) Geology}

Geological information is primarily limited to Ada county, which is mainly composed of the Idaho Batholith and the Idaho Group. The Idaho Batholith is of granitic origin and is found along the steep face and crest 
of the Boise Ridge while the Idaho Group represents the valley fill materials, composed of gravel, sand, silt, and clay (Ada Council of Governments, 1973).

The general geology of the area is summarized as follows. Cenozoic flows include: 1) the Basalt flows of the Idaho and Snake River groups in the Boise area; 2) alluvial, glacial, and lake deposits in Canyon, Payette, and Gem counties; 3 ) sedimentary rocks of the Idaho Group, including lake and stream deposits of the Chalk Hills formation in upper Canyon and lower payette counties; 4) sedimentary rocks associated with the Columbia River Basalt in Payette and Gem counties; and 5) Columbia River Basalt in Gem, Payette, and Washington counties. Mesozoic rocks include granite rocks of the Idaho Batholith in Ada county (BLM, 1976).

\section{(3) Soils}

Available soil data for the entire study area are inadequate for a precise description. Soils in Ada and Canyon counties are moderately to very deep with silty subsoils on gentle to strong slopes. The frost-free season ranges from 120-160 days. Crops, including cereals, potatoes, sugar beets, beans, and hay, require irrigation. Rangeland soils include both coarse-silty and fine-silty soils. Parent materials are alluvium on the terraces and loess on the uplands. The profile depth ranges from 51-152 $\mathrm{cm}$ with moderate permeability. The major soil problems appear to be erosion, alkaline conditions and droughtiness. These are being mitigated by residue management, crop sequencing, irrigation, and rangeland management and crossslope operations (BLM, 1976). Land in the Weiser area is subhumid grassland and semiarid grazing land; some is irrigated.

\section{d. Water Resources}

\section{(1) Surface}

Surface water features in the study area include the Snake River, Payette River, Weiser River, Boise River, Arrowrock and Lucky Peak reservoirs (on the middle fork of the Boise River). Spangler Reservoir in Washington County, Lowell Lake in Canyon County, and Black Canyon Reservoir on the Payette River in Gem County. Additionally, irrigation canals and drainage ditches have been constructed throughout principal irrigation areas.

Swan Falls Dam, constructed in 1901 on the Snake River south of Boise, creates a slack water pool for approximately $19 \mathrm{~km}$. Otherwise, the snake River is free flowing. The snake River receives pollutants from agri- 
cultural practices, industrial processing plants (primarily potato and sugar refining), untreated domestic sewage, and irrigation returns. Water quality of the river is degraded by input from the owyhee, Payette, and Boise rivers (BLM, 1976).

The Boise River flows in an east to west direction through Ada County and drains about $6993 \mathrm{~km}^{2}$ of mountainous terrain north and east of Ada County. Since this river receives a large part of its water from seasonal runoff and snowmelt, it is characterized by high flows in spring through early summer and low flows from late summer through winter.

Water quality data for the region is summarized in Table B-1 (USGS, 1976). Lake Lowell near Caldwell is formed by two earth embankments. Storage began in 1908, with the capacity $218 \mathrm{hm}^{3}$ (cubic hectometer). The lake receives water from the Boise River and local drainage; water is used primarily for irrigation. The maximum observed content $\left(221 \mathrm{hm}^{3}\right)$ was recorded on $4 / 27 / 22$ and the minimum $\left(6.7 \mathrm{hm}^{3}\right)$ was observed on $10 / 22 / 24$.

Lucky Peak Reservoir near Boise is formed by an earth-fill dam. storage began in 1954. Water (capacity $378.6 \mathrm{hm}^{3}$ ) is stored for flood control and irrigation of Boise valley lands. The maximum observed content $\left(376 \mathrm{hm}^{3}\right)$ was recorded on $6 / 25 / 55$ and the minimum $\left(35.5 \mathrm{hm}^{3}\right)$ was observed $12 / 21 / 61$.

Arrowrock Reservoir on the Boise River is formed by a gravity-section concrete-arch dam which was completed in 1915 and raised $1.5 \mathrm{~m}$ in 1937. Water (current capacity $353 \mathrm{hm}^{3}$ ) is used for irrigation in Boise valley; silt deposition has decreased the storage capacity over time. The maximum content $\left(371 \mathrm{hm}^{3}\right)$ was recorded $5 / 29 / 48$ and the minimum occurred during several years when the gates were open and natural river flow passed through the reservoir.

The Boise River is clean as it leaves Lucky Peak Reservoir; however, the quality is degraded as the river leaves Boise. The most severe degradation occurs after the water flows by Eagle Island where the combined effluent from Meridian, Nampa, and Caldwell enter the river along with wastewater returns from vast areas of irrigated farmland (Bureau of Reclamation, 1977) The major pollutants are nitrogen, phosphorus, bacteria, and sediment.

\section{(2) Groundwater}

Detailed groundwater data is lacking for the entire study area. However, groundwater data are 
TABLE B-1

SURFACE WATER DATA FOR THE BOISE-WEISER STUDY AREA

(Water chemistry data are for the water year $10 / 75$ - 9/76, expressed as mean sample values and standard deviation (USGS, 1976])

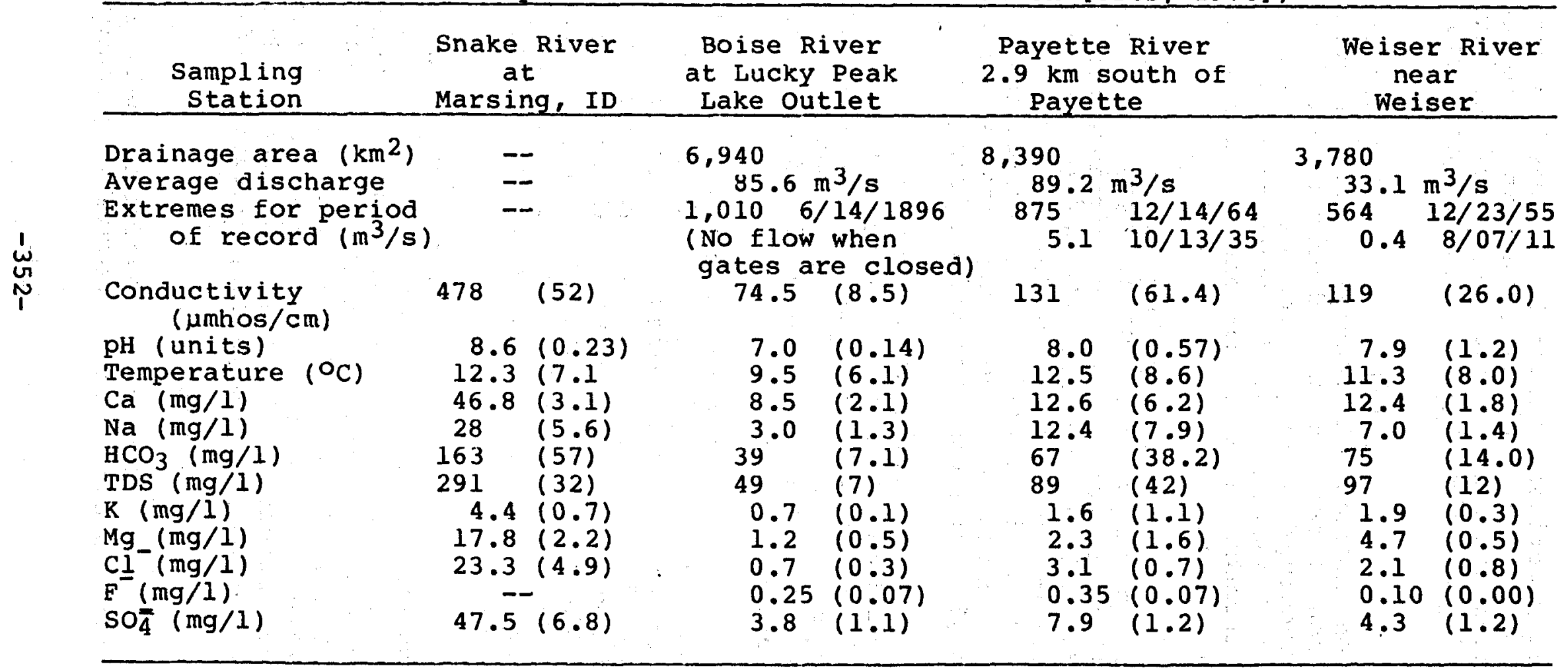


available for Ada County, where ample water is available for domestic, industrial, and irrigation purposes. Water within Ada County is primarily available from deep permeable sediments of the Glenns Ferry Formation, shallow alluvial or stream deposits, and Snake River Basalt lava flows (Ada Council of Governments). The Glenns Ferry Formation provides the deep aquifer with both clay and sand strata. Clay beds produce $0.32-1.6$ lps (liter per second) while sand and gravel beds produce up to 102 lps. Well yields from shallow alluvial or stream terrace deposits range from 32 to 64 lps. The Snake River basalt formation is responsible only for shallow, domestic water resources. Ada County groundwaters are mainly calcium-magnesium bicarbonate type. Total dissolved solids (TDS), however, often exceed the U.S.P.H.S. drinking water standard of $200 \mathrm{mg} / 1$. Water quality problems are associated with excessive hardness, dissolved iron, and magnesium levels.

The Boise River Valley has wells that are utilized mainly for domestic purposes. of 60 major wells monitored by $\mathrm{CH}_{2} \mathrm{M} \mathrm{Hill}, 15$ percent were contaminated by coliform bacteria, gram negative, nonsporulating, rod-shaped bacteria that are natural flora to the gastro-intestinal tract of warm-blooded animals.

The Boise Front is the major deep groundwater recharge system for the area, while irrigation seepage and surface water seepage and precipitation recharge the shallow aquifers.

Available information indicates that a decline in groundwater levels is not occurring and that recharge is balancing water removal from the aquifer.

The Weiser River basin drains approximately $4100 \mathrm{~km}^{2}$. The principal use of water is for irrigation, with surface waters meeting the bulk of the demand. Groundwater is supplied by two main aquifers: 1) in the basalt of the columbia River Basalt Group and 2) in overlying Tertiary and Quaternary sedimentary rocks. Individual wells and springs supply domestic and stock supplies. Municipal water for the towns of Council, Cambridge, and Midvale are derived from seven wells open to the Columbia River Basalt Group. Weiser obtains its water from three wells open to the sedimentary-rock aquifer (Young, Harenberg, and Seitz, 1977).

Groundwater in the Weiser River basin is recharged mainly from precipitation falling within the basin. The basalt aquifers are recharged via precipitation on the surrounding uplands and mountains, with snowmelt the greatest contributor. The sedimentary rock aquifers are recharged primarily during snowmelt runoff and the irriga- 
tion season, with water infiltration from streams, canals, ditches, and irrigated fields. Water levels in the various aquifers vary with snowmelt conditions.

Groundwater supplies are affected by the thermal waters known to occur in the region. Wells in the Midvale area discharge water in the $28^{\circ} \mathrm{C}$ range. Municipal wells at Weiser, which draw water from the shallower sedimentary rocks, have TDS concentrations in the 393-514 mg/1 range, considerably "harder than from the deeper basalt aquifer.

\section{Natural Environment}

\section{a. Flora}

Species expected to occur in the valleys of Payette, Gem, Washington, and upper Canyon counties include those that are found in the payette Forest. Examples are ponderosa pine, bluebunch wheatgrass, Idaho fescue, big sage, and western yarrow.

Adjacent to the Snake River lies a salt desert shrub plant community which boasts common stands of white sage or winterfat (Eurotia lanata), once common throughout the intermountain area. The sagebrush-grassland community found throughout Ada and Canyon counties has species such as big sagebrush, low sagebrush (Artemesia arbuscula), bluebunch wheatgrass, Idaho fescue, Indian ricegrass (Oryzopsis hymenoides) and cheatgrass brome (Bromus tectorum). Repeated fires, overgrazing, and agricultural conversion has altered this once diverse and abundant plant cover to little more than a sagebrush and/or annual grass community.

A forest community is found along the northeastern border of Ada County, comprised of yellow pine (Pinus ponderosa) and Douglas fir (Pseudotsuga menziesii) with an associated shurb understory.

b. Fauna

include:

Animal species which inhabit the study region

\section{(1) Mammals}

Large mammals are limited by cover, forage, and water availability. Limited numbers of mule deer are found along the Snake River Canyon with a few migrants from the Boise drainage basin. Predator species include the coyote, bobcat (Lynx rufus), skunk, and short-tailed weasel (Mustela erminea). Rodents include the yellow-bellied mar- 
mot (Marmota flaviventris), muskrat, Townsend's ground squirrel (Citellus townsendi), and Columbian ground squirrel.

\section{Birds}

Birds associated with the area total 110 species, including 40 waterfowl or aquatic species, 4 upland game birds, 22 raptors, and 44 other smaller species (Ada Council of Governments, No. 9): The birds of prey are discussed in the Bruneau-Grand View section of this report. Game species include pheasant (Phasianus colchicus), ruffed grouse, chuker (Alectaris graeca), Hungarian partridge (Perdix perdix), and quail (Oreortyx pictus). Duck species include mallard (Anas platyrhynchos), pintail (Anas acuta), blue wing teal (Anas discors), ruddy (Oxyrua jamaicensis) and cinnamon teal (Anas cyanoptera).

\section{(3) Reptiles/Amphibians}

Reptiles/amphibians occur in rocky canyons and desert lowlands where the prey base is good. Representative species are: leopard lizard (Cortaphytas wislizenii), western skunk (Eumeces skiltonianus), Great Basin gopher snake (Pituophis melanoleucus), and western rattlesnake.

\section{c. Aquatics}

The Boise Front tributaries are sediment-laden from ground disturbances and contribute to an excessive sediment load in the Boise River which adversely impacts the ecosystem and has eliminated the fisheries in some portions. The only trout habitat is between Barber Dam to Middleton, a distance of $35 \mathrm{~km}$. The $13 \mathrm{~km}$ length of the Boise River between Discovery state Park and Barber Dam is severely silted and does not support a fish community. Fish species in the river include Rocky Mountain whitefish (Coregonus sp.), suckers (family Catistomidae), carp (Cyprinus carpio), sculpin (Cottus sp.), shiners (Notropis sp.), and squawfish (Ptychocheilus oregonensis). Gamefish and invertebrate populations are severely impacted by the 7-14 day annual shutdown of Lucky Peak Dam for inspection purposes. This results in a $1: 1$ ratio of sewage effluent: river water below the Boise sewage treatment plant, with residual chlorine at levels toxic to trout and whitefish. Additionally insect larvae are wiped out with the drastic flow decrease and excessive siltation. It is felt that the trout fishery could be reestablished in the Boise River in both Ada and Canyon counties. (A second tunnel has been authorized by Congress and is expected to be under construction within the next two years. This will eliminate the annual shutdown of Lucky Peak flows.) 
Healthy fish populations are found in the Snake River below Swan Falls Dam, including channel catfish (Icatlurus punctatus), largemouth bass (Micropterus salmoides), smallmouth bass (M. dolomieu), and crappie (Poxomis sp.).

The Weiser River supports a trout fishery with supplemental stocking from the Idaho Department of Fish and Game. Game species include brook trout, rainbow trout, cutthroat trout, and Dolly Varden. Additionally, nongame species are also in the Weiser River.

3. Cultural Environment

a. Land Use

Land ownership and use in the five counties within the Boise-Weiser study area are listed in table B-2.

TABLE B-2

LAND OWNERSHIP AND USE IN BOISE-WEISER AREA

\begin{tabular}{lrrrrrr}
\hline & \multicolumn{7}{c}{ Ada } & Canyon & Payette & Gem & Washington \\
\cline { 2 - 6 } & & & & & \\
\& Federal Land & 46.2 & 4.3 & 25.9 & 37.9 & 37.0 \\
\& State Land & 6.7 & 0.6 & 3.5 & 6.6 & 6.8 \\
\& Private Land & 45.9 & 94.9 & 69.8 & 55.0 & 55.9 \\
Total Land (ha) & 270,223 & 149,784 & 104,095 & 143,827 & 378,773 \\
\& Urban or & & & & & \\
built-up & 4.5 & 2.9 & 1.1 & 0.5 & 0.4 \\
\& Agricultural & 25.6 & 84.4 & 33.7 & 18.5 & 13.8 \\
\& Rangeland & 69.0 & 7.7 & 64.0 & 66.3 & 74.6 \\
\& Forest & 0.3 & 3.0 & 0.0 & 13.9 & 9.9 \\
\& Water & 0.6 & 2.0 & 1.2 & 0.8 & 1.3 \\
\hline
\end{tabular}

\section{b. Socioeconomics and Demography}

The study area is varied and diverse in that it includes the densest county (Ada) in the state as well as sparsely populated counties (Washington and Gem). The socioeconomic data for the area are summarized in table B-3.

Employment data are summarized in table B-4. 
TABLE B-3

SOCIOECONOMIC DATA FOR THE BOISE-WEISER AREA

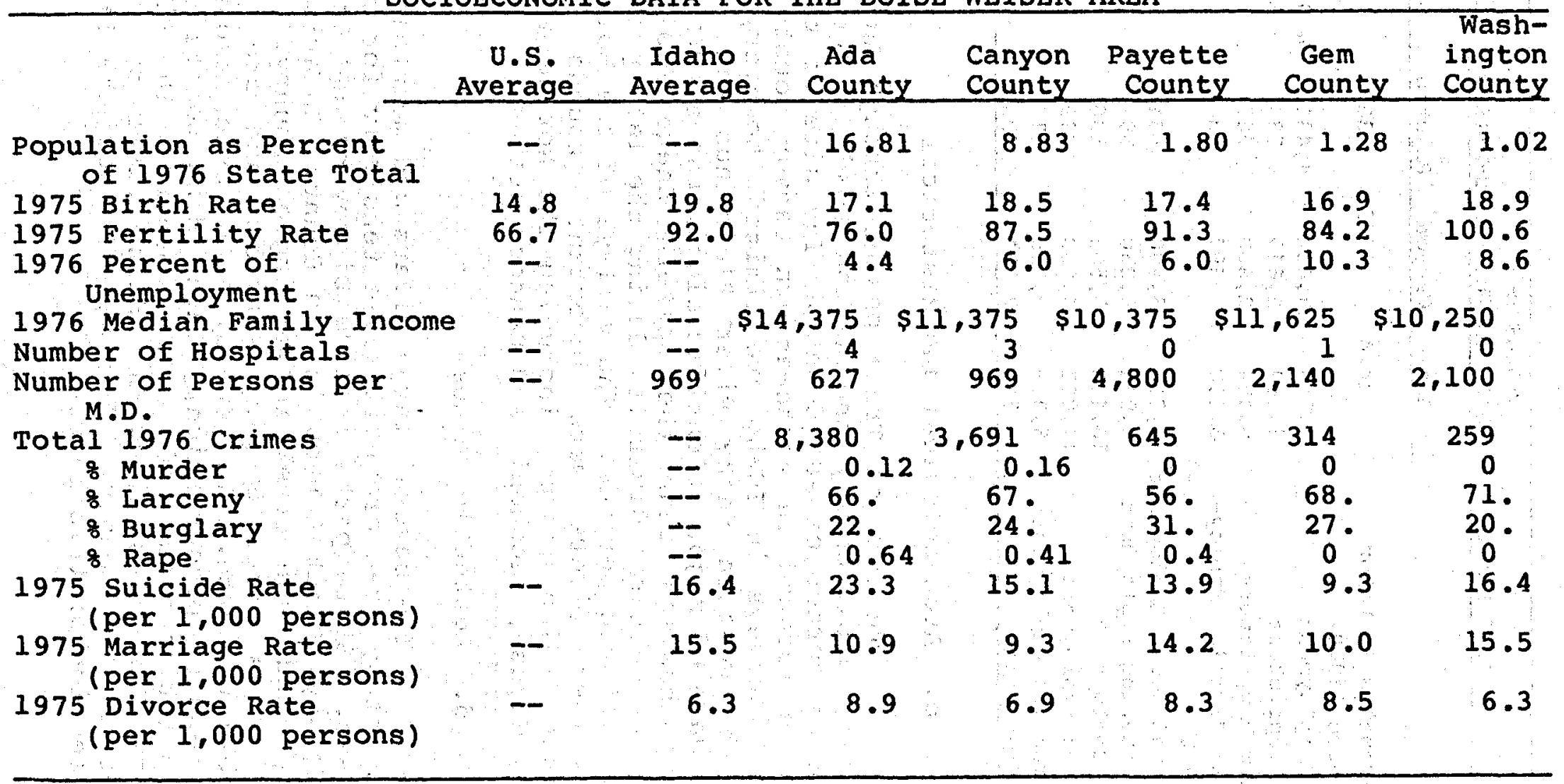


TABLE B-4

1975 EMPLOYMENT DATA FOR THE BOISE-WEISER AREA

\begin{tabular}{|c|c|c|c|c|c|}
\hline : & Ada & Canyon & Payette & Gem & $\begin{array}{c}\text { Washing- } \\
\text { ton }\end{array}$ \\
\hline $\begin{array}{l}\text { of Females in Labor } \\
\text { Force (1970) }\end{array}$ & 44.4 & 41.2 & 38.9 & 29.1 & 34.1 \\
\hline Total Employment & 68,744 & 31,464 & 4,431 & 4,007 & 3,352 \\
\hline Farm Proprietors & 1,664 & 2,619 & 734 & 637 & 598 \\
\hline Nonfarm Proprietors & 5,481 & 2,853 & 667 & 370 & 455 \\
\hline $\begin{array}{l}\text { Federal Civilian Employ- } \\
\text { ment }\end{array}$ & 3,208 & 191 & 38 & 59 & 50 \\
\hline State and Local Employment & 10,866 & 3,480 & 631 & 510 & 501 \\
\hline Manufacturing Employment & 6,014 & 6,250 & 597 & 733 & 382 \\
\hline Trade Employment & 16,143 & 5,581 & 536 & 498 & 574 \\
\hline Services Employment & 11,062 & 4,563 & 319 & 377 & 190 \\
\hline Construction Employment & 5,089 & 1,035 & 132 . & 30 & 95 \\
\hline Farm Employment & 511 & 2,581 & $390^{\circ}$ & 644 & 339 \\
\hline
\end{tabular}

\section{c. Archaeological and Historical}

The oregon Trail passes through Ada and Canyon counties; additionally the Kelton Road is located in the northeast corner of Ada County. The site of the 1834 Fort Boise is located in northwestern Canyon county. Archaeological surveys in Idaho are limited; however, it is felt that the western snake River Plain has the potential to yield data of major scientific significance (BLM, 1976). It is hypothesized that the western snake Plain contained extensive cultural diversity during the late prehistoric and early historic periods. The valleys of the Boise, Payette, and Weiser rivers were important grounds for several distinct Indian groups, including the Northern Paiute, Nez Perce, Cayuse, Shoshoni, and Bannock tribes.

\section{d. Aesthetic Values}

The several lárge rivers and mountainous regions in the study area are utilized extensively for recreational purposes. State parks include Discovery and Lucky Peak in Ada county, Black Canyon in Gem County, Ontario in Payette County, and Mann Creek in Washington County. Several of these parks offer camping services and are therefore a valuable resource. In general, aesthetic resources in the area require preservation, since Idaho boasts some of the most pristine areas left in the country. The Birds of prey Natural Area lies along the snake River on the southern border of Ada County. For details see the Bruneau-Grand View section of this report. 


\section{BRUNEAU-GRAND VIEW}

\section{Physical Environment}

\section{a. Climate}

The climate of Owyhee County is moderate, ranging from $0^{\circ} \mathrm{C}$ in January to $270^{\circ} \mathrm{C}$ in July. Extremes of -33 to $46^{\circ} \mathrm{C}$ have been recorded for Grand View. Rainfall averages 20 to $25 \mathrm{~cm}$ per year along the snake River, with May and June the heaviest precipitation months. Relative humidity is characteristically low, with moderate winds frequent. The growing season in the study approximates 140 days.

\section{b. Air Quality}

Prevailing wind currents are from the westnorthwest and follow the Bruneau River and snake River valleys. Wind speeds average $8-32 \mathrm{~km} / \mathrm{hr}$ with infrequent gusts up to $96 \mathrm{~km} / \mathrm{hr}$. The air quality is considered very good, with agriculture the main contributor to particulate matter. Range fires also contribute smoke and ash to the particulate load during the dry season; however, air pollution on the whole is minimal. Concentration levels of $\mathrm{CO}$, $\mathrm{NO}_{\mathrm{x}}, \mathrm{SO}_{\mathrm{x}}$, and hydrocarbons are unknown but are thought to be low since no major point sources exist in the study area.

\section{c. Land Resources}

\section{(1) Topography}

The Bruneau-Grand View area lies in the western part of the snake River Plain east of the Owyhee Mountains. The area includes: 1) the snake River valley ranging in altitude from 700 to $999 \mathrm{~m}$; 2) the plateau ranging from 900 to $2130 \mathrm{~m}$; and the 3 ) eastern portion of the Owyhee uplift with altitudes from 900 to $2560 \mathrm{~m}$ (Rightmire and others, 1976). Both the Bruneau and Snake River valleys are bordered by flat-topped bench plateaus, some of which have been dissected by steep walled canyons and ravines, thus forming buttes. Slopes range from less than 2 percent to vertical (EAR No. 11-010-5-77).

\section{(2) Geology}

The lithology of the area includes Cretaceous age granite rocks, Miocene age rhyolitic rocks, Pliocene age volcanic rocks, and the Idaho Group of $\mathrm{Pl}$ iocene and Pleistocene age. The mountainous region is composed of granite core overlain by younger igneous and sedimentary rocks. Mineralized rhyolitic core, overlain by a similar sequence of rocks, characterizes the rolling upland areas. Foothill and lowland areas consist of poorly consolidated sedimentary formations interspersed with basaltic lava. 


\section{Bruneau-Grandview Study Area}

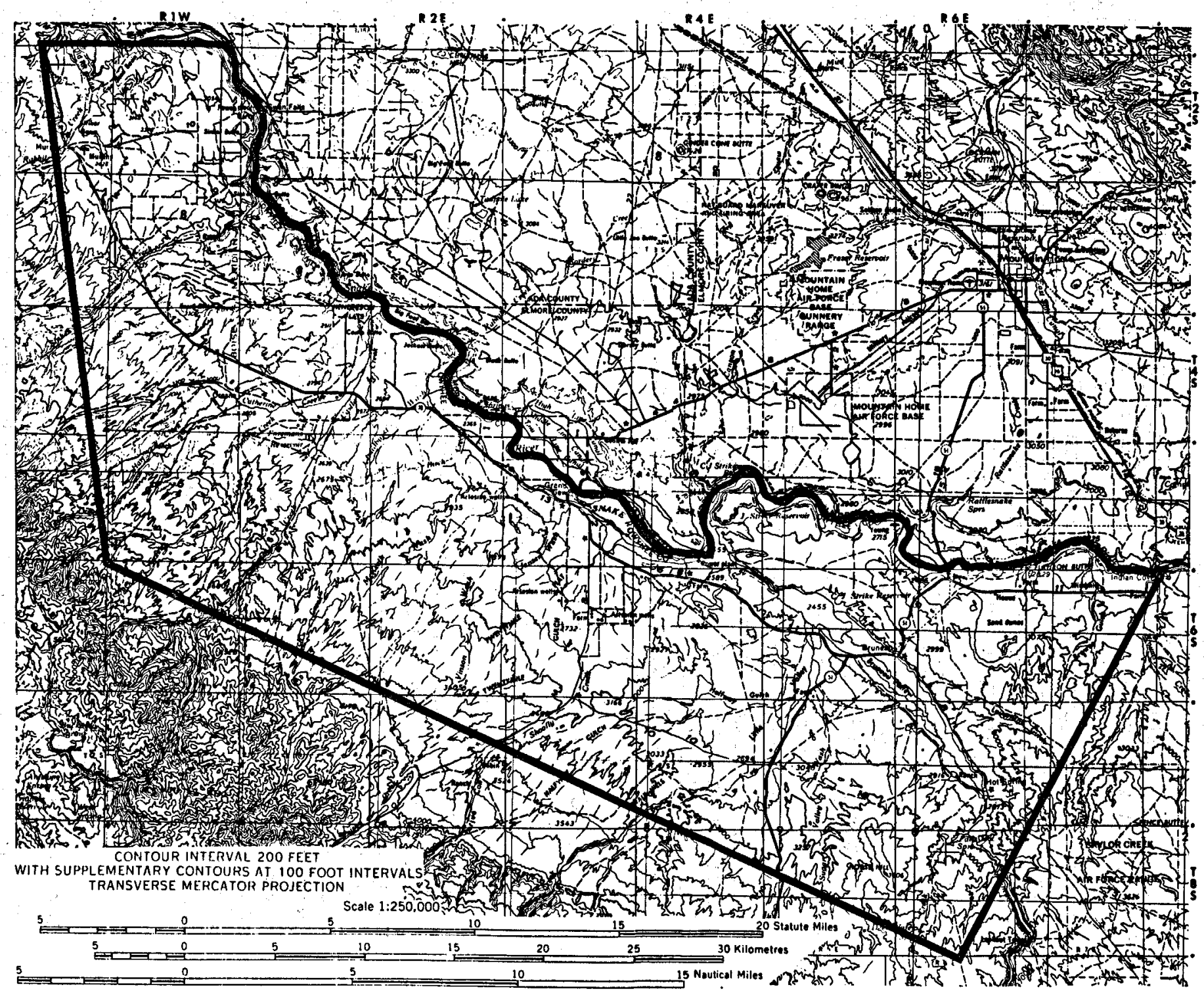




\section{(3) Soils}

The soils in the area of the Bruneau KGRA (known geothermal resource area) are primarily developing in mixed alluvium and lacustrine sediments on stream bottoms, alluvial fans and terrace escarpments. These soils are deep, with few areas that are shallow. Surface textures are dominated by siltloam and loam with minor areas of fine sandy loam, cobbly sandy loam, and silty clay loam. The soils of the area are nearly level to gently sloping, with few steep slopes. Mean soil temperature is approximately $9-11^{\circ} \mathrm{C}$ with the frost-free period greater than 120 days (BLM, 1977).

\section{d. Water Resources}

\section{(1) Surface}

The study area lies primarily in the Bruneau River drainage basin which rises in Nevada's Jarbidge Mountains and flows in a northerly direction to the Snake River in Idaho. The main water sources for agricultural purposes are groundwater and water taken from the Snake River and C.J. Strike Reservoir. Additionally, intermittent feeder streams are used for irrigation and agricultural purposes. The snake River comprises the entire northern border of the Bruneau-Grand view study area. The Bruneau River drainage area above Hot Spring, Idaho, measures approximately $6810 \mathrm{~km}^{2}$ with a mean altitude of $1710 \mathrm{~m}$.

The Bruneau River gaging station near Hot Spring yields an average discharge over 38 years of 11.3 $\mathrm{m}^{3} / \mathrm{s}$ with extremes of $0.71 \mathrm{~m}^{3} / \mathrm{s}$ and $184 \mathrm{~m}^{3} / \mathrm{s}$ for 1964 and 1910, respectively. Water quality for 1975-1976 sampling season are as follows: 1) mean conductivity 198 umhos/cm (standard deviation $\lfloor s . d\rfloor=97$.$) , 2) mean \mathrm{pH} 7.5$ (s.d.= 1.3); 3) mean hardness $45 \mathrm{mg} / 1$; 4) mean dissolved solids 121 $\mathrm{mg} / 1$ (average of 2 sampling periods only); and 5) alkalinity $64 \mathrm{mg} / 1 \mathrm{CaCO}_{3}$. The Bruneau River is under consideration by Congress for addition to the National Wild and Scenic Rivers system, created to assure a heritage of protected waterways.

The Snake River gaging station located near Murphy in the northwestern portion of the study region yielded an average discharge over 63 years of $314.4 \mathrm{~m} / \mathrm{s}$ with extremes of $110 \mathrm{~m}^{3} / \mathrm{s}$ and $1340 \mathrm{~m}^{3} / \mathrm{s}$ recorded for 1949 and 1918, respectively. Mean water quality data for the 1975-1976 sampling season are as follows: 1) conductivity 460 umbos $/ \mathrm{cm}(\mathrm{s} . \mathrm{d} .=53) ; 2) \mathrm{pH} 6.4$ (one sample only); 3) haraness $175 \mathrm{mg} / 1$ ( 2 samples only); 4) dissolved solids 281 $\mathrm{mg} / 1$ ( 2 samples only); and 5) alkalinity $161 \mathrm{mg} / 1 \mathrm{CaCO}_{3}$ (2 samples only). 


\section{(2) Groundwater}

Groundwater resources in the Murphy area have not been developed on a major scale, while both shallow and deep aquifers have been developed in the Grand View area. However, the major development has occurred in the Bruneau region where the deep aquifer has been extensively developed by irrigation wells.

The source of groundwater in the Murphy area is thought to be precipitation on the Owyhee Mountains, with local precipitation making only a small contribution to groundwater recharge. Aquifers in the Murphy area include the Poison Creek Formation, Banbury Basalt, Glenns Ferry Formation, and Bruneau Basalt. Water level decline or well interference have not been reported in the area. The temperature of the groundwater ranges from 21 to $32^{\circ} \mathrm{C}$. Water quality ranges from poor from the sediments to good from basalt (Ralston and Chapman, 1969).

The groundwater resources in the Grand View area have been developed for both domestic and irrigation usage. The three aquifer systems of importance in the area are: 1) a hot artesian. system in the Tertiary silicic Volcanics; 2) a warm artesian system in the sediments of the Idaho Formation; and 3) a cold water table system in the alluvium and upper portion of the Idaho Formation. The source of groundwater to the deep aquifers is primarily Owyhee Mountains precipitation while some water is recharged from streams flowing over fractured outcrops of the Banbury Basalt. Recharge to the shallow aquifer is directly from precipitation, canal seepage, and sewage and irrigation effluent (Ralston and Chapman, 1969). Wells in the Grand View area include shallow domestic, irrigation, and unused flowing wells. Shallow domestic wells along the Snake River are characteristically less than $15 \mathrm{~m}$ deep. It is thought that some of these wells located near Grand View may experience degradation of water quality due to sewage disposal methods. Irrigation well depth varies from 30 to $1097 \mathrm{~m}$, with 50 percent of the wells penetrating the hot ( 52 to $66^{\circ} \mathrm{C}$ ) artesian groundwater system. Unused flowing wells range in temperature from 27 to $38^{\circ} \mathrm{C}$. Declines in water levels in wells of less than $152 \mathrm{~m}$ have been reported, indicating that groundwater recharge is not keeping pace with consumption of the resource. Water quality in the area varies, with TDS (total dissolved solids) content ranging from $190-334 \mathrm{mg} / 1$.

The source of groundwater in the Bruneau area is thought to be recharge from the Owyhee Mountains and Owyhee Uplift. The geologic formations important as aquifers include: 1) Tertiary Silicic Volcanics; 2) Banbury Basalt; and 3) the Glenns Ferry Formation. Irrigation well 
depths vary from 213 to $640 \mathrm{~m}$ and exhibit discharges from 6 to 158 lps. Domestic well depths are less than $152 \mathrm{~m}$ with their prime water source the Glenns Ferry Formation. Annual water level declines have been recorded from 1966 to the present in Little Valley but not in Bruneau Valley. Total dissolved solids for the area range from 200 to $400 \mathrm{mg} / \mathrm{l}$. The thermal groundwater has excessive concentrations of Eluorides (Ralston and Chapman, 1969).

In general, groundwater in the BruneauGrand View area is derived from Owyhee Mountains rainfall, with a portion being heated at great depths. Due to this thermal effect, higher than normal salinities render the water only fair for irrigation purposes. Soils in the area tend to be fine grained; thus leaching of salts from the soil is limited.

\section{Natural Environment}

\section{a. Flora}

The five vegetative communities in the area include: 1) streamside; 2) sagebrush-grass; 3) shadscalegrass, 4) annual grass and 5) crested wheatgrass seedlings. It is felt that overgrazing disrupted natural sagebrushgrass ecosystems, with resultant invasion by less productive annual grasses such as cheatgrass. The ecosystem is now dominated by an overstory of big sagebrush with an understory of cheatgrass brome (Bromus tectorum). Other species include Indian ricegrass (Oryzopsis sp.), bottlebrush squirreltail (Sitanion sp.) and Sandberg bluegrass (Poa secunda). The shadscale-grass ecosystem is dominated by shadscale (Atriplex confertifolia) with an understory of cheatgrass. The annual grass system exists as a function of fire-altered shrub-grass ecosystems. Characteristic species include cheatgrass and tumble mustard (sisymbrium altissimum). Crested wheatgrass (Agropyron desertorum) has been introduced following overgrazing and range fires to prevent erosion and promote livestock grazing. The streamside vegetation includes willows (Salix sp.), cottonwood (Populus sp.), wild rose (Rosa woodsii), golden gooseberry (Ribes grossularia), chokecherry, poison ivy (Roxicodendron radicans), elderberries (Sambucus coerulea), currants (Ribes satiuum), honeysuckle (Lonicera sp.), yellow foxtail (Alopecurus sp.), sagebrush, grasses, and yarrow.

\section{b. Fauna}

A large variety of wildlife inhabits the area, including ruminants, large predators, song birds, raptors, reptiles, and waterfowl and upland game birds. Mammal species include (but are not limited to) the mule deer, pronghorn antelope (Antilocarpa americana), yellow bellied 
marmot, coyotes, bobcats, jackrabbits (Lepus townsendii), ground squirrels, and mice (Perognathus sp., Reithrodontomys sp., and Peromyscus sp.). Numerous passeritormes are found in the area. Raptors include (but are not limited to) the bald eagle, golden eagle, prairie falcon (Falco mexicanus), red-tailed hawk (Buteo jamaicensis), and great horned owl (Buteo virginianus). Waterfowl include Canadian geese (Branta canadensis) and Mallard ducks, Representative game species are chukars, Hungarian partridge, and pheasant. Reptiles include numerous snakes, frogs, and lizards; rattlesnakes are very common.

Little is known of energy flow through the food web; however, the diversity and abundance of plant and animal species indicate a complex, rather stable ecosystem with all major ecological compartments well represented.

\section{c. Aquatics}

Abundant plant and animal species occur within streams of the study area. Trout and whitefish are found in the Bruneau River. Additionally, area streams support warm water fish populations, of which largemouth bass, bluegill (Lepomis macrochirus), yellow perch (Perca flavescens) and channel catfish are representative. Insect species include caddisflies (Trichoptera), mayflies (Ephemeroptera), stone flies (Plecoptera), and snails (scientific taxa not known). Aquatic flora are abundant, including several algal species, cattail (Typha sp.), duckweed (Lemna sp.), and spike rush (Eleocharis sp.).

\section{Cultural Environment}

\section{a. Land Use}

The land in the area is owned primarily by the Bureau of Land Management (BLM) which administers 77 percent of Owyhee County's 1,975,256 ha, 7 percent is state owned, and 16 percent is owned privately. Irrigated land in the area is very limited (approximately 18,650 ha) and is adjacent to the Snake River, Bruneau River, or Little valley Creek with the major crops being potatoes, alfalfa, sugar beets, corn, and small grains. Little arable land exists in the Bruneau-Grand View area and is found only along the Snake River, Little Valley Creek, and Bruneau River. Approximately 37,300 ha east and west of Bruneau have been identified as a proposed area for new irrigation development between 1974 and 2020 (BLM, 1976). Ninety-three point five percent of Owyhee County is utilized for rangeland, 2.1 percent is forest land, and 3.9 percent is agricultural land. 


\section{b. Socioeconomics and Demography}

Owyhee County, with 7900 persons in 1976, comprises less than one percent of the state's total population. Both the birth and fertility rates exceed those for the state and nation. In 1976, 5.5 percent of the labor force was unemployed. Employment data report that 2,512 people were employed in 1975. The greatest number of people are employed as farm labor, followed by state and local government, trade, and services. Median family income in 1976 was $\$ 7,875$. A total of 235 criminal offenses was reported for 1976, 74 percent of which were attributable to larceny. Suicide rates were quite high in 1975: 165 percent of the state rate. Marriage and divorce rates are both low, only 37 percent and 19 percent of state values, respectively.

\section{c. Archaeological and Historical}

The Oregon Trail runs through the study area south of the Snake River, with wagon wheel ruts still evident in many areas. Silver mining in the $1860^{\prime} \mathrm{s}$ in Owyhee County was responsible for the first large-scale permanent settlement in the state, with farming, banking, and commerce responding to the population growth (BLM, 1976).

\section{d. Aesthetic Values}

The C.J. Strike Recreation Area lies within the study region; however, no wilderness or Rare II regions have been designated. The Bruneau Dunes state Park is also located within the study area and is used for recreational purposes.

A significant feature in the study area is the Snake River Birds of Prey Natural Area (BPNA), established by the secretary of the Interior in 1971 to protect eagles, hawks, owls, falcons, vultures, and ospreys. The BPNA encompasses 12,546 ha, 10,522 ha of which is federally owned. The excellent raptor habitat is provided by the rugged river canyon and is utilized as a recreational resource by large numbers of visitors. For the 14 species of raptors sighted at the BPNA, the BLM protects vital habitat and nesting grounds.

D. MOUNTAIN HOME

1. Physical Environment

$$
\text { a. Climate }
$$

Mountain Home is located in Elmore County in southwestern Idaho in a semiarid region characterized by hot 


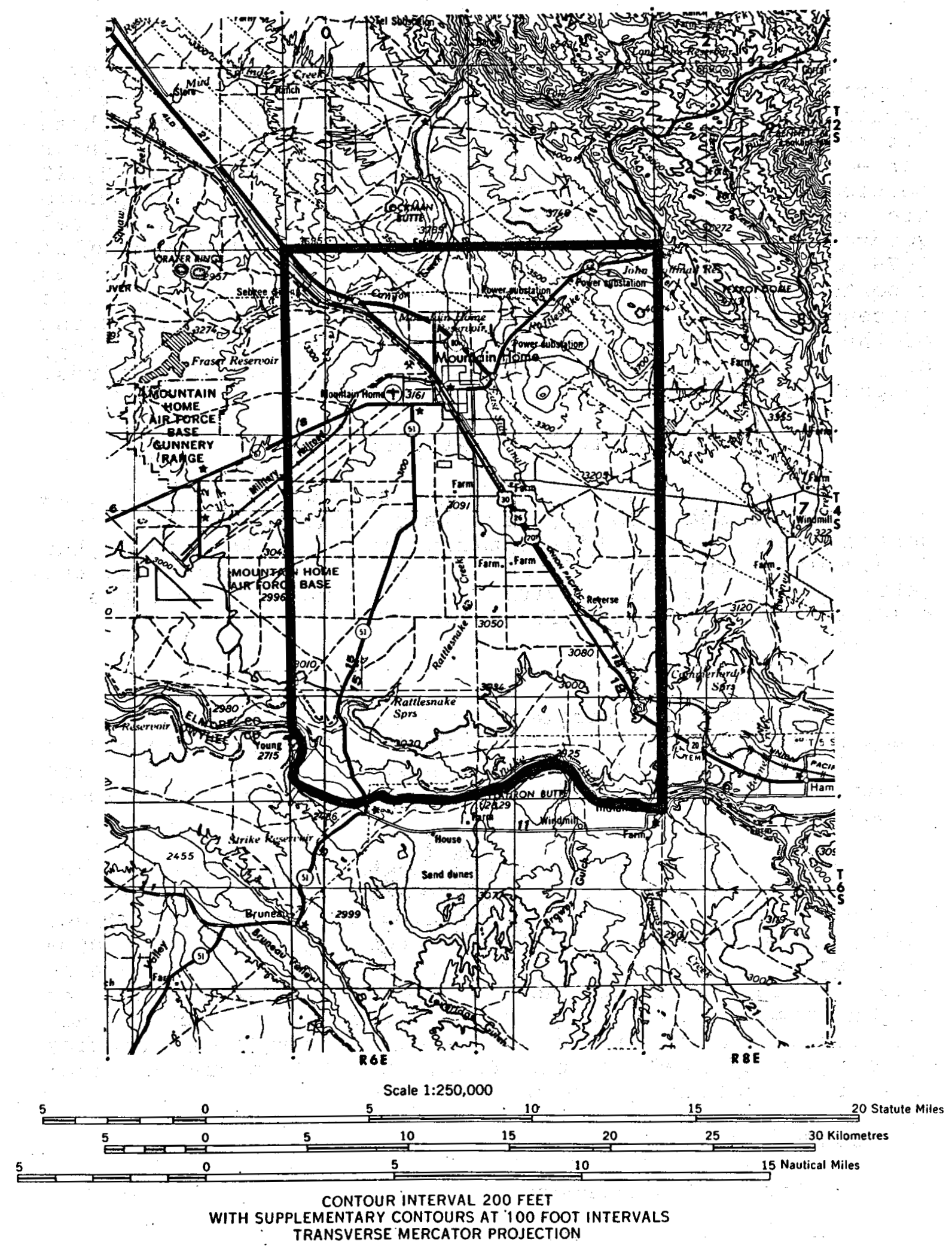

D. Mountain Home Study Area 
summers and cool winters. The average annual temperature is approximately $10^{\circ} \mathrm{C}$ with the mean annual precipitation estimated as $24 \mathrm{~cm}$. Extreme recorded temperatures are -37 and $43^{\circ} \mathrm{C}$.

\section{b. Air Quality}

Prevailing wind currents are from the northwest; east, or southeast. Wind speeds average less than $9.6 \mathrm{~km} / \mathrm{hr}$ (kilometer per hour) 39 percent of time and $11-24 \mathrm{~km} / \mathrm{hr} 41$ percent of the time (Longyear and others, 1978). Air quality is considered very good, with agricultural particulates contributing to the ambient air load during certain seasons. No significant point sources exist for $\mathrm{NO}_{x}, \mathrm{SO}_{\mathrm{x}}$ hydrocarbons or Co; thus preservation of air quality is an important consideration in the area.

\section{c. Land Resources}

\section{(1) Topography}

The Mountain Home area lies north of the Snake River in the western part of the Snake River Plain. Geographic features in the area include: 1) the Mt. Bennett Hills, 2) the Mountain Home Plateau, and 3) the Snake River Canyon. The Mt. Bennett Hills are a high relief mountain range north of the city of Mountain Home, with an average elevation of $1828 \mathrm{~m}$. The Plateau ranges from $1219 \mathrm{~m}$ adjacent to the Mt. Bennett Hills to $914 \mathrm{~m}$ near the snake River. The Snake River Canyon drops $91-152 \mathrm{~m}$ below the plateau to the Snake River.

\section{(2) Geology}

The study area is located between the central Idaho Tertiary and cretaceous granitics and the Tertiary and Quaternary rocks of the Snake River plain to the west. Mountain Home lies on the northwest-southeast trending fault that marks the relatively abrupt transition zone northwest of the KGRA near Boise. The major hot springs in the area are controlled by faulting. The lithologic types found in the Mountain Home area are Pliocene and Pleistocene sediments, Pleistocene Basalts, and Tertiary silicic volcanics overlying cretaceous granite. The silicic volcanics are Miocene Rhyolites. The Idavada volcanics underlying the Idaho group are considered to be the most important aquifer and the source of hot water. The Idavada volcanics are lower silicic volcanics, and generally the water produced from the complex are at significantly higher temperatures than those at nearby wells from overlying units. 


\section{(3) Soils}

Only limited, generalized soil data are available (BLM, 1976) to assess soil types and characteristics. The frost free season is approximately 120-140 days. Agricultural products include cereals, alfalfa, and potatoes, with 70 percent of such crops irrigated. Surface soils are primarily silt loam on clay or silt loam with profile depths ranging from 3 to $18 \mathrm{~m}$. Parent materials include loess, a basic igneous rock ( 35 percent), and alluvium ( 45 percent). Water retention capabilities range from low on the surface to good at greater depths. Major soil problems are associated with drought, erosion, soil alkalinity, and inability of roots and water to penetrate clay subsoils. . Rangeland management is currently employed to minimize problems associated with erosion.

\section{d. Water Resources}

\section{(1) Surface Water}

The Snake River comprises the entire southern boundary of the study area. An important surface water feature is Canyon Creek, which flows southwesterly from Long Tom Reservoir to the Snake River; however, no water quality data are available for either the reservoir or river.: Surface runoff-from the Mt. Bennett Hills is ultimately to Canyon Creek and is regulated by Long Tom Reservoir. Irrigation waters are drawn from the Mountain Home Feeder Canal, Canyon Creek, Rattlesnake Creek, Bennett Creek, Cold Springs Creek and King Hill Creek. Data for the Murphy gaging station on the Snake River are included in the Bruneau-Grand View section of this report.

\section{(2) Groundwater}

Groundwater resources have been developed for both domestic and irrigation purposes. Ralston and Chapman (1968) studied the hydrology of the Mountain Home area and subdivided the region into five areas based on water levels, we $1 \perp$ yield, water temperature, water quality, geologic character of the aquifer. The subdivisions are summarized as follows: 1) the Mt. Bennett Hills subarea, 2) Hot Springs, 3) Mountain Home, 4) Air Base, and 5) Glenns Ferry.

The Mt. Bennett Hills region is the primary area for recharge to the Mountain Home plateau aquifers.

The Hot Springs region runs along the Mt. Bennett Hills and includes a hot artesian groundwater system. Hot Springs has an estimated natural discharge of 35 lps with a mean temperature of $66^{\circ} \mathrm{C}$. Groundwater 
recharge is thought to be from precipitation, irrigation seepage and streamflow; however, little of the recharge enters the warm water system. Hot water $\left(38-71^{\circ} \mathrm{C}\right)$ has been reported at three locations at three water level elevations, indicating a series of subparallel northwest trending faults. The faults are believed to allow the downward flow of cold recharge water and the upward flow of heated water and steam. The cold groundwater system is limited in the region.

The Mountain Home area surrounds the city of Mountain Home with both domestic and irrigation water derived from the aquifer. sources of recharge include precipitation, streamflow, irrigation seepage, and sewage effluent. The aquifer has been well developed for both irrigation and domestic purposes, with wells ranging in depth from $1.8-183 \mathrm{~m}$.

The Air Base area (adjacent on the west side of the Mountain Home areal includes the groundwater systeln south and west of Mountain Home as well as the deep wells developed in the city of Mountain Home. Recharge to the area is limited as a function of low precipitation and the deep static water level. An estimate of well development puts the number of wells for irrigation, municipal, and domestic use at 50 , ranging in depth from $122-274 \mathrm{~m}$. Water temperatures are generally uniform, in the $21-24^{\circ} \mathrm{C}$ Range.

The Glenns Ferry area (adjacent on the east side of the Mountain Home area) is north of the Snake River and surrounds the towns of Hammett and Glenns Ferry. Groundwater recharge within the area is minimal, with streamflow, irrigation seepage, and precipitation as sources. Groundwater resources have not been extensively developed, with most wells located along the snake River, ranging in depth from $3-439 \mathrm{~m}$. Shallow wells tap the cold water aquifer while deeper wells penetrate the warm (70-1000 F) aquifer system. Indications are that a deep groundwater gradient towards the snake River exists, with aquifers discharging into the river.

In summary, the main sources of groundwater are the Bruneau and Glenns Ferry Formations with their basalts and fine-grained sediments, respectively. Available records do not indicate declines in groundwater levels; however, data are limited.

2. Natural Environment

a. Flora

The study region is characterized by modified sagebrush-grass communities, typically found along unculti- 
vated portions of the Snake River Plain. Annual grasses found with sagebrush include Western cheatgrass, filagree (Erodium cicutarium), balsamroot (Balsamorhiza hookere). Shadscale is found on saline or heavier soils. Crested wheatgrass is common. Information indicates that three plants on the endangered or threatened list have been found in the western portion of the snake River Plain: Henderson's desert parsley (Lomatium hendersonnii), loco weed (Astrogalus comptopus) and pepper grass (Lepidium montanum), however, it is not known if these species are in the Mountain Home study area. Juniper (Juniperus sp.) trees are found within the Snake River canyon. Greasewood and rabbitbrush are found adjacent to streams, ponds, and river.

\section{b. Fauna}

Examples of animal species that inhabit the sagebrush-grass communities include Richardson's ground squirrel (Citellus richardsonii), kangaroo rat (Dipodomys sp.), sagebrush vole (Lagurus curtatus), jackrabbit, mule deer, pronghorn antelope, golden eagle, Swainson's hawk (Buteo swainsoni), and sparrow hawk (Falco sparverius). Game birds include sage grouse (Centrocercus urophasianus), chukar, pheasant, and mourning dove (Zenaidura macroura). Reptiles include sagebrush lizard (Sceloporus graciosus) and striped whipsnake (Masticophis taeniatus).

\section{c. Aquatics}

The variety in habitat types renders the area suitable to diverse and abundant aquatic communities. Both native and introduced $f$ ish species are found in the snake River. Native species include rainbow trout, cutthroat trout, and mountain whitefish. Introduced species include brown trout (Salmo trutta), largemouth bass, bluegill, channel catfish, carp, and suckers. Freshwater clams and molluscs are expected to occur in the Snake River since a diverse variety of habitats are available. Insect species include mayflies, midges (Piptera), caddisflies, and beetles (Coleoptera).

3. Cultural Environment

\section{a. Land Use}

Land in the Mountain Home study area comprises approximately 55,944 ha, of which 18,648 ha is federally owned (BLM), 9,324 ha is state owned, and 27,972 ha is under private ownership. The area was heavily grazed by sheep prior to the advent of high lift pump irrigation practices which rendered such ventures profitable. Land use within Elmore County in 1976 was as follows: 66 percent rangeland, 26 percent forest land, 7 percent agricultural land, 1 percent water, and 0.6 percent urban or built-up. 


\section{b. Socioeconomics and Demography}

The Mountain Home study area is located entirely within Elmore County, with socioeconomic data available only on a county-wide basis. The population of Elmore county was 19,500 people in 1976 , or 2.34 percent of Idaho's total. The population density increased from $5.7 \mathrm{~km}^{2}$ in 1950 to $16.6 / \mathrm{km}^{2}$ in 1976. The birth rate for the county was 28.0 in 1975, as compared with a state rate of 19.8. The fertility rate is quite $h i g h, 127.9$ in 1975 as compared to Idaho and U.S. rates of 92.0 and 66.7 , respectively.

Unemployment is steadily rising; the 1970 average was 3.9 percent and rose to 7.4 percent in 1976 . Wage and salary employment indicate the greatest number of people are employed by the military (Mountain Home Air Force Base employed 3,935 people in 1975); followed by federal civilians $(1,027)$; trade $(808)$; state and local government (786): farm (636) and services (389); trade, commerce and public utilities (276); and finance, insurance and real estate (203). The 1976 HUD (Housing and Urban Development) estimate for the median family income was $\$ 10,125$.

Health care in the county is comparatively poor. The average number of persons per medical doctor was 4,950 in Elmore County for 1975, as compared to 969 for the state average. Two hospitals are located in the county with 77 acute care beds.

Criminal oftenses rose trom 464 in 1973 to 555 in 1976. In both years, larceny was the prime ottense and rose from 63 to 71 percent of the total offenses. No murders were reported in 1973 with two committed in 1976. The suicide rate of $15.2 / 100,000$ persons in 1975 was very close to the state rate of 16.4/100,000.

\section{c. Archaeological and Historical}

Both the Oregon Trail and Kelton Road are historical markers of importance in the Mountain Home study area and run through the northeast portion of the region. There is no archaeological survey recorded; however, the probability of archaeological sites is very high and likely cover a time span ranging from prehistoric times to the present.

\section{d. Aesthetic Values}

A rural and open space atmosphere predominates in the study area. Mountains to the north and the Snake River plain to the south and east comprise the scenery. Island crossing state Park is located within the region and has facilities for overnight camping. No wilderness or Rare II lands are found within the Mountain Home area of concern. 
E. BLUE GULCh, TWIN FALLS, AND ARTESIAN CITY

1. Physica $\perp$ Environment

a. Climate

Normal annual precipitation ranges from $20 \mathrm{~cm}$ in the Blue Gulch area to $30 \mathrm{~cm}$ near Artesian City. With only $20 \mathrm{~cm}$ of precipitation, the Blue Gulch area is one of the driest parts of the Snake River plain. Most of the precipitation in the area falls as snow during the winter months. The source of this precipitation is storms originating off the Pacific Coast; as a result, rain and snowfall patterns are erratic. Summers are generally warm and dry, with mean temperatures of $21^{\circ} \mathrm{C}$ and ranges of -6 to $36^{\circ} \mathrm{C}$. Although local wind patterns are affected by topography, winter winds are generally southeast winds, while summer winds generally trend from the northwest.

\section{b. Air Quality}

Air quality in this part of the snake River Plain is good, although particulates are sometimes high in a general area north and east of Blue Gulch. There are no large point sources of significant air pollution in the area, even near Twin Falls. The annual geometric mean particulate level at two stations in Twin Falls in the period from 1971 to 1974 averaged $94 \mu \mathrm{g} / \mathrm{m}^{3}$ during the same period.

\section{c. Land Resources}

\section{(1) Topography}

The three areas under consideration lie on the southern edge of the snake River Plain and are bounded on the north by the canyon of the Snake River. Elevations range from $880 \mathrm{~m}$ at the mouth of Salmon Falls Creek to 1275 m at Artesian City. The Blue Gulch and Twin Falls areas are relatively flat with gradients of approximately $12 \mathrm{~m} / \mathrm{km}$. Artesian City lies at the base of the foothills of the Rock Creek Hills. Monument Peak, $32 \mathrm{~km}$ south of Artesian City, has an elevation of $2400 \mathrm{~m}$.

\section{(2) Geology}

Blue Gulch, Twin Falls, and Artesian City lie in the eastern Snake River Plain geomorphic province. This area is geologically unique, characterized by horizontal flows of basalt. The surface of the plain is a youthful lava plateau partially. covered with loess. Basalt flows on the plain can be classified in two age groups: older Miocene-Pliocene and younger Pliocene-Recent. Surface flows 


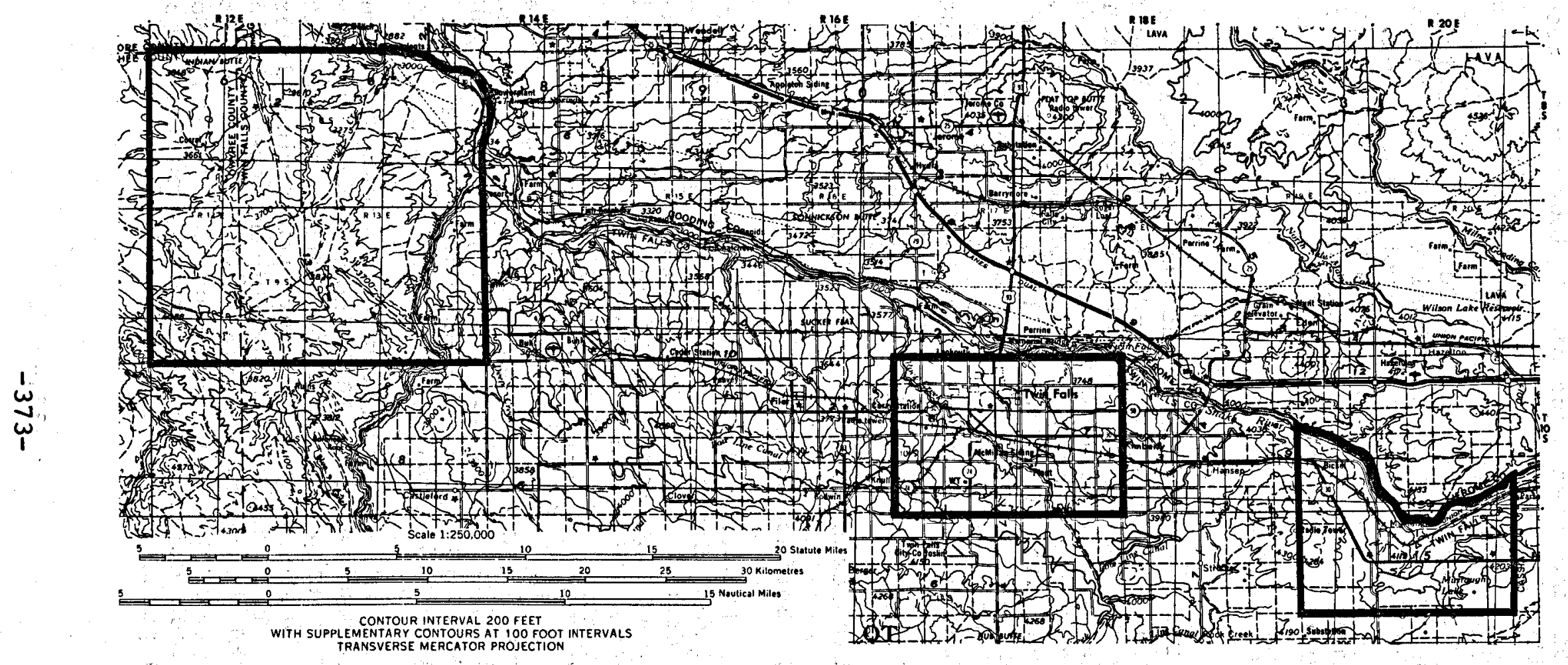

E. Blue Gulch, Twin Falls, and Artesian City study Areas 
through most of the area consist of lower pleistocene to Pliocene basalts and associated tuffs. A small area of Pliocene olivine basalts occurs along the canyon of the Snake River from Twin Falls to the mouth of salmon Falls Creek. Some pleistócene and Pliocene colluvium, fanglomerate, and stream and lake deposits overlie the basalts northwest of the lower portion of Salmon Falls creek. Major faults occur in two locations: parallel to the Snake River across the Salmon Falls Creek Canyon and trending north and northwest along the northern edge of the Rock Creek Hills.

\section{(3) Soils}

Soils throughout the area consist primarily of loess of varying depths over basalts. Mineral fertility is generally high but organic content is low. Along stream valleys, alluvial deposits overlie alluvial outwash from mountains to the south. Siltloams, ranging in depth from 25 $\mathrm{cm}$ to $150 \mathrm{~cm}$, overlie bedrock on gentle to moderate slopes in both the Blue Gulch and Twin Falls areas. Forty percent of soils in the Artesian City area are a fine-loamy mixed soil while 20 percent are a fine montmorillontic soil. These soils range in depth from $40 \mathrm{~cm}$ to $100 \mathrm{~cm}$. Permeabilities in all soils range from slow to moderate and the most significant soil problem is erosion.

\section{d. Watex Resources}

\section{(1) Surface water}

Primary streains in the areas under consideration include: Snake River, Salmon Falls creek, Rock Creek, and Dry Creek. Salmon Falls Creek flows through the Blue Gulch area to the snake River and drains an estimated $5490 \mathrm{~km}^{2}$ of Idaho and Nevada. Flow in the creek is regulated at the Salmon Creek Reservoir $71 \mathrm{~km}$ upstrearn from the mouth. Except for significant leakage all of the water supply above this dam is diverted for irrigation. Diversions below the dam are used to irrigate land outside the drainage basin. Average discharge at the mouth of Salmon Falls creek is $4.87 \mathrm{~m} 3 / \mathrm{s}$ and extremes at this point are $0.34 \mathrm{~m}^{3} / \mathrm{s}$ and $38.5 \mathrm{~m}^{3} / \mathrm{s}$.

Rock Creek drains an estinated $483 \mathrm{~km}^{2}$ and discharges to the Snake River $10 \mathrm{~km}$ northwest of Twin Falls. Flow in the creek is partially regulated by a fish hatchery and irrigation waste flow and many irrigation diversions exist upstream. The mean discharge for the creek during the period of record ( 1 year) is $6.6 \mathrm{~m} 3 / \mathrm{s}$, and the extremes during this period were $2.6 \mathrm{~m}^{3} / \mathrm{s}$ and $13.5 \mathrm{~m} 3 / \mathrm{s}$. Monthly Elows in the creek during that year differed from the nean by less than 50 percent. 
During low flow years, all flow is topped in the Snake River at Milner Dam, $19 \mathrm{~km}$ northeast of Artesian City. The largest inflow below the dam is Thousand Springs which contributes an estimated $184 \mathrm{~m}^{3} / \mathrm{s}$ to the river as inflow from the snake River Plain aquifer. The water quality of the snake River declines gradually as it flows west through the area receiving pollutants from agricultural activity, industrial processing plants, and untreated domestic water return. Twin Falls has been listed by the EPA as needing improved waste treatment facilities. Nitrate and phosphate in the river from natural and manmade sources contribute to periodic excessive algal and weed growth. The only lake occurring in the area is Murtaugh Lake in the Artesian City area. This manmade lake is on Dry Creek and has a surface area of approximately 250 ha. Surface water quality for streams in the area is shown in Table E-l.

\begin{tabular}{|c|c|c|c|}
\hline & $\begin{array}{r}\text { TABLE E- } \\
\text { URFACE WATER } \\
(\mathrm{mg} / \mathrm{l}) \\
\end{array}$ & LITY & \\
\hline & $\begin{array}{c}\text { Salmon Falls } \\
\text { Creek }\end{array}$ & $\begin{array}{l}\text { Snake River } \\
\text { (Kimberly) }\end{array}$ & $\begin{array}{l}\text { Snake River } \\
\text { (King Hill) }\end{array}$ \\
\hline $\begin{array}{l}\mathrm{Ca} \\
\mathrm{K} \\
\mathrm{Mg} \\
\mathrm{Na} \\
\mathrm{Cl}^{-} \\
\mathrm{F}^{-} \\
\mathrm{HCO}_{\overline{3}}^{-} \\
\mathrm{TDS}_{4} \\
\mathrm{TSS} \text { (Total Suspended }\end{array}$ & $\begin{array}{l}70 \\
7.8 \\
23 \\
53 \\
41 \\
0.9 \\
239 \\
111 \\
480 \\
103\end{array}$ & $\begin{array}{c}45 \\
5.2 \\
19 \\
31 \\
24 \\
0.5 \\
200 \\
47 \\
289 \\
-\end{array}$ & $\begin{array}{l}47 \\
-4.5 \\
18 \\
27 \\
23 \\
0.7 \\
187 \\
45 \\
298 \\
27\end{array}$ \\
\hline Specific Conductance & $\begin{array}{r}8.6 \\
766 \\
\end{array}$ & $\begin{array}{r}8.7 \\
468 \\
\end{array}$ & $\begin{array}{r}8.5 \\
434 \\
\end{array}$ \\
\hline
\end{tabular}

\section{(2) Groundwater}

Groundwater occurs in the basalts and alluvial deposits throughout the area. Depths to water range from $24 \mathrm{~m}$ in the Rock Creek Basin to $40 \mathrm{~m}$ at Artesian City, to $50 \mathrm{~m}$ near kimberly, and as much as $240 \mathrm{~m}$ in the Blue Gulch area. The few functioning irrigation wells in the Salmon Falls creek basin are near the salmon Falls Reservoir. Groundwater outflow at Thousand Springs provides water from one of the world's most extensive aquaculture programs. Water from the springs has significantly better quality than surface water or groundwater on the south side of the snake River. 
Because of limited water supply and extensive use of groundwater for irrigation, three areas have been designated critical groundwater areas by the Idaho Department of Water Resources. This designation effectively closes these areas to further applications to appropriate groundwater. The three areas included are:

Artesian City - 14,500 ha (est.) including land in T. 11 and 12 S.. R. 19 and 20 E., B.M. Nearly all land included in the geothermal area of interest is included in the critical groundwater designation.

Cottonwood - 16,000 ha (est.) adjacent to the Artesian City area on the south.

Blue Gulch - 76,000 ha (est.) on the west side of Salmon Falls Creek. All but approximately 2000 ha of the Blue Gulch geothermal area is included in this designation.

2. Natural Environment

a. Flora

Native vegetation in undisturbed areas is classified in the sagebrush association. Primary species found in the area are big sagebrush and cheatgrass. Early records indicate that much of the area was once covered with bunchgrasses and some sagebrush. Heavy use of the area by livestock led to the establishment of the present native species. A small stand of pinion-juniper is located just southeast of Artesian City. Where native vegetation has been disturbed, areas have been reseeded with crested wheatgrass. Much of the land in the areas of interest is currently cultivated.

\section{b. Fauna}

Major habitat areas that have been identified include: deer habitat along the lower $10 \mathrm{~km}$ of Salmon Falls creek, birds of prey habitat along the canyon of the snake River, a curlew habitat area southwest of Twin Falls, and a high density of rough-legged hawks and chukar partridge in the Salmon Falls Creek Canyon. Animals well adapted to the sagebrush habitat include the Richardson ground squirrel, Great Basin kangaroo rat, sage grouse, vesper sparrow, and sagebrush lizard. Year-round residents of the area include the coyote, ground squirrel, blacktail jackrabbit, golden eagle, sparrow hawk, pheasant, house finch, and horned lark. snakes, particularly the western rattlesnake, the pygmy rabbit and the ord kangaroo rat are declining as native habitats are converted to cropland. 


\section{c. Aquatics}

Aquatic plants, including duckweed, cattail, sedge (Carex), and a common reed (Phargmites), are common in streams throughout the area. The snake River has annual extensive algal blooms. Construction of dams on the Snake river has replaced free-flowing habitat preferred by coldwater. game $f$ ish with lake-like situations. Small numbers of rainbow and cutthroat trout are native in this stretch of the river. Suckers and squawfish thrive in the reservoirs. Sixteen species of $\mathrm{E}$ ish have been identified by the Idaho Fish and Game Department in the snake River below Shoshone Falls and eleven species have been identified above. Trout occur in both sections, while coho salmon (Oncorhynchus kisutch) occur only in the upper section. Sunfish (Lepomis sp.), catfish, and sucker are common in the lower section.

\section{Cultural Environment}

\section{a. Land Use}

Arable land occurs on both sides of the snake River and along its tributaries. The Salmon Falls Creek drainage contains an estimated 82,000 ha of arable land. Cultivation of these lands is limited by availability of water. Approximately 80 percent of the croplands in the area are irrigated. Most of the Artesian City area, acreage south of Twin Falls, and the western part of the Blue Gulch area are included in proposed areas for new irrigation development in the next 30 years.

Most of the land being considered is privately owned and used for grazing and crop production. Intermittent areas of private ownership are generally associated with the livestock, industry, mining, and recreation. Approximately 37,300 ha of BLM land, 1550 ha of state land (school endowment), and 4150 ha of private land occur in the Blue Gulch area. No nonprivate land occurs in either the Artesian City or the Twin Falls area. The metropolitan area of Twin Falls includes about $1500 \mathrm{ha}$.

\section{b. Socioeconomics and Demography}

The three areas under consideration are in Twin Falls County, which has a population of 47,300 (1976). Towns included in these areas are Twin Falls (1970 population 21,194), Kimberly $(1970$ population 1,557$)$, and Murtaugh (1970 population 124). The population density of the area is nine people/ $\mathrm{km}^{2}$. The birthrate and fertility rate for the county are 20.6 and 98.8 , respectively, and compare to values of 19.8 and 92.0 for the state and 14.8 and 66.7 for the United states. The number of new housing units authorized annually increased from 85 in 1971 to 221 in 1976 
in Twin Falls and from 1 to 23 in Kimberly during the same period. The unemployment in the county in 1976 was 6.2 percent, an increase of 1.6 percent over the 1970 value. The main employers in the county are trade, services, nonfarm proprietors, and manufacturing. Larceny and burglary accounted for 84 percent of all crimes in 1976.

\section{c. Archaeological and Historical}

This area of Idaho contained great cultural diversity during the late prehistoric and early historic periods. Several distinct Indian groups inhabited the snake River Plain in the recent past. Although only limited archaeological surveys have been conducted in the area, indications are that the western snake River Plain is exceptional in its potential to yield archaeological data of major scientific significance.

Fur trappers were the first white people in the area in any number. Immigration in the 1840's, 1850's, and $1860^{\prime} \mathrm{s}$ brought thousands of people through the area, however, permanent settlements were slow in developing. Farming began in the late 19th century. Historical areas are generally associated with the immigrant trails, and a segment of the Oregon Trail at the mouth of Salmon Falls Creek is being considered for historical status. The only other historic or natural area in this region is the Hagerman Fossil Natural Area established by the BLM in the Blue Gulch area.

\section{d. Aesthetic Values}

Recreational and/or aesthetic sites in the three study regions are diverse. Balance Rock is a scenic anomaly located on Salmon Falls Creek Canyon near Blue Gulch and is quite unusual and picturesque. The Snake River Canyon through Twin Falls plunges with sheer cliffs and dropoffs and is quite magnificant. Murtaugh Lake located near Artesian City is utilized for recreational purposes. As is true for most of Idaho, the open, rolling land and clean, fast rivers afford the viewer a sense of solitude and freedom in an area not yet overpopulated with resultant industrial development and environmental degradation.

\section{F. POCATELLO}

1. Physical Environment

$$
\text { a. Climate }
$$

Pocatello is located in the southeast corner of the Snake River Plain where the climate is a middle-latitude steppe type. Spring months are the wettest and windiest, 


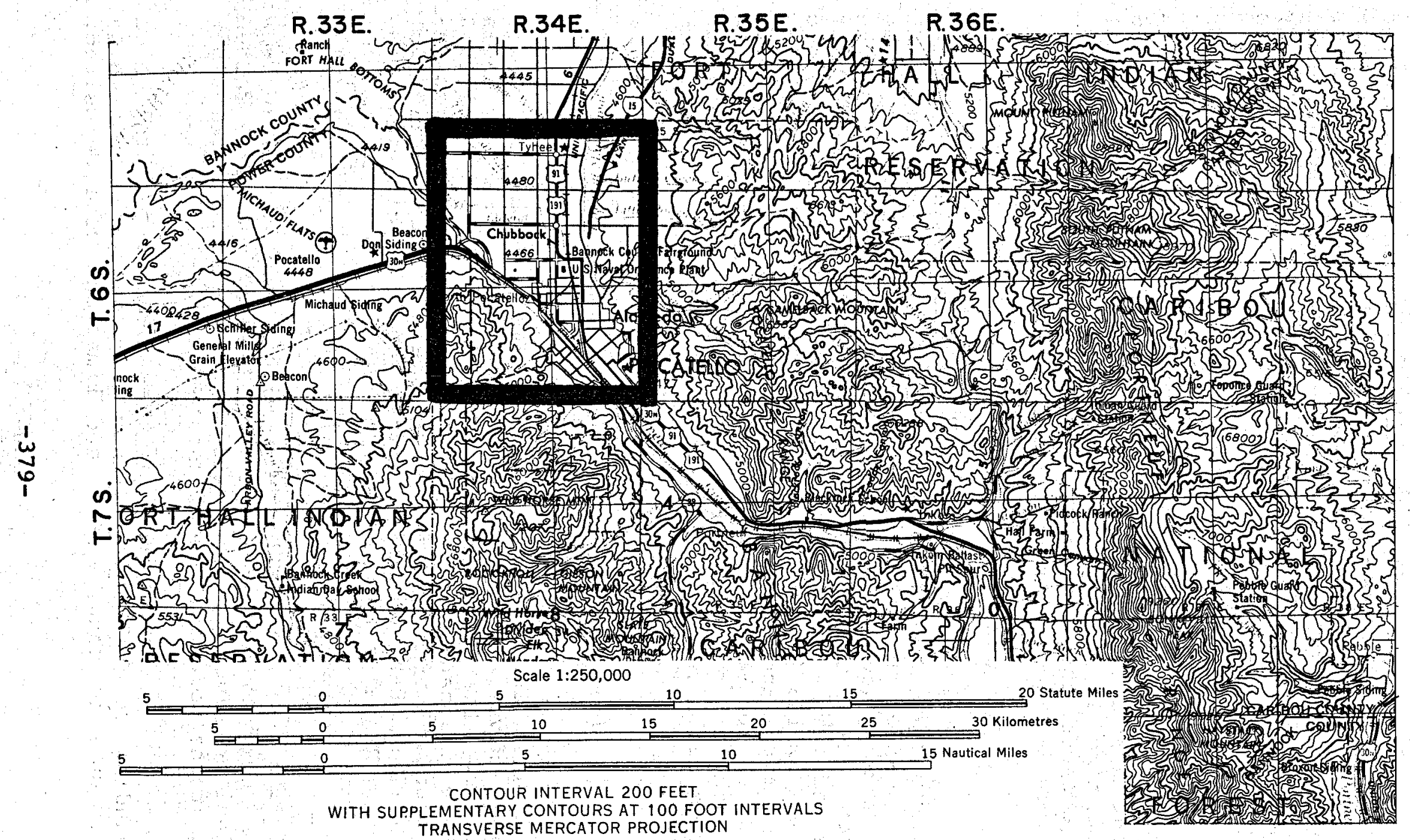

F. Pocatello Study Area 
while cool nights and warm days predominate during the summer. Percent of possible sunshine averages over 80 percent in July, August, and September. General snowcover begins in December and freezing temperatures occur until May. Mean monthly temperatures range from $-4^{\circ} \mathrm{C}$ in $\mathrm{January}$ to $23^{\circ} \mathrm{C}$ in $\mathrm{July}$. Maximum and minimum recorded temperatures are 40 and $-34^{\circ} \mathrm{C}$. Wind directions reflect the orientation of nearby mountain ranges, with over 50 percent of the winds orginating in the southwest quadrant. Thirty percent of wind speeds are less than $2 \mathrm{~m} / \mathrm{s}$, while 5 percent occur within the $2 \mathrm{~m} / \mathrm{s}$ to $6 \mathrm{~m} / \mathrm{s}$ range. Relative humidity exceeds 30 percent only a third of the time during July and only a half of the time in January. Average potential evapotranspiration exceeds the average precipitation all months except November, December, January, and February (USFS, 1977).

$$
\text { b. Air Quality }
$$

The primary sources for air pollution in the Pocatello area are the phosphate and elemental phosphorus plants west of the city. Air quality measurements that have been taken have been directed at characterizing the effluents from these plants. The annual geometric mean of suspended particulates from four Pocatello stations ranged from 41 to $145 \mu \mathrm{g} / \mathrm{m}^{3}$ during the period from 1971 to 1974 . The primary and secondary standards for suspended particulates are exceeded at $1 \mathrm{~km}$ from the plants. During a ten-month period in 1972 and 1973, the 24-hour standard for sulfates was exceeded 14 times.

\section{c. Land Resources}

\section{(1) Topography}

Elevations in the area of interest range from $1700 \mathrm{~m}$ in the southwest to $1340 \mathrm{~m}$ along the lower Portneuf River near its confluence with American Falls Reservoir. The city of Pocatello has an elevation of 1360 $\mathrm{m}$. Here the canyon of the Portneuf River meets the southeast boundary of the snake River plain. The foothills of the Bannock Range are southwest of the city and the Pocatello Range is to the east.

\section{(2) Geology}

Pocatello lies within the margin of the middle Rocky Mountain Province typified by complexly folded and faulted ranges of the extreme southeastern snake River Plain of the Columbia Intermountain Province.

Beginning in the Precambrian, the area surrounding Pocatello lay within a geosyncline into which vast amounts of sand, shale, and limestone were deposited. 
These sediments underwent metamorphism to produce quartzites, argillites, and marbles now exposed in the ranges southeast of Pocatello. During early Paleozoic era a geosyncline reappeared collecting sand shales and Iimestones. The relative coarseness of these sediments exposed suggest that the paleo shoreline was very near the Pocatello area.

Beginning in late Cretaceous, major folding and faulting (including thrust faulting) warped and broke great thicknesses of sediments in southeastern Idaho, moving rock units from west to east. The most noticeable in the area is the Bannock overthrust extending from Idaho Falis southward near Pocatello to the Idaho-Utah border. Subsequently, basin and range structures developed, related to those of the Great Bas in in Utah and Nevada.

At the same time, the introduction of felsic and basaltic lava began on the snake River plain. The tunnel of the newly forming snake River plain cut across the northwest trending landforms developed from Laramide and Basin and Range structures and is now the most prominent physiographic element in the area. By late pliocene, pediment fans began to encroach on the newly developed basins. Concurrently, tension faults allowed lava to again spread across the countryside. The most notable in the area are those flows now exposed at Ross Park in Pocatello. The distribution of these flows with the forthcoming glacial activity prompted damming of the major drainages including the Snake River and the outlet of pluvial Lake Bonneville. Numerous lake bed deposits are identified northwest of pocatello in the area where American Falls Reservoir is now located. To the south, Lake Bonneville was filling due to the increased precipitation and decreased evaporation until the water level overlapped Red Rock Pass. Enormous volumes of water swept down Marsh Creek and the portneuf River to the snake River. As the flood waters entered the snake River Plain, their energy decreased leaving large boulder and gravel deposits which now skirt the foothills and mountains flanking Pocatello.

\section{(3) Soils}

Soils in the pocatello area are generally loess deposited on bedrock of snake River Basalt and the Salt Lake Formation. Slopes of the foothills are moderately stable and depth to bedrock usually exceeds $3 \mathrm{~m}$ throughout the area. Surface soils are primarily silt loams and subsoils range from silty clay loams to heavy silt loams. Natural vegetation occurring on these soils include sagebrush, grasses, and mountain brush. soils near the processing plants west of Pocatello show increased concentrations of trace elements. 


\section{d. Water Resources}

\section{(1) Surface Water}

The Portneuf River is the primary stream in the area, draining approximately $3300 \mathrm{~km}^{2}$. It rises on the Ft. Hall Indian Reservation approximately $38 \mathrm{~km}$ northeast of Pocatello and flows south to Lava Hot springs. Here, it turns west through a gap in the Portneuf Range, then flows north for $18 \mathrm{~km}$. At its confluence with Marsh Creek, the main tributary of the Portneuf, the river turns to the northwest and empties into the American Falls Reservoir. Flows in the river are regulated by the Portneuf Reservoir and the Chesterfield Reservoir. Diversions from the river are used to irrigate an estimated 17,000 ha upstream from Pocatello. The average flow of the Portneuf at Pocatello is $7.6 \mathrm{~m} 3 / \mathrm{s}$ and the extremes during the 63-year period of record are 84.7 and $0.01 \mathrm{~m}^{3} / \mathrm{s}$. In the 1976 water year, 42 percent of the total flow of the river occurred in April and May. Streams draining the Pocatello Range flow into the Fort Hall Main Canal, from which a series of laterals run to the west across the area of interest. Uses of surface water include municipal, industrial, irrigation, domestic use, stock watering, recreational use and power generation. Patterns of streamflow are affected by regulation of supply for these uses.

Quality of the Portneuf River in the area of interest is shown in table $\mathrm{F}-1$. Sources of inflow in this section of the river include an oil separation plant, elemental phosphorus and fertilizer plant effluent, sewage treatment plant, springs, and a fish hatchery. The estimated flow from these sources is $0.5 \mathrm{~m} / \mathrm{s}$.

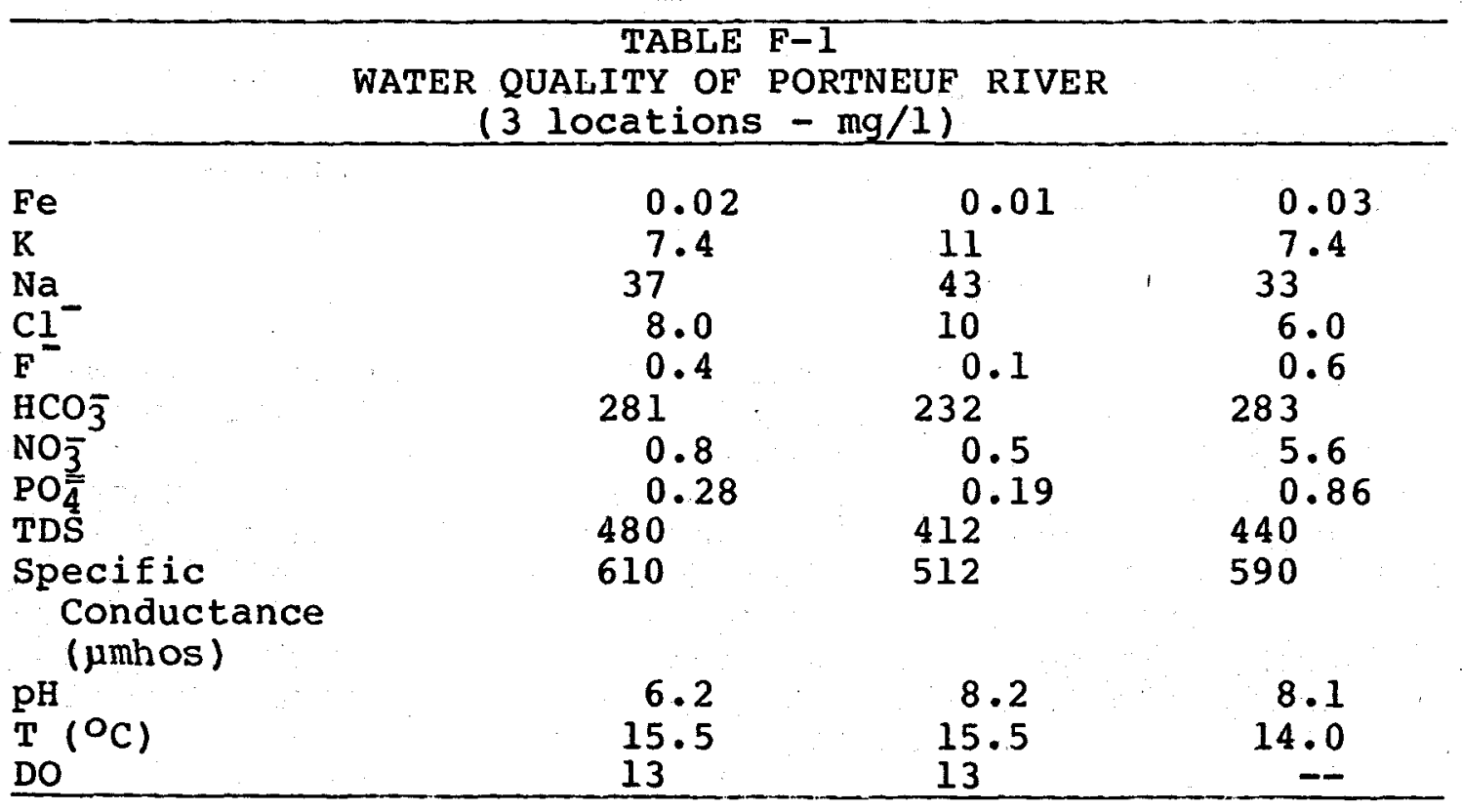




\section{(2) Groundwater}

Groundwater in the Pocatello area occurs in alluvium and alluvial-fan deposits and in the underlying volcanics which range in depth from $30 \mathrm{~m}$ to $120 \mathrm{~m}$. Wells in the alluvium north and northwest of pocatello have yields ranging from 0.06 to $0.19 \mathrm{~m} 3 / \mathrm{s}$ with less than $30 \mathrm{~m}$ of drawdown. Recharge in the flatlands northwest of the city comes from precipitation and underflow from the surrounding hills. There is significant groundwater outflow to the Portneuf River in the Pocatello area. The combined discharge of these springs is approximately $9 \mathrm{~m}^{3} / \mathrm{s}$.

Uses of groundwater include municipal, industrial, irrigation, private residence, and stock supplies. Municipal uses account for withdrawals of about $0.4 \mathrm{~m} / \mathrm{s}$, while withdrawals for the phosphorus and phosphate plants average $0.5 \mathrm{~m} 3 / \mathrm{s}$. Groundwater quality from three wells in the Pocatello area is shown in table F-2. The source of the nitrate in the city wells is unclear, since these wells are several kilometers upstream from the processing plants. In many wells, the total dissolved solids content is higher than the drinking water standard of $500 \mathrm{mg} / \mathrm{l}$.

\begin{tabular}{|c|c|c|c|c|c|c|}
\hline & GROUND & $\begin{array}{l}\text { PABLE F- } \\
\text { DWATER } \\
(\mathrm{mg} / \mathrm{l})\end{array}$ & $\begin{array}{l}-2 \\
\text { 2UALIT }\end{array}$ & & & \\
\hline We 11 & Date & $\begin{array}{l}\text { Dis- } \\
\text { solved } \\
\text { Solids } \\
\end{array}$ & $\begin{array}{c}\text { Cal- } \\
\text { icum }\end{array}$ & $\begin{array}{c}\text { Ni- } \\
\text { trate } \\
\text { as } \mathrm{NO}_{3} \\
\end{array}$ & $\begin{array}{l}\text { Phos- } \\
\text { phate, } \\
\text { as } \mathrm{PO}_{4} \\
\end{array}$ & $\begin{array}{l}\text { Fluo- } \\
\text { ride }\end{array}$ \\
\hline$\underset{\text { Do }}{80 \text { Acres No. } 1}$ & $\begin{array}{l}4-27-65 \\
5-20-66\end{array}$ & $\begin{array}{l}360 \\
750\end{array}$ & $\begin{array}{r}104 \\
90\end{array}$ & $38^{6.6}$ & - & $\begin{array}{l}0.05 \\
0.32\end{array}$ \\
\hline$\underset{\text { Do }}{\text { Pocatello No. } 3}$ & $\begin{array}{l}1-04-61 \\
8-31-66\end{array}$ & $\begin{array}{ll}1 & 320 \\
6 & 440\end{array}$ & $\begin{array}{l}58 \\
72\end{array}$ & $27^{5.3}$ & $\begin{array}{l}0.02 \\
0.00\end{array}$ & $\begin{array}{l}0.22 \\
0.53\end{array}$ \\
\hline $\begin{array}{c}\text { Pocatelio No. } 23 \\
\text { Do }\end{array}$ & $\begin{array}{r}10-21-64 \\
8-31-66 \\
\end{array}$ & $\begin{array}{l}700 \\
750 \\
\end{array}$ & $\begin{array}{r}75 \\
123 \\
\end{array}$ & $\begin{array}{r}58 \\
345 \\
\end{array}$ & 0.12 & $\begin{array}{l}0.35 \\
0.44 \\
\end{array}$ \\
\hline
\end{tabular}

2. Natural Environment

a. Flora

Regional flora is transitional between the Great Basin vegetation to the south and the Rocky Mountain vegetation on the north. Two primary native cover classifications have been identified in the area:

Mountain/brush - dominated by species such as bitterbrush (Purshia tridentata), serviceberry (Amalanchier 
alnifolia), and juniper. Sagebrush is almost always present.

Sagebrush/grass - dominated by sagebrush, bitterbrush, bluegrass, and Indian ricegrass.

The mountain-brush association occurs on all aspects at lower elevations, but is generally confined to south and west slopes at higher elevations. The sagebrush-grass association occurs at lower elevations on less productive soils. No plant species included on the 1974 Smithsonian Institute plant list are known to occur in the area.

\section{b. Fauna}

Elk and mule deer winter in the mountains south of Pocatello. Other game species which occur in the area include sage/grouse, sharptailed grouse (Pedioecetes phasianellus), Hungarian partridge, and chukar partridge. Small mammals which are found in all cover types include whitetail jackrabbit (Lepus townsendi), cottontail (Sylvilagus nuttalli), and pygmy.

Mourning doves are found in the area in the summer and "are associated with the sagebrush-grass, mountain-brush, and agricultural cover types. The area is located in the Pacific waterfowl flyway and a large number of ducks and geese concentrate at the American Falls Reservoir before moving south. The most common insectivorous birds in the area include the western meadowlark (sturnella neglecta), swallows (Hirundinidae), and nighthawks (Chordeiles minor). Several species of reptiles and amphibians inhabit the area, including western toad (Bufo boreas), leopard frog, gopher snake, and western rattlesnake.

\section{c. Aquatics}

Rainbow trout are stocked in the Portneuf River; other species found in the river include brook trout and brown trout. The upper Portneuf and its tributary, Marsh Creek, are classed as Class IV streams by the Idaho Department of Fish and Game, and fishing pressure is moderate to intense in some areas.

3. Cultural Environment

\section{a. Land Use}

All land in the area of interest is privately owned. The Fort Hall Indian Reservation, which was established in 1868 , borders the area on the west and north, and Caribou National Forest lands lie to the south. 
Approximately 3880 ha of land is included with the metropolitan area of Pocatello. Additional land uses include grazing, dry and irrigated farming, and phosphate processing. The simplot plant, a completely integrated fertilizer complex, was established in 1945 and processes about 750,000 tons of phosphate rock annually. The FMC elemental phosphorus plant, established in 1949, has an annual production capacity of 127,000 metric tons.

\section{b. Socioeconomics and Demography}

The population (1970) of Pocatello is 40,000, about 77 percent of the population of Bannock County. The population has steadily increased and forecasts (some controversial) indicate that the population of the city may increase by 30,000 by 1980 . The projected increase is primarily based on growth of the Bucyrus-Erie plant. The birth rate and fertility rate for the county in 1975 were 23.3 and 101.5, respectively. They compare to respective values of 19.1 and 92.0 for Idaho and 14.8 and 66.7 for the United States as a whole. Eighty-three new housing units were authorized in Pocatello in 1970; in 1976, 1104 were authorized. Primary employers in the county in 1975 were trade $(5,065)$, state and local $(4,547)$, services $(3,437)$, transportation and utilities $(2,859)$, and manufacturing $(2,653)$. The percent of the labor force unemployed in 1970 was 5.7 percent; in 1976 it had dropped to 4.9 percent. Ten percent of families were below the poverty level in 1969, and an average of 1,400 persons utilized welfare in 1975 . Larceny offenses accounted for 66 percent of all crime in the county in 1976, while murder accounted for less than 0.1 percent.

\section{c. Archaeological and Historical}

The Pocatello area was an area of extensive travel by fur traders and immigrants in the early $1800^{\prime} \mathrm{s}$. The Oregon Trail, its south alternate, and the Lander Road all entered Idaho east of Pocatello. The latter two trails met the Oregon Trail on what is now the Fort Hall Indian Reservation, $40 \mathrm{~km}$ northeast of Pocatello. They continued west to the snake River, then followed its course to the southwest. The California Trail took off from the oregon Trail at soda springs and traversed the area south of Pocatello. By 1860 , permanent settlements were underway.

Southeast Idaho is part of the Great Basin ethnographic culture area. The natives were hunters and gatherers. Because of their seasonal treks, there is no large accumulation of artifacts in any one area. 


\section{d. Aes thetic Values}

Poor air quality is a major problem in the Pocatello area and impacts the recreational value of the region. The main recreational asset of the area is American Falls Reservoir, which lies outside the pocatello study area. Pocatello is located at the foot of rather picturesque mountains, which affords some aesthetic value to the local residents.

\section{G. HAILEY}

\section{Physical Environment}

\section{a. Climate}

The Hailey area is characterized by long, cold winters and short, dry summers. Average monthly temperatures range from $-70^{\mathrm{C}}$ in January to $20 \mathrm{O}_{\mathrm{C}}$ in July. The normal annual precipitation ranges from $38 \mathrm{~cm}$ at Hailey in the wood River valley to over $48 \mathrm{~cm}$ in the nearby foothills. Nearly 50 percent of the annual precipitation falls as snow from December through February. The snow depth peaks in March at $113 \mathrm{~cm}$ ( $1890 \mathrm{~m}$ elevation). The maximum snow depth recorded at this station is $183 \mathrm{~cm}$. Wind patterns are determined almost entirely by topography and vary significantly over the area.

\section{b. Air Quality}

The are no major air-polluting industries in the central Idaho region; as a result, the air quality of the Hailey area is extremely good. There are two air quality stations in the region, one $110 \mathrm{~km}$ south on the southern Snake River Plain and one at Craters of the Moon National Monument, $80 \mathrm{~km}$ to the east. The normal suspended particulate concentrations at these two stations are $40 \mu \mathrm{g} / \mathrm{m}^{3}$ and less than $10 \mathrm{\mu g} / \mathrm{m}^{3}$, respectively. Estimates of the particulate levels around Hailey indicate that normal concentrations approximate those at Craters of the Moon.

\section{c. Land Resources}

\section{(1) Topography}

The general topography of the area is steep and rough and exhibits the effects of both extensive glaciation and stream erosion. Elevations in the area of interest range from $1630 \mathrm{~m}$ at Hailey to $2700 \mathrm{~m}$ on Kelly Mountain. Elevations in the main Sawtooth Mountains to the northwest exceed $3150 \mathrm{~m}$. The valley of the Wood River, which forms the eastern boundary of the area, opens onto the Snake River Plain $24 \mathrm{~km}$ south of Hailey. East-west trending 

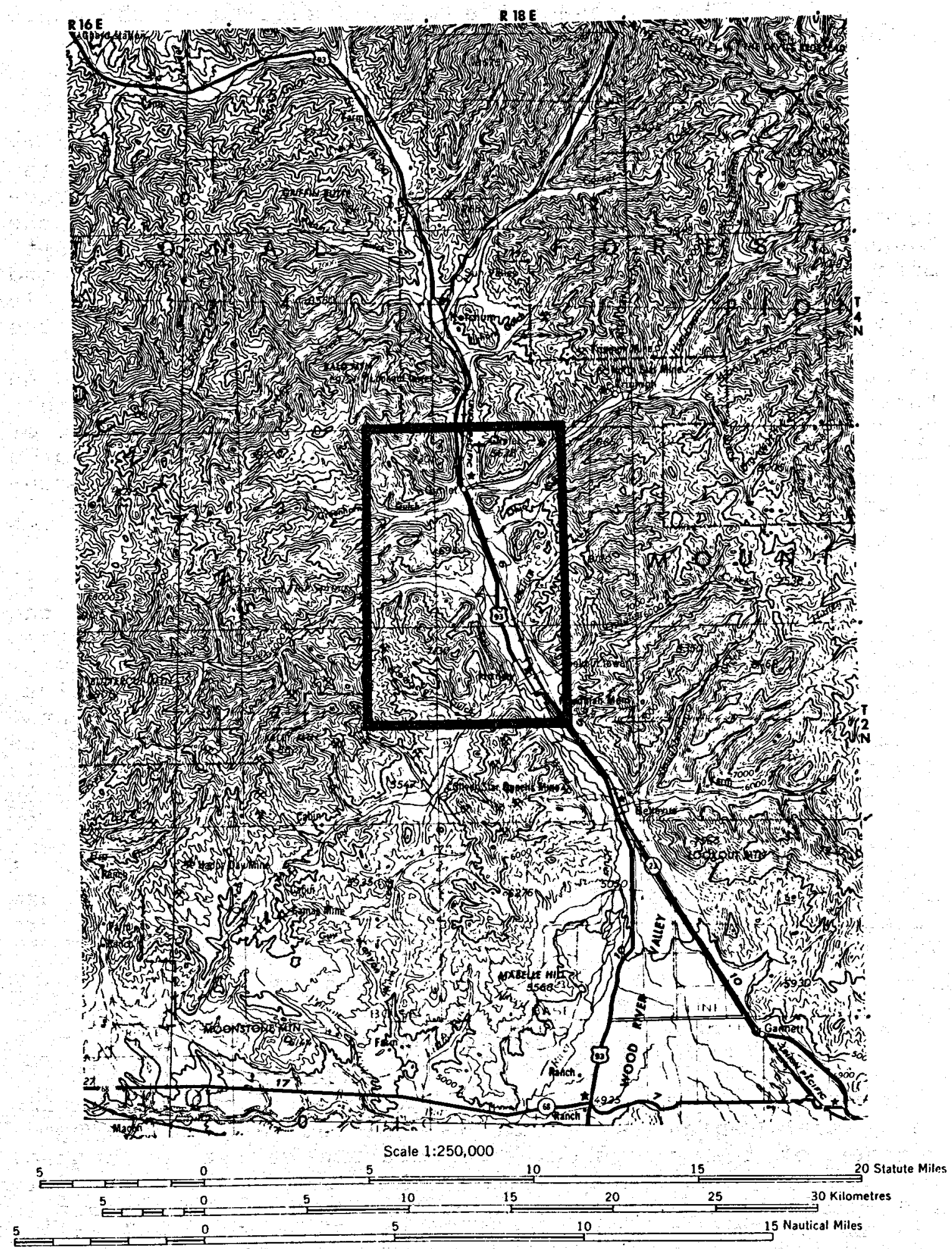

CONTOUR INTERVAL 200 FEET

WITH SUPPLEMENTARY CONTOURS AT 100 FOOT INTERVALS TRANSVERSE MERCATOR PROJECTION

G. Hailey Study Area 
ridges and valleys dissect the area, resulting in the steep slopes and high relief characteristic of the region.

\section{(2) Geology}

The geology of the Hailey area reflects uplift, intrusion, glaciation, vulcanism, and stream erosion, all of which have played a major role in the structure of the area. Hailey is located at the boundary of the Idaho Batholith and the snake River Plain. As a result, both the granitics of the Batholith and volcanic flows and debris predominate. Glacial deposits and alluvium overlie volcanic debris, marine detritus, and quartzite in the normal-faulted wood River valley. In addition to the faults bounding the valley, a major northeast-southwest trending thrust-block boundary fault is evident along Deer creek canyon extending into the pioneer Mountains to the east of the valley. Like the Snake River Plain, the Hailey area seems aseismic, although a large number of earthquakes occur in the Sawtooth Mountains north of Stanley.

\section{(3) Soils}

Soils range from deep and productive in the valley bottons to shallow and unproductive on the steep south slopes. Much of the area is characterized by fluvial slopes with soils formed from underlying granitics, sandstone, volcanic rhyolites, and metamorphosed sediments. Soils derived from the granitics of the Batholith are generally gravelly, sandy loams or loamy sands. The profile is not well developed and ranges in depth from $25 \mathrm{~cm}$ to 90 cm. Sedimentary soils are moderately deep clays or clayloams over well-fractured bedrock. Soils whose parent material is volcanic are loams or clay loams with shallow to moderately deep profiles. The soils of the Batholith are highly erosive, while the sedimentary and volcanic soils are very cohesive and much less erosive.

\section{d. Water Resources}

\section{(1) Surface water}

The primary strean in the area is the Big Wood River, which is fed largely by snowmelt in the upper reaches of the watershed. Temperature variations control the stream discharge during the high spring runoff. Precipitation rarely contributes directly to high runoff in the basin. The Big Wood River drains over $1660 \mathrm{~km}^{2}$ of the Boulder, Pioneer, and southern Sawtooth Mountains. The river empties into the Magic Reservoir which provides irrigation water supply for Lincoln and Gooding counties, $25 \mathrm{~km}$ south of Hailey. Diversions above Hailey are used to irrigate an average of $4000 \mathrm{ha}$. The average discharge of the 
river at Hailey is $10.8 \mathrm{~m}^{3} / \mathrm{s}$, with recorded extremes of 141 $\mathrm{m}^{3} / \mathrm{s}$ and $0 \mathrm{~m}^{3} / \mathrm{s}$. Forty-seven percent of the total flow of the river in the 1976 water year occurred in May and June. Average water quality of the river in 1975 and 1976 just south of Hailey is shown in table G-1. Irrigators are generally short of water each year. Decreed water rights on the river above the Magic Reservoir total approximately 28 $\mathrm{m}^{3} / \mathrm{s}$.

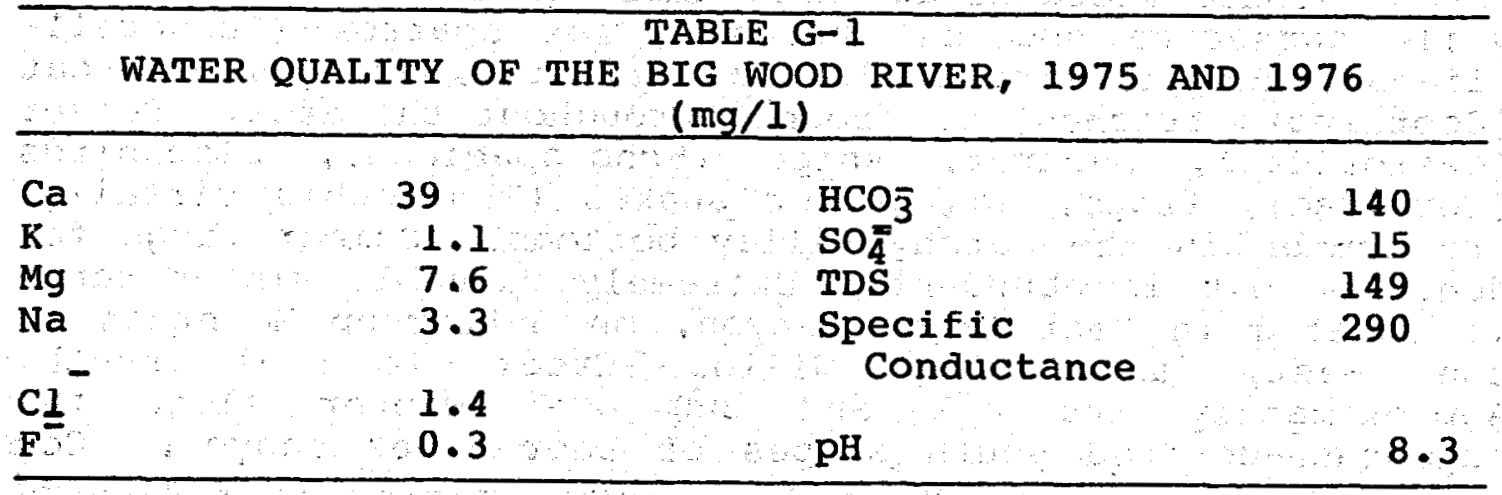

(2) Groundwater

The Wood River aquifer is unconfined fluvio-glacial sedimentary deposit underlying the valley to depths of more than $90 \mathrm{~m}$. Beds of sand and gravel interbedded with clays and silt yield large supplies of water to wells up to $30 \mathrm{~m}$ deep in the valley. The water table, which has an average gradient of $7.6 \mathrm{~m} / \mathrm{km}$, is deepest in late winter and shallowest in June. The groundwater is of uniformly good quality, although it ranges from moderately hard to hard. Groundwater outflow from the upper Big Wood Basin totals about $6000 \mathrm{hm}^{3}$ annually.

\section{Natural Environment}

\section{a. Flora}

The dominant vegetation types around Hailey and in the mountains to the west are conifer timber and sagebrush-grass. Lodgepole pine (Pinus contorta) and Douglas fir occur primarily on the north and east slopes, while mountain big sagebrush, bitterbrush, blue bunch wheatgrass, and chokecherry generally occur on the south and west slopes. Associated vegetation types found in the valley bottoms include grassland, meadow, aspen, and riparian. slopes along the north side of upper Deer Creek are highly sensitive and difficult to revegetate. Although vegetation types throughout the area are well-established, forest fires and timber harvests result in local short-term changes. 
b. Fauna

Primary large mammals in the area include mule deer, elk, black bear, and mountain goats (Oreamnos americanus). Predators include bear, mountain lion (Felis concolor), lynx (Lynx canadensis), bobcat, and coyote. Common rodents include the Columbian ground squirrel, red squirrel (Tamiasciurus hudsonicus), chipmunk (Eutamias sp.), deer mouse (Peromyscus maniculatus), and snowshoe rabbit. Forest grouse (Teraonidae) are common in the timbered areas, while passerine species including fox sparrow (Passerella iliaca), song sparrow (Melospiza melodia), and yellowthroat (Geothlypis trichas) are found throughout the area. Beaver (Castoridae), muskrat, snipe (Scholopacidae), blackbirds (Corvidae), frogs, and garter snakes (Thamnophis sirtalis) are common in the marshy valley bottoms. Summer range for deer and elk is abundant. Extremely valuable winter range is located in Deer Creek canyon, on Buttercup Mountain to the west, and along Willow creek to the south. Approximately $100 \mathrm{elk}$ and 300 deer winter along the sagebrush-covered south slopes of Deer Creek canyon. Cow Creek canyon in the northern part of the area is vegetated with aspen and provides good elk forage during calving in May and June. From 40 to 60 elk can be found in the area during this period.

\section{c. Aquatics}

Fish found in the major streams of the region include rainbow, cutthroat, eastern brook trout, and whitefish. Dolly Varden trout and kokanee salmon (Oncorhynchus nerka) are found in the south Fork of the Boise River just west of the area of interest. Fisheries capability is low throughout the tributaries of the Big Wood River. These streams do contain some native rainbow trout. Several times a year, $f$ ish are planted in Soldier creek, Willow Creek, and Deer Creek.

\section{Cultural Environment}

\section{a. Land Use}

of the 30,600 ha in the area of interest, an estimated 11,700 ha are under the jurisdiction of the Sawtooth National Forest, 9800 ha are controlled by the Bureau of Land Management, 1500 ha belong to the state of Idaho, and the remainder is private land. Land uses on the USFS and BLM in the western half of the area of interest include snowmobiling, hunting, cross-country skiing, scenic travel, and summer recreation, mining (16 lead and silver mines are located in the area), and cattle and sheep grazing. Recreational facilities at clarendon Hot springs are the only geothermal development in the area. The 
eastern half of the area is used for grazing, farming, a travel corridor, and residential.

\section{b. Socioeconomics and Demography}

All of the area of interest is located in Blaine County, which had a population in 1976 of 7900 . The population density in the county in that year was 1.7 people $/ \mathrm{km}^{2}$. Eighteen percent of the county population is classed as rural-farm, while 82 percent is classed as rural-nonfarm. Hailey, the county seat, had a population in 1970 of 1425 . The county population increased 38 percent in the six years from 1970 to 1976 , compared to a 16.5 percent population increase in the state of Idaho during the same period. Migration accounted for 79 percent of the county's population increase.

The unemployment rate in the county in 1976 was 14.4 percent, ranging from 10.6 percent in september to 22 percent in May at the end of the ski season. Services as a group employ the largest number of people $(27$ percent of total), with trade, state and local, and nonfarm proprietors together accounting for an additional 40 percent. Per capita income in 1970 was 114 percent of the state average.

\section{c. Archaeological and Historical}

Archaeological surveys in the region indicate that primitive man inhabited the area; however, no extensive archaeological studies have been conducted which yield specific data for the area. The first white man in the area was a trapper traversing the mountains to Boise in 1824. A gold discovery in 1863 led to the founding of Hailey and Ketchum. Many of the mining towns established during the subsequent 30 years are now ghost towns. Homesteading fluorished in the 1880 's and sheep grazing was extensive until the Sawtooth National Forest was established in 1905. The Union Pacific Railroad began construction of the Sun Valley Resort in 1936, marking the advent of recreation as a major industry in the area.

\section{d. Aesthetic Values}

The Hailey area is highly prized for both its abundant wildlife and near-pristine wilderness. Located on the edge of the Sawtooth National Recreation Area, the only road into the region is heavily utilized by recreational travelers. The study area receives heavy use in summer by backpackers and campers and in winter by skiers, who frequent the area from all parts of the world. preservation of the environment in this area would be a major concern to potential developers. 


\section{POTENTIAL ENVIRONMENTAL IMPACTS}

The environmental impacts that may result from the development of geothermal resources in the areas under consideration will vary significantly. In general, the developments will be, on a relatively small scale, so that cumulative impacts in any one area will be minor.

\section{A. AIR QUALITY}

Sources of air pollution from geothermal development include dust from cleared areas and roads, vehicle emissions, dissolved gasses in the geothermal fluids, and emissions from industrial processes. Dust can be controlled to a certain extent by gravelling, watering, or oiling roads and sites. The dissolved gas content (especially hydrogen sulfide) in most geothermal resources in Idaho is very low. Geothermal systems will be a closed cycle unit in most processes, resulting in no release of dissolved gasses to the environment. Where this is not the case, gas emissions can be reduced through the use of scrubbing units. Emissions from industrial processes will vary and can be controlled, if necessary, to meet state and federal regulations.

\section{B. NOISE}

Noise levels during geothermal development will generally be highest during well drilling. Noise levels from drill rigs range from less than $50 \mathrm{dBA}$ at $6 \mathrm{~m}$ for cable tool rigs to higher than $70 \mathrm{dBA}$ at $6 \mathrm{~m}$ for oil rigs. Drill rigs may operate for 24 hours a day where the noise does not cause disruption. The noise from open water discharge Iines from a geothermal well rarely exceeds 70 dBA at $1.5 \mathrm{~m}$. Any of these noise levels should be reduced to less than $60 \mathrm{dBA}$ at $300 \mathrm{~m}$.

\section{SOILS}

The primary environmental impacts of geothermal development on soils will be increased erosion on cleared land and instabilities on steep slopes. To a great extent, these impacts can be reduced through careful siting of well and plant sites. The hills surrounding pocatello and the canyons in the Hailey area are especially susceptible to soil stability problems.

\section{WATER RESOURCES}

The impact of goethermal resources on water quality and supply is one of the major concerns in the state of Idaho. 
Water contamination can result from casing leaks, seepage from holding ponds, uncontrolled discharge from wells, and improper disposal of the geothermal fluids. Regulations require that geothermal wells be cased and cemented through shallow groundwater aquifers to reduce the chance of geothermal fluids leaking into these aquifers through the wellbore. Drilling muds help to reduce the seepage from holding ponds; however, if seepage of poor quality fluids is high, the holding ponds can be lined proper design of wells, wellheads, piping systems, and discharge systems should reduce the chances of water contamination from these sources. Samples from thermal wells and springs across the state indicate total dissolved solids ranging from 180 to $13,000 \mathrm{mg} / 1$, with a mean of $630 \mathrm{mg} / 1$. The quality of some geothermal fluids, then, can be expected to be compatible with surface and shallow groundwaters. Indications are that geothermal systems in Idaho are not completely separated from other groundwater aquifers. As a result, production of geothermal fluids may interfere with groundwater supplies in some places.

\section{E. SEISMICITY}

Geothermal areas have been associated with areas of significant seismic activity. Production and injection of geothermal fluids may increase the activity in some areas. The Snake River Plain in Idaho is considered very aseismic and background levels of seismic activity in the areas under consideration are low. Depending on the amount of faulting and the imbalance created by production and injection in these areas, microseismic activity may or may not increase.

\section{F. SUBSIDENCE}

Whenever large quantities of fluids are withdrawn from unconsolidated sediments or when declining reservoir pressures reduce the support for overburden, subsidence may result. In some areas in Idaho, subsidence due to the withdrawal of water for irrigation has been documented. The adverse impacts of subsidence depend on the location. Significant subsidence in a city may result in structural damage to many buildings. The same amount of subsidence in an undeveloped or agricultural area may not result in any damage.

\section{G. FLORA}

The major impact to flora generally results from the clearing of land for roads, drill sites, and process facilities. If those disturbed lands are revegetated with native species following development, the impact can be reduced. If not, soil erosion may increase and a significant invasion of noxious species such as halogeton 
(Halogeton glomeratus) may result. Reestablishment of native vegetation on unstable slopes is difficult and in areas with low moisture availability, this reestablishment may take decades.

H. FAUNA

The impact on local fauna in developed agricultural or metropolitan areas will be minimal. The prime species displaced by development in those areas will be small mammals. In the undeveloped areas of Hailey, Blue Gulch, and Bruneau-Grand View, development may result in major impacts to fauna. Each of these areas is prime habitat for elk, mule deer, and raptors. Nesting and calving areas are particularly vulnerable in the spring and early summer and development in these areas should be avoided. Aquatic species may be impacted as a result of increased erosion or discharge of poor quality goethermal fluids to streams. In most cases, design of facilities will reduce this impact.

\section{SOCIOECONOMICS}

If major development occurs in sparsely populated areas, the population influx may result in significant social and economic impacts. These impacts would include lack of housing, strain on utilities and service, especially water supply and medical services. If development occurs in an orderly manner, there may be an opportunity for planning early in the development phase which could reduce many of the adverse impacts. The kinds of development that can be expected in the areas under consideration are either retrofitting existing processes to utilize geothermal fluids or small-scale new processes. These developments should result in few adverse socioeconomic impacts.

\section{J . ARCHAEOLOGICAL AND HISTORICAL}

All of the areas under consideration are known to or are expected to have significant heritage resources. Where these resources have been documented $(\mathrm{e} . \mathrm{g}$. , the route to the Oregon Trail), they should be protected during development. Archaeological curves should be conducted in undisturbed areas where no data exist. If archaeological resources are uncovered during development, state archaeologists will be consulted. 


\section{REFERENCES}

Ada Council of Governments, 1973. Background Information for Ada County, Idaho. Environmental Planning Report 3.

Ada Council of Governments. Waste Water Sources and Water Use, Environmental Report 8.

Ada Council of Governments. Ada County Ecology. Environmental Report 9.

Bureau of Land Management, 1976. Environmental Analysis Record for the Agricultural Development Program.

Bureau of Reclamation, 1977. Watex Quality Study-Boise Valley, Vol. 1. Bureau of Reclamation, Pacific Northwest Region, Boise, Idaho.

EAR No. 11-010-5-77. Geothermal Leasing and Development on Potential Areas within the Boise District-Bruneau, Grandview and Bennett Mountain. Bureau of Land Management, Boise District, Boise, Idaho.

Longyear, A.B., W.R. Brink, L.A. Fisher, R.H. Matherson, J.A. Neilson, S.K. Sanyal, 1978. Mountain Home Geothermal Project - 1st Quarterly Report IDO/1704-1. U.S. Department of Energy, August 1978.

National Oceanic \& Atmospheric Administration, 1977. Climatological Data Annual Summary. Vol. 80 (No. 13), National Climatic Center, Asheville, N.C.

Ralston, D.R. and S.L. Chapman, 1969. Ground-Water Resources of Northern Owyhee County, Idaho. Water Information Bulletin 14. Idaho Dept. of Reclamation.

U.S.E.P.A., 1972. Idaho Environmental Status and Program Evaluation. Region IX EPA, Seattle, Washington.

U.S. Forest Service, 1975. Proposed Land Use Plan, Council Planning Unit, Payette National Forest.

U.S. Forest Service, 1977. Final Environmental Impact Statement, Development of Phosphate Resources in Southeastern Idaho.

U.S. Geological Survey, 1976. Water Resources Data for Idaho, Water Year 1976. Report ID-76-1.

Young, H.W. and R.L. Whitehead, 1975. Geothermal Investigations in Idaho - Part 3: An Evaluation of Thermal Water in the Weiser Area, Idaho. Idaho Department of Water Resources Water Information Bulletin 30 . 
$-7$

Young, H.W., W.A. Harenberg, and H.R. Seitz, 1977. Water Resources of the Weiser River Basin, West-Central Idaho. Water Information Bulletin No. 44, Idaho Department of Water Resources. 


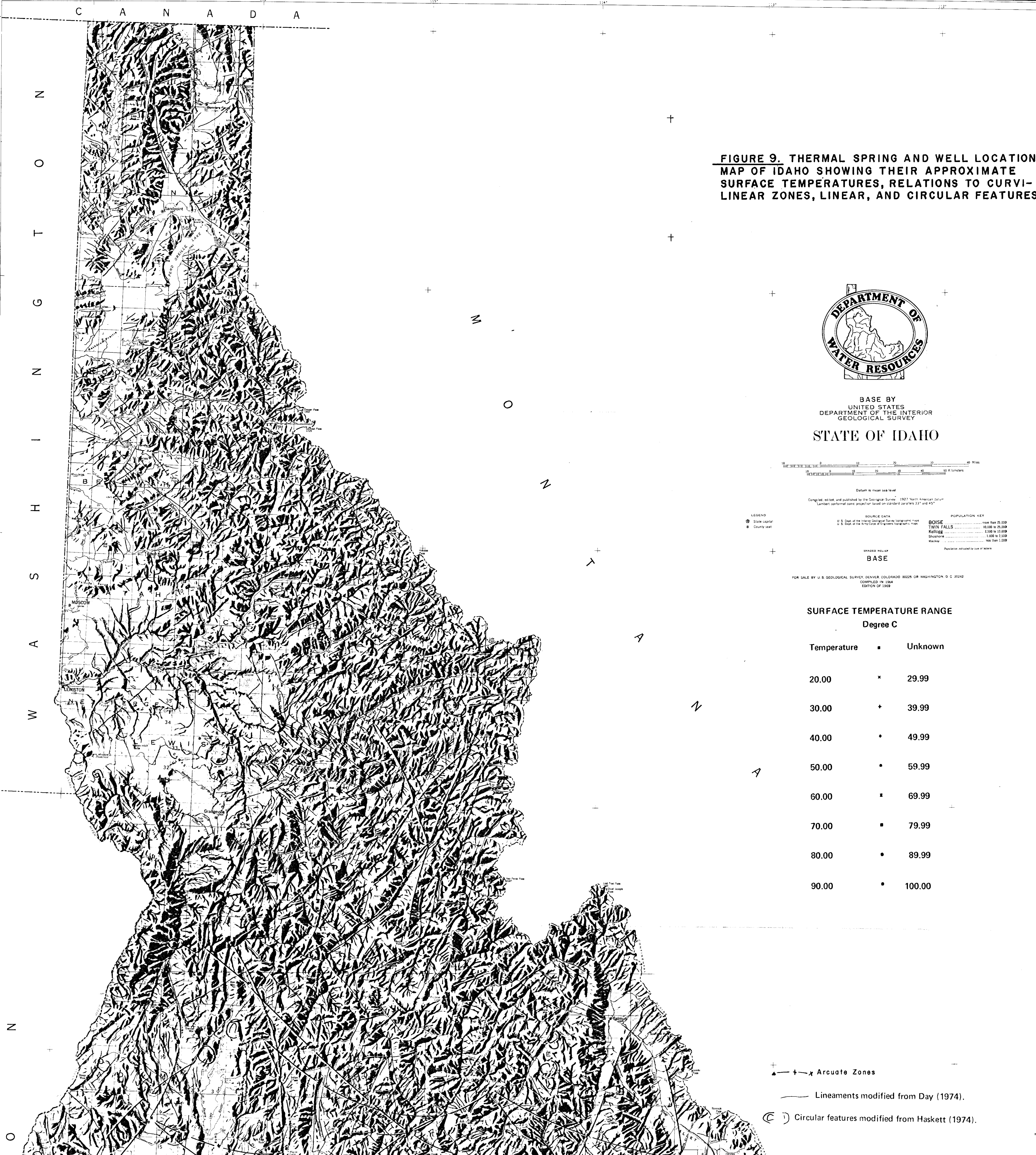

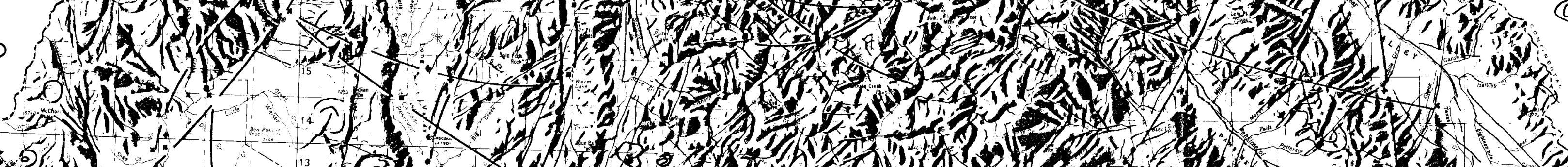
(5) (1)

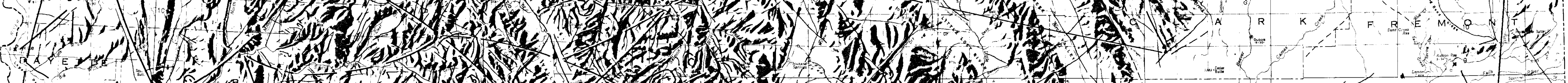

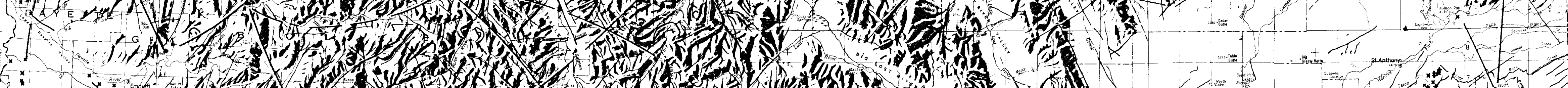

(1)

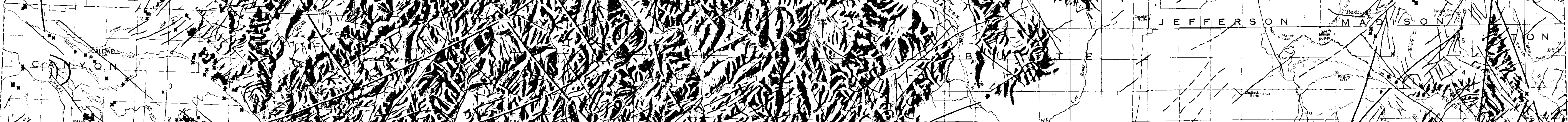

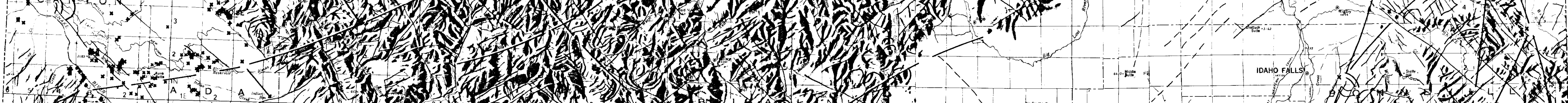

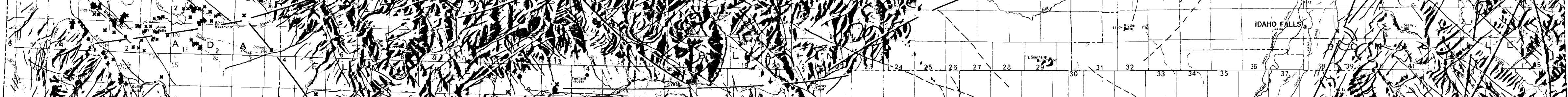

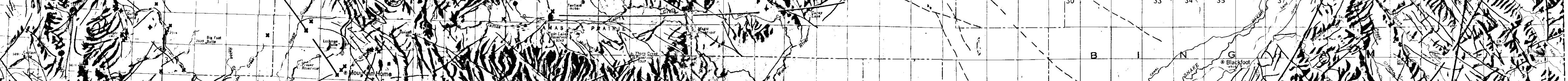

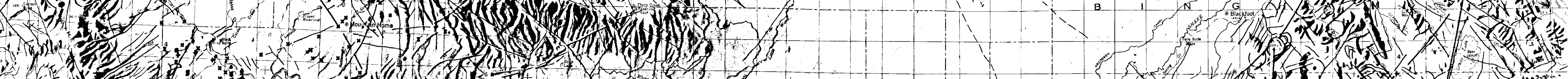

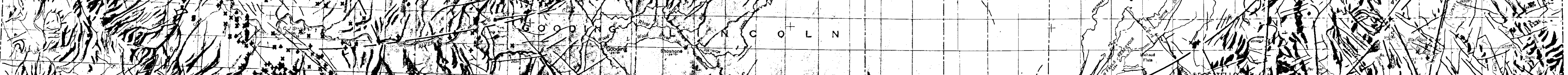

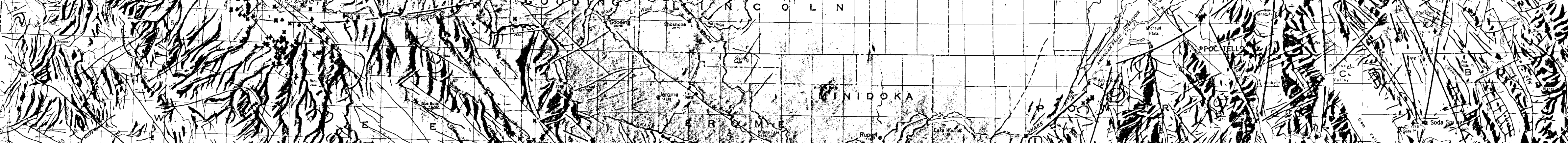

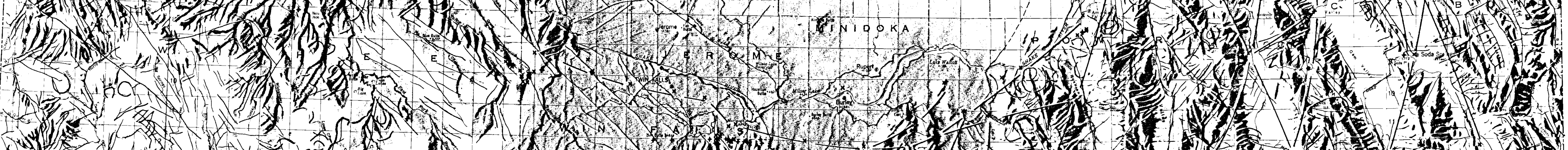
-

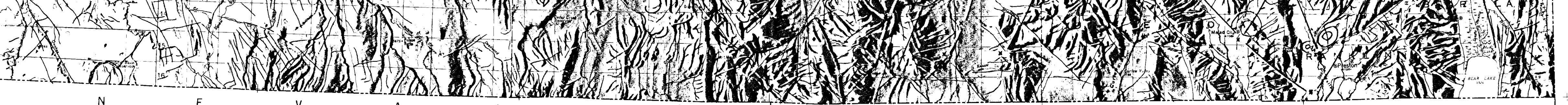


